

\section{Geology of the}

\section{Flaming Gorge Area}

\section{Utah-Colorado-Wyoming}

By WALLACE R. HANSEN

GEOLOGICAL SURVEY PROFESIONAL PAPER 490

A reexamination of an area first made known through the Territorial Surveys of Powell, King, and Hayden

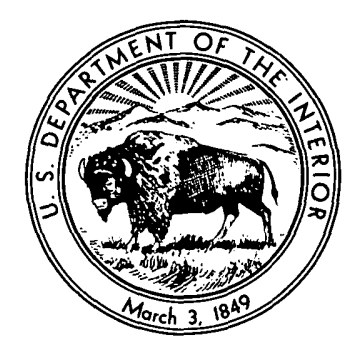




\section{UNITED STATES DEPARTMENT OF THE INTERIOR \\ STEWART L. UDALL, Secretary \\ GEOLOGIGAL SURVEY}

Thomas B. Nolan, Director

The U.S. Geological Survey Library has cataloged this publication as follows :

\section{Hansen, Wallace $R \quad 1920$}

Geology of the Flaming Gorge area, Utah-Colorado-Wyoming. Washington, U.S. Govt. Print. Off., 1964.

viii, 196 p. illus., maps $(1$ col. $)$ diagrs. $(1$ col. $)$ tables. $30 \mathrm{~cm}$. (U.S. Geological Survey. Professional paper 490)

Part of illustrative matter fold. in pocket.

Bibliography : p. 188-192.

1. Geology-Utah-Daggett Co. 2. Geology-Colorado-Moffat Co. 3. Geology-Wyoming-Sweetwater Co. I. Title. II. Title: Flaming Gorge area, Utah-Colorado-Wyoming. (Series)

For sale by the Superintendent of Documents, U.S. Government Printing Office Washington, D.C. 20402 


\section{CONTENTS}

Abstract

Introduction.

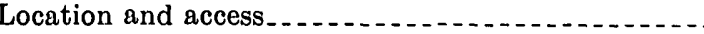

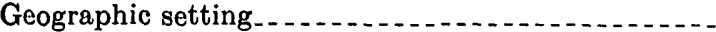

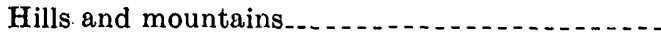

Drainage and valleys..........................

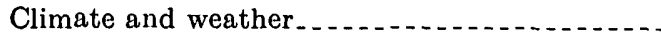

Vegetation summary

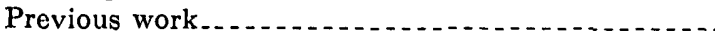

Fieldwork by the author

Acknowledgments

Stratigraphy

Precambrian rocks. ... . . . . . . . . . . . . . . . .

Red Creek Quartzite (middle Precambrian)....

Uinta Mountain Group (younger Precambrian).

Paleozoic rocks.......

Mississippian System.....................

Lower and middle units . . . . . . . . . . . . .

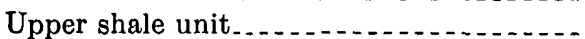

Pennsylvanian System...................... Round Valley Limestone...............

Morgan Formation.....................

Weber Sandstone. . . . . . . . . . . . . . .

Permian System ................

Park City Formation ................

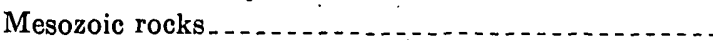

Triassic System ................ Dinwoody Formation . . . . . . . . . . . . .

Moenkopi Formation..................

Chinle Formation

Triassic(?) and Jurassic Systems............. Navajo Sandstone. . . . . . . . . . . . . .

Jurassic System . . . . . . . . . . . . . . .

Carmel Formation. . . . . . . . . . . . . .

Entrada Sandstone.......................

Curtis Formation . . . . . . . . . .

Jurassic and Cretaceous Systems............. Morrison Formation and younger rocks...

Cretaceous System................. Dakota Sandstone. . . . . . . . . . . . . .

Mowry Shale..........................

Frontier Formation . . . . .

Hilliard Shale . . . . . . . . . . . . .

Blair Formation . . . . . .

Rock Springs Formation........

Ericson Sandstone. . . . . . . . . . . . .

Cenozoic rocks

Tertiary System......................... Fort Union Formation (Paleocene) .......

Wasatch Formation (Eocene) . . . . . . . . . Green River Formation (Eocene) ............ Browns Park Formation (Miocene?) ........

Quaternary System

Alluvium . . . . . . . . Bench gravels of Pleistocene age . . . . . . . Recent alluvial fills

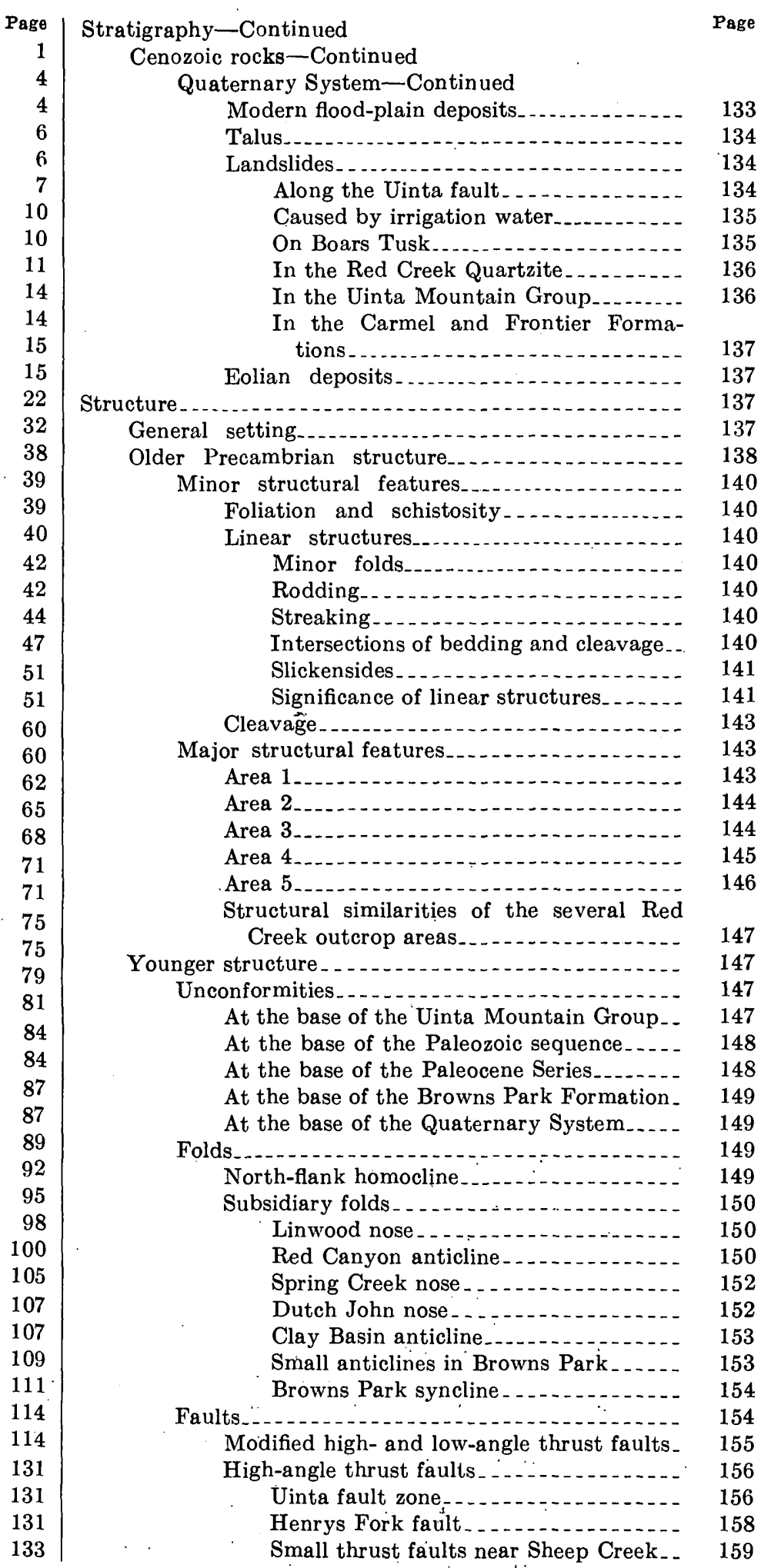


Structure-Continued

Younger structure-Continued

Faults-Continued

Normal fault

Upper Red Canyon area..........

Dutch John and Little Hole area .....

North of Browns Park

In the younger rocks north of the Uinta fault ............................

Time and significance of normal faulting ...............................

Gravitative movements on the Uinta

fault ............................

Tertiary warping and tilting..................

Extent and character.......................

Tilting south and west from Goslin Mountain

Regional evidence of tilting south and west of Goslin Mountain...........

Time of warping

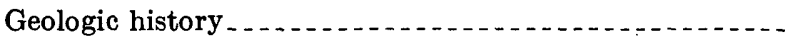

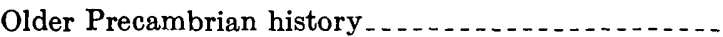

Younger Precambrian history . . . . . . . . .

Paleozoic history

Mesozoic history

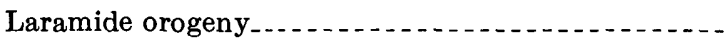

Early Tertiary tectonic and depositional history ....

Middle and late Tertiary tectonics, erosion, and de-

positional history

Gilbert Peak erosion surface

Gravity faulting following cutting of the Gilbert

Peak erosion surface

Browns Park Formation and canyon cutting -

Post-Browns Park tilting.

\section{CONTENTS}

Page

159

160

160

161

161

162

162

162

164

164

166

166

166

167

167

169

169

170

171

171

171

172

174
Geologic history-Continued

Quaternary history

Planation and terracing.

Quaternary drainage adjustments...........

Sheep Creek...........

Capture upstream...............

Capture near mouth..............

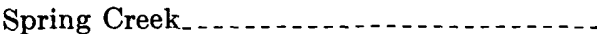

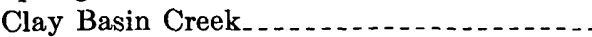

Beheading of Jesse Ewing Canyon...-

Beheading of Cottonwood Draw ......

Beheading of Bender Draw........

Beaver Creek.................................

Other drainage adjustments..................

Recent changes in the course of the Green

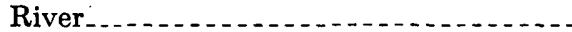

Drainage modifications caused by man . . .

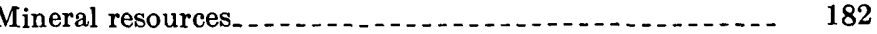

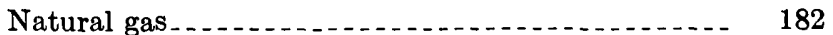

Coal _.

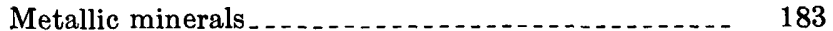

Copper .

Gold _................ 183

Manganese._._._.

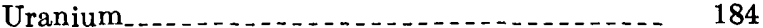

Phosphate....... 184

Barite.

Clay and shale.

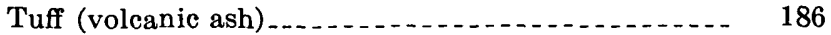

Limestone...... 186

Sand and gravel . . . . . .

Riprap.

Silica__._.

Gypsum .

References cited. .

Index.

\section{ILLUSTRATIONS}

[Plates are in pocket]

Plate 1. Geologic map and sections of the Flaming Gorge area, Utah-Colorado-Wyoming.

2. Shaded relief diagram showing major topographic features of the Flaming Gorge area, Utah-Colorado-Wyoming, and partial extent and outline of Flaming Gorge Reservoir.

3. Comparative stratigraphic sections, Browns Park Formation, Flaming Gorge area, Utah-Colorado-Wyoming.

Figure 1. Vicinity map showing access roads

2. Photograph of view northeast down canyon of Sheep Creek toward Flaming Gorge

3. Chart showing distribution, by altitude, of common woody plants

4. Photograph showing canyon of Red Creek as viewed upstream toward Two Horse Butte.

5. Photomicrograph of typical metaquartzite, Red Creek Quartzite

6. Photograph showing close view of quartz-muscovite schist at Red Creek

7-9. Photomicrographs of-

7. Staurolite-quartz-muscovite schist

8. Anthophyllite-plagioclase schist

9. Granitic variants of amphibolite

10. Drawing of small carbonate veins in amphibolite 
Frgure 11. Map showing correlation of stratigraphic sequence across O-Wi-Yu-Kuts fault

12. Photomicrograph of sedimentary quartzite, Uinta Mountain Group

13. Sketch of Band Box Butte, an outlier of the basal conglomerate of the Uinta Mountain Group. ....... 14-17. Generalized thickness maps-

14. Mississippian sandstone and limestone unit

15. Mississippian shale unit.

16. Round Valley Limestone.....

17. Morgan Formation and Weber Sandstone

18. Photograph of Weber Sandstone at Kingfisher Canyon

19. Generalized section of Franson Member of Park City Formation

20. Generalized thickness map of Park City Formation

21. Photograph of Triassic section exposed on slope west of Horseshoe Canyon

22. Generalized thickness map of Lower Triassic rocks.

23. Generalized thickness map of Dinwoody Formation

24. Photograph of Navajo Sandstone at Finch Draw

25. Photomicrograph of silicified Navajo Sandstone

26. Photograph showing characteristic topographic expression of Carmel Formation

27. Diagram showing lithologic changes in Carmel Formation between Sheep Creek Gap and Clay Basin .....

28. Diagram showing variations in thickness of Curtis Formation

29. Sketch showing panoramic view northeast across Finch Draw

30. Generalized thickness map of Morrison Formation

31. Photograph showing impression of large ammonite, Neogastroplites

32. Photograph of massive littoral sandstone in Frontier Formation

33. Photograph of Lucerne Valley as viewed southwest toward Leidy Peak

34. Diagrammatic relationship of Hilliard Shale to Blair, Rock Springs, and Ericson Formations

35. Photographs showing comparative views of Mesaverde Group

36. Sketch of deformed blocks and rolls of sandstone, Ericson Sandstone

37. Photograph of conglomeratic channel fill in Wasatch Formation

38. Photograph of view south across Browns Park near mouth of Jesse Ewing Canyon

39. Photograph of conglomeratic channel fill in Browns Park Formation

40. Graph showing lithologic proportions in Browns Park Formation

41. Photograph of view to northeast in Browns Park toward O-Wi-Yu-Kuts Mountain

42. Geologic section $L-L^{\prime}$ across benches north of Henrys Fork

43. Diagram showing effect of differential insolation on stability of slopes....

44. Diagram showing general relationships of landslide on northeast slope of Boars Tusk

45. Generalized structure map of Uinta Mountains

46. Generalized geologic map showing distribution of Red Creek Quartzite

47. Diagram showing axial coordinates of a fold

48. Diagram showing lineation formed by staurolite crystals oriented parallel to fold axis .

49. Diagram showing use of tadpole structure in determining sequence of beds

50. Contour diagrams of linear structures in Red Creek Quartzite

51. Contour diagrams of linear structures measured at Red Creek and Beaver Creek:

52. Diagram showing cleavage and drag folds in Red Creek Quartzite

53. Three geologic sections across northeast corner of Goslin Mountain

54. Geologic section $R-R^{\prime}$ through area 4.

55. Plot of lineation plunges in Red Creek Quartzite, Bender Mountain .

56. Photograph of unconformity between Ericson Sandstone and Fort Union Formation

57. Geologic section $M-M^{\prime}$ across Linwood nose

58. Photograph of view east from Bear Mountain along axis of Red Canyon anticline

59. Diagrammatic section across small anticline at mouth of Jesse Ewing Canyon

60. Geologic section $N-N^{\prime}$ through area 1, Red Creek Quartzite

61. Photograph of view northeast toward Beehive Point and sketch of geologic features

62. Sketch of Boars Tusk as viewed from the east

63. Photograph of view south from Willow Creek Butte showing westward tilt of Gilbert Peak erosion surface

64. Sketch map showing generalized distribution of Browns Park Formation

65. Sketch maps showing drainage adjustments of the Sheep Creek-Lucerne Valley area.

66. Photograph of view due east down Sheep Creek Canyon from rimrock of Navajo Sandstone

67. Sketch map showing drainage diversion at Minnies Gap.

68. Sketch map showing drainage adjustments in the Red Creek area 


\section{TABLES}

TABLE 1. Summary description of rocks exposed in Flaming Gorge area

2. General groupings of Precambrian rocks in the Middle Rocky Mountain region.

3. Summary description of selected tuff samples, Browns Park Formation, Utah and Colorado $\ldots . . .119$

4. Rapid rock analyses of tuffs, Browns Park Formation, Utah

5. Semiquantitative spectrographic analyses of tuffs, Browns Park Formation, Utah

6. Mesozoic depositional environments

7. Phosphate analyses, Horseshoe Canyon section 


\title{
GEOLOGY OF THE FLAMING GORGE AREA, UTAH-COLORADO-WYOMING
}

\author{
By Wallace R. Hansen
}

\begin{abstract}
The Flaming Gorge area is mainly in Utah on the northeast slope of the Uinta Mountains, entirely north of the crestline of the range and partly in a belt of foothills and outliers that grade into the arid tablelands of the Green River Basin. Much of this country has not changed greatly since the historic visits of Major Powell, Clarence King, and F. V. Hayden nearly a century ago, but the present construction activity centered around Flaming Gorge damsite is bringing dramatic changes. Dutch John, a completely new town, has arisen from the sagebrush of Dutch John Flat.

Owing partly to a varied geologic and geomorphic history and partly to a wide physical range of rock types, the Flaming Gorge area has a diversity of geographic and geologic features exceeded by few areas of similar size. The Green River meanders throngh a succession of deep canyons; some of its major tributaries flow in canyons that rival in size those of the Green River itself. The area has varied topographic relief, both strong and subdued. The highest point is on the crest of Kleins Fill at an altitude of 9,048 feet in the northeast corner of the area; the lowest point is at river level in Browns Park at an altitude of about 5,360 feet. The total relief of the area is thus nearly 3,700 feet. Relief is much greater nearby in the high Uinta Mountains to the southwest.
\end{abstract}

Rocks of the area range in age from Precambrian to Recent. Lower and middle Paleozoic rocks are lacking, but each system from Mississippian to Quaternary is represented by one or more formations.

Precambrian rocks are divisible into two major units, the Red Creek Quartzite and the Uinta Mountain Group. The Red Creek, which has a probable thickness of more than 20,000 feet, was crenulated, injected with mafic magma, refolded and metamorphosed, injected with pegmatite, faulted, and deeply eroded before the overlying Uinta Mountain Group was deposited.

Several rock types characterize the Red Creek: metaquartzite predominates; mica schist and amphibolite are common, and green chrome-bearing quartzite is widespread but not abundant. Other minor associated rocks are chloritic schist, carbonate rock, epidiorite, quartz-albite gneiss, and pegmatite. Pelitic mineral assemblages contain quartz, muscovite, staurolite, garnet, kyanite, and biotite as common constituents. These minerals indicate dynamic metamorphism at great depths and relatively high temperatures.

The Uinta Mountain Group was deposited on the deeply eroded Red Creek Quartzite on a surface of low rolling relief. Although the early geologists who visited the area made much of the supposed great relief on the unconformity, this relief is on the order of hundreds of feet rather than thousands. The. Uinta Mountain Group consists chiefly of red medium- to coarse-grained massive to crossbedded siliceous sandstone and quartzite. It also contains considerable shale and conglomerate.
The conglomerate is derived from the underlying Red Creek; its pebbles, cobbles, and boulders contain most of the lithologic types of the Red Creek-abundant white, gray, tan, and green quartzite, rare amphibolite, and schist. The red color of the Uinta Mountain Group is attributed to lateritic alteration of iron-rich rocks (amphibolites) in the source area.

A section of the Uinta Mountain Group near the west end of Cold Spring Mountain is about 20,600 feet thick, but the base of this section is unexposed and the top is a faulted contact. Probable correlations with another partial section across a fault nearby indicate that the total thickness of the Uinta Mountain Group in the area is about 24.000 feet.

Paleozoic rocks of the Flaming Gorge area are separated from Precambrian rocks by the large east-trending Uinta fault However, a few miles west and east of the area the Madison Limestone rests on the Uinta Mountain Group in depositional contact. Throughout most of early and middle Paleozolc timeLate Cambrian excepted-the eastern Uinta Mountains area probably was exposed to erosion. Upper Cambrian rocks are present locally; elsewhere they have been removed by preMississippian erosion. In late Paleozoic time the area was intermittently submerged in a shelf environment bordering the deep Cordilleran geosyncline on the west. Seven Paleozoic formations, all marine or largely marine, are recognized as follows: The lower limestone, middle limestone and sandstone, and upper shale units of Mississippian age; the Round Valley Limestone, Morgan Formation, and Weber Sandstone of Penn. sylvanian age; and the Park City Formation of Permian age. The Park City Formation contains a phosphatic-shale sequence that is identified as the Meade Peak Phosphatic Shale Tongue of the Phosphoria Formation.

During the Mesozoic Era the Flaming Gorge area lay on the unstable shelf of the craton, bordering the Cordilleran geosyncline to the west. The area thus was intermittently submerged and exposed to erosion. Fifteen Mesozoic formations, as follows, are recognized in the Flaming Gorge area: Dinwoody, Moenkopi, and Chinle Formations of Triassic age; Navajo Sandstone of Triassic(?) and Jurassic age; Carmel Formation, Entrada Sandstone, and Curtis Formation of Jurassic age; Morrison Formation, of Jurassic age, which was mapped with Lower Cretaceous rocks; Dakota Sandstone and Mowry Shale of Early Cretaceous age; and Frontier Formation, Hilliard Shale, Blair and Rock Springs Formations and Ericson Sandstone of Late Cretaceous age. Mesozóic sedimentation was characterized by a wide variety of deposits and depositional environments, both marine and nommarine. Sedimentation was terminated by the mountain-making movements of the Laramide orogeny. which began in the area sometime after deposition of the Ericson Sandstone but before deposition of the Fort Union Formation.

Near the beginning of the Cenozoic Era, sedimentation in the Flaming Gorge area took on a new complexion. The Uinta 
Mountains had begun to rise in response to the first local disturbances of the Laramide orogeny, and sediments shed from the newly formed highlands became a chief constituent of the early Tertiary stratigraphic sequence. As the Uinta Mountains were denuded, progressively older formations were exposed to erosion and in turn contributed debris to the deposits accumulating in the newly formed basins at the flanks of the range.

Cenozoic rocks of the area comprise the following formations : Fort Union (Paleocene), Wasatch and Green River (Eocene), Browns Park (Miocene?), and various Quaternary units including several types of alluvium, landslides, dunes, and talus accumulations. The Fort Union and Wasateh formations are predominantly fluviatile; the Green River Formation is lacustrine. The Browns Park Formation contains a complex sequence of interbedded vitric rhyolitic tuffs and tuffaceous sandstones derived from a distant volcanic source, nontuffaceous fluviatile sandstones and conglomerates derived from the adjacent highlands, and various lacustrine clays, clayey shales, and siltstones. Quaternary deposits are mostly unconsolidated surfieial materials; certain bench gravels of Pleistocene age, however, are cemented locally to form hard well-indurated conglonerate

The dominant structural feature of the Flaming Gorge area is the north-limb homocline of the Uinta anticline. The Cinta anticline has an axial length of about 160 miles and a mean width of about 30 miles. It is compound in that it contains two major closures on subequal elongate domes alined on a single east-west axis. The Flaming Gorge area is mostly on the easternmost dome and is mainly north of the fold axis, altihough the fold axis crosses the eastern part of the area beneath the sediments of Browns Park.

Modifications to the north-limb homocline are caused by subsidary folds, by faults, and by the complicated internal structure of the older Precambrian Red Creek Quartzite. The Red Creek crops out in seven different areas, each separated from the others by intervening outcrops of the Cinta Mountain group. Each area of the Red Creek is bounded partly or wholly by faults. Some of these are normal faults of "Tertiary age, but some are thrust faults that moved prior to the Laramide arching of the Uinta anticline. These faults carried the Red Creek up and over the Uinta Mountain group; Laramide arching tilted the faults to steeper attitudes than they had initially.

The Red Creek Quartzite was foliated by regional dynamic metamorphism during an early deformational episode. At that time, the original sandstones and shales of the formation were converted to quartzite and schist. Mafic magma then was injected into the formation; renewed deformation and metamorphism next converted the mafic rock to amphibolite and further deformed the quartzite and mica schist.

Countless minor folds in the Red Creek Quartzite range in size from structures a few score feet across the limbs to minute wrinkles a fraction of a centimeter across. These folds in aggregate constitute a strong $b$-axis lineation which has marked consistency over wide areas. Its predominant trend and plunge is northeastward. Lineation measurements show the presence of two distinct linear maxima separated in trend direction by several degrees of azimuth. These maxima represent the folding that occurred during the two aforementioned deformational episodes.

A single large anticline about 2 miles across the limbs is mapped in the Red Creek Quartzite. This fold, called the Garnet Canyon anticline, is well exposed in the canyon of Red Creek just east of Goslin Mountain. It is partly flanked by younger rocks not involved in the folding and partly overlapped by younger rocks. Two synclines of comparable magnitude are also recognized in the Red Creek-one contiguous to the Garnet Canyon anticline on Goslin Mountain and one farther west on Dutch John Mountain. Elsewhere the Red Creek is mostly homoclinal, although it is modified by small-scale folds and by faults.

Younger structural features have been imposed on any or all formations, including the Red Creek, but they date from times later than the relatively complex structure imposed only on the Red Creek. Younger structural features include unconformities at several stratigraphic horizons, folds of two orders of magnitude, faults, and joints.

Major anconformities occur at five horizons in the stratigraphic section as follows: (1) At the base of the Uinta Mountain Group, (2) between the Uinta Mountain Group and the overlying Paleozoic sequence, (3) at the base of the Paleocene Series, (4) at the base of the Browns Park Formation (Miocene?) and (5) at the base of the Quaternary System. Less significant unconformities occur at possibly a dozen other places in the stratigraphic section.

On the north-flank homocline of the large Uinta anticline, dips are steepest in a rather narrow zone along both sides of the Uinta farlt. In this narrow zone, rarely more than a mile wide, overturning is common. Overturning occurs also along the Henrys Fork fault and other thrust faults, but at a much reduced scale compared to that along the Uinta fault.

Strike deflections along the trend of the north-flank homocline are cansed by subsidiary folds. In terms of orientation relative to the Uinta aniticline, subsidiary folds are of two types-(A) those parallel in trexd to the Uinta anticine and (B) those mormal in trend. From west to east, the following subsidiary anticlinal folds are recognized: The linwood nose (type B), the Red Canyon anticline (type A), the Spring Creek nose (type B), the Dutch John nose (type B), and the Clay Basin anticline (type A). A few small unnamed folds in the Uinta Mountain Group north of Browns Park are drag features related to movements on faults.

Faults are abundant in some parts of the area but rare in others. They are much more abundant in the Precambrian rocks than elsewhere, possibly because the mountainward block in which the Precambrian is exposed was the actively moving element in the Laramide folding whereas the basinward block was passive or stationary.

Most faults of the area conform to three general habits dependent on time and cause of failure; (1) modified thrust or reverse faults, which moved prior to the Laramide arching of the Uinta anticline; (2) high-angle thrust or reverse faults of Laramide age, including the Uinta and Henrys Fork faults; and (3) normal or gravity faults, mostly of Tertiary age.

Extensive middle to late Tertiary warping and tilting along the northeast flank of the Uinta Mountains is closely related to the normal faulting and probably was concomitant in its development. Tilting has several components in several different localities: along and south of the crestline of the range, tilting was mainly northward and eastward; north of Red Canyon in the Goslin Mountain area and also in the Mountain HomeHead of Cottonwood area, tilting was southward with east-west components; on O-Wi-Yu-Kuts Mountain, tilting was chiefly westward. The establishment of eastward drainage through the Red Canyon area probably was facilitated by Tertiary faulting and warping; initial drainage off the range must have been northward down the Gilbert Peak erosion surface.

Beginning with deposition of the Red Creek Quartzite, the Flaming Gorge area has had a long and varied geologic history. Older Precambrian events are summarized in seven steps: (1) 
deposition of the Red Creek Quartzite, probably on a slowly subsiding shelf; (2) severe deformation, caused by stress directed from the north; (3) injection of mafic magma as dikes; sills, and irregular bodies; (4) renewed deformation accompanied by high-grade regional metamorphism; (5) pegmatization and albitization, both on a small scale; $(6)$ severe deformation, largely cataclastic and unaccompanied by metamorphism; and (7) uplift and degradation.

Following degradation of the Red Creek Quartzite, the Uinta Mountain Group was deposited mostly in shallow water in a rapidly subsiding east-trending trough. The chief source of sediments in the Flaming Gorge area probably was a nearby quartzitic mountain range which stood to the north in Wyoming. Deposition of the Uinta Mountain Group was terminated by broad regional uplift.

Early and middle Paleozoic time is unrepresented in the Flaming Gorge area. During most of this time the area probably was; above sea level and probably was being eroded. A Late Cambrian seaway may have covered the area, but if so, its' deposits: were removed by pre-Mississippian erosion. A generall d'ownwarping in Mississippian time caused shallow epeiric seas to spread widely over the western interior of the United: States, including the Flaming Gorge area. Intermittent subsidence and emergence followed through most of succeeding late Paleozoic time, and a shallow trough over the site of the present. Uinta. Mountains intermittently influenced deposition. On the west this trough merged with the Cordilleran geosyncline.

In the Flaming Gorge area the Mesozoic Era began without any marked tectonic activity. A shallowing of the seaway is in. dicated by an abrupt upward lithologic change across the Park City-Dinwoody boundary. The depositional environment fluctuated repeatedly during the Mesozoic era. Through most of Trinssic and Jurassic time the source of clastic sediments was to the east, with possible occasional northern or southern sources; a deep trough lay to the west. In Late Jurassic time the Cordilleran geosyncline was drained by orogenic movements. Newly formed mountains shed their sediments to the east over the site of the present Uinta Mountains and Flaming Gorge area. The terrestrial deposits of the Morrison Formation and Dakota Sandstone probably were largely derived from that source. Renewed subsidence followed deposition of the Dakota Sandstone and was accompanied by a readvance of the seaway across the area. The coastal shelf on which the Triassic, Jurassic, and Lower Cretaceous sediments had been deposited subsided into the broad foredeep of the Late Cretaceous seaway. This seaway extended north to south from the Arctic Ocean to the Gulf of Mexico and reached east from central Utah to the Great Plains. It was displaced from the area by encroaching continental sediments in Late Cretaceous time; as a structural trough, it was destroyed by uplift during the Laramide orogeny.

Laramide deformation began in the area sometime after deposition of the Ericson Sandstone but before the deposition of the Fort Union. Compressional uplift accompanied by high-angle thrust faulting continued intermittently until about middle Eocene time. Two periods of thrust movement are recorded on the Uinta fault-one before Fort Union time and one after Wasatch time. During Wasatch time the. Uinta anticline was eroded to its Precambrian core, and a flood of red quartzitic debris was deposited in the Wasatch Formation north of Clay Basin.

Most of the lower Tertiary rocks that accumulated in the urea following mountain building were derived from the newly formed Uinta Mountains. Downwarping in the adjacent Green River Basin produced a topographic as well as structural basin, and a large lake resulted. This lake lay mostly north of the Flaming Gorge area. Lacustrine conditions were terminated in: middle Eocene time, probably by encroaching fluviatile deposits accompanying a fliminishing rate of downwarp. Tectonic aetivity, meanwhile, continued; large-scale normal faulting. displaced the rocks: on the ffanks of the range, possibly as a tensionall release of earlier compressional stress. Many faults were active in the Red Canyon, Duteh John, Little Hole, and Browns: Park areas: Farly or middle Tertiary faulting was followed hy a relatively long interval of crustal stability, at which time the Gilbert Peak erosion surface was cut. Cutting of this surface was halted by renewed normal faulting and by warping. Some faults: that had moved earlier were reactivated. The net effiect was to lower the crestal part of the eastern: Uinta: Mountainis: relative to their flanks and to inditiate eastward drainage through the Red Canyon-Browns Park area. Jewly excavated. valleys in those areas were then filled with the Browns. Park Formation.

Deposition of the Browns eark Formation seems to have been accompanied by continued but diminished crustal activity. Periodically, the drainage in the valley of Browns Park was ponded by either alluvial or tectonic barriers, so that l'acustrine deposits, accumulated. Alluvial fans reached into the basin firom the adjacent highlands. Vitric rhyolitic volcanic: ash repeatedly blanketed the whole area. Probably only the highest peaks and ridges of the eastern Linta Mountains were not buried beneath the Browns Park Formation.

If the early Tertiary drainage of the Flaming Gorge area was eastward to the Gulf of Mexico, as suggested by W. H. Bradley, of the U.S. Geological Survey, a major step in the evolution of modern drainage was its shift southward to the Gulf of California - that is, to the Colorado River system. In the event that early drainage was eastward, degradation (and cessation of the Browns Park depositional cycle) could have been initiater by a vigorous tributary of the Colorado River eroding headward across the Uinta Basin and capturing the eastward drainage of the Uinta Mountains. Rejuvenation of the entire system would have ensued. Such capture would have been facilitated by broad upwarping of the present Continental Divide athwart the course of the east-flowing stream. Major canyon cutting in the area probably began shortly or immediately after Browns Park deposition ended.

The Quaternary Period has been a time of repeatedly interrupted erosion cycles in the Flaming Gorge area. Each incomplete cycle began with degradation, was followed by lateral planation, and ended with aggradation. Each erosion cycle probably reflects a physiographic response to cyclic climatic changes in the Pleistocene Epoch. The result is a succession of gravel-capped benches.

When downcutting was resumed at the end of the Browns Park depositional cycle, most streams probably followed consequent courses down initial depositional slopes or strusturally modifled initial slopes. Adjustment by streams to the structure of the underlying bedrock soon began, however, and many changes hive since modified the initial drainage pattern. Structural adjustments have modified drainage in the Sheep Creek-Lucerne Valley area, the Spring Creek-Antelope FlatJarvies Canyon area, the Clay Basin-Jesse Ewing Canyon area, and the Beaver Creek area of Browns Park. Minor drainage adjustments are still in progress or are imminent. The course of the Green River has been fixed since it was incised, but minor channel displacements have been caused by debris fans at the mouths of tributaries. 
Mineral resources of the Flaming Gorge area are mostly untapped but have considerable potential value. To date (1961), only natural gas, sand and gravel, and crushed stone have been utilized commercially to any extent. Other mineral resources that have been prospected or noted but not developed include coal, copper, gold, manganese, uranium, phosphate, barite, clay and shale, volcanic ash, limestone, riprap, silica, and gypsum. Some of these materials have no foreseeable market value, owing to low grade or unproved reserves. Others have high potential value.

\section{INTRODUCTION}

Flaming Gorge and vicinity first came to the attention of geologists through the historic explorations of John Wesley Powell, Clarence King, and Ferdinand V. Hayden before the last quarter of the 19th century. Many now basic concepts resulted from the work of these men, and the Uinta Mountains became a classic area of American geology. Despite such early activity, however, much of the country around Flaming Gorge received little or no geologic attention from the time of Powell, King, and Hayden until the investigations outlined in this report; some localities in this area have been visited by many geologists, but few detailed reports have been published. Of late, considerable local activity has been stimulated by the petroleum industry, by the reclamation potential of the Green River, and, in the last decade, by an almost frenetic but fruitless search for uranium.

The present report summarizes the findings of four seasons of fieldwork and several shorter term visits to the area. Work was started in August 1951 between Flaming Gorge and the town of Manila, the unincorporated county seat of Daggett County, Utah (pl. 2). Work was extended eastward and southward into Moffat County, Colo., in the summers that followed. This investigation was a part of a program of the U.S. Geological Survey to study areas containing the sites of major construction projects contemplated by the Department of the Interior in the Upper Colorado River Basin. The immediate objective of these studies was to provide geologic background data to aid the construction agencies in finding raw materials, interpreting ground conditions at the construction sites, and uncovering potential or actual problems related to the construction but outside the immediate construction area.

Detailed mapping of lands to be inundated by reservoir waters is a corollary to this objective and is all the more important because such lands once inundated are forever withdraiwn from future investigation.

A secondary but equally important objective of the program is partial fulfillment of the Geological Survey's obligation to complete the geologic atlas of the United States. This objective calls for resolving the geologic structure of the area, describing the stratigraphy of the rocks, and reconstructing the geologic history. Without so doing, of course, the immediate objectives of the program could not be attained.

One of the key units of the Upper Colorado River Basin plan is the Flaming Gorge project. Under construction at the time of this writing, Flaming Gorge Dam will back water from Red Canyon below Flaming Gorge nearly to Green River, Wyo., a distance of about 91 miles.

Throughout much of its length, Flaming Gorge Reservoir will be narrow and fjordlike in a setting of steep slopes and cliffs. Its shoreline will be well timbered in parts of Red Canyon but bare, even of soil, over wide areas elsewhere. An embayment will extend about 3 miles up Sheep Creek canyon at high water, making a triangular island of the area between Red Bench and Kingfisher Canyon; a similar island wili be formed of the high rocky mass inside the loop of Horseshoe Canyon. Just upstream from Flaming Gorge the reservoir will flare out into a wide basin where water will back up into Henrys Fork to about 5 miles beyond Linwood and form minor embayments in the draws that join the river on the east (pl. 2).

Much of the country around Flaming Gorge has changed little since the visits of Powell, King, and Hayden; construction activity centered at the damsite, however, is bringing dramatic changes. A completely new town, Dutch John, Utah, has risen from the sagebrush of Dutch John Flat; but the area still is sparsely settled, and much of it still is remote. Despite a fair network of dirt roads and jeep trails, many places still are inaccessible except on foot or horseback.

As recently as 1953 Daggett County was reached only via unpaved, unsurfaced roads, and in winter months it was isolated from the rest of Utah by the heavy snows of the Uinta Mountains; some parts still are isolated by snows in the winter. But during the first half of the 1950's a hard-surfaced all-weather road was constructed south from Green River, Wyo., to Linwood. In 1960 a modern black-topped highway, which incidentally is very scenic, was completed between Linwood and Vernal, Litah. In 1956 the REA brought electricity to Manila, and in 1958 the area received telephones. Modernization was complete.

\section{IOCATION AND ACCESS}

Figure 1 shows the geographic setting of the area in relation to the surrounding country. The area lies on the northeast slope of the Uinta Mountains, chiefly in Daggett County, Utah, but partly in Moffat County, Colo., and Sweetwater County, Wyo. It covers about 366 square miles and includes all of the Manila, Flaming Gorge, Dutch John Mountain, Goslin Mountain, 

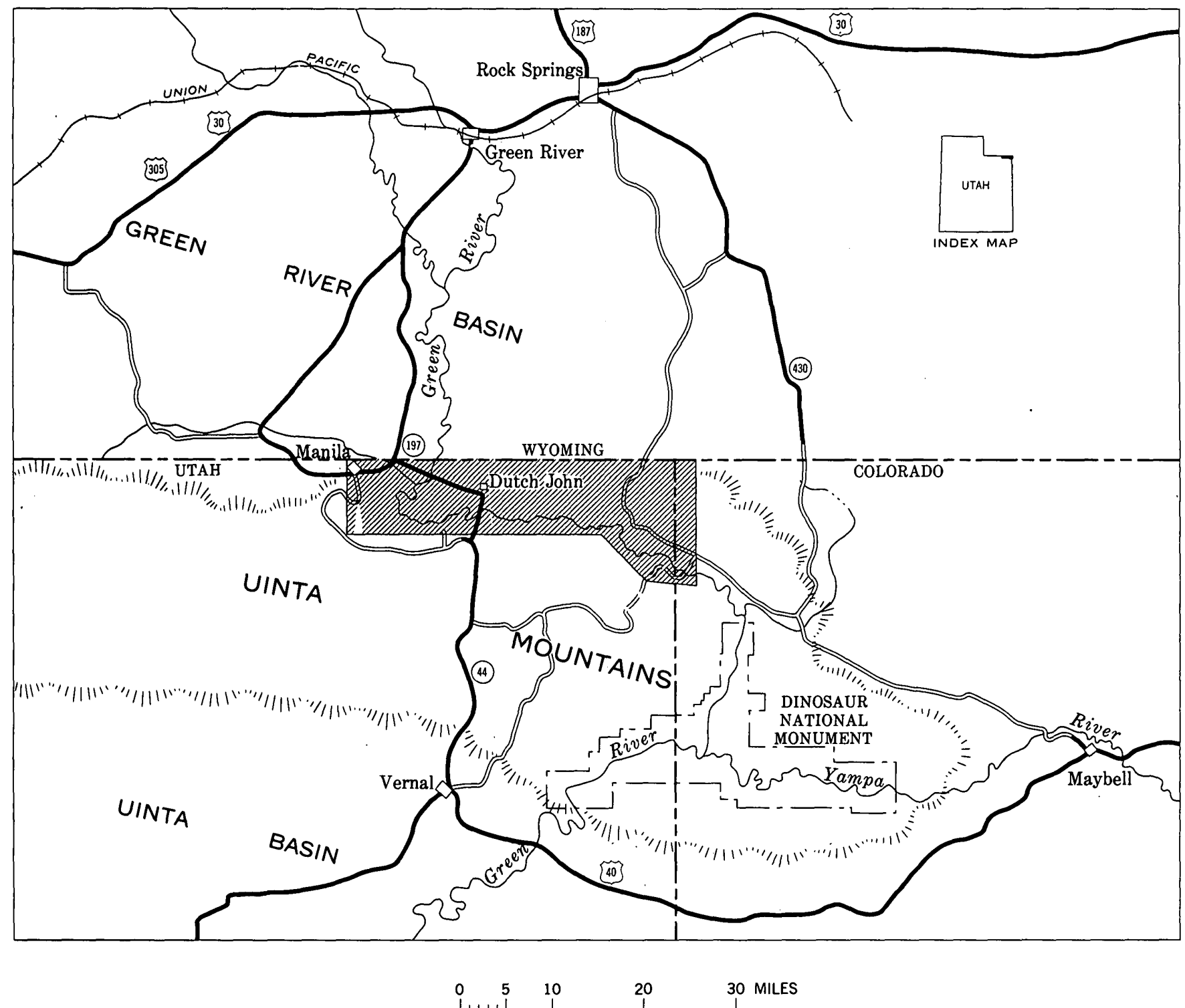

Fraure 1.-Vicinity map showing access roads. Heavy lines are paved roads.

Clay Basin, and Willow Creek Butte quadrangles as well as the northern parts of the Warren Draw and Swallow Canyon quadrangles. (See pl. 2.) The eastern part of the Willow Creek Butte and Swallow Canyon quadrangles, a strip about $21 / 2$ miles wide, is in Moffat County. $\Lambda$ very narrow strip averaging only about 600 feet in width along the north margin of the Manila, Flaming Gorge, and Dutch John Mountain quadrangles is in Sweetwater County, Wyo.

Few roads lead into or pass through this country, and many places are somewhat inaccessible. The Union Pacific, the nearest railroad, passes through Green River and Rock Springs, Wyo., both about 50 miles to the north. Rock Springs is also served by Frontier Airlines.
Widely separated automobile roads lead into the area from the north, east, and south (fig. 1). Recently paved all-weather roads connect Manila and Linwood with Green River and Vernal; other roads into the area are unpaved. A road leading south from Rock Springs enters the area at Clay Basin, continues south into Browns Park, and extends east beyond the area to a junction with Colorado Highway 318, which leads to Maybell, Colo. Although this road is unpaved, it is drained and graded most of the way and is passable most of the time. At this writing, another road is being built south from Rock Springs toward Dutch John.

Two roads, both rough but serviceable, provide additional entry into Browns Park except in winter and early spring. One of these enters Browns Park near 
the mouth of Crouse Creek and, by way of rugged Crouse Canyon leads to Vernal, Utah; this road has been greatly improved in the past few years. The other road enters the area near the northwest corner of the Willow Creek Butte quadrangle and connects with roads leading to Colorado Highway 318 and Wyoming Highway 430.

From the south, Utah Highway 44 connects Vernal with Manila a distance of about 75 miles, and by way of side roads affords access to such places as Green Lakes, Greendale, and Little Hole. Improvement of this scenic route is in progress, and although the highway is rough in some places and is closed by snow from December to May, it probably will be maintained eventually on a year-round basis. As its time of opening and closing varies from year to year, local inquiry should be made before crossing is attempted in spring or.late fall. A more direct route from Manila to Vernal is provided by the new road through Dutch John and the Flaming Gorge damsite.

Because of the Green River and its canyons, the area is effectively divided into several disjointed parts. Until late 1954 when an automobile bridge was built a few miles downstream from Swallow Canyon, the Green River could not be crossed by automobile between Green River, Wyo., and Jensen, Utah. Since then, the river has been bridged near the mouth of Henrys Fork and in Red Canyon.

In addition to light-duty and unimproved roads shown on the maps, many truck or wagon trails not shown afford good access for field vehicles to remote sections of the area. 'Travel by passenger car on most such trails, is unadvisable. Conveniently, and at a great saving in time, cars equipped with heavy-duty transmissions can be driven far off the roads in many of the more open parts of the area, especially in such places as Lucerne Valley, Antelope Flat, Clay Basin, Browns Park, and on the tops of some of the mountains. The chief obstacles to cross-country travel in such places are steep-sided washes and occasional sharp projections of bedrock. Travelers who plan to depart from welltraveled routes should carry extra gasoline and would do well to equip their cars with heavy-duty tires.

\section{GEOGRAPHIC SETTING}

The Middle Rocky Mountains, of which the Uinta range is a part, extend from southern Montana through eastern Idaho and western Wyoming into central Utah. The Uinta Mountains trend eastward 150 miles or so from a junction with the Wasatch range in north-central Utah. They stand between the Uinta Basin on the south and the Green River Basin on the north. The Flaming Gorge area, as here mapped, lies mainly on the northeast slope of the Uinta Mountains, entirely north of the crestline of the range and partly in a belt of foothills and outliers that grade transitionally into the arid tablelands of the Green River Basin.

Owing partly to a varied geologic and geomorphic history and partly to a wide range of physical characteristics in the several rock formations, the area has a diversity of geographic features and landforms exceeded by few other areas of its size. The canyons of the Green River divide the area into isolated geographic units and effectively hamper travel from one unit to another. Some of the tributaries of the Green flow through canyons that rival those of the river itself and as barriers to travel are hardly less formidable.

Physiographic features show a marked response in form to the character and structure of the underlying bedrock, and distinctive landforms typify each major stratigraphic unit. The various strata dip generally northward off the Uinta anticline and are eroded into a succession of ridges and valleys. 'This arrangement of ridges and valleys is most noticeable in terranes of post-Precambrian rocks-for example, the striking double hogback of The Glades, the sharp-crested ridges of Boars Tusk and Dutch John Mountain, and the alternate ridges and valleys south of the town of Manila. In the more homogeneous Uinta Mountain Group (Precambrian), structurally controlled ridges and valleys are less evident but locally are very marked.

\section{HILLS AND MOUNTAINS}

Plate 2 shows the general distribution and form of the major topographic features of the area. Although the area lies chiefly in the foothills of the Uinta Mountains and structurally is very much a part of the Uinta Mountains, most of it is separated from the main range by the valley of the Green River. Except for this valley, the largest single relief feature of the area is a nearly continuous but very diversified highland of hills and mountains lying mainly north of the east-flowing segment of the Green River but extending the entire length of the area from west to east. The crestline of this highland is a composite drainage divide that is breached in two places-at Flaming Gorge by the Green River and east of Goslin Mountain by Red Creek. Drainage north of this divide and west of Goslin Mountain flows into the Green River north of Flaming Gorge; drainage north of the divide but east of Goslin Mountain flows first into Red Creek via second-order tributaries before reaching the river. Drainage south of the divide flows into the river at various points between Flaming Gorge and Browns Park.

This divide was produced mainly by differential erosion of the soft Hilliard Shale, probably in late Tertiary time, along what are now some of the major valleys 
of the area-Iucerne Valley, Antelope Flat, and Clay Basin. Much of the former drainage seems to have flowed south at a high level across what is now the divide. Some of the noteworthy drainage adjustments that led to the formation of the divide and to the present drainage pattern are outlined in the section of this report on geologic history.

Most of the major hills and mountains of the area lie along the highland that forms the above-noted divide. This highland attains its greatest height and complexity in the eastern part of the area where it includes the broad O-Wi-Yu-Kuts Mountain-Cold Spring Mountain upland. Kleins Hill, at an altitude of 9,048 feet, is the highest point in the area. The lowest point in the area, at an altitude of about 5,360 feet, is 11 miles south of Kleins Hill at river level in Browns Park. West from Kleins Hill, steep but rounded Willow Creek Butte and Bender Mountain together separate the drainage of Willow Creek from that of Red Creek. Northwest of Bender Mountain, standing mostly in Wyoming, is isolated Teepee Mountain; all its drainage is into Red Creek. South of Clay Basin on the same divide as Willow Creek Butte and Bender Mountain are Head of Cottonwood and Mountain Home, which are steepsided but flat-topped ridges that stand between Clay Basin on the north and Browns Park on the south.

Between Mountain Home and Goslin Mountain, next west, a narrow valley about 1,500 feet deep has been carved by Red Creek. Early maps identify this valley as Garnet Canyon, a name still useful for reference but not longer commonly used. Garnet Canyon and Flaming Gorge of the Green River are the only major breaches in what is otherwise a continuous divide ex: tending the length of the area. West from broad flattopped Goslin Mountain, just west of Garnet Canyon, the highland narrows to a single steep-sided ridge comprising Dutch John Mountain (often referred to as Dutch John Ridge) and Boars Tusk, which terminates at Flaming Gorge. South of Boars Tusk and mostly back from the main divide is isolated mesalike Bear Mountain; southwest of Bear Mountain across Red Canyon is very similar Dowd Mountain. The steep flanks of these mountains form the head of Red Canyon.

West of Boars Tusk across Flaming Gorge the structural and topographic extension of Boars Tusk is a sharp-crested ridge of Navajo Sandstone. This ridge extends to the west boundary of the area and forms the divide between the drainage of Henrys Fork and that of Sheep Creek; it forms the high north wall of Sheep Creek Canyon and is largely responsible for the imposing appearance of that segment of the canyon. Despite its coṇsiderable relief, however, as viewed from the north it is completely dominated by the much higher mountains to the south.

South of the Green River canyons the country rises first gently, then steeply, toward the crest of the Uintas. The entire crestline and most of the highest summits are south or west of the area covered by this report, but because the area boundary is cartographic rather than topographic, these summits are integral parts of the landscape. Two prominent unnamed summits, one in sec. 30, T. 2 N., R. 23 E., and one in sec. 30, T. 2 N., R. 24 E., stand inside the area boundary on high spurs north of the crestline.

\section{DRAINAGE AND VALLEYS}

In flowing across the soft Tertiary rocks of the Green River Basin, the Green River meanders through a series of dry twisty canyons. Just before entering Utah it emerges onto a short but broad segment of flood plain which it shares with Henrys Fork, one of its chief tributaries. A short distance below the mouth of Henrys Fork it abruptly enters the foothills of the Uinta Mountains beneath the high cliffs of Flaming Gorge. (See frontispiece.)

Flaming Gorge was named nearly a hundred years ago by Major Powell: "The Green River enters the Uinta Mountains by a flaring, brilliant, vermilion gorge, a conspicuous and well-known locality, to which, several years ago, I gave the name Flaming Gorge" (Powell, 1876, p. 146). The sweep and grandeur of Flaming Gorge are due largely to imposing walls of Navajo Sandstone, which forms the rims and caprock; but the name alludes mainly to the riot of reds, oranges, and ochers in the soft Triassic rocks of the slopes below. Altogether, the name is well deserved (see frontispiece). Between Flaming Gorge and Browns Park, the Green River flows through a succession of deep canyons separated by sage-covered alluvial flats.

Between the Wyoming State line and Beehive Pointthrough Flaming Gorge, Horseshoe Canyon, and Kingfisher Canyon-the river flows placidly at a uniform low gradient of about 2 feet per mile. At Beehive Point the current increases suddenly as the river crosses its first rapid. The gradient steepens abruptly to average nearly 12 feet per mile through the following 30 miles or so of Red Canyon. Numerous white-water rapids in Red Canyon are due to rock debris that has fallen from the canyon walls and to obstructions of material washed into the river channel from the tributaries; the river flows across exposed bedrock ledges-at only one point in its course through the area-at a point about half a mile below the mouth of Pipe Creek in Red Canyon. EIsewhere it flows on a fill of bed gravels and sand. Below Red Canyon in Browns Park the river 
maintains a rather steep gradient of about 8 feet per mile as far as Swallow Canyon. At Swallow Canyon the current slackens as the gradient flattens to about 1.7 feet per mile.

Each canyon of the Green is distinctive in itself. Flaming Gorge owes its depth and sweep to its high rimrock of Navajo Sandstone, but its coloration, from which it was named by Powell, is due to the bright-red beds of the underlying Triassic formations (frontispiece). Horseshoe and Kingfisher Canyons, following in order balow Flaming Gorge, resemble one another in that both are carved from massive Weber Sandstone capped by resistant beds of the Park City Formation; but Horseshoe Canyon is narrower and deeper than Kingfisher Canyon, and its walls are generally smoother. Below Kingfisher Canyon is Red Canyon, which heads at Hideout Flat and is the largest and deepest of all. Red Canyon is carved entirely from the darkred beds of the Uinta Mountain Group. Impressive overlooks into this canyon are maintained near Green Lakes by the U.S. Forest Service. At Little Hole, Red Canyon flares out to form a small parklike area that is a pleasant contrast to the rugged canyons upstream and down. Modest gardens and hay crops are produced in Little Hole on benchlands irrigated with the water of Little Davenport Creek.

Below Red Canyon the river emerges into Browns Park and for several miles swings across the soft beds of the Browns Park Formation. At Swallow Canyon, in a classic example of drainage superposition, it resumes a course through the hard rocks of the Uinta Mountain Group. It flows about $21 / 2$ miles through this vertical-walled canyon before returning again to a course across the Browns Park Formation.

Most of the major tributaries of the Green in the Flaming Gorge area join the river on the right. (west or south) bank, chiefly because they head in the higher, better watered mountains to the south and mostly have larger catchment basins than those that drain areas north or east of the river.

Henrys Fork, renowned since the early days of the Rocky Mountain fur trade, is the largest tributary of the Green in the area, having a 30-year average discharge at Linwood (through 1958) of 76.6 cubic feet per second. Henrys Fork rises 40 miles west of the area at the foot of Gilbert Peak in the highest part of the Uinta range and after flowing north into Wyoming, loops eastward and southward back into Utah to join the Green at Flaming Gorge. Henrys Fork meanders across Iucerne Valley in a broad shallow trench that contains some of the most productive ranch land in the area. Considerable water is withdrawn from Henrys
Fork along its length to irrigate the fields and meadows along its banks.

Most of Lucerne Valley, in the northwest part of the area, is drained by Birch Spring Draw, a minor tributary of Henrys Fork. Birch Spring Draw has little perennial runoff, and much of that which it has is surplus irrigation water derived from Sheep Creek.

Sheep Creek is the third largest tributary in the area, having an average discharge at its mouth of 23.9 cubic feet per second over a 12-year period ending in 1958. It is exceeded in size only by Henrys Fork and Carter Creek. It is the chief source of irrigation water for the ranches of Lucerne Valley and South Valley, and much of its runoff, especially at the peak of the irrigation season, is diverted out of its basin. Most of the flow remaining in Sheep Creek at such times issues from springs below the diversion points. Sheep Creek flows across. the area in a picturesque valley (fig. 2) carved through most of its length in soft Triassic rocks that lie below high cliffs of Navajo Sandstone on the north side of the valley and long limestone dip slopes of the Park City Formation on the south. A mile and a half above its mouth, Sheep Creek swings to the right across the Park City Formation and flows to its mouth through a narrow canyon cut in Weber Sandstone.

Downstream from Sheep Creek, the first large tributary to enter the river is Carter Creek, which, toward its mouth, flows through a canyon that rivals the canyons of the Green in steepness. depth, and width. Carter Creek is a dashing splashy stream and had an average discharge of 68.8 cubic feet per second for the period 1946-51. At the time geologic mapping was in progress, work was under way to divert drainage from the headwaters of Carter Creek to the Sheep Creek basin to augment the Lucerne Valley irrigation system. This project has since been completed.

Numerous small perennial streams, several of which have names, join the Green River from the south in Red Canyon between Carter Creek and Browns Park. Most of these streams flow in canyons that deepen rapidly toward the river. Some have deep gorges that can be crossed only on foot. Most of them are choked with cottonwood, alder, water birch, rose, willow, aspen, boxelder, and other small trees and shrubs, so that travel upstream or down is arduous; many are blocked here and there by beaver ponds. The flow of none of these streams has been gaged, and their discharge rates are unknown. Cart Creek, which joins the Green about: half a mile above Flaming Gorge damsite, is the largest. stream below Carter Creek and also has the most impressive canyon. By way of comparison, its flow appears to be about $1 / 2$ or $3 / 4$ that of Sheep Creek. 


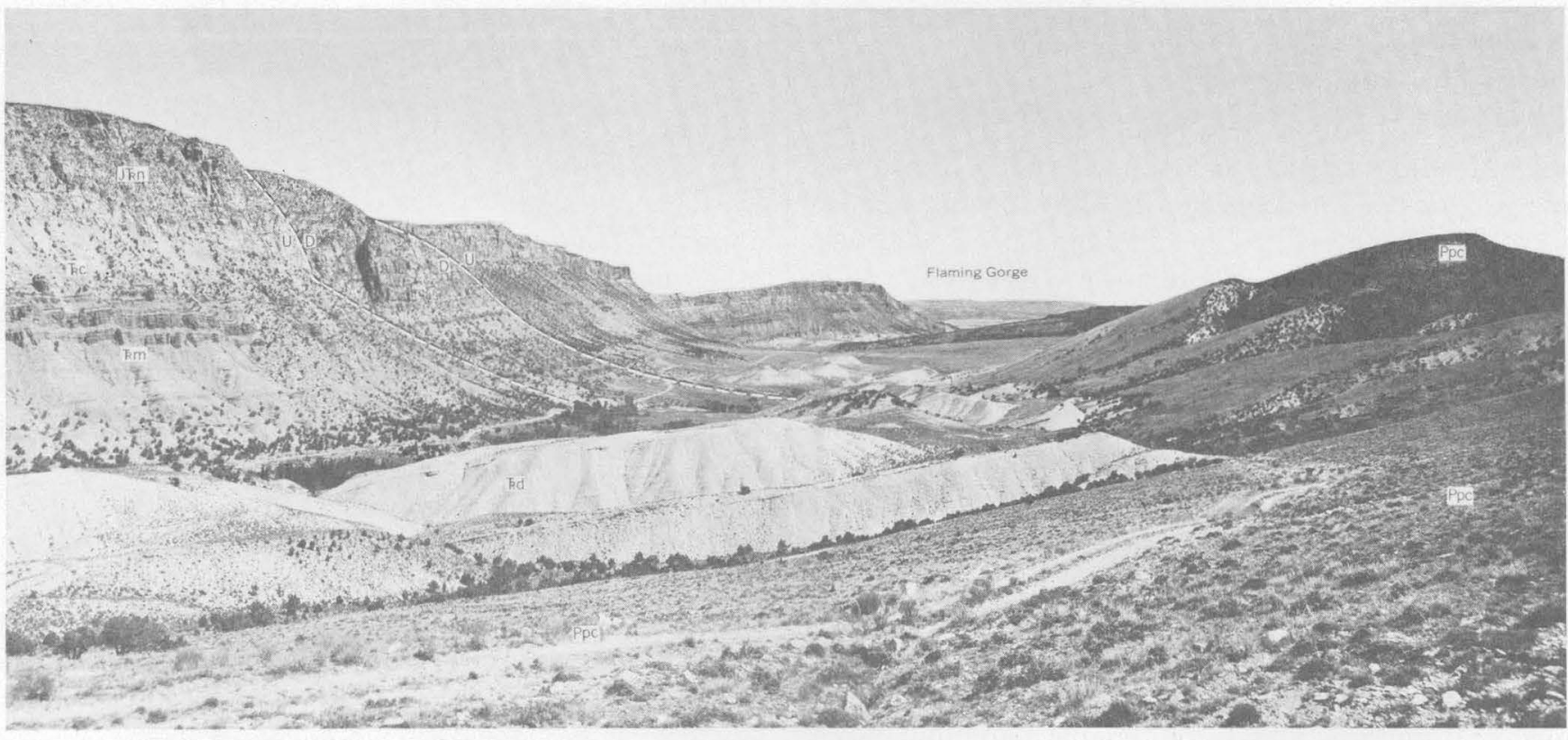

FIGURE 2.-View northeast down canyon of Sheep Creek toward Flaming Gorge. Faulted rim in left background consists of Navajo Sandstone ( $\mathrm{k}$ n) undrelain by Chine $(\bar{k} \mathrm{C})$ and Moenkopi Formations $(\mathrm{Km})$. Low gray ridges in foreground are eroded from Dinwoody Formations ( $\mathrm{k} d$ ). Dip slope in foreground and flatirons in right background formed on Franson Member of Park City Formation (Ppc).

The rest of the streams-Pipe Creek, Gorge Creek, Little Davenport Creek, and Jackson Creek-are considerably smaller than Cart Creek and, during low stages, flow at most about a few cubic feet per second. A few small perennial streams join the river from the south in Browns Park also. These streams leave the mountains in deep canyons before emerging onto the flats of Browns Park. At one time they supported large ranches near their mouths. In the heyday of Browns Park, about the turn of the century, a wagon road connected the park with Vernal via Sears Creek and Sears Canyon; this road is now passable only on foot or horseback. A few miles down the river the deep canyon of Crouse Creek provides access to Browns Park by way of a rough truck road that leads south to Vernal; passenger cars can travel this road only with difficulty, though it has been improved in recent years. Crouse Creek irrigates a ranch at its mouth; spring fed, it receives supplemental water during irrigation season from a storage reservoir on Pot Creek several miles south of the area.

On the left bank of the Green River, the first perennial tributary south of the Wyoming State line is Spring Creek. Throughout most of its length this stream flows through a vertical-sided wash entrenched into recent alluvium. Despite a large catchment basin, which includes most of Antelope Flat and Pigeon Basin, Spring Creek has a very small flow, owing to the aridity of its watershed. It provides a modest but reliable water supply for livestock and game animals that graze the adjoining range.

Downstream from Spring Creek no perennial drainage enters the river on the left bank for 23 miles. At that point, in Red Canyon, North Skull Creek discharges a very small flow into the river. North Skull Creek is noteworthy for the large alluvial fan at its mouth; this fan has deflected the river to the right in a semicircular course (fig. 58).

Below North Skull Creek, a few small streams enter the river at widely separated points in Red Canyon. Largest of these are Dutch John, Goslin, and Red Creeks; a few still smaller creeks are unnamed. Like their counterparts south of the river, they pass through deep canyons toward their mouths. All are overgrown with trees and shrubs in their lower reaches except Red Creek, which carries considerable dissolved salts.

Red Creek has a large drainage basin that includes all of Clay Basin and an area north of Clay Basin in Wyoming covering more than 100 square miles. It has a very small mean flow, however, and during the hot part of the summer it sometimes is intermittent. Much of its flow is diverted in Wyoming for irrigation. Because of rapid surface runoff in its large catchment area, it is subject to flash floods during summer thundershowers; because of its high competence during flash floods, it transports much coarse debris and has built a large bar at its mouth in the channel of the Green 
River. This bar causes one of the fastest and roughest rapids in Red Canyon.

The chief tributary of Red Creek is Clay Basin Creek, a small stream fed mainly by springs in Clay Basin Meadows near its headwaters. All of its normal flow is diverted for irrigation in Clay Basin; it is intermittent, therefore, at its junction with Red Creek.

No perennial drainage enters the Green River from the north between Red Creek and Willow Creek, 16 miles farther downstream. The several rugged canyons and ravines that drain Mountain Home and Head of Cottonwood are dry most of the time. Some of them, such as Jesse Ewing Canyon and Cottonwood Draw, contain small springs that flow several tens or hundreds of feet before sinking into the gravels of their beds.

Willow Creek enters the river just below the mouth of Swallow Canyon. Beaver Creek enters the river $23 / 4$ miles farther downstream. Both of these streams head in the high uplands of O-Wi-Yu-Kuts and Cold Spring Mountains and have reliable perennial flows. Before entering Browns Park they pass through deep narrow canyons. Whereas the canyon of Willow Creek is fairly open for most of its length and is easily traversed on foot or horseback, the canyon of Beaver Creek is nearly impassable above its junction with Little Beaver Creek because of a tangled growth of trees and shrubs. Much water is withdrawn for irrigation from both streams between the canyon mouths and the river, so that flow at their mouths is greatly reduced.

\section{CLIMATE AND WEATHER}

Like most of the high piedmonts in the Rocky Mountains, the Flaming Gorge area has a dry genial climate; weather suitable for geologic fieldwork lasts from May or earlier until November. Summer days are warm but seldom hot; nights are cool. Winters are cold, at times extremely so, and subzero temperatures are frequent; although snowfall generally is light, occasional storms block most roads for short periods. Winter storms result chiefly from the passage of well-defined pressure systems. Summer storms in the form of afternoon thundershowers result from local air-mass disturbances.

Owing to a considerable range in altitude and to marked local relief, climate and weather are characterized by pronounced local variations both in temperature and in amount of precipitation. Strong cold winds on the mountain tops often accompany near calm in the valleys. Because temperature normally decreases with altitude, the thermometer may read $90^{\circ}$ on a warm summer day in Browns Park and only $65^{\circ}-70^{\circ} \mathrm{F}$ on Kleins Hill or O-Wi-Yu-Kuts Mountain. But in winter, blankets of chilled air frequently spread over the bottom lands, especially along the river. These blankets cause local temperature inversions, so that the air is several degrees colder in the bottom lands than in the nearby uplands.

In general, precipitation increases substantially with altitude. Some of the higher areas, particularly toward the west, reportedly receive as much as 35 inches annually; Lucerne Valley and Antelope Flat, on the other hand, probably average no more than a third that amount, and Clay Basin and Browns Park probably receive even less.

The Uinta Mountains influence local weather conditions by deflecting passing air masses, by forcing them aloft, or both. On summer afternoons towering cumulus clouds often build up over the mountains while the arid basins to the north are bathed in sunshine; fastmoving squalls that originate in the high mountains and cross the area in narrow east-trending tracks parallel to the mountains, quickly fill the gullies in their paths while nearby watercourses remain parched.

\section{VEGETATION SUMMARY}

Plant associations respond more noticeably to limiting factors of geology, topography, and local climate in the semiarid regions of the West than they do in more humid regions. The Flaming Gorge area is no exception; its altitude range of nearly 3,700 feet, its varied local climate, and its varied topography and geology all favor diverse plant associations, and differences are very striking in short distances. The moist bottom of a ravine may contain a rank growth of deciduous trees and shrubs; a north-facing slope above may support a dense stand of conifers; and a south-facing slope may have but a sparse cover of sage, grasses, and pricklypear. Further complications of geology and soils, such as alkalinity, may cause even more striking contrasts.

Floral zones as a function of altitude and climate range upward from the Upper Sonoran zone-which covers most of the area-through the Transition zone, and locally through the Canadian zone, into the lower part of the Hudsonian zone. Superimposed on the floral zones are various local geologic and topographic settings which in combination give rise to the numerous plant associations. In the nearby Uinta Basin, Graham (1937, p. 61) recognized 21 such associations, each characterized by a different group of plant varieties. Geologic factors that influence plant associations are mainly texture, permeability, water content, and chemistry of the various soils and rock formations. Markedly different plant associations grow on different soil or rock types within a single floral zone, or even on similar rock types under different topographic settings. Topographic factors other than altitude that modify plant associations are variables of slope exposure to sunlight and to prevailing wind directions; these 
factors cause variations in air temperature, soil moisture, and evaporation-transpiration rates on plant surfaces. Vegetation patterns thus vary in response to many different combinations of altitude, topography, and geology.

Topographic maps that have the green woodland overprint show that about half of the area is covered by timber. Of this area, the greater part supports a juniper-pinyon pigmy forest. In most places the pigmy forest is open and airy ; but locally it is very dense, and the crowns of the trees form a nearly continuous bower overhead. The pigmy forest thrives best where drainage is good, as on sandstone terranes; it generally terminates abruptly against shaly terranes or against silty alluvium. In many such places the edge of the woods coincides closely with the mapped boundary between alluvium and bedrock. On shaly, poorly drained soils the pigmy forest is supplanted by an alkali-tolerant desert shrub association. Pinyon and juniper thus do poorly on areas underlain by the Hilliard and Mowry Shales, for example, but flourish on the sandstone outcrops of the intervening Frontier Formation; they even thrive on sandstone talus slopes mantling the Hilliard Shale. Pinyon and juniper are lacking on the outcrop of the Morrison Formation, but they grow well on the dip slopes of the adjacent Dakota Sandstone and Curtis Formation. In areas underlain by the Uinta Mountain Group, long treeless strips of ground commonly coincide with shaly zones or alluvium.

Along the perennial tributaries of the Green River, at the lower altitudes of the Upper Sonoran zone, the pigmy forest is supplanted by thickets of deciduous trees and shrubs dominated by the western cottonwood and the boxelder. Blue spruce joins this association along Sheep Creek and along Galloway Creek.

In untimbered areas at all altitudes, sagebrush is the most conspicuous plant. It is associated with a profusion of other small woody and herbaceous plants, including grasses. Sagebrush, however, favors well-drained soils; and in areas of high water table or poor drainage, other plant associations, including greasewood, shadscale, and salt-grass associations, are dominant.

At altitudes ranging mostly from 6,500 to 7,000 feet, but in favorable locations at lower altitudes, the pigmy forest gives way to plants of the Transition zone. This zone is characterized by open stands of yellow pine and patchy, locally dense groves of aspen. Trees of the Transition zone form the forested top of Dowd Mountain, where some lumbering is done, and the high tablelands to the east at Green Lakes and Greendale. Isolated groves of yellow pine are found also on Bear Mountain, Dutch John Bench, and Goslin Mountain, and on the slopes above Little Hole. Yellow pine favors well-drained sandstone terranes; the aspens of the same zone often thrive on shaly terranes. Mountain mahogany forms dense thickets on exposed ridges in the Transition zone and occasionally attains the stature of a small tree. On Dutch John Mountain some heavytrunked specimens stand 15 feet tall. Large specimens are present also at higher altitudes on $\mathrm{O}-\mathrm{Wi}-\mathrm{Yu}-\mathrm{Kuts}$ Mountain. Douglas-fir is common in this zone and in the next higher zone as well; in favorable locations it also grows at lower altitudes in the Upper Sonoran zone.

Above an altitude of 7,000 feet or so, the Transition zone grades irregularly upward into a mixed forest dominated by groves of aspen and thick occasionally pure stands of lodgepole pine. This association characterizes the Canadian zone; it occurs chiefly on $\mathrm{O}-\mathrm{Wi}$ Yu-Kuts Mountain, Kleins Hill, Buck Knoll and vicinity, and some of the higher spurs of the mountains south of Red Canyon. On the upper mountain slopes south of Red Canyon, it forms almost impenetrable forests.

The Canadian zone contains scattered specimens of alpine fir and Engelmann spruce. These trees are more characteristic of the next higher Hudsonian zone and are rare in the area. In the more exposed places, often with their roots in firm bedrock, are scattered specimens of limber pine. This tree is common on $\mathrm{O}-\mathrm{Wi}-\mathrm{Yu}$ Kuts Mountain and Buck Knoll and is seen rarely at much lower altitudes. Occasional Rocky Mountain juniper grow on shaded hillsides in this zone, and the bush variety, Juniperus sibirica, flourishes in the shelter of the aspen groves. As in the zones below, the conifers favor well-drained stony soils, whereas aspen favors or at least tolerates shaly soils. The pattern of vegetation is sometimes striking where such soil types form alternate bands; even faults in heavily timbered areas can be recognized readily on aerial photographs by means of differences in the vegetation.

The following chart (fig. 3) shows the general altitude ranges of some of the more common woody plants of the area. Most of these plants are easily identified at any season of the year. Associated with them, but not listed, is a profusion of annual and peremnial herbs.

\section{PREVIOUS WORK}

A list of early visitors to the eastern Uinta Mountains would include the names of many notable American geologists. Geologic exploration was materially assisted, and perhaps stimulated, by completion of the Union Pacific Railroad across southem Wyoming in 1868. With railheads nearby at Green River and Rock Springs, outfitting of expeditions into the mountains was greatly simplified.

Geologic investigations were started almost simultaneously by three famous territorial surveys led, 


\begin{tabular}{|c|c|c|c|c|c|c|c|c|}
\hline \multirow[b]{2}{*}{ PLANT } & \multicolumn{8}{|c|}{ FEET } \\
\hline & 总 & 8 & 8 & 8 & 总 & ষి & 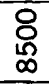 & 8 \\
\hline
\end{tabular}

Greasewood (Sarcobatus sp.)

Shadscale (Atriplex sp.)

Rabbit brush (Chrysothamnus sp.)

Shrub maple (Acer grandidentatum)

Pricklypear (Opuntia sp.)

Mormon tea (Ephedra sp.)

Boxelder (Acer negundo)

Wild rose (Rosa sp.)

Squaw bush (Rhus trilobata)

Cottonwood (Populus sargentii)

Mountain alder (Alnus tenuifolia) Willow (Salix spp.)

Sagebrush (Artemesia tridentata)

Water birch (Betula fontinalis)

Chokecherry (Prunus melanocarpa)

Dogwood (Cornus instolonea)

Service berry (Amelanchier sp.)

Blue spruce (Picea pungens)

Antelope-brush (Purshia tridentata)

Red cedar (Juniperus scopulorum)

Common juniper (Juniperus sibirica)

Utah juniper (J. utahensis)

Pinyon pine (Pinus edulis)

Yellow pine (Pinus ponderosa)

Mountain mahogany (Cercocorpus sp.)

Douglass-fir (Pseudotsuga mucronata)

Aspen (Populus tremuloides)

Limber pine (Pinus flexilis)

Lodgepole pine (Pinus murrayana)

Coral berry (Symphoricarpos sp.)

Cinquefoil (Potentilla quinquifolia)

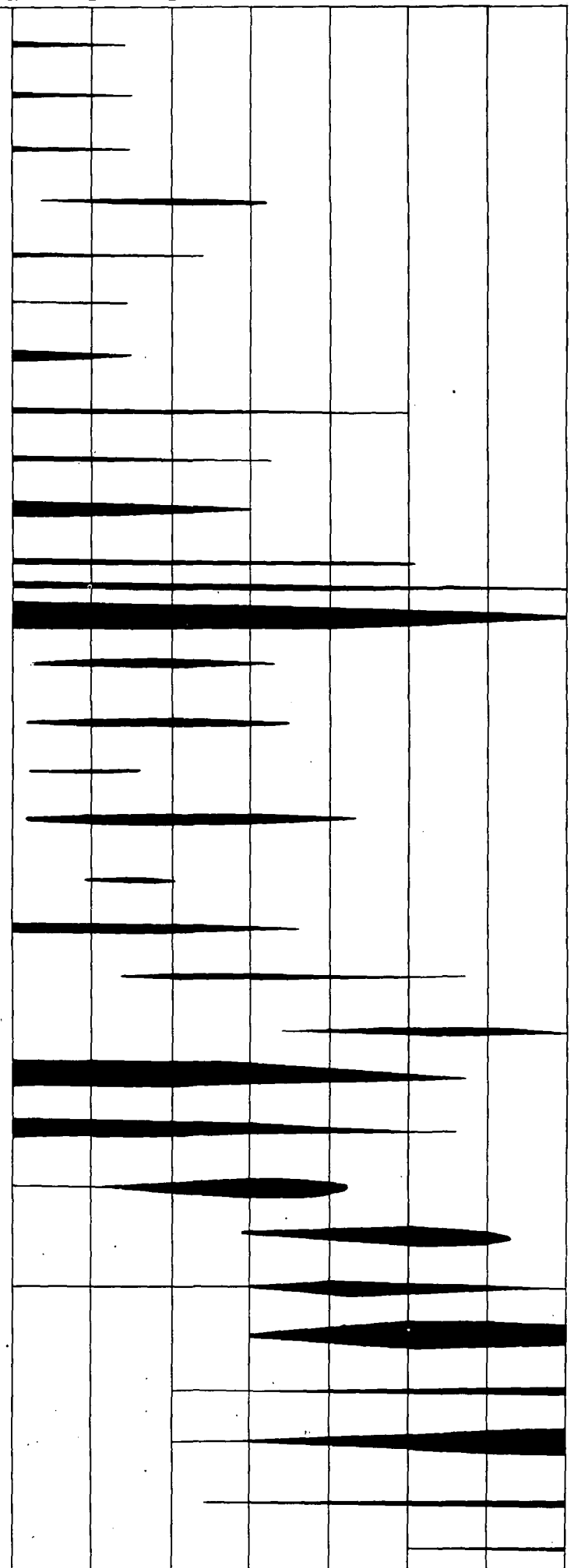

Figure 3.-Distribution, by altitude, of common woody plants. Relative abundance indicated by width of bar. 
respectively, by John Wesley Powell, Clarence King, and Ferdinand V. Hayden. Major Powell made the area classical in his report on the eastern part of the Uinta Mountains. He entered the area in the fall of 1868, having first traveled north around the east end of the Uinta Mountains from the White River country to Green River, Wyo., then south over a circuitous route to Flaming Gorge and Browns Park, and finally back to the White River. In $\mathbf{1 8 6 9}$, after reexamining much of the area visited the previous season, Powell embarked on his famous first boat trip down the Green and Colorado Rivers; his second trip was made 2 years later. In 1874 and 1875 he again visited the area and completed the studies begun 6 years before.

The geologic exploration of the 40th Parallel, better known simply as the 40th Parallel Survey, was headed by Clarence King. King began working eastward from California in 1867; the Uinta Mountain area was mapped in the summers of 1869 and 1871 by S. F. Emmons, who also wrote the sections of King's report covering the descriptive geology of the Uinta Mountains and Green River Basin. King (1878, p. 4) emphasized that the 40th Parallel Survey was a rapid exploration of a very large area, as the formal title of his report indicates, rather than a detailed survey; nevertheless, the maps and descriptions in the report reflect a rather thorough examination and a comprehensive understanding of the Flaming Gorge area-equal to, certainly, and in some respects greater than that of King's contemporaries, Powell and Hayden. F. B. Meek, James Hall, and R. P. Whitfield identified the fossil collections of the survey. Ferdinand Zirkel described petrographically the various metamorphic rocks.

F. V. Hayden visited the area in the fall of 1870 , descending the valley of Henrys Fork to the Green River after having examined the higher part of the range to the west. The various formations of the area as now subdivided are easily recognized in Hayden's description (1872, p. 61) of the stratigraphic section at Finch Draw, 11/2 miles west of Flaming Gorge. Most of Hayden's observations in the area, however, were cursory, and he repeatedly expressed regret at having insufficient time for more detailed studies. In reference to the Red Creek area south of Clay Basin, he remarked dryly $(1872$, p. 67) that "**** the geology of this portion of the Uinta range is very complicated and interesting. To have solved the problem to my entire satisfaction would have required a week or two."

O. C. Marsh also visited the area briefly in the fall of 1870. Marsh followed Henrys Fork to Flaming Gorge and crossed the Uinta Mountains south of Browns Park. On his return trip he crossed Sheep Creek Canyon about 10 miles above its mouth by way of Sheep Creek Gap, which he described (1871, p. 197) as "* * * a narrow and almost impassable side ravine."

In 1899 C. R. Van Hise briefly examined the Red Creek quartzite. Curiously, he (Van Hise and Leith, 1909, p. 781) found it to be composed largely of feldspar. F. B. Weeks examined the Red Creek Quartzite during a reconnaissance of the Uinta Mountains in 1906. Weeks (1907, p. 444) concluded that the Red Creek was equivalent to the upper part of the Uinta Mountain Group, despite abundant evidence to the contrary cited by earlier workers. H. S. Gale visited the area briefly in 1906 in connection with a study of the coal fields of northwestern Colorado and northeastern Utah. Shortly thereafter, A. R. Schultz mapped and described the area both in comnection with a study of the coal deposits of the Rock Springs uplift and, later, in connection with the oil possibilities of the same area. In 1915 (published in 1918) he mapped the entire Uinta Range, giving special reference to the Permian phosphate deposits. Many of Schultz' observations have stood the test of time. In view of the size of the area mapped, the short time spent in the field, and the primitive transportation then available, Schultz' investigation was indeed remarkable. Schultz abandoned much of the stratigraphic nomenclature introduced by Powell and applied names used in the Wasatch Mountains; some of these names, unfortunately, were improperly applied, and several long-standing errors of correlation resulted.

In 1921 and 1922 J. D. Sears mapped part of Moffat County, Colo., and Sweetwater County, Wyo. Sears' work did not extend into the area of this report, but he brought into focus and clarified many problems that pertain to the area. Sears was assisted by W. H. Bradley, K. K. Landes, and James Gilluly. Bradley became interested in the remarkable erosion surfaces of the area while studying the sediments of the adjacent Tertiary basins during the years 1928 to 1933 . In 1936 he published his memorable "Geomorphology of the North Flank of the Uinta Mountains."

Meanwhile, the search for petroleum had begun in the area; natural gas was discovered at Clay Basin in 1927 , but a description of the field did not appear in the published literature until 1945 (Dobbin and Davison, 1945; Fidlar, in Hansen, G. H., and Bell, 1949).

In 1933 and 1934 J. D. Forrester reexamined the Uinta range as a whole; in 1937 he published his new stratigraphic, structural, and diastrophic interpretations of the range. Forrester's authoritative views are still widely quoted.

Further publications on the area did not appear until the close of World War II. Since World War II, a sizable literature-mostly of stratigraphic papers--has 
accumulated. Pertinent publications are cited at appropriate places in the text and are listed alphabetically in the bibliography. ${ }^{1}$ In recent years the literature has become so voluminous that some references may have been overlooked inadvertently.

\section{FIELDWORK BY THE AUTHOR}

In June of $1951 \mathrm{~J}$. Mark Cattermole accompanied me on a short preliminary reconnaissance of the Flaming Gorge area. Besides acquiring a general familiarity with the area, my purpose was to learn what transportation, supply, and staffing problems might be expected during the fieldwork. Fortunately, none of these problems proved large. The decision was made at that time to use two vehicles-one to be kept on the left bank of the Green River at Antelope Flat and one at field headquarters in Manila; the river was crossed by a handpowered cable car. (An automobile bridge was built later, but not in time for my use.)

Actual fieldwork did not get under way until the first of August and was suspended in October. Thomas B. Piper served as field assistant during that period and helped measure sections of several formations near Finch Draw and Horseshoe Canyon. Geologic mapping was confined to the area between Manila on the northwest and Bear Mountain on the southeast, between the 41st parallel on the north and Sheep Creek and Red Canyon on the south.

In 1952 David J. Varnes joined me for 2 weeks in June, primarily to help interpret some of the faulted areas near Sheep Creek south of Manila. Manuel G. Bonilla came to the field early in July 1952 and remained for 2 months. Mr. Bonilla also assisted with the fieldwork during the seasons of 1953 and 1954 . During 1952, mapping of the Manila, Flaming Gorge, and Dutch John Mountain quadrangles was completed, and the area between Dutch John Canyon and Pigeon Basin was mapped in the Goslin Mountain quadrangle. In September 1952 Julius Schlocker visited the project for 10 days. Traverses at that time were made to Flaming Gorge damsite, Dutch John Bench, Dutch John Flat, and the area between Dutch John Mountain and Dutch John Canyon.

In 1953 Bonilla and I completed the mapping in the Goslin Mountain quadrangle and mapped the country north of the Uinta fault in the Clay Basin and Willow Creek Butte quadrangles. We finished the areas south of the Green River from camps set up on Jackson Creek in Little Hole and on Crouse Creek in Browns Park, and we field checked parts of the Dutch John Mountain and

\footnotetext{
${ }^{1}$ A valuable contribution, though unpublished, is a Princeton University doctoral thesis by George G. Anderman entitled. "Geology of a Portion of the North Flank of the Uinta Mountains in the Vicinity of Manila, Utah," (1955).
}

Manila quadrangles that had been mapped the previous summer. At that time there were no vehicular bridges across the Green River between Jensen, Utah, and Green River, Wyo.

In 1954, field headquarters were made in Browns Park at the Willow Creek Ranch of Steve and Arlie Radosevich-genial hosts whose hospitality is renowned throughout the "three-corners" area. Between May and July the remainder of the area was mapped and formal field work was completed. In May 1955 and June 1956 I returned to the area for short visits to gather additional data and to resolve problems that had come to light during the ensuing winters; in $1955 \mathrm{I}$ was accom. panied by Lawrence P. Buck, and in 1956, by Robert D. Miller.

Most of the geology of the area was first plotted on aerial photographs obtained from the Soil Conservation Service of the U.S. Department of Agriculture. In was then transferred by stereoscopic inspection to a topographic compilation map at a scale of $1: 20,000$. Some parts of the geology, however, were more expeditiously mapped directly on a topographic base. In Red Canyon, for example, certain faults and other contacts were plotted directly on the map by means of the graphic locator, a simple device with which to locate inaccessible points on a topographic map using only azimuths and vertical angles (Varnes, 1946).

Bedding attitudes were obtained mostly by direct measurement on the ground. Some, however, were obtained by the three-point method after the trace of a given bed was plotted on the topographic map. This method was especially useful in mapping the Uinta Mountain Group where reliable attitudes on many massive sandstone beds could not otherwise have been obtained. In some places, beds that could not be followed on the ground were easily traced on aerial photographs, and their traces then were transferred to the topographic map.

Most of the stratigraphic sections were measured with a steel tape. Direct measurements were made wherever possible, and most traverses were run normal to the strike of the beds. Most thicknesses were computed graphically. Many sections in the flat-lying Browns Park Formation were measured directly with a Locke hand lever and a folding carpenter's rule.

\section{ACKNOWLEDGMENTS}

Full acknowledgment of the many courtesies extended by the people of Daggett County would be an impossible task, and to mention all individuals who helped make staying there very pleasant would be to name a large part of the local population. The names of a few people who stand out include Mr. and Mrs. Steve Radosevich of Browns Park; Mr. and Mrs. G. E. 
Untermann, Directors of the Utah Field House of Natural History at Vernal and widely known authorities on the eastern Uinta Mountains; Mr. and Mrs. Nelson Philbrick and Mr. and Mrs. Dick Bennett of Manila; and $\mathrm{Mr}$. Ernest Hirsch, District Ranger of Ashley National Forest at Manila at the time of my mapping.

Mountain Fuel Supply Co. kindly provided much subsurface data on the Clay Basin gas field. The Ohio Oil Co. likewise provided a $\log$ of its Government.test 1 on the Spring Creek nose south of Antelope Flat.

Enthusiastic help was given by the several members of the Geological Survey who visited the project from time to time. In particular, the help of Manuel G. Bonilla was outstanding, and many ideas presented in this report rose from discussions with him. J. D. Sears was another source of continued interest and stimulating thoughts, and pleasant associations with him will long be remembered. W. H. Bradley kindly criticized the manuscript.

\section{STRATIGRAPHY}

Rocks of the area range in age from Precambrian to Recent (table 1). Lower and middle Paleozoic rocks are lacking, but each system from Mississippi to Quaternary is represented by one or more formations. The large Uinta fault, a high-angle thrust which extends the length of the area, separates Precambrian rocks on the south from younger rocks on the north. Mississippian rocks, which crop out only in the extreme southwest corner of the area, abut against, and are truncated by, the Uinta fault; toward the east, successively younger rocks are truncated by the fault. Just west of the area and a few miles to the east, Mississippian rocks rest uncomformably on Precambrian rocks; in many parts of the Uinta Mountains, however, Cambrian rocks intervene. At the head of Sols Canyon, about 7 miles west of the area, a sequence of gray to green partly micaceous soft shale and green and red sandstone intervenes between the limestone of Mississippian age and the red quartzite of the Uinta Mountain Group (Precambrian). This sequence may possibly occur at depth in the area of this report. Its age is unknown, but it resembles in some ways the Upper Cambrian Lodore Formation of the Dinosaur National Monument area. On the other hand, it also resembles the Red Pine Shale of Williams (1953, p. 2738) which crops out in the western part of the Tinta Mountains and, according to Williams, is of Precambrian age. Some of the gray shales at Sols Canyon contain unidentified organic remains in the form of minute orbiculate encrustations.

The total thickness of stratified rocks exposed in the area, excluding the metasedimentary Red Creek Quartzite, exceeds 42,000 feet. Of this thickness, more than 20,000 feet-possibly as much as 24,000 feet-is younger Precambrian (Uinta Mountain Group), about 3,800 feet is Paleozoic, about 13,000 feet is Mesozoic, and about 5,000 feet is Tertiary. Thicker, more complete Tertiary sections underlie areas a few miles to the north. The Red Creek Quartzite (middle Precambrian) has an exposed thickness of perhaps 20,000 feet.

Following deposition of the Red Creek Quartzite but priar to deposition of the overlying Uinta Mountain Group (younger Precambrian), a period of deformation ensued that far exceeded in intensity and magnitude any succeeding event in the geologic history of the area. During that period the Red Creek was deformed several times and was subjected to high-grade regional metamorphism. After that time and prior to the Laramide revolution in Late Cretaceous and early Tertiary time, the area underwent a long period of gentle subsidence and deposition that was interrupted intermittently by gentle uplift and erosion. Erosion intervals are indicated at several places in the geologic column. Most of these intervals were of short duration and minor consequence, but a long interval preceded the Mississippian Period, perhaps lasting most of early Paleozoic time. During most of late Paleozoic time and until the ancestral Nevadan mountain belt began to rise to the west in Jurassic time, the area was marginal to the Cordilleran miogeosyncline and marine waters occupied the area repeatedly. Until the ancestral Nevadan mountains began to rise, deposition was mostly from source areas to the east. The ancestral Nevadan mountains, which rose on the site of a former miogeosyncline in eastern Nevada and western Utah, provided a source to the west for most of the subsequently deposited Jurassic and Cretaceous formations. Some of those formations (Morrison, Dakota, Ericson) are continental; others are marine, having been deposited in the foredeep of the Rocky Mountain geosyncline which was then subsiding between the active mountain belt to the west and the stable platform to the east.

With the onset of the Laramide revolution, the Rocky Mountain geosyncline was destroyed. Subsequent Tertiary deposits were formed largely from detritus carried off the adjacent rising mountains and from the ash falls of distant volcanoes.

\section{PRECAMBRIAN ROCKS}

Precambrian rocks of the area are divisible into two major units, the Red Creek Quartzite and the Uinta Mountain Group. The Red Creek Quartzite was repeitedly deformed and metamorphosed and was deeply eroded prior to deposition of the overlying unmetamorphosed Uinta Mountain Group.

In the Middle Rocky Mountain region, three general subdivisions of Precambrian rocks can be distinguished: 
TABLE 1.-Summary description of rocks exposed in Flaming Gorge area

\begin{tabular}{|c|c|c|c|c|c|c|c|c|c|c|c|c|}
\hline Era & System & Series & Unit & $\begin{array}{c}\text { General lithologic } \\
\text { description }\end{array}$ & $\begin{array}{c}\text { Thickness } \\
\text { (feet) }\end{array}$ & $\begin{array}{l}\text { Depositional } \\
\text { conditions }\end{array}$ & $\begin{array}{c}\text { Relationship of } \\
\text { basal contact }\end{array}$ & $\begin{array}{c}\text { Fractures and } \\
\text { joints }\end{array}$ & $\begin{array}{l}\text { Exposure and topo- } \\
\text { graphic expression }\end{array}$ & Drainage & Slope stability & Workability \\
\hline \multirow{8}{*}{ 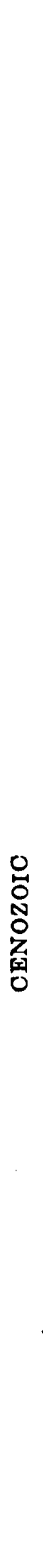 } & \multirow{7}{*}{ 望 } & \multirow{3}{*}{ 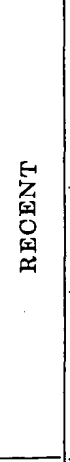 } & $\begin{array}{l}\text { Flood-plain } \\
\text { deposits. }\end{array}$ & $\begin{array}{l}\text { Mostly compact silt } \\
\text { and fine sand, but } \\
\text { also lenses and } \\
\text { bars of gravel. } \\
\text { Include islands } \\
\text { and bars in } \\
\text { channel of Green } \\
\text { River. } \\
\end{array}$ & $5-50(?) \ldots \ldots \ldots$ & $\begin{array}{l}\text { Flood plains of } \\
\text { Green River } \\
\text { and its major } \\
\text { tributaries. }\end{array}$ & Unconformable & $\begin{array}{l}\text { Vague and } \\
\text { poorly } \\
\text { formed. }\end{array}$ & $\begin{array}{l}\text { Exposed in cut } \\
\text { banks. Form } \\
\text { flat bottom } \\
\text { lands along } \\
\text { major streams. }\end{array}$ & $\begin{array}{l}\text { Generally poor, } \\
\text { but fair to good } \\
\text { along Sheep } \\
\text { Creek. }\end{array}$ & Low & $\begin{array}{l}\text { Easily worked } \\
\text { with hand tools } \\
\text { or light power } \\
\text { machinery. }\end{array}$ \\
\hline & & & Dune sands & $\begin{array}{l}\text { Fine to medium } \\
\text { sand. }\end{array}$ & $5-50(?) \ldots$ & \begin{tabular}{|l|} 
Chiefly protected \\
pockets to lee \\
of sandstone \\
outcrops.
\end{tabular} & -....do... & None... & $\begin{array}{l}\text { Form flats and } \\
\text { low mounds; } \\
\text { occasional } \\
\text { dunes. }\end{array}$ & $\begin{array}{l}\text { Very permeable. } \\
\text { Little surface } \\
\text { runoff. }\end{array}$ & ....... & $\begin{array}{c}\text { Very easily } \\
\text { worked. }\end{array}$ \\
\hline & & & $\begin{array}{c}\text { Landslides } \\
\text { deposits. }\end{array}$ & $\begin{array}{l}\text { Unstratififed mix- } \\
\text { tures of angular } \\
\text { rock fragments } \\
\text { derived from } \\
\text { bedrock and soil } \\
\text { mantle. }\end{array}$ & $20-100(?) \ldots \ldots$ & $\begin{array}{l}\text { On or below } \\
\text { steep unstable } \\
\text { slopes. }\end{array}$ & -....do....... & Vague or none & $\begin{array}{l}\text { Exposed by } \\
\text { subsequent } \\
\text { gullying; form } \\
\text { hummocky } \\
\text { slopes on steep } \\
\text { hillsides. }\end{array}$ & $\begin{array}{l}\text { Generally poor. } \\
\text { seeps and } \\
\text { springs common }\end{array}$ & $\ldots$ do & $\begin{array}{l}\text { Tool requirements } \\
\text { depend on } \\
\text { character of } \\
\text { source rock. } \\
\text { Large fragments } \\
\text { may require } \\
\text { special handling. }\end{array}$ \\
\hline & & \multirow{3}{*}{ 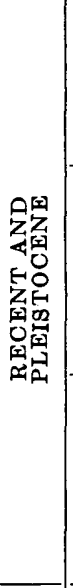 } & Talus_._-_._._... & $\begin{array}{l}\text { Unstratified slope } \\
\text { veneer of angular } \\
\text { rock fragments } \\
\text { and boulders. }\end{array}$ & $5-20(?) \ldots \ldots$ & $\begin{array}{l}\text { Steep slopes } \\
\text { below cliffs and } \\
\text { ledges. }\end{array}$ & -....do........... & None & $\begin{array}{l}\text { Forms steep } \\
\text { slopes below } \\
\text { cliffs and } \\
\text { ledges. Many } \\
\text { small patches } \\
\text { have not been } \\
\text { mapped. }\end{array}$ & Very good_........ & $\begin{array}{l}\text { Moderate, but } \\
\text { subject to creep. } \\
\text { Angular frag- } \\
\text { ments common- } \\
\text { ly "keyed" } \\
\text { together. }\end{array}$ & $\begin{array}{l}\text { Easily worked } \\
\text { with power } \\
\text { machinery. } \\
\text { Large fragements } \\
\text { may require } \\
\text { special handling. }\end{array}$ \\
\hline & & & $\begin{array}{l}\text { Alluvial fans, } \\
\text { undifferentiated. }\end{array}$ & \begin{tabular}{|l|} 
Variously sorted \\
torrential de- \\
positsof mixed silt, \\
sand, gravel, and \\
boulders.
\end{tabular} & $5-50(?) \ldots \ldots$ & $\begin{array}{l}\text { Deposited by } \\
\text { over loaded } \\
\text { intermittent } \\
\text { streams at } \\
\text { mouths of } \\
\text { ravines and } \\
\text { canyons. }\end{array}$ & ..... do & $\begin{array}{l}\text { None to vague } \\
\text { in silty } \\
\text { layers. }\end{array}$ & $\begin{array}{l}\text { Well exposed in } \\
\text { fresh cuts } \\
\text { along washes } \\
\text { and gullies. } \\
\text { Gentle stony } \\
\text { slopes below } \\
\text { mouths of } \\
\text { ravines and } \\
\text { canyons. } \\
\end{array}$ & $\begin{array}{l}\text { Generally very } \\
\text { good. }\end{array}$ & $\begin{array}{l}\text { Moderate. } \\
\text { Occasional } \\
\text { slumps along } \\
\text { steep cuts. }\end{array}$ & $\begin{array}{l}\text { Easily worked } \\
\text { with hand tools } \\
\text { or power } \\
\text { machinery. }\end{array}$ \\
\hline & & & $\begin{array}{l}\text { Tributary valley } \\
\text { alluvium. }\end{array}$ & $\begin{array}{l}\text { Mostly loose silt } \\
\text { and silty } \\
\text { sand but includes } \\
\text { stringers and } \\
\text { lenses of dirty } \\
\text { subangular gravel. }\end{array}$ & $5-30$ & \begin{tabular}{|l|} 
Fluviatile; de- \\
posited in bot- \\
toms and on \\
bottomward \\
sides of valleys.
\end{tabular} & ......do.... & $\begin{array}{l}\text { Vague in } \\
\text { sandy } \\
\text { material to } \\
\text { conspicuous } \\
\text { in silt. }\end{array}$ & \begin{tabular}{|l|} 
Well exposed in \\
sides of gullies \\
and washes. \\
Forms flattish \\
valley bottoms \\
commonly con- \\
taining steep \\
sided washes or \\
gullies.
\end{tabular} & $\begin{array}{l}\text { Rapid surface } \\
\text { runoffi. Rather } \\
\text { low permea- } \\
\text { bility. }\end{array}$ & $\begin{array}{l}\text { Low; subject to } \\
\text { slumping along } \\
\text { steep cuts. } \\
\text { Somewhat } \\
\text { plastic when } \\
\text { wet. }\end{array}$ & Do. \\
\hline & & 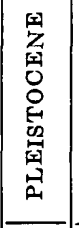 & Bench deposits... & $\begin{array}{l}\text { Poorly sorted gravel } \\
\text { and sand com- } \\
\text { monly containing } \\
\text { abundant cobbles } \\
\text { and, locally, } \\
\text { boulders. In } \\
\text { places loosely } \\
\text { cemented with } \\
\text { calcium carbonate. }\end{array}$ & $5-30 \ldots \ldots \ldots \ldots$ & $\begin{array}{l}\text { Fluviatile; de- } \\
\text { posited on pedi- } \\
\text { ments and } \\
\text { along stream } \\
\text { courses. }\end{array}$ & ......do.......... & None & \begin{tabular}{|l|} 
Fair to good \\
exposures at \\
edges of benches. \\
Form flat- \\
topped or \\
gently sloping \\
surfaces.
\end{tabular} & $\begin{array}{l}\text { Generally good, } \\
\text { but high water } \\
\text { tables locally. }\end{array}$ & $\begin{array}{l}\text { Moderate; stands } \\
\text { at angle of re- } \\
\text { pose of loose } \\
\text { gravel. }\end{array}$ & $\begin{array}{l}\text { Easily worked } \\
\text { with hand tools } \\
\text { or power } \\
\text { machinery in } \\
\text { most places, } \\
\text { but requires } \\
\text { special handling } \\
\text { locally where } \\
\text { cemented into } \\
\text { frrm rock. }\end{array}$ \\
\hline & & 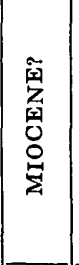 & $\begin{array}{l}\text { Browns Park } \\
\text { Formation. }\end{array}$ & $\begin{array}{l}\text { Gray to white } \\
\text { loose to compact } \\
\text { tuff and tufface- } \\
\text { ous sandstone } \\
\text { interbedded with } \\
\text { loosely cemented } \\
\text { fine to coarse } \\
\text { conglomerate, } \\
\text { pale-orange to } \\
\text { gray siltstone and } \\
\text { sandstone, and } \\
\text { olive-drab clay. }\end{array}$ & $\begin{array}{l}\text { 820+ exposed. } \\
\text { An unde- } \\
\text { termined } \\
\text { thickness } \\
\text { unexposed. }\end{array}$ & $\begin{array}{l}\text { Fluviatile, lacus- } \\
\text { trine, and } \\
\text { eolian. Tuffs } \\
\text { airborne from a } \\
\text { distant volcanic } \\
\text { source, probably } \\
\text { to the west. }\end{array}$ & ....do do.......... & $\begin{array}{l}\text { Inconspicuous; } \\
\text { poorly form- } \\
\text { and widely } \\
\text { spaced. }\end{array}$ & $\begin{array}{l}\text { Commonly under- } \\
\text { lies broad } \\
\text { benches. } \\
\text { Forms sharp } \\
\text { breaks and, } \\
\text { locally, low } \\
\text { cliffs. Bad- } \\
\text { lands in dis- } \\
\text { sected areas. }\end{array}$ & $\begin{array}{l}\text { Generally good, } \\
\text { but poor in } \\
\text { clayey zones. }\end{array}$ & $\begin{array}{l}\text { Generally high. } \\
\text { Natural slope } \\
\text { failures are rare. } \\
\text { Clay beds } \\
\text { plastic when } \\
\text { wet. }\end{array}$ & $\begin{array}{l}\text { Mostly easily } \\
\text { worked with } \\
\text { power machin- } \\
\text { ery. Some } \\
\text { sandstone and } \\
\text { conglomerate } \\
\text { beds would re- } \\
\text { quire special } \\
\text { handling. }\end{array}$ \\
\hline
\end{tabular}




\begin{tabular}{|c|c|c|c|c|c|c|c|c|c|c|c|}
\hline 究 & 㫌 & $\begin{array}{l}\text { Green River } \\
\text { Formation. }\end{array}$ & $\begin{array}{l}\text { Chiefly dense gray } \\
\text { limestone. some } \\
\text { fine-grained } \\
\text { sandstone. } \\
\text { Black chert beds } \\
\text { toward base. } \\
\text { Beds exposed in } \\
\text { area are not } \\
\text { typical of most of } \\
\text { formation } \\
\text { elsewhere. } \\
\end{array}$ & $\begin{array}{c}600+\text { Section } \\
\text { incomplete. }\end{array}$ & \begin{tabular}{|l} 
Lacustrine; \\
chiefly depos- \\
ited on bottom \\
of extinct fresh- \\
water lake.
\end{tabular} & $\begin{array}{l}\text { Conformable; } \\
\text { grades down- } \\
\text { ward into } \\
\text { and inter- } \\
\text { tongues with } \\
\text { Wasatch } \\
\text { formation. }\end{array}$ & Inconspicuous. & $\begin{array}{l}\text { Fair to good ex- } \\
\text { posures. Forms } \\
\text { slopes and } \\
\text { breaks. }\end{array}$ & Fair to good...... & High in this area & $\begin{array}{l}\text { Drilling and } \\
\text { blasting re- } \\
\text { quired in most } \\
\text { excavations in } \\
\text { firm rock. }\end{array}$ \\
\hline & 焉 & $\begin{array}{l}\text { Wasatch Forma- } \\
\text { tion. }\end{array}$ & $\begin{array}{l}\text { Red, gray, and } \\
\text { cream-colored } \\
\text { medium- to coarse- } \\
\text { grained well- } \\
\text { cemented sand- } \\
\text { stone; conglomer- } \\
\text { ate, in part very } \\
\text { coarse, near } \\
\text { middle or section. } \\
\text { Varicolored sandy } \\
\text { silt toward base } \\
\text { of section. }\end{array}$ & $\begin{array}{l}2,000+\text {. Sec- } \\
\text { tion } \\
\text { incomplete. }\end{array}$ & \begin{tabular}{|l} 
Fluviatile; depos- \\
ited in inter- \\
montane basin \\
at foot of rising \\
Uinta \\
Mountains.
\end{tabular} & Gradational... & $\begin{array}{l}\text { Joints well } \\
\text { formed in } \\
\text { harder beds } \\
\text { but gener- } \\
\text { ally widely } \\
\text { spaced. }\end{array}$ & $\begin{array}{l}\text { Forms flattish } \\
\text { surface under- } \\
\text { lying Manila; } \\
\text { forms rugged } \\
\text { hogbacks north } \\
\text { and west of } \\
\text { Manila, high } \\
\text { round-topped } \\
\text { hills east of } \\
\text { Clay Basin. }\end{array}$ & $\begin{array}{l}\text { Mostly permea- } \\
\text { ble and well } \\
\text { drained. Some } \\
\text { impermeable } \\
\text { zones toward } \\
\text { baise. }\end{array}$ & $\begin{array}{l}\text { Mostly very } \\
\text { stable, but } \\
\text { lower beds } \\
\text { somewhat } \\
\text { plastic when } \\
\text { wet. }\end{array}$ & Do. \\
\hline & 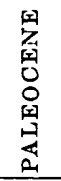 & $\begin{array}{l}\text { Fort Union } \\
\text { Formation. }\end{array}$ & $\begin{array}{l}\text { Drab gray to pale } \\
\text { yellowish-gray } \\
\text { compact silts, } \\
\text { friable lenticular } \\
\text { sandstones, and } \\
\text { pebble } \\
\text { conglomerates. }\end{array}$ & $1,200-2,300 \ldots$ & $\begin{array}{l}\text { Fluviatile, in part } \\
\text { paludal. }\end{array}$ & \begin{tabular}{|} 
Unconformable; \\
in places \\
angular but \\
elsewhere \\
concordant.
\end{tabular} & Inconspicuous. & $\begin{array}{l}\text { Poor to very good } \\
\text { exposures. } \\
\text { Concealed in } \\
\text { many places } \\
\text { but forms bad- } \\
\text { lands locally. }\end{array}$ & $\begin{array}{l}\text { Poor; rapid sur- } \\
\text { face runoff. }\end{array}$ & $\begin{array}{c}\text { Probably low, but } \\
\text { no feld evi- } \\
\text { dence of failure. }\end{array}$ & $\begin{array}{l}\text { Easily worked } \\
\text { with power } \\
\text { machinery. } \\
\text { Drilling and } \\
\text { blasting in some } \\
\text { sandstones. }\end{array}$ \\
\hline \multirow{3}{*}{ 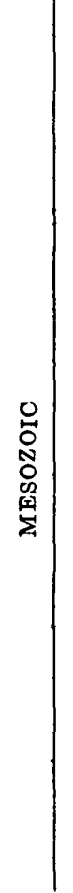 } & \multirow{4}{*}{ 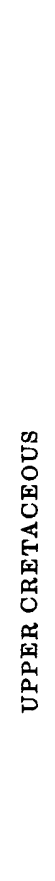 } & $\begin{array}{l}\text { Ericson } \\
\text { Sandstone. } \\
\text {. }\end{array}$ & $\begin{array}{l}\text { Light-gray to white } \\
\text { medium to coarse } \\
\text { grained sandstone } \\
\text { containing many } \\
\text { chert grains. } \\
\text { Conglomeratic } \\
\text { lenses in western } \\
\text { sections. Dark- } \\
\text { gray punky } \\
\text { shales in Clay } \\
\text { Basin area. } \\
\end{array}$ & $290-900 \pm \ldots$ & $\begin{array}{l}\text { Largely fluviatile. } \\
\text { Possibly littoral } \\
\text { in part. Part- } \\
\text { ly paludal at } \\
\text { Clay Basin. }\end{array}$ & Conformable & $\begin{array}{l}\text { Large widely } \\
\text { spaced dip } \\
\text { joints. }\end{array}$ & $\begin{array}{l}\text { Well exposed. } \\
\text { Forms cliffs, } \\
\text { hogbacks, and } \\
\text { dip slopes. }\end{array}$ & $\begin{array}{l}\text { Good drainage } \\
\text { and high per- } \\
\text { meability. }\end{array}$ & Very high.......... & $\begin{array}{l}\text { Drilling and blast- } \\
\text { ing required in } \\
\text { sandstone. }\end{array}$ \\
\hline & & $\begin{array}{c}\text { Rock Springs } \\
\text { Formation. }\end{array}$ & $\begin{array}{l}\text { Light-gray to pale } \\
\text { grayish-orange } \\
\text { massive fine- } \\
\text { grained sandstone } \\
\text { interbedded with } \\
\text { brown punky } \\
\text { carbonaceous } \\
\text { shale and coal. } \\
\end{array}$ & $\begin{array}{l}1,090 \text { to a } \\
\text { wedge edge. }\end{array}$ & $\begin{array}{l}\text { Marine, littoral; } \\
\text { and onshore } \\
\text { coastal swamps. }\end{array}$ & $\begin{array}{l}\text { Gradational, } \\
\text { both verti- } \\
\text { cally and } \\
\text { laterally. }\end{array}$ & $\begin{array}{l}\text { Large widely } \\
\text { spaced dip } \\
\text { joints in } \\
\text { sandstone. } \\
\text { Small in- } \\
\text { conspicuous } \\
\text { joints in } \\
\text { shale. } \\
\end{array}$ & $\begin{array}{l}\text { Sandstone beds } \\
\text { form prominent } \\
\text { cliffs and ledges. } \\
\text { Shales and coal } \\
\text { crop out poorly. }\end{array}$ & $\begin{array}{l}\text { Mostly good, but } \\
\text { fair to poor in } \\
\text { shale. }\end{array}$ & $\begin{array}{l}\text { Very high in } \\
\text { sandstone. } \\
\text { Moderate to } \\
\text { low in shale. }\end{array}$ & Do. \\
\hline & & Blair Formation.. & $\begin{array}{l}\text { Pale grayish-orange } \\
\text { massive fine- } \\
\text { grained sandstone } \\
\text { interbedded with } \\
\text { dark-gray shale. }\end{array}$ & $\begin{array}{l}360 \text { to a wedge } \\
\text { edge. }\end{array}$ & $\begin{array}{c}\text { Marine; littoral } \\
\text { zone to shallow } \\
\text { water offshore. }\end{array}$ & -...do_... & $\begin{array}{l}\text { Large widely } \\
\text { spaced dip } \\
\text { joints in } \\
\text { sandstone. } \\
\text { Smantlight } \\
\text { inconspic- } \\
\text { uous joints } \\
\text { in shale. }\end{array}$ & $\begin{array}{l}\text { Well exposed. } \\
\text { Forms hogback } \\
\text { and high cliff } \\
\text { north of Ante- } \\
\text { lope Flat ("GGol- } \\
\text { den Wall" of } \\
\text { J. W. Powell). }\end{array}$ & $\begin{array}{l}\text { Good in sand- } \\
\text { stone; poor in } \\
\text { shale. }\end{array}$ & $\begin{array}{l}\text { High in sand- } \\
\text { stone. Mod- } \\
\text { erate to low in } \\
\text { shale. }\end{array}$ & Do. \\
\hline 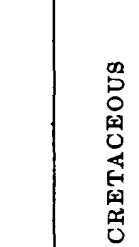 & & Hilliard Shale... & $\begin{array}{l}\text { Chiefly drab-gray } \\
\text { calcareous soft } \\
\text { shale containing } \\
\text { numerous beds of } \\
\text { fine-grained } \\
\text { ripple-marked } \\
\text { sandstone and } \\
\text { scattered beds of } \\
\text { nodular lime- } \\
\text { stone, somewhat } \\
\text { gypsiferous. }\end{array}$ & $\begin{array}{l}\text { 6,200+ } \\
\text { (varies } \\
\text { laterally). }\end{array}$ & Marine, offshore - & - do $_{2}$ & $\begin{array}{l}\text { Closely space } \\
\text { but incon- } \\
\text { spicuous } \\
\text { joints. }\end{array}$ & $\begin{array}{l}\text { Generally poor } \\
\text { exposures. } \\
\text { Forms round } \\
\text { knobs and low } \\
\text { hillocks. Un- } \\
\text { derlies Lucerne } \\
\text { Valley. }\end{array}$ & $\begin{array}{l}\text { Low permeabil- } \\
\text { ity and rapid } \\
\text { surface runoff. } \\
\text { High water } \\
\text { tables locally. }\end{array}$ & $\begin{array}{l}\text { Low; plastic } \\
\text { when wet. } \\
\text { Subject to } \\
\text { slumping and } \\
\text { sliding, espe- } \\
\text { cially along } \\
\text { terrace margins. }\end{array}$ & $\begin{array}{l}\text { Easily excavated } \\
\text { with hand tools } \\
\text { and light } \\
\text { machinery. }\end{array}$ \\
\hline
\end{tabular}


TABLE 1.-Summary description of rocks exposed in Flaming Gorge area-Continued

\begin{tabular}{|c|c|c|c|c|c|c|c|c|c|c|c|c|}
\hline Era & System & Series & Unit & $\begin{array}{c}\text { General lithologic } \\
\text { description }\end{array}$ & $\begin{array}{c}\text { Thickness } \\
\text { (feet) }\end{array}$ & $\begin{array}{l}\text { Depositional } \\
\text { conditions }\end{array}$ & $\begin{array}{c}\text { Relationship of } \\
\text { basal contact }\end{array}$ & $\begin{array}{c}\text { Fractures and } \\
\text { joints }\end{array}$ & $\begin{array}{l}\text { Exposure and topo- } \\
\text { graphic expression }\end{array}$ & Drainage & Slope stability & Workability \\
\hline & \multirow{3}{*}{ 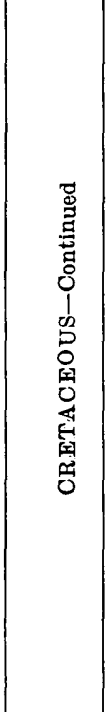 } & 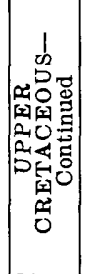 & $\begin{array}{l}\text { Frontier Forma- } \\
\text { tion. }\end{array}$ & $\begin{array}{l}\text { Upper unit: light- } \\
\text { brown to light- } \\
\text { gray fine-grained } \\
\text { evenly bedded } \\
\text { in part ripple- } \\
\text { marked sandstone. } \\
\text { Lower unit: light- } \\
\text { brown to light- } \\
\text { gray soft shale } \\
\text { with scattered } \\
\text { lenses of blue } \\
\text { limestone. }\end{array}$ & $170-190$ & $\begin{array}{l}\text { Upper unit: } \\
\text { shoreward } \\
\text { marine. } \\
\text { Lower unit: } \\
\text { marine; brack- } \\
\text { ish water to } \\
\text { paludal. }\end{array}$ & $\begin{array}{l}\text { Probably dis- } \\
\text { conformable. }\end{array}$ & $\begin{array}{l}\text { Joints con- } \\
\text { spicuous } \\
\text { but widely } \\
\text { spaced in } \\
\text { upper unit, } \\
\text { vague in } \\
\text { lower unit. }\end{array}$ & $\begin{array}{c}\text { Excellent expos- } \\
\text { ures. Forms } \\
\text { continuous } \\
\text { cuesta or hog- } \\
\text { back south of } \\
\text { Lucerne Valley. }\end{array}$ & $\begin{array}{l}\text { Good drainage } \\
\text { and high per- } \\
\text { meability in } \\
\text { upper unit. } \\
\text { Poor drainage } \\
\text { in lower unit. }\end{array}$ & $\begin{array}{l}\text { Generally very } \\
\text { stable, but } \\
\text { possible } \\
\text { slumping in } \\
\text { lower unit. }\end{array}$ & $\begin{array}{l}\text { Drilling and } \\
\text { blasting re- } \\
\text { quired in all } \\
\text { excavations in- } \\
\text { volving upper } \\
\text { unit. Lower } \\
\text { unit worked } \\
\text { with power } \\
\text { tools. }\end{array}$ \\
\hline & & \multirow{2}{*}{ 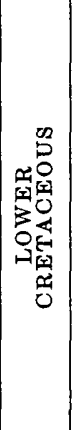 } & Mowry Shale... & $\begin{array}{l}\text { Dark-gray fissile } \\
\text { siliceous shale; } \\
\text { weathers silvery } \\
\text { gray. Contains } \\
\text { massive beds of } \\
\text { porcelanite and } \\
\text { beds or seams of } \\
\text { bentonite. } \\
\end{array}$ & $200-220$ & Marine offshore... & $\begin{array}{l}\text { Apparently } \\
\text { conformable. }\end{array}$ & $\begin{array}{l}\text { Closely } \\
\text { spaced } \\
\text { joints. } \\
\text { Outerops } \\
\text { splintery. }\end{array}$ & $\begin{array}{l}\text { Fair to good ex- } \\
\text { posures. } \\
\text { Forms bare } \\
\text { slopes and un- } \\
\text { even-bottomed } \\
\text { strike valleys. }\end{array}$ & $\begin{array}{l}\text { Fair except in } \\
\text { bentonitic } \\
\text { zones, where it } \\
\text { is low. }\end{array}$ & Moderate..... & $\begin{array}{l}\text { Eassly excavated } \\
\text { with light power } \\
\text { machlnery. }\end{array}$ \\
\hline & & & $\begin{array}{l}\text { Dakota Sand- } \\
\text { stone. }\end{array}$ & $\begin{array}{l}\text { An upper and a } \\
\text { lower unit of } \\
\text { medium- to } \\
\text { coarse-grained } \\
\text { crossbedded well- } \\
\text { cemented sand- } \\
\text { stone separated } \\
\text { by carbonaceous } \\
\text { shale. Lower } \\
\text { unit locally non- } \\
\text { existent. }\end{array}$ & $132-250=-$ & $\begin{array}{l}\text { Fluviatile and } \\
\text { paludal. }\end{array}$ & $\begin{array}{l}\text { Unconform: } \\
\text { able; basal } \\
\text { beds fill } \\
\text { shallow } \\
\text { channels in } \\
\text { top of } \\
\text { Morrison } \\
\text { Formation. }\end{array}$ & $\begin{array}{l}\text { Joints widely } \\
\text { spaced and } \\
\text { not con- } \\
\text { spicuous. }\end{array}$ & $\begin{array}{l}\text { Good to excellent } \\
\text { exposures. } \\
\text { Forms low } \\
\text { cliffs and hog. } \\
\text { back or cuestas. }\end{array}$ & $\begin{array}{l}\text { High permeabil- } \\
\text { ity and good } \\
\text { drainage. }\end{array}$ & High.... & $\begin{array}{l}\text { Drilling and } \\
\text { blasting re- } \\
\text { quired in all } \\
\text { excavations in } \\
\text { frm rock. }\end{array}$ \\
\hline \multirow{3}{*}{ 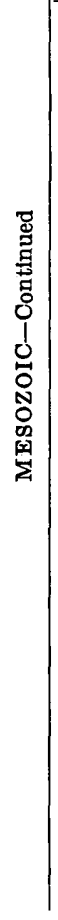 } & \multirow[b]{3}{*}{ 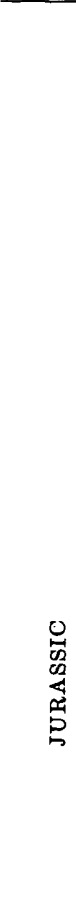 } & \multirow{3}{*}{ 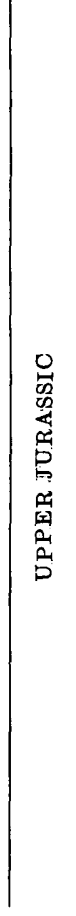 } & $\begin{array}{l}\text { Morrison Forma- } \\
\text { tion and } \\
\text { younger rocks. }\end{array}$ & $\begin{array}{l}\text { Mostly variegated } \\
\text { red and gray } \\
\text { compact silt; beds } \\
\text { and lenses of } \\
\text { poorly sorted } \\
\text { friable sandstone; } \\
\text { considerable } \\
\text { chert-pebble con- } \\
\text { glomerate. Includ- } \\
\text { es in upper part } \\
\text { probable equiva- } \\
\text { lents of Cloverly } \\
\text { and Cedar Moun- } \\
\text { tain Formations }\end{array}$ & $800-940 \ldots$ & $\begin{array}{l}\text { Fluviatile; pre- } \\
\text { dominantly } \\
\text { flood plain, }\end{array}$ & $\begin{array}{l}\text { Sharp con- } \\
\text { tact but no } \\
\text { other evi- } \\
\text { dence of dis- } \\
\text { conformity. }\end{array}$ & Not apparent & $\begin{array}{l}\text { Poorly exposed. } \\
\text { Underlies } \\
\text { South Valley. } \\
\text { Harder beds } \\
\text { form low strike } \\
\text { ridges. }\end{array}$ & $\begin{array}{l}\text { Poor to fair. } \\
\text { High water } \\
\text { tables locally. }\end{array}$ & $\begin{array}{l}\text { Probably low, } \\
\text { but no field } \\
\text { evidence of } \\
\text { failure. }\end{array}$ & $\begin{array}{l}\text { Easily excarated } \\
\text { with hand tools } \\
\text { and light power } \\
\text { machinery. } \\
\text { Drilling } \\
\text { and blasting } \\
\text { required to ex- } \\
\text { cavate hard } \\
\text { sandstone and } \\
\text { conglomerate. }\end{array}$ \\
\hline & & & $\begin{array}{l}\text { Curtis For- } \\
\text { mation. }\end{array}$ & $\begin{array}{l}\text { Upper unit: blocky- } \\
\text { to slabby beds of } \\
\text { glauconitice, of } \\
\text { ooliticic, fossilif- } \\
\text { erous limestone } \\
\text { and glauestonitic } \\
\text { sandstone. } \\
\text { Lower unit: green- } \\
\text { ish-gray friable } \\
\text { glauconitic silt- } \\
\text { stone and sand- } \\
\text { stone with lenses } \\
\text { of limestone. }\end{array}$ & $145-180$ & $\begin{array}{l}\text { Marine; offshore } \\
\text { deposits of of } \\
\text { shallow interior } \\
\text { seaway. }\end{array}$ & $\begin{array}{l}\text { Sharp but ap- } \\
\text { parently con- } \\
\text { formable. }\end{array}$ & $\begin{array}{c}\text { Conspicuous } \\
\text { joints in } \\
\text { upper unit; } \\
\text { inconspic- } \\
\text { uous in } \\
\text { lower unit. }\end{array}$ & $\begin{array}{l}\text { Exposures good to } \\
\text { excellent in } \\
\text { upper unit, } \\
\text { poor in lower } \\
\text { unit. Upper } \\
\text { unit forms dip } \\
\text { slopes, strike } \\
\text { ridges and cliffs; } \\
\text { lower unit } \\
\text { forms rubbly } \\
\text { slopes. }\end{array}$ & $\begin{array}{l}\text { Very good in } \\
\text { upper unit; } \\
\text { good in lower } \\
\text { unit. }\end{array}$ & High........ & $\begin{array}{l}\text { Drilling and } \\
\text { blasting re- } \\
\text { quired in all ex- } \\
\text { cavations in } \\
\text { firm rock. }\end{array}$ \\
\hline & & & $\begin{array}{l}\text { Entrada Sand- } \\
\text { stone. }\end{array}$ & $\begin{array}{l}\text { Upper unit: Mod- } \\
\text { erate reddish- } \\
\text { orange massive } \\
\text { to flaggy very } \\
\text { fine-grained sand- } \\
\text { stone and silt- } \\
\text { stone; somewhat } \\
\text { friable. } \\
\text { Lower unit: Cream } \\
\text { colored crossbed- } \\
\text { ded fine-grained } \\
\text { well-cemented } \\
\text { sandstone, lo- } \\
\text { cally pink or red; }\end{array}$ & $200-245 \ldots$ & $\begin{array}{c}\text { Mainly shore- } \\
\text { ward deposits } \\
\text { of shallow in- } \\
\text { terior seaway. } \\
\text { In part eolian. } \\
\text { especially in, } \\
\text { eastern sections. }\end{array}$ & $\ldots d o_{,} \ldots$ & $\begin{array}{l}\text { Conspicuous } \\
\text { but gener- } \\
\text { ally widely } \\
\text { spaced } \\
\text { joints. }\end{array}$ & $\begin{array}{l}\text { Exposures good } \\
\text { to excellent. } \\
\text { Forms clifs, } \\
\text { hogbacks, and } \\
\text { strike ridges. } \\
\text { Upper unit } \\
\text { generally forms } \\
\text { slopes. }\end{array}$ & Fair tọ good... & $=\mathrm{do}_{r-}$ & Do. \\
\hline
\end{tabular}




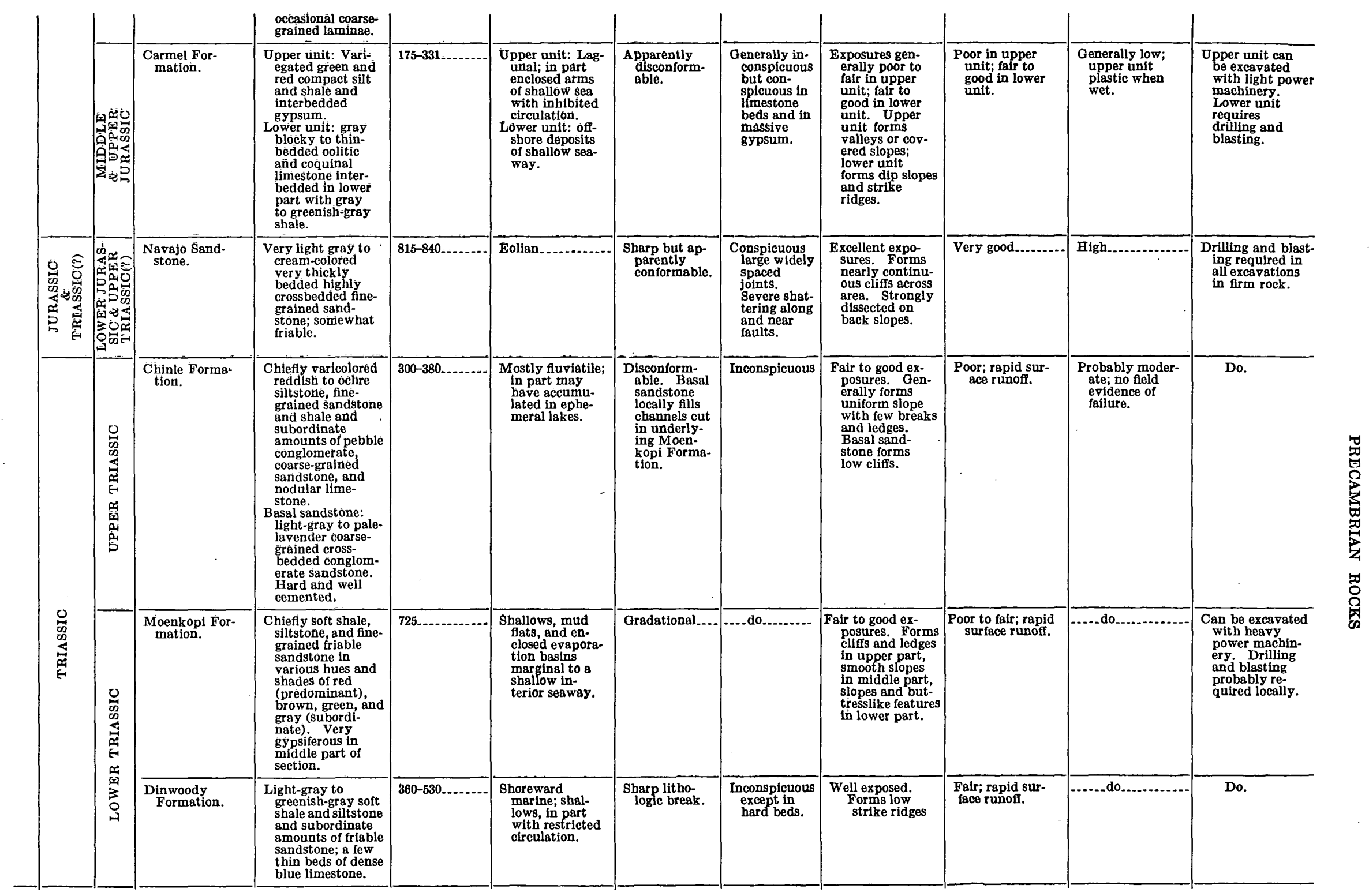


TABLE 1.-Summary description of rocks exposed in Flaming Gorge area-Continued

\begin{tabular}{|c|c|c|c|c|c|c|c|c|c|c|c|c|}
\hline Era & System & Series & Unit & $\begin{array}{c}\text { General lithologic } \\
\text { description }\end{array}$ & $\begin{array}{l}\text { Thickness } \\
\text { (feet) }\end{array}$ & $\begin{array}{l}\text { Depositional } \\
\text { conditions }\end{array}$ & $\begin{array}{c}\text { Relationship of } \\
\text { basal contact }\end{array}$ & $\begin{array}{c}\text { Fractures and } \\
\text { joints }\end{array}$ & $\begin{array}{l}\text { Exposure and topo- } \\
\text { graphic expression }\end{array}$ & Drainage & Slope stability & Workability \\
\hline \multirow{6}{*}{ 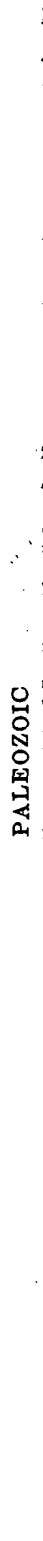 } & 萦 & & $\begin{array}{l}\text { Park City } \\
\text { Formation. }\end{array}$ & $\begin{array}{l}\text { Franson Member: } \\
\text { gray cherty lime- } \\
\text { stone, gray dolo- } \\
\text { mite, and brown- } \\
\text { ish sandstone. } \\
\text { Gray, green, and } \\
\text { red shale. } \\
\\
\text { Meade Peak Phos- } \\
\text { phatic Shale } \\
\text { Tongue of Phos- } \\
\text { phoria Formation: } \\
\text { phoshatic shale, } \\
\text { mudstone, lime- } \\
\text { stone, and dolo- } \\
\text { mite. } \\
\text { Lower member: } \\
\text { gray limestone, } \\
\text { dolomite, and } \\
\text { sandstone. }\end{array}$ & $44 \ldots$ & $\begin{array}{l}\text { Marine; offshore } \\
\text { to near shore } \\
\text { in part with } \\
\text { restricted } \\
\text { circulation. } \\
\text { Relatively deep } \\
\text { water offshore. } \\
\text { Offshore to near } \\
\text { shore. }\end{array}$ & $\begin{array}{l}\text { Disconform- } \\
\text { able. }\end{array}$ & $\begin{array}{l}\text { Joints a few } \\
\text { feet to } \\
\text { several feet } \\
\text { apart. }\end{array}$ & $\begin{array}{l}\text { Generally well } \\
\text { exposed. Forms } \\
\text { prominent flat- } \\
\text { irons, dip slopes, } \\
\text { and low cliffs; } \\
\text { Meade Peak } \\
\text { Tongue un- } \\
\text { exposed in some } \\
\text { places. }\end{array}$ & Fair to good......- & $\begin{array}{l}\text { Moderate to } \\
\text { high. }\end{array}$ & $\begin{array}{l}\text { Drilling and blast- } \\
\text { ing required in } \\
\text { most firm-rock } \\
\text { excavations, } \\
\text { some shaly } \\
\text { zone excepted. }\end{array}$ \\
\hline & \multirow{5}{*}{ 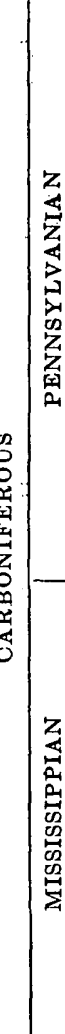 } & \multirow[t]{2}{*}{ 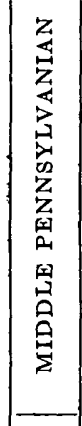 } & Weber Sandstone. & $\begin{array}{l}\text { Pale yellowish-gray } \\
\text { fine- to medium- } \\
\text { grained very } \\
\text { thickly bedded to } \\
\text { massive cross- } \\
\text { bedded sand- } \\
\text { stone; well } \\
\text { cemented; inter- } \\
\text { bedded in lower } \\
\text { 600 feet with } \\
\text { massive thick- } \\
\text { bedded gray- } \\
\text { cherty limestone. }\end{array}$ & $1,555 \ldots$ & $\begin{array}{l}\text { Marine; littoral } \\
\text { to offshore. } \\
\text { Some sandstone } \\
\text { beds may have } \\
\text { been deposited } \\
\text { as onshore } \\
\text { dunes. }\end{array}$ & Gradational.... & $\begin{array}{l}\text { Joints widely } \\
\text { spaced but. } \\
\text { very con- } \\
\text { spicuous. } \\
\text { Some joints } \\
\text { extend en- } \\
\text { tire thick- } \\
\text { ness of for- } \\
\text { mation. }\end{array}$ & $\begin{array}{c}\text { Excellent expo- } \\
\text { sures. Forms } \\
\text { high cliffs and } \\
\text { rugged canyons. }\end{array}$ & $\begin{array}{l}\text { Permeable and } \\
\text { well drained. }\end{array}$ & $\begin{array}{l}\text { Very high; forms } \\
\text { sheer cliffs. }\end{array}$ & $\begin{array}{l}\text { Drilling and blast } \\
\text { ing required in } \\
\text { all excavations } \\
\text { in firm rock. }\end{array}$ \\
\hline & & & $\begin{array}{l}\text { Morgan Forma- } \\
\text { tion. }\end{array}$ & $\begin{array}{l}\text { Interbedded red } \\
\text { shale and silt- } \\
\text { stone and laven- } \\
\text { der limestone. }\end{array}$ & $80 \pm$ & $\begin{array}{l}\text { Marine; near } \\
\text { shore to shallow } \\
\text { offshore. }\end{array}$ & Conformable & $\begin{array}{l}\text { Inconspicu- } \\
\text { ous; mostly } \\
\text { a few feet } \\
\text { apart. }\end{array}$ & $\begin{array}{l}\text { Fair to poor ex- } \\
\text { posures on } \\
\text { partly covered } \\
\text { slopes. }\end{array}$ & Fair to good... & High.... & Do. \\
\hline & & 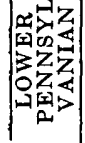 & $\begin{array}{l}\text { Round Valley } \\
\text { Limestone. }\end{array}$ & $\begin{array}{l}\text { Thick-bedded blue- } \\
\text { gray cherty } \\
\text { limestone. }\end{array}$ & $\begin{array}{l}260 \text { (thickens } \\
\text { westward). }\end{array}$ & $\begin{array}{l}\text { Marine; offshore. } \\
\text { Deposited in a } \\
\text { shallow east- } \\
\text { trending } \\
\text { trough. }\end{array}$ & $\begin{array}{l}\text { Unexposed in } \\
\text { area. Ap- } \\
\text { parently con- } \\
\text { formable. }\end{array}$ & \begin{tabular}{|l} 
Well jointed; \\
joints \\
mostly a \\
few feet \\
apart.
\end{tabular} & $\begin{array}{l}\text { Forms steep } \\
\text { ledgy slopes or } \\
\text { stony ridge } \\
\text { tops. }\end{array}$ & Very good.... & Very high_.. & Do. \\
\hline & & \multirow{2}{*}{ 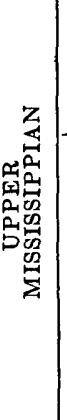 } & Upper shale unit_ & $\begin{array}{l}\text { Black clay shale } \\
\text { overlying brick- } \\
\text { red clay shale; a } \\
\text { few thin beds of } \\
\text { limestone. }\end{array}$ & About 300 & $\begin{array}{l}\text { Marine; probably } \\
\text { near shore. } \\
\text { Onshore coal } \\
\text { swamps. }\end{array}$ & $\begin{array}{l}\text { Poorly ex- } \\
\text { posed but } \\
\text { possibly un- } \\
\text { conformable. }\end{array}$ & Not evident... & $\begin{array}{l}\text { Poorly exposed; } \\
\text { forms covered } \\
\text { slope. }\end{array}$ & Very poor.... & $\begin{array}{l}\text { Low; plastic } \\
\text { when wet. }\end{array}$ & $\begin{array}{l}\text { Easily worked } \\
\text { with hand tools } \\
\text { or light power } \\
\text { machinery. }\end{array}$ \\
\hline & & & $\begin{array}{l}\text { Middle and } \\
\text { lower and } \\
\text { stone and } \\
\text { limestone } \\
\text { units. }\end{array}$ & $\begin{array}{l}\text { Middle sandstone } \\
\text { and limestone } \\
\text { unit: interbedded } \\
\text { red, pink, and } \\
\text { yellow sandstone } \\
\text { and bluish lime- } \\
\text { stone. Well ce- } \\
\text { mented. } \\
\text { Lower limestone } \\
\text { unit: massive } \\
\text { light-blue cherty } \\
\text { limestone. }\end{array}$ & $\begin{array}{l}\text { Not deter- } \\
\text { mined. }\end{array}$ & $\begin{array}{l}\text { Marine; littoral } \\
\text { to offshore. }\end{array}$ & $\begin{array}{l}\text { Middle unit } \\
\text { conformable. } \\
\text { Base of } \\
\text { lower unit } \\
\text { unexposed. } \\
\text { Fault con- } \\
\text { tact this } \\
\text { area. }\end{array}$ & $\begin{array}{l}\text { Widely } \\
\text { spaced and } \\
\text { inconspicied- } \\
\text { ous joints. } \\
\text { Irregular } \\
\text { fractures in } \\
\text { lower unit. }\end{array}$ & $\begin{array}{l}\text { Fair exposures. } \\
\text { In part form } \\
\text { clifis and } \\
\text { ledges. }\end{array}$ & $\begin{array}{l}\text { Good. Lower } \\
\text { limestone unit } \\
\text { somewhat } \\
\text { cavernous. }\end{array}$ & High..- & $\begin{array}{l}\text { Drilling and } \\
\text { blasting re- } \\
\text { quired in all } \\
\text { excavations in } \\
\text { firm rock. }\end{array}$ \\
\hline
\end{tabular}




\begin{tabular}{|c|c|c|c|c|c|c|c|c|c|c|}
\hline \multirow{2}{*}{ 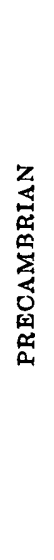 } & $\begin{array}{l}\text { Uints Mountain } \\
\text { Group. }\end{array}$ & $\begin{array}{l}\text { Chiefly red me- } \\
\text { dium- to coarse- } \\
\text { grained siliceous } \\
\text { sanastone and } \\
\text { quartzite. Con- } \\
\text { siderable red } \\
\text { shale and con- } \\
\text { glomerate. } \\
\text { Bedding massive } \\
\text { to flaggy to } \\
\text { crossbedded. }\end{array}$ & $24,000 \pm$ & $\begin{array}{l}\text { Marine; littoral } \\
\text { and shoreward. } \\
\text { Shallow water } \\
\text { in rapidly sub- } \\
\text { siding trough. } \\
\text { In part sub- } \\
\text { aerial. }\end{array}$ & $\begin{array}{l}\text { Angular un- } \\
\text { conformity. }\end{array}$ & $\begin{array}{l}\text { Conspicuous } \\
\text { joints a few } \\
\text { to several } \\
\text { feet apart. } \\
\text { Two sets or } \\
\text { more. }\end{array}$ & $\begin{array}{l}\text { Fair exposures in } \\
\text { this area. } \\
\text { Generally sup- } \\
\text { ports a thin } \\
\text { veneer of sandy } \\
\text { stony soil. }\end{array}$ & Good__._.............. & $\begin{array}{l}\text { Variable, but } \\
\text { mostly high. }\end{array}$ & $\begin{array}{l}\text { Drilling and } \\
\text { blasting re- } \\
\text { quired in most } \\
\text { excavations. }\end{array}$ \\
\hline & $\begin{array}{l}\text { Red Creek } \\
\text { Quartzite. }\end{array}$ & $\begin{array}{l}\text { Predominantly } \\
\text { white, gray, tan, } \\
\text { and pale-green } \\
\text { metaquartzite; } \\
\text { subordinant } \\
\text { quartz-muscovite } \\
\text { schist and am- } \\
\text { phibolite; minor } \\
\text { amounts of car- } \\
\text { bonate rock } \\
\text { (marble in part), } \\
\text { epidiorite, and } \\
\text { pegmatite. }\end{array}$ & $20,000+$. & $\begin{array}{l}\text { Probably marine } \\
\text { on a stable } \\
\text { slowly sub- } \\
\text { siding shelf. } \\
\text { Subsequentiy } \\
\text { deformed and } \\
\text { metamor- } \\
\text { phosed. }\end{array}$ & Unexposed.. & $\begin{array}{c}\text { Much frac- } \\
\text { tured, in } \\
\text { places } \\
\text { severely. }\end{array}$ & $\begin{array}{l}\text { Ranges from } \\
\text { rugged craggy } \\
\text { outcrops in } \\
\text { massive meta- } \\
\text { quartzite to } \\
\text { smooth sub- } \\
\text { dued slopes in } \\
\text { severely frac- } \\
\text { tured rock and } \\
\text { schistose zones. }\end{array}$ & Very good... & $\begin{array}{l}\text { Mostly very high. } \\
\text { Rare landslides } \\
\text { in shattered or } \\
\text { schistose zones. }\end{array}$ & $\begin{array}{l}\text { Drilling and } \\
\text { blasting re- } \\
\text { quired in all } \\
\text { excavations in } \\
\text { firm rock. }\end{array}$ \\
\hline
\end{tabular}


a lower, a middle, and an upper subdivision, based on lithologic characteristics, metamorphic grade, and stratigraphic position. The Red Creek Quartzite is placed within the middle subdivision, the Uinta Mountain Group within the upper. Firm correlations of specific formations with one another in this region are not yet generally possible. Broad tentative correlations seem to be warranted, if only to call attention to the similarities and dissimilarities of the various rock units. Rocks within a given division, region wide, are similar in lithology, metamorphic grade, and general structural complexity, often strikingly so.

Rocks of the lower subdivision have been subjected to high-grade regional metamorphism and are characterized by extreme structural complexity. They are distinguished by widespread feldspathization, migmatization, and pegmatization. Most of them are intruded by several varieties of igneous or metaigneous rocks. Ptygmatic folding is common. Sillimanite is a key metamorphic mineral. The Farmington Canyon Complex of Eardley (1939) of the Wasatch Mountains is a typical representative.

Rocks of the middle subdivision have been subjected to low-grade to high-grade regional metamorphism and are characterized by moderate to great structural complexity; but they are little feldspathized, migmatite is rare, and pegmatite is not abundant. Radiometric ages overlap those of the lower subdivision. The predominant rock type is a pure metaquartzite, commonly in shades of pale tan, gray, or green to milky white. It is thoroughly recrystallized and, at many places, strongly lineated. Amphibolite and carbonate rock are characteristic subordinate lithologic types; pelitic schist is generally present. A rock type common to nearly all formations of the subdivision is a distinctive green metaquartzite. Its green color is caused by disseminated chrome-bearing mica. Kyanite is a key metamorphic mineral; some formations contain sillimanite. Rocks of the middle subdivision crop out west to east in mountainous uplifts over a distance of about 600 miles from northwest Utah and southern Idaho to southern and east-central Wyoming. The rocks include such units as the Albion Range Group (Anderson, 1934, p. 377) of southern Idaho and northwest Utah, the Red Creek Quartzite of the Uinta Mountains, and the Medicine Peak Metaquartzite of Blackwelder (1926, p. 632) of southern and eastern Wyoming.

Rocks of the upper subdivision are characterized by structural simplicity and lack of regional metamorphic effects. They consist chiefly of variously sorted sandstones and sedimentary quartzites (many of which are ferruginous), shales or argillites, and conglomerates. They rest on rocks of the middle or older subdivisions (where contact relationships are exposed) with a pronounced angular unconformity. Rocks of this subdivision include the Big Cottonwood Formation of the Wasatch Mountains and the Uinta Mountain Group.

The following chart (table 2) shows general groupings of some of the Precambrian formations of the Middle Rocky Mountain region. Firm correlations are not intended, and no attempt is made at completeness; the chief purpose of the chart is to show the general Precambrian stratigraphic framework of the region and to show the approximate position within this framework of the Red Creek Quartzite and the Uinta Mountain Group.

\section{RED CREEK QUARTZITE (MIDDLE PRECAMBRIAN)}

The Red Creek Quartzite takes its name from excellent exposures in the canyon of Red Creek (Garnet

TABLE 2.-General groupings of Precambrian rocks in the Middle Rocky Mountain region

[Taken in part from Blackwelder, 1926, p. 621]

\begin{tabular}{|c|c|c|c|c|c|c|c|c|}
\hline \multirow[b]{2}{*}{ Inferred sequence } & \multicolumn{8}{|c|}{ Locality } \\
\hline & $\begin{array}{l}\text { Albion Range of } \\
\text { southern Idaho } \\
\text { and Grouse } \\
\text { Creek Moun- } \\
\text { tains of north- } \\
\text { west Utah } 1\end{array}$ & \multicolumn{2}{|c|}{ Wasatch Mountains } & $\begin{array}{l}\text { Eastern Uinta } \\
\text { Mountains }\end{array}$ & \multicolumn{4}{|c|}{ Southern and eastern Wyoming } \\
\hline \multirow{2}{*}{ Upper } & & \multicolumn{2}{|c|}{ Mutual Formation } & \multirow{2}{*}{$\begin{array}{l}\text { Uinta Moun- } \\
\text { tain Group }\end{array}$} & & & & \\
\hline & & \multicolumn{2}{|c|}{ Big Cottonwood Formation } & & & & & \\
\hline Middle & $\begin{array}{l}\text { Albion Range } \\
\text { Group }\end{array}$ & $\begin{array}{l}\text { Quartzite-phyllite- } \\
\text { marble } \\
\text { sequence of } \\
\text { Willard } \\
\text { Canyon }\end{array}$ & $\begin{array}{l}\text { Little } \\
\text { Willow } \\
\text { Series }\end{array}$ & $\begin{array}{c}\text { Red Creek } \\
\text { quartzite }\end{array}$ & $\begin{array}{l}\text { Quartzite-schist- } \\
\text { marble } \\
\text { sequence of } \\
\text { Emcampment } \\
\text { district }\end{array}$ & $\begin{array}{l}\text { Whalen Group } \\
\text { of Hartville } \\
\text { district }\end{array}$ & $\begin{array}{c}\text { Medicine Peak } \\
\text { metaquartzite } \\
\text { of Blackwelder } \\
\text { (1926) and re- } \\
\text { lated phyllites } \\
\text { and carbonates }\end{array}$ & $\begin{array}{l}\text { Schists and } \\
\text { quartzities of } \\
\text { Attantic Pass }\end{array}$ \\
\hline Lower & & \multicolumn{2}{|c|}{$\begin{array}{l}\text { Farmington Canyon Complex } \\
\text { of Eardley (1939) }\end{array}$} & & \multicolumn{4}{|c|}{ Gneisses of earlier Precambrian age } \\
\hline
\end{tabular}

I B. F. Stringham, oral communication, 1960. 
Canyon of old reports) between Clay Basin and Browns Park, where it was noted by Major Powell (1876, p. 137) many years ago. In that area the various rock types are well represented, and the structural complexity of the formation is well displayed.

For convenience of mapping and presentation, various rocks are included in the formation which in a strict sense, perhaps, should be excluded. These rocks include certain metamorphosed igneous rocks, now chiefly amphibolite, and rare or uncommon bodies of pegmatite. They are younger than the metasedimentary rocks that make up the greater bulk of the Red Creek but are clearly much older than the overlying Uinta.Mountain Group.

The mineral content and petrographic character of the Red Creek Quartzite indicate rocks of moderately high metamorphic grade. As defined by their mineral assemblage, these rocks are placed in the almandine amphibolite facies of Fyfe, Turner, and Verhoogen (1958, p. 228). Local mineral assemblages conform to the staurolite-quartz subfacies and to the kyanite-muscovite-quartz subfacies. A composite mineral assemblage taken from the various rock types in the formation includes quartz, muscovite, hornblende, and plagioclase as chief constituents, and anthophyllite, apatite, biotite, calcite, chlorite, clinozoisite, epidote, garnet, hematite, ilmenite, kyanite, magnetite, microcline, orthorhombic pyroxene staurolite, tourmaline, tremolite, sphene, and zircon as minor but locally abundant constituents. Typical mineral assemblages include (1) quartz-muscovite, (2) quartz-muscovite-staurolite-almandine (biotite), (3) quartz-muscovite-kyanite (-biotite-tourmaline), (4) hornblende-plagioclase (-quartz-almandine).

\section{DISTRIBUTION AND PHYSIOGRAPHIC EXPRESSION}

All known exposures of the Red Creek Quartzite are within the area shown on the geologic map, plate 1 . Within this area, which totals less than 16 square miles, the formation crops out at several localities, mostly in a rough east-west alinement; each locality is separated from the others by intervening areas of younger rocks. At each of these localities the formation is bounded partly or wholly by faults along which it has been elevated relative to the younger adjacent formations. Its unconformable relationship with the Uinta Mountain Group is exposed in several places-notably, near the mouth of the canyon of Red Creek, at Jesse Ewing Canyon, and in the Beaver Creek area. The formation crops out west to east over a distance of about 24 miles, extending discontinuously from a small exposure area against the Uinta fault near the west end of Dutch John Mountain to the extensive outcrops along Beaver Creek and vicinity. For convenience, the five major areas of outcrop are referred to as areas 1 to 5 , respectively, from west to east, as shown on figure 46.

The Red Creek has diverse physiographic expression. Many outcrops present a rough craggy appearance unlike that of any other formation in the area; outcrops at the mouth of the canyon of Red Creek are typical. In many other places, however, especially where the rock has been severely crushed by cataclastic deformation, steep but smoothly contoured slopes almost free of prominent outcrops are veneered with fine angular rubble: Two Horse Butte is typical (fig. 4). Between these two topographic extremes are many gradations of form and slope.

\section{THICKNESS}

Owing to structural complexities, to a lack of persistent key horizons, and to the discontinuity of the several outcrop areas of the Red Creek Quartzite, only a rough estimate of the total exposed thickness of the formation is possible. With due acknowledgment of possible errors, a thickness of 20,000 feet, in round numbers, is obtained. This thickness seems to be minimal, but it is presented with caution and reservations.

For the three largest outcrop areas of the formation, separate thicknesses of exposed rocks can be estimated. In the Goslin Mountain-Red Creek area (area 2), about 8,000 feet of strata is exposed, not taking into account, for the time being, possible thickening due to minor folding or repetitions or deletions due to minor shearing. In the Jesse Ewing Canyon area (area 3), about 6,000 feet of strata is exposed, again ignoring the same possible sources of error. As there appears to be no repetition of sequence between areas 2 and 3 , the combined exposed thickness in the two areas is about 14,000 feet. In the Beaver Creek area (area 5), about 11,000 feet of strata is exposed. The Beaver Creek section is relatively straightforward, but it also is complicated by minor folding and shearing. It also appears to contain no repetitions of the sequence exposed in either area 2 or area 3 , so that a combined total for all three areas yields a thickness of 25,000 feet. If it is then assumed arbitrarily that the formation has been thickened 20 percent by minor multiple folding-a figure that seems to be reasonable from examinations of thickening on individual outcrops-the total exposed thickness of the formation is about 20,000 feet.

\section{LITHOLOGY}

Three rock types-metaquartzite, amphibolite, and mica schist-make up the bulk of the Red Creek Quartzite. In total volume, metaquartzite far exceeds all other rock types combined. Amphibolite probably is next, but bodies of mappable size at the scale used in this report are less extensive than those of mica schist. 


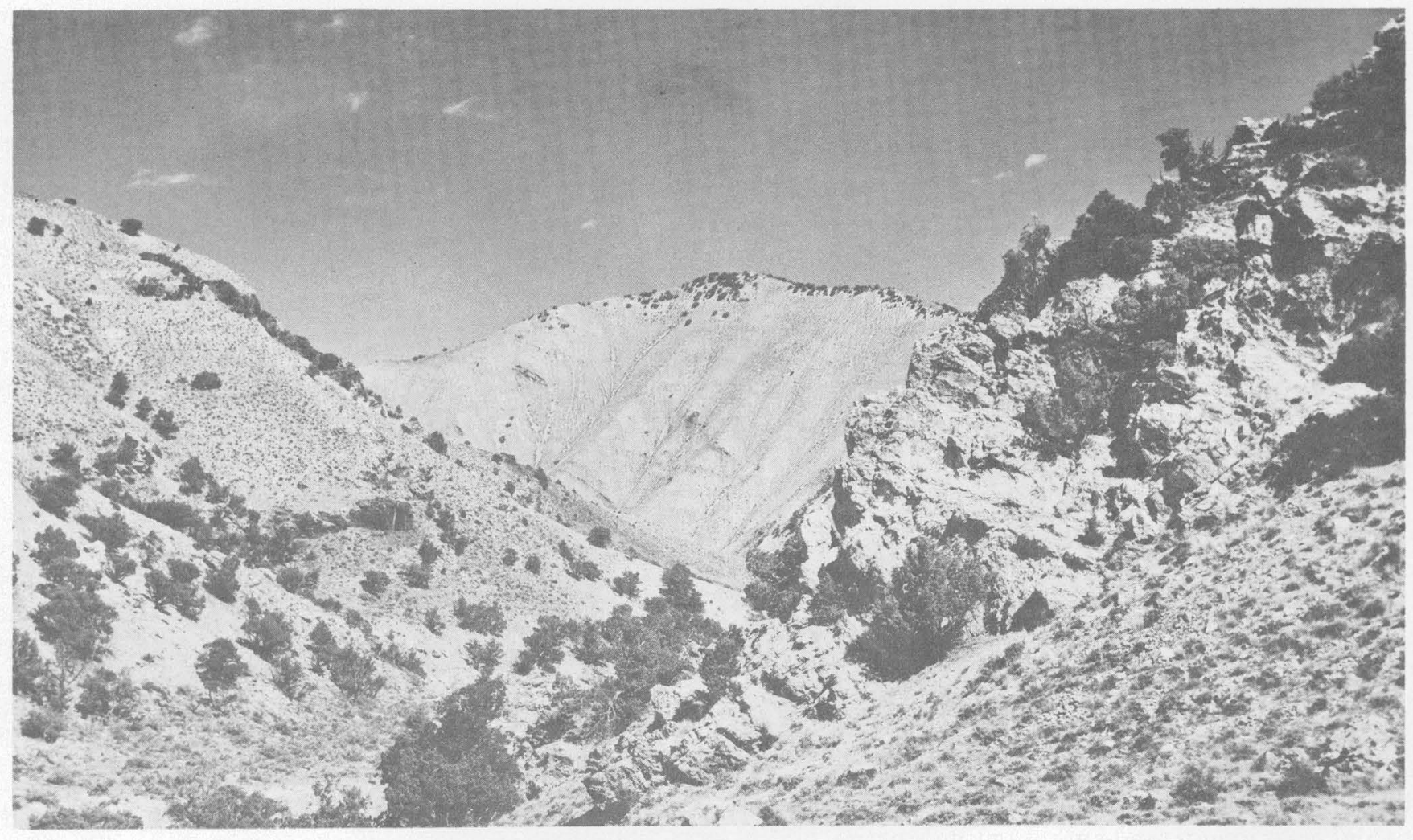

FIGURe 4.-Canyon of Red Creek viewed upstream (northwest) toward Two Horse Butte in distance, showing topographie expression of Red Creek Quartzite. Smoothly contoured slopes of Two Horse Butte contrast with craggy outcrop at right. Metaquartzite at both places.

Other volumetrically minor types, in approximate descending order of abundance, are epidiorite (metagabbro), carbonate rock, pegmatite, localized granitic variant rocks associated with amphibolite and epidiorite, magnesian schist, and chloritic schist. Of these minor rocks, only areas of epidiorite and carbonate rock appear on the map (pl.1).

\section{METAQUARTZITE}

The chief constituent of the Red Creek Quartzite is highly crystalline white, gray, tan, or green metaquartzite of variable but commonly high purity. Primary sedimentary structures other than bedding are largely obscured in most exposures of this rock, and even bedding cannot be recognized with assurance in some exposures. The original sand grains have recrystallized, so that the rock is massive or vaguely foliated and superficially resembles vein quartz. In many places the rock has a coarse linear or mullion structure which gives the outcrop a fluted appearance; this structure is a $b$ axis lineation caused by tight multiple folding. Over wide areas it is the only consistently oriented structural element.

Under the microscope the texture of the rock is seen to be dominantly crystalloblastic, with elongate inter- locking or sutured grains, commonly with considerable intergranular crushing (fig. 5). A small proportion of muscovite oriented subparallel to the elongation of the quartz gives the rock its foliation. Dichroic green tourmaline is a usual but minor constituent; in some places, megascopic black tourmaline is abundant. Feld-

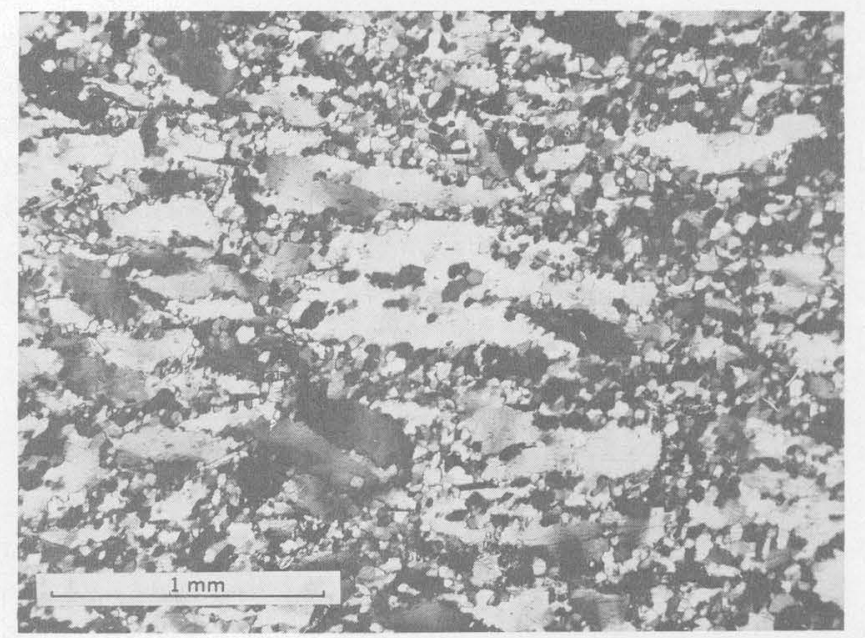

FIGURE 5.-Photomicrograph of typical metaquartzite, Red Creek Quartzite. Note undulatory extinction, extreme elongation of grains, and cataclastic granulation. Crossed nicols $\times 29$. Photograph by Wendell Walker. 
spar is an uncommon constituent, but it is abundant locally where metaquartzite grades into gneiss; gneissic quartzites containing as much as 20 percent albite and minor amounts of microcline crop out along the north slope of Mountain Home, near the junction of Galloway and Willow Creeks, and along Beaver Creek.

Results of semiquantitative spectrographic analyses of two samples of metaquartzite are given below-C510 is a selected sample of grayish-green $(5 G 5 / 2)^{2}$ metaquartzite collected near Willow Creek (Willow Creek Butte quadrangle) in the $\mathrm{SW} 1 / 4$ sec. $27, \mathrm{~T} .3 \mathrm{~N} .$, R. 25 E.; C511 is a grab sample of white metaquartzite collected in a traverse about 400 feet long across the strike of a large outcrop on Goslin Mountain in the NW1/4 sec. 27, T. 3 N., R. 24 E.

Semiquantitative spectrographic analyses of metaquartzite

\begin{tabular}{|c|c|c|c|c|c|}
\hline \multirow{2}{*}{ Eloment } & \multicolumn{2}{|c|}{ Sample } & \multirow{2}{*}{ Element } & \multicolumn{2}{|c|}{ Sample } \\
\hline & $\mathrm{C} 510$ & C511 & & $\mathrm{C} 510$ & C511 \\
\hline $\begin{array}{l}\mathrm{Si} \\
\mathrm{A} \\
\mathrm{Fe} \\
\mathrm{Ti} \\
\mathrm{M} \mathrm{n} \\
\mathrm{Ca} \\
\mathrm{Mg} \\
\mathrm{Na} \\
\mathrm{K} \\
\mathrm{B}\end{array}$ & \begin{tabular}{|c|}
$\times \times$. \\
$\times .-$ \\
$.0 \times-$ \\
$.0 \times+$ \\
$.00 \times$ \\
$.00 x^{+}$ \\
$.0 x^{+}$ \\
.$x^{-}$ \\
$\times .0 \times$ \\
$.00 \times+$
\end{tabular} & $\begin{array}{c}\times \times . \\
. \times \\
. \times x- \\
.0 \times- \\
.0 \times- \\
.0 \times- \\
.0 \times \\
0 \\
0 \\
.00 \times\end{array}$ & $\begin{array}{l}\mathrm{Ce} \\
\mathrm{Cr}{ }_{-} \\
\mathrm{Cu} \\
\mathrm{Ga} \\
\mathrm{La} \\
\mathrm{Ni} \\
\mathrm{S} \mathrm{H} \\
\mathrm{V} \\
\mathrm{Y} \\
\mathrm{Y} \\
\mathrm{Y} \mathrm{b}\end{array}$ & $\begin{array}{l}0.0 \times- \\
. \times- \\
.000 \times- \\
.000 \times- \\
.000 \times+ \\
.000 \times+ \\
.000 \times \\
.00 \times \\
.00 \times \\
.000 \times+ \\
.0 \times\end{array}$ & $\begin{array}{l}0 \\
.000 x^{-} \\
.00 \times- \\
0 \\
0 \\
.000 \times- \\
.000 \times- \\
.00 \times- \\
0 \\
0 \\
.00 \times+\end{array}$ \\
\hline
\end{tabular}

[Note: Symbols used denote analytical limits as follows: $X X$, major constituent; $X^{+}, 4.61-10.0$ percent; $X, 2.15-4.64$ percent; $X^{-}, 1.0-2.15$ percent; $0 . X^{+}, 0.464-1$. porcont; $0 . \times, 0.215-0.464$ percent; $0 . X^{-}, 0.1-0.215$ percent; and so on; 0 , looked for but not detected. Also looked for but not detected: P, Ag, As, Au, Be, Bi, Cd Ru, Sb, Sc, Sn, Sm, Ta, Th, Tl, Te, U, W, and Zn. Paul R. Barnett, analyst]

Sample C510 contains appreciable aluminum, potassium, iron, sodium, and chrome. Indicated chrome content is between 0.1 and 0.215 percent and probably is responsible for the green color of the sample. Inasmuch as the sample as seen in thin section consists chiefly of quartz with considerable mica and very minor tourmaline, the chrome probably is in the mica crystal lattice, although an X-ray diffractometer pattern for the mica closely matches that for muscovite (sericite) rather than that of published patterns for chrome mica (A. .J. Gude, analyst, written commun., 1956).

Sample C511 is a very high silica metaquartzite and contains only about 0.5 percent total impurities, mostly aluminum and iron. Metaquartzite similar to sample Ca11 but perhaps slightly less pure, is the most abundant rock type in the formation. Green metaquartzite is widespread, but the color value generally is lighter than that of sample C510, hence the chrome content probably is less; the numerical color designation for most green

Where numerical color designations are used in this report, they refer to the "Rock-Color Chart" of the National Research Council (Godilurd und others, 194\$). metaquartzite in the formation is near $10 G 8 / 2$, although all gradations exist between that color and $5 G 5 / 2$.

MICA SCHIST

By an increase in the proportion of muscovite to quartz, the predominant metaquartzite grades into quartzose mica schist. All gradations are found from nearly pure metaquartzite to nearly pure mica schist. Several zones or belts of mica schist are sufficiently well defined to be shown separately on the map. The best and most continuously exposed belt crops out in a broad arc centèring on the canyon of Red Creek. Good exposures of this schist in the bottom of the canyon in the SW $1 / 4$ sec. 4, T. 2 N., R. 24 E., can be reached by automobile. From this area the schist can be traced in continuous exposure to the head of the canyon at Clay Basin where it crops out on the north slope of Two Horse Butte and on the northeast slope of Goslin Mountain. Other small, apparently discontinuous masses of mica schist crop out here and there on Goslin Mountain. Farther east, in the Mountain Home area, thick sections of mica schist are well exposed between Mountain Home Draw and Jesse Ewing Canyon. In Mountain Home Draw the schist is tightly crenulated and has a wellformed slip-strain or fracture cleavage. The crenulations manifest the same linear structure as that seen in the metaquartzite. In other parts of the Red Creek Quartzite, mica schist crops out locally but in minor amounts that lack sufficient continuity to be mapped.

The mica schists along Red Creek (fig. 6) have been of interest to petrographers for many years. In the report of the 40th Parallel Survey, Ferdinand Zirkel (1876, p. 28) compared them to the mica schists of the St. Gotthard in Switzerland. Zirkel identified the sodium mica, paragonite, in the schists at Red Creek. Samples X-rayed for me by the Geological Survey (J. W. Adams, analyst) failed to show peaks ascribable to paragonite, but a semiquantitative spectrographic analysis, according to Mr. Adams, showed 1-2. percent sodium and 2-5 percent potassium, which suggests at least partial substitution of sodium for potassium.

Some of the mica schists, particularly those along Red Creek contain several varieties of minerals that form interesting metacrysts. The most abundant of these are almandine garnet, staurolite, and kyanite. Garnet is particularly widespread and is found in most of the schists of the area, as well as in metaquartzite and in some amphibolite. Staurolite is more restricted in its occurrence but is very abundant locally, especially in the schists along Red Creek. Kyanite has been observed only along Red Creek and in Mountain Home Draw.

Well-formed garnets occur mostly in schist that is relatively free of interlayered quartz. Where quartz 


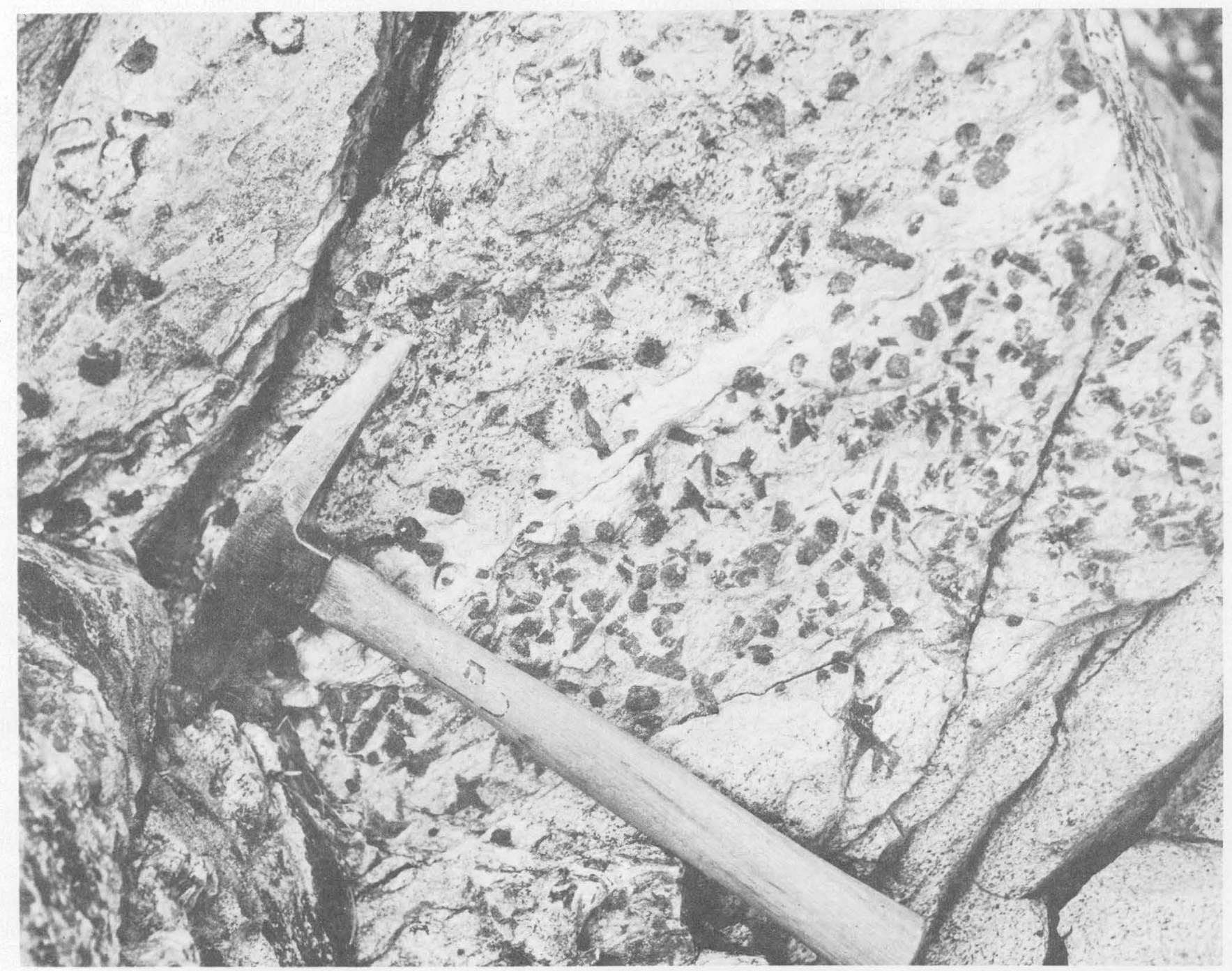

Figure 6.-Close view of quartz-muscovite schist at Red Creek near SW. corner sec. 4, T, 2 N., R. 24 E. Metacrysts of staurolite and garnet. Abundant specks near point of hammer and near butt of handle are biotite. Note twinned staurolite crystals.

laminae are abundant the garnets are mostly lens or wafer shaped, owing to restricted growth normal to the foliation. Some garnets exceed $50 \mathrm{~mm}$ in diameter, but most are much smaller. Gem-quality garnet has not been found, but well-crystallized specimens are abundant.

Although staurolite is less widespread than garnet, it is the chief metacryst of the schists along Red Creek. In the SW1/4 sec. 4, T. 2 N., R. 24 E., dark-reddishbrown to nearly black staurolite exceeds 30 percent by volume of some rocks. Prismatic crystals $40 \mathrm{~mm}$ long or more are common. Twinned crystals $\left(60^{\circ}\right.$ penetration twins) are abundant, but $90^{\circ}$ cruciform twins are rare. In general the crystals are randomly arranged in the plane of schistosity, but in places they are rudely oriented subparallel to a lineation formed by wrinkles in the schist (fig. 48) or form trains of randomly ori- ented crystals parallel to the lineation. Under the microscope the schist is seen to be chiefly quartz, muscovite, and staurolite (fig. 7). Some specimens also contain abundant garnet. Other constituents are biotite, apatite, magnetite (often as inclusions in staurolite), hematite, chlorite, and tourmaline. Most of the minerals are xenoblastic; staurolite, garnet, apatite, and tourmaline are idioblastic. The staurolite has a characteristic sieve texture caused by crowded inclusions of quartz; in some crystals the volume of included quartz exceeds that of the enclosing staurolite.

Kyanite is locally abundant in some schists along Red Creek and along Mountain Home Draw, where it occurs in the metaquartzite as well. At Red Creek, kyanite is associated with minor biotite and black tourmaline in a very quartzose mica schist. It forms large metacrysts, commonly as long as $30 \mathrm{~mm}$ and occasionally more than 


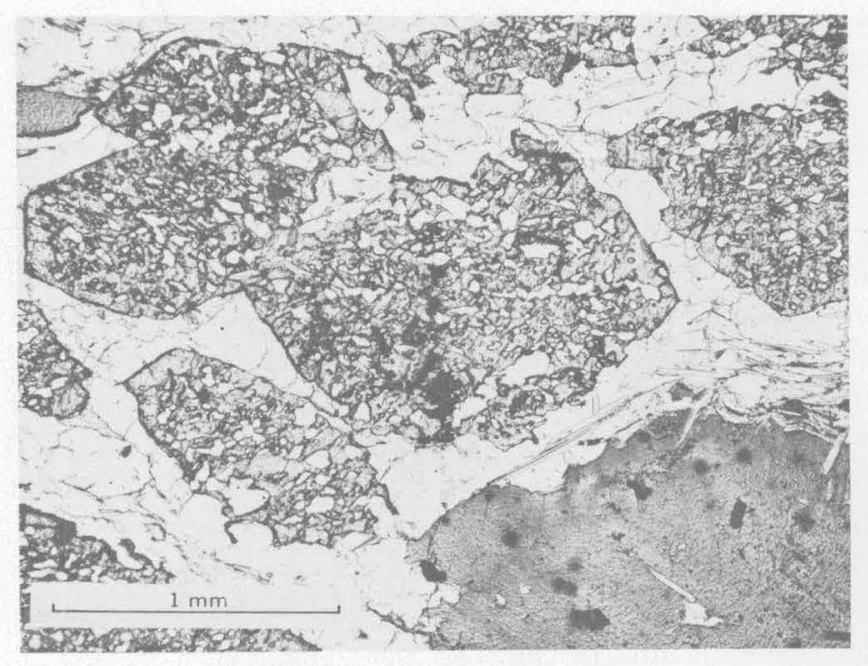

Figure 7.-Photomicrograph of staurolite-quartz-muscovite schist. Idioblastic staurolite contains crowded inclusions of quartz. Quartz and muscovite in matrix. Large biotite crystal with pleochroic halos, lower right. Black material in staurolite and biotite is magnetite. Plain light $\times 29$. Photograph by Wendell Walker.

$60 \mathrm{~mm}$. Lath-shaped crystals are randomly arranged in the plane of schistosity relative to (001) but have a preferred orientation of (100) parallel to the schistosity. In metaquartzite in Mountain Home Draw near the contact between mica schist and metaquartzite, bladed crystal aggregates $30-40 \mathrm{~mm}$ long are oriented at random.

Anthophyllite is a chief constituent of certain magnesian schists in the first large ravine east of Mountain Home Draw in the SW $1 / 4$ NE1/4 sec. 11, T. 2 N., R. 24 E. (fig. 8). These schists probably are derivatives of mafic intrusive rocks. They grade vertically into mica schist and are closely associated with thick bodies of amphibolite. They contain about 60 percent granular crystalloblastic plagioclase and 35 percent anthophyllite; minor constituents are sphene, hematite, biotite, and chlorite. Most of the anthophyllite is randomly oriented in the plane of schistosity and forms prismatic needles 5 or $6 \mathrm{~mm}$ in length.

\section{AMPHIBOLITE}

Amphibolite is far more abundant in the Red Creek Quartzite than the map indicates, mainly because countless small masses cannot be traced beyond single outcrops and hence cannot be portrayed adequately at the scale of the map. Virtually every outcrop area of any considerable size contains some amphibolite. The longest and thickest bodies crop out in the Mountain Home Draw-Jesse Ewing Canyon area (area 3) and are visible from the flats below in Browns Park. In the area around Beaver Creek (area 5), small thin bodies not shown on the map are exceedingly abundant and probably aggregate 30-40 percent of the total rock volume. Amphibolite is less abundant in the Goslin Mountain-

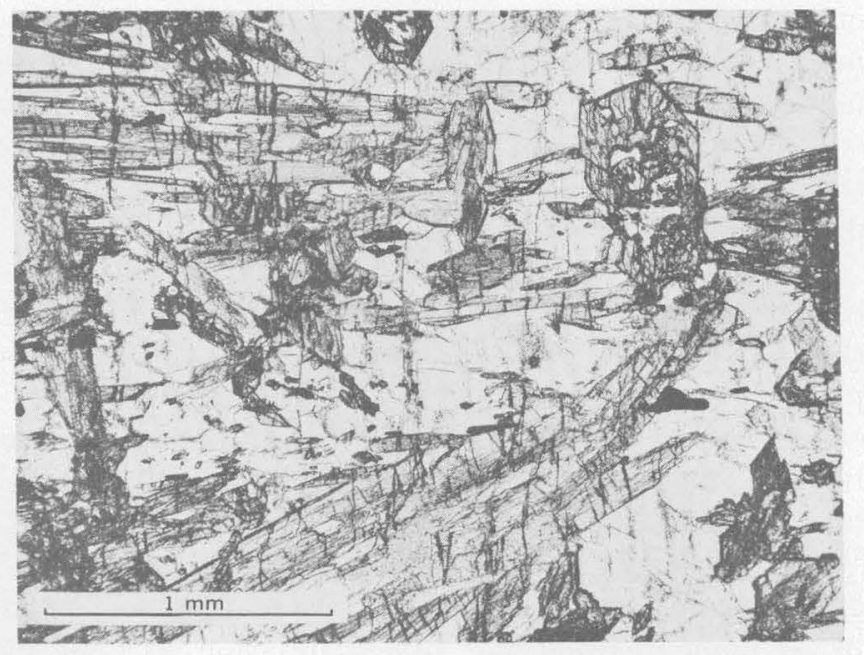

FIGURE 8.-Photomicrograph of anthophyllite-plagioclase schist, southeast slope of Mountain Home. Idioblastie anthrophyllite in matrix of untwinned plagioclase. Accessory hematite and sphene. Section cut normal to foliation, plain light $\times 29$. Photograph by Wendell Walker.

Red Creek area (area 2), but it is a major rock type even so; area 2 , because of its ready access, is one of the best places to view and study the rock.

Amphibolite in the Red Creek is derived from mafic igneous rock that was intruded into the country rock as sills, dikes, and irregular bodies and subsequently modified by regional dynamic metamorphism. Despite complete reconstitution, a generally foliated character, and other textural changes, the amphibolite retains abundant evidence of its intrusive origin, and many of the spatial relationships of amphibolite to metaquartzite probably are much the same as at the time of intrusion. Viewed from a short distance, many amphibolite bodies appear as unmodified intrusive bodies; close examination reveals their metamorphic textures. Most amphibolite bodies have sharp contacts and are concordant, or nearly so, having been intruded as sills; many, however, cut across the bedding in the country rock at various angles or, after paralleling bedding for some distance, turn abruptly across bedding to follow a joint plane or to fill an angular reentrant in the wallrock. Some bodies terminate abruptly against a joint plane; others taper to a blunt or a sharp wedge; still others feather out along bedding planes as thin lit-par-lit injections. Some contain angular xenoliths of metaquartzite. Quite clearly, the quartzite-schist country rock was strongly deformed before the amphibolite was injected as mafic igneous rock. It was redeformed after injection, and the mafic rock was amphibolitized in the ensuing metamorphism.

Most of the amphibolite has a strong secondary foliation, but all gradations exist between strongly foliated amphibolite on the one hand and nonfoliated epidiorite 
on the other. Thick bodies of foliated amphibolite commonly contain indefinite masses of vaguely foliated or nonfoliated material, especially well in from their borders. This material probably has inherited its texture-which is mostly blastophitic-from an originally diabasic intrusive parent rock.

Foliation in the amphibolite is due partly to segregation banding but chiefly to a preferred orientation of the constituent hornblende laths. This orientation is planar, linear, or both. In most exposures, planar orientation is pronounced; linear orientation-parallel to linear elements in the metaquartzite and mica schistis widespread but not generally strongly marked. Where the foliation is planar but not linear, the $C$ crystallographic axes of the laths are randomly oriented in the plane of foliation. Linear foliation is caused by parallelism of $c$ axes.

Under the microscope the amphibolite is seen to be composed chiefly of green hornblende, which makes up as much as 95 percent of some rocks. Individual grains are rarely more than $1 \mathrm{~mm}$ long and generally are much shorter. Sections cut normal to the lineation (the $b$ fold axis) generally show a crystalloblastic texture. Some grains, however, show well-formed prismatic faces. In some slides the texture is cataclastic. Highly saussuritized plagioclase makes up as much as 50 percent of some rocks but averages nearer 20 percent. Where determinations can be made the plagioclase ranges mostly from oligoclase to andesine, but in some slides it is as calcic as labradorite. Quartz is a usual minor constituent, generally forming less than 5 percent of the rock.

Accessory minerals are garnet, magnetite, ilmenite, sphene, leucoxene, hematite, apatite, and calcite. Garnet is relatively uncommon in amphibolite but is abundant locally, as in exposures on the north slope of Two Horse Butte where it forms crystals as much as $15 \mathrm{~mm}$ across. Magnetite is almost ubiquitous, generally as irregular grains but occasionally as idioblastic crystals. Ilmenite altering to leucoxene is common. In places ilmenite grains are enclosed by rinds of titanite. Most of the titanite, however, forms aggregates of droplike grains not directly associated with ilmenite. Hematite is a common minor accessory in amphibolite, generally forming flakes that lie in the plane of foliation. Apatite forms minute rods and grains, commonly idioblastic. Calcite mostly forms thin crosscutting veins but also forms irregular grains in the groundmass of the rock.

In many places, small masses of chloritic schist probably derived from amphibolite through retrograde metamorphism grade into amphibolite; practically all observed chloritic schist in the area in some way is associated with amphibolite. The chlorite schist min- eral suite resembles that of amphibolite except that chlorite, abundant muscovite, and, in some thin sections, clinozoisite and biotite are present instead of amphibole.

\section{EPIDIORITE}

The term "epidiorite" is applied to certain nonfoliated dioritelike rocks that are rather widely exposed but are of mappable dimensions only on the northeast slope of Goslin Mountain. These rocks would be called metagabbro by some geologists. The largest and most accessible body of epidiorite crops out in sec. 25, T. 3 N., R. 23 E., and in sec. 30, T. 3 N., R. 24 E., adjacent to the Uinta fault, which truncates it on the north. This stocklike body is about 7,000 feet long and about 1,200 feet wide. A small mass of similar rock crops out about a mile to the west near the NW. cor. sec. 26 , T. 3 N., R. 23 E. Both of these bodies possess foliated outer shells or borders of amphibolite. Likewise, many thick masses of amphibolite possess nonfoliated cores of epidiorite, although in this type of occurrence epidiorite is too restricted areally to be shown on the map. In the field, all gradations may be observed from nonfoliated to strongly foliated rocks. The epidiorite appears to be pretectonic in that its emplacement was followed by deformation, but it appears to have largely resisted internal deformation; smaller, thinner bodies of mafic intrusive rock and the margins of large bodies have yielded to deforming stress by conversion to amphibolite; the epidiorite retains the general texture of its igneous parent, although it is modified mineralogically.

Wide variations in texture and grain size, even within single rock bodies, characterize the epidiorite. Textures range from blastophitic to coarse granoblastic but for the most part may be described as blastophitic; they show irregularly bounded, ragged hornbleinde crystals partly enclosing lath-shaped to xenoblastic feldspar. Hornblende constitutes 60 percent or more of the rock and generally is somewhat poikilitic. The larger grains are $\mathbf{5 - 1 0} \mathrm{mm}$ in diameter; these grains may be single optically continuous crystals, multiple twins, or aggregates of numerous small intergrown crystals. Highly saussuritized feldspar-now mostly epidote and sericite-constitutes about 30-40 percent of the rock; unaltered remnants of feldspar are chiefly oligoclase or andesine; some remnants are as calcic as labradorite. Common minor constituents of the epidiorite are much the same as those of the amphibolite and include quartz, which forms less than 5 percent of the rock; ilmenite or magnetite; sphene; apatite; hematite; and a metallic sulfide, probably pyrite. Some rocks appear to contain both magnetite and ilmenite. Leucoxene, the titanium alteration product, is common in most thin sections. Sphene is common in 
drop-shaped grains, mostly in clusters. Carbonate rock, or veinlets of carbonate material, are frequent associates.

GRANITIC VARIANTS OF EPIDIORITE AND AMPHIBOLITE

Granitic variants of amphibolite and epidiorite are among the most unusual rocks in the entire area, but they are very minor in bulk and are restricted areally and hence are not differentiated on the map. These rocks have the megascopic appearance of gray mediumgrained granite and have the composition of albite granite. Their chief constituents are albite and quartz in a ratio of about 3 to 2 , and they appear to have formed by albitization and silicification of parent amphibolite or epidiorite. Very minor constituents are blue-green hornblende, magnetite, titanite, apatite, and epidote, and abundant veinlets of calcite. Granitic variants crop out in area 2 (Goslin Mountain quadrangle) in the SW $1 / 4$ SW $1 / 4$ NE $1 / 4$ sec. 25 , T. 3 N., R. 23 E., on the north slope of Goslin Mountain; in area 3 (Clay Basin quadrangle), they crop out in the center of sec. 11, T. 2 N., R. 24 E., on a small knoll east of Mountain Home Draw and in the SW1/4 SW1/4 sec. 6, T. 2 N., R. 25 E., in a large outcrop in a side ravine of Jesse Ewing Canyon. In the latter two localities the enclosing rock is amphibolite; in the former, epidiorite. The variant rock grades indefinitely into the enclosing parent rock.

Under the microscope, quartz and albite are seen in irregular to subgeometric micrographic intergrowths in which albite is the host (fig. 9). Albite grains are penetrated by tongues, veinlets, or rounded protuberences of quartz. The albite is fresh and clear, in contrast with the altered saussuritic feldspar seen in amphibolite and epidiorite.

Two forms of albite are seen in most thin sectionsan untwinned or simply twinned form and a complexly twinned form. The complexly twinned albite is intergrown with quartz; it forms combinations of pericline and albite twins. The untwinned albite contains little or no intergrown quartz. Very commonly the two forms of albite have a zonal structure caused by an untwined quartz-free core enclosed by a complexly twinned shell that contains abundant intergrown quartz (fig. 9). The zone boundary commonly coincides with crystallographic planes and gives a pseudoeuhedral appearance to the untwinned albite, but optical continuity extends from the untwinned core into the twinned intergrown shell. Apparently some factor interposed by the quartz during replacement of the albite, such as strain caused by crystallization pressure, promoted twinning in the albite.

Sharp extinction of the quartz in the variant rock contrasts with the undulatory extinction of the quartz
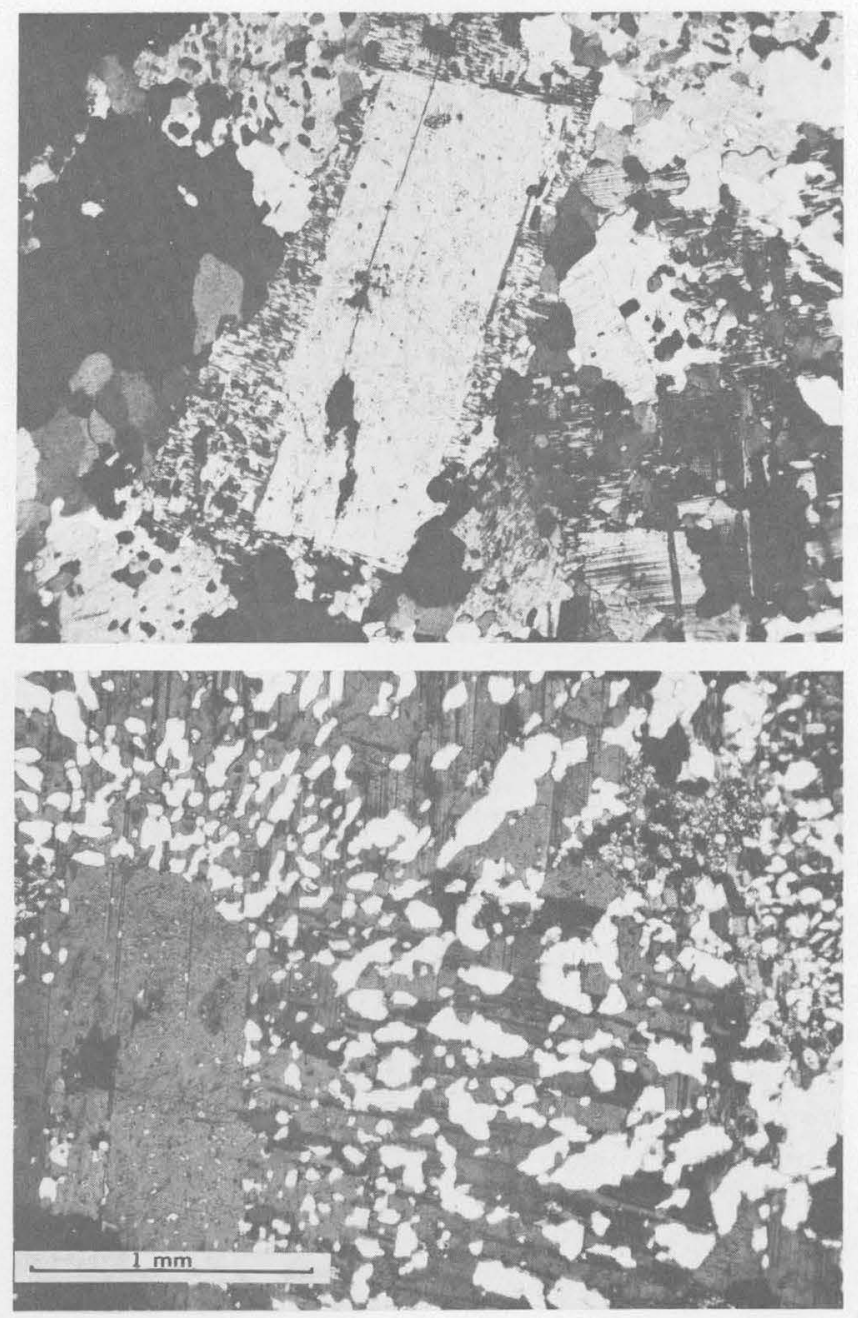

Figure 9.-Photomicrographs of granitic variants of amphibolite, Jesse Ewing Canyon area. Quartz replacing albite. Irregular albite grain (upper photograph) has untwinned pseudoeuhedral core; core is optically continuous with complexly twinned shell. Similar pseudoeuhedral core in albite grain (lower photograph) and complexly twinned shell. Micrographic intergrowth of quartz and albite in shell (lower photograph); quartz-free core. Albite is the host. Quartz and albite are each optically continuous. Crossed nicols $X$ 29. Photographs by Wendell Walker.

in the amphibolite, epidiorite, and metaquartzite; it suggests that silicification of the variant rock was largely posttectonic. A general lack of foliated structure in the variant rock suggests that albitization was posttectonic also. Similarly, the freshness of the albite suggests an age difference between the albite and the saussuritic feldspars of the adjoining amphibolite and epidiorite.

In at least one location, near the road in Jesse Ewing Canyon at the boundary between secs. 6 and 7, T. 2 N., R. 25 E., the variant rock has a cataclastic texture - the quartz and feldspar are considerably granulated and the hornblende is arranged in streaks or wisps. The feldspar, however, is not saussuritized. The variant rock thus appears to have been subjected to a relatively 
shallow cataclastic deformation, along with all earlier formed rocks, but not to the deep-seated metamorphism and deformation of the earlier formed rocks.

In summary, most of the granitic variants possess the following characteristics: (1) Localization within larger masses of amphibolite of epidiorite, (2) the composition and appearance of albite granite, (3) irregular or micrographic intergrowths of albite and quartz, in which albite is the host, (4) no twinning or very simple twinning in unintergrown feldspar and very complex albite-pericline twinning in intergrown feldspar, (5) very slight saussuritization of the feldspar, and (6) small amounts of blue-green hornblende.

\section{CARBONATE ROCK}

Carbonate rock-chiefly calcite rock-is quantitatively very minor in the Red Creek Quartzite, but is of considerable significance. Its origin is not entirely clear, but two possibilities seem likely: (1) part of it almost certainly is metamorphosed limestone, and (2) part of it is epigenetic and possibly is derived from preexisting mafic rocks through metamorphism, perhaps through transformation of calcic feldspar to less calcic feldspar, accompanied by a release of calcium oxicle.

Several large masses of carbonate rock crop out in area 2 on the northeast slope of Goslin Mountain, especially near the east end of the large epidiorite body there; one mass about 400 feet long and 100 feet or so wide forms a gray craggy outcrop visible from the road below in Clay Basin. Many small deposits of carbonate rock, some deep red in color, crop out on the southern slopes of Mountain Home in area 3 (Clay Basin quadrangle), especially in the $\mathrm{NE}^{1} / 4$ sec. 11 , T. 2 N., R. 24 E. Layered deposits of probable sedimentary origin are common near Jesse Ewing Canyon, especially on the ridge northwest of Band Box Butte; on weathered surfaces these deposits show a banded habit that appears to be relict bedding.

Much carbonate rock has been observed in association with amphibolite or epidiorite and appears to have been derived from these rocks by metamorphism. In any event, field relationships appear to rule out a syngenetic origin inasmuch as the carbonate rock cuts across other rocks and occurs chiefly in irregular podlike or veinlike masses clearly younger than the rocks with which it is in contact (fig. 10). Conceivably, however, earlier formed carbonate rock may have been mobilized by intense diastrophic pressures and injected as a plastic solid.

The carbonate rocks are mostly medium to coarse grained and range in color from very pale pink to deep red $(5 R 4 / 4)$; weathered surfaces have an overall dull gray or pink appearance. Some of the rocks contain

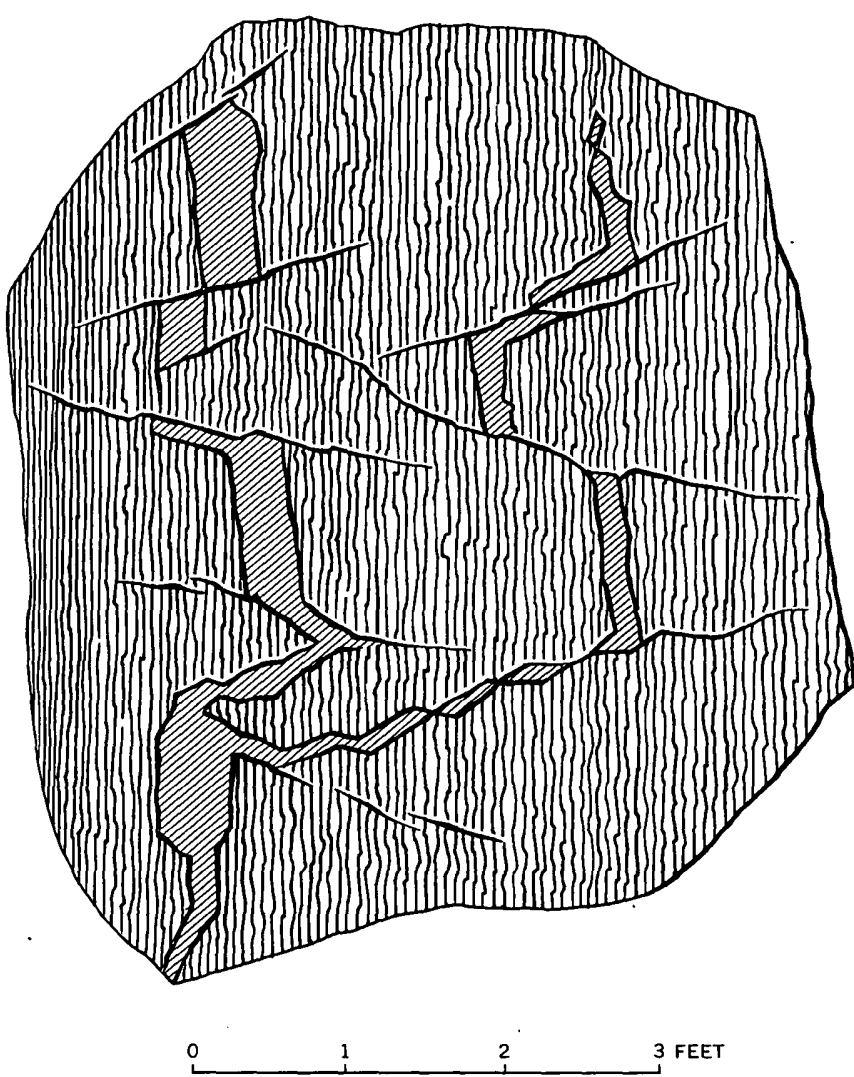

FIGURE 10.- Small carbonate velns in amphibolite, Red Creek Quarzite, east slope of Goslin Mountain. Veins controlled by foliation and small transverse joints. From a field sketch.

pearly white tremolite forming rosettes or fibrous aggregates or, where iron and magnesia are more abundant, showy crystals of pale-green actinolite and minute bright-green blebs of chlorite. Apatite and quartz are common minor constituents but are visible only under magnification.

Some deep-red (on the outcrop) carbonate rocks produce an earthy hematitic gossan associated with limonite on which prospectors in the past opened small exploratory pits. Some veinlike deposits of carbonate rock are associated with occurrences of copper minerals.

\section{PEGMATITE}

For a unit that has undergone relatively highgrade metamorphism, the Red Creek Quartzite contains comparatively little pegmatite. Many large exposures of the formation, however, display some pegmatitic material in the form of small dikes, sheets, pods, and irregular masses. Most of these bodies are confined to single outcrops and rarely exceed a few feet in length; in such form, pegmatite is fairly common in parts of the Beaver Creek area. A few large bodies crop out on the southeast slopes of Mountain Home in secs. 11 and 12, T. 2 N., 
R. $24 \mathrm{E}$. In the $S W 1 / 4$ sec. 11 , one tabular mass about 100 feet wide and 1,200 feet long forms a high prominent outcrop. Other large bodies crop out in the same vicinity.

Pegmatite is distinctly younger than the metasedimentary rocks that make up the bulk of the Red Creek Quartzite. These rocks had been severely deformed, injected with mafic magma, redeformed, and metamorphosed before the pegmatite was introduced. In a strict sense, therefore, the pegmatite is not a part of the Red Creek Quartzite, but it is so described partly for convenience of presentation and partly because the many small pegmatite bodies in the formation cannot be mapped separately at the scale used in this report. The pegmatite lacks the foliation and other evidences of strong deep-seated deformation that characterize the bulk of the formation, hence its intrusion must have been largely posttectonic. . Most pegmatite bodies, however, have been mildly deformed at a relatively shallow depth chiefly by shearing or by displacement along small faults.

In structure and composition the pegmatite bodies are simple; they lack obvious zoning and consist mainly of feldspar, quartz, and muscovite. The feldspar is microcline, perthite, and albite. Microcline and quartz form fairly common graphic intergrowths. Black tourmaline is a common megascopic accessory mineral, both in the pegmatite itself and in the immediately adjacent wallrock. Apatite forms minute rods; metallic sulfide occurs locally as minute grains; beryl has been noted in a single outcrop. A prospect hole in albite-quartz-muscovite pegmatite in the SW1/4 sec. 35 , T. 3 N., R. 24 E., near the east end of Mountain Home contained mica books 2 inches in diameter.

Most pegmatite bodies have a pink or salmon color, caused by the predominant microcline or perthite; but the overall color on the outcrop is generally neutral or milky white, owing to surface weathering of the feldspars. For this reason, many outcrops of pegmatite lack distinction except on close examination and from short distances are easily overlooked or mistaken for metaquartzite.

\section{AGE AND CORRELATIONS}

Muscovite from schist in the Red Creek Quartzite, collected in Jesse Ewing Canyon, sec. 6, T. 2 N., R. 25 E., has been dated at 2,320 m.y. (million years) by the rubidium-strontium method and at $1,520 \mathrm{~m} . \mathrm{y}$. by the potassium-argon method. Muscovite from a pegmatite that intrudes the Red Creek on the east shoulder of Mountain Home, sec. 35, T. 3 N., R. 24 E., was dated by Geochron Laboratories, Inc., at 1,550 20 m.y. by the potassium-argon method. The similarity of potassiumargon ages for the schist and the younger pegmatitic muscovite suggests a thermal event or period of metamorphism at or subsequent to the time the pegmatite was emplaced. Muscovite from a pegmatite at Bountiful Peak, near Salt Lake City, Utah, was dated by Giletti and Gast (1961) at approximately 1,500 m.y. by the rubidium-strontium method. They also reported several rubidium-strontium ages in the range 1,460-1,700 m.y. from southwestern Montana.

In the light of the 1,500 m.y. ages, the 2,320 m.y. age for the muscovite schist from the Red Creek Quartzite must be regarded as a minimum age. Precambrian rocks, 2,500 m.y. or older, have been reported (Gast, Kulp, and Long, 1958; Giletti and Gast, 1961) from Montana and Wyoming. It is possible that the Uinta Mountains have had a similar early history and that the Red Creek Quartzite was metamorphosed 2,500 million or more years ago. The rubidium-strontium age of 2,320 m.y. is then a survival value.

Isotopic age analyses of Red Creek Quartzite

[Asterisk (*) indicates radiogenic isotope]

ANALYSIS OF MUSCOVITE FROM SCHIST, JESSE EWING CANYON, UTAH

Potassium-argon analysis

[Analysts: H. H. Thomas, R. F. Marvin, P. L. D. Elmore, and H. Smith]

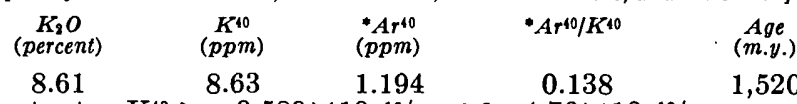

Constants: $\mathrm{K}^{10} \lambda_{\epsilon}=0.589 \times 10^{-10} / \mathrm{yr}, \lambda \beta=4.76 \times 10^{-10} / \mathrm{yr}$. $\mathrm{K}^{40}=1.21 \times 10^{-4} \mathrm{gm} 1 \mathrm{gm} \mathrm{K}$

Rubidium-strontium analysis [Analysts: C. E. Hedge and F. G. Walthall]

$\begin{array}{ccccc}\begin{array}{c}R b^{87} \\ (p p m)\end{array} & \begin{array}{c}\text { Normal } S r \\ (p p m)\end{array} & \begin{array}{c}* S r^{87} \\ (p p m)\end{array} & * S r^{87} / R b^{87} & \begin{array}{c}\text { Age } \\ (m . y .)\end{array} \\ 73.25 & 158.48 & 2.54 & 0.0347 & 2,320\end{array}$

Constants: $\operatorname{Rb}^{87} \lambda \beta=1.47 \times 10^{-11} / \mathrm{yr}$ $\mathrm{Rb}^{87}=0.283 \mathrm{gm} / \mathrm{gm} / \mathrm{Rb}$

POTASSIUM-ARGON ANALYSIS OF MUSCOVITE FROM PEGMATITE INTRUDING RED CREEK QUARTZITE, MOUNTAIN HOME, UTAH

[Analysts: Geochron Laboratories, Ino.]

\begin{tabular}{|c|c|c|c|c|}
\hline $\begin{array}{c}\mathrm{K}_{2} \mathrm{O} \\
\text { (average percent) }\end{array}$ & $\begin{array}{c}K^{40} \\
(p p m)\end{array}$ & $\begin{array}{l}* A r^{40} \\
(p p m)\end{array}$ & $A r^{40} / K^{40}$ & $\begin{array}{c}A g e \\
(m . y .)\end{array}$ \\
\hline $\begin{array}{c}8.49 \\
\text { onstants: }\end{array}$ & $\begin{array}{l}10.36 \\
\epsilon=0.5\end{array}$ & $\begin{array}{l}1.460 \\
0^{-10} / \mathrm{y}\end{array}$ & $\begin{array}{l}0.141 \pm 0.002 \\
3=4.72 \times 10^{-10} \\
K\end{array}$ & 1,550 \\
\hline
\end{tabular}

Detailed correlations of the Red Creek Quartzite with other Precambrian formations of the Middle Rocky Mountain region are not yet possible, but favorable comparisons based on lithology, metamorphic grade, and structural complexity can be made with several units (table 2). The Red Creek is very similar to rocks found by Stringham in the Albion Range Group exposed in the Grouse Creek Mountains in northwestern Utah (B. F. Stringham, oral commun., 1960), to the Little Willow Series of the central Wasatch Mountains, and to the Medicine Peak Metaquartzite of Blackwelder (1926) of southern Wyoming. Similar rocks crop out in several other ranges of southern and eastern Wyoming. Rocks of similar lithology but some- 
what lower metamorphic grade, and perhaps younger age, crop out in the northern Wasatch Mountains near Willard, Utah, near Promontory Point, Utah, and on some of the islands of Great Salt Lake (Eardley and Hatch, 1940, p. 800).

Certain lithologic types are common to the rocks of all the above formations and localities. These include quartzites, pelitic schists (or lower grade equivalents), and, in part, amphibolites. Nearly identical green quartzites are found at most of the above localities, although they are variably recrystallized. In some degree, all the quartzites possess crystalloblastic textures, and the variations within a given unit are nearly as great as those within the several units. The quartzites of the Albion Range Group seem to be the most severely deformed; those of the Red Creek Quartzite and Little Willow Series are next in order; and those of the Willard, Great Salt Lake, and Medicine Peak areas are perhaps least deformed.

\section{ENGINEERING CHARACTERISTICS}

Most of the Red Creek Quartzite is highly pure massive metaquartzite and as such is among the hardest and toughest of all existing rocks. The rock is very brittle, however, and large parts of the formation have been thoroughly fractured or even shattered by repeated deformations since the rock was formed. Such fracturing would greatly facilitate quarrying or excavation of the rock. Preliminary drilling and blasting would be required in virtually all excavations into firm rock, including most schists and amphibolites as well as quartzites, although power tools alone might suffice locally in some schistose or shattered zones. Except for its resistance to the drill, the Red Creek Quartzite presents few foreseeable engineering problems. It is stable on very steep slopes, some mica schist zones possibly excepted, is well drained, and has relatively great bearing strength. In most excavations the formation could be expected to stand unsupported in near-vertical cuts, except again, perhaps in some schistose and shattered zones.

\section{UINTA MOUNTAIN GROUP (YOUNGER PRECAMBRIAN)}

The Uinta Mountain Group is the most widely exposed and, except possibly the Red Creek Quartzite, the thickest unit in the Uinta Mountain area. It crops out in virtually continuous exposure from one end of the range to the other-a distance west to east of about 140 miles-in a belt that ranges in width from 15 to 20 miles or more. It forms the main divide and the major peaks of the range proper as well as the greater part of the highland north of the Green River between Flaming Gorge and Cold Spring Mountain. Underlain by the Uinta Mountain Group are Dowd Mountain,
Bear Mountain, and both rims of Red Canyon (fig. 58) ; most of Goslin Mountain, Mountain Home, Head of Cottonwood, and O-Wi-Yu-Kuts Mountain; and Cold Spring Mountain, Swallow Canyon, and all of the area south of Browns Park. In Browns Park the Uinta Mountain Group passes beneath the Browns Park Formation. It underlies more of the mapped area than all other formations combined, and its significance to the ultimate engineering development, and hence to the future economic development, of the area is proportionately large. Flaming Gorge Dam and its appurtenant structures lie deep in Red Canyon within the outcrop area of the Uinta Mountain Group.

\section{AGE AND CORRELATIONS}

For many years the age and correlations of the Uinta Mountain Group were in doubt. Marsh (1871, p. 191), who examined the group but briefly, believed that it was at least in part Silurian; Hayden (1872, p. 50) "strongly suspected" that the upper part of the group was Lower Silurian and compared it with the Potsdam Sandstone ${ }^{3}$, but he considered the lower greater part to be Huronian (that is, Precambrian) and comparable to the Sioux Quartzite of the North Central States. Despite Hayden's essentially correct appraisal, many years passed before the Precambrian age of the group was widely accepted. With some reservation, Powell (1876, p. 70, 141) considered it to be Devonian, though, according to White $(1889$, p. 687$)$, Powell as early as 1879 believed that the Uinta Mountain Group was Precambrian. Emmons (1877, p. 189, 199) and King (1878, p. 140) correlated it with the Weber Quartzite and assigned it to the Carboniferous, "6*** not, however, without some questioning, ***" mainly because they were unable to find an unconformity between the Uinta Mountain Group and the overlying rocks. By 1907 Emmons (p. 301) regarded the group as undoubtedly Precambrian; Berkey (1905, p. 529) mapped it as Cambrian; and Weeks (1907, p. 432) considered it to be Precambrian. In 1910 Gale (p. 47) assigned the group to the Algonkian (?) ; 10 years later Butler, Loughlin, and Heikes (1920, pl. 4) mapped it as Cambrian; Schultz (1920, table opposite p. 24) considered it to be Precambrian. General acceptance of a Precambrian age came during the 1920's and 1930's, and in 1934 the Geological Survey accepted the Precambrian age without question.

Comparisons have been made between the Uinta Mountain Group and other younger Precambrian rocks

\footnotetext{
3 At the time of Hayden's report the term Lower Sllurian referred to what is now the Ordovician System. At that time, also, the name Potsdam Sandstone was loosely applied to various sandstones between the Lower Silurian and the Precambrian. The U.S. Geological Survey now classifies the Potsdam Sandstone as Upper Cambrian (Wilmarth, now classifies the
1938 , p. 1719).
} 
of the western interior such as the Big Cottonwood Formation of the Wasatch Mountains, the Belt Series of the northern Rockies, and the Grand Canyon Series of Arizona. Williams (1953, p. 2737) correlated the exposed section in the western Uinta Mountains with the Wasatch Mountain section and extended Wasatch Mountain nomenclature into the western Uinta Mountains. Although there is no reason to doubt the general equivalence of the units as a whole, no detailed correlation has yet been made between the units of Williams in the western Uinta Mountains and the sections exposed in the eastern Uinta Mountains, and the stratigraphic position of the western units relative to the eastern section is uncertain. A thick buff to white quartzite section noted in the western part of the range (Williams, 1953, p. 2737; Crittenden, 1955, p. 22) is lacking in the eastern part. Forrester (1937, p. 638) noted an upper and a lower red unit separated by a buff zone in the Mount Lovenia-Hayden Peak area 50 to 60 miles west of Flaming Gorge. This buff zone is the same as that noted by Williams and by Crittenden. . It either feathers out eastward, in which case equivalent red beds occur in the Flaming Gorge area, or it has been removed by erosion and only the underlying red beds remain.

\section{LITHOLOGY AND THICKNESS}

In Daggett County, Utah, and Moffat County, Colo., the Uinta Mountain Group consists predominantly of dark-red medium- to coarse-grained massive to crossbedded siliceous sandstone and quartzite. It contains considerable shale and conglomerate, however, and both of these rock types are well represented in the Flaming Gorge area. The group forms bold rugged outcrops and, in places, high sheer cliffs, so that thick and wellexposed sections can be viewed in many parts of the area. Impressive views of the group are had from the rims of Red Canyon near Green Lakes, where rim overlooks served by a short automobile road are maintained by the U.S. Forest Service. The short side trip to these points is recommended to persons traveling Utah Highway 44.

It has not been possible to determine with any great precision the total thickness of the Uinta Mountain Group in this area, but a reasonably good approximation is possible. Present estimates indicate that the group is about 24,000 feet thick, or about twice as thick as early estimates indicated (Powell, 1876, p. 142, 143).

On the west end of Cold Spring Mountain a very thick section uncomplicated by significant folding or faulting extends from the Uinta fault on the north at the top of the section to Browns Park on the south, where the group passes beneath the Browns Park Formation of Miocene(?)age. This section, based on a profile plotted from the new topographic map and on attitudes of bedding measured in the field, has an approximate thickness of 20,600 feet (Hansen, 1955b, p. $27)$. The section is incomplete, as it includes only those beds between the Uinta fault and the lowest exposures not concealed by the overlapping Browns Park Formation-the base and the top of the group are unexposed.

Just west of Cold Spring Mountain, however, across the O-Wi-Yu-Kuts fault, the basal beds of the Uinta Mountain Group are exposed in depositional contact with the underlying Red Creek Quartzite, and about 16,000 feet of beds is exposed between the basal contact and the Uinta fault. A correlation of beds across the $\mathrm{O}-\mathrm{Wi}-\mathrm{Yu}$-Kuts fault, though tentative, can be made with considerable confidence (fig. 11), so that a composite section can be constructed from beds exposed on opposite sides of the fault. (At the same time, the stratigraphic throw on the fault can be obtained.) This composite section has a thickness of about 24,000 feet; the throw of the fault is about 7,000 feet. Again, the composite section is incomplete inasmuch as the uppermost beds exposed are truncated by the Uinta fault. But the section appears to be very near the maximum for the possible thickness of the group inasmuch as the uppermost beds exposed against the Uinta fault, where correlated eastward on Cold Spring Mountain with the aid of aerial photographs, are found to directly underlie Mississippian strata with a sedimentary contact.

Despite its Precambrian age, the Uinta Mountain Group is little if at all metamorphosed. The hard, well-indurated sandstones that constitute the greater part of the group are cemented with hematite, which gives the rock its color, and with silica. In the more quartzitic beds an overgrowth of quartz completely fills the interstices between the original sand grains; optical continuity exists between the overgrowth and the original grains, and under crossed nicols the rock shows an interlocking texture, but the original grains are identified by the thin coating films of hematite (fig. 12).

The more vitreous quartzite was used widely by the prehistoric Indians for making various projectile points, scrapers, and other artifacts. Some of this material is cemented by chalcedony which entered the sandstone along thin veins and forms aureoles of highly vitreous quartzite around the veins; at some such places the ground is littered with chips and flakes of waste rock left by the Indians.

Conglomerate is common in the Uinta Mountain Group. In the Flaming Gorge area it attains its greatest thickness and widest areal extent at Jesse Fwing Canyon north of Browns Park. At the head of Jesse Ewing Canyon, in an unusual occurrence probably best. visualized as an alluvial-fan deposit, continuous sec- 


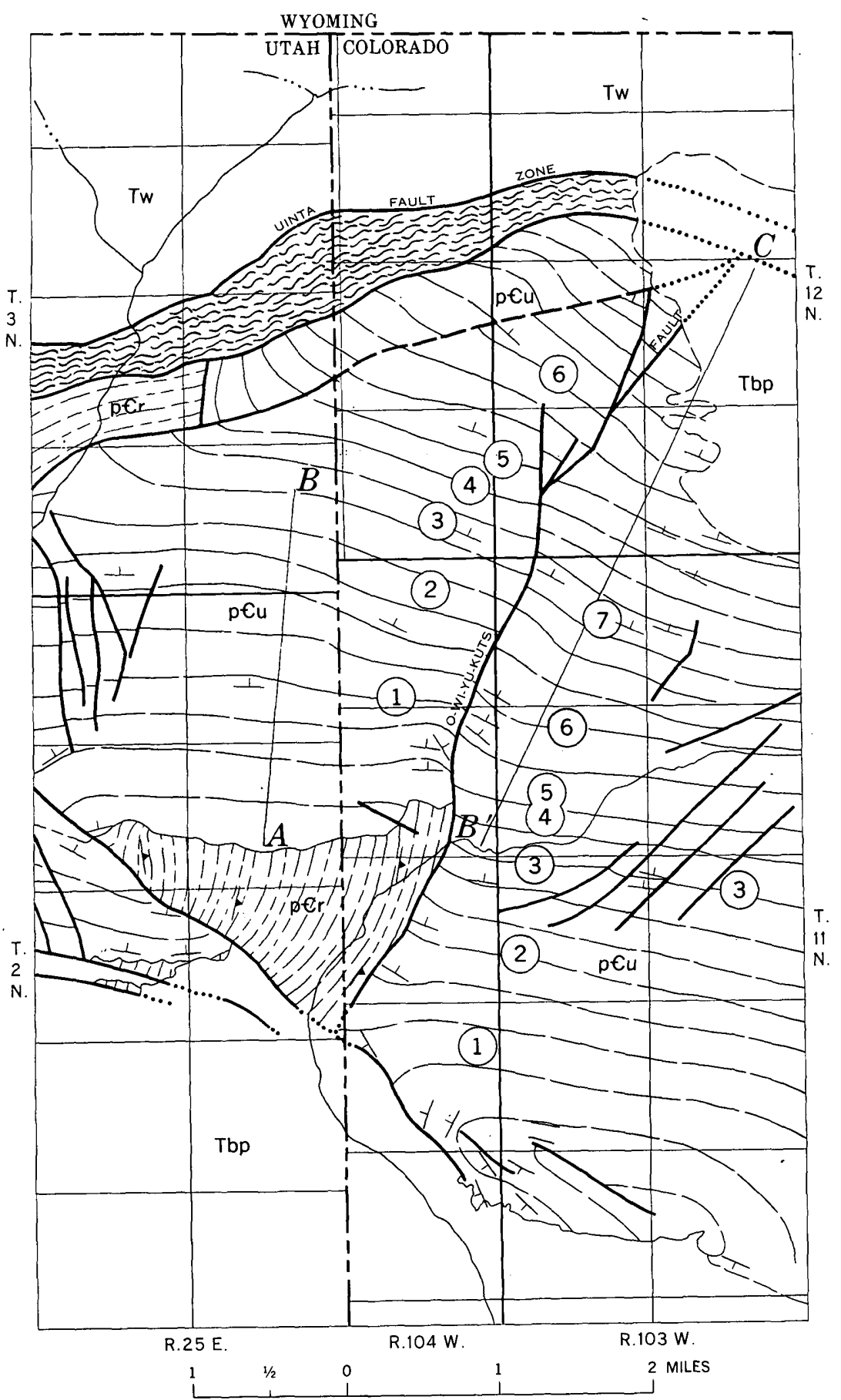

EXPLANATION

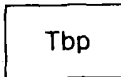

Browns Park Formation

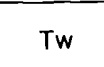

Wasatch Formation

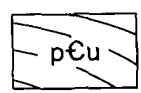

Uinta Mountain Group

Showing generalized structural trends

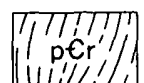 \\ Red Creek Quartzite \\ Showing generalized structural trends
}

Beds below 1: Alternate massive resistant ridgeforming tan to red quartzites and thick sections of nonresistant red shales and quartzites

1 to 3: Uniformly resistant well-bedded quartzite; occasional thin shale interbeds. Section forms very distinctive tonal pattern on aerial photographs. Two thin shaly units at 2 form parallel bands on aerial photographs

3: Key horizon; a prominent ledge- to ridgeforming red quartzite flanked below and above by nonresistant shaly rocks

3 to 4: Sequence of nonresistant shales and occasional ledge-forming quartzites

4 to 5: Sequence of alternate resistant ledgeforming quartzites and nonresistant valleyforming shales and quartzites, in about equal proportions

5 to 6: Sequence of nonresistant red shales and occasional ledge-forming quartzites. Similar to section between 3 and 4

6 to 7: Similar to section between 4 and 5. Quartzites form sharp ridges

Figdre 11.-Diagram to show correlation of stratigraphic sequences across O-Wi-Yu-Kuts fault and to show how composite thickness of 24,000 feet for Uinta Mountain Group was obtained by correlating beds across fault. Approximately 7,400 feet of strata is exposed between $A$ and $B$; about 20,600 feet of strata is exposed east of $O-W i-Y u-K u t s$ fault, of which approximately 16,600 feet is exposed between $B^{\prime}$ and $C$. (Beds concealed just south of $C$ crop out farther east.)

tions of conglomerate hundreds of feet thick tongue out rapidly into the adjacent quartzite. Along the west side of Jesse Ewing Canyon between the Uinta fault and the first outcrops of the Red Creek Quartzite to the south, the exposed section is mostly conglomerate. Less than a mile to the east on the Head of Cottonwood and to the west on Mountain Home, stratigraphic equivalents of the conglomerate are mostly quartzite, although conglomerate is still plentiful. Conglomerate is abundant on O-Wi-Yu-Kuts Mountain yet farther east and on Goslin Mountain farther west, but in greatly diminished amounts relative to that at Jesse Ewing 
Canyon. West from Goslin Mountain to the limits of the area, just a few thin pebbly beds have been observed in the great thicknesses of quartzitic sandstone.

The most accessible outcrops of conglomerate in the area are found about half a mile above the mouth of Jesse Ewing Canyon in the NW1/4 sec. 7, T. $2 \mathrm{~N}$., R. $25 \mathrm{E}$., where lenses of massive conglomerate interbedded with shale are faulted against the Red Creek Quartzite. Although not typical in all respects, these outcrops serve well to illustrate many of the features found in the various conglomerates in other parts of the Uinta Mountain Group. The conglomerates of the Uinta Mountain Group consist chiefly of well-rounded pebbles and cobbles of milky white metaquartzite in a siliceous sandstone matrix. Pebbles of amphibolite and other metamorphic rock types also derived from the Red Creek Quartzite are minor, relatively uncommon constituents. In many places the rock is so thoroughly indurated that it fractures across pebbles, cobbles, and matrix alike. Abundant hematite in the matrix and in films coating the pebbles and cobbles gives outcrops an overall pink to red cast. The metaquartzite undoubtedly was derived from the Red Creek Quartzite, and, in some places, where only broken weathered rock is exposed at the surface, Uinta Mountain Group conglomerate is easily mistaken for the Red Creek Quartzite.

Shale is widely distributed in the Uinta Mountain Group but, like conglomerate, is very subordinate in volume to siliceous sandstone and quartzite. Most shale beds are but thin partings in the more massive sandstones and quartzites, although some attain considerable thickness and areal extent. In the Hideout Canyon area, rapid erosion of shale is largely responsible for the development of subsequent drainage in the Uinta Mountain Group along the Uinta fault. One shale unit is conspicuous in the depths of Red Canyon near Green Lakes where it forms long steep slopes below high cliffs of red quartzite; although several hundred feet thick at this locality, this shale unit feathers out rapidly toward the east (Hansen, 1955a). In some places shale units can be traced for several miles along essentially continuous outcrops, but because of a lack of distinctive lithologic features and because of rapid lateral facies changes, no beds of any kind - shale, sandstone, or conglomerate - have been correlated with confidence across areas of structural complication or extensive cover. Shale units are well exposed rear the mouth of Jesse Ewing Canyon in the core of a small anticline, but they pass under cover toward the west and are faulted out toward the east. Thick shale beds crop out at the mouth of Red Canyon along the north side of the Green River near the head of Browns Park, but their continuity is obscured by slide rock, slope wash, and other overburden. Shale beds also crop out at various places in

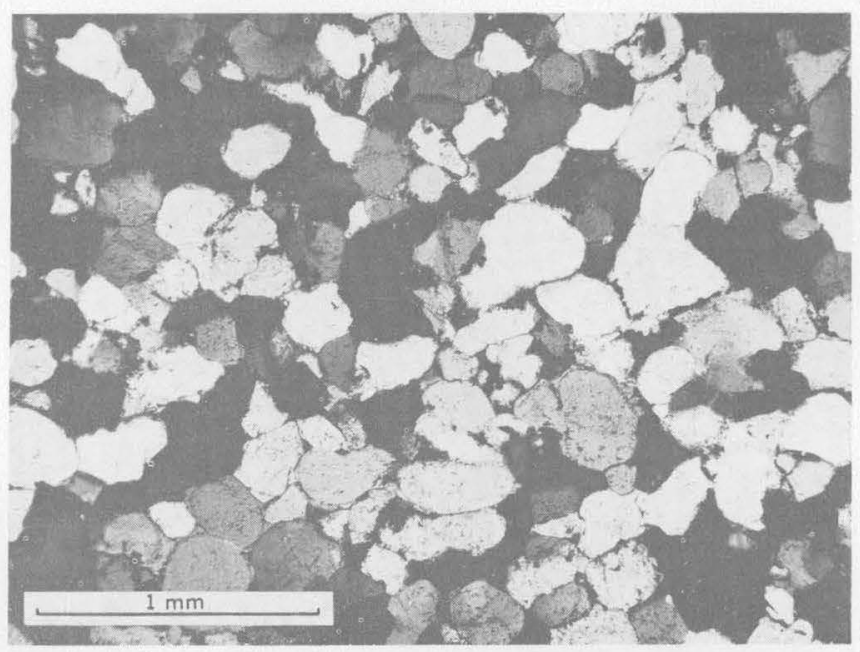

FIgUre 12.-Photomicrograph of sedimentary quartzite, Uinta Mountain Group near Beaver Creek. Well-sorted subrounded quartz grains firmly cemented by optically continuous quartz overgrowths. Note sharp extinction. Contrast with metaquartzite of Red Creek Quartzite, figure 5. Cross nicols $\times \quad 29$. Photograph by Wendell Walker.

the mountains north of Browns Park and in the Dutch John area north of Red Canyon; owing to their discontinuity, most of these occurrences have not been mapped.

Most of the shale is moderately well indurated owing to rather high-grade diagenesis, and some of it is sufficiently hard to be called argillite; a small proportion of the shale is soft and is semiplastic when wet. Ripple marks and occasional mud cracks suggest deposition in an intermittently flooded to shallow-water environment. The shales range in color from shades of red and lavender through olive green to light gray. The gray shales generally are the softer ones. The green color of some of the shales seems to be due to reduction of the iron, possibly by ground water, in shales that originally may have been red. In fresh roadcuts near the town of Dutch John, red and green coloration is seen cutting across bedding planes.

\section{BASAL CONTACT}

Exposures of the basal contact of the Uinta Mountain Group are confined to the area north of Browns Park where outcrops of the group are contiguous with the older Red Creek Quartzite. In most exposures, the basal beds, and several tens of feet of beds overlying the base, are coarse conglomerate, but in a few places the base is overlain directly by sandstone or quartzite. Good exposures of the contact can be seen at several places on the southeast slopes of Mountain Home where thick conglomerates overlie the Red Creek Quartzite. Band Box Butte on the west wall of Jesse Ewing Canyon (fig. 13) is an outlier of basal conglomerate. Good exposures of the contact can also be seen near the foot of the mountains between Willow Creek and Beaver Creek, near the 


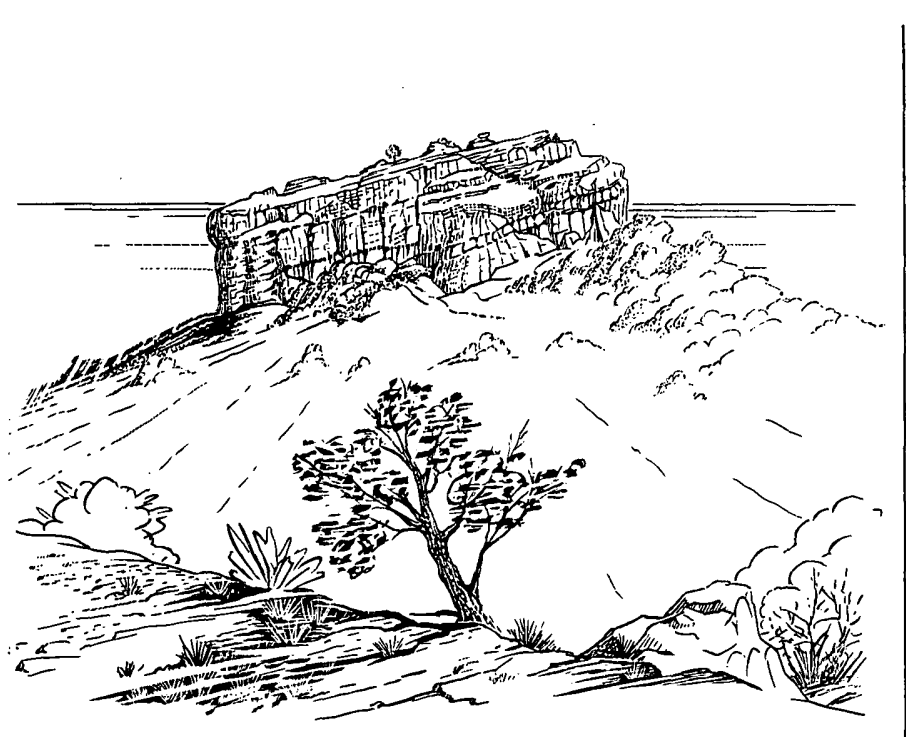

Figure 13.-Band Box Butte, an outlier of the basal conglomerate of the Uinta Mountain Group resting on the Red Creek Quartzite Conglomerate dips about $15^{\circ} \mathrm{N}$. Underlying Red Creek is about vertical. From a field sketch.

head of George Draw ; in that area the unconformity is overlain directly by nonconglomeratic quartzite.

The Uinta Mountain Group rests on the Red Creek Quartzite with an angular unconformity of considerable local relief. No way has been found to measure the total relief on the unconformity, but a local relief of several tens of feet or more is evident. At several places in the Clay Basin quadrangle (Hansen, 1957a) the relief exceeds 50 feet, and on the east side of Jesse Ewing Canyon it possibly is several hundred feet in a horizontal distance of about 1 mile. The early geologists who visited the area, notably Powell (1876, p. 139), made much of the supposed great magnitude of the unconformity. In deducing 8,000 feet or more of exposed relief, Powell apparently noted correctly the sharp local relief on the unconformity but misidentified the Goslin fault as an unconformable contact. Most early geologists also envisaged the Red Creek Quartzite as a buried Precambrian ridge (for example, King, 1878 , p. 139), largely because of its exposure on the limb rather than on the axis of the Uinta anticline-a belief that lent credence to the supposed great unconformity. But Hayden's view (1872, p. 66) was much more modern: "I am inclined to believe that the immense thickness of quartz was thrust up beneath the red quartzites, carrying the latter so high up that they have been swept away by erosion." The Red Creek Quartzite, we now know, was uplifted relative to the adjoining younger formations by faulting, and, as near as can be determined, the total relief on the unconformity at the base of the Uinta Mountain Group is hundreds rather than thousands of feet.
SOURCE OF SEDIMENTS AND DEPOSITIONAL CONDITIONS

The source of the Uinta Mountain Group in this area appears to have been northeastward. That direction is suggested by intertonguing of shales and sandstones (or quartzites), by foreset bedding in crossbedded sandstones, by feathering out of conglomerates, and by the lithology of the component pebbles, cobbles, and boulders in the conglomerates. As mentioned, most of the shales, particularly the very thick units exposed in Red Canyon, thin markedly eastward by intertonguing with sandstone beds that thicken eastward. Due south of the Flaming Gorge area on the south flank of the Uinta Mountains, Kinney (1955, p. 21) noted a rapid eastward thinning of shale units. Although Kinney attributed the thinning in that area to erosion prior to Late Cambrian time, he acknowledged the possibility of a facies change from shale to quartzite; in view of the relationships shown in Red Canyon on the north flank, the possibility of a facies change on the south flank seems good also.

Foreset bedding in the sandstones and quartzites of the Uinta Mountain Group suggests that the source of the material was to the north. A statistical coverage of the crossbedding of so large an area was prohibited by the limited time allowed for field mapping, but in examining the Uinta Mountain Group in countless exposures between Red Canyon and Cold Spring Mountain, I became convinced that the greater part of the foreset bedding had a westward or southward component of dip.

The greatest concentration of conglomerates in the Uinta Mountain Group is in the vicinity of Jesse Ewing Canyon, from whence conglomerates tongue out rapidly both toward the west and toward the east. Farther east near Galloway Creek, however, thick conglomerates are also very abundant. Nothing comparable occurs in the western part of the area, as for example in the Red Canyon-Greendale area, or in adjoining areas south of Jesse Ewing Canyon on the south side of Browns Park. On the northeast side of Goslin Mountain, a coarse cobbly bed of conglomerate more than a hundred feet thick feathers out southwestward into quartzite in less than half a mile of continuous exposure. Thick conglomerates crop out on the northwest shoulder of Goslin Mountain at the corner of secs. 29, 30,31 , and 32 , but their relationship to adjacent beds is beclouded by faulting. Apparently they have been uplifted relative to the adjacent beds. In any event, it appears that large fanlike deposits which accumulated in the northeastern part of the area thinned rapidly toward the west and south.

Conditions under which a great thickness of mostly coarse clastic material, such as the Uinta Mountain 
Group, may have accumulated are best satisfied by a rapidly subsiding trough (Eardley and Hatch, 1940, p. 840; Kinney, 1955, p. 22; Crittenden, 1955, p. 22) adjoined by nearby highland areas. Forrester $(1937$, p. 634) referred to this trough, which was well defined during much of post-Precambrian time also, as the Uinta trough, a usage that is followed here. Ripple marks in sandstones and quartzites as well as in shales, crossbedding, scour-and-fill structures, and sun cracks all suggest deposition in shallow water or in subaerial environments intermittently flooded by shallow water. Some sandstones near Hideout Flat at the head of Red Canyon contain glauconite, and thus probably were deposited in shallow marine waters.

How far the Uinta Mountain Group extends laterally beneath the Green River Basin to the north and the Uinta Basin to the south-hence the shape of the Precambrian Uinta trough-is problematical, because no wells have yet penetrated the thick columns of younger sediments that underlie the basins. Chances seem good that the group wedges out rapidly both to the north and to the south. North of the Green River Basin on the southwest side of the Wind River Mountains, quartzite of Cambrian age directly overlies granite of Precambrian age (Love, 1950, p. 26). South of the Uinta Basin in the San Rafael Swell, quartzite of Cambrian age also rests on granite (Bass, 1944, sheet 2). A clue to the possible lateral extent of the group is found to the west in the central Wasatch Mountains near Salt Lake City, where a thick sequence of younger Precambrian rocks similar to the Uinta Mountain Group emerges at the Wasatch front in alinement with the Uinta Mountain axis (Eardley and Hatch, 1940, p. 819). This sequence thins rapidly both to the north and to the south. It disappears just north of Salt Lake City. Fifty miles south of Salt Lake City, near Santaquin, the younger Precambrian is only 500-1,000 feet thick (Eardley, 1933, p. 313). Near Provo, the outcropping Precambrian rocks are slightly metamorphosed and appear to be older than the Uinta Mountain Group. These rocks, moreover, and those near Santaquin, are in the upper plate of a large thrust fault; they have been moved to their present position from a source many miles to the west (Max D. Crittenden, Jr., written commun., 1961). Thus, in the Wasatch Mountains area, younger Precambrian rocks similar to those of the Uinta Mountain Group form a thick sequence only in areas immediately northeast and southeast of Salt Lake City along the western projection of the Uinta Mountain arch; the distribution of these rocks in the Wasatch Mountains and the absence of similar rocks to the north and south of the Uinta Mountains suggest that the Uinta Mountain Group forms a thick prism of sediments that extends many miles west to east but thins rapidly to the north and to the south.

To yield so great a thickness of quartz sand as is found in the Uinta Mountain Group, the source area itself must have been of siliceous composition. A likely source of such material is the highly quartzose older Precambrian terrane east and northeast of the area-the rocks now exposed in the cores of the eastern Uinta Mountains, the Sierra Madre, and the Medicine Bow Range. The predominant red color of the sandstone is due to ferric iron, which coats but does not penetrate the individual sand grains. Iron, therefore, is a conspicuous but volumetrically relatively minor component of the rock; abundant iron-rich amphibolite in the older Precambrian rocks is a possible source. Lateritic alteration in the source area is a probable cause of red, oxidized state.

An obvious nearby source of sediment for the Uinta Mountain Group is the Red Creek Quartzite. As noted previously, pebbles, cobbles, and boulders lithologically identical with this rock are the chief components of the conglomerates of the Uinta Mountain Group. In some places, the basal conglomerate grades downward from moderately well rounded components, through a zone of brecciated metaquartzite, into undisturbed Red Creek Quartzite.

\section{ENGINEERING CHARACTERISTICS}

Because of its wide areal distribution, the Uinta Mountain Group inevitably will play a part in the enformation or combination of formations will become as much involved. A major part of the potential engineering development of the area lies within the outcrop limits of this group, as do Flaming Gorge Dam and its appurtenant structures of the Flaming Gorge reclamation project. In addition, all roads constructed across the mountains or extended into the Red Canyon area, most bridges that will be built across the Green River and virtually all good bridge sites below Flaming Gorge damsite, all aqueducts and canals through and along the mountains, most recreation sites, and most scenic overlooks possibly connected with recreation development or with road construction rising from the Flaming Gorge project are within the outcrop area of the Uinta Mountain Group. Practically all construction problems related to any such developments will involve the rocks of this group.

Fortunately, the physical characteristics of the Uinta Mountain Group are fairly uniform and in a large measure are predictable. For engineering purposes, the sandstones, quartzites, and conglomerates all behave similarly. All are resistant to erosion, and all possess great compression and shear strength. Much of their 
strength results from an overgrowth of secondary quartz around the original sand grains, which, as seen under the microscope, gives the rock an interlocking granular texture (fig. 12) and a physical homogeneity. The rock fractures across the grain rather than around it, and even conglomerate commonly breaks across the pebbles rather than along pebble boundaries. Although the strength of these rocks varies greatly, judging from physical manifestations observed in the field, it will in most instances well exceed the minimum requirements called for by any superincumbent manmade structure. The rocks are resistant to the drill, but they are brittle and break cleanly on blasting. They may be expected to stand at high angles without support in artificial cuts, and they will provide stable foundations for heavy structures of all types.

Shales of the Uinta Mountain Group, on the other hand, have a wide range of physical properties, depending on their composition, purity, and diagenetic grade. Some of them may behave in much the same way (for engineering purposes) as do the other rocks of the group, although most of them will act quite differently. Slope failure, for example, is much more common in shale than in any other rock type. Shear and compression strength are generally much lower; natural slopes are gentler, and artificial slopes will not stand as steeply without support. Explosives may be unnecessary for removal of material from deep excavations, although most shale sequences contain interbedded sandstone or quartzite that cannot be handled without blasting, and some of the shale itself is sufficiently indurated to necessitate blasting. A small part of the shale is slightly plastic when wet, but the greater part is argillitic and is nonplastic.

Landslides are uncommon in the Uinta Mountain Group, and most of those that have been examined involve either shale or dipping beds that have been undercut by erosion so that slippage along bedding planes has caused slope failure (that is, rock slides). In areas where bedding planes dip steeply, therefore, situations should be avoided that might lead to artificial rock slides. The most common manmade cause of rock sliding in such circumstances is the excavation of roadcuts into inclined strata where the angle of cut exceeds the dip of the bedding. Strata containing interbedded shales are particularly susceptible.

Most terranes underlain by the Uinta Mountain Group are well drained. Although the fresh rock is fairly impermeable, abundant near-surface joints, bedding planes, and miscellaneous fractures promote free drainage in most areas. The sandy residual soils that develop on the Uinta Mountain Group by mechanical disintegration of the rock are well drained also. Drainage problems might rise, however, in certain situations where the surface rock is shale, such as in road alinements in shale areas.

\section{PALEOZOIC ROCKS}

Paleozoic and Mesozoic rocks flanking the Uinta Mountains in this area are separated from Precambrian rocks by the large east-trending Uinta fault. The throw of the fault increases in magnitude from west to east and, concomitantly, successively younger formations toward the east are truncated by the fault. The easternmost outcrops of Paleozoic rocks in the area, except for fault slivers and fragments, are at the north base of Bear Mountain in sec. 4, T. 2 N., R. 21 E., where the Weber Sandstone and Park City Formation become faulted out. East from Bear Mountain, large detached slivers and blocks of limestone and sandstone of Paleozoic age, as well as younger rocks, crop out sporadically along the Uinta fault as far as Kleins Hill. East of Kleins Hill the fault passes into concealment beneath the Browns Park Formation. The best and most complete sections of Paleozoic rocks, therefore, are found where the throw of the fault is least-between Flaming Gorge and the southwest corner of the area.

Throughout most of early and middle Paleozoic time-late Cambrian time excepted-the eastern Uinta Mountains area probably was exposed to erosion. The Lodore Formation, the oldest Paleozoic unit, is of Late Cambrian age. Although these rocks are lacking in the Flaming Gorge area, they or their correlatives appear in many sections along the flanks of the range and probably once completely extended over the range. No Ordovician and Silurian rocks crop out in the Uinta Mountains; Devonian rocks are reported only in the extreme western part of the range (Williams, 1953). The lack of representative sections of lower and middle Paleozoic rocks in the Flaming Gorge area probably is due mainly to nondeposition rather than to erosion since deposition; only Upper Cambrian rocks appear to have been deposited, and these have since been removed. In short, the Uinta Mountains area was an elevated landmass in Early and Middle Cambrian time. It subsided and was submerged in Late Cambrian time, and it reemerged after, or perhaps during, Late Cambrian time. (See Lochman-Balk, 1955, p. 36, for a summary of existing knowledge.) If any resubmergence occurred prior to Mississippian time, evidence of it has not been found. Moderately sharp pre-Mississippian uplift is indicated on Cold Spring Mountain just east of the mapped area: Mississippian rocks there truncate about 5,000 feet of Uinta Mountain Group strata in a horizontal distance of about 4 miles.

A general downwarping took place in Mississippian time, and shallow epeiric seas spread widely over the foreland of the Westem Interior, including the Uinta 
Mountains area. Throughout most of succeeding late Paleozoic time a shallow intermittently subsiding trough coincided approximately with the old Precambrian Uinta trough and with the present Uinta Mountains (Forrester, 1937, p. 631). The general configuration of this trough can be outlined by means of isopachs drawn for the various rock formations, but the details must be generalized, owing to incomplete data in many places and a complete lack of data in others. By and large, the trough deepened to the west, for in that direction it merged with the deep Cordilleran miogeosyncline. It shallowed gradually to the east and rapidly to the north and to the south, although its shape and depth and its rate of subsidence varied from time to time. It was best defined during the Pennsylvanian, when the Morgan Formation and Weber Sandstone were accumulating, and was most poorly defined during the Permian. The rocks of the trough retain surprising lithologic identity from the Wasatch Mountains on the west to the Uintas on the east; but they differ markedly in thickness (Baker, 1947; Baker, Huddle, and Kinney, 1949 , p. 1192). Between the western and the eastern Uintas a gradual thinning of deposits is due to a shallowing of the trough in an eastward direction. Be tween the western Uinta Mountains and the southern Wasatch Mountains the section is telescoped by thrust faulting, and very marked changes in thickness occur between the geosynclinal and the shelf facies on opposite sides of the fault zone (Baker, Huddle, and Kinney, 1949, p. 1196). Changes are less marked between the Uinta Mountains and the central Wasatch Mountains.

The oldest Paleozoic rocks in the Flaming Gorge area are of Mississippian age. These rocks crop out only in the westernmost part of the mapped area. To the east they have been deleted from the surface section by faulting.

\section{MISSISSIPPIAN SYSTEM}

Mississippian rocks are exposed along the north side of Spring Creek between Death Valley and Dowd Mountain in secs. 23 and 24, T. 2 N., R. 19 E. East of there, except for in a small outcrop or two along the Uinta fault in Hideout Canyon, the Mississippian rocks have been truncated by the Uinta fault and do not appeir in the surface section. Several large slices of limestone in the Uinta fault in the Dutch John Mountain area resemble the Deseret Limestone as that unit has been identified in the Uinta Mountains; the age of these rocks, is uncertain, although they undoubtedly are late Paleozoic. One slice northwest of Goslin Mountain contains abundant Pennsylvanian fossils and is correlated with the Round Valley Limestone.

On the advice of Mackenzie Gordon, Jr., and Helen M. Duncan, outcrops of Mississippian rock along the north side of Spring Creek are assigned to three units without formal names: a lower limestone unit, a middle sandstone and limestone unit, and an upper shale unit. These units have been referred incorrectly by some geologists to the Deseret Limestone, Humbug Formation, and Manning Canyon Shale, respectively. The rocks making up these formations, together with socalled Madison Limestone of Early and Late Mississippian age, were referred to the Redwall Group by Powell $(1876$, p. 148) ; this was a very good correlation for that time. King $(1878$, p. 141$)$ referred the rocks erroneously to the Upper Coal Measures, largely as a result of miscorrelating the Uinta Mountain Group with the Weber Quartzite. The so-called Madison Limestone has been faulted out in the vicinity of Spring Creek, but it is recognized a few miles to the west near Sheep Creek and a few miles east of the mapped area on Cold Spring Mountain (Sears, 1924b, pl. 1) ; at those localities it rests unconformably on the Uinta Mountain Group and is overlain by the unit here called the lower limestone. A large fault slice in the central part of sec. 24 , T. 2 N., R. 19 E. (Manila quadrangle), is considered to belong to the same unit.

Mississippian rocks are only moderately well exposed in the Spring Creek area, and their structure is complicated somewhat by close proximity to the Uinta fault. The lower limestone and the middle sandstone and limestone units have not been differentiated from one another on the map (pl. 1). To have accurately located their contact would have necessitated extensive fieldwork along their outcrop west of the mapped area and would have required more time than was available. The upper shale unit is virtually unexposed, and for the details of its lithology one must search elsewhere; the entire Mississippian section is much better exposed and is more complete a few miles west of the area near Sheep Creek and still farther west near Sols Canyon.

\section{LOWER AND MIDDLE UNITS}

The Deseret Limestone and the Humbug Formation of Late Mississippian age are typically exposed in central northern Utah, the Deseret Limestone in the Oquirrh Mountains (Gilluly, 1932, p. 26) and the Humbug Formation in the Tintic mining district (Tower and Smith, 1899, p. 625). These formations were supposedly traced into the eastern Uinta Mountains by Baker, Huddle, and Kinney (1949, p. 1174). The recognition of similar units on the north flank of the mountains near Spring Creek is based on their lithologic and stratigraphic similarities to rocks so identified on the south flank by Baker, Huddle, and Kinney. However, restudy of the faunas from the so-called Deseret of the eastern Uintas (Duncan in Crittenden, 1959, p. 71) indicates that essentially all the unit is a Madison 
equivalent and hence pre-Deseret in age (Mackenzie Gordon, Jr., and H. M. Duncan, written commun., 1961). For this reason, the limestone unit of Mississippian age and the overlying middle sandstone and limestone unit, for which no faunal data are available, are discussed without formal names in this report. No attempt was made to obtain the thickness of these units or to record their lithology in detail, as only a fraction of the lower limestone crops out in the mapped area, and much of the overlying middle sandstone and limestone unit is concealed or poorly exposed. A few miles west of the area, Anderman ${ }^{4}$ obtained a thickness of 611.5 feet for the so-called Deseret and 359 feet for the so-called Humbug.

At Spring Creek the lower limestone unit is lightgray fine- to medium-grained mostly thick bedded hard massive cherty limestone that resists erosion and forms prominent outcrops. Its bedding planes are poorly defined; near the Uinta fault, where deformation was severe and the attitude of the bedding is hard to recognize, subalined nodules of blue or gray chert are the best attitude indicators. In many places this unit is partly dolomitic.

The lower limestone unit grades upward into the overlying middle sandstone and limestone unit. The sandstones of the middle, sandy unit are mostly light brown to pinkish brown or red, fine to medium grained, and massive to coarsely crossbedded. They are mostly well cemented with either a limy or a siliceous matrix. The limestones are gray to blue gray, fine grained, massive, and hard. As widely noted elsewhere, some beds are brecciated, particularly toward the top of the formation in this area. The breccias are autochthonous and consist in large part of fragments that have moved but little from their original place in the rock; fragmentation was penecontemporaneous with deposition.

\section{DEPOSITTONAL CONDITIONS}

The lower and middle. limestone and sandstone, units were deposited in a shallow seaway that covered all of the Uinta Mountains region and much of Utah in Late Mississippian time. Uniform offshore conditions existed during deposition of the lower limestone unit, and nearly uniform thicknesses of limestone and dolomitic limestone accumulated over very wide areas. Shoreward and perhaps onshore conditions developed during deposition of the middle unit. Most of the sandstone beds appear to have been deposited near the strand line; crossbedding and ripple marks suggest a littoral environment. Intraformational breccias near the top of

Anderman, G. G., 1955, Geology of a portion of the north flank of the Uinta Mountains in the vicinity of Manila, Utah: Princeton Univ. unpub. Ph. D. thesis.

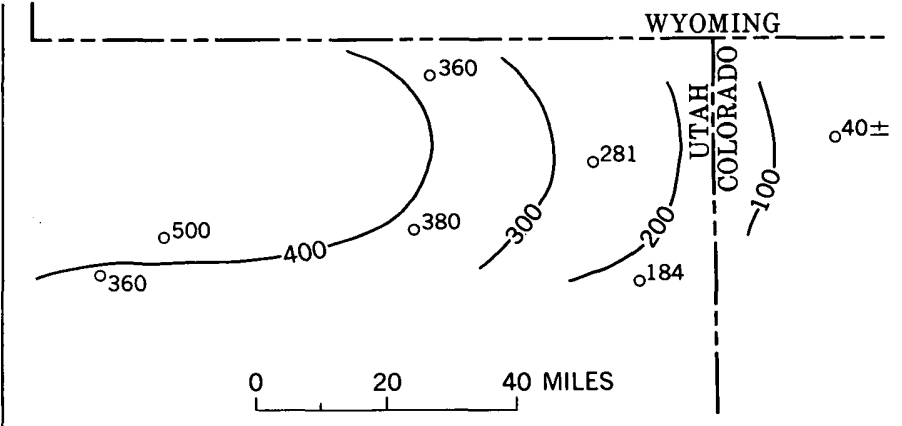

FigURE 14.-Generalized restored-thickness map of Mississippian middle sandstone and limestone unit. Isopach interval 100 feet.

the formation probably were caused by occasional slight emergence and exposure to subaerial agencies-drying and cracking, and reworking by waves. The middle unit thins eastward along the Uinta Mountains and seems to have accumulated in an east-trending trough which coincided approximately with the present Uinta Mountains and which shoaled rapidly to the north on the Wyoming shelf (Sadlick, 1955, p. 49, 53). (See also fig. 14.)

\section{ENGINEERING CHARACTERISTIOS}

Surface exposures indicate that the lower and middle units possess high shear and compressional strength and would stand unsupported at steep angles in artificial cuts. Any excavation into firm rock would require the use of explosives. Both formations possess good subsurface drainage; in fact, the lower limestone unit contains solution cavities and in some places is cavernous.

Owing to their remote occurrence and restricted areal distribution, these units probably will not be part of any engineering or construction problems in the mapped area in the foreseeable future.

\section{UPPER SHALE UNIT}

A unit of black and red shale which contains fossils of probable Late Mississippian age overlies the middle sandstone and limestone unit in the Spring Creek area. At Spring Creek the upper unit is about 300 feet thick, although it is virtually unexposed and both its top and its base are concealed. On the south side of the ridge between Spring Creek and Death Valley it forms a smooth slope between outcrops of the underlying middle unit and the overlying Round Valley Limestone. It also crops out to the southeast against the Uinta fault in Hideout Canyon.

Little is known of the upper shale unit in this area because of poor exposures. A few miles west of the mapped area in Sols Canyon, along a roadcut above the creek, exposures are somewhat better. At Sols Canyon the shale is about 545 feet thick (Sadlick, 1955, p. 53). 
The lower part, about 125 feet thick, is soft red calcareous shale; most of the remainder is black plastic clay shale. At the top of the red shale is a lenticular limestone bed about 3 feet thick from which D. J. Varnes and I collected the following fossils in June 1952:

U.S. Geological Survey collection 13964, obtained in the $S W 1 / 4$ sec. $11, T .2$ N., R. $18 \mathrm{E}$.

Dictyoclostus aff. D. inflatus (McChesney)

Dictyoclostus? sp.

Buxtonia cf. B. arizonensis (Hernon)

Rhynchopora sp.

Spirifer cf. S. leidyi Norwood and Pratton

Composita sp.

Fish remains

According to Mackenzie Gordon, Jr. (written commun., 1953), who examined the above collection, a Late Mississippian age is indicated.

A small coal prospect has been opened about 360 feet above the base of the shale in Sols Canyon. The portal of this prospect has long since caved so that entry is impossible, and bedrock is only doubtfully exposed around the opening. Fragments of limestone picked up on the dump contain unidentifiable linear impressions of leaves and casts of plant axes with spinelike emergences (S. H. Mamay, written commun., 1953), in addition to abundant ostracodes. The ostracodes, according to I. G. Sohn (written commun., 1954), probably are a new species of the fresh-water genus Cypridopsis as defined by Scott and Summerson (1943). According to Mr. Sohn, if the ostracodes are Mississippian in age, they are the oldest known occurrence of this genus in the United States. Schemel (1950, p. 232) reported a spore assemblage apparently collected from the same coal prospect as Late Mississippian (Chester) in age.

\section{CORRELATIONS}

The upper shale unit of the Spring. Creek area is considered to be the same as that which crops out in a similar stratigraphic position along the south slope of the Uinta range from the Duchesne River area (Huddle and McCann, 1947b, p. 5 and 15) to Dinosaur National Monument (Untermann and Untermann, 1954, p. 31). Various correlations for this unit have been suggested in the past. Brill (1944, p. 632) and Thomas, McCann, and Raman (1945) placed it in the Morgan Formation of Pennsylvanian age. Baker (in Huddle and McCann, 1947 b, p. 5) first suggested a correlation with the Manning Canyon Shale of Late Mississippian and Pennsylvanian age. Baker, Huddle, and Kinney (1949, p. 1193) later suggested that the upper shale unit might correlate with a similar shale at the base of the Great Blue Limestone of Late Mississippian age in central northern Utah, but they left the door open for a correlation with the Manning Canyon Shale. Untermann and Untermann (1954, p. 32) and Sadlick (1955, p. 53) correlated the unit with the Manning Canyon Shale. Crittenden $(1959$, p. 72$)$ extended the name Doughnut Formation from the central Wasatch Mountains into the Uinta Mountains for the upper shale unit. Paleontologic evidence indicates that the upper shale unit is of Late Mississippian age and is apparently the temporal equivalent of the Doughnut Formation, which has been correlated with parts of both the Great Blue Limestone and Manning Canyon Shale (Crittenden, 1959, p. 66, $70)$.

\section{CONTACT RELATIONSHIPS}

Neither the lower nor the upper contact of the unit is exposed in this area. In Dinosaur National Monument, Untermann and Untermann $(1954$, p. 32) found a possible unconformity at the base indicated by a downward coarsening of grain, a basal conglomerate, and an uneven surface of deposition. The shale thins eastward but is essentially uniform in sections along the Uinta Mountains; it is similar, although thicker, in sections farther west. It apparently is the time equivalent of at least part of the Great Blue Limestone.

DEPOSITIONAL CONDITIONS

On the basis of the fragmentary data available in this and adjoining areas, it seems probable that the upper shale unit formed in a shallow-water environment that was mainly marine but was partly or intermittently terrestrial. Over most of the Uinta Mountains the shale thins eastward, suggesting a source to the west, although a local basin may have centered in the Sols Canyon area where an unusual thickness of shale has been measured (Sadlick, 1955, p. 53; see also fig. 15). Apparently, a Late Mississippian sea advanced eastward over the slightly eroded outcrop of the middle unit, possibly reworking a lateritic regolith on the middle unit into the basal red beds of the upper unit. Terrestrial conditions developed after an interval of marine shale and limestone deposition. Carbonaceous shales containing fresh-water organisms were deposited widely at that time, and coal swamps flourished locally (Kinney, 1955, p. 38). Marine conditions that presumably returned before deposition of the formation was completed foreran the oncoming carbonate sequence of the overlying Round Valley Limestone.

ENGINEERING CHARACTERISTICS

Because of its restricted areal distribution and its remote occurrence, the upper shale unit presents little likelihood of being encountered in engineering works that might be planned in the future within the area of 


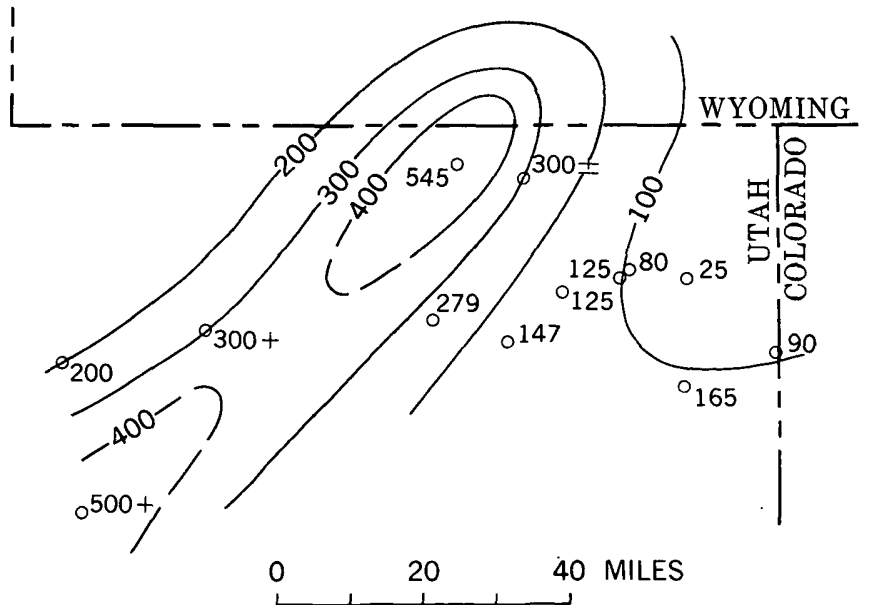

FigURE 15.-Generalized thickness map of Mississippian upper shale unit. Isopach interval 100 feet.

this report. The shale has low stability and high plasticity when wet. Permeability is low, and unless precautions are taken, drainage problems probably would arise were any structure, such as a road, built across it. Probably any excavation made into the shale could be handled without drilling or blasting; most excavations could be made with light power machinery. Some limestone beds might require special handling.

\section{PENNSYLVANIAN SYSTEM}

Pennsylvanian rocks are widely and well exposed in the western part of the area where their outcrops form picturesque cliff's and canyons (figs. 18, 61). East of Bear Mountain the Pennsylvanian rocks are faulted out, and they appear at the surface only as slivers or fragments in the Uinta fault zone; some of these fragments are large and attain lengths of hundreds or thousands of feet. Three Pennsylvanian formations are recognized south of Sheep Creek and in the HorseshoeKingfisher Canyons area. In ascending stratigraphic order these formations are the Round Valley Limestone, the Morgan Formation, and the Weber Sandstone

Rocks composing the Round Valley Limestone apparently were included in the Red Wall Group by Powell (1876, p. 147). The Morgan Formation was a part of his Lower Aubrey Group, and the Weber Sandstone-referred to by him as the Yampa Sandstonewas a part of his Upper Aubrey Group. King (1878, p. 140) included the whole Pennsylvaniar sequence in the Upper Coal Measures.

\section{ROUND VALLEY IIMESTONE}

The Round Valley Limestone was named and defined by Sadlick (1955, p. 56). It is typically exposed at Round Valley in the northern Wasatch Mountains about 3 miles east of Morgan, Utah, where it overlies the "Brazer Formation" and underlies the Morgan Formation. It has been regarded by some geologists as a member (the lower member) of the Morgan Formation and was so regarded by me (Hansen, 1955a; Hansen and Bonilla, 1956) in previous reports. But since my mapping was finished and these reports were written, Sadlick has pointed out the distinction of the Round Valley from the typical Morgan Formation of the northern Wasatch Mountains.

When Blackwelder (1910, p. 529) first published the name Morgan Formation, he referred it to a red-bed sequence overlying what was then called the Wasatch Limestone ${ }^{5}$ and underlying and passing upward into the Weber Quartzite. The Wasatch Limestone was considered to be of Ordovician to Mississippian age although the upper part-now called the Round Valley Limestone-was assigned to the Early Pennsylvanian by G. H. Girty (Blackwelder, 1910, p. 530). Thus, in the type locality of the Morgan Formation the Round Valley Limestone underlies and is excluded from the Morgan. The Round Valley Limestone and the Morgan Formation are not coextensive, and in areas where the red beds are lacking, use of the new name calls attention to the absence of the Morgan rather than obscures it, as pointed out by Max D. Crittenden, Jr. (written commun., 1955).

Prior to Sadlick's defining it, the Round Valley of the Uinta Mountains had been referred to various units and had been assigned various names. It had generally been included in the Morgan Formation, either as a lower member (Baker, Huddle, and Kinney, 1949, p. 1181; Untermann and Untermann, 1949, p. 691, and 1954, p. 35 ; Huddle and McCann, 1947b, p. 4 ; Hansen, $1955 \mathrm{a}$ ) or as a middle member (Thomas, McCann, and Raman, 1945). It was included in the Brazer Formation by J. Stewart Williams (1943, p. 612) and in the Belden by M. L. Thompson (1945, p. 22).

\section{DISTRIBUTION AND PHYSIOGRAPHIC EXPRESSION}

The Round Valley Limestone is resistant to erosion and forms bold outcrops. It forms the crestline of the high ridge between Death Valley and Spring Creek, and it forms prominent but discontinuous ledges along the north side of Hideout Canyon. East of the Green River it crops out along the Uinta fault as far as Bear Mountain, where it is faulted out. A large mass of limestone in the fault, covering perhaps 25 acres of ground at the head of North Skull Creek in the NW1/4

5 The name Wasatch Limestone was abandoned by Richardson in 1913. 
sec. 2, T. 2 N., R. 21 E., is probably Round Valley Limestone-cursory search for fossils yielded a few fragmentary spiriferoids. Any of several large limestone slices east of there in the Dutch John Mountain area may be Round Valley also, although their bedding appears to be too massive, and they may be Mississippian. A large slice that caps hill 7346 , forming a prominent butte northwest of Goslin Mountain in the NE1/4 sec. 30, T. 3 N., R. 23 E., contains abundant Pennsylvanian fossils and almost assuredly is Round Valley Limestone. It is wedged between the Uinta Mountain Group in the hanging wall of the fault and Hilliard Shale in the footwall.

\section{LITHOLOGY AND THICKNESS}

As exposed in the Flaming Gorge area, the Round Valley Limestone is chiefly light-gray to light-bluishgray dense hard thin-bedded to massive cherty limestone. Pink or red jasperoid chert has been reported in the formation in many places but has not been observed in this area; most of the chert seen here is blue gray to yellowish gray.

The best exposed section of the Round Valley Limestone in the mapped area is on the north side of Hideout Canyon in the $\mathrm{N} 1 / 2$ sec. 15, T. 2 N., R. 20 E. At Hideout Canyon the formation is about 260 feet thick, but this section is very near the Uinta fault, and the actual base of the formation may be missing. The formation may be more complete on the ridge between Death Valley and Spring Creek, but it is not nearly as well exposed. At Sheep Creek, 3 miles west of Hideout Canyon, the unit is about 335 feet thick (M. L. Thompson, 1945 , p. 25). About 10 miles west of Hideout Canyon, at Sols Canyon, according to Sadlick (1955, p. 57 ), it is 481 feet thick, or almost a full order of magnitude thicker than at Hideout Canyon. In the nearest measured section on the south flank of the range, at Whiterocks Canyon, it is 415 feet thick (Kinney, 1955$, p. 40$)$. These disparities suggest a possible deletion of beds at Hideout Canyon.

Section of the Round Valley Limestone in Hideout Canyon in the N1/2 sec. 15, T. 2 N., R. $20 \mathrm{E}$.

[Mensured by W. R. Hansen and M. G. Bonilla, July 15, 1952]

Morgan Formation: Limestone, interbedded with finegrained quartzitic sandstone.

Rouni Valley Limestone:

1. Timestone, light-gray, fine-grained; somewhat cherty toward base

2. Covered interval, appenrs to be mostly fine-orained thin-hedded blocky limestone._._._._._.......

3. Limestone, gray, cherty

4. Ismestone, light-gray, and light-gray flaky shale; very thin bedded; a few fossils at top.
Feet

8 13 2 14

Round Valley Limestone-Continued

5. Limestone, blue-gray, massive, hard, cherty. Chert masses range from mere specks to lenses 3-4 ft long and several inches thick. Chert is yellowish gray but appears dark owing to numerous dark fractures. Lower $50 \mathrm{ft}$ contains less chert. Lower $7 \mathrm{ft}$ thin-bedded. Occasional fossils throughout

6. Limestone, yellowish-gray, thin-bedded; contains Derbyia crassa (Meek and Hayden)

7. Limestone, blue, massive

8. Limestone, light-yellowish-gray, thin-bedded, fragmental

9. Limestone, light-gray to blue-gray, alternately massive and thin-bedded, cherty. Poorly exposed, and base could be faulted out

Feet and base could be faulted out

Total

Upper shale unit: shale, dark-gray, clayey; contains fragments of coal ; churned up by Uinta fault.

Both the lower and the upper contact of the Round Valley Limestone appear to be conformable. The lower: contact is unexposed in the mapped area but is conformable elsewhere. The upper contact in Hideout Canyon is marked by lithologic and color changes but lacks other physical evidence of stratigraphic discontinuity. In fact, the contact could be selected at any of several places within a transition zone of several feet. At the measured section the major color change-from gray to red-occurs about $81 / 2$ feet above the horizon selected as the contact on purely lithologic groundswhere clastic beds first appear in the section in significant quantity.

Judging from faunal sequences, M. L. Thompson $(1945$, p. 39) recognized an unconformity at the top of the Belden Formation of Morrow age. Thompson noted a lack of Atoka faunas but found no physical evidence of an unconformity. The position of the unconformity at the top of Thompson's Belden Formation relative to the Round Valley, Morgan, and Weber sequence of the Flaming Gorge area is uncertain ; the only physical evidence of a possible unconformity that $I$ observed in this sequence is near the top of the Morgan Formation. Sadlick (1955, p. 58) concluded that an unconformity exists at the top of the Round Valley, "*** based on the evolutionary sequence of fusulinids."

FOSSILS AND AGE

The Early Pennsylvanian (Morrow) age of the Round Valley Limestone is well established paleontologically (M. L. Thompson, 1945, p. 25; Untermann and Untermann, 1954, p. 120; Sadlick, 1955, p. 56). Fossils are fairly abundant in the Hideout Canyon area, and diligent search probably would yield an extensive fauna. Brachiopors are common, particularly Derbyia 
and Spirifer. The following fossils (from U.S. Geol. Survey colln. 13065, examined by Mackenzie Gordon, Jr., Helen Duncan, and Ellis Yochelson) were collected at hill 7346 ; as the rocks of hill 7346 are bounded by faults, their exact stratigraphic position is uncertain, but they resemble the Round Valley Limestone and are probably part of it.

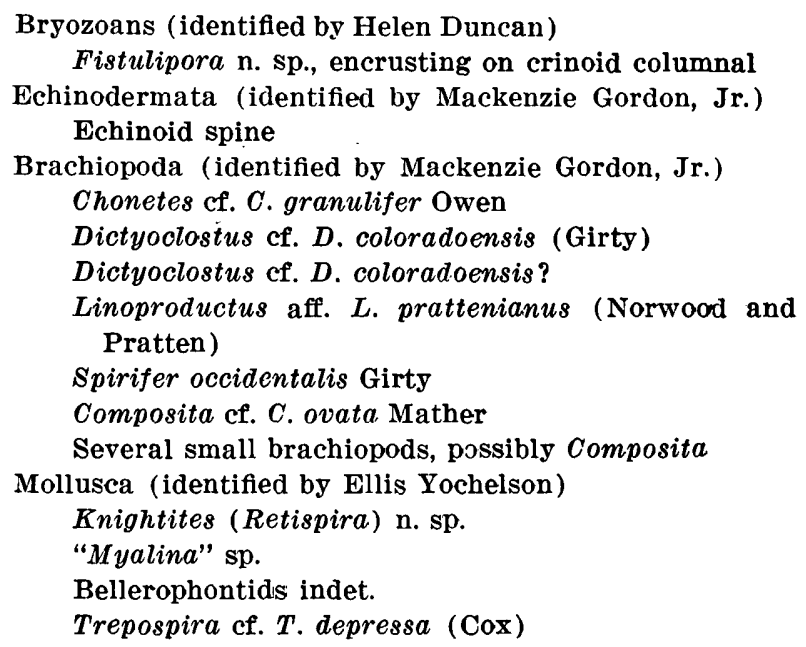

According to Mr. Gordon (written commun., 1952), the age of the collection is Pennsylvanian, probably early. The bryozoan Fistulipora has a wide range, but its presence in a Pennsylvanian assemblage, according to Miss Duncan, is noteworthy because incrusting and laminar fistuliporoid bryozoans comparable to this specimen are very common in Early and Middle Pennsylvanian (Des Moines and older) faunas of the Rocky Mountain region. The mollusks, according to Mr. Yochelson, would likely be of Des Moines age or younger in the midcontinental United States, but little is known of their range in the Western United States.

DEPOSITIONAL CONDITIONS

The Round Valley Limestone accumulated in a relatively stable but slowly subsiding offshore marine environment. The relative stability of the sea floor, both in time and in place, over a wide area is indicated by the vertical and lateral lithologic uniformity of the formation. The marine environment is shown by the fauna. Thickness variations from place to place, however, although not great, suggest variations in rates of deposition and subsidence. Sadlick $(1955$, p. 54) believed that the unusual thickness (481 ft) of Round Valley Limestone in the Sols Canyon area indicates a local depositional basin that probably trended southwest across the Uinta Mountains area in Morrow time. A thickness map of the formation seems to substantiate the existence of such a basin (fig. 16) but suggests that the basin was troughlike and was elongated more nearly east-west, coincident with the old Uinta trough.

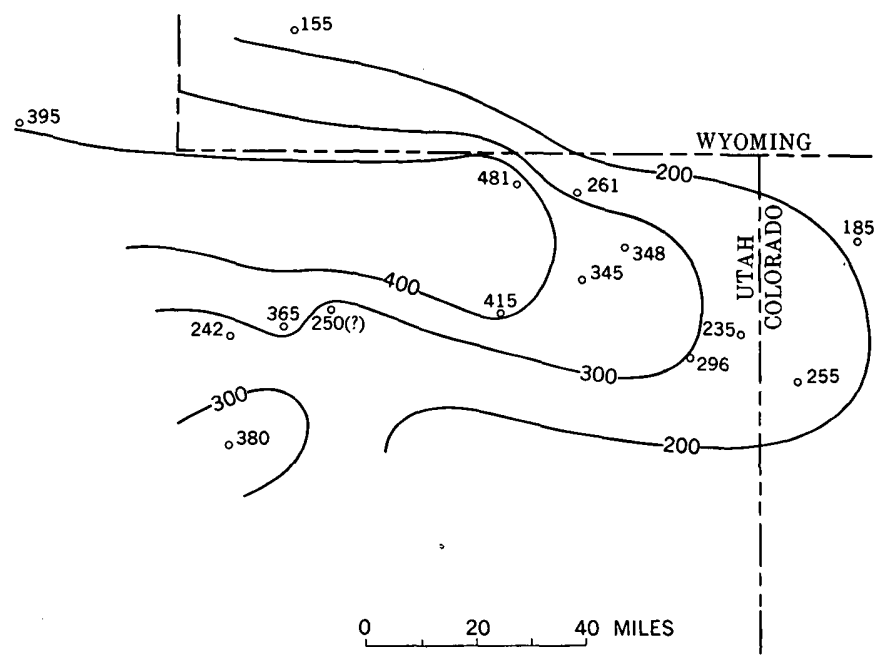

Figure 16.-Generallzed thickness map of Round Valley Limestone. Isopach interval 200 feet.

ENGINEERING CHARACTERISTICS

Being resistant to erosion and possessing high slope stability and high shear strength, the Round Valley Limestone may be expected to maintain steep faces without support in artificial excavations. Any large excavation would require the use of drilling equipment and explosives. Well-formed dip joints spaced a few feet apart in most places should be an aid to excavation.

The formation is not cavernous in this area and contains no large solution cavities, but it is well drained and should present no drainage problems. In favorable topographic situations in other parts of the Uinta Mountains, such as the Jones Hole section of Dinosaur National Monument, the Round Valley is a major aquifer and carries large volumes of water (Untermann and Untermann, 1954, p. 123).

\section{MORGAN FORMATION}

The Morgan Formation of this area, as here defined, is restricted to a sequence of predominantly interbedded red beds and limestones of Middle Pennsylvanian (Des Moines) age. It excludes the underlying Round V'alley Limestone, previously considered by me to be part of the Morgan, and an overlying sequence of sandstone and limestone now included in the Weber but previously included in the Morgan. As thus restricted, the Morgan differs in its upper and lower limits from the Morgan as defined by many recent workers, but it agrees closely with the Morgan of the eastern Uinta Mountains as first described by J. Stewart Williams $(1943$, p. 613$)$. It also accords more closely with the typical Morgan Formation of the Wasatch Mountains as originally defined by Eliot Blackwelder (1910, p. 529). Blackwelder did not closely define the top of the Morgan Formation in its type area, but he 
noted that it passes upward into the Weber Quartzite through a transition zone of grey shales, limestones, and sandstones.

As selected in this report, the top of the Morgan Formation in the Death Valley-Spring Creek-Hideout Canyon area is sharp and well defined and is at the same stratigraphic horizon throughout the area. Recent pleas for a return to the usage of J. Stewart Williams have been made by Sadlick (1955, p. 56-57). In previous reports (see Hansen and Bonilla, 1954, p. 5) the upper contact was placed at the top of the highest limestone bed in the overlying sequence of interbedded limestone and sandstone now placed in the Weber. This procedure had been adopted earlier in defining the formation top on the south flank of the range, where the color change is less marked. Thomas, McCann, and Raman, 1945; M. L. Thompson, 1945, p. 34; Baker, Huddle, and Kinney, 1949, p. 1181; Untermann and Untermann, 1954, p. 33), even though it was known that the individual limestone beds wedge out westward, that the sandstone beds merge with the Weber, and that the top of the formation as drawn was heterochronous.

\section{DISTRIBUTION AND PHYSTOGRAPHIC EXPRESSION}

The Morgan Formation crops out discontinuously from the west boundary of the area to the east side of the Green River north of Hideout Flat. It is well exposed locally, but in most places it is partly concealed by slide rock or colluvium. Wherever it crops out its bright-red color is conspicuous against the drab beds of the Weber Sandstone above and the Round Valley Limestone below. East of Hideout Flat it is deleted from the surface section by the Uinta fault. It reappears at the surface a few miles east of Clay Basin at the east end of Cold Spring Mountain.

Detailed examination of the formation is possible at three localities. The most accessible of these is on the high ridge between Death Valley and Spring Creek, at the east end of the large craggy outcrop formed by a slice of limestone of Mississippian age in the NE1/4 soc. 24, T. 2 N., R. 19 E. The lower part of this section, however, is not well exposed, and part of the formation may be faulted out. A better but less accessible section is exposed on the northwest side of Hideout Canyon in the N1/2 sec. 15, T. 2 N., R. 20 E. Exposures at this locality are excellent. A fairly good section a few miles to the east can be seen just north of Hideout Flat in the SW1/4 sec. 12, T. 2 N., R. 20 E.

\section{LITHOLOGY AND THICKNESS}

Although the Morgan Formation is only slightly more than 80 feet thick, it is one of the most heterogeneous formations in the area. It contains about 60 per- cent varicolored (chiefly red) shales and siltstones, about 35 percent gray to lavender limestones, and about 5 percent sandstone.

\section{Composite section of the Morgan Formation}

[Units 1-6 measured in NE $1 / 4$ sec. 24, T. 2 N., R. 19 E.; units $.7-13$ measured in $\mathrm{N} 1 / 2$ sec. 15 , T. 2 N., R. 20 E. Measured by W. R. Hansen and M. G. Bonilla, July 1952]

Weber Sandstone: Sandstone, gray (mottled with rusty brown), hard ; quartzitic toward top.

Morgan Formation :

1. Siltstone, brick-red but somewhat mottled, hard; $14 \mathrm{ft}$ above base is breccia of red siltstone and limestone fragments._._.

2. Limestone, light-gray, sandy; sand grains arranged in cross-laminated layers and weather dark brown

Feet

3. Sandstone, light-gray, fine-grained, quartzitic

4. Siltstone, purplish-red, very thin bedded; a few thin ochre-colored beds.

5. Limestone, light-gray, mottled, cherty. Lower 8 ft covered, but float consists of limestone fragments.

6. Limestone, gray, sandy ; similar to bed 2

7. Limestone, lavender (gray in lower 8 in., thinbedded, very fossiliferous (colln. Mo $16 a$ and Mo 16b) ; good marker bed-

8. Shale, red, flaky-

9. Limestone, light-gray, massive, crossbedded at base.

10. Limestone, gray, thin-bedded, interbedded with red shale, poorly exposed.... 4

11. Limestone, light-gray

12. Mudstone, olive-green, hackly__-___-_._. 2.5

13. Limestone, interbedded with fine-grained quartzitic sandstone.-3. 3

Total_____._. 81.2

Round Valley Limestone: limestone, light-gray, fine-grained; somewhat cherty toward base.

The lower contact of the formation has already been mentioned in the discussion of the Round Valley Limestone. In the Flaming Gorge area the lower contact is selected as the horizon above the thick limestones of the Round Valley where clastic sediments first appear in significant quantities. The section below is nearly all limestone; that above is intercalated limestone, shale, siltstone, and sandstone. The major color change, which typifies the Morgan Formation but in itself is an unsound basis for placing the contact, is about $81 / 2$ feet above the harizon selected as the base of the formation.

There is no physical evidence of discontinuity at the base of the Morgan Formation in this area although some geologists feel that a discontinuity is indicated by paleontological evidence (Sadlick, 1955, p. 58). Clear physical evidence of an uncomformity in the type area was reported by Blackwelder (1910, p. 530); the weathered upper surface of the Wasatch Limestone of former usage (lower part now called Brazer; upper part now 


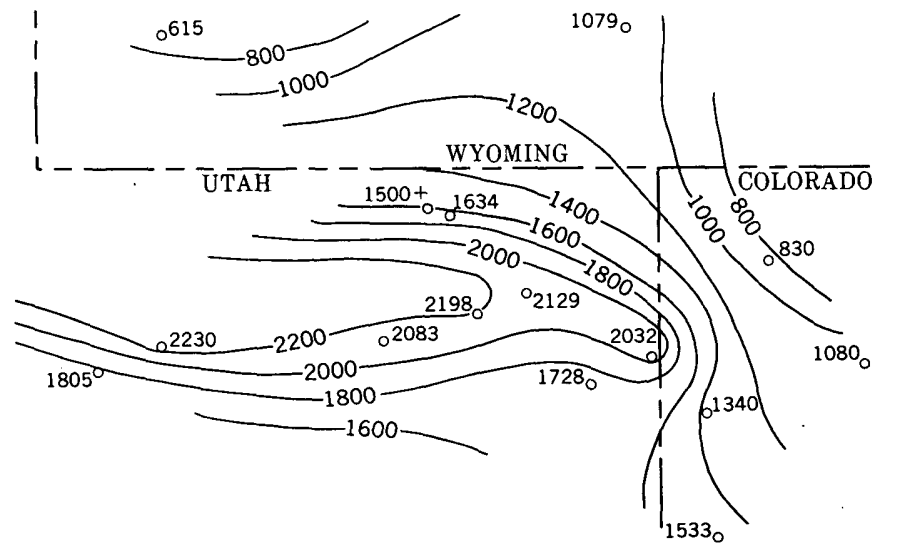

$0 \quad 20 \quad 40$ MILES

Figure 17.-Generalized thickness map of Morgan Formation and Weber Sandstone. Isopach interval 200 feet.

called Round Valley) is overlain by coarse conglomeratic sandstone containing fragments of the underlying rock.

The contact of the Morgan Formation with the overlying Weber Sandstone is placed at the top of the uppermost red bed and appears to be conformable. It is a sharp and well-defined lithologic break as well as a good color break, but it presents no evidence of interrupted sedimentation.

If any stratigraphic gap exists in the Des Moines (Morgan and Weber) part of the Pennsylvanian sequence, it probably lies within the Morgan Formation rather than between the Morgan and the Weber. The brecciated zone in bed 1 of the measured section has the physical appearance of a diastem or an unconformity. It consists chiefly of angular fragments of blue limestone in a matrix of mottled red siltstone, but it also contains siltstone fragments that apparently were fragmented shortly after deposition. Although fossil datings do not indicate a significant hiatus, the break may have been of sufficient duration to account partly for large local variations in the thickness of the formation.

At Hideout Canyon the formation is about 80 feet thick; 7 miles west at Sheep Creek it is only 36 feet thick (M. L. Thompson, 1945, p. 68) ; 10 miles west at Sols Canyon it is 120 feet thick; ${ }^{6} 17$ miles west at Birch Creek it is 58 feet thick; ${ }^{7}$ and 25 miles south at Whiterocks Canyon, in the nearest exposures on the south slope of the mountains, it is 370 feet thick (Kinney and

\footnotetext{
- Anderman, G. G., 1955, Geology of a portion of the north flank of the Uinta Mountains in the vicinity of Manila, Utah: Princeton Univ., unpub. Ph. D. thesis.

${ }^{7}$ MeMinn, P. M., 1948, Pennsylvanian stratigraply of Doggett County, Utah: Wisconsin Univ., unpub. Master's thesis.
}

Rominger, 1947). Some of these thickness variations, especially at Whiterocks Canyon, undoubtedly are due partly to differences in rates of deposition from place to place; for during Des Moines time the axis of the Uinta trough lay well to the south of the Flaming Gorge area, and thicker deposits accumulated in the axial area than in the Flaming Gorge area. (See fig. 17.)

$$
\text { FOSSILS AND AGE }
$$

The Middle Pennsylvanian (Des Moines) age of the Morgan Formation is widely acknowledged and has been established by fossil suites collected in many areas by many geologists. Fossil collections Mo 16a and Mo $16 \mathrm{~b}$, which were obtained from bed 7 near Spring Creek and at Hideout Canyon, contain the following fossils:

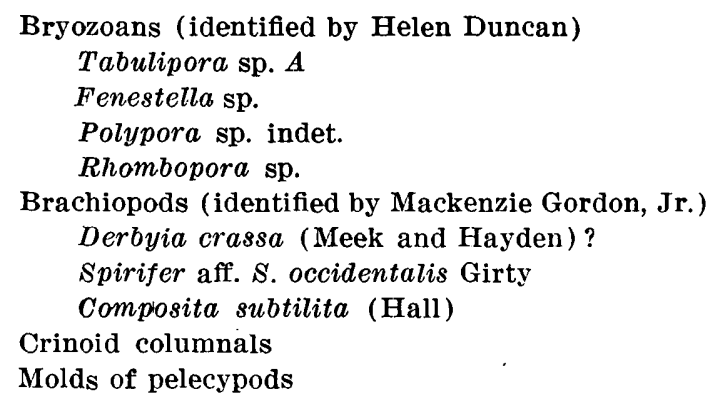

Mr. Gordon (written commun., 1952) remarked that the fossils of bed 7 are many in number but few in species. He added that the Spirifer differs from S. occidentalis Girty by having flatter plicae, a shallower fold and sinus, and a less curved umbo; that it may be an undescribed subspecies or even a new species; but that it has affinities with Middle Pennsylvanian forms. Miss Duncan (written commun., 1952) noted that the bryozoan assemblage is typical of the Pennsylvanian in the Rocky Mountain region.

\section{DEPOSITIONAL CONDITIONS}

The Morgan Formation accumulated under fluctuating depositional conditions in a shallow but offshore marine environment. Alternate limestone and finegrained clastic beds suggest fluctuating shorelines and unstable bottom conditions throughout deposition of the formation. The ecologic significance of the fossiliferous limestones seems evident; these beds, which in part teem with fossils, probably were deposited in freely circulating marine waters capable of supporting large populations of marine life. But the meaning of the red beds is not clear. Kinney (1955, p. 45) believed that the red color is indigenous-that it was not caused by any environmental factors operative during or since deposition of the Morgan but that it is an original color inherent in the sediment itself. He believed that the source of this sediment was an area to the east or south- 
east, probably the ancestral Uncompahgre highland or some other adjacent Pennsylvanian landmass. The ancestral Front Range highland also may have been a source.

Variations in the thickness of the formation from place to place suggest a shallow trough in the Uinta Mountains area during deposition of the Morgan Formation, although various geologists have selected different horizons in different places as the top of the formation, and many problems of interpreting thicknesses arise. The formation thins appreciably to the north as it grades into the upper part of the Amsden Formation in Wyoming, but shallow seas probably covered the Green River Basin area (J. Stewart Williams, 1955, p. 44). A landmass lay to the southeast in the Uncompahgre area and to the east in the Front Range area. North of the Uncompahgre area the formation merged with the thick Maroon Formation of the Southern Rocky Mountain zeugogeosyncline (Brill, 1944, p. 633).

\section{ENGINEERING CHARACTERISTICS}

There is little likelihood that the Morgan Formation will ever become a major factor in any engineering problem or development in the Flaming Gorge area, because it is relatively thin, has a narrow exposure belt, and crops out only in relatively remote parts of the area.

Because of its high shale-siltstone content, it is one of the less competent units in the Paleozoic sequence. Even so, natural slopes have considerable stability, and slope failures involving the Morgan Formation are unknown in the area.

Excavations into the formation probably could be made with relative ease using heavy machinery, without general recourse to explosives. Some of the more massive limestone beds probably could not be excavated without preliminary blasting.

\section{WEBER SANDSTONE}

The Weber Sandstone, or Quartzite, was named by King (1876, p. 477) for exposures of the formation along Weber Canyon in the Wasatch Mountains. For occurrences in the Wasatch Mountain area the term "quartzite" is generally affixed to the name; elsewhere the term "sandstone" is more applicable and is more widely used. In the same year that King introduced the name Weber, Powell (1876, p. 41) introduced the name Yampa Sandstone for the same formation in the eastern Uinta Mountains. King and Powell were unaware that they were dealing with the same formation; under King's direction, in fact, Emmons (1877, p. 140) miscorrelated the Uinta Mountain Group with the Weber Quartzite. In fairness to Emmons and the 40th
Parallel Survey, it should be reiterated that the correlation was made with reservations and that the unconformable relationship of the Uinta Mountain Group to the overlying rocks, although well known to Powell at the time of the survey, was not made known to Emmons until Powell's report was published. In 1904 Boutwell (p. 225), by finding Mississippian fossils in the overlying (Madison) limestone, proved that the Uinta Mountain Group could not be equivalent to the Weber. Two years later, Berkey (1905, p. 529) correctly identified the Weber in the western Uintas but failed to recognize its continuity with the Yampa Sandstone of Powell in the eastern Uintas. In 1907 Weeks (p. 438) established the correlation, and the name Yampa was abandoned.

DISTRIBUTION AND PHYSIOGRAPHIC EXPRESSION

Widely exposed in the eastern Uinta Mountains, the Weber Sandstone forms some of the most picturesque and impressive canyons in North America. Those of Dinosaur National Monument are most notable and most famous, but they are rivaled by others on both flanks of the range. In the Flaming Gorge section the Weber is confined largely to the western third of the area, for it is truncated by the Uinta fault just south of Boars Tusk. East of there it reappears at the surface only as small slivers or fragments in the Uinta fault zone. A few miles east of the map area it crops out again in normal sequence along Irish Canyon and Vermilion Creek.

Between the west boundary of the area and Boars Tusk the Weber Sandstone forms a continuous outcrop of rugged canyons and great cliffs. It is very well exposed-particularly the upper third-in Death Valley. Just to the east of Death Valley, along Spring Creek and along the north side of Hideout Canyon, the full thickness of the formation is exposed in near-vertical cliffs hundreds of feet high. Across the Green River from Hideout Canyon at Beehive Point and to the northeast, the Weber forms a jagged knife-edge ridge, largely because the strata are upturned sharply along the Uinta fault (fig. 61); the lower several hundred feet of the formation is overturned, and the resistant limestone beds in that part of the section form a series of great ramparts flanking the ridge northwest of Hideout Flat.

Upstream from Beehive Point, Kingfisher Canyon (fig. 18) is carved from the Weber Sandstone, although the Park City Formation forms the rims. The canyon of Sheep Creek in the same vicinity is also carved from the Weber Sandstone. The Hideout-Kingfisher Canyon-Sheep Creek area is now accessible to automobiles, but it will be partly inundated by Flaming Gorge Reservoir. 


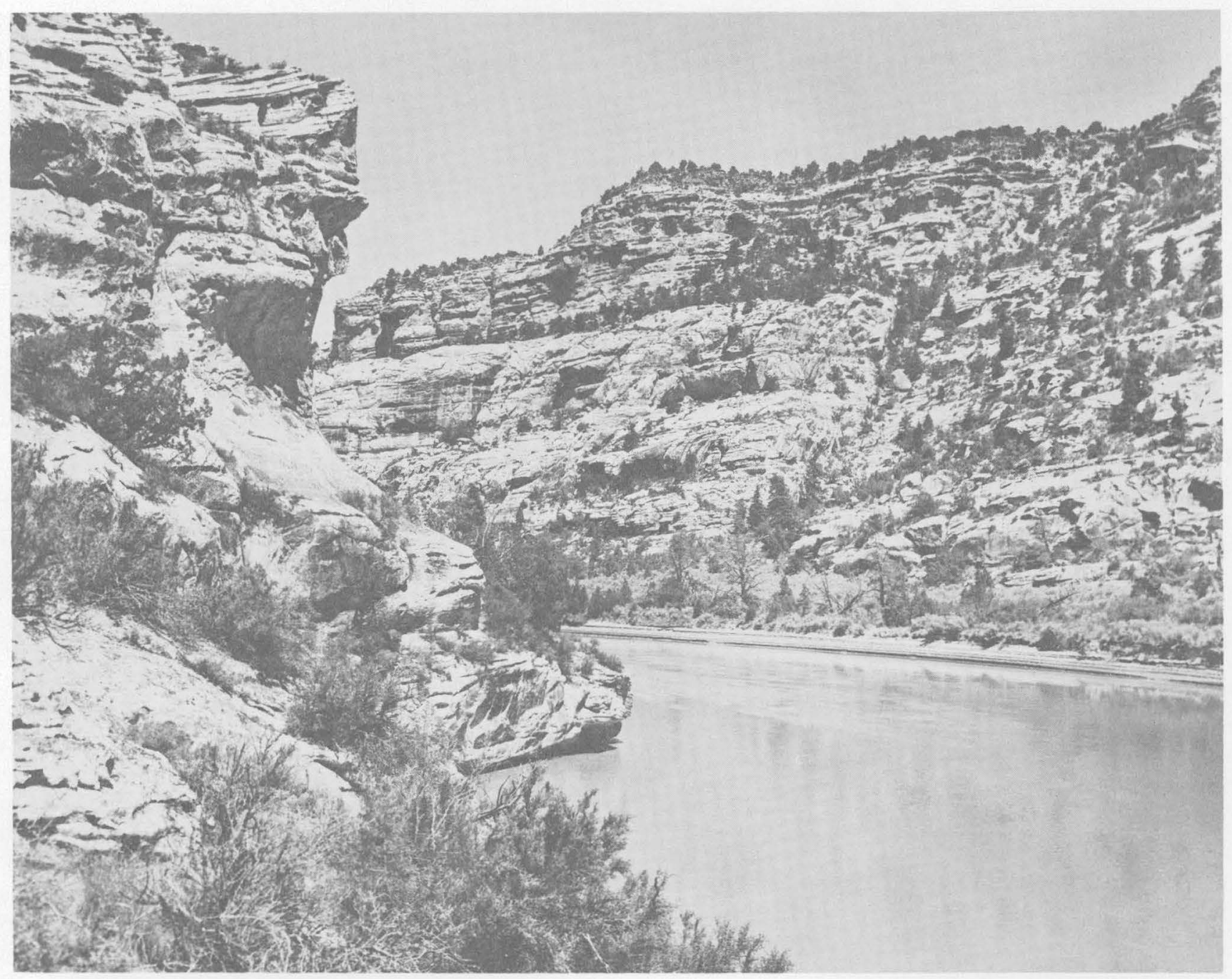

Figure 18.-Weber Sandstone forming walls of Kingfisher Canyon, showing typical bedding habit and characteristic "slick-rim" weathering habit. Cliff in background is about 600 feet high and is capped by basal beds of Park City Formation. Flaming Gorge Reservoir, at high water, will cover the lower third of the cliff.

Less accessible than Kingfisher Canyon but possibly more impressive is Horseshoe Canyon, a classic entrenched meander 1,200 feet deep. Sheer cliffs hundreds of feet high rise from the river without room at their base for a foot path. The canyon walls owe their monolithic appearance to the massive character of the Weber at that locality.

\section{IITHOLOLGY AND THICKNESS}

The Weber Sandstone, which has a thickness of about 1,555 feet, is remarkably uniform in lithology and appearance through hundreds of feet of section. It is divisible, however, into two mappable units - a lower unit about 600 feet thick containing fossiliferous limestone beds as well as sandstone, and an upper unit about 955 feet thick consisting exclusively of sandstone. The sandstone is very uniform throughout the formation, although some beds of the lower unit are slightly darker in shade and somewhat more uniformly bedded than those of the upper unit. Some beds, also, are harder. The limestone beds of the lower unit thin and wedge out toward the west, so that the lower unit merges with the upper unit and loses its identity a few miles west of the area. $^{8}$

The lower unit of the Weber Sandstone was measured on the ridge between Death Valley and Spring Creek in the NE $1 / 4$ sec. 24, T. 2 N., R. 19 E., and a thickness of 596 feet was obtained. The rocks are nearly vertical, and the true thickness of most beds was measured directly with a steel tape. The top of the unit was selected as the top of the highest limestone bed in the interbedded limestone-sandstone sequence; the base is the bottom of a sandstone bed resting on the Weber-Morgan contact.

\footnotetext{
8 Thesis, 1948 , p. 20 ; see footnote 7 , p. 46.
} 
Section of the lower unit of the Weber Sandstone [Measured by W. R. Hansen and M. G. Bonllla, July 1952] Bed

Weber Sandstone: Upper unit, not measured Lower unit:

I 1 Limestone, light-gray, fine-grained, slightly cherty, fossiliferous -

I. 2 Sandstone, cream-colored, fine-grained, crossbedded, hard, calcareous

l. 3 Iimestone, light-glay, massive, prominent; contains rounded cream-colored chert nodules

I 4 Sandstone, cream-colored, fine-grained, thinbedded, crossbedded, calcareous

I. $5 \quad$ Limestone, light-gray, somewhat cherty; berls 2 in. to $1 \mathrm{ft}$ thick

I 6 Sandstone, cream-colored to pale-pink and buff, fine-grained, thick-bedded, massive; contains marblelike concretions.

I. 7 I.imestone, light-gray, fine-grained, thin-bedded, somewhat crossbedded, hard. Numerous fossil fragments ; somewhat cherty

I. 8 Sandstone, similar to bed I, 6

I. 9 Limestone, light-blue-gray, massive, cherty-_.-

L 10 Sandstone, similar to bed L 6

I. 11 Limestone, light-gray, massive, hard, cherty --

I. 12

I. 1.3

Sandstone, similar to bed $\mathrm{L}, 6$

Sandstone, pale-yellowish-orange (color chart) fine-grained

I. 14 Sandstone, light-gray, fine-grained, crossbedded, calcareous

I. 15 Limestone, gray to pale mottling of lavender massive, cherty, fossiliferous

r, 16 Sandstone, light-pink to light-yellowish-orange fine-grained

L 17 Limestone, light-gray, sandy (brown sand grains), crossbedded, very fossiliferous

I. 18 Sandstone, similar to bed $\mathrm{I} 16$

r. 19 Sandstone, very light gray, fine-grained, calcareous

I, 20 Sandstone, gray mottled with rusty brown, very hard; quartzitic toward top

I. 12 Limestone, dark-gray, fine-grained, cherty_...-

L 22 Sandstone, similar to bed I, 20; lower $40 \mathrm{ft}$ mostly covered: calcareous toward base...-

Total

Morgan Formation: siltstone, brick-red.

Limestone totals only about 16 percent of the lower unit, but because of its high resistance to erosion as compared with that of the interbedded sandstone, it appears to total more in most sections. In dipping sections, especially, the limestone crops out more prominently than the sandstone, hence it commonly forms wider surface exposures. Above Hideout Flat it forms great ramparts or flatirons. As noted before, the contact between the lower and upper units is gradational; the two units merge into one a few miles west of the area.

No section was found in the area that was suitable for measuring the thickness of the upper unit, chiefly because of the inaccessibility of either the upper or the lower contact in most sections but partly because of strong deformation toward the exposed base of the unit along the Uinta fault. A few miles west of the area, where the contacts are easily reached and are less disturbed, McMinn ${ }^{\theta}$ obtained a thickness of 956 feet. 7 This figure seems to be of the right order of magnitude for the thickness of the unit in this area. It compares to thicknesses of about 1,000 feet to more than 1,200 feet in adjacent areas on the south flank of the range (Kinney, 1955, p. 46) and to only about 690 feet at Vermilion Creek 35 miles or so to the east (Thomas, McCann, and Raman, 1945). The upper unit consists entirely of light-gray to buff fine- to medium-grained massive friable well-sorted crossbedded mostly calcareous sandstone.

Crossbedding is very conspicuous, especially in the upper several hundred feet of the formation where it resembles and rivals that of the Navajo Sandstone in size and development of foreset wedges. It is especially noticeable on rounded, weathered outcrops; on fresh angular joint faces it hardly shows at all. The angles between crossbedding and true bedding range from a tangent upward to a maximum of about $25^{\circ}$. True bedding is very coarse and widely spaced and contributes to the massive appearance of the formation (fig. 18). Few beds are less than 10 feet thick, and many exceed 50 feet.

About 200 feet below the top of the formation the outcrop of the Weber shelves back to form a conspicuous sloping ledge. This ledge is accented by stands of pinyon and yellow pine growing along the slope break. Although the reason for its existence is unclear, the ledge is nearly continuous throughout the area. It is well formed in Horseshoe and Kingfisher Canyons (fig. 18), behind Hideout Flat, along Hideout Canyon and Spring Creek, and in Death Valley. No lithologic difference is noticeable at the break, unless the rock is slightly softer and, eroding back, forms a ledge. The rock above the ledge to the top of the formation is a slightly darker shade of buff than the rock below. It seems doubtful that difference in shade or hardness is detectable in a drill hole, but for surface mapping, especially on aerial photographs, the ledge provides a valuable horizon marker.

Another minor but very noticeable characteristic of the Weber outcrop is its tendency to develop small cavities-"honeycomb structure"-in favorable locations where weathering is slow. Some of these cavities are 20 feet across, but most are much smaller. They are caused by leaching out of the calcareous cement and subsequent removal of the friable product by deflation. The process necessarily is restricted to areas where ero-

\footnotetext{
O Thesis, 1948 , p. 33 ; see footnote 7, p. 46.
} 
sion by other means is slow, and the abundance of these cavities in so many places suggests that cliff retreat by spalling and rock fall, caused by vigorous erosion at the base of the cliff, has nearly stopped in the geologically recent past.

Fossils AND AGE

A Middle Pennsylvanian age for the lower unit of the Weber Sandstone is well established by numerous fossils collected by various workers in the Uinta Mountains area, although these rocks have been assigned to other formations by other geologists. J. Stewart Williams (1943, p. 615) identified Middle Pennsylvanian (Des Moines) fossils near the base of the Weber in the Duchesne River area. M. L. Thompson (1945, p. $34,44)$ identified fusulinids of Middle Pennsylvanian age in what he referred to as the Youghall Formation and concluded that the Youghall corresponds in age to part of the Cherokee Formation of the typical Des Moines Series of Iowa. The Youghall Formation of Thompson is the same rock sequence as the lower unit of the Weber of this report. Many collections by subsequent workers (McCann, Raman, and Henbest, 1946, p. 5-9; Baker, Huddle, and Kinney, 1949, p. 1194; Untermann and Untermann, in Hansen and Bell, 1949, p. 223; Kinney, 1955, p. 42) have verified the Middle Pennsylvanian age of the unit.

The following fossils were collected from limestone in the lower unit of the formation on the ridge between Death Valley and Spring Creek:

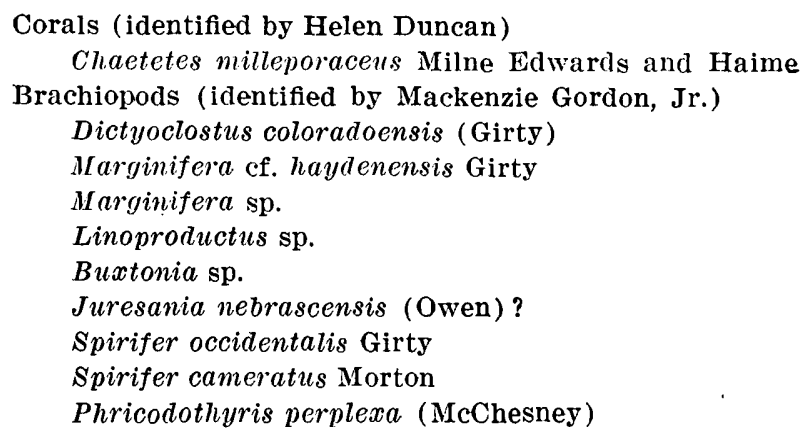

According to Miss Duncan, the coral Chaetetes milleporaceus, which was collected from bed $\mathrm{L} 15$, is one of the most characteristic fossils of the Middle Pennsylvanian in the United States. Mr. Gordon reported that the spirifers and Dictyoclostus collected from bed L 17 are typical of the widespread Lower and Middle Pennsylvanian (Des Moines or older) fauna in the Western United States.

Fossils have not been found in the upper unit of the Weber Sandstone, hence its age is undetermined. Some geologists have suggested an age as young as Permian. Brill (1952, p. 823), for example, suggested that it might $" * * *$ conceivably be a transgressive sandstone belonging to several or all of the following epochs: Des Moinesian, Missourian, Virgilian, Wolfcampian, and Leonardian." In view of the lateral and downward gradation of the upper unit into the well-dated lower unit, the upper unit in this area probably is Pennsylvanian and probably is little younger than Des Moines.

CONTACT RELATIONSHIPS

Although the contact of the Weber Sandstone with the underlying Morgan Formation is sharp, well defined, and marked by an abrupt lithologic change, it appears to be conformable. Brick-red siltstone at the top of the Morgan Formation is overlain by the characteristic fine-grained sandstone of the Weber. Inasmuch as the rocks below as well as above the contact are Middle Pennsylvanian (Des Moines) in age, any possible stratigraphic break between the two formations would have to represent a relatively short span of time.

The contact of the Weber with the overlying Park City Formation, on the other hand, appears to be disconformable. Field evidence in the area in support of this view is not unequivocal, but other indications support its likelihood. For one thing, a rather wide span of geologic time seems to be unrepresented by deposits or fossils. This matter is further discussed in connection with the description of the Park City Formation.

\section{DEPOSITIONAL CONDITIONS}

The relative purity of the sand that composes the Weber and its relatively high degree of size sorting, the considerable thickness of the formation, and the wide geographic distribution all join to suggest deposition under conditions of tectonic and climatic stability. The source of the sand itself may have been a highly quartzose terrane, although the winnowing action of waves and shore currents, given sufficient time, would have sufficed to sort out the quartz sands and carry off the impurities. Some material may have been derived from areas to the east or southeast, such as the ancestral Front Range and the Uncompahgre highlands, which were positive areas in Pennsylvanian time; these terranes were feldspathic. The bulk of the material probably had a source to the west; such a source is indicated by the west to east intertonguing of sandstone and limestone in the lower unit of the formation and by the gradual thickening of the formation toward the west.

One such source, according to Heaton (1933; p. 138), was "Cascadia," a positive area of quartzite of Precambrian age which lay to the northwest and which, in Heaton's view, also provided the quartz sand for the Wells Formation of southeastern Idaho and northern Utah and the Tensleep Sandstone and Quadrant For- 
mation of Wyoming and Montana. Kinney (1955, p. 47) noted possible sources in the Pennsylvanian highlands of Nevada. These highlands also provided vast quantities of detritus to the deep Oquirrh Basin of central northern Utah. A contrary view that the source of the Weber was to the northeast and that the sediments are eolian is presented by Opdyke and Runcorn $(1960$, p. 963$)$.

The Uinta trough was well defined in Des Moines time, and it exerted a marked influence on the thickness and distribution of the Weber Sandstone (fig. 17). To the west the trough joined the geosynclinal Oquirrh Basin; to the east and southeast it merged with the zeugogeosyncline of Colorado (Brill, 1952, p. 817, fig. 5 and p. 841). Thus, the Weber thins to the north across the Wyoming shelf-it is only 615 feet thick near Leroy in Uinta County, Wyo., and only 1,079 feet thick near Rock Springs. It also appears to thin beneath the Uinta Basin to the south where it probably intertongues with the Hermosa Formation, although the data for that area are inconclusive. To the east it intertongues with the thick Maroon Formation, and to the west it thickens and merges with the lower part of the very thick Oquirrh Formation.

Shallow marine conditions during deposition of the Weber are suggested by the lithology of the sediments. The well-washed highly crossbedded sandstones probably were deposited in a littoral environment. Some of them may have accumulated as dunes on the shore and may have been reached only by storm waves. The interbedded limestones of the lower unit were deposited in shallow water beyond the shore in an environment that teemed with marine invertebrates.

\section{ENGINEERING CHARACTERISTICS}

Major travel routes south into (or through) the Uinta Mountains, including the Vernal-Manila highway (Utah Highway 44), cross the Weber Sandstone; but except for the ruggedness of its terrain, the formation presents few special problems to possible engineering developments on or in its outcrop.

Even its rugged terrain is not necessarily a serious obstacle. Just west of the area, for example, in the gorgelike canyon of Sheep Creek, Utah Highway 44 crosses the Weber Sandstone mainly on an alluvial fill. The road makes but a few shallow cuts into bedrock even though towering cliffs hundreds of feet high rise almost from the shoulders of the road. Any substantial realinement or grade change directed toward improving Highway 44 would probably require considerable cutting into the Weber Sandstone, hence drilling and blasting.

Although small rockfalls have occurred along Highway 44 in Sheep Creek Canyon, very steep unsupported cuts should generally be possible in the Weber Sandstone. It is the prime cliff former in the eastern Uinta Mountains - except, perhaps, the Uinta Mountain Group - and its very high slope stability is shown clearly by bold outcrops and sheer cliffs. Its massive homogeneity, moreover, indicates a high degree of uniformity in physical properties from bed to bed and from place to place.

The limestone beds of the lower unit of the Weber Sandstone are hard, dense, and tough and are resistant to erosion. They ring when struck with the hammer, and they shatter to sharp angular fragments. Explosives would be needed to excavate them.

\section{PERMIAN SYSTEM \\ PARK CITY FORMATION}

The Park City Formation is typically exposed in the central Wasatch Mountains at the Park City Mining district, where it is the chief host rock for the replacement ore bodies (Boutwell, 1907, p. 439). It has been recognized for many years in the eastern Uinta Mountains. The name Park City was first applied in the eastern Uintas by Schultz (1918, p. 46), but Permian rocks had been known there since the time of the Territorial Surveys. The Bellerophon limestone of Powell $(1876$, p. 55) is identical with the Park City Formation as here described and mapped.

Usage of the name Park City Formation has varied markedly over the years and from place to place. It became much restricted when the names Wells and Phosphoria Formations were introduced for partly equivalent rocks in southeast Idaho, southwest Wyoming, and northern Utah (Richards and Mansfield, 1912, p. 683). McKelvey. and others (1956) reviewed the relationship of the Park City Formation to the Phosphoria and proposed a plan of nomenclature that clarifies the intertonguing of the two units and extends both formation names into areas where one or the other name previously was applied exclusively. In brief, they applied the name Park City to the carbonate rock and greenish-gray shale facies and the name Phosphoria to the phosphatic, cherty, and cherty shale facies. Rocks that cartographically are Park City, therefore, commonly contain tongues of Phosphoria, and rocks that cartographically are Phosphoria commonly contain tongues of Park City. To the phosphatic unit of the type locality at Park City, previously referred to as the phosphatic middle member of the Park City Formation, they applied the new name Meade Peak Phosphatic Shale Tongue of the Phosphoria Formation (McKelvey, 1956, p. 2845). This tongue is present also in the Park City Formation throughout most of the Uinta Mountains, including the Flaming Gorge area. 
DISTRIBUTION AND PHYSIOGRAPHIC EXPRESSION

In the Flaming Gorge area the outcrop belt of the formation lies generally just to the north of that of the underlying Weber Sandstone and is nearly coextensive with it. The hard basal beds of the Park City form a caprock that protects from erosion the cliffs of the softer Weber Sandstone (fig. 23). Both formations wedge out to the east against the Uinta fault just south of Boars Tusk 11/2 miles east of Horseshoe Canyon. West from Horseshoe Canyon the Park City Formation extends to the boundary of the area and beyond in a long line of flatirons and dip slopes; it is widely and well exposed in easily reached outcrops (figs. 2,66). A nearly complete section is exposed at the mouth of Horseshoe Canyon. Good sections can be seen at the head of Kingfisher Canyon, along the lower course of Sheep Creek, along Spring Creek, and along Death Valley Creek, as well as at several other less accessible places. The old Vernal road crosses the entire formation, and the uppermost beds are well exposed along the switchbacks in secs. 8, 9,16 , and 17, T. 2 N., R. 20 E. The lower units farther up the road are not so well exposed.

Alternate hard and soft strata divide the formation into a succession of ridges and valleys of very characteristic appearance-three prominent ledge formers are separated by softer slope or valley formers. Where dips are steep, the hard units form hogbacks or flatirons; the soft units form valleys. Where dips are gentle, a stairlike arrangement results; the hard beds form the "treads," the soft beds the "risers." In some places the upper units have been stripped back by erosion, and a dip slope has developed on the top of the middle or the lower hard unit. Thus, the "elbow" of Horseshoe Canyon is capped mainly by the uppermost beds of the formation, as are the broad gentle dip slopes at the head of Kingfisher Canyon and southaast of Red Bench. High up on the south side of Sheep Creek Canyon where dips generally are steeper than those in the Horseshoe-Kingfisher Canyons area, the uppermost beds have been stripped off in many places and lower units in the formation are widely exposed.

LITHOLOGY AND THICKNESS, LOWER MEMBER

In the Flaming Gorge-Sheep Creek area the Park City Formation consists of a lower and an upper (Franson) member-both dominantly carbonate rock and sandstone-separated by the Meade Peak Phosphatic Shale Tongue of the Phosphoria Formation. This relationship is characteristic throughout most of the Uinta Mountains, although the lower member tapers out eastward and is nonexistent on the south flank in sections in the eastern part of the range. The formation as a whole thickens westward from Flaming Gorge and thins toward the north, east, and south.
The lower member of the Park City Formation is 108.6 feet thick at the mouth of Horseshoe Canyon, as measured in 1950 by R. G. Waring, R. A. Smart, H. W. Pierce, and T. M. Cheney of the Geological Survey in connection with a regional study of the Park City and Phosphoria Formations (Cheney and others, 1953, p. 22). Much of the information that follows is based on data collected by these geologists and on subsequent informal discussions with Mr. Cheney.

At Horseshoe Canyon the lower member is about 65 percent sandstone, 26 percent dolomite, and 8 percent limestone. The sandstone occurs chiefly in light-yellow to light-brown or grayish-brown massive blocky beds. The beds are calcareous, mostly hard, and generally well sorted, and they range in texture from fine- to coarsegrained. The dolomites and limestones are generally light brown to grayish brown (darker than the sandstones) and form massive thick, commonly irregular, beds. Many beds are sandy, and some grade into sandstone.

In overall color, as seen on the ground and from a distance, the lower member is light to moderate brown or locally dark brown. This coloration is due in part to desert varnish encrusting the outcrop and, on screecovered slopes, to the blending and admixture of brown to grayish-brown dolomite and limestone fragments with yellow to brown sandstone. The color contrasts well with the paler shade of the underlying Weber Sandstone and serves to identify the contact between the two formations even in distant views of such inaccesible exposures as the faces of cliffs and craggy ledgesfor example, in the walls of Horseshoe and Kingfisher Canyons and along the high northwest side of Hideout Draw.

From Horseshoe Canyon the lower member of the Park City Formation thickens rapidly toward the west and thins rapidly toward the north, east, and south. Concomitantly, it changes gradually in lithology. At Sols Canyon, 14 miles west of the Horseshoe Canyon, it is 206.4 feet thick and consists almost entirely of carbonatic sandstone (Cheney and others, 1953, p. 34). Between Horseshoe Canyon and Clay Basin, 25 miles to the east, the Park City Formation has no surface exposure, but in the subsurface at Clay Basin the lower member is about 85 feet thick and consists entirely of sandstone. At Vermilion Creek about 30 miles farther east, the lower member is unrecognized and probably is nonexistent. Due south of Horseshoe Canyon on the south flank of the Uinta Mountains (at Ashley Creek) the lower member is nonexistent (Kinney, 1955, p. 48), and the Meade Peak Phosphatic Shale Tongue lies directly on the Weber Sandstone. 
MEADE PEAK TONGUE OF THE PHOSPHORIA FORMATION

The Meade Peak Phosphatic Shale Tongue of the Phosphoria Formation is typically exposed in Bear Lake County, Idaho; where it ranges from about 125 to 225 feet in thickness (McKelvey and others, 1956, p. 2846). From the type area it thickens appreciably toward the south and thins toward the north, east, and southeast. At Horseshoe Canyon it is 43.7 feet thick (Cheney and others, 1953, p. 23). It is present in the subsurface at Clay Basin but seems to wedge out completely between Clay Basin and Vermilion Creek, 30 miles farther east. Due south of Horseshoe Canyon, on the south flank of the mountains, the unit is about 17-20 feet thick (Kinney, 1955, p. 168).

Fairly good sections of the Meade Peak Tongue can be observed at several places in the Horseshoe CanyonSheep Creek area, but in general the unit is poorly exposed and forms debris-covered slopes between the harder beds of the Park City Formation above and below. Its line of outcrop is a narrow sinuous band that outlines the broad flatirons formed on the upper member of the Park City.

At Horseshoe Canyon the Meade Peak Tongue consists of medium- to low-grade phosphate rock, commonly argillaceous or carbonatic, interbedded with phosphatic carbonatic mudstones and phosphatic argillaceous dolomites and limestones. The overall rock color is predominantly of greenish cast, ranging from very pale green through shades of olive green and greenish gray in the upper part of the unit to grayish brown toward the base.

Most beds are oolitic, pisolitic, or nodular, are crumbly, and break and weather into small phosphatic shards and pellets. Textural and lithologic variations are wide. Detailed petrographic descriptions of various phosphorite rock types have been presented by Sheldon (1957, p. 116), who recognized the following six types of grains forming the chief constituents of phosphorite: (1) Structureless pellets and nodules, (2) oolites and pisolites, (3) apatite fossil fragments, (4) compound pellets and nodules, (5) phosphate sand, and (6) euhedral apatite crystals. Descriptive names such as oolitic phosphorite and pelletal phosphorite are applied to the rock on the basis of the chief constituent grains. The dolomites and limestones, which are confined largely to the upper fourth of the unit, contain abundant small nodules of chert arranged in narrow bands. Samples analyzed for phosphate $\left(\mathrm{P}_{2} \mathrm{O}_{5}\right)$ content by the U.S. Bureau of Mines (Cheney and others, 1953, p. 23) indicate that virtually the entire Meade Peak Tongue is phosphatic, but that the higher percentages of $\mathrm{P}_{2} \mathrm{O}_{5}$ occur in the lower half of the unit where phosphate rock is most prevalent.
FRANSON MEMBER

In redefining the Park City and Phosphoria Formations, McKelvey and others (1956, p. 2842) applied the new name Franson Member of the Park City Formation to rocks formerly known in the type area simply as the upper member of the Park City. This procedure helped to obviate difficulties of nomenclature that had risen in some areas where rocks correlative with the upper member of the type area are overlain by higher units of both Park City and (or) Phosphoria lithology. Following the lead of McKelvey and others, the name Franson is adopted in this report for use in the Flaming Gorge area.

At Horseshoe Canyon the Franson Member of the Park City Formation is approximately 175 feet thick (Cheney and others, 1953, p. 22). Like the lower member and the Meade Peake Tongue, it thickens toward the west and thins toward the north, east, and south. In the subsurface at Clay Basin it seems to be 137 feet thick, although the exact placing of its contacts in the stratigraphic section is doubtful. Regardless, it is considerably thinner than at Horseshoe Canyon. East of the area at Vermilion Creek the entire Park City Formation, which here probably consists only of the Franson Member, has a maximum probable thickness of only 113 feet (Sears, 1924b, p. 281; Thomas, McCann, and Raman, 1945) and may be as thin as 35 feet, depending on where the upper contact is placed. At the nearest exposures south of the Horseshoe Canyon-Sheep Creek area on the south flank of the range, the Franson Member is 80-100 feet thick (Kinney, 1955, p. 49).

The Franson Member has greater lithologic diversity in the Flaming Gorge-Sheep Creek area than either the lower member of the formation or the Meade Peak Tongue. (See measured section and fig. 19.) Its physiographic expression accordingly is more diverse also. It is divisible into four distinctive units that are easily recognized throughout the area and that appear to be correlative with similar units described from the type area (Cheney, in McKelvey and others, 1956, p. 2843).

Unit 1 , at the bottom of the member, is about 25 feet thick. It is a gray cherty carbonate sequence consisting chiefly of hard cherty dolomite and lesser amounts of limestone and mudstone. It forms a slope break above the underlying nonresistant Meade Peak.

Unit 2, next higher, consists entirely of tan-gray sandstone and is about 36 feet thick. On the outcrop it generally is deeply stained by desert varnish. It is calcareous toward the base and siliceous or quartzitic toward the top. It is fine to medium grained throughout, except at the top where in most places there is a coarse-grained sandstone or chert-pebble conglomerate layer about 1 foot thick. This bed is a good marker, 


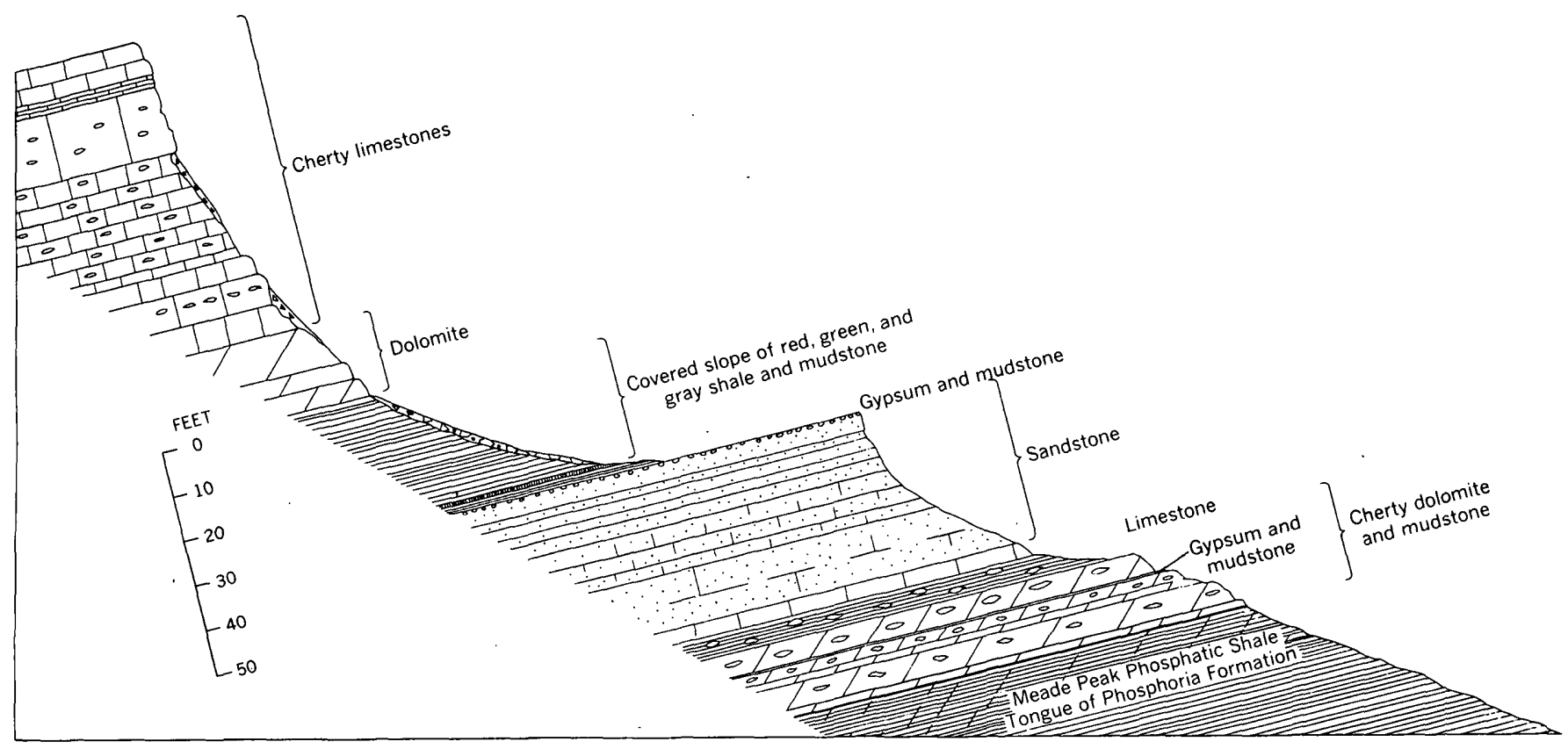

Figure 19.-Generalized section showing diverse lithology and characteristic outcrop habit of Franson Member of the Park City Formation.

as it is hard and resistant to erosion and commonly caps a prominent ledge or a dip slope. In some places a cliff extends down from the top of unit 2 to the base of unit 1 . Unit 2 appears to correlate with a similar sandstone sequence noted by Kinney $(1955$, p. 50-51) on the south flank of the Uinta Mountains in the Whiterocks-Red Mountain-Little Brush Creek area. At Red Mountain it is topped by a chert-pebble conglomerate much like that noted above.

Overlying unit 2 is a red-bed shale-siltstone-sandstone sequence about 28 feet thick. This sequence, unit 3 , is soft and nonresistant and hence is rarely exposed except in saddles on the crestlines of some of the narrow ridges south of Sheep Creek. It crops out in a fair exposure beside the Hideout Canyon road a mile above the mouth of Sheep Creek. Exposed there and elsewhere about 2 feet above the base of the unit is a rather persistent gypsum bed 1 foot thick.

Beds correlative with unit 3 on the south flank of the Uinta Mountains were noted more than 20 years ago by J. Stewart Williams $(1939$, p. 91), who proposed the name Mackentire "Red-beds" Tongue. The Mackentire Tongue of Williams and its relationship to the underlying and overlying rocks on the south flank of the range have been discussed by several authors ( $\mathrm{J}$. Stewart Williams, 1939, p. 91; Thomas and Krueger; 1946, p. 1264-1267; Kinney, 1955, p. 50; Cheney, 1955, fig. 3 opposite p. 66). The unit wedges out toward the west in the western Uinta Mountains and supposedly thickens toward the east. Kinney noted, however, that it thins drastically toward the east between Red Mountain and Little Brush Creek. It apparently does the same on the north flank east from Horseshoe Canyon, for in the subsurface at Clay Basin the Franson consists largely of dolomite; and although several red-bed layers occur in the Park City Formation at Clay Basin, they total less than half the thickness of the red beds in the Franson at Horseshoe Canyon.

The uppermost unit of the Franson Member, unit 4, is about 87 feet thick and consists mostly of limestone in the Sheep Creek area, although the lower part is dolomite. The upper 25 feet or so is very resistant to erosion and forms the flatirons along the south side of Sheep Creek Canyon. It also caps the dip slopes inside the bends of the meanders of the Green River in the canyons between Flaming Gorge and the mouth of Sheep Creek. On back slopes and side slopes it generally forms a cliff. The underlying part of unit 4 is softer and generally forms steep blocky slopes which support little vegetation. The upper beds are stained on the outcrop by desert varnish and hence contrast in color as well as in surface expression with the lighter colored beds below.

Chert is abundant in the limestone of unit 4, except in the uppermost 10 feet. The chert is mostly gray to pale blue, and it forms nodules and occasional quartz-lined geodes 3 or 4 inches across. Open cavities or vugs a few inches across are common also in the same beds. The uppermost beds of unit 4 are free of chert but contain local concentrations of shell fragments and other fossils 
including the bellerophontid, Euphemitopsis subpapillosus (White). Struck with a hammer, these beds emit a fetid odor.

Section of the Park City Formation in Horseshoe Canyon in sec. 36, T. 3 N., R. $20 \mathrm{E}$.

[Measured by R. G. Waring, R. A. Smart, H. W. Pierce, and T. M. Cheney,

Bed

Dinwoody Formation: siltstone, gray, thinbedded.

Park City Formation:

Franson Member:

F 29 Limestone, upper $3.5 \mathrm{ft}$ weak yellowish gray, massive, chunky, hard; lower $0.5 \mathrm{ft}$ yellowish gray, thick bedded, medium hard, very coarsely crystalline; nearly pure calcite. .......................

F 28 Limestone, yellowish-gray, thick-bedded, chunky, hard, finely crystalline; lower $0.5 \mathrm{ft}$ yellowish gray, thick bedded, medium hard, very coarsely crystalline; nearly pure calcite........................

F 27 Limestone, white, thin-bedded, platy, hard, argillaceous .............................

Limestone, white, chunky, medium-hard; contains chert inclusions $1-50 \mathrm{~mm}$ in diameter; weathers to pinkish tan; dolomitic near base; grades from lime-

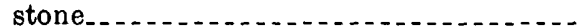

F 25 Limestone, pale-yellowish-orange (weathers darker), chunky, soft earthy to mediumhard; chert inclusions and calcite vugs throughout............................

F 24 Limestone, yellowish-gray, massive, chunky, hard, dolomitic .... . . . . . . . . . . .

F 23 Limestone, yellowish-orange to yellowishgray, chunky, finely crystalline, medium hard. Calcite oolites one-fourth millimeter in diameter. Contains discontinuous chert bands $0.05 \mathrm{ft}$ thick and 0.5

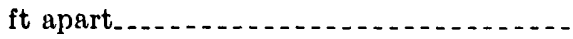

F 22 Limestone, weak-yellowish-orange, thinbedded, dolomitic, medium-hard to soft and earthy; shaly chert inclusions in lower $1.0 \mathrm{ft}$. . . . . . . . . . . . . . . . . . .

F 21 Dolomite, weak-yellowish-orange, chunky, medium-hard to soft and earthy, argil-

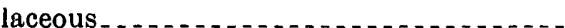

F 20 Dolomite, light-gray, massive, chunky, hard; limonite $0.1 \mathrm{ft}$ thick at $1.0 \mathrm{ft}$ and $2.0 \mathrm{ft}$ along bedding planes; desert varnish on weathered surface; grades to dolomite

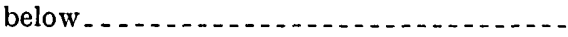

F 19 Dolomite, very pale green, chunky, medium-hard; desert varnish on weathered surface; lower contact covered............

Covered interval, approximately 26 stratigraphic feet; red and greenish-gray shales

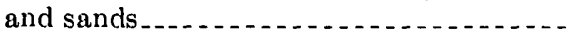

F 18 Gypsum, white, massive, soft, coarsely crystalline . . . . . . . . . . . . . . . . . . .

F 17 Mudstone, light-gray, massive, chunky, calcareous, gypsiferous ................

Park City Formation-Continued

Franson Member-Continued

Bed

F 16

F 15

Feet

F 14

F 13

4. 0

3. 6

F 10

2. 6

4. 1

F 2

F 9

F 8

F 6

(1)

4. 2

F 1

1. 0

1. $8(?)$
Sandstone, yellowish-gray, medium-grained, chunky, medium-hard; bands of gypsum $0.02 \mathrm{ft}$ thick at 0.2 -ft intervals . . . . . . . .

Sandstone, light-brownish-gray, mediumfine-grained, thin-bedded, chunky, medium-hard .......................

Sandstone, weak-yellowish-orange, finegrained, thin-bedded, chunky, mediumhard . ............................

Sandstone; very pale brown, very fine grained, thin-bedded, chunky, mediumhard . . . . . . . . . . . . . . . . . . . . .

Sandstone, weak-yellowish-orange, finegrained, thin-bedded, chunky, mediumhard ............................

Sandstone, yellowish-gray, medium-grained, thick-bedded, crossbedded, chunky, hard to medium-hard and crumbly, calcareous; grades to sandstone below . . . . . . . . . . . .

Sandstone, medium-grained, crossbedded, chunky, medium-hard to soft and crumbly, calcareous, finely pisolitic.......

Sandstone, calcareous; similar to F 10_....

Sandstone, yellowish-gray, medium-finegrained, chunky, medium-hard, crumbly, calcareous; becomes finer grained toward limestone at base . . . . . . . . . . . . . .

Limestone, -light-brownish-gray, very fine grained, thick-bedded, chunky, hard ... -

Mudstone, yellowish-gray, chunky, hard, cherty; contains approximately 10 percent chert in nodules $8-25 \mathrm{~mm}$ in diameter, gypsum throughout in more or less nodular form, and coarsely crystalline limestone in concretions or inclusions 25-30 mm across . . . . . . . . . . . . . . .

Dolomite, yellowish-gray, chunky, hard; contains chert and gypsum nodules like those in unit (F 6) above...........

Gypsum, white, thin-bedded, soft, crystal-

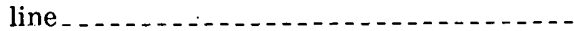

Mudstone, yellowish-gray, thin-bedded, chunky, medium-hard ................

Dolomite, upper $2.1 \mathrm{ft}$ pale brown, massive, chunky, hard; contains chert nodules; lower $1.9 \mathrm{ft}$ yellowish gray, thick bedded, chunky, hard.

Dolomite, upper $5.3 \mathrm{ft}$ pale yellowish orange, massive, chunky, hard; contains chert and gypsiferous nodules 8-20 $\mathrm{mm}$ in diameter; lower $2.3 \mathrm{ft}$ yellowish gray, massive, chunky, hard; grades to dolomite below . . . . .

Total, Franson Member.

Meade Peak Phosphatic Shale Tongue:

Dolomite, very pale green, chunky, hard to medium-hard, phosphatic, coarsely oolitic; finely pisolitic at top and near base.....................................
Feet 
Park City Formation-Continued

Meade Peak Phosphatic Shale Tongue-Con.

M 27 Dolomite, very pale green, chunky, mediumhard; chert nodules in upper $0.5 \mathrm{ft}$; moderately oolitic and pisolitic in $0.2-\mathrm{ft}$ zone 0.6 foot above base.................

M 26 Dolomite, very pale green, chunky, mediumhard to hard; 0.5 -ft-thick zone of $10-\mathrm{mm}$ chert nodules $0.5 \mathrm{ft}$ above base; slightly pisolitic throughout and moderately pisolitic and oolitic in two zones $0.2 \mathrm{ft}$ thick at $0.4 \mathrm{ft}$ and $1.0 \mathrm{ft}$ above base . . -

M 25 Dolomite and chert, very pale green, soft; dolomite 30 percent; hard light-gray chunky and nodular chert 70 percent; 0.1-ft-thick zone of moderately pisolitic and oolitic dolomite $2.5 \mathrm{ft}$ above base

M 24 Phosphate rock and dolomite, uppermost $0.4 \mathrm{ft}$ greenish-gray very coarsely oolitic soft crumbly phosphate rock; $0.3 \mathrm{ft}$ hard very pale green chunky nodular (chert $15 \mathrm{~mm}$ ) dolomite; lowermost $0.7 \mathrm{ft}$ dolomitic coarsely oolitic soft crumbly greenish-gray phosphate rock; grades from dolomite below . . . .

M 23 Dolomite and limestone, upper $0.6 \mathrm{ft}$ very pale yellowish green chunky dolomite, hard; slightly finely pisolitic, cherty nodules, sulfur and limonite crystals; lower $0.6 \mathrm{ft}$ phosphatic finely pisolitic soft crumbly light-brownish-green lime-

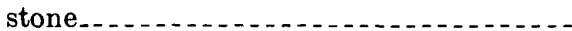

M 22 Dolomite(?), very pale brown, thick-bedded, chunky, medium-hard, finely pisolitic, phosphatic.............................

Mudstone, grayish-brown, platy, fissile, medium-hard, coarsely oolitic, finely pisolitic, phosphatic.

Mudstone, grayish-brown, platy to chunky, fissile, medium-hard, dolomitic(?) ........

Mudstone, grayish-brown, thin-bedded, platy and chunky, medium-hard, dolomitic(?); grades from mudstone below...

M 18 Mudstone, pale-brown, chunky, mediumhard, cherty

M 17 Mudstone, pale-brown, irregular, chunky, soft, phosphatic, finely oolitic; grades from phosphate rock below..........

Phosphate rock, brownish-gray, chunky, soft, finely oolitic, calcareous........

Phosphate rock, light-brown, thick-bedded, irregular, medium-hard to soft, finely oolitic, calcareous.

Phosphate rock, brownish-gray, soft, chippy, finely oolitic.................................

Mudstone, pale-brown, soft, chippy, nodular; contains fine to coarse oolites; calcareous; phosphatic......................

M 12 Mudstone, pale-brown, thin-bedded, soft, chippy; grades from mudstone below ....

M 11 Mudstone, grayish-brown, platy, fissile, soft.

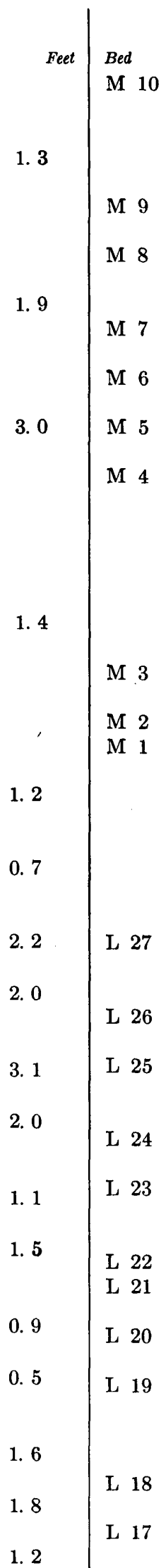

Park City Formation-Continued

Meade Peak Phosphatic Shale Tongue-Con.

Phosphate rock and mudstone, upper $1.3 \mathrm{ft}$ brownish-gray soft to medium-hard very oolitic irregular argillaceous phosphate rock; lower $0.1 \mathrm{ft}$ brownish-gray platy fissile soft mudstone.................

Phosphate rock, light-brownish-gray, thickbedded, irregular, soft, finely oolitic.....

Phosphate rock, light-brownish-gray, soft, blocky, finely oolitic, calcareous; gypsum on fracture surfaces . . . . . . . .

Mudstone, brownish-black, platy and

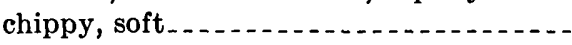

Phosphate rock, brownish-gray, soft, blocky, finely oolitic...............................

Mudstone, brownish-gray, chippy and platy,

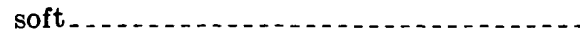

Phosphate rock and mudstone; uppermost $0.9 \mathrm{ft}$ light-brownish-gray blocky finely oolitic medium-hard argillaceous phosphate rock; $0.2 \mathrm{ft}$ grayish-brown platy fissile soft mudstone; $0.2 \mathrm{ft}$ brownish-gray thin-bedded soft finely oolitic calcareous chippy phosphate rock; lowermost $0.1 \mathrm{ft}$ grayish-brown platy fissile soft mudstone.

Phosphate rock, brownish-gray, chippy, soft, finely oolitic, calcareous.......

Phosphate rock, similar to $M 3$ Mudstone, pale-brown, medium-coarsegrained, sandy, chunky, medium-hard to soft, calcareous; chert nodules $0.2 \mathrm{ft}$ in

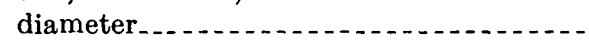

Total, Meade Peak Phosphatic Shale Tongue.................. 43.7

Lower member:

Sạndstone, light-brown, uniform coarse well-rounded grains, irregular, mediumhard, calcareous _.........

Dolomite, very pale brown, thin-bedded, blocky, silty, medium-hard.........

Sandstone, very pale brown, rounded grains, massive, medium-hard, calcareous; grades to dolomite below.....

Dolomite, pale-brown, thick-bedded to massive, irregular, hard, quartzitic........

Sandstone, yellowish-gray, fine, rounded grains, massive, irregular, medium-hard, calcareous.............. 20.6

Covered interval._.

Sandstone, light-yellow, medium-hard, calcareous............. 10.8

Sandstone, yellowish-gray, fine-grained, medium to hard, calcareous.......... 5.3

Limestone and mudstone(?), upper $0.4 \mathrm{ft}$ gray-brown medium-hard irregular limestone; lower $0.4 \mathrm{ft}$ grayish-brown thinbedded medium hard to soft mudstone(?)-

Limestone, brownish-gray, massive, irregu-

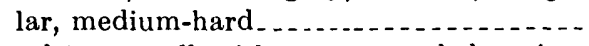

Sandstone, yellowish-gray, rounded grains, medium-hard, calcareous..............
Feet 
Park City Formation-Continued

Lower member-Continued

Bed

I. 16

I 15

I. 14

I. 13

L 12

I 11

L 10

L 9

L 8

L 7

I. 6

L 5

L 4

L 3

L 2

I. 1
Sandstone, weak-yellowish-orange, mediumcoarse-grained, irregular, medium-hard,

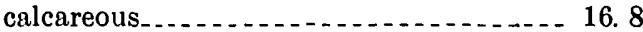

Dolomite, yellowish-gray, fine-grained, sandy, irregular, massive, hard . . . . . . . .

Dolomite, grayish-brown, thick-bedded, medium-hard. . . . . . . . . . . . . . . . . . .

Siltstone, fissile, soft, calcareous. . . . ....

Dolomite, grayish-brown, thick-bedded, medium-hard . . . . . . . . . . . . . . . . . . ....

Dolomite, pale-brown, massive, hard; grades from sandstone below . . . . . . . . . . . . .

Sandstone, very pale brown, coarse-grained, medium-hard, calcareous...............

Dolomite, sandy, like L 8

Dolomite, pale-brown, coarse-grained, sandy, massive, irregular, hard.........

Dolomite, yellowish-gray, thick-bedded, chunky, hard, quartzitic..............

Sandstone and dolomite, uppermost $0.5 \mathrm{ft}$ pale-brown fine-grained thick-bedded medium-hard sandstone; $0.1 \mathrm{ft}$ pale-brown thin-bedded medium-hard dolomite; 0.1 ft pale-brown fine-grained thin-bedded medium-hard sandstone; lowermost $0.2 \mathrm{ft}$ light-gray thin-bedded medium-hard dolomite. . . . . . . . . . . . . . . . . . . .

Limestone, light-gray, coarse-grained, sandy, thin-bedded, medium-hard; $0.02 \mathrm{ft}$ gypsum at base. . . . . . . . . . . . .

Sandstone, yellowish-gray, fine-grained, thick-bedded, chunky, hard, calcareous.-

Limestone, yellowish-gray, sandy, massive, hard . . . . . . . . . . . . . . . . . . .

Sandstone, yellowish-gray, fine-grained, rounded, medium-hard to hard, calcare-

Limestone, very pale brown, very fine grained, sandy, irregular, medium-hard; thickens and thins laterally; contains limonite bands......... 1 (?)

Total, lower member. . . . . 108. 6

W 1 Weber Sandstone: sandstone, pale-brown, hard, calcareous.

FOSSILS, AGE, AND CORRELATIONS

The age and correlations of the Park City Formation have recently been reviewed by James Steele Williams (in McKelvey and others, 1956, p. 2856-2861). According to Williams, the lower member of the Park City Formation probably is of Wolfcamp age (Permian) in most places, but in some places it contains beds of Leonard age (higher Permian), and in other places it may include beds of Pennsylvanian age. In the southern Wasatch Mountains a fauna has been found that suggests at least part equivalence between the lower member and the Kaibab Limestone of the Colorado
Plateau (Baker and Williams, 1940, p. 624). In the northern Wasatch Mountains the Wells Formation has recently been restricted, and the upper siliceous limestone has been correlated with, and designated as, the lower member of the Park City Formation (McKelvey and others, 1956, p. 2842).

A small assemblage of fossils (USGS colln. 12083) collected from a limestone bed about 10 feet above the base of the lower member at the head of Kingfisher Canyon and submitted to Mackenzie Gordon, Jr., for examination yielded the following fauna:

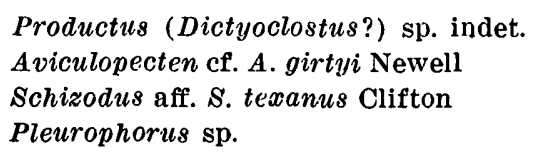

Although these fossils are not diagnostic of either a Pennsylvanian or a Permian age, they suggest a Permian rather than a Pennsylvanian age, according to $\mathrm{Mr}$. Gordon. In regard to the fossils themselves, Mr. Gordon (written commun., 1952) stated:

As far as could be determined, the Schizodus and Pleurophorus represent undescribed species. The Schizodus is similar to several species in the upper Pennsylvanian and Permian, particularly Schizodus texanus Clifton which is found in the Blaine and Dog Creek formations (Permian) of Texas and San Andres group of New Mexico. The Aviculopecten fits the description of A. girtyi Newell from the Word formation of Texas and the Manzano group of New Mexico, but lacking comparative material and noting the geographical distance that separates the localities, we are at present only comparing it with that species. It might be mentioned that Aviculopectens with this type of nodose ornament are at present known only from beds of Permian age.

The Meade Peak Tongue of the Phosphoria Formation contains many small but poorly preserved phosphatic fossils in the Sheep Creek area. In view of the numerous collections made by previous investigators in many parts of the Uinta Mountains, including Horseshoe Canyon, I made no effort to collect fossils from the Meade Peak. Fossils collected in the Horseshoe Canyon area by Waring, Smart, Pierce, and Cheney have been under study by the Geological Survey (T. M. Cheney, oral commun., 1956); but at the time of this writing (1958), the fossils had not been reported upon in the literature. According to Williams (in McKelvey and others, 1956, p. 2857), the Meade Peak is probably, but not definitely, Word (late Early and Late Permian) in age, the correlations by most authorities having been based mainly on cephalopods and brachiopods. Judging, however, from an ammonoid fauna collected in the Sublette Range of western Wyoming, Miller, Furnish, and Clark (1957, p. 1057) considered the Meade Peak to be Leonard. The upper part of the Meade Peak, moreover, has recently been correlated in the subsurface 
with the Minnekahta Limestone (E. K. Maughan, oral commun., 1958), which in turn is similarly correlated in part with the Blaine Gypsum of the Oklahoma-Texas Panhandle area (M. R. Mudge, oral commun., 1958). The Blaine was formerly considered to be equivalent to the top of the Leonard, but it is now considered to be equivalent to the lower part of the Guadalupe.

Faunas from units of the Park City above the Meade Peak, including the Franson, are not definitely known to be younger than Word, although some may be younger (Williams, in McKelvey and others, 1956, p. 2858). Again, I made no specific effort to collect fossils from the Franson in the Sheep Creek area, although fossils have been noted at several horizons. Two of the most characteristic forms are the gastropod Euphemitopsis and the scaphopod Plagioglypta. Euphemitopsis is abundant in the uppermost bed of the member but occurs lower in the section as well. Plagioglypta occurs generally below the red beds, where the brachiopod Orbiculoides has been observed also.

\section{CONTACT RELATIONSHIPS}

Throughout the Flaming Gorge-Sheep Creek area the contact of the Park City Formation with the underlying Weber Sandstone is mapped at the base of the lowest limestone bed in the lower member and at the top of the massive cliff-forming sandstone of the Weber. Some of the sandstones in the lower member of the Park City sufficiently resemble those of the Weber to make placing of the contact doubtful, especially in local areas where exposures are poor or whare insufficient section is exposed below the contact to clearly establish the identity of the Weber. In most places, however, the contact can be selected within a few feet stratigraphically, and in many places it is clearly exposed and well defined. From a distance the darker color of the basal Park City contrasts with the lighter color of the underlying Weber and helps to identify the contact. In addition, the sandstones of the Weber are more highly crossbedded than are those of the Park City.

Where exposures are good, the contact is seen to be disconformable. The very marked crossbedding in the upper part of the Weber, however, causes the illusion of sharper truncation in some places than actually exists. Along the Hideout Canyon road, several feet of relief on the contact was noted by Thomas and Krueger (1946, p. 1293). Along Death Valley rim, as viewed at a distance from higher ground to the south, the Park City appears to cut across the Weber at a low angle, the contact gradually rising stratigraphically on the Weber eastward; in other words, the Park
City appears to rest on older beds of the Weber toward the west along the rim and on younger beds toward the east, and about 100 feet of Weber Sandstone appears to be truncated by the contact in a horizontal distance of about 1 mile.

Although local evidence of disconformity between the Park City and the Weber is equivocal or lacking in some places, there is strong support for its reality when area-wide relationships are considered. In the Uinta Mountains area the Park City was deposited during a time of general transgressive overlap. Lithologic variations, of course, indicate intermittent shoaling and subsidence of the bottom, and at least one major regression of the shore is indicated by the red-bed unit of the Franson, but the overall pattern is that of transgression. The lower member of the formation thins irregularly eastward and disappears between Lake Fork and Whiterocks River on the south slope (Huddle, Mapel, and McCann, 1951; Kinney, 1955, p. 54) and between Clay Basin and Vermilion Creek on the north slope. The overlying Meade Peak Tongue of the Phosphoria Formation, which rests directly on Weber east from Whiterocks River, likewise thins eastward and eventually disappears between Brush Creek and Dinosaur National Monument on the south slope (Untermann and Untermann, 1954, p. 38) and between Clay Basin and Vermilion Creek on the north slope. At Dinosaur National Monument and at Vermilion Creek the Franson Member-itself much thinned-rests directly on Weber Sandstone. Evidently then, the Park City Formation was deposited in the Uinta Mountains area in a seaway whose shoreline advanced with time southeastward across the Weber Sandstone.

The time span represented by the difference in ages of fossils contained in the Weber and in the Park City also supports the probability of an intervening hiatus and disconformity. Although the thick upper beds of the Weber are devoid of fossils, the limestones of the lower part of the Weber contain Des Moines fossils, and the probability seems good that the upper part of the formation is of Des Moines age also. In any event, that all of Pennsylvanian time later than Des Moines is represented by the upper part of the Weber Sandstone seems improbable. At the same time, the lower member of the Park City Formation in the Uinta Mountains probably is no older than Wolfcamp, and the Meade Peak and Franson probably are Word or Leonard.

$$
\text { DEPOSITIONAL CONDITIONS }
$$

Many data have been published, including an excellent summary by McKelvey, Swanson, and Sheldon (1953), on the marine environmental conditions under 
which the Park City and Phosphoria Formations accumulated. Sheldon (1957) summarized the sedimentary and physical-chemical conditions that accompanied deposition of these formations in northwestern Wyoming, as well as the diagenetic changes that ensued following deposition; many of his conclusions can be extrapolated to the Uinta Mountains area. Phosphorite-mudstone-chert facies, such as characterize the Meade Peak Tongue, accumulated in relatively deep water-down to probable depths of 1,000 meters (McKelvey, Swanson, and Sheldon, 1953, p. 59) ; carbonatesandstone facies accumulated in shallower water; red beds and evaporites accumulated in yet shallower water, the evaporites under conditions of restricted circulation, high rate of evaporation, and high salinity (Sheldon, 1957, p. 154). Lateral zoning of facies in the western phosphate field indicates that depth of water probably increased toward the west (McKelvey, Swanson, and Sheldon, 1953, p. 58). Both the deepest part of the basin and the position of the shoreline shifted considerably during Permian time, but the deeper parts were mostly in east-central Idaho and perhaps adjacent parts of Montana and Utah (McKelvey and others, 1956, p. 2829). A general thickening of the total section toward the west and the wedging out of red beds in that direction support the same view (fig. 20).

Marked vertical facies variations indicate local physical-chemical changes in environment caused principally by changing depths of water. which in turn are believed to have been brought on chiefly by mild tectonic activity (Sheldon, 1957, p. 153). Thus, in the Uinta Mountains area, unstable shelf conditions are indicated during that part of Permian time represented by the Park City and Phosphoria Formations. Besides depth of water, however, other factors must have influenced types of sediment and associations of types : these muist have included climate; distance to, lithology of, and topography of the source area ; currents within the depositional basin; and the concentration of elements in the waters of the basin and of the inflowing streams (Cressman, 1955, p. 27).

Krumbein and Garrels (1952, p. 8-9) indicated that precipitation of phosphorite, like carbonate, is strongly dependent on the $\mathrm{pH}$ value of the water, that the solubility curves of phosphate and carbonate ions are essentially parallel, but that the absolute value of the phosphate is less than of the carbonate; other factors such as salinity and pressure have relatively slight effect. Thus, if the $\mathrm{pH}$ value is relatively high (more than about 7.8, according to Krumbein and Garrels), the calcium is first precipitated with carbonate, as limestone, and little calcium phosphate is deposited. As the $\mathrm{pH}$ is lowered, less carbonate and more phosphate is

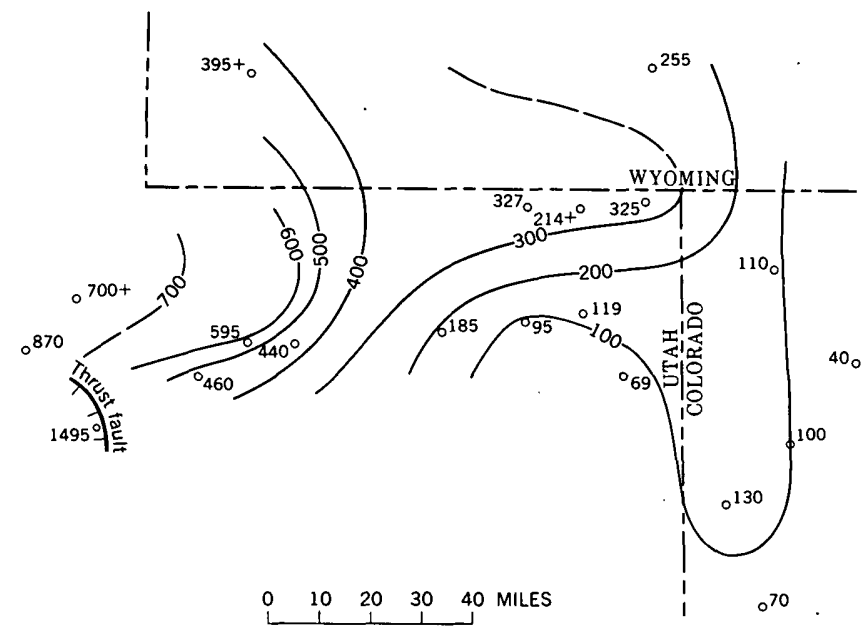

Frgure 20.-Generalized thickness map of Park City Formation. Isopach interval is 100 feet.

precipitated. Under truly acid conditions ( $\mathrm{pH}$ less than 7.0), neither will become saturated.

The environment favoring deposition of phosphorite in the Phosphoria sea was thus visualized by McKelvey, Swanson, and Sheldon (1953, p. 62) as follows:

The Phosphoria formation accumulated in a large shelving embayment bordered by lands of low relief that contributed little detritus to the sea. Cold, phosphate-rich waters upwelled into this basin from the ocean reservoir to the south or southwest. Phosphorite was deposited from these ascending waters, probably in depths of 1,000 to 200 meters, as their pH increased along with increase in temperature and decrease in partial pressure of $\mathrm{CO}_{2}$. Carbonates were precipitated from these waters when they reached möre shallow depths, at a somewhat higher pH. The phosphate-rich waters nurtured a luxuriant growth of phytoplankton, as well as higher forms of plant and animal life, some remains of which were concentrated with fine-grained materials in deeper waters away from shore. Part of the phosphate and probably some of the fine-grained silica in the formation were concentrated by these organisms.

The significance of organisms in precipitating phosphorites was minimized, however, by McKelvey, Swanson, and Sheldon (1953, p. 60), who pointed out that even though a compound may be extracted from the water by an organism, the compound will be resorbed on the death and decay of the organism unless the water is essentially saturated with the compound.

\section{ENGINEERING CHARACTERISTICS}

Because of its high resistance to erosion, the Park City Formation has an outcrop that is disproportionately wide for its thickness. The chance of its eventually becoming a factor in some engineering problem, therefore, is correspondingly high. West from Horseshoe Canyon its outcrop is continuous to the boundary of the area, except where it is interrupted by the canyons of the Green River and Sheep Creek. Any road south 
through this area would cross its outcrop. Just east of Horseshoe Canyon the formation disappears from the surface section owing to faulting.

Virtually any excavation into undisturbed rock, including the Meade Peak Phosphatic Shale Tongue of the Phosphoria Formation, would require explosives and power equipment for adequate operations. By the same token, the bearing strength of the rock is high (more so in the members of the Park City than in the Meade Peak Member of the Phosphoria), and the stability of slopes in excavated cuts should be high also. In areas of steeply dipping beds-south and west of Sheep Creek Gap, for example-cuts that slope in the same direction as the dip of the bedding should not exceed the angle of dip, as a precaution against rock falls. Cuts sloping in the opposite direction, however, should be stable to angles approaching vertical. Intermittent small-scale spalling is likely in most steep cuts, however, because the formation is closely jointed.

Evidence of natural slope failure on any part of the Park City Formation or on the Meade Peak Tongue has not been observed in the area. The red beds in the Franson Member, judging from natural slopes and lithology, are the least competent rocks in the formation and hence probably have the lowest bearing strength and shear strength and are most apt to fail, other things being equal.

\section{MESOZOIC ROCRS}

During most of the Mesozoic Era the Flaming Gorge area lay on the unstable shelf of the craton, bordering the Cordilleran geosyncline to the west. (See table 6.) The old Uinta trough, which was poorly defined in the Permian and Triassic Periods (figs. 25, 27), once more exerted influence on sedimentation during the Jurassic and Cretaceous, and a column of sediments aggregating more than 12,000 feet in thickness accumulated over the site of the eastern Uinta Mountains; appreciably thinner sections accumulated in the areas to the north and south.

Mild tectonic activity brought recurrent incursions of marine waters across the area, and a great variety of marine and nonmarine sediments was deposited. Marine conditions existed during at least part of Early Triassic time, two incursions followed in Late Jurassic time, and, after the Dakota interval, marine conditions extended into Late Cretaceous (Montana) time.

Throughout the Triassic Period and most of the Jurassic, sediments were derived largely from the craton. As the sea oscillated across the shelf in a broad belt north to south, marine sediments on the west interfingered with nonmarine sediments on the east.

A marked change in direction of sedimentation followed in Late Jurassic time with the rise of the ancestral
Nevadan Mountains to the west. Thenceforth, sediments were derived principally from this new landmass, and apparently little material came from the east. As a further effect of the orogenic impulses then building up in the west and moving eastward, the unstable shelf of the Triassic, Jurassic, and Early Cretaceous sea gave way to the broad foredeep of the Late Cretaceous seaway. Although the thickest deposits of this trough accumulated generally to the west of the Flaming Gorge area (Reeside, 1944), more than 8,000 feet of marine sediments was deposited in the area.

Final emergence of the land followed in later Montana time, and deposition was terminated by the first local movements of the Laramide orogeny.

\section{TRIASSIC SYSTEM}

Flaming Gorge was named by Major Powell for the brilliant canyon walls where the Green River enters the foothills of the Uinta Mountains. The brilliance of the walls is due to the varicolored, but mostly red, Triassic formations in the lower slopes of the gorge. Triassic rocks are well exposed southwest from Flaming Gorge toward Sheep Creek Canyon and along Sheep Creek Canyon toward the west boundary of the area. Possibly the best exposures are just west of Flaming Gorge on the high slopes north of Red Bench and Horseshoe Canyon where near-complete sections lack cover or structural complication (fig. 21). Farther west toward Sheep Creek Gap, parts of the section are concealed by alluvium and talus, and parts are involved in faulting. Three miles or so southeast from Flaming Gorge the entire Triassic section is cut at the surface by the Uinta fault. Discontinuous sections are exposed 4-8 miles farther east near Dutch John Gap in the downthrown block of the fault, but east from there, Triassic rocks are not exposed west of Vermilion Creek, 15 miles beyond the boundary of the area, except in a small sliver in the Uinta fault southeast of Clay Basin.

Over the years various correlations have been made with the Triassic rocks of the Uinta Mountains, and various names have been applied. A good deal of confusion has existed also. To the present day full agreement has not been reached among geologists as to the preferred nomenclature, although fairly general agreement has been reached as to the correlations of the rocks with units of adjoining areas. Powell $(1876$, p. 41, 68) recognized the similarity of the Uinta Mountains section to that of the Colorado Plateau and applied the name Shinarump Group to both areas; he distinguished an Upper Shinarump Sandstone, a Shinarump Conglomerate, and a Lower Shinarump Sandstone. The names Moenkopi and Chinle Formations later supplanted Lower and Upper Shinarump, respectively, in usage on the plateau; and a new set of names, mean- 


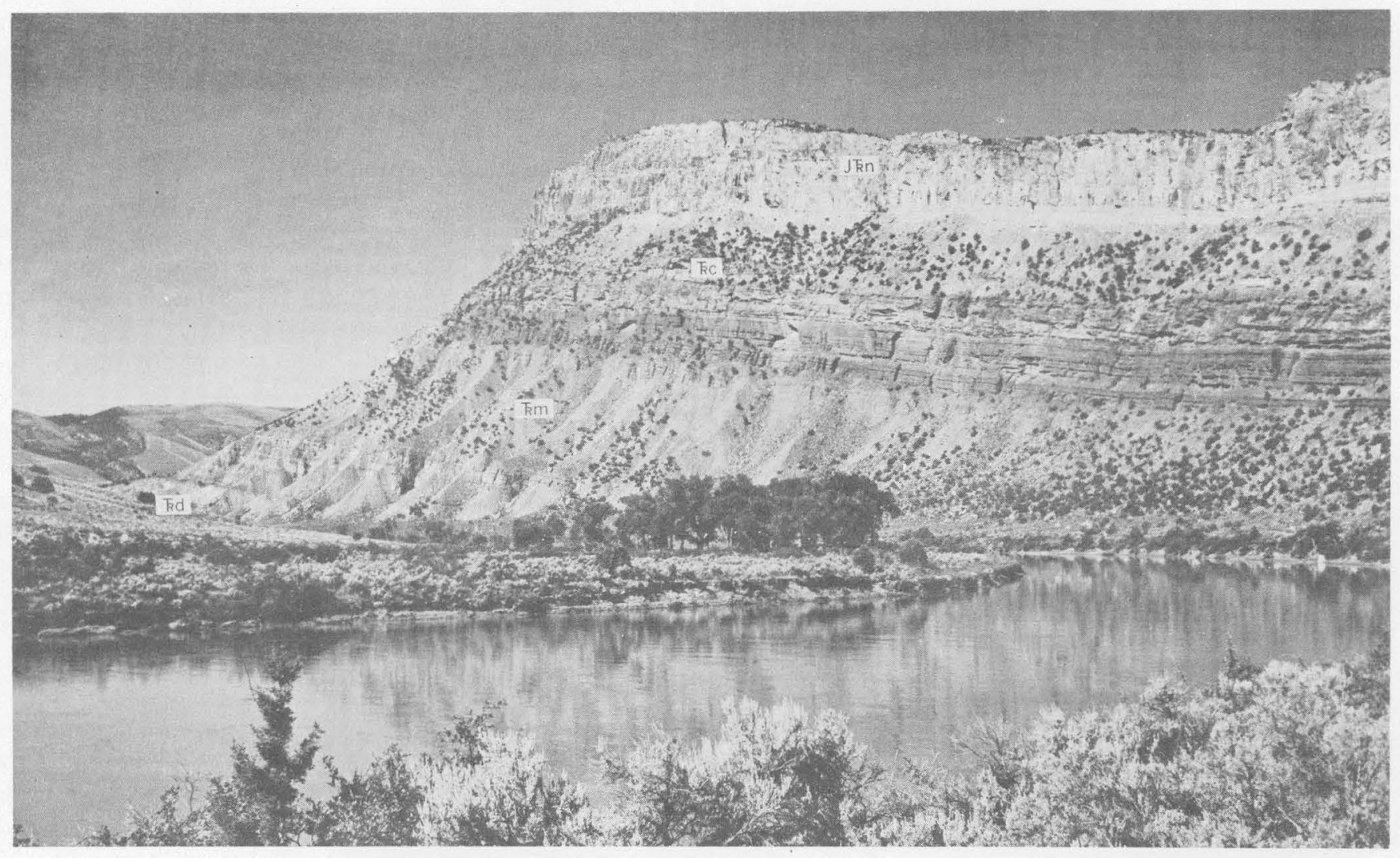

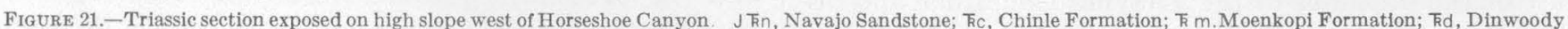
Formation. Threefold character of Moenkopi Formation shown clearly above and to left of cottonwood grove, center of picture. Navajo Sandstone rim is about 1,300 feet above river level. Flaming Gorge Reservoir at this locality will be about 200 feet deep at full storage.

while, was introduced into the Uinta Mountains by A. R. Schultz.

In 1914, during a reconnaissance directed primarily toward a study of the Permian phosphate deposits, Schultz $(1918$, p. $54 ; 1920$, p. 36) applied the names Woodside, Thaynes, and Ankareh throughout the Uinta Mountains-names first used by Boutwell (1912, p. 52) for the Triassic rocks of the Park City district of the Wasatch Mountains. At the same time, Schultz considered these formations to be equivalent to the Chugwater and Dinwoody Formations of central Wyoming; but he ignored, except in passing, the terminology of Powell.

Although the Wasatch Mountain nomenclature applies well to the western Uinta Mountains, it loses most of its meaning in the eastern part of the range where facies changes materially alter the physical appearance of the rocks and give rise to a section more comparable to that of the San Rafael Swell to the south or of central Wyoming to the north. Viewed in the light of what is now known about Triassic paleogeography, marked west to east facies changes are not surprising; the Early Triassic seaway that covered much of west- ern Utah, southern Idaho, and western Nevada shoaled toward the east and southeast, and nonmarine beds on the east supplant marine beds on the west.

The Triassic stratigraphy of the Uinta Mountains in relation to that of adjacent areas has been reviewed in some detail by J. Stewart Williams (1945), by Thomas and Krueger (1946, p. 1267-1275), and more recently by Kinney $(1955$, p. 56$)$. Each of these investigators proposed somewhat different solutions to the name problem.

In brief, the Triassic sequence thins eastward along the mountains (fig. 22); the limestones of the Thaynes Formation completely, or nearly completely, wedge out; and the overlying and underlying red beds merge into a single thick unit. The upper part of the Ankareh Formation, as now recognized by most geologists working in the Wasatch Mountain area (Calkins and Butler, 1943 , p. 33, pl. 5; A. A. Baker, 1947; Granger and Sharp, 1952, p. 12; Granger, 1953, p. 4), changes appre ciably in lithology but retains its essential identity throughout the Uinta Mountains and passes into the Shinarump Conglomerate and Upper Shinarump Sandstone of Powell. This is the unit that Schultz called 


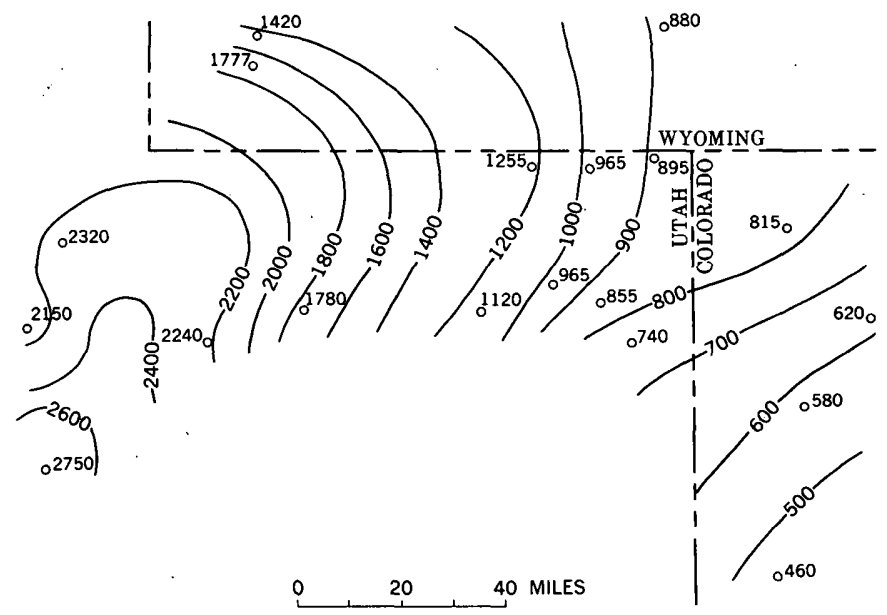

Figure 22.--Generalized thickness map of Lower Triassic rocks. Isopach intervals 100 and 200 feet.

Ankareh in the eastern Uintas; in the Flaming Gorge area it has much of the character of the Popo Agie Member of the Chugwater Formation of central Wyoming. The lower part of the Woodside Formation concomitantly grades eastward from red beds into gray strata, and in the easternmost part of the range the entire Triassic section below the Shinarump is gray.

J. Stewart Williams (1945, p. 477) proposed the new name Red Wash Formation for the merged red beds east of the pinchout of the Thaynes Limestone and below the Shinarump of Powell. He restricted the Ankareh to beds above the Thaynes and below the Shinarump, retained the name Shinarump, and adopted the name Chinle for beds above the Shinarump. In the same year, Thomas, McCann, and Raman (1945) used the San Rafael Swell (Colorado Plateau) nomenclature-Moenkopi, Shinarump, and Chinle-in a series of measured surface and subsurface sections in eastern Utah and northwestern Colorado.

Thomas and Krueger (1946, p. 1269) followed Williams in restricting the Ankareh west of the pinchout and in dropping it to the east, but they proposed retaining the name Woodside for the entire section east of the pinchout and below the Shinarump Conglomerate of Powell, believing that the rocks of the interval consist mainly, but not entirely, of beds equivalent to the type Woodside. They further proposed the new names Gartra Grit Member and Stanaker Formation for the overlying rocks, and correlated them with the Shinarump Member of the Chinle and the overlying parts of the Chinle, respectively. Kinney and Rominger (1947), Kinney (1955, p. 56), and Untermann (1954, p. 41) adopted the San Rafael Swell nomenclature. For the Flaming Gorge area, Hansen and Bonilla (1954, p. 4) and Hansen (1955a) also used the San
Rafael Swell nomenclature but applied the name Dinwoody Formation to the thick gray shale-siltstone sequence between the Park City Formation below and the red beds sequence above.

In an effort to simplify and clarify the nomenclature of post-Thaynes Triassic rocks in the Wasatch and Uinta Mountains, Kummel (1954, p. 179-180) proposed retaining the name Ankareh in the Wasatch Mountains in the generally used sense and reducing the Stanaker and Gartra to member rank in the Wasatch Mountains and using the San Rafael Swell (Colorado Plateau) names in the Uinta Mountains. This proposal has merit, but it takes the awkward stand of recognizing Gartra and Stanaker in the Wasatch Mountains but not recognizing them in their type area-that is, the eastern Uintas. In the Wasatch Mountains, moreover, the name Suicide Grit Member of the Ankareh Formation (J. Stewart Williams, 1945, p. 474; Granger, 1953, p. 10) has been used for many years and has priority of usage over the name Gartra.

\section{DINWOODY FORMATION}

The name Dinwoody Formation is applied to a sequence of light-gray to greenish-gray soft ripplemarked shales, siltstones, and sandstones between the Franson Member of the Park City Formation below and the Moenkopi Formation above. Although this unit contains a few thin dense crystalline limestone beds, no fossils have been found, and its correlation with the Dinwoody Formation of Wyoming rests on lithologic similarity and stratigraphic position. Physical tracing across the Green River Basin is impossible, owing to deep burial beneath younger rocks, but beds of similar lithology and position have been identified in deep wells at South Baxter in the Rock Springs uplift and at Shell Oil Co.'s Leroy Well 1 and Brinkerhoff Co.'s Unit 1-31 in Uinta County, Wyo. In all probability the Dinwoody sequence passes unbroken beneath the Green River Basin.

The Dinwoody Formation is typically exposed in the Wind River Mountains of Wyoming at Dinwoody Canyon, about 160 miles north of Flaming Gorge. As originally defined by Blackwelder (1918, p. 425), it included all beds between the top of the Park City Formation below and the base of the red beds of the Chugwater Formation above and had a thickness of about 250 feet. The type section was redefined by Newell and Kummel (1942, p. 941), who restricted the Dinwoody to the lower 90 feet of the original section and included the remainder with the Chugwater. In most places, however, the upper boundary is still placed at the change from gray beds below to red beds above. 


\section{DISTRIBUTION AND PHYSIOGRAPHIC EXPRESSION}

Excellent exposures of the Dinwoody Formation can be seen along the south side of Sheep Creek in the western part of the area where a double row of low gray miniature hogbacks rests against the high dip slopes of the Park City Formation (fig. 2). The entire thickness of the Dinwoody Formation is exposed along the old Vernal road just below the switchbacks in the SE1/4 sec. 8, T. 2 N., R. 20 E., 2 miles east of Sheep Creek Gap. Farther east across Sheep Creek the unit is exposed discontinuously at Red Bench and Neilsons Bench and on toward Flaming Gorge. Across Flaming Gorge the formation extends southeast to Chokecherry Draw, about 2 miles east of Horseshoe Canyon, where it is cut out at the surface by the Uinta fault. From that point east it is concealed and does not reappear anywhere in the area. It has been penetrated, however, by Ohio Oil Co.'s test (Government 1) on the Spring Creek nose south of Antelope Flat in sec. 34, T. 3 N., R. 22 E., and by Mountain Fuel Supply Co.'s R. D. Murphy 6-W well in Clay Basin in sec. 22, T. 3 N., R. 24 E.

Because it is relatively nonresistant, the Dinwoody Formation occupies low ground and forms soft rounded outcrops. It supports little vegetation, and its stark gray-white outcrop contrasts markedly with the brilliant reds of the overlying Moenkopi. Likewise, it contrasts physically with the resistant uppermost limestone of the underlying Franson Member of the Park City Formation.

\section{LITHOLOGY AND THICKNESS}

In the Sheep Creek-Flaming Gorge area the Dinwoody Formation consists chiefly of light-gray to lightgreenish-gray mostly calcareous thinly bedded siltstone and shale with interbedded thin-bedded friable finegrained sandstone. Seams and veinlets of gypsum or anhydrite are common, especially in the lower twothirds of the formation. Thin gray crystalline limestone or dolomite beds occur here and there, and sandy to silty limestones about 100 feet above the base of the formation form a nearly continuous ledge 4-6 feet high. This resistant ledge, which is largely responsible for the miniature hogback in the lower part of the formation, shows penecontemporaneous deformational features near the Hideout Canyon road where one of the limestone beds slumped along a soft clay interbed before the next higher bed was deposited.

Finely disseminated pyrite common in Dinwoody samples from Ohio Oil Co.'s Government 1 well indicates reducing conditions during deposition. Pyrite is also reported from the Mountain Fuel Supply Co.'s R. D. Murphy 6-W well in Clay Basin, but it has not been observed in surface exposures, probably because of subaerial oxidation on the outcrop.

At Flaming Gorge the Dinwoody Formation is about 530 feet thick. This thickness is much greater than that at the type area in Dinwoody Canyon but is comparable to the thickness at sections just west of the DarbyAbsaroka overthrust belt of western Wyoming (fig. 23). In Ohio Oil Co.'s Government 1 well the unit is about 500 feet thick, and in Clay Basin it is about 360 feet thick, although it could be considered to be somewhat thicker depending on where the upper contact is placed. In Clay Basin, in particular, the top of the formation is indefinite, inasmuch as it grades upward transitionally through several tens of feet into the base of the overlying Moenkopi Formation.

Section of the Dinwoody Formation in the NE1/4 sec. $36, T .3 \mathrm{~N}$., $R$. $20 \mathrm{E}$., on the lower slope of the canyon wall starting at the saddle northwest of Horseshoe Canyon

[Measured by W. R. Hansen and T. B. Piper, August 1951]

Moenkopi Formation : sandstone, gray; interbedded with chocolate-brown to gray shale and siltstone; overall color, pale pinkish gray.

Dinwoody Formation:

Siltstone and sandstone, light-gray, soft, friable; very little gypsum. Beds as thick as $2 \mathrm{ft}$ except toward base where they are thin bedded and ripple marked. Gray to pale yellow gray toward base-_...--

Siltstone and sandstone, gray to pale-brown, fine- to medium-grained, thin-bedded, friable; numerous veinlets of gypsum.

Sandstone, light-gray, fine-to medium-grained, thinbedded, friable, somewhat crossbedded, calcareous; forms ledge; in places grades into limestone.--_--

Clay-shale, gray, with gypsum seams and veinlets; interbedded toward base with gray thin-bedded siltstones and fine-grained sandstone

$$
\text { Total }
$$

Park City Formation :

Franson Member: limestone, mottled gray, and pale yellow ; blocky; hard ; fossiliferous.

\section{AGE, CONTACT RELATIONSHIPS, AND CORRELATIONS}

The Dinwoody Formation is regarded as Early Triassic in age. Diagnostic fossils have not been found in the Flaming Gorge area, although diligent search might yield a few specimens. Thomas and Krueger (1946, p. 1293 ) reported "obscure molds of pelecypods in talus" about midway in the section along Hideout Canyon road. In the absence of index fossils, the age of the formation in the Flaming Gorge area must be inferred from correlations with rocks of known age elsewhere.

In other areas the formation has yielded abundant Early Triassic faunas (Newell and Kummel, 1942). Although fossils are not generally abundant in the 


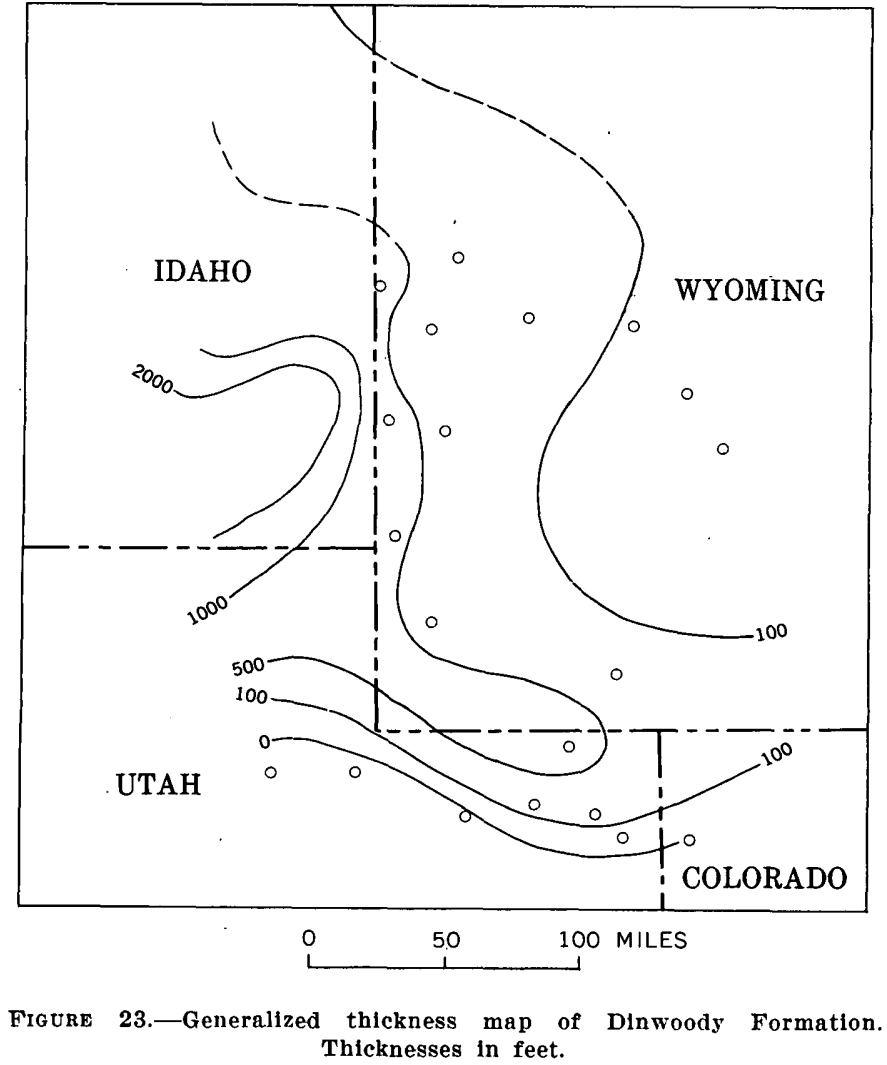

lower part of the formation, Kummel (1954, p. 168) reported lower Scythian (Early Triassic) ammonites and Claraia in southwestern Montana within 5 feet of the base. Kummel also pointed out that "*** fossils are not abundant in the lower part of the Dinwoody formation, but it is not uncommon to find poorly preserved specimens of ceratites, Anodontophora and Claraia, which are typical Early Triassic fossils."

Although the underlying Franson Member of the Park City Formation is not known to be younger than Word (Williams, in McKelvey and others, 1956, p. 2858 ), and hence the lower age limit of the Dinwoody might be Permian, there is reason to suspect the existence of a significant hiatus between the Dinwoody and the Park City, even though the contact in the Flaming Gorge area lacks physical evidence of a stratigraphic break other than a marked lithologic change across the contact. Newell and Kummel (1942; cited by Kummel, 1954 , p. 167) reported an unconformity between the Permian and the Dinwoody in southwestern and central Wyoming and gave as evidence (1) the marked leaching of cherty beds at the top of the Phosphoria, (2) the marked northeastward overlap of the lower part of the Dinwoody strata by the upper part of the Dinwoody, and (3) the local truncation of the upper beds of the Phosphoria by basal beds of the Dinwoody. Love and others (1945) also noted an unconformity at the base of the Dinwoody in central Wyoming.
To the west in the Wasatch Mountains, the Woodside Formation, which intertongues with the Dinwoody and in part, therefore, is the time equivalent of the Dinwoody, is dated as Early Triassic by its relation to the overlying fossiliferous Thaynes Formation, which contains an abundant fauna of Early Triassic ammonites. In the central Wasatch Mountains the Woodside lies unconformably on the Park City (Boutwell, 1933, p. $39,75)$; in the southern Wasatch it bevels nearly 3,000 feet of Permian beds in a horizontal distance of about 10 miles (Baker and Williams, 1940, p. 617). Similarly, the Moenkopi Formation, which partly intertongues with the Dinwoody in the area between Sheep Creek and Clay Basin and partly overlies it, is dated as Early Triassic in the San Rafael Swell by the fossils of the Sinbad Limestone Member in the lower part of the formation (Gilluly, 1929, p. 83). The Sinbad contains the same fauna as the Thaynes and is correlated with it (MacLachlan, 1957, p. 83). A possible correlative of the Sinbad has been found at Sheep Creek, as is pointed out in the section of this report on the Moenkopi Formation. In the San Rafael Swell an unconformity separates the Moenkopi Formation from the underlying Kaibab (Gilluly, 1929, p. 82), which is correlated with the lower member of the Park City Formation (Baker and Williams, 1940, p. 624).

East of the Uinta Mountains the relationship between Permian and Triassic rocks is unclear, partly because of uncertain correlations due to similar lithologies in the two systems. At Elk Creek in Garfield County, Colo., equivalents of the Dinwoody and Moenkopi apparently are missing, and Upper Triassic rocks rest directly on Permian rocks (Thomas, McCann, and Raman, 1945). Judging from extensive studies of surface and subsurface sections, supplemented by electric log correlations, Walter Hallgarth (oral commun., 1958) favored the possibility that the top of the Park City is an eroded surface in northwestern Colorado, hence that an unconformity exists between the Permian and the Triassic Systems.

In summary, rocks equivalent to the Dinwoody Formation rest unconformably on Permian rocks to the north, west. and south, and possibly to the east, although physical evidence of unconformity is lacking locally. Rocks equivalent to the Dinwoody also grade upward or laterally into fossiliferous rocks of Early Triassic age. The Dinwoody Formation of the Flaming Gorge area is correlated in a general way with the typical. Dinwoody of southwestern and central Wyoming by its stratigraphic position and lithology. It intertongues toward the west with the red shale of the Woodside of the Wasatch Mountains. To the south it intertongues with, and is overlain by, the Moenkopi Formation. Gray beds 100 to 150 feet thick at the base of the 
Moenkopi north of Vernal on the south slope of the Uinta Mountains are regarded as a tongue of the Dinwoody Formation (Kinney, 1955, p. 61). Gray-bed counterparts of the Dinwoody also occur in the lower part of the Moenkopi Formation in the San Rafael Swell (Gilluly, 1929, p. 84-86). East of the Uinta Mountains in the Vermilion Creek basin the entire Lower Triassic section is gray and presumably could be called Dinwoody, although it contains rocks equivalent in age to the Moenkopi Formation of the Flaming Gorge area. Farther east, the State Bridge Siltstone Member of the Maroon Formation of Bassett (1939, p. 1864) may possibly contain beds correlative with the Dinwoody.

\section{DEPOSITIONAL CONDITIONA}

A marine origin for the Dinwoody Formation is indicated by the widespread occurrence of marine fossils in the formation. The almost total lack of fossils in the formation along Sheep Creek and Flaming Gorge, however, indicates somewhat special environmental conditions either unsuited for the growth of organisms or for their preservation after death. The presence of considerable gypsum throughout much of the formation suggests shallow water, restricted circulation, evaporation, and high concentrations of dissolved sulfates and brines unfavorable for the development of organisms. Ripple marks further suggest shallow water. Disseminated pyrite in the siltstones, as well as the greenish-gray color of the rocks themselves, indicates strong reducing conditions during deposition, hence low oxygen content of the water, also unfavorable for the growth of living organisms. In order for sulfates (gypsum) and sulfides (pyrite) to coprecipitate, the salinity of the water probably must exceed about 200 parts per thousand, and the oxidation-reduction ratio must be negative (Krumbein and Garrels, 1952, p. 25, 26). Such conditions favor the preservation of organic remains but are unsuited to the growth of living organisms. In all probability, therefore, the shallow waters of the Dinwoody sea in the Uinta Mountains area supported very little life. Similar conditions probably prevailed south and southeast of the Uinta Mountains area where assentially the same rock types exist. Such conditions could be promoted by a broad flat shallow sea bottom-above wave base but below low-tide level-across which circulation is inhibited by the very shallowness of the water and perhaps by an arid climate under which inflow from fresh-water sources is much reduced. For comparable rocks in the San Rafael Swell area, Gilluly $(1929$, p. 86$)$ visualized possible deposition on a delta under arid climatic conditions, the gray beds being deposited in stagnant muddy delta pools.
ENGINEERING CHARACTERISTICS

The linear shape of the Dinwoody outcrop belt limits consideration of the formation in possible engineering activities to a relatively small area. Moreover, the topographic setting of the formation is such that there is little likelihood of structures other than roads, perhaps, being built on or across the outcrop.

In the event of excavations, probably most of the formation can be dug with power tools without recourse to explosives. A few limestone and sandstone beds, however, would require blasting before removal.

The formation apparently possesses moderately high natural stability, although its bearing strength is not high. Common natural slopes as steep as $45^{\circ}$ or more suggest that cuts can be excavated in most places to $1: 1$ without danger of serious slumping. Natural slope failures in the formation have not been observed.

Surface runoff on the formation is rapid. Little water soaks into the ground because of the tight silty or shaly matrix of the rock.

\section{MOENKOPI FORMATION}

The name Moenkopi Formation is applied to the thick red-bed sequence between the gray beds of the Dinwoody Formation below and the unconformable basal sandstone of the Chinle Formation above. Correlation of the beds on the north slope of the Uinta Mountains with the typical Moenkopi of the Colorado Plateau (Ward, 1901, p. 401) is based largely on stratigraphic position and lithology. The few fossils that have been found are poorly preserved and are not very diagnostic. As exposed along Sheep Creek and in the walls of Flaming Gorge, the formation is virtually identical in most respects with the Moenkopi north of Vernal on the south slope of the mountains. The latter beds are similarly correlated with the Moenkopi of the San Rafael Swell (Kinney, 1955, p. 56-57). Owing to the isolated character of the Uinta Mountains, isolated by deep Tertiary basins to the north and to the south and by Tertiary cover to the east and west, physical tracing of any but Tertiary rocks into adjacent areas is impossible.

\section{DISTRIBUTION AND PHYSIOGRAPHIC EXPRESSION}

The Moenkopi Formation has a nearly continuous outcrop in the lower walls of Sheep-Creek Canyon and on the high slopes northwest of Red Bench and Horseshoe Canyon (figs. 2, 21). Excellent exposures can be seen opposite the old Vernal road on the north wall of Sheep Creek Canyon in sec. 8 and 9, T. 2 N., R. 20 E., although the lower part of the formation is concealed by the alluvium of Sheep Creek. Full sections of the entire formation are exposed without cover in secs. 35 and 36, T. 3 N., R. 20 E., at the north end of Red Bench 
and on the high slopes southwest of Flaming Gorge. Southeast of Flaming Gorge the formation extends about 3 miles-largely covered with a thin veneer of rubble-before it is cut out at the surface by the Uinta fault. It reappears at the surface at Dutch John Gap in the footwall of the fault and can be traced east for about $11 / 4$ miles, but only the upper part of the formation is exposed; the rest is cut out. East of Dutch John Gap the full thickness of the formation has been penetrated by Ohio Oil Co.'s Government 1 test south of Antelope Flat and by Mountain Fuel Supply Co.'s R. D. Murphy 6-W well in Clay Basin.

In the main, the Moenkopi Formation is nonresistant to erosion and forms slopes or valleys. The strikevalley part of Sheep Creek Canyon is carved chiefly from the Moenkopi Formation. More resistant beds at several positions in the section, however, form ledges or breaks, and the upper part of the formation forms vertical cliffs in many places. The formation is divisible into three distinctively colored lithologic. units that can be recognized throughout the area of surface exposure and that have characteristic physiographic expression. These units are recognizable also on the south flank of the Uinta Mountains near Vernal. The lower unit, unit 1, is about 215 feet thick, has a pale-pink cast, and forms breaks and ledges and, in places, peculiar buttresslike features. The middle unit, unit 2 , is about 330 feet thick, is reddish orange, and forms a uniformly smooth continuous slope except for an occasional break near the top. The upper unit, unit 3, is about 180 feet thick, is moderate reddish brown, and commonly forms near-vertical cliffs; in most places there is a slope break somewhat below the middle of the cliff.

\section{LITHOLOGY AND THICKNESS}

In Sheep Creek Canyon, above Red Bench, and at Flaming Gorge, unit 1 of the Moenkopi Formation consists of interbedded shale, siltstone, and fine-grained sandstone and occasional gypsum beds and veinlets. Some of the shale beds are marly, and there are a.few thin gray beds of limestone or dolomite. The overall color of the unit is pale pink, but individual beds range widely in color from gray to chocolate brown and green. The proportion of gray beds increases toward the base, where the unit passes transitionally into the underlying Dinwoody Formation.

Unit 2 also consists of highly variegated beds of several colors and lithologic types that have been blended by slope wash and staining so that in distant views the overall color is moderate reddish orange. Shale predominates, but siltstone, sandstone, and gypsum are abundant also. The lower 115 feet of unit 2 is composed largely of chocolate-brown to cream-colored soft shale and siltstone containing minor gypsum as seams and veinlets; the succeeding 160 feet is highly gypsiferous, consisting of thin-bedded gypsum interbedded with flaky blue to lavender shale; the uppermost part of unit 2 consists of reddish-orange shale and siltstone, a few thin beds of sandstone, and an occasional gypsum veinlet.

Cliff-forming unit 3 contains some shale but consists mostly of massive siltstone and fine-grained sandstone. Its color is moderate reddish brown throughout, but it is darkened locally on the outcrop by desert varnish. Individual beds range in thickness from 1 inch to as much as 6 feet. The total thickness of the unit is not uniform, due chiefly to truncation by an unconformity at its top. Unlike the units below, unit 3 contains no gypsum.

At Flaming Gorge, where the following section was measured, the Moenkopi Formation is about 725 feet thick. At Spring Creek nose south of Antelope Flat, Ohio Oil Co.'s Government 1 well penetrated about 500 feet of beds here referred to the Moenkopi. Farther east in Clay Basin, Mountain Fuel Supply Co.'s R. D. Murphy 6-W well penetrated 535 feet of the unit. The boundary between Moenkopi and Dinwoody in the Clay Basin well, however, is very indefinite and was selected somewhat arbitrarily from a rather wide stratigraphic interval. The marked decrease in thickness of the Moenkopi from Flaming Gorge east to Antelope Flat and Clay Basin, a decrease of roughly 200 feet in only 10 miles, probably is due partly to normal eastward thinning of the formation as a whole and partly to truncation at the top of the formation by postdepositional pre-Chinle erosion. The latter factor probably is more responsible than the former; unit 3 of the Flaming Gorge section appears to be lacking entirely from both Ohio Oil Co.'s Antelope Flat well and Mountain Fuel Supply Co.'s Clay Basin well. At Antelope Flat the upper part of the formation is thin bedded and gypsiferous-characteristics of unit 2. At Clay Basin it is similarly thin bedded and, in addition, contains greenish-gray shale interbeds, also characteristic of unit 2. Unit 3 is readily recognized over wide areas in the eastern Uinta Mountains, and its apparent absence at Antelope Flat and Clay Basin, therefore, is best explained by truncation.

Section of the Moenkopi Formation in the NE1/4 sec, 36 and the SE $1 / 4$ sec. $25, T .3$ N., R. 20 E., at the west end of Flaming Gorge just north of Horseshoe Canyon.

[Measured by W. R. Hansen and T. B. Piper, August 1951]

Chinle Formation:

Basal sandstone member: sandstone, pale-lavender to grayish-pink, coarse-grained, conglomeratic. 
Moenkopi Formation:

Unit 3:

Siltstone, moderate-reddish-brown (brick-red), and fine-grained sandstone. Forms cliff. Beds 1-6 in. thick; a few beds toward base as thick as

$4 \mathrm{ft}$

Shale, moderate-reddish-brown. Forms slope.

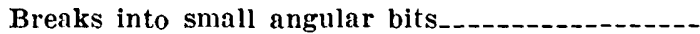

Siltstone, moderate-reddish-brown, and fine-grained sandstone. Somewhat nodular. Beds 1 or 2 in. to $6 \mathrm{ft}$. thick-_-_-

Unit 2:

Shale, moderate-reddish-orange, and interbedded siltstone. Forms slope

Sandstone and siltstone, chocolate-brown to palered, fine-grained; abundant seams and reins of grpsum. Forms vertical break -

Shale, blue to lavender, interbedded with massive white to pale-blue gypsum. Most beds 1 in. or less in thickness, but more massive toward base. Shale, soft and flaky. Overall color is moderate orange pink due to staining from beds above

Shale and siltstone, chocolate-brown to cream-colored; stained moderate reddish orange. A few gray shale beds; very little gypsum. Forms slope

Unit 1:

Siltstone and shale, chocolate to gray; overall color moderate red. Forms ledge. A few white thinbedded fine-grained sandstones.

Gypsum, white, with red shale partings.

Gnondstone, Bras, inte grained gray shale and chocolate shale and siltstone. Occasional gypsum beds 6 in. thick; gypsum veinlets. Some beds limy; a few thin gray limestone or dolomite layers. Proportion of gray beds increases toward base, where some beds are pale greenish gray

Total

FOSSILS, AGE, AND CORRETATIONS

Fossils are exceedingly rare in the Moenkopi Formation of the Flaming Gorge area, and diagnostic specimens have not been found. A few small mollusks collected from a thin limestone bed near the top of unit 1 on the Bennett Ranch, NW $1 / 4$ sec. 3, T. 2 N., R. 19 E., just west of the mapped area, were examined by John B. Reeside, Jr., who reported (written commun.),

This lot contains the mold of a pelecypod that is either Ironotis or Aviculopecten and half a dozen molds of gastropods. None of the gastropods is identiflable with assurance eren to genus, but one has a shouldered whorl unlike any known Triassic nonmarine form and like several marine forms. I have no doubt that the assemblage, even though small, is marine. Very similar rock, also containing molds of small gastropods, is found in the Shnabkaib Member of the Moenkopi of southwestern $\mathrm{Ctah}$ and is there considered marine.

Despite a lack of diagnostic fossils in the Moenkopi of the Flaming Gorge area, an Early and Middle(?) Triassic age is indicated. This age has been assigned to correlative rocks in contiguous areas where fossils are plentiful. The bed from which the above specimens were collected and several other thin limestone beds in the same part of the section are regarded as shoreward deposits of an eastern extension of the Early Triassic Thaynes seaway which covered much of the western Cordilleran region in Early Triassic time and which. shoaled toward the east. The interbedding of these deposits with thin-bedded gypsiferous shale, siltstone, and sandstone suggests shallow water and restricted circulation characteristic of an evaporitic lagoonal environment. It seems certain that both units 1 and 2 of the Moenkopi Formation of the Flaming Gorge area are time equivalents of the Thaynes Limestone of the Wasatch Mountains. The Thaynes, in fact, is recognized with certainty on the south flank of the Uinta Mountains where it thins gradually eastward and passes into the gypsiferous interval of the Moenkopi (Kinney, 1955, p. 62). The Thaynes Limestone contains a prolific Early Triassic fauna.

Unit 3 of the Moenkopi Formation of the Flaming Gorge area physically resembles the Mahogany Member (Kummel, 1954, p. 180) of the Ankareh Formation of the Wasatch Mountains area, and as it occupies the same stratigraphic interval as the Mahogany Member, it probably is correlative. The Mahogany Member of the Ankareh Formation is also considered to be Early and Middle (?) Triassic in age.

At the time the Flaming Gorge area was being mapped, serious consideration was given to the proposition of applying the stratigraphic nomenclature of central Wyoming to the local Triassic section; the Moenkopi at Flaming Gorge is correlated in a general way - on the basis of stratigraphic position and lithology-with the Red Peak Member of the Chugwater Formation. For the sake of uniformity, however, the Colorado Plateau nomenclature was adopted, except the name Dinwoody, largely because this nomenclature had already come into general usage for the same stratigraphic interval and for very similar rocks on the south flank of the Uinta Mountains only 25 miles from Flaming Gorge.

\section{DEPOSITIONAL CONDITIONS}

The Moenkopi Formation of the Flaming Gorge area was deposited marginally to a broad miogeosynclinal seaway which covered much of western Utah, eastern Nevada, southeastern Idaho, southwestern Montana, and westernmost Wyoming in Early Triassic time (Kummel, 1954, p. 165-163). This geosyncline probably received most of its sediments from a broad upwarp or geanticline that lay to the west in Nevada (Nolan, 1943 , p. 172), a view supported in part by the gradual eastward thinning of the Lower Triassic rocks. Along 
the eastern shelf, however, including the eastern Uinta Mountains area, much sediment probably was derived from the ancient Uncompahgre highlands to the southeast, for there is a significant coarsening of sediment in that direction (Kinney, 1955, p. 61).

Occasional eastward incursions of the Early Triassic seaway into the eastern Uinta Mountains area introduced true marine conditions into the Flaming Gorge area and produced the thin sparsely fossiliferous limestones of unit 1. More commonly, the environment was lagoonal; it featured recurrent flooding by, and withdrawal of shallow waters and was characterized by alternate reducing and oxidizing conditions and by concomitant accumulations of interbedded green and red clastic sediments. The rather abundant gypsum of units 1 and 2 must have accumulated during intervals of restricted circulation and high evaporation-in other words, during times of relatively high climatic aridity.

Unit 3 probably was deposited under conditions appreciably different from those of units 1 and 2 . The bedding of unit 3 is thicker and more uniform and lacks the gray, green, and gypsiferous constituents of units 1 and 2 ; it suggests a condition of slow, more or less uniform subsidence beneath quiet shallow water balanced by slow uniform sedimentation.

\section{ENGINEERING CHACTERISTICS}

Engineering characteristics of the Moenkopi Formation are comparable with those of the underlying Dinwoody Formation. Exposures are somewhat more extensive, however, so that the likelihood of the formation being involved at some future date in some kind of engineering activity is proportionately greater. Even so, the topographic setting of the Moenkopi Formation-mainly steep slopes on the sides of strike valleyslargely precludes extensive utilization of lands underlain by the formation.

In the event of excavation-for example, roadcuts in the lower Sheep Creek canyon area-most of units 1 and 2 could be dug with power tools without recourse to explosives; unit 3 , on the other hand, could not be excavated to any extent without the use of explosives.

Some parts of the formation will be inundated by Flaming Gorge Reservoir. Although a little slumpage may result locally, it seems doubtful that large-scale landsliding will occur. Natural slope failures have not been observed in the formation in this area, and the structural-topographic setting generally favors stability; that is, the formation occurs more commonly on back slopes than on dip slopes, so that the strata commonly dip into the slope. The chief natural planes of potential weakness, the bedding planes, dip opposite the direction of potential slope failure.
Owing to the fine-grained shaly or silty character of most of the formation, surface runoff is rapid, and infiltration is slow. Thus, the formation is suitable for water-tight embankment material but is inferior for use as pervious fill.

\section{ChINLE FORMATION}

The Chinle Formation as here described includes a massive basal conglomeratic sandstone that was formerly correlated with the Shinarump Member. Recent work by numerous field parties throughout eastern and southern Utah has shown that beds formerly called Shinarump in many localities-despite a similarity in appearance-occupy a position higher in the section than the typical Shinarump and hence do not correlate with it. The name Moss Back Member of the Chinle Formation is now applied to these beds (Stewart and Smith, 1954, p. 29). In some localities, both the Shinarump and the Moss Back are exposed in the same cliff. The name Shinarump, therefore, is now restricted to areas where correlation is unquestionable. In these areas, furthermore, the Shinarump has been reduced in rank from a separate formation to a member of the Chinle Formation.

Chances seem good that the unit previously identified as Shinarump Conglomerate in the Uinta Mountains is equivalent to the Moss Back Member, but the correlation has not been firmly established, and additional conglomeratic beds, moreover, occur higher in the section. Thomas and Krueger (1946, p. 1267) showed much insight in proposing entirely new names for the Upper Triassic sequence of the Uinta Mountains; in so doing they anticipated the nomenclature problem by nearly a decade. Considerable merit supports their introduction of the name Gartra grit Member for the basal sandstone (which they correlated with the Shinarump), although it does not support their use of the name Stanaker, which they applied unnecessarily to rocks clearly correlative with the Chinle Formation.

\section{DISTRIBUTION AND PFYGIOGRAPHIC EXPRESBION}

In surface distribution, the Chinle Formation is approximately coextensive with the underlying Moenkopi Formation. Toward the west boundary of the area the formation is mostly concealed by the alluvium of Sheep Creek. Half a mile east of Sheep Creek Gap the Chinle crops out on the north slope of the canyon, and eastward from there it crops out more or less continuously to Flaming Gorge, although its outcrop is littered in some places with talus from the overlying Navajo Sandstone. East from Flaming Gorge the formation crops out poorly on the steep south slope of Boars Tusk. Near the east end of Boars Tusk, at Chokecherry Draw, it is truncated by the Uinta fault. East of Chokecherry 
Draw it is missing from the surface section for the next $31 / 2$ miles. It reappears in the footwall of the Uinta fault near Dutch John Gap, crops out for about 2 miles, is again truncated by the fault, reappears once more about 1 mile farther east, and finally disappears from the surface about $1 \frac{1}{2}$ miles still farther east.

On the whole, the Chinle Formation crops out poorly (figs. 2,21). The basal sandstone, however, is relatively resistant to erosion and commonly forms a prominent ledge or a low cliff. But between the basal sandstone below and the high cliffs of the Navajo Sandstone above, the greater part of the unit forms a slope broken only here and there by a discontinuous ledge and commonly mantled with debris fallen from the cliffs above. A.t Flaming Gorge and on the steep slopes north of Nielsons Bench, where the centrifugal sweep of the Green River has kept such debris cleared away, the entire formation is well exposed. The Nielsons Bench locality was selected for a detailed stratigraphic measurement.

LITHOLOGY AND THICKNESS

North of Nielsons Bench the Chinle Formation is divisible into five contrasting units on a basis of color and lithology. These units are seen also at Flaming Gorge and to the southwest toward Sheep Creek Gap, but some of them are not recognized in the section exposed at Dutch John Gap. The lowest unit is the basal sandstone, the Gartra Grit Member of the Stanaker Formation of Thomas and Krueger (1946, p. 1271). The basal sandstone is pale lavender to grayish pink and massive to coarsely crossbedded. It contains streaks and lenses of limestone-pebble conglomerate, of which some of the pebbles are as large as 5 inches in diameter. It also contains fragments of petrified wood and impressions of twigs. The rock has a blocky outcrop habit, and great boulders commonly litter the slopes below the outcrop. As the unit was deposited on an irregular eroded surface, it varies appreciably in thickness in very short distances. Just north of Nielsons Bench a large channel filling is well exposed in cross section on the high slopes across the Green River. The channel cuts deeply into the underlying Moenkopi Formation, and the sandstone that fills the channel forms a cliff 90 feet high - a thickness probably near the maximum for the basal sandstone in this area. A half mile west the sandstone is 60 feet thick; elsewhere it is as thin as 20 feet, and in some places it seems to be nonexistent. At Ohio Oil Co.'s Antelope Flat test the basal sandstone is 28 feet thick (the thickness is corrected for dip), and at Clay Basin (Mountain Fuel Supply Co.'s R. D. Murphy (6-W well) it is 26 feet thick.

Overlying the basal sandstone, in ascending order, are a unit of mostly brick-red sandstone and siltstone about 80 feet thick; a highly varied unit of ochre, maroon, and brown beds of mostly nodular limestone, dolomite, siltstone, and shale about 140 feet thick; a unit of mostly red sandstone about 50 feet thick; and, finally, a unit of pale-greenish-gray fine-grained sandstone and shale about 15 feet thick. The ochre-colored unit is of special stratigraphic significance because it provides a direct correlation between the Chinle Formation of the Uinta Mountains and the Popo Agie Member of the Chugwater Formation of central Wyoming. A widespread association of analcime with this unit is reported by Keller $(1952 ; 1953$, p. 10).

A mile east of Dutch John Gap, near the Uinta fault, the pale-greenish-gray unit is not represented. In that area dips are nearly vertical, and some beds conceivably could have been removed by subsidiary strike faulting, but the Chinle section appears to be free of such structural involvement. The total thickness of the formation there is about 210 feet, including a typical basal sandstone about 41 feet thick. The ochre-colored beds apparently are missing from a section measured west of Sheep Creek Gap by Thomas and Krueger (1946, p. 1292). Of special note in the section east of Dutch John Gap are several conglomerate beds in a sequence of quartzitic crossbedded sandstone. These beds occur in a section between 53 and 80 feet below the top of the formation. Unlike conglomerate beds observed elsewhere in the Chinle Formation in the Flaming Gorge area, they contain subrounded to subangular pebbles of gray, green, and pink limestone in a matrix of limestone. (The matrix of the basal sandstone is quartz sand.) Most of the pebbles are less than half an inch across. The uppermost conglomerate bed is the thickest-about 3 feet; those below are mostly less than 1 foot. Limestone-pebble conglomerates occur also in the Popo Agie Member of the Chugwater Formation in the Wind River Basin (Love, 1948, p. 99) and in the Jelm Formation of southeastern Wyoming (Thomas and Krueger, 1946, p. 1273).

The Chinle Formation thins generally but irregularly eastward along the north flank of the Uinta Mountains. At the section on Sheep Creek measured by Thomas and Krueger (1946, p. 1293), the formation is 302 feet thick and includes a basal sandstone 18 feet thick; 9 miles east at Nielsons Bench it is about 340 feet thick and includes a basal sandstone 60 feet thick. The difference in thickness between these two sections is due wholly to the difference in thickness of the basal sandstone. A mile east of Dutch John Gap the formation is 210 feet thick and includes 41 feet of basal sandstone; $11 / 2$ miles farther east at Ohio Oil Co.'s test on Spring Creek nose it is about 165 feet thick and includes 28 feet of basal sandstone. About 11 miles farther east at Clay Basin it is 246 feet thick and includes 75 feet of basal sandstone, and 30 miles east of Clay Basin at Vermilion 
Creek (outside the mapped area) it is 200 feet thick and includes 55 feet of basal sandstone (Thomas, McCann, and Raman, 1945).

Section of the Chinle Formation in the $S W 1 / 4$ sec. 26, T. $3 N$., $R$. $20 \mathrm{E}$. on the high slopes above the Green River just north of Nielsons Bench

[Measured by W. R. Hansen and T. B. Piper, August 1951]

Navajo 'Sandstone : sandstone, highly crossbedded; forms cliff.

Chinle Formation:

Sandstone, pale-greenish-gray, fine-grained, massive ; prominent near-vertical strike joints

Shale, gray to pale-bluish-green; siltstone at top

Sandstone, cream-colored, fine-grained; thick bedded, pink toward base; forms vertical break

Sandstone, pale-cream-colored, fine-grained, thinbedded; interbedded with gray to brick-red shale. Some sandstone is also brick red.

Sandstone, cream-colored to red, crossbedded; interbedded with chocolate-colored shale. Beds 3-24 in. thick. Conglomeratic at base and very channeled near base. Bottom bed $4 \mathrm{ft}$. thick. Forms vertical break.

Shale, pink-violet, crossbedded, fissile, ripple-marked

Pebble conglomerate, pink; pebbles of shale and sandstone.

Siltstone, lavender _..._.

Siltstone, ochre to olive-drab, hackly ; forms slope-----

Limestone, brown, fine-grained, nodular. Abundant nodules average $3-4$ in. in diameter

Mudstone, brown, limy -

Shale, maroon and ochre, clayey, poorly exposed

Sandstone, white to cream-colored, coarse-grained, crossbedded, poorly sorted, siliceous. Forms scarp_-

Mudstone and shale, brick-red.

Sandstone, brick-red, fine-grained, massive, soft; silty toward base. Generally forms an outcrop; weathers with rounded contours. Lightly mottled

Sandstone, basal member; pale lavender to grayish pink, crossbedded, massive. Contains streaks and isolated short thick lenses of limestone conglomerate; pebbles as large as $5 \mathrm{in}$. in diameter. Twig impressions in float rock. Fills channels in eroded surface of Moenkopi Formation, hence thickness varies considerably from place to place; a few hundred yards east of measured section the unit is probably $90 \mathrm{ft}$. thick. Forms cliff

Total

Disconformity.

Moenkopi Formation: siltstone, red, massive.

AGE AND CORRELATIONS

'The name Chinle Formation has been extended to rocks in the eastern Uinta Mountains by several geologists, and the unit is now widely recognized in that area. Correlation with the typical Chinle Formation of the Colorado Plateau is based largely on stratigraphic position and general lithologic content (J. Stewart Williams. 1945, p. 473; Thomas, McCann, and Raman, 1945; Kinney and Rominger, 1947), inasmuch as physical tracing is made impossible by a thick cover of younger formations in and around the intervening Uinta Basin. In general character the Chinle of the Flaming Gorge area is very similar to that of equivalent rocks in the nearest exposures on the south slope of the range; it differs appreciably in detail, but its correlation is unquestionable. Farther northeast in the Rock Springs uplift, very similar beds in the same stratigraphic interval, penetrated by gas wells of the Baxter Basin field, are assigned by Fidlar (1950a, p. 109) to the Jelm Formation. The Jelm Formation of that area correlates with the Popo Agie Member of the Chugwater Formation of central Wyoming. The ochre-colored beds of the Flaming Gorge area undoubtedly correlate with the Popo Agie Member.

Westward from the Flaming Gorge area the Chinle Formation passes into the upper part of the Ankareh Formation of the Wasatch Mountain area. Physical tracing, again, is impossible along the north slope of the Uinta Mountains, owing to faulting, but on the south slope outcrops are nearly continuous from one formation to the other. The basal sandstone of the Chinle Formation is equivalent to the Suicide Grit ( $\mathrm{J}$. Stewart Williams, 1945 , p. 474; Granger, 1953, p. 10) of the Ankareh-named for "Suicide rock" at the mouth of Parleys Canyon east of Salt Lake City; the remainder of the Chinle Formation correlates approximately with the upper member of the Ankareh Formation.

Williams (1945, p. 473) further correlated the Chinle Formation of the Uinta Mountains with the Higham Grit and the Wood Shale of southeastern Idaho; the Higham Grit correlates with the basal sandstone. These rocks, and all the correlative units noted above, are - generally considered to be Late Triassic in age. In support of this view, F. G. Poole (oral commun., 1959) found phytosaur remains in the Chinle Formation of Dinosaur National Monument.

\section{DEPOSITIONAL CONDITIONB}

Among geologists who have considered the origin of the Chinle Formation there is general agreement that it was deposited by nonmarine, mainly fluviatile agencies. Conspicuous current and torrential crossbedding in the sandstones, ripple marks, scour and fill structures, stringers of conglomerate, and occasional desiccation cracks all support such a view. Although the seaway that covered much of the western interior of the United States in Early Triassic time had long since vanished by Late Triassic time, subsidence was relatively rapid west of the Uinta Mountains area, and thick Upper Triassic sediments accumulated there. Over the eastern Uinta Mountains area the crust was more stable. 
The nodular dolomitic limestone of the ochre-colored beds of the Chinle Formation, as well as the associated calcareous silty mudstone and shale, probably is lacustrine. The occurrence of analcime in this section is of special significance. Analcime was not specifically searched for or identified in the ochre beds of the Flaming Gorge area, but its widespread occurrence in equivalent beds elsewhere makes its presence there seem certain. Keller $(1952$, p. 81$)$ concluded that the analcime was formed by a reaction of hydrous aluminum silicate (derived probably from clay minerals such as montmorillonite) with the sodium-rich waters of a wide marshy lake or playa. Volcanic ash may have been a source of the silicate, but Keller found no physical evidence that it was. Keller also pointed out that the faunas contained in the ochre beds-reptiles, amphibians, and mollusks-as well as the associated plant fossils, also indicate a marshy environment.

The source of the clastic material in the Chinle Formation of the north slope of the Uinta Mountains has not been firmly established. Along the south slope of the range the basal sandstone contains much quartz and considerable feldspathic material evidently derived from a crystalline-rock terrane; the ancestral Uncompahgre highland, which provided detritus for the Moenkopi Formation, has been suggested as a probable source (Thomas and Krueger, 1946, p. 1273). The basal sandstone and the several higher conglomeratic beds in the formation on the north slope of the range contain mainly limestone fragments rather than quartz and feldspathic material and, hence, probably had a different source. Limestone-pellet conglomerates are found also in the Popo Agie Member of the Chugwater Formation in the Wind River Basin of Wyoming (Love, 1948, p. 99), and resemblance to the conglomerate in the Jelm of southeastern Wyoming has been noted by Thomas and Krueger (1946, $\left.\mathrm{p}_{2} 1273\right)$. Inasmuch as correlative rocks to the west and northwest contain mainly quartzitic debris (Mansfield, 1927, p. 192; Calkins and Butler, 1943, p. 33) and rocks immediately to the south are feldspathic or quartzitic, it seems probable that the source of the limestone debris of the north-slope area was to the east or north.

It seems altogether possible that several source areas provided detritus to the Chinle Formation both simultaneously and from time to time and that interfingerings of materials of various provenances occurred in various places. Some of the sandstone beds above the basal sandstone penetrated by the R. D. Murphy 6-W well in Clay Basin, for example, contain abundant biotite that must have had a crystalline-rock source whereas the limestone-pebble conglomerates had a carbonatic source. The formation seems to have accumulated on a very broad alluvial plain which had low monotonous relief and received sediment from adjacent highlands in several directions. A persistent geanticline in eastern Nevada (Nolan, 1943, p. 173) afforded a source to the west, the aforementioned Uncompahgre highland and possibly the ancestral Rocky Mountains afforded a source to the south and east, and a postulated unknown landmass to the northeast afforded a possible source to the northeast.

The physiographic nature of this Late Triassic alluvial plain is interpreted somewhat differently by different workers, the views of each worker probably being colored somewhat by the location and type of facies with which he was most concerned. Mansfield (1927, p. 192) regarded the thick (500 feet) Higham Grit of southeast Idaho as the product of sloping coalesced alluvial fans. Longwell (1928) regarded the Shinarump of southeast Nevada and adjacent Utah as a product of slope wash and intermittent streams under an arid or semiarid climate; he regarded the Chinle as a fan or delta deposit. Baker, Dane, and Reeside (1936, p. 4950) considered the Chinle to be the deposit of a wellgraded but rather arid plain across which streams meandered and on which perhaps were scattered lakes. Stokes (1948) held that the Shinarump is a pediment deposit, a view developed before the Shinarump and Moss Back relationship was discovered. All these views stress the aridity or semiaridity of the Late Triassic climate; all have local support and do not necessarily contradict one another. They do point up the probably complex physiographic setting under which the Chinle and correlative formations accumulated.

\section{ENGINEERING CHARACTERISTICS}

In view of its unusual physiographic setting the Chinle Formation is perhaps less apt to be significantly involved in any future engineering works than any other formation in the area. The road alinement to the Dutch John Flat area crosses the formation in one or two places near Dutch John Gap, but elsewhere the formation lies at the top of a high slope below impassable cliffs of Navajo Sandstone.

In the event that any excavating is done in the Chinle Formation, drilling and blasting will be required. Although much of the formation crops out poorly, most of it is fairly well indurated and should stand well in steep cuts. The basal sandstone and some of the overlying beds form natural cliffs or breaks. Natural slope failures other than rockfalls have not been observed in the area.

\section{TRIASSIC(?) AND JURASSIC SYSTEMS NAVAJO SANDSTONE}

The highly crossbedded Navajo Sandstone was named by Gregory $(1915$, p. 102) for its widespread occurrence in the Navajo country of the Colorado Pla- 
teau. Prior to Gregory's time the rocks composing the formation had generally been correlated with the White Cliff Group of Powell (1876, p. 41, 51), a name that has long been abandoned.

In the Flaming Gorge area the Navajo Sandstone comprises the rocks between the top of the Chinle Formation and the base of the Carmel. On the Colorado Plateau this interval of rocks normally is occupied by the Glen Canyon Group, which, in ascending order, consists of the Wingate Sandstone, Kayenta Formation, and Navajo Sandstone. Neither the Wingate nor the Kayenta is differentiated or recognized in sections along the Uinta Mountains; time equivalents of all or part of both formations possibly exist in what is called Navajo Sandstone. Previous investigators have expressed the view that the Wingate and Kayenta wedge out northward and disappear beneath the Uinta Basin (Baker, Dane, and Reeside, 1936, p. 14 and pl. 10; Stokes and Holmes, 1954, p. 36). Judging from a study of well logs, MacLachlan (1957, p. 82) suggested that these formations do not wedge out but instead interfinger with the Navajo of the Uinta Mounutains somewhere beneath the Uinta Basin; this suggestion seems consistent with the observed conformity of the NavajoChinle contact in the Uinta Mountains and, therefore, with a possible Triassic age for at least the lower part of the Navajo in that area (Kinney, 1955, p. 75; Hansen, 1955a).

DISTRIBUTION AND PHYSIOGRAPHIC EXPRESSION

From the west boundary of the area to the east end of Dutch John Mountain, a distance of about 20 miles, the Navajo Sandstone forms a nearly continuous line of rugged cliffs that includes some of the most prominent topographic landmarks in the area. West of Flaming Gorge these cliffs are breached only by Sheep Creek Gap, which, in the view of O. C. Marsh (1871, p. $197)$, is " *** a narrow and almost impassable side ravine." Sheep Creek Gap now affords passage for Utah Highway 44 connecting Manila and Vernal.

Just a mile or so west of Flaming Gorge at the head of Finch Draw, the Navajo Sandstone is picturesquely eroded into a badland of walls, alcoves, "beehives," and hoodoos. On cliff faces, where joints strongly influence recession of the outcrop, the internal character of the formation is largely masked, and the rock appears to be very homogeneous and extremely thick bedded. At Finch Draw, however, and farther southwest along the broad back slopes of the Navajo Sandstone outcrop, mechanical weathering, gullying, and wind erosion are more effective than joint controls, and the crossbedding that so characterizes the formation is well displayed (fig. 24).

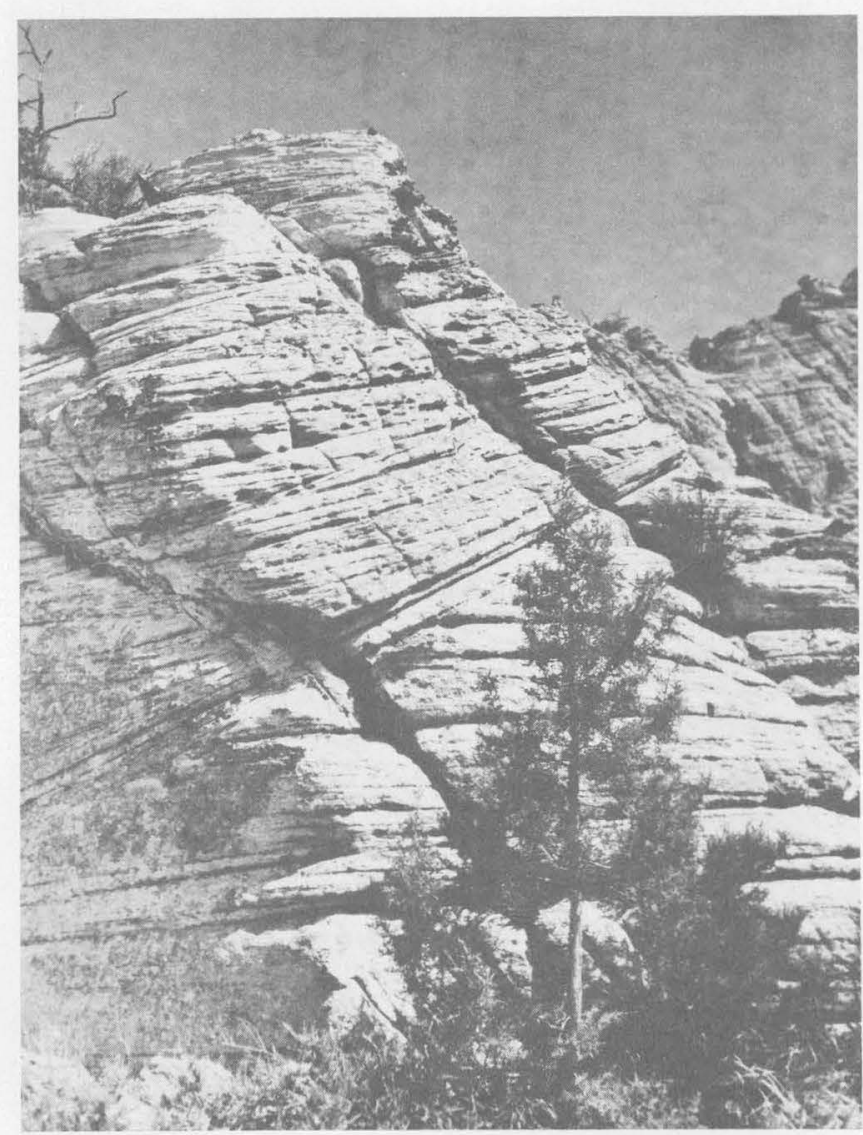

FIGrre 24-Navajo Sandstone at Finch Draw, about a mile west of Flaming Gorge. Characteristic wind-seulptured outcrop of back slope areas, showing bedding details and weathering habit. Sweeping tangential crossbedding indicates eolian origin.

Flaming Gorge derives its name from the bright red Triassic rocks in its lower slopes, but it gains most of its grandeur from the looming wall of Navajo Sandstone above the west bank of the river. (See frontispiece.) On the east bank, the sharp line of Boars Tusk, also Navajo Sandstone, is even higher, but it is less abrupt and is a good deal less imposing. East of Boars Tusk the long ridge of Dutch John Mountain has a core of Navajo Sandstone. Dutch John Mountain separates the broad valley of Antelope Flat to the north from the dissected back country of Red Canyon to the south. The ridge is asymmetrical, owing partly to the dip of the beds and partly, perhaps, to the difference in exposure of its two sides. The south side is much steeper and is correspondingly more impressive, even when viewed from points as distant as Greendale beyond the south rim of Red Canyon. The new road to Dutch John townsite crosses the ridge at Dutch John Gap, where a complete section of the Navajo Sandstone, standing vertically, is well exposed. 
In lithologic character the Navajo Sandstone is the most homogeneous formation in the area. It consists almost entirely of fine- to medium-grained sandstone composed of subangular to rounded frosted quartz grains. The sandstone is pink, tan, or brown on longexposed cliff faces, owing largely to desert varnish. Pyrite is reported in drill-hole cuttings, and its oxidation products probably provide the pigment for surface colorations. Local zones are rusty yellow. Fresh rockfalls (see frontispiece) expose the true color, cream-colored to almost white; the true color is seen also on the sculptured outcrops of the back slopes, where the surfaces are kept fresh by mechanical weathering and frequent sandblasting. This is the color most often seen also in drill-hole cuttings.

In general, the sandstone is rather loosely cemented, even friable, despite the boldness of its outcrop. Its hardness, or induration, is related to the type and extent of cementation, which may be either calcareous or siliceous. Siliceous zones grade locally into resistant sedimentary quartzite; such rock caps Jesson Butte, a prominent landmark just west of the area. This particular phase is quite local and does not extend into the mapped area in place, but boulders litter the slopes at the head of South Valley. This rock was much utilized in the past by Indians for making scrapers and spear points. The Indians carried fragments many miles from the source, both as large blanks and as finished artifacts. Figure 25 is a photomicrograph of this material cut from a fragment of an artifact found near Little Hole; the cementing material is spherulitic chalcedony; the rock is very hard and vitreous.

Where the Navajo is brecciated or otherwise much deformed, as in or near fault zones, it commonly is quartzitic also.

Possibly the best known and most striking characteristic of the Navajo Sandstone is its large-scale crossbedding (fig. 24), a feature widely ascribed to eolian deposition. Individual crossbed sets are mostly wedge shape in section. They consist of parallel laminae which extend many feet laterally in graceful sweeping curves. At the top each set is truncated at random by the base of a succeeding set. Here, the laminae of the succeeding set meet the beveled surface at varied angles-steep in a given set, tangential in another. Slight differential erosion etches alternate laminae into low relief, creating a coarsely ribbed texture on the surface of the outcrop. High-angle joints accentuated by erosion lend a fluted architectural appearance; joints and the crossbedding, modified by slope variation, produce a complex pattern of lines and surfaces. In the

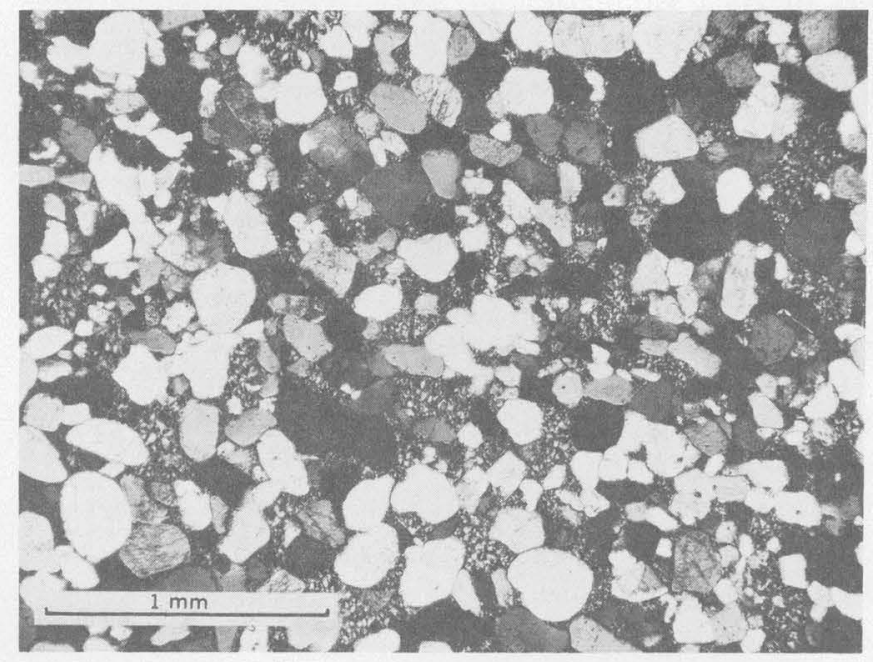

Figure 25.-Photomicrograph of silicified Navajo Sandstone. Subrounded to well-rounded moderately well sorted quartz grains firmly cemented by matrix of chalcedony. Crossed nicols $\times 29$. Photograph by Wendell Walker.

brilliance of the western sun, few other formations so stir the imagination of the observer.

In thickness, the Navajo Sandstone diminishes gradually and persistently eastward along the Uinta Mountains. From Sheep Creek east to Clay Basin, a distance west to east of about 30 miles, it thins almost uniformly at a rate of slightly less than 4 foot per mile. At Sheep Creek near the west boundary of the mapped area it measures about 840 feet (Thomas and Krueger, 1946, p. 1275). At Flaming Gorge a thickness of 815 feet was computed graphically by resecting the upper and lower contacts and correcting for dip; at Ohio Oil Co.'s Government 1 test on Spring Creek nose south of Antelope Flat, 800 feet of Navajo was penetrated, again correcting for dip in the drill hole; at Mountain Fuel Supply Co.'s R. D. Murphy 6-W well in Clay Basin, 759 feet was penetrated. Comparable eastward thinning along the south slope of the Uinta Mountains has been noted by Thomas and Krueger $(1946$, p. 1275) and by Kinney $(1955$, p. 74$)$.

The formation also thins markedly northward and southward from the Uinta Mountains. Equivalent rocks (Nugget Sandstone) to the north are 650 feet thick at South Baxter in the Rock Springs uplift (Fidlar, 1950a, p. 109). Farther north near the Wind River Range the Nugget thins to about half that thickness and ultimately wedges out in the Wind River Basin (Love and others, 1945). Southward thinning from the Uinta Mountains is less pronounced than northward thinning but is considerable. In southern Uintah County, Utah, in the Uinta Basin, the entire Glen Canyon Group is represented by slightly more than 500 
feet of rock (MacLachlan, 1957, p 89), whereas Navajo sections to the north along the mountains range from appreciably more to twice that thickness. As noted before, way of emphasis, the Navajo Sandstone of the Uinta Mountains probably is equivalent to the entire Glen Canyon Group of areas immediately to the south. South of the Uinta Basin, the Navajo thickens again toward the San Rafael Swell, where, however, it still is thinner than in the Uinta Mountains.

Causes of such marked thinning along and away from the Uinta Mountains are unclear, and several factors may have contributed to it. As the upper surface of the formation is an unconformity, beveling by erosion may be partly responsible, as suggested by Love (1948, p. 101) for the equivalent Nugget Sandstone. A second factor, an original variation in thickness due to different rates of accumulation from place to place, seems compatible with the probable eolian origin of the formation. Yet another fossible factor influencing the thickness of the formation, a factor which I favor, may have been continued subsidence of the old Unita trough. This factor is suggested by the symmetrical pattern of thinning relative to the Uinta Mountains and by similarly disposed patterns of thinning in other formations both lower and higher in the section.

AGE AND CORRELATTONS

The Navajo Sandstone of the Uinta Mountains is separated from its counterpart of the Colorado Plateau by thick younger deposits to the south in the Uinta Basin. Its continuity with the Navajo to the south, however, is supported by well logs, stratigraphic position, and lithologic identity. The probability seems good that the Navajo of the Uinta Mountains contains time equivalents of the entire Glen Canyon Group of the northern Colorado Plateau and hence is partly Triassic in age.

Toward the west the Navajo can be traced with confidence into the Nugget Sandstone of the central Wasatch Mountains, and the two formations, therefore, are regarded as direct correlatives. The Nugget of the Wasatch Mountains and the Navajo of the Uintas are separated from the typical Nugget (Veach, 1907, p. 56) of southwest Wyoming by a wide intervening cover of younger rocks, but the correlation is well established by stratigraphic position and lithologic similarity.

Use of the name Navajo in the Uinta Mountains area is somewhat open to question. In some respects the name Nugget seems preferable for the rocks of this section in the Uinta Mountains, and to some extent the two names have been used interchangeably. The stratigraphic relationships of the formation to adjacent units are more akin to those of the Nugget than to the typical Navajo in that the formation rests directly and with apparent conformity on Upper Triassic rocks. Hence, the formation probably is equivalent to the entire Glen Canyon Group of the Colorado Plateau rather than to the typical Navajo only. Some further support for use of the name Nugget derives from antecedence of usage in the literature of the Uinta Mountains. Although Powell equated the formation with the Colorado Plateau section by using the name White Cliffs Group for both areas, the first definitive mapping of the unit was by Schultz $(1910$, p. $214 ; 1918$, p. 54$)$, who applied the name Nugget. Schultz, however, included rocks now assigned to the Carmel Formation and Entrada Sandstone in his Nugget and identified the succeeding Curtis Formation as Twin Creek.

Use of the name Navajo in the Uinta Mountains, as opposed to Nugget, is supported by the closer lithologic identity of the unit with the typical Navajo. Whereas the Nugget in many places is flaggy in habit and quartzitic in character and contains shaly units, the Navajo typically is crossbedded and friable. Coarse eolian-type crossbedding, to be sure, is widespread in some parts of the Nugget; but the even bedding which also is found in the Nugget-and the shaly units-indicate a type of depositional environment foreign to the Navajo of the Uinta Mountains, at least in the exposed surface section. (Shaly sections in the upper third of the formation, however, are reported from the subsurface section at Clay Basin.)

Current usage of the name Navajo by most geologists lends weight to retaining the name, although this consideration lacks force when taken by itself. There is also some question of propriety, other things being equal, in interjecting a term from the Middle Rocky Mountains (Nugget) into a sequence of names from the Colorado Plateau. Finally, the name Glen Canyon could be used in a formational sense in the Uinta Mountains. Such usage at the present time seems premature as it would necessarily hinge on a demonstrated correlation of the Uinta Mountains unit with the group to the south. Although this correlation seems highly probable, more evidence than is now available is needed to substantiate it.

\section{DEPOSITIONAL CONDITIONS}

An eolian origin for the Navajo Sandstone has been accepted by most geologists; such an origin was first suggested many years ago by Huntington and Goldthwait $(1904$, p. 203). This view is supported both by the presence of abundant features in the formation that characterize modern wind-drift deposits (W. O. Thompson, 1937, p. 750) and by a lack of features that characterize water-laid deposits. There is a preponderance of large-scale tangential crossbedding as opposed to a minimum of very widely spaced true bedding 
planes. There also is a notable lack of silt-size material, ripple marks, mud cracks, torrential bedding, or other evidence of water action (Baker, Dane, and Reeside, 1936, p. 52). Individual sand grains are frosted and pitted, and in some localities the formation contains polished faceted pebbles that are regarded as ventifacts (Baker, Dane, and Reeside, 1936, pls. 13, 14; Kinney, 1955, p. 74).

The expanse of desert dunes that ultimately formed the Navajo Sandstone was very broad. Vast areas of eastern and southern Utah, large parts of southwestern Wyoming, western Colorado, northern Arizona, and considerable parts of Nevada and New Mexico were covered by a single great blanket of sand (McKee and others, 1956, pl. 5). The source of this material is not adequately known, but present thinking favors a general source area to the west, largely because the deposits thicken generally in that direction. On the south slope of the Uinta Mountains, however, Kinney (1955, p. 76) found evidence of a local southward advance of the dunes. F. G. Poole (oral commun., 1959), judging from measurements of foreset beding over wide areas, concluded that the prevailing winds over the northern part of the Navajo desert blew from the north and that those over the Uinta Mountains area blew from the northeast.

East from Flaming Gorge, thin dolomite beds near the middle of the formation in the subsurface section in Ohio Oil Co.'s 1 Government test at Antelope Flat and red shale beds in the upper part of the formation in Mountain Fuel Supply Co.'s R. D. Murphy 6-W well at Clay Basin indicate local and temporary flooding of the desert floor. Such deposits probably accumulated in ephemeral lakes or playas. They become increasingly more abundant toward the north in areas occupied by the correlative Nugget Sandstone.

\section{ENGINEERING CHARACTERISTICS}

Inasmuch as the Navajo Sandstone forms a nearly continuous barrier eastward from the west boundary of the area almost to Goslin Mountain, any contemplated road or similar development southward across that part of the area will encounter it. In the event that any excavating is done in the Navajo, drilling and blasting will be required. If drilling time in the Ohio Oil Co.'s 1 Government well is indicative, the formation is substantially harder to drill than other Jurassic and Triassic units above and below it. In shallow surface cuts where the formation is weathered and friable, it should drill very easily.

As shown in nature by its cliff-forming habit, the Navajo has high slope stability and probably has correspondingly high bearing strength also. In artificial cuts, therefore, it should stand well at high angles with little or no support. For the most part, it is porous and permeable. In most places it should present few serious problems.

Large-scale jointing is prevalent in the Navajo Sandstone. On the north slope of the Uinta Mountains, joints are conspicuous wherever the formation crops out. Individual joints, however, are spaced widely apart-generally as much as several feet to a few tens of feet apart. Drill-water circulation was lost at 10 different levels in the Navajo Sandstone in Ohio Oil Co.'s 1 Government well. These losses probably can be attributed to jointing.

\section{JURASSIC SYSTEM}

CARMEL FORMATION

The name Carmel Formation is applied to a marine sequence of limestone, shale, and gypsum that occupies the interval between the massive Navajo Sandstone below and the massive Entrada Sandstone above. The formation was named for its occurrence near the town of Mount Carmel in southern Utah. According to Wilmarth $(1938$, p. 350$)$, the name was adopted at a joint conference of H. E. Gregory, R. C. Moore, James Gilluly, and J. B. Reeside, Jr. It was first extended into the eastern Uinta Mountains by Baker, Dane, and Reeside (1936, fig. 2) for rocks that previously had been included in the Nugget Sandstone. In the original investigations of Powell $(1876$, p. 51), the limestone sequence in the lower part of the formation was called the White Cliff Limestone of the Flaming Gorge Group. Powell's early and correct correlations of this unit throughout eastern and southern Utah were essentially the same as those of Baker, Dane, and Reeside, although his terminology has long been abandoned.

\section{DISTRIBUTION AND PHYSIOGRAPHIC EXPRESSION}

The Carmel Formation crops out discontinuously eastward from the west boundary of the area to the east end of Dutch John Mountain, a distance west to east of about 20 miles. East of Dutch John Mountain it has been truncated by the Uinta fault and does not appear at the surface, although it is penetrated by gas wells in Clay Basin.

Under most conditions of exposure, the Carmel Formation forms a partly covered slope or a valley, depending on dip (fig. 26). West of Boars Tusk, resistant limestone beds in the lower part of the formation give rise to a twofold outcrop habit-a slope- or valleyforming interval above and a ledge-forming interval below. Only rarely is the upper interval well exposed; it is concealed in most places by mantle rock derived from the overlying Entrada Sandstone. But the lower interval forms. prominent miniature cuestas or flatirons capping the underlying Navajo Sandstone. The best 


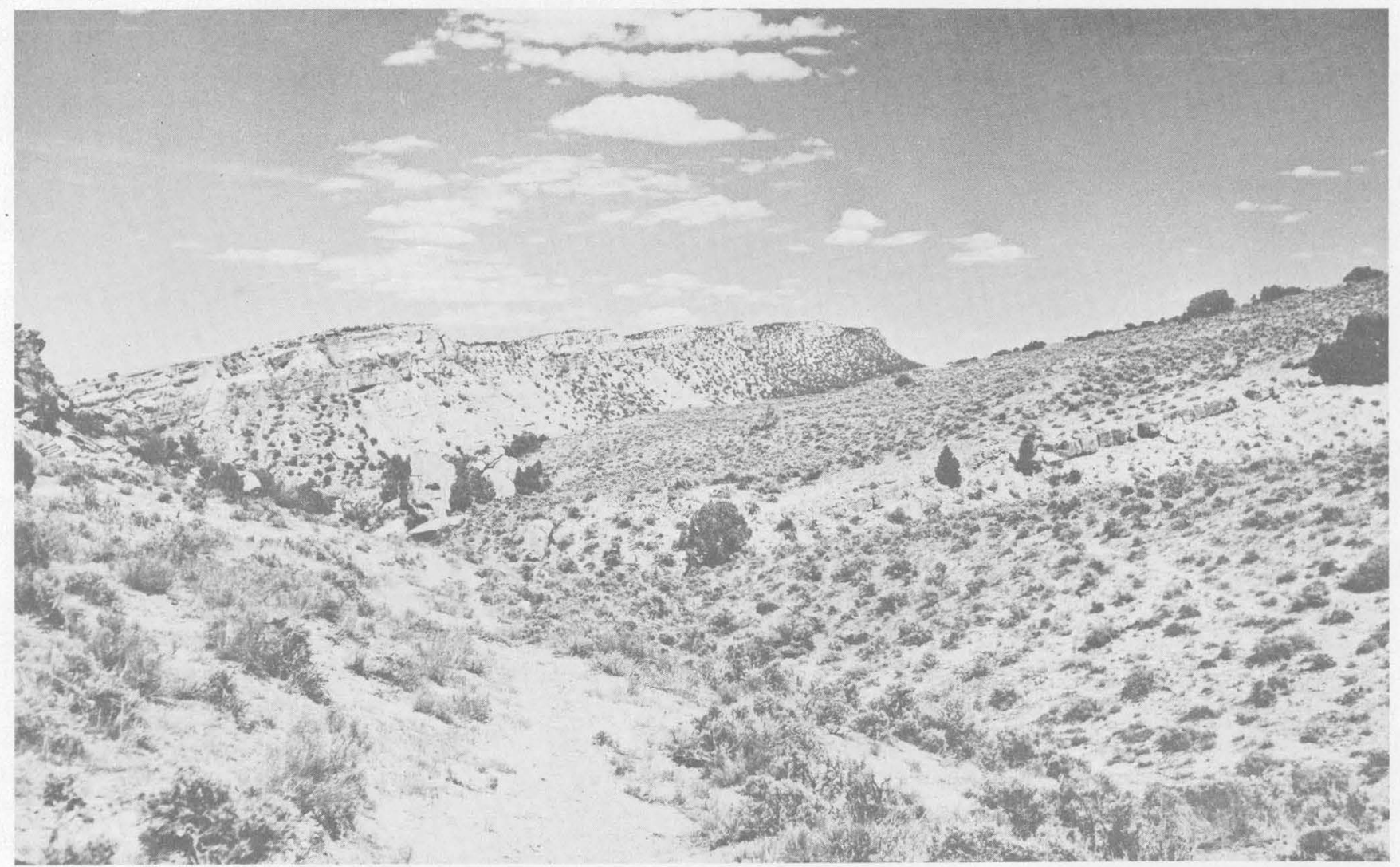

Figure 26.-Characteristic topographic expression of Carmel Formation west of Flaming Gorge as seen in dry strike valley about 11/2 miles northwest of Red Bench. Dip slope at right formed on resistant limestone beds in lower part of formation; covered slopes at left and in background formed on soft shales in upper part. Cliffs on skyline eroded from Entrada Sandstone. View toward northeast.

and most completely exposed single section is in Sheep Creek Gap (Manila quadrangle) in the SW1/4 sec. 6, T. 2 N., R. 20 E. This section is also the most accessible in the area, as it is adjacent to Utah Highway 44, which passes through the gap. Good exposures also can be seen 4 miles northeast of Sheep Creek Gap in the east side of a dry ravine near the NW. cor. sec. 34, T. 3 N., R. $20 \mathrm{E}$, and 2 miles farther east at Finch Draw.

\section{LTTHOLOGY AND THICKNESS}

As noted above, the Carmel Formation is divisible into two distinctive units dependent on lithologic character and topographic expression. A more detailed subdivision has been worked out by Imlay (1950a, p. 37) based on careful study of many stratigraphic sections of the formation along the Uinta Mountains and of the partly equivalent Twin Creek Formation farther west in the Wasatch Mountains and north in Idaho and Wyoming. Imlay divided the Twin Creek and Carmel Formations into seven members, $\mathrm{A}$ to $\mathrm{G}$ in ascending order, defined by lithologic character and fossil content. As the Twin Creek Formation passes eastward into the Carmel Formation, it thins markedly and, concomi- tantly, changes lithologically. The seaway in which it was deposited transgressed eastward during deposition across a terrane of Navajo or Nugget Sandstone, and progressively higher units, therefore, are successively in contact with Navajo or Nugget toward the east. At Sheep Creek Gap, members A and B never were deposited, and member $\mathrm{C}$ rests directly upon Navajo Sandstone.

At Sheep Creek Gap, members C, D, and E consist chiefly of limestone and calcareous shale; members $\mathrm{F}$ and $\mathrm{G}$ consist of soft interbedded green, gray, and red shale, siltstone, and gypsum.

Section in Sheep Creek Gap in the $\$$ W $1 / 4$ sec. 6, T. 2 N., R. 20 E. adjacent to Utah Highway 44 about 4 miles south of Manila

[Measured by Ralph W. Imlay, Aug. 31, 1949]

Entrada Sandstone.

Carmel Formation:

Member G :

Shale, greenish-gray, soft_____________

Siltstone, red._... 4

Shale, green_____

Siltstone, red____

Sandstone, light-gray, fine-grained, shaly to thin-bedded. 
Carmel Formation-Continued

Member F :

Siltstone, red, soft.

Shale, greenish-gray, soft._-_.

Siltstone, red.

Gypsum, white-_.-_-_-

Shale, brownish-gray, soft; contains thin beds of white gypsum; 1-ft gypsum beds at 33 and $42 \mathrm{ft}$ above base.

Gypsum, white, massive; forms prominent cliff

Siltstone, red; contains many thin beds of gypsum; soft_.-.---_-_-_-

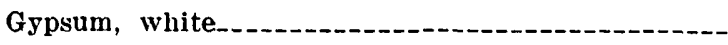

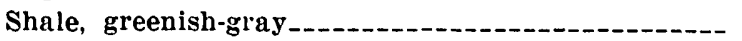

Gypsum, white, massive; forms top of cliff

Siltstone, red, and thin beds of white gypsum

Siltstone, green, and gypsum_-_.....-...--

Sandstone, light-gray, fine-grained; shaly at base,

thin-bedded above-_.

Shale, medium-gray, soft_-_...-.

Siltstone, red, soft

Gypsum, thin-bedded.................

Siltstone, greenish-gray, soft_.......-.--

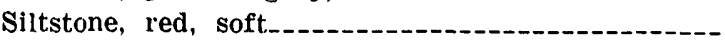

Sandstone, light-pink to greenish-gray, fine-grained,. shaly

Siltstone, red, soft._._.

Member E :

Limestone, medium-brownish-gray; weathers reddishbrown; slightly sandy; upper $7 \mathrm{ft}$. crossbedded ; forms top of cliff ; massive; oolitic

Limestone, oolitic to coquinoid; in two 10-in. beds separated by gray shale. Contains Camptonectes, Ostrea, and gastropods (Mesozoic loc. 21627) -..--

Oolite, medium-brownish-gray; weathers reddishbrown, massive.

Member D:

Limestone and shale, yellowish-gray, interbedded. Limestone beds range from 2 to 14 in. in thickness; most are oolitic and slightly sandy but some are dense, and all bear many Camptonectes and oysters on bedding planes

Member C :

Shale, dark-gray to yellowish-gray, soft

Limestone, oolitic (Mesozoic loc. 21626)

Shale, medium-gray, soft.

Shale, light-greenish-gray, soft, rests sharply on Navajo Sandstone.

Total Navajo Sandstone.

Section on the northeast side of a dry ravine in the $S W 1 / 4$ sec. $27, T .3$ N., R. $20 \mathrm{E}$.

[Measured by W. R. Hansen and T. B. Piper, Aug. 29, 1951]

Entrada Sandstone: sandstone, moderate-reddish-orange, very fine grained.

Carmel Formation :

Members $\mathbf{G}$ and $\mathbf{F}$ :

Paper shale, pale-greenish-gray, ripple-marked. A 2 - $\mathrm{ft}$ bed of reddish-brown clay-shale $6 \mathrm{ft}$ below ton. Thin gypsum seams in lower $5 \mathrm{ft}$

\begin{tabular}{|c|c|c|}
\hline Feet & $\begin{array}{l}\text { Carmel Formation-Continued } \\
\text { Members G and F-Continued }\end{array}$ & Feet \\
\hline 5 & Clay-shale, dark-reddish-brown & $\mathbf{y}$ \\
\hline 33 & Gypsum, fibrous white. Flbers lie flat. & 2 \\
\hline 10 & Clay-shale, pale-greenish-gray, somewhat fissile_-_.-- & 45 \\
\hline 1 & $\begin{array}{l}\text { Gypsum, white to green, massive; interbedded with } \\
\text { thin green shale seams }\end{array}$ & 0 \\
\hline & Clay-shale, green; contains gypsum veinlets_......-- & $\mathbf{3}$ \\
\hline 50 & Clay-shale, reddish-brown; contains gypsum veinlets_ & 7 \\
\hline 10 & Gypsum and green clay-shale- & \\
\hline & Clay-shale, pale-greenish-gray--_-_-_-_-------- & 15 \\
\hline 6 & Gypsum, (alabaster), massive-_-_-_-_------ & $\mathbf{2}$ \\
\hline 1 & Clay-shale, reddish-brown & 10 \\
\hline 26 & Gypsum ; contains green clay seams & 2.5 \\
\hline $\mathbf{5}$ & Clay-shale, pale-greenish-gray & 18 \\
\hline 6 & Clay-shale, dark-reddish-brown & 10 \\
\hline 2 & Gypsum_-_-_- & 2 \\
\hline & Clay-shale, pale-greenish-gray & 13 \\
\hline 21 & Clay-shale, dark-reddish-brown & 5 \\
\hline 10 & Gypsum, white, massive & 1 \\
\hline 3 & Clay-shale, dark-reddish-brown & 4 \\
\hline $\mathbf{3}$ & Limestone, buff, thin-bedded, dolomitic & $\mathbf{1}$ \\
\hline 7 & Clay-shale, dark-reddish-gray & 5 \\
\hline 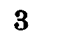 & Limestone, pale-gray, thin-bedded-_- & 1 \\
\hline & Clay-shale, dark-reddish-brown & \\
\hline
\end{tabular}

Note-Although the red beds above are dark where freshly exposed, they appear pale on weathered slopes owing to dilution with lighter colored material and gypsum.

Member $\mathbf{E}$ :

Limestone, pink to cream-colored, very thin bedded; crinkled by penecontemporaneous deformation. Shaly at base

Limestone, pale-gray, blocky oolitic; beds about 1 foot thick. Shaly partings

Limestone, pale-yellowish-orange, massive, very fossiliferous_.-.

Members D and C:

Limestone, shaly ; forms poorly exposed slope. Includes several beds of coquina and very fossiliferous limestone (lot A), in part oolitic

Limestone, shaly, and shale, olivedrab; covered, poorly exposed

Total33

Navajo Sandstone: Sandstone, highly crossbedded. 322.8

Note-A mile or so east of above measured section, a pebbly limestone lies at the base of the Carmel. Locally this is a true conglowerate, but generally it is a fine-grained gray limestone that contains scattered pebbles.

In an area of steep dips along the north slopes of Boars Tusk and Dutch John Mountain, the Carmel Formation is anomalously thin. In that area the entire stratigraphic section from Navajo to Mowry Shale is overturned by drag in the footwall of the Uinta fault. At Chokecherry Draw immediately east of Boars Tusk, only the competent lower beds of the Carmel, which total about 75 feet in thickness, are present; the gypsiferous and shaly beds of the upper part of the formation are missing and apparently have been omitted tec- 
tonically, probably by flowage of incompetent material away from the tightly compressed footwall zone of the fault but possibly by subsidiary strike faulting in the footwall in a plane nearly parallel to the bedding.

The contact of the Carmel Formation with the underlying Navajo Sandstone is distinct and well defined and suggests a significant stratigraphic hiatus, but clear evidence of an unconformity is lacking in the Flaming Gorge area. Because of the highly crossbedded character of the Navajo, the contact relationship is open to more than one interpretation. In general, the base of the Carmel Formation truncates the crossbedding laminae of the Navajo at sharp angles. Such a relationship could arise whether or not a considerable period of time intervened between deposition of the two formations. Thus, the unconsolidated dunes of the Navajo would have been as susceptible to planation by the waves of an encroaching Carmel sea as the lithified Navajo Sandstone would have been to waves, or to subaerial erosion for that matter. The complete lack of a transition from Navajo lithology to Carmel lithology favors belief in a significant time break.

In some places the base of the Carmel Formation is marked by a foot or two of dull brown fine-grained sandstone that may be reworked Navajo. Northwest of Flaming Gorge the contact is marked by a fine-grained gray limestone that contains scattered chert pebbles and that locally is a true conglomerate. The pebbles, however, do not appear to have been derived from the Navajo.

$$
\text { - Fossils, AGE, AND CORRElations }
$$

Some limestone beds in the lower part of the Carmel Formation contain abundant marine fossils. In the oolitic limestone of member C at Sheep Creek Gap, $\mathbf{R}$. W. Imlay (written commun., 1952) found the following forms (Mesozoic loc. 21626) :

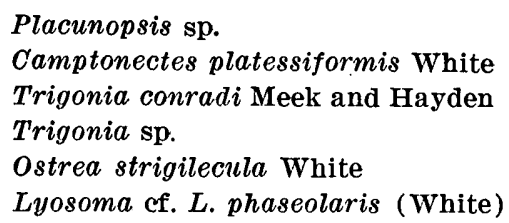

The following fossils, which I collected in the uppermost bed of member D 4 miles northeast of Sheep Creek Gap, were also identified by Mr. Imlay :

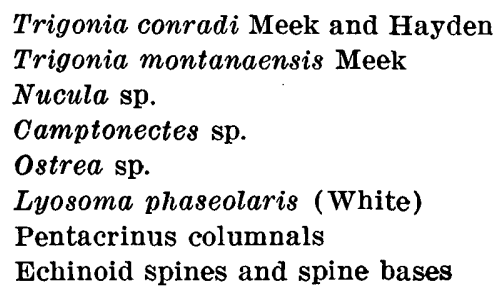

Regarding the age of the above collections, Imlay stated that they contained

* * * species of which most range through the Middle Jurassic into the basal Upper Jurassic (Lower Callovian) in the Rocky Mountain region. However, Lyosoma phaseolaris (White) has been collected hitherto only in the lower part of the Twelvemile canyon member of the Arapien shale in central Utah and in the lower limestone beds of the Carmel formation on the San Rafael Swell..

These beds are Late Jurassic. On the basis of fossils collected elsewhere in the Twin Creek Formation, Imlay (1950a, p. $39 ; 1953$, p. 54) considered member $\mathrm{C}$ to be early Middle Jurassic, member D probably late Middle Jurassic, member $\mathrm{E}$ earliest Late Jurassic, and members $\mathrm{F}$ and $\mathrm{G}$ early Late Jurassic.

Correlations of the Carmel and other Jurassic formations were discussed in detail by Imlay (1952a), so they are mentioned only briefly here. The relationship of the Carmel to the Twin Creek Formation has already been noted. There is a general correlation between the Carmel Formation of the Uinta Mountains and the "lower Sundance" of central Wyoming; detailed correlations can be made between specific members or zones. The Carmel also is correlated with the Sawtooth and Rierdon Formations of the Ellis Group of Montana and with the thick Arapien Shale of central Utah.

From Sheep Creek Gap to Clay Basin, the Carmel Formation thins about 60 percent and changes markedly in lithology (fig. 27). At Sheep Creek Gap it is about 330 feet thick and has a well-defined twofold lithologic character-members $\mathrm{C}, \mathrm{D}$, and $\mathrm{E}$ are chiefly ledgeforming limestone and gray calcareous shale; members $F$ and $G$ consist of interbedded soft gray, green, and red shale, siltstone, and gypsum; the proportion of gray and green beds to red is about 2 to 1 . Four miles farther northeast the character of members $\mathrm{C}, \mathrm{D}$, and $\mathrm{E}$ is little changed although $\mathrm{C}$ and $\mathrm{D}$ are somewhat thicker. Members $\mathbf{F}$ and $G$, however, have thinned from about 280 feet at the gap to about 235 feet. The proportion of gray and green to red remains about 2 to 1 . At Clay Basin, 25 miles or so farther east, in Mountain Fuel Supply Co.'s R. D. Murphy 6-W well, the entire formation is only 133 feet thick and consists almost entirely of shale; in addition, the proportion of gray and green beds to red has fallen to about 1 to 2 . Thinning has been accomplished largely through disappearance of the carbonate sequence at the base and through thinning and wedging out of gray and green rock intervals above.

DEPOSITIONAL CONDITIONS

The Carmel Formation was deposited in shallow marine water on the shelving margin of an encroaching 

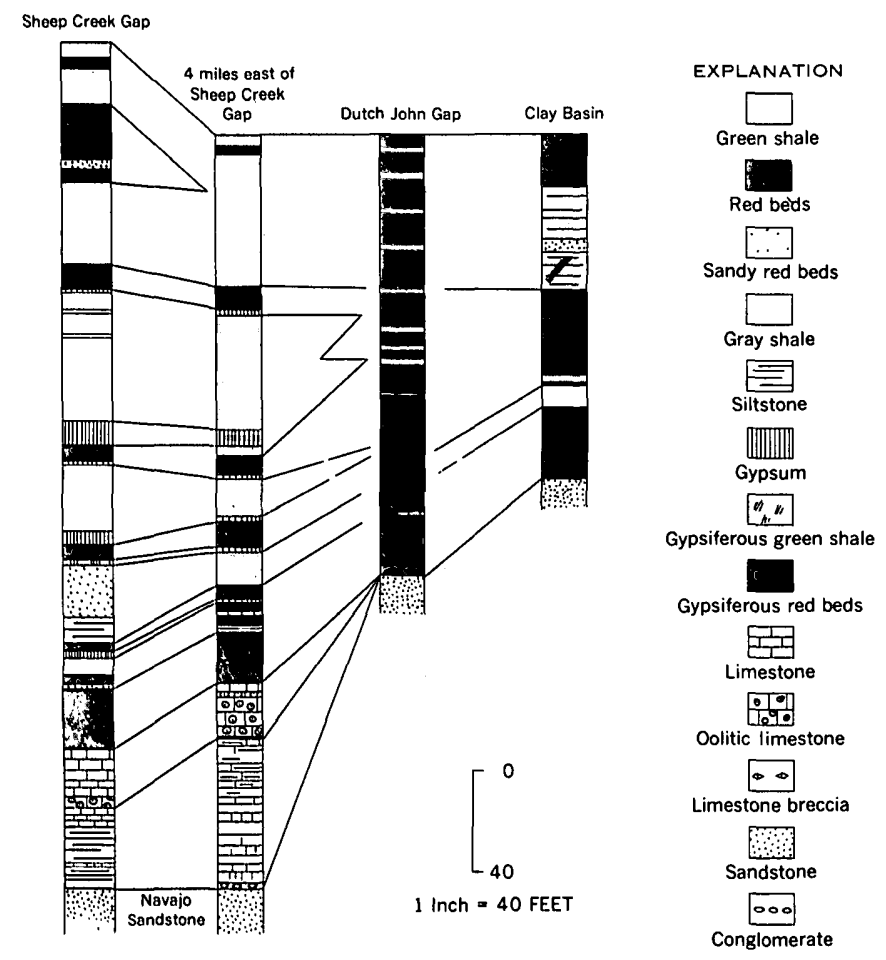

Figurn 27.-Diagram showing lithologic changes in Carmel Formatlon between Sheep Creek Gap and Clay Basin. Eastward thinning due largely to disappearance of carbonate sequence at base and thinning or disappearance of gray and green rock intervals.

seaway. The shore of this seaway advanced eastward across the Flaming Gorge area during accumulation of the Carmel Formation, and the uppermost beds of the Navajo Sandstone-then exposed on shore as a low landmass - were reworked by waves to form the sandy basal beds of the Carmel. Basal conglomerates accumulated locally just northwest of Flaming Gorge.

Free circulation of the water and attendant conditions suited to the survival of organisms are indicated by the fossiliferous carbonates of members C, D, and E, but these conditions. did not extend to the eastern part of the area (Clay Basin and eastward) where members C, D, and $\mathrm{E}$ are unrecognized. Impeded circulation, stagnation, excessive evaporation, and climatic aridity are indicated by the gypsiferous sequences of members $F$ and G. Complete emergence of the land was followed by deposition of the overlying eolian Entrada Sandstone. A detailed account of the paleoecology of the Jurassic seas of the Western Interior of the United States was presented by Imlay (1950b).

\section{ENGINEERING CHARACTERISTICS}

Owing to a wide range of lithologic characteristics, the engineering behavior of the Carmel Formation can be expected to vary widely from place to place and in different parts of the section. The limestone beds in the lower part of the formation (members $C, D$, and $E$ ) are hard and resistant to erosion, and any excavation into firm rock in these beds would require drilling and blasting. By the same token, they possess relatively high slope stability and bearing strength. The soft shaly and gypsiferous upper parts of the formation, on the other hand, would be relatively easy to excavate, but they lack strength and are unstable at relatively low slope angles. Small landslides have been caused by failures in these beds three-quarters of a mile east of Sheep Creek Gap. In the gap itself, some gypsum beds are highly contorted by flowage, and small slumps have formed in various gypsiferous intervals.

Abundant joints in the competent beds in the lower part of the formation give the outcrop a blocky appearance. They also provide good moisture infiltration and free subsurface drainage. Drill-water circulation losses occurred in this interval in Ohio Oil Co.'s Government test 1 south of Antelope Flat. Joints are inconspicuous in the upper incompetent part of the formation. This interval is water tight and surface runoff is rapid, which might cause drainage problems to arise in a construction project-a road grade for example-unless provisions for drainage were made in the planning stage.

\section{ENTRADA SANDSTONE}

The Entrada Sandstone is typically exposed in the San Rafael Swell of east-central Utah (Gilluly and Reeside, 1928, p. 75). The name was first extended into the Flaming Gorge area by Baker, Dane, and Reeside (1936, p. 14), who differentiated it as beds earlier grouped with the Nugget Sandstone but shown by them to be clearly younger than the Nugget. The Entrada is now recognized throughout the eastern Uinta Mountains.

\section{DISTRIBUTION AND PHYSIOGRAPHIC EXPRESSION}

The Entrada Sandstone crops out in near-continuous exposure from the west boundary of the area at South Valley to the east end of Dutch John Mountain. East of Dutch John Mountain it is cut from the surface section by the Uinta fault, but it is penetrated farther east by gas wells in Clay Basin. Between South Valley and the east end of Dutch John Mountain its outcrop varies widely in character. Under favorable conditions it forms a sharp-crested ridge bounded by clifl's and dip slopes. At Sheep Creek Gap, where the entire formation is exposed, less resistant slope-forming red beds in the upper part of the formation and more resistant cliffforming gray beds in the lower part give the outcrop a twofold character. The outcrop is most prominent and most accessible between Sheep Creek Gap and Flaming 
Gorge (fig. 26). West from Sheep Creek Gap and east from Flaming Gorge the outcrop is generally more subdued. For reasons not entirely clear, the outcrop in general is more prominent where dips are gentle and less prominent where dips are steep, possibly because of structural weakening where the formation is sharply flexed.

Complete sections of the formation are exposed at Sheep Creek Gap, at Finch Draw, and at the large dry ravine halfway between. Many good partial sections are exposed along the line of outcrop between these areas.

\section{LITHOLOGY AND THICKNESS}

In the Sheep Creek-Flaming Gorge area the Entrada Sandstone has a twofold lithologic character consisting of a lower predominantly gray to cream-colored fineto medium-grained highly crossbedded sandstone unit and an upper uniformly moderate reddish-orange evenbedded very fine grained silty sandstone unit. A short distance east of Flaming Gorge the red beds feather out, and the formation appears as a single homogeneous gray unit. The gray to cream-colored beds probably are eolian in origin, the red beds marine. West of Flaming Gorge the gray unit contains moderate reddish-orange sections identical in character with the upper unit; these rock intervals probably are marine also. Essentially the same twofold red and gray character has been noted in sections on the Colorado Plateau (Baker, Dane, and Reeside, 1936, p. 7), where the red beds occupy areas to the west and the gray beds occupy areas to the east.

West of Flaming Gorge, the moderate reddishorange sections of the lower unit thicken generally toward the west and feather out toward the east. They are especially conspicuous northeast of Sheep Creek Gap, roughly between BM 6744 near the trace of the South Valley fault and Finch Draw 11/2 miles west of Flaming Gorge, where they make up the greater volume of the lower unit. Southwest of BM 6744 the gray sections in the lower unit thicken toward Sheep Creek Gap, and eastward from Finch Draw they thicken toward Flaming Gorge.

The upper moderate reddish-orange unit of the formation is very uniform in character and color, but it thins toward the east. It disappears entirely along the north side of Boars Tusk, and from Chokecherry Draw eastward the entire formation is essentially gray, although locally a pink cast cuts across bedding planes. In most places the upper unit of the formation is less resistant to erosion than the lower unit; it commonly forms a soil-mantled slope above the ledge- or cliffforming outcrop of the lower unit.
Section of the Entrada Sandstone on the northwest side of a dry ravine in the $S E 1 / 4$ sec. $28, T, 3 N ., R$. $20 \mathrm{E}$.

[Measured by W. R. Hansen and T. B. Piper, Aug. 29, 1951]

Curtis Formation: siltstone, greenish-gray, glauconitic. Entrada Sandstone:

Upper unit :

Sandstone and siltstone, moderate reddish-orange, very fine grained, massive; in places slabby. Weathers into rounded forms, commonly forms slopes; base not exposed.

Lower unit:

Sandstone, cream-colored to pale-yellow, fine-grained, crossbedded; lower part forms cliff; upper $30 \mathrm{ft}$ forms slope and is poorly exposed.-

Sandstone, cream-colored, fine- to medium-grained, very massive; forms cliff. Exposed faces light brown.

Sandstone, cream-colored, very fine-grained, soft, massive ; commonly forms recess in face of cliff.- 10

Sandstone, moderate orange-red, very fine grained; massive; forms cliff.

Total_ $-245$

Carmel Formation: shale, pale-greenish-gray.

Like many formations in the area, the Entrada Sandstone thins generally but unevenly toward the east. At Sheep Creek Gap, Thomas and Krueger (1946, p. 1292) obtained a thickness of 201 feet, of which 84 feet constituted the upper unit. The section is thicker $(245 \mathrm{ft})$ $31 / 2$ miles northeast of Sheep Creek Gap, largely because of a greater thickness of gray eolian beds in the lower unit, but farther east at Ohio Oil Co.'s test at Spring Creek nose the formation has thinned to about 210 feet and consists entirely of gray beds-although the total thickness at Spring Creek nose is less, the gray bed sequence actually is thicker than in sections to the west. Still farther east at Clay Basin, the formation is entirely gray and is only about 115 feet thick.

The contact of the Entrada Sandstone with the underlying Carmel Formation is marked by a change of lithology and an abrupt topographic break. It appears, however, to be conformable.

\section{AGE AND CORRELATIONS}

Fossils have not been found in the Entrada Sandstone of the eastern Uinta Mountains, and the chance of any ever being found, especially diagnostic ones, seems remote. Fortunately, the formation is bracketed by well-dated beds below and above in the Carmel and Curtis Formations. On this basis, the age of the Entrada was considered by Imlay (1952b, p. 1747) to be early Late Jurassic (late Callovian): Imlay (1952a, p. 961) also described in detail the correlations of the formation, which are mentioned by briefly below. 
The Entrada Sandstone grades westward into the Preuss Sandstone of southern Idaho, of the central Wasatch Mountains (northern Utah), and of the western Uinta Mountains, a relationship first described by Heaton (1939, p. 1172) and noted since by many geologists. As pointed out by Thomas and Krueger (1946, p. 1277-1278), the red-bed units of the Entrada Formation of the Sheep Creek-Flaming Gorge area almost certainly are eastward continuations or tongues of the Preuss Sandstone. The typical earthy facies of the Entrada of the San Rafael Swell is correlated with the Preuss also (Heaton, 1939, p. 1175). The Entrada is also correlated with the Twist Gulch Member of the Arapien Shale of the Gunnison Plateau area and southern Wasatch Mountains of central Utah (Imlay, 1925b, p. 1746). To the north, the Entrada is correlated with the "red zone" of the Sundance of central Wyoming and with the Lak Member of the Sundance Formation of eastern Wyoming and adjacent areas.

DEPOSITIONAL CONDITIONS

The two dissimilar color lithofacies of the Entrada Sandstone were deposited under dissimilar, although perhaps gradational, conditions. As noted for correlative rocks elsewhere (Baker, Dane, and Reeside, 1936, p. 54; Imlay, 1952b, p. 1739), the very fine grained red sandstone facies probably is marine, and the fine-grained gray sandstone facies probably is eolian. Evidence of a marine origin for the Preuss Sandstone, with which the red facies of the Entrada is correlated, was presented by Imlay (1952b), who cited, among other things, the combination of even grain size, even bedding, oscillation ripple marks (in some places), and gradational relationships with the underlying Twin Creek Formation. These characteristics are generally valid for the red facies of the Entrada in the Sheep Creek-Flaming Gorge area. Imlay further suggested that the Preuss was deposited in a highly saline lagoon or series of lagoons connected westward with normal marine waters, a suggestion supported by the occurrence of gypsum beds in Idaho and casts of salt crystals in parts of the Uinta Mountains (Huddle and McCann, 1947a). Imlay attributed the red color of the facies to lateritic soils in the source area.

Most geologists regard the very extensive gray sandstone facies of the Entrada as an eolian deposit, mainly because of its massive crossbedding. It probably accumulated mainly as dune sand on a desert which bordered the Preuss seaway on the east. Intertonguing of red and gray facies in the Sheep Creek-Flaming Gorge area indicates that the shoreline pulsated back and forth across the area. In all probability the thick gray sandstone at Sheep Creek Gap, with red beds below and above, accumulated very close to the beach or even on it. The gray sand was buried beneath shoreward bottom deposits as the shoreline advanced eastward across the area. A lack of red beds east of Boars Tusk, however, suggests that the shore never advanced much beyond Boars Tusk.

In summary, the red beds of the Entrada in the Flaming Gorge-Sheep Creek area are regarded as shoreward bottom deposits of a restricted marine waterway. The gray beds are regarded as beach and (or) onshore dune deposits in the western area where gray and red facies intertongue and as desert dune deposits in the eastern area where gray beds occur exclusively.

\section{ENGINEERING CHARACTERISTICS}

The Entrada Sandstone should present few serious problems to possible engineering use of land along its outcrop. The outcrop is highest and most formidable west from Flaming Gorge for a distance of 4-5 miles, where it forms a prominent hogback. Elsewhere it generally is more subdued, especially east of Flaming Gorge.

All excavations into firm rock in the Entrada Sandstone would require drilling and blasting, but drilling should be relatively easy and rapid. As the Entrada forms cliffs or steep slopes, it can be expected to stand unsupported at relatively steep angles in artificial excavations.

Both the gray and the red facies of the formation are lightly cemented with calcium carbonate and are porous; the gray beds are more porous than the red beds owing to a higher degree of sorting and of grain sphericity. Drainage from both facies, therefore, is good.

Large but widely spaced joints are characteristic. Most of these are spaced tens of feet apart, and some extend through the formation from top to bottom. Where such joints are cut by water-lubricated drill holes, circulation losses are expectable.

\section{CURTIS FORMATION}

Along with the Carmel Formation and Entrada Sandstone, the Curtis Formation is typically exposed in the San Rafael Swell (Gilluly and Reeside, 1928, p. 79). In the eastern Uinta Mountains, where it once had been correlated with the Twin Creek Formation, it was first noted by Baker, Dane, and Reeside (1936, p. 8). In the early studies of Powell $(1876$, p. 51$)$ it was referred to as the Mid-Group limestone of the Flaming Gorge Group. In recent years, the Curtis Formation as such has been widely recognized throughout the Uinta Mountains, although in the western sections equivalent rocks commonly are referred to as the Stump Sandstone. 
DISTRIBUTION AND PHYSIOGRAPHIC EXPRESSION

The Curtis Formation has a twofold lithologic character; it consists of an upper resistant limestone and sandstone unit and a lower nonresistant siltstone and sandstone unit. It most places these units have differential topographic expression in that the upper unit forms dip slopes, cliffs, and ledges, and the lower unit forms debris-mantled front slopes or valleys.

The outcrop of the Curtis Formation is practically coextensive with that of the underlying Entrada Sandstone. South of Manila and Linwood, along the south margins of South and Lucerne Valleys and eastward toward Flaming Gorge, the resistant upper unit forms broad dip slopes or flatirons. Near the west end of South Valley, where the formation is overturned along a small reverse fault, the upper unit forms a low but sharp hogback. Between Flaming Gorge and the east end of Dutch John Mountain, the formation is nearly vertical to overturned at most places, owing to the influence of the Uinta fault, and the hard upper unit crops out as a narrow, straight, inconspicuous but easily identified ridge. The soft lower unit is poorly exposed as a slope or a hollow.

At the east end of Dutch John Mountain the Curtis Formation is cut out at the surface by the Uinta fault. East of there, small slivers of limestone containing typical Curtis fossils appears at a few places in the gouge and breccias of the Uinta fault-for example, where the fault zone crosses the head of Jesse Ewing Canyon in Clay Basin. The formation has been identified at depth at Clay Basin in the Mountain Fuel Supply Co.'s R. D. Murphy 6-W well.

\section{LITHOIOGY AND THICKNESS}

At Finch Draw, where the section that follows was measured, the twofold Curtis Formation is about 146 feet thick. The nonresistant lower unit, 75 feet thick, consists of greenish-gray to light-olive-green thin-bedded friable glauconitic sandstone and siltstone containing numerous layers and lenses of concretionary limestone. The mineral glauconite is highly characteristic and gives the rock its green cast. The belemnite Pachyteuthis "densus" (Meek and Hayden) and casts and molds of pelecypods are common in the lower unit.

The resistant upper unit, 71 feet thick, is one of the most distinctive lithologic markers in the area. It consists of blocky to slabby light-gray limestone, in part oolitic and glauconitic, and glauconitic fine-grained sandstone. It contains abundant shells of the brachiopod Kallirhynchia myrina (Hall and Whitfield), in places so crowded as to be a coquina.
Section of the Curtis Formation in Finch Draw in the NW1/4 sec. 25, T. 3 N., R. $20 \mathrm{E}$.

[Measured by W. R. Hansen and T. B. Piper, Aug. 22, 1951]

Morrison Formation : clay-shale, variegated red and gray. Curtis Formation:

Upper unit:

Limestone, light-gray, thick-bedded, crossbedded, massive

Sandstone, gray, fine-grained, ripple-marked, limy -.Limestone, blue-gray to light-gray, oolitic, and sandstone limy ; crossbedded in long flat slabs; glauconitic toward base. Abundant Kallirhynchia. Forms cliff and dip slope. Mostly thin bedded.--Sandstone, gray, fine-grained, glauconitic, friable-..Limestone, gray-brown, thick-bedded and massive, glauconitic, oolitic; sandy toward base...-...-.-.Lower unit:

Sandstone, light-olive-green, glauconitic, friable, calcareous.--

Limestone, light-gray buff weathering, oolitic. A few belemnites, gastropods, and pelecypods.....-

Sandstone and siltstone, greenish-gray, thin-bedded, friable, glauconitic; numerous concretionary layers of limestone. Contains belemnites and abundant casts and molds of pelecypods.

Total

Entrada Sandstone: siltstone, moderate reddish-orange.

As shown by the following diagram (fig. 28), the thickness of the formation varies appreciably and unevenly from place to place. The upper unit thickens gradually eastward from Sheep Creek to Clay Basin; the lower unit thins generally in the same direction. Beyond the limits of the area the entire formation thins eastward to about 135 feet at Vermilion Creek 30 miles east of Clay Basin (Thomas, McCann, and Raman, 1945) and thins northward to about 152 feet in South Baxter Basin 30 miles north of Clay Basin (Thomas and Krueger, 1946, p. 1281). Toward the south the formation thickens to 263 feet in the vicinity of Vernal (Kinney, 1955, p. 87) about 30 miles south of Flaming Gorge and thickens to 260 feet at Dinosaur National Monument headquarters 20 miles east of Vernal (Untermann and Untermann, 1954, p. 51).

The contact of the Curtis Formation with the underlying Entrada Sandstone is rarely well exposed, owing to the nonresistant character of the beds below and above. Where well exposed, it is sharp and well defined, but it presents no. clear local evidence of unconformity. Elsewhere in the Uinta Mountains, however, an unconformity is strongly suggested by scour or truncation at the top of the Entrada or Preuss and by a conglomerate at the base of the Curtis (Thomas and Krueger, 1946, p. 1279 ; Kinney, 1955, p. 88; Untermann and Untermann, 1954, p. 52). As noted by 


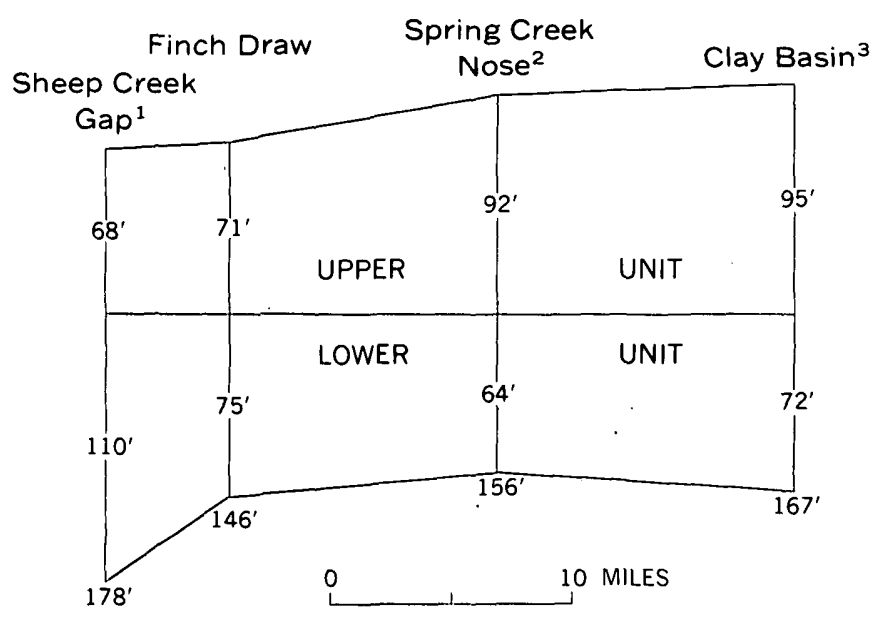

'Thomas and Krueger (1946, p. 1292)

${ }^{2}$ Ohio Oil Co. Government test 1

${ }^{3}$ Mountain Fuel Supply Co. R. D. Murphy $6-W$ well

Figure 28.-Variations in thickness of Curtis Formation between Sheep Creek Gap and Clay Basin.

Imlay (1952a, p. 962), the contact may be conformable in some places and unconformable in others. Where the Curtis Formation is fully developed, the unconformity probably represents only a small part of Callovian time (Imlay, 1952a, p. 963) ; such probably is the case in the Flaming Gorge area, at least near Sheep Creek Gap. If post-Entrada pre-Curtis erosion has occurred in this area, however, it would help to explain why the upper red facies of the Entrada wedges out so rapidly toward the east and would help to account for the variant thicknesses of the lower unit of the Curtis from place to place.

\section{FOSSILS, AGE, AND CORRELATIONS}

Marine fossils are abundant in the Curtis Formation, and the age and correlations of the formation are well established. Specimens that.I collected at Finch Draw were examined by Ralph W. Imlay, who noted the following forms:

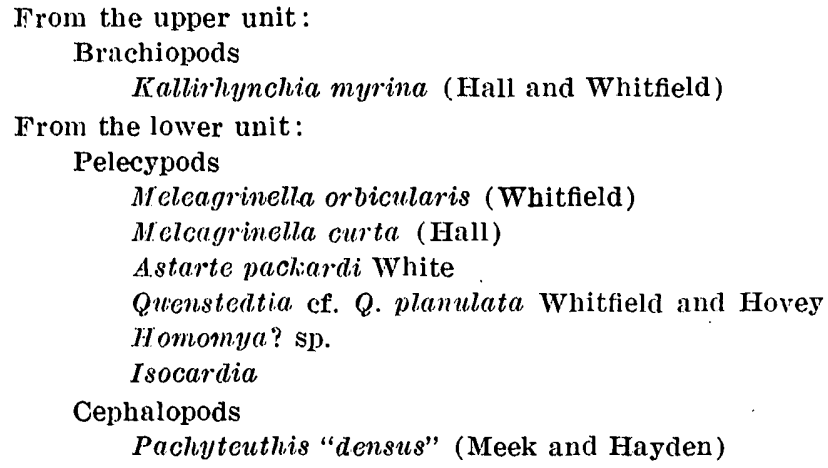

Careful collecting probably would yield additional forms. In regard to the above collection, Imlay added,

Lot $B$ contains species common in the Curtis formation and the equivalent Stump standstone of the Wyoming-Idaho border and the Upper Sundance formation of central Wyoming. The brachiopod Kallirhynchia myrina (Hall and Whitfield) and Astarte packardi White have been found only in those formations. The belemnite Pachyteuthis "densus" (Meek and Hayden) occurs in abundance only in these formations and their equivalents but has been found rarely in older beds.

The Curtis Formation is Late Jurassic in age and was correlated in time by Imlay (1952a, chart $8 C$ ) with the Oxfordian Stage of the Jurassic of Europe. Equivalent formations in other parts of the Western Interior, as shown on Imlay's chart, include the Stump Sandstone into which the Curtis grades westward along the Uinta Mountains (Heaton, 1939, p. 1173), the "upper Sundance" of central Wyoming, the Swift Formation of western Montana, the Summerville Formation (in part) of the Colorado Plateau, and the Wanakah Formation of the San Juan Mountain area of Colorado.

\section{DEPOSITIONAL CONDITIONS}

Deposition of the Curtis Formation marked a reexpansion of the Western Interior Jurassic seaway into the eastern Uinta Mountains area. In contrast with the underlying red silty facies of the Entrada Sandstone, which probably accumulated in an environment of oxidation, stagnation, and restricted circulation, and with the eolian gray facies of the Entrada, which accumulated on a desert, the Curtis Formation accumulated in shallow but freely circulating marine water under conditions favorable to the growth and preservation of organisms. The mineral glauconite, a hydrous potassium aluminum silicate which is abundant in the Curtis Formation, forms under reducing conditions in shallow marine water (Williams, Turner, and Gilbert, 1958, p. 367368 ). Crossbedded sandstone and crossbedded oolitic limestone in both the upper and lower units of the Curtis Formation also indicate deposition in shallow water.

A comprehensive discussion of the depositional environment of the Curtis Formation was presented by Imlay (1950b), who also described the depositional environments of the Twin Creek, Carmel, and Preuss and made many references to the Jurassic rocks of the Uinta Mountains.

\section{ENGINEERING CHARACTERISTICS}

The Curtis Formation is most apt to present serious future engineering problems in the western part of the area, west from Flaming Gorge to South Valley, where its outcrop is broad and well exposed. The resistant upper unit, particularly, forms extensive dip slopes in that area. 


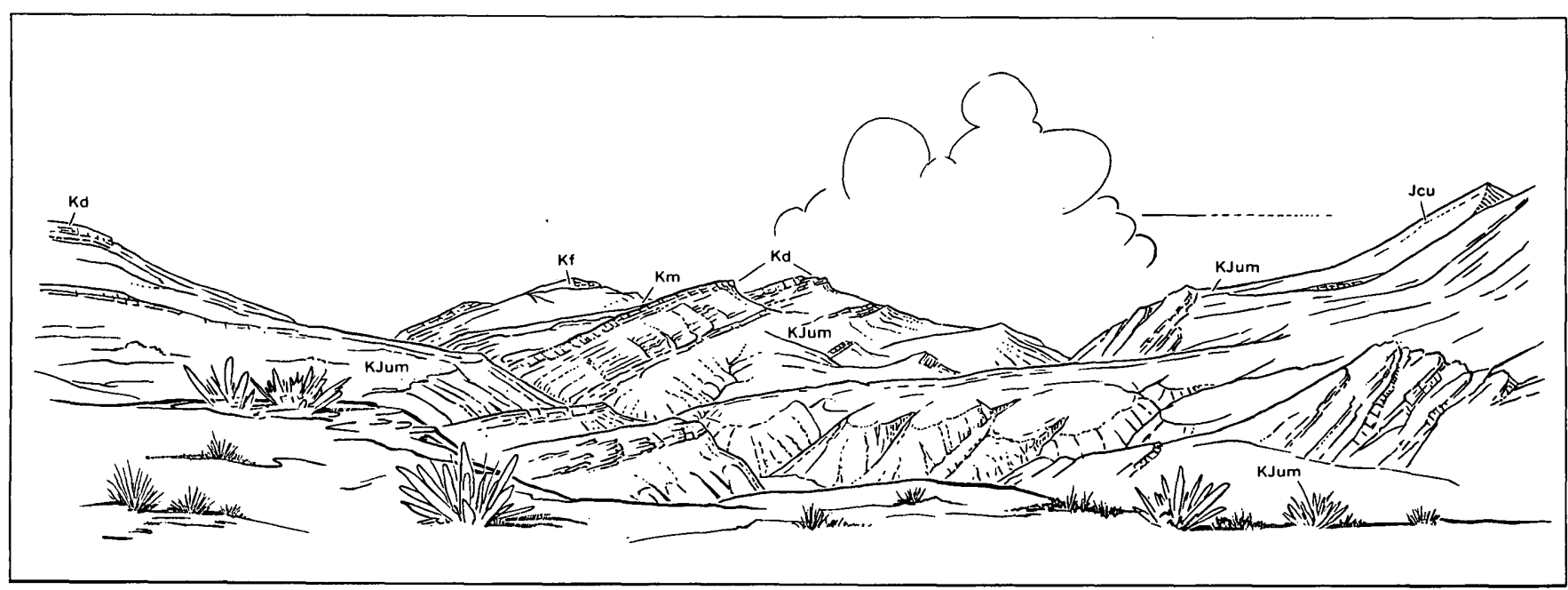

Figure 29.-Panoramic view northeast across Finch Draw, a mile northwest of Flaming Gorge. Unusally good exposures of Kf, Frontler Formation; Km, Mowry Shale; Kd, Dakota Sandstone; KJum, Unnamed Lower Cretaceous rocks and Morrison Formation; and Jcu, Curtis Formation. From a fleld sketch.

Because of diverse lithologic characteristics, the formation has a wide range of physical properties. It has moderate to high slope stability and bearing strength and hence should stand well in artificial excavations at moderate to steep slope angles. The lower unit is more easily excavated than the upper unit and for the most part probably could be removed with power machinery without recourse to explosives, although some of the harder limestone and sandstone interbeds might require drilling and blasting. The hard upper unit would require the use of explosives in any excavation into firm rock. Because of the flaggy character of its bedding, however, the rock of the upper unit is amenable to removal, once broken. It has been used on a small scale in the Manila area for flags or dimension stone in the foundations of various farm and ranch buildings. It is suitable also for use as riprap for small stock ponds and for bank protection along streams.

The Curtis Formation is permeable and well drained on the outcrop. In South Valley, wells drilled into it yield modest supplies of hard but potable water.

\section{JURASSIC AND CRETACEOUS SYSTEMS}

\section{MORRISON FORMATION AND YOUNGER ROCKS}

The Morrison Formation was named by G. H. Eldridge (1896, p. 22) for the town of Morrison in the Front Range of Colorado near Denver. Correlative beds in the eastern Uinta Mountains were referred to in the early reports of Major Powell (1876, p. 51) as the badland sandstones of the Flaming Gorge Group. They were called the Beckwith Formation by Schultz $(1920$, p. 75$)$, together with the overlying Dakota Sandstone. The name Morrison was first applied to these rocks by Sears $(1924 b$, p. 279); under this name the formation is now one of the most widely recognized units in the Western Interior of the United States. It is renowned to geologists and laymen alike for its remarkable dinosaur remains discovered at such localities as Morrison, Colo., Como Bluff, Wyo., and Dinosaur National Monument, Utah. More recently it has become known for extensive uranium deposits being mined on the Colorado Plateau. Uranium deposits in the Morrison Formation were known prior to World War I, but they have gained public attention mostly since world War. II.

\section{DISTRIBUTION AND PHYSIOGRAPHIC EXPRESSION}

In the Unita Mountains, as elsewhere, the Morrison Formation consists chiefly of soft nonresistant beds that. crop out well only in especially favorable localities. Resistant beds here and there form prominent outcrops. In the area of this report the outcrop belt of the formation extends eastward from the west boundary of the area at South Valley to the east end of Dutch John Mountain, where it is truncated by the Uinta fault. In that distance the greater part of the formation is concealed or poorly exposed. It is well exposed only at Finch Draw 11/2 miles northwest of Flaming Gorge and in a deep ravine on Spring Creek nose south of Antelope Flat. Of these exposures, the one at Finch Draw is the more complete (fig. 29); exposure is more or less continuous from the west side of the draw eastward to the south bank of Henrys Fork, where is can be seen from the benchlands across the river. Dips are steep in the Finch Draw-Henrys Fork area, and the full thickness of the formation can be seen and traversed to advantage in a relatively short horizontal distance.

Good exposures of some parts of the formation can also be seen in South Valley at points accessible to 
automobiles, but much of the formation there is concealed by valley alluvium and slope wash. Dips, moreover, are low, and the outcrop belt is correspondingly wide.

A fairly good section is exposed in Chokecherry Draw at the east end of Boars Tusk. As this section is in the overturned footwall of the Uinta fault, it is highly disturbed.

\section{LITHOLOGY AND THICKNESA}

The Morrison Formation consists chiefly of variegated soft bentonitic shales or mudstones, but it has a highly diverse total lithology and includes beds of nodular limestone, marl, medium- to coarse-grained sandstone, grit, and conglomerate. These beds are mostly lenticular, and few of them can be traced individually for any considerable distance; some of them, such as the nodular limestones and certain sandstones, seem to occur discontinuously at fairly well restricted zones or horizons. The section at Finch Draw illustrates the general lithologic character and diversity of the formation. Sections elsewhere show the same gross lithology but differ in detail, especially in regard to the quantity and stratigraphic position of conglomerate. At Finch Draw, for example, a sandy pebble-conglomerate section 280 feet above the base of the formation totals 85 feet in thickness and forms a sharp cliff but is unrecognized in nearby sections. At Spring Creek nose a hard conglomeratic sandstone 60 feet above the base of the formation and 25 feet thick forms a strike ridge about 2 miles long. This bed also feathers out rapidly to the west and east, the same stratigraphic interval at Finch Draw is occupied by variegated mudstone, and at Clay Basin, by fine-grained sandstone.

Section in Finch Draw about $1 \frac{1}{2}$ miles northwest of Flaming Gorge, mainly in the $5 W 1 / 4$ sec. 24, T. 3 N., R. $20 \mathrm{E}$.

[Measured by W. R. Hansen and T. B. Piper, Aug. 22, 1951]

Dakota Sandstone : sandstone, medium- to coarse-grained, crossberded.

Morrison Formation:

Mudstone, variegated red and olive. Contains gastroliths. Limestone nodules $45 \mathrm{ft}$. below top___._._._. 116

Sandstone, dull gray, medium- to coarse-grained, crossbedded, moderately cemented. Thickens to west and forms low hogback in South Vailey

Mudstone, variegated red and gray. Sandstone lens $97 \mathrm{ft}$. below top

Sandstone, gray, medium-grained, crossbedded ; coarsegrained lenses and a few pebbles. Forms ridge

Mudstone, gray.

Sandstone and fine conglomerate, light-gray, crossbedderl. Weathers buff and is lenticular; chert and clay pebbles.

Mudstone, variegated red and gray; olive colored toward base.

Sandstone, white to cream-colored, medium-grained, calcareous.
Morrison Formation-Continued

Clay, tan.

Feet

Pebble conglomerate, loosely cemented, porous; composed mostly of subrounded black chert and gray quartzite pebbles less than half an inch in diameter, some with pressure cracks; interbedded crossbedded sandstone. Dip slope

Conglomerate, fine, interbedded with crossbedded sandstone. More of a grit than above unit. A channel deposit of variable thickness. Forms cliff_-_.-.--_

Sandstone, gray, coarse-grained ; contains conglomerate lenses.

Mudstone, variegated red and olive. Contains gastroin lower two-thirds

Total_ 939

Sharp contact.

Curtis Formation: limestone, light-gray, massive, thickbedded.

From Finch Draw the Morrison Formation thickens westward and thins gradually eastward (fig. 36). Near Dutch John Gap it is about 800 feet thick, and at Clay Basin, about 600 feet. It thins northward away from the Uinta Mountains to about 340 feet at South Baxter, Wyo., south of Rock Springs (Fidlar, 1950a, p. 110).

Aside from differences in thickness from place to place due to thickening or thinning of the formation, differences in local reported measured thicknesses may possibly result partly from different measuring techniques used by various investigators. This might be true especially in areas of low dips and wide nonresistant outcrop belts. In part, however, differences in such reported thickness are due to differences of opinion as to where the upper contact of the Morrison Formation should be placed in the section. Thus, Stokes (1955, p. 84) measured 1,065 feet of nonmarine strata between the Curtis Formation and Mowry Shale 2 miles west of Flaming Gorge, a short distance west of Finch Draw. Of this thickness, Stokes placed 560 feet in the Morrison, 265 feet in the Lower Cretaceous, and 240 feet in the Dakota. In the same general vicinity, B. F. Curtis ${ }^{10}$ measured a total of 1,305 feet of beds and included all but 80 feet in the Morrison. Judging from Curtis' sections, I would place all but 210 feet, or a total of 1,095 feet, in the Morrison Formation and the remainder in the Dakota Sandstone, using as the contact the same channeling conglomeratic sandstone that appears just to the east at Finch Draw.

As mapped throughout the Uinta Mountains by most geologists, the Morrison Formation contains beds of Early Cretaceous age in its upper part. These beds cannot be mapped separately in most places, although they can be recognized in some well-exposed sections.

${ }^{10}$ Curtis, B. F., 1949, Structure and stratigraphy of the Linwood Spring Creek area, Utah-Wyoming : Harvard Univ. unpub. Ph. D. thesis. 
The top of the Morrison Formation is thus drawn at the top of a sequence of variegated red, lavender, and olive-colored clay shales beneath a massive conglomeratic sandstone bed which fills channels in the underlying beds. This boundary is easily identified in the field throughout the greater part of the Uinta Mountains and can be mapped with reasonable accuracy in most places, even where the bulk of the Morrison Formation is concealed or poorly exposed, because the overlying sandstone bed is resistant to erosion. West of Utah Highway 44 in South Valley, however, this bed thins out, and the contact is less well defined.

FOSSILS, AGE, AND CORRELATIONS

Age and correlations of the Morrison Formation are mentioned briefly in the previous paragraphs. A Late Jurassic age is now widely accepted (Baker, Dane, and Reeside, 1936, p. 58; Imlay, 1952a, p. 953). Throughout the Uinta Mountains, Early Cretaceous beds have been mapped with the Morrison. Imlay considered the formation to be temporally equivalent mainly to the Kimmeridgian Stage of Europe. Raymond E. Peck (written commun., 1959) collected Early Cretaceous charophytes and ostracodes from the upper part of the section near Hanna on the Duchesne River and near Vernal along Utah Highway 44. He also collected abundant specimens of the following forms from the nodular limestone beds near Henrys Fork :

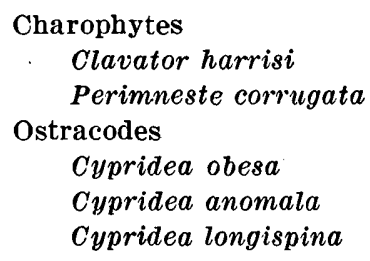

All the above forms are fairly common and characteristic Early Cretaceous fossils, according to Mr. Peck. Cypridea obesa has been seen by him elsewhere only in the Cloverly Formation northwest of Lander, Wyo.

From clays about 200 feet below the base of the Dakota Sandstone, Mr. Peck collected the following forms :

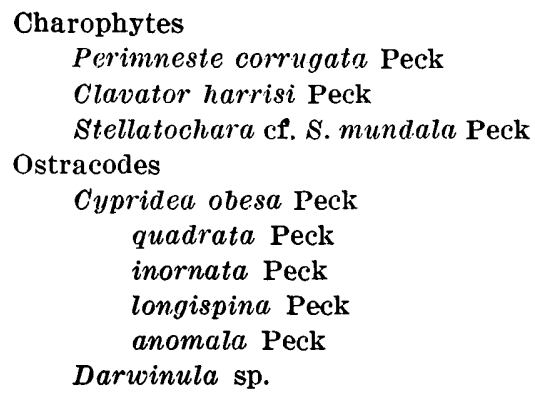

The above is a typical Early Cretaceous (Aptian) assemblage, according to Mr. Peck, and many of the species are widespread in the Cloverly, Kootenai, and Cedar Mountain Formations and in the Gannett Group. Lower in the section, below a black-chert conglomerate, Mr. Peck collected the following typically Morrison assemblage:

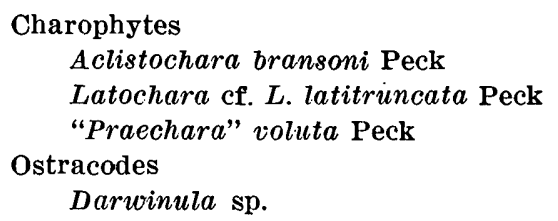

Nondiagnostic fossils from the Morrison Formation include a few disarticulated fragments of dinosaur bone found in South Valley.in the NW1/4 sec. 1, T. 2 N., R. 19 E., and petrified wood fragments found at several places elsewhere.

The Morrison Formation of the Flaming Gorge area is correlated with the famous dinosaur-bearing formation at Dinosaur National Monument whose dinosaur fauna resembles that of the type area. The formation is partly equivalent to the Beckwith Formation of southwestern Wyoming, although that formation contains rocks of diverse ages-both older and younger than the Morrison Formation-and needs to be redefined (Stokes, 1944, p. 969). The upper part of the section mapped with the Morrison Formation in the Flaming Gorge area is of early Cretaceous age and is correlated with the Cloverly Formation of the Wind River basin of Wyoming. It probably is equivalent also to at least part of the Cedar Mountain Formation of the Colorado Plateau (L. C. Craig, oral commun., 1959).

No effort has been made to subdivide the Morrison of the Flaming Gorge area into units recognized elsewhere, as no basis for so doing has been found. From general appearance and lithology, however, the greater part of the unit resembles the Brushy Basin Shale Member of the Morrison Formation which is widespread on the Colorado Plateau (Gregory, 1938, p. 59).

$$
\text { DEPOSITIONAI, CONDITIONS }
$$

Deposition of the Morrison Formation followed that of the underlying Curtis Formation without any apparent significant break in sedimentation. As the Morrison Formation is a terrestrial deposit, the onset of its deposition marked the disappearance of the interior Jurassic seaway from the area. Sedimentation, however, was influenced by the old Uinta trough (fig. 30).

Virtually all investigators agree that the formation accumulated on a broad flat alluvial plain and that the conglomerates and sandstones accumulated as fillings in the channels of meandering streams. The mudstones 


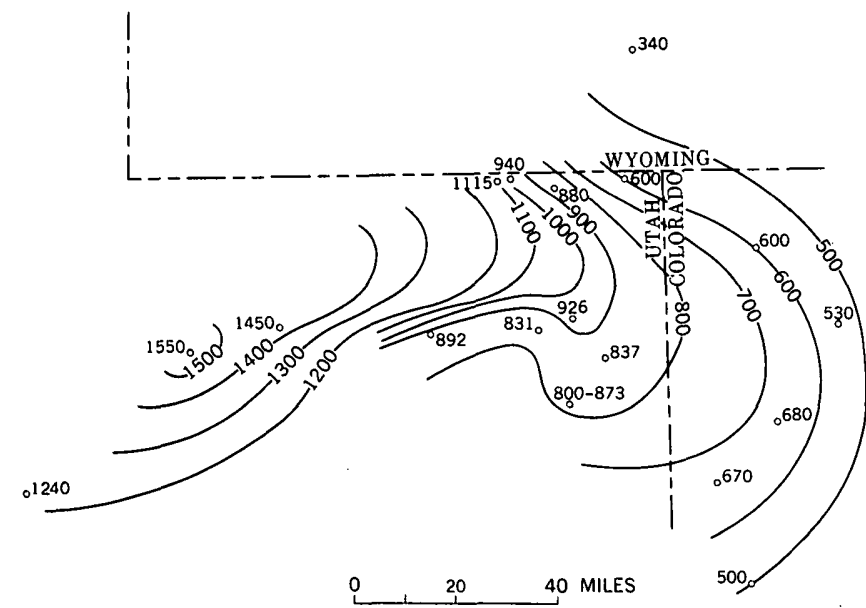

Figure 30.-Generalized thickness map of Morrison Formation. Includes beds of Early Cretaceous age underlying Dakota Sandstone. Isopach interval 100 feet.

probably accumulated mainly as overflow deposits on flood plains; their bentonitic content generally is attributed to ash falls from a distant volcanic source, probably in the ancestral Nevadan Mountains then rising to the west. The limestones probably accumulated in shallow ephemeral lakes. Semiarid conditions are inferred (Baker, Dane, and Reeside, 1936, p. 55 ; Stokes, 1944, p. 975).

\section{ENGINEERING CHARACTERISTICS}

From the west boundary of the area at South Valley to the east end of Dutch John Mountain the Morrison Formation has a rather broad outcrop belt. It is especially wide at South Valley and hence is most apt to be found there in possible future engineering activities. Utah Highway 44 crosses the Morrison Formation in South Valley, and any future improvement of that highway would involve grade alinements on the Morrison Formation.

For the most part, the formation is easily excavated without recourse to explosives, except the hard sandstone and conglomerate beds. Owing to a high clay content, the mudstones are plastic when wet and, therefore, would possess low bearing strength and stability for the foundations of roads, bridges, or other structures. The formation occupies low ground in most places, hence natural slope failures are uncommon, but landslides have formed near the east end of Dutch John Mountain where the beds are flexed upward near the Uinta fault. In artificial cuts, drainage should be provided, and slope angles should be kept low to promote stability.

The clay content of the mudstones also causes rapid surface runoff and low moisture infiltration, so that local badland areas have resulted where the alluvial cover has been removed by erosion. The formation is a poor aquifer and provides very little underground water.

\section{CRETACEOUS SYSTEM}

The Cretaceous System was introduced uneventfully into the Flaming Gorge area while the Morrison Formation was accumulating. Fluviatile sandstones and paludal shales of the Dakota Sandstone accumulated on the channeled surface of the Morrison Formation (as mapped), perhaps without a significant time break. Following deposition of the Dakota Sandstone the area began to subside beneath a new interior seaway along the foredeep of the Rocky Mountain geosyncline. High mountains stood to the west. A resulting thick sequence of shallow-water marine sediments is now represented by the Mowry Shale, Frontier, Hilliard, and Blair Formations, and partly by the Rock Springs Formation. Intermittent slight emergence or nondeposition is indicated by faunal breaks at various places in the section and by nonmarine beds in the Frontier and Rock Springs Formations, although physical evidence of disconformity in the sequence has not been observed. Final emergence of the land and complete withdrawal of the seaway accompanied deposition of the nonmarine Ericson Sandstone of Montana age, the youngest Cretaceous formation in the area. Thus ended an intermittent occupancy of the area by shallow-marine waters-an occupancy that began millions of years before, in Precambrian time.

\section{DAKOTA SANDSTONE}

The name Dakota Sandstone is applied to a sequence of Lower Cretaceous rocks correlated in a general way with the typical Dakota Sandstone of the High Plains of Nebraska and adjacent States.

Major Powell (1876, p. 50) included the Dakota Sandstone, as it is now known, in his Henrys Fork Group, together with the overlying Mowry Shale and Frontier Formation. This was a logical grouping, as the Mowry and Frontier are more closely linked topographically and lithologically with the Dakota than with the overlying Hilliard, which Powell referred to as the Sulphur Creek Group. Powell's type locality for his Henrys Fork Group was the well-exposed area at the mouth of Finch Draw, and the base of the group as he described it was exactly as here identified for the base of the Dakota Sandstone. The Henrys Fork Group of Powell was identical with the Dakota Group as recognized in the Uinta Mountains by the 40th Parallel Survey of King (1878, p. 303).

$$
\text { DISTRIBUTION AND PHYSIOGRAPHIC EXPRESSION }
$$

The Dakota Sandstone is about coextensive with the underlying Morrison Formation (fig. 29). It forms a 
near-continuous outcrop from the west boundary of the area at South Valley to the east end of Dutch John Mountain, where it is truncated by the Uinta fault. It is unexposed east of Dutch John Mountain but instead is deeply buried beneath younger rocks on the downthrown side of the fault. At Clay Basin it is the principal gas-producing formation.

Except locally, the Dakota has a characteristic threefold lithologic habit that is reflected by topography-a lower cliff-or ledge-forming conglomeratic sandstone unit, a middle slope-forming shale unit, and an upper hogback- or dip-slope-forming conglomeratic-sandstone unit. West of Utah Highway 44 in South Valley the lower unit is locally nonexistent. The formation crops out well, and near-complete exposures of the full section are common. The section at Finch Draw is especially well exposed. Almost equally good sections can be seen along Utah Highway 44 in South Valley, along Chokecherry Draw at the east end of Boars Tusk in the north part of sec. 3, T. 2 N., R. 21 E., and on the Spring Creek nose in the NE1/4 sec. 27 , T. 3 N., R. $22 \mathrm{E}$.

\section{LITHOLOGY AND THICKNESS}

In the Flaming Gorge area the tripartite character of the Dakota Sandstone is distinctive, and on a largescale map the three units could easily be portrayed separately. At the map scale used in this report, differentiating them would have questionable value.

The lower unit of the Dakota fills channels in the Morrison Formation, and hence varies greatly in thickness. Locally it is nonexistent. It consists chiefly of light-colored, gray to yellowish-gray medium- to coarsegrained crossbedded porous sandstone. It is conglomeratic and characteristically contains lenses and stringers of pebble conglomerate composed mainly of chert but including shale pellets and bits of petrified wood. In places parts of the lower unit are quartzitic, owing to a siliceous matrix.

The middle shaly unit consists mostly of soft darkgray clay shale or mudstone, in part carbonaceous and in part gypsiferous. It contains abundant twig fragments and charcoal. In places it is sandy, and it commonly contains thin sandstone interbeds. It is conformable with the underlying lower sandstone unit.

The upper sandstone unit consists chiefly of lightcolored, gray to yellowish-gray medium- to coarsegrained porous sandstone. In many places it has a pinkish-gray cast on the outcrop, probably as a result of surficial oxidation. The bedding habit of the unit varies from blocky to slabby to crossbedded; ripple marks are common. Large "cannonball" concretions occur occasionally.
Representative sections of the Dakota Sandstone are as follows:

Section of the Dakota Sandstone at Finch Draw in the $S W 1 / 4$ sec. $24, T .3 \mathrm{~N} ., \mathrm{R} .20 \mathrm{E}$.

[Measured by W. R. Hansen and T. B. Piper, August 1951] Feet

Mowry Shale: shale, gray, silvery-gray weathering, siliceous, fissile; numerous fish scales.

Dakota Sandstone:

Upper unit :

Sandstone, cream-colored, medium-grained, crossbedded, blocky and slabby. Weathers buff. Lenses of conglomerate and coarse sandstone. Scattered "cannonball" concretions. Conspicuous outcrop_-_-

Middle unit:

Clay-shale, dark-gray ; contains gypsum._-_.-_-_-

Sandstone, buff, medium-grained, crossbedded....--

Clay-shale, gray-

Lower unit:

Sandstone, pale-cream-colored to white, coarse- to fine-grained, lime-cemented. Grains well rounded_Clay-shale, dark-gray ; contains gypsum_-_-_..... Sandstone, gray, medium- to coarse-grained, crossbedded ; chert-pebble conglomerate lenses, especially toward base; bits of petrified wood. (A few hundred yards east of measured section, unit is 47 ft thicker)

Total

Morrison Formation: mudstone, red.

Section of the Dakota Sandstone on the Spring Creek nose in $N E 1 / 4$ sec. $27, T$. 9 N., R. $22 E$.

[Measured by W. R. Hansen and M. Bonilla, September 1953]

Mowry Shale: shale, dark-gray, siliceous.

Dakota Sandstone:

Upper unit:

Sandstone, pale-yellow with rusty streaks, mediumgrained, well-rounded. Pink near middle of unit. Upper $5 \mathrm{ft}$ is slabby and ripple marked in beds 6-8 in. thick, partly quartzitic. Fills channels in middle member; channels have $3 \mathrm{ft}$ or more of relief...--

Middle unit:

Shale, gray, soft, sandy ; in part carbonaceous

Lower unit:

Sandstone, light-yellowish-gray, medium grained, crossbedded; contains cherty grit and shale pellets; base fills channels scoured in top of Morrison

Total

Morrison Formation.

The Dakota Sandstone thins irregularly from west to east within the mapped area, but whether or not this thining is a regional variation is doubtful. Probably it does not. Local irregularities in thickness are due in large part to the lenticularity of most of the beds, particularly those in the lower unit. Numerous closely spaced sections would have to be measured to determine 
adequately the true variations of the formation across the area.

\section{AGE AND CORRELA'TIONS}

Owing to a lack of diagnostic fossils, the age of the Dakota Sandstone must be inferred. Fortunately, the overlying Mowry Shale, which appears to be conformable on the Dakota, contains fossils of Early Cretaceous age, hence an Early Cretaceous age is indicated-for the Dakota. Cobban and Reeside (1952b, chart 10b) assigned an Aptian and Albian Age, in terms of the standard European section.

Several possible correlations with formations in nearby areas are suggested by the lithologic character and position of the Dakota. It probably is partty equivalent to the upper part of the Beckwith Formation of southwestern Wyoming; the upper unit of the Dakota may be equivalent to part of the Bear River Formation of the same area and to the Kelvin Conglomerate of Mathews (1931) of the Salt Lake City region. A partial correlation with the Cloverly Formation of central Wyoming is probable; in fact, the name Cloverly could be applied reasonably to the Dakota of the Uinta Mountains if the lower boundary were redefined. A general correlation of the lower, middle, and upper units with the Chilson and Fuson Members of the Lakota Formation, and with the Dakota Sandstone of eastern Wyoming also is probable; these names are used locally by some geologists (Fidlar, 1950b, p. 114).

The lower and middle units of the Dakota Sandstone may be partly equivalent to the Burro Canyon Formation of the Colorado Plateau, which in turn is equivalent probably to the Buckhorn Conglomerate and Cedar Mountain Formation of Stokes of southeastern Utah (Stokes, 1944, p. 965-966; Stokes and Phoenix, 1948). Although the Dakota Sandstone of southeastern Utah is regarded as Early and Late Cretaceous in age where the Burro Canyon cannot be differentiated, it may be continuous with the upper unit of the Dakota in the Uinta Mountains; if so, as a rock-stratigraphic unit, it crosses time lines downward toward the north.

\section{DEPOSITIONAL CONDITIONS}

As indicated by its heterogeneous character, the Dakota Sandstone was deposited under varied terres. trial conditions. The lower and upper sandstone units are typically fluviatile in habit, being characterized by poor sorting and a wide range of grain size, torrential crossbedding. channeling, and cut-and-fill structures. The middle shaly unit appears to have been deposited in fresh or brackish water, probably in an extensive swamp.

A source to the west is probable for the sadiments that constitute the Dakota, although direct local evi- dence is lacking. Correlative rocks in the Wasatch Mountains area-the Kelvin Conglomerate of Mathews, for example-are much coarser and attain relatively great thicknesses. They probably. were derived from a newly risen high mountain mass still farther west (Nolan, 1.943; - p. 177). But the effect of such distant mountains on sedimentation in the. Flaming Gorge area appears to have been slight, or at least not marked. There is, moreover, no appreciable systematic variation in the character or thickness of the Dakota Sandstone eastward or westward along the flanks of the Unita Mountains or within adjacent areas to the north and south. The Rocky Mountain geosyncline had only begun to subside, and a broad almost featureless plain extended eastward from the Uinta Mountains area at least to the midcontinent.

\section{ENGINEERING CHARACTERISTICS}

Owing to the resistance of the upper and lower units and to the prominence of their nearly continuous outcrops between the west boundary of the area and the east end of Dutch John Mountain, the Dakota Sandstone is apt to be met in some kind of future construction work; particularly a road, highway, or canal alinement. A limiting factor is the narrow width of its outcrop. At present, Utah Highway 44 crosses the outcrop about 2 miles south of Manila at South Valley.

All excavations into the lower or upper units of the formation, and some into the middle unit, would require drilling and blasting. The lower and upper units should stand well without support in steep near-vertical cuts. The middle unit, on the other hand, probably has very low long-term stability and is susceptible to slow creep and probably to sudden en masse slumping, especially in high or steep cuts.

The lower and upper units should provide excellent foundations for all types of structures, but the middle unit is inferior as a foundation because of its low bearing strength.

The lower and upper units are relatively permeable and probably would allow leakage from unlined canals or reservoirs constructed in them. Their permeability is promoted by their open connected-pore structure and by large generally widely spaced joints. For the same reasons, they are good aquifers and are good potential sources of ground water. They are relatively unsusceptible to erosion. In contrast, the middle unit is highly impervious, is a poor aquifer, and is very susceptible to erosion.

\section{MOWRY SHALE}

The Mowry Shale is one of the most distinctive and readily recognized formations in the area. Its outcrop 
is practically coextensive with that of the underlying Dakota Sandstone, extending almost uninterruptedly from the west boundary of the area near South Valley to the east end of Dutch John Mountain, where the formation is truncated by the Uinta fault. The formation is recognized in the subsurface section at Clay Basin:

Owing to its siliceous character, the shale is but moderately susceptible to erosion. It has a subdued rolling relief, forming in most places a shallow hummockyfloored strike valley between the hogbacks of the adjacent Dakota and Frontier Formations. The shalenormally dark-weathers silvery gray and, because it supports little soil or vegetation, is further distinguished as a light-colored band traced by its outcrop across the terrain.

Good exposures of the formation are abundant. The most accessible are $2 \frac{1}{2}$ miles south of Manila along Utah Highway 44. Other good exposures can be seen at the west end of South Valley, at various places between South Valley and Finch Draw, and at various places south of Antelope Flat along the north slope of Dutch John Mountain.

\section{LITHOLOGY AND THICKNESS}

The most distinctive feature of the Mowry Shale is its siliceous composition, which gives it a physical character unlike that of any other shale unit in the area. Analyses have not been made from the Mowry of this area, but a sample collected near Thornton, Wyo., by Rubey (1928, p. 157) contained 84.14 percent silica. The rock is relatively hard-about three or slightly less on Mohs' scale-or about the same hardness as crystalline limestone. Case-hardened surfaces are slightly harder, and some porcelanitic beds are almost flinty. Although the rock commonly possesses a marked fissility, it frequently also has a hackly to subconchoidal fracture, and on the outcrop it disintegrates into splinterlike or chiplike fragments. It lacks the slippery-when-wet characteristic of many shales and hence is as trafficable in unsurfaced roads when wet as when dry.

Where fresh, the shale is dark gray to bluish gray, but it is distinctively silver gray where weathered. Almost equally distinctive is an abundance of fish scales, well known since the days of Powell and distributed throughout the formation. Powell (1876, p. 51), in fact, referred to the Mowry as the teleost shale.

Interbedded with the shales beds are many seams and beds of porcelanite, a hard siliceous nonfissile rock with a conchoidal fracture. Also present are occasional beds of bentonite, some of which have been staked by prospectors as mineral-clay claims. Thin gray limestone beds occur toward the base of the formation near South Valley.
The contact of the Mowry Shale with the underlying Dakota Sandstone appears to be conformable. It is placed at the sharp change from sandstone below to shale above. In some places a few feet or tens of feet. of soft dark-gray shale intervenes. This rock resembles the Thermopolis Shale of northwestern Wyoming and may conceivably be a correlative of it. On the map it is included with the Mowry. The contact of the Mowry with the overlying shale of the Frontier Formation is marked on weathered slopes by a conspicuous color change from the silvery gray of the Mowry to a pale brown on the Frontier.

A thickness of 204 feet of Mowry Shale was measured just north of Finch Draw. A mile east of Dutch John Gap, where the section below was measured, the formation is 221 feet thick. In the subsurface at Clay Basin it is about 185 feet thick (Fidlar, 1950b, p. 114). The section east of Dutch John Gap, as follows, is representative of the Mowry Shale in this area:

Section of the Mowry Shale in the NE1/4 sec. 27, T. 3 N., R. 22 E., about 1 mile east of Dutch John Gap

[Measured by M. G. Bonilla and W. R. Hansen, September 1953]

Frontier Formation : shale, brownish-gray, soft, silty.

Mowry Shale: $\quad$ Feet

Shale, dark-gray to bluish-gray, fissile_______._. 3.5

Bentonite._. 2.5

Shale, dark-gray to bluish-gray, fissile_________ 17.0

Bentonite_. 4.0

Shale, dark-gray to bluish-gray, fissile; prominent porcelanite bed forms break in slope $21 \mathrm{ft}$ below top. Many interbeds of porcelanite. Occasional impressions of Inoceramus and Neogastroplites. A bed of bentonite 16 in thick $9 \mathrm{ft}$ above base

Total 221. 0

Dakota Sandstone: sandstone, pale yellow.

FOSSILS, AGE, AND CORRELATIONS

Already noted are the abundant teleost fish scales found in virtually every outcrop of the Mowry Shale. They have been cited by many geologists at many localities, and together with the siliceous character of the shale, they provide an invaluable and unmistakable key for identifying small or isolated outcrops of the formation. In the Flaming Gorge area, individual scales seem to average about $5 \mathrm{~mm}$ across, but occasional specimens exceed $20 \mathrm{~mm}$. Fish bones such as ribs, vertebrae, and fin rays are seen here and there also, but articulated skeletons have not been found in the area. An impression of a crablike crustacean was found near the base of the formation in South Valley by D. J. Varnes.

Ammonites of the genus Neogastroplites, including specimens of unusual size (fig. 31), occur sparingly in the lower half of the formation. Most of these form fragile impressions visible only on recently exposed 


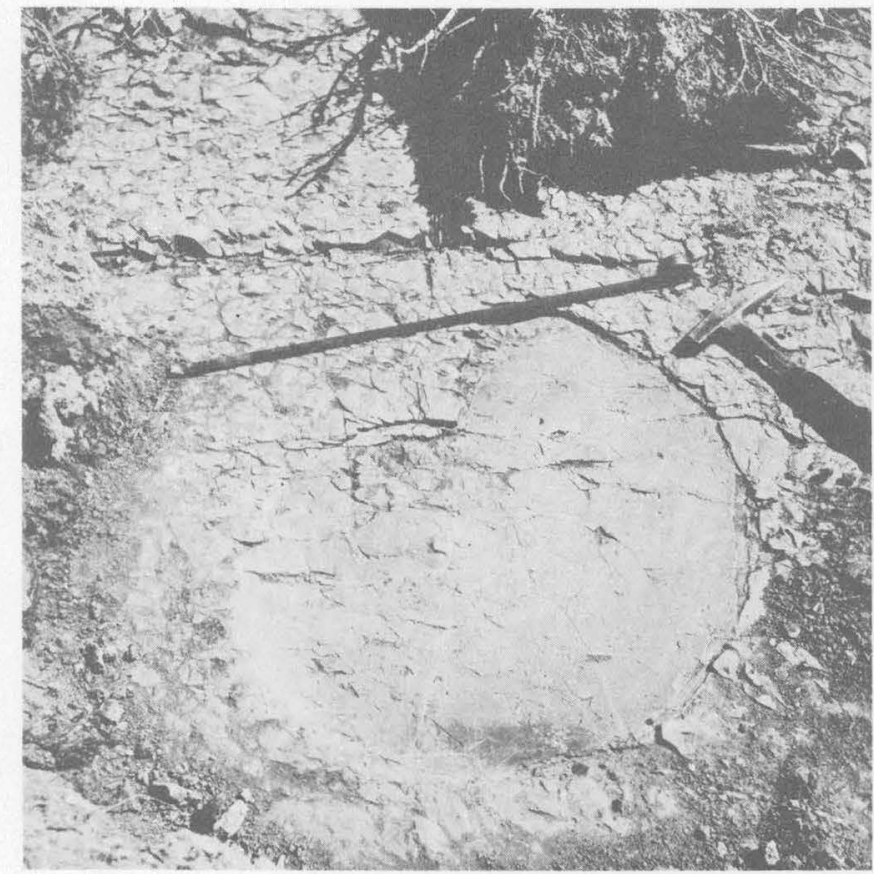

Figure 31.- Impression of large ammonite, Neogastroplites, in Mowry Shale in SW $1 / 4$ sec. 29 , T. 3 N., R. 22 E. Specimen is about 630 $\mathrm{mm}$ in diameter. Large smooth-shelled ammonites of this genus are not identifiable specifically. Smaller individuals collected in the same area have been identified by John B. Reeside, Jr., as Neogastroplites cornutus (Whiteaves). Photograph by Robert D. Miller.

bedding planes. The following fossils, collected by R. D. Miller and me in 1956 , were examined by J. B. Reeside, Jr., who identified them as species widespread in the Mowry Shale and its equivalents and representative of the lowest of four ammonite levels in the Mowry:

\section{Inoceramus anglicus Woods \\ Neogastroplites cornutus (Whiteaves) var. B. \\ Fish scales, undet.}

Large impressions of Neogastroplites were photographed in the field but could not be collected because of their fragility. The photographs were also examined by Mr. Reeside, who reported as follows (written commun.):

I would judge from the scale that the impressions are about 630 and $560 \mathrm{~mm}$ in diameter, which is somewhat larger than the largest forms we have (about $500 \mathrm{~mm}$ diameter). All of the large smooth forms look alike and can be assigned only to the genus Neogastroplites, but the small individuals can usually be assigned to one of the five species Bill Cobban and $I$ are recognizing.

The Mowry shale is late Early Cretaceous in age. Cobban and Reeside (1952a, chart 10b) correlated it temporally with the upper part of the Albian Stage of the standard European section. A possible earlier Albian hiatus may exist between the Mowry and the underlying Dakota Sandstone (Cobban and Reeside, 1952a, p. 1022). Such a stratigraphic break is suggested by the discontinuous occurrence of Thermopolis-like shale beds at the base of the Mowry.

Chart $10 \mathrm{~b}$ of Cobban and Reeside also shows temporal equivalents of the Mowry in the Western Interior of the United States. Thus, the Mowry is equivalent to, and passes laterally into, the thick Aspen Shale of western Wyoming. It is equivalent to the lower part of the Graneros Shale of some areas of the High Plains and to the lower part of the Benton Shale elsewhere. It also is equivalent to the lower part of the Mancos Shale of the Uinta Basin, where its distinctive lithology has long been recognized and where it is mapped by most geologists as a member of the Mancos.

\section{DEPOSITIONAL CONDITIONS}

A marine origin for the Mowry Shale is indicated by its enclosed fossils. The problem of its unusual character has been studied by Rubey (1928), who attributed the high silica content of the shale and the presence of interbedded bentonite to alteration of water-laid volcanic ash. The source of the ash probably was a volcanic center somewhere near southwestern Wyoming, possibly in the Great Basin, inasmuch as the formation thickens greatly in that direction. In considering various possible mechanisms for deriving the shale from volcanic ash, Rubey concluded that the original ash was highly siliceous (rhyolitic), that it was decomposed by long exposure to sea water, and that the silica dissolved from the ash was precipitated by decaying organic matter. He further concluded that accumulations of interbedded bentonite probably were caused by more prolonged ash falls and thicker accumulations of ash and by concomitant more complete destruction of organisms by such ash falls-after prolonged ash falls, organic matter would not be available on the sea floor to serve as a precipitant, and bentonite would form instead of siliceous shale. A lack of organic matter in the bentonite, as opposed to an abundance of it is the shale, supports this view.

\section{ENGINEERING CHARACTERISTICS}

The outcrop belt of the Mowry Shale is generally widest in the western part of the area, and hence its chances of involvement in future engineering works are greatest there. The outcrop belt also broadens locally on the Spring Creek nose east of Dutch John Gap.

Because of its high silica content, the Mowry Shale lacks most of the undesirable physical propertiessuch as plasticity when wet and low shear strengththat are associated with most other shales. Most excavations into firm rock would require drilling and blasting. At the surface, however, and to a depth of a foot or two, 
the shale commonly is weathered to chips and fragments, and excavation is possible with bulldozers or power shovels. On sloping hillsides, fresh rock extends locally to the ground surface. Practically everywhere the formation is very closely fractured by joints in two or more sets spaced a very few inches apart; these joints facilitate easy removal of the rock.

No field evidence has been observed as to the stability of the formation beneath steep slopes. In natural terranes, steep slopes are uncommon, but it seems likely that the formation has moderately high slope stability and that rock could be excavated safely at angles of $1: 1$ without fear of subsequent slumping. Steeper slopes probably would stand in shallow cuts.

The Mowry Shale seems to be quite impermeable where unweathered. Percolation may occur, however, along strong joints or bedding planes.

\section{FRONTIER FORMATION}

The Frontier Formation is typically exposed near the small coal-mining town of Frontier near Kemmerer in southwestern Wyoming (Knight, 1902). At Frontier, the formation is much thicker and is more complex stratigraphically than it is in the Flaming Gorge area, but the lithology is basically similar. The formation is recognized throughout the Uinta Mountains area and west into the Wasatch Mountains, where it is thousands of feet thick and includes beds probably equivalent in age to part of the Hilliard Shale. In the Uinta Mountains the Frontier Formation was first identified as such by. Schultz (1920, p. 73). Earlier, Powell (1876, p. 51) had included it in his Henrys Fork Group, and King (1878, p. 303), in his Dakota Group.

In the Uinta Basin and along the south flank of the Uinta Mountains, where the name Mancos is applied to the overlying shale, the Frontier is reduced in rank to member status by most geologists and is designated as a member of the Mancos Shale, inasmuch as the typical Mancos Shale includes all beds between the top of the Dakota Sandstone and the base of the Mesaverde Group. On the north flank of the range, at the suggestion of John B. Reeside, Jr., (written commun., 1952), I applied the name Hilliard to the overlying shale - following the early usage of Schultz (1920, p. 36) and thereby automatically raised the Frontier and the underlying Mowry Shale to formational rank consistent with their designations elsewhere north of the Uinta Mountains. At the same time, the Uinta Mountains provide a convenient demarcation line for limiting the Mancos Shale to the south and the Hilliard Shale to the north.
DISTRIBUTION AND PHYSIOGRAPHIO EXPRESSION

Owing to the resistance to erosion of massive sandstone beds at the top of the formation, the Frontier has a conspicuous and near-continuous outcrop. Where dips are gentle, as in the western part of the area, it forms a cuesta; where steep, it forms a hogback. The outcrop is especially prominent near Manila, where it bounds Lucerne Valley on the south and extends uninterruptedly from the western limits of the area east to Henrys Fork.

At Henrys Fork the formation passes beneath the flood-plain alluvium of the river, reappears east of the Green River near Flaming Gorge, and continues eastward to the east end of Dutch John Mountain, at which point it is truncated by the Uinta fault. Just east of Flaming Gorge the formation is nearly vertical, and the outcrop accordingly is narrow; a mile or so farther east the dip flattens and the outcrop widens to more than a half a mile. Still farther east the outcrop narrows irregularly in response to changes in dip and topography until at the east end of Dutch John Mountain the rocks once more are vertical or are overturned and the outcrop again is a narrow band, partly concealed, incidentally, by landslides. Still farther east at Clay Basin the formation is deeply buried beneath younger deposits, but it is penetrated by gas wells and is a secondary producer of gas.

Along its outcrop the Frontier Formation consists of two dissimilar lithologic units, a lower shaly unit and an upper sandstone unit, having dissimilar topographic expression. The lower shaly unit is relatively nonresistant to erosion and hence forms debris-mantled slopes or valleys beneath ledges or cliffs of the upper sandstone unit above. The upper sandstone unit, besides forming. ledges or cliffs, forms broad bare dip slopes largely devoid of soil but supporting open stands of gnarled pinyon pine and juniper. Joint faces on this unit generally are coated with dark desert varnish, which was much favored by the prehistoric Indians for inscribing petroglyphs (fig. 32).

LITHOLOGY AND THICKNESS

The twofold lithologic character of the Frontier Formation is evident in all good exposures. There is a considerable variation in total thickness from place to place, owing partly perhaps to the gradational relationship of the formation to the overlying Hilliard Shale and hence to the difficulty of everywhere choosing the same horizon as the contact. In practice the boundary is drawn at the top of the highest prominent sandstone of a rather gradational zone of interbedded sandstones and shales between predominant sandstone below and 


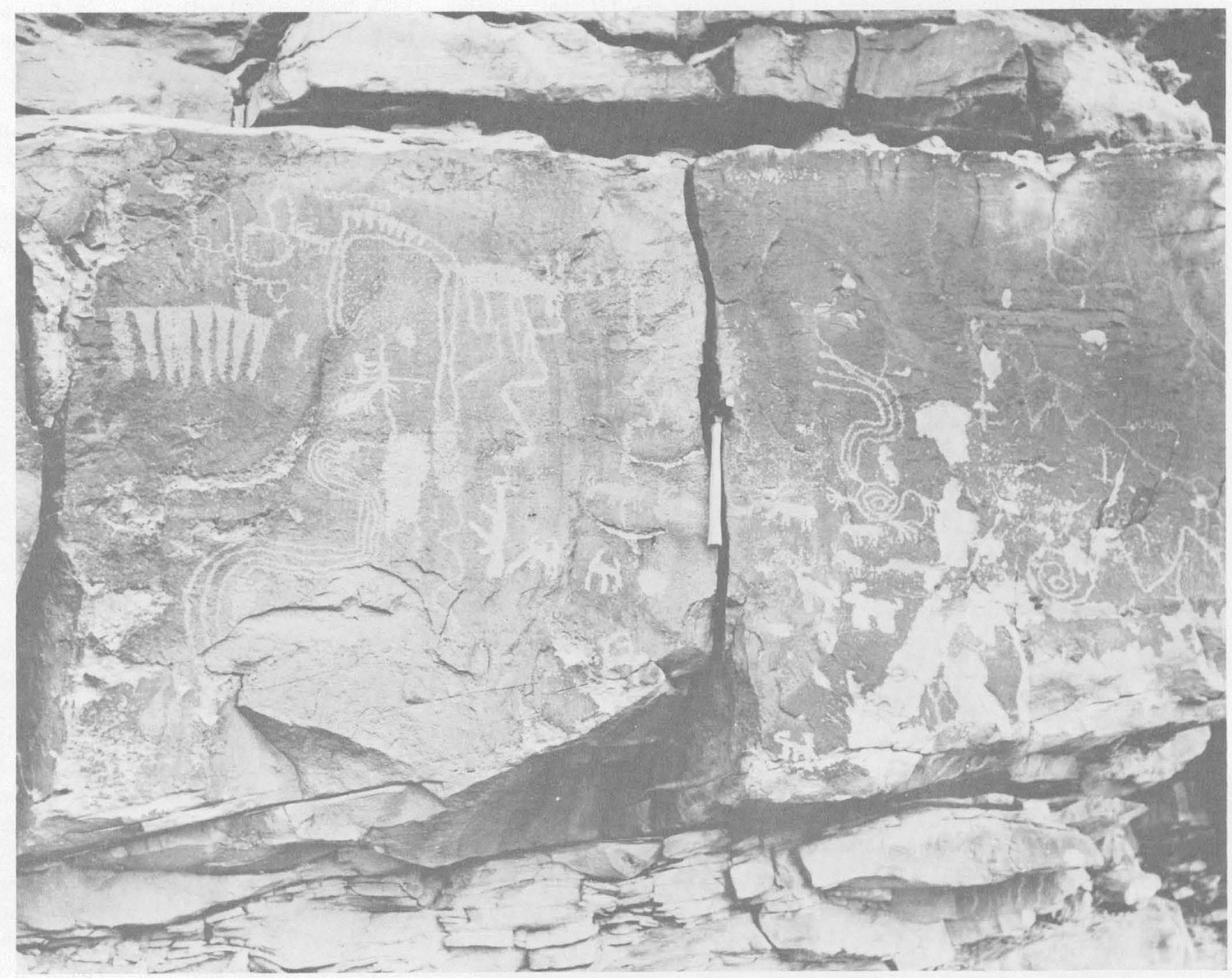

Figure 32.-Massive littoral sandstone near base of upper unit of Frontier Formation, South Valley, Utah. Blocky bedding habit is characteristic. Desert-varnished joint faces such as this were much favored by the prehistoric Indians as a base for inscribing petroglyphs. Note numerous bighorn sheep, especially left and right below hammer; serpent, lower left; deer or elk, diagonally left above hammer; anthropomorphic figure, somewhat varnished over, upper right. These figures are regarded as products of the late Fremont culture, dating possible from about A.D. 900 to 1300. (Alice B. Hunt, written commun., 1954.)

predominant shale above. The sandstones form a bold outcrop, the shales a subdued one. The lower and upper units of the Frontier Formation themselves also vary widely in thickness from place to place. At Finch Draw the formation totals about 190 feet in thickness, farther east near Dutch John Gap it is about 170 feet thick, and still farther east at Clay Basin it is about 117 feet thick.

The lower shaly unit of the Frontier Formation consists chiefly of soft partly calcareous somewhat gypsiferous light- to dark-gray marine shale, weathered light brown. It also contains considerable fine-grained thin-bedded gray to buff sandstone and minor silty limestone. A few feet below the top of the lower unit at Finch Draw there is a discontinuous coal seam. Near the west end of Dutch John Mountain in the NE $1 / 4$ sec. 35, T. 3 N., R. 21 E., there is a coal seam about 2 feet thick near the middle of the lower shale unit. Overlying the coal is a few feet of sandstone.

The upper sandstone unit consists of fine-grained flaggy to thick-bedded, in part crossbedded, massive light-brown to light-gray sandstone. Locally it displays ripple marks and bits of petrified wood or impressions of wood on ripple-marked surfaces. Inoceramus is common, as well as occasional molds of other pelecypods. In some places the sandstone contains 
peculiar filled tubelike structures that possibly are worm burrows.

The following sections illustrate the character and diversity of the Frontier Formation : Section of the Frontier Formation 1.1 mile due south of Linwood
in SE1/4 sec. $23, T .3 N ., R .20 \mathrm{E}$.

[Measured by W. R. Hansen and T. B. Piper, August 1951]

Hilliard Shale : shale, dark-gray, soft, fissile.

Frontier Formation:

Upper unit :

Sandstone, cream-colored to almost white, finegrained, well-sorted, massive. Forms crest of hogback and long dip slope.

Lower unit :

Shale, interbedded light- and dark-gray ; coal horizon near top, but coal lacking in this section. A few poorly preserved pelecypods just below coal level. Scattered gypsum crystals.

Sandstone, light-brown, friable

Clay-shale, dark-gray, carbonaceous

Shale, dark-gray ; interbedded with thin-bedded sandstone.

Sandstone, buff, fine-grained, poorly cemented, irregularly bedded

Shale, buff, sandy

Total

Farther west toward Manila and farther east on the Spring Creek nose, the upper unit is considerably thicker.

Section of the Frontier Formation on Spring Creek nose in NE1/1sec. 2 i, T. $3 N$., R. $22 E$.

[Measured by W. R. Hansen and M. G. Bonilla, September 1953]

Base of Hilliard Shale.

Frontier Formation :

Upper unit :

Sandstone, gray, fine-grained, crossbedded ; contains shale beds $0.5-1.0 \mathrm{ft}$ thick

Sandstone, light-brown to almost white, flaggy, finegrained; shale interbeds toward top.

Sandstone, light-brown to cream-colored, massive---

Lower unit:

Shale, dark-gray ; interbedded with fine-grained gray sandstone. Upper $18 \mathrm{ft}$ mostly fine-grained gray thin-bedded sandstone containing casts of Inoceramus

Total.

Towry shale.

Top of Mowry Shale.

FOSSILS, AGE, AND CORRELATIONS

The Late Cretaceous age of the Frontier Formation is well established. Cobban and Reeside (1952a, chart $10 \mathrm{~b} ; 1952 \mathrm{~b}$, p. 1913) assigned probable Cenomanian to Turonian and Coniacian Ages to the formation at Cumberland Gap, Wyo., near the type area. Its age in the Uinta Mountains is more restricted; for the Vermilion
Creek section, which is about 50 miles east of Flaming Gorge and is very similar to the Frontier near Flaming Gorge in lithology and position, Reeside (1955, p. 85) assigned a late Turonian Age.

A late Turonian Age was also assigned by Cobban (written commun., 1958) to fossils collected by M. G. Bonilla and me from sandy shales in South Valley near the center of sec. 36 , T. 3 N., R. 19 E., about 50 feet above the base of the Frontier Formation and 5 feet below the lowest massive brown sandstone of the upper unit. Cobban identified the following pelecypods:

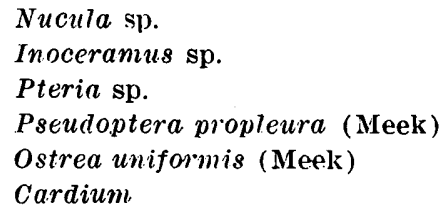

Cobban further remarked that " $* * *$ these pelecypods are shallow-water marine forms. Ostrea uniformis dates the collection as early or middle Carlile age (late Turonian of standard European Cretaceous stages)."

The sandstones of the upper unit are littoral or beach deposits and commonly are crossbedded and ripple marked. They contain occasional casts or impressions of Inoceramus and fragments or impressions of fossil wood.

It is significant to note that between the Mowry Shale of late Albian Age and the Frontier Formation, which in this area is late Turonian, equivalents of the Cenomanaian and the lower part of the Turonian Stages (the Belle Fourche, Greenhorn, and lower part of the Carlile Formations) have not been recognized (Cobban and Reeside, 1952b, p. 1914; 1939) and either are very thin or are lacking entirely, despite a lack of apparent field evidence of a hiatus. For the Vermilion Creek section, Reeside $(1955$, p. 86$)$ suggested that these units more likely are missing than thin and unrecognized, a suggestion that applies to the Flaming Gorge area as well.

\section{DEPOSITIONAL CONDITIONS}

The Frontier Formation accumulated mainly in shallow open seas under offshore to shoreward and onshore conditions. The lower shaly unit accumulated in shallow marine water, as indicated by its contained fauna, but out of the reach of waves. Thin coal beds seen here and there near the top of the lower shaly unit must have accumulated in coastal swamps, perhaps behind a barrier beach. The sandy upper unit was winnowed by waves and probably accumulated in or near the tidal zone, as indicated by littoral crossbedding, ripple marks, and occasional impressions or bits of fossil wood and casts of Inoceramus. 
A transition from offshore deposits in the lower shaly unit to coal-swamp deposits toward its top and to onshore or near-shore sandstones in the upper unit indicates a shoaling sea during deposition of the Frontier Formation. A transition from the littoral sandstones in the upper part of the formation to offshore shales in the overlying Hilliard Shale, on the other hand, indicates a subsiding sea floor and a transgressive shoreline.

ENGINEERING CHARACTERISTICS

Because the Frontier Formation has a prominent and near-continuous outcrop from the west boundary of the area to the east end of Dutch John Mountain, the unit is likely to be involved in some future construction activity. At present, two highways cross the outcropone on the north side of Dutch John Mountain and the other on the south margin of Lucerne Valley. In both localities, explosives were used to excavate the sandstones of the upper unit. Explosives would be needed to excavate the upper unit anywhere along the outcrop, but power shovels or ripper-equipped bulldozers could generally excavate the lower unit. Both units could be expected to stand well in cuts of $1: 1$, the upper unit even in near-vertical cuts.

Landslides involving the Frontier Formation are abundant toward the east end of Dutch John Mountain and occur locally on the north slope of Boars Tusk. These slides are due in part to slumpage of the upper unit across the lower unit, prompted by steep dips near the dragged downthrown block of the Uinta fault, and in part to passive downhill movement of the Frontier and other formations on disrupted masses of the Morrison Formation. Of itself, the Frontier Formation has moderately high stability, except where bedding attitudes are steep. By the same token, it should provide a stable foundation for most engineering works in most topographic and structural settings.

Surface drainage is good in the upper unit of the formation, and at depth the unit is a good ground-water aquifier. The lower unit is much less permeable, both at the surface and at depth; it should be provided with drains wherever saturation might become a problem.

A possible source of riprap, especially for protecting stream or ditch banks and dikes of small stock reservoirs, is available in the blocky sandstone beds of the upper unit. Some of these beds are slabby and have had limited use as flagstone or cellar foundation stone.

\section{HILLIARD SHALE}

W. C. Knight (1902, p. 721) first used the name Hilliard for the thick gray shale of Late Cretaceous age in southwest Wyoming and adjacent areas. This formation takes its name from the small town of Hilliard which no longer exists but once stood a few miles west of Kemmerer, Wyo., on the Oregon Short Line Railroad. Another town by the same name, but not to be confused with it, once stood about 10 miles southeast of Evanston, Wyo. The type locality west of Kemmerer is about 65 miles northeast of Manila, Utah. Schultz (1920, p. 71 and pl. .1) extended the name to the Manila area, Lucerne Valley, Antelope Flat, and Clay Basin on the north slope of the Uinta Mountains, and his usage is followed here.

Some geologists have applied the names Mancos Shale and Baxter Shale to the same rocks. Schultz (1920, p. 33) first used the name Baxter, but he limited its use to the Baxter Basin area near Rock Springs. The Hillard Shale of the north slope of the Uinta Mountains undoubtedly merges laterally at depth with the Baxter Shale of the Rock Springs area (as Schultz was well aware), with the Mancos Shale of Moffat County, Colo., and with the Hillard of the type area. Prior to Schultz' time the name Mancos was used by Gale (1910, p. 61) for essentially the same rocks (but including the Mowry and Frontier Formations) in his discussion of the so-called Henrys Fork coal field. Before Gale, Powell (1876, p. 49-50) had applied the nowobsolete names Sulphur Creek and Salt Wells Groups to the lower and upper parts respectively, of the formation.

My reasons for following Schultz in using the name Hilliard in preference to Mancos are (1) to retain the underlying Mowry and Frontier as formations-which, by definition, they could not be if the name Mancos were used-in the area north of the Uinta Mountains, and (2) to limit somewhat the usage of the name Mancos to areas south of the Uinta Mountains. The type locality of the Mancos Shale, of course, is much farther from the north slope of the Uinta Mountains than is the type locality of the Hilliard Shale, and the Uinta Mountains provide a good demarcation line for limiting geographically the usage of the two names. The Mancos Shale, moreover, is physically separated from the Hilliard of the north slope of the Uinta Mountains by older rocks along the Uinta Mountain axis. Sears (1924b, p. 286) used the name Mancos in Moffat County, Colo., where he recognized equivalents of the Frontier and Mowry Formations but did not differentiate them. My reasons for using the name Hilliard in preference to the name Baxter stem from the priority held by the former name and from the general practice among geologists of restricting use of the latter name to areas within or near Baxter Basin in the Rock Springs uplift.

DISTRIBUTION AND PHYSIOGRAPHIC EXPRESSION

The outcrop belt of the Hilliard Shale in the mapped area is exceeded in width and extent only by that of the 


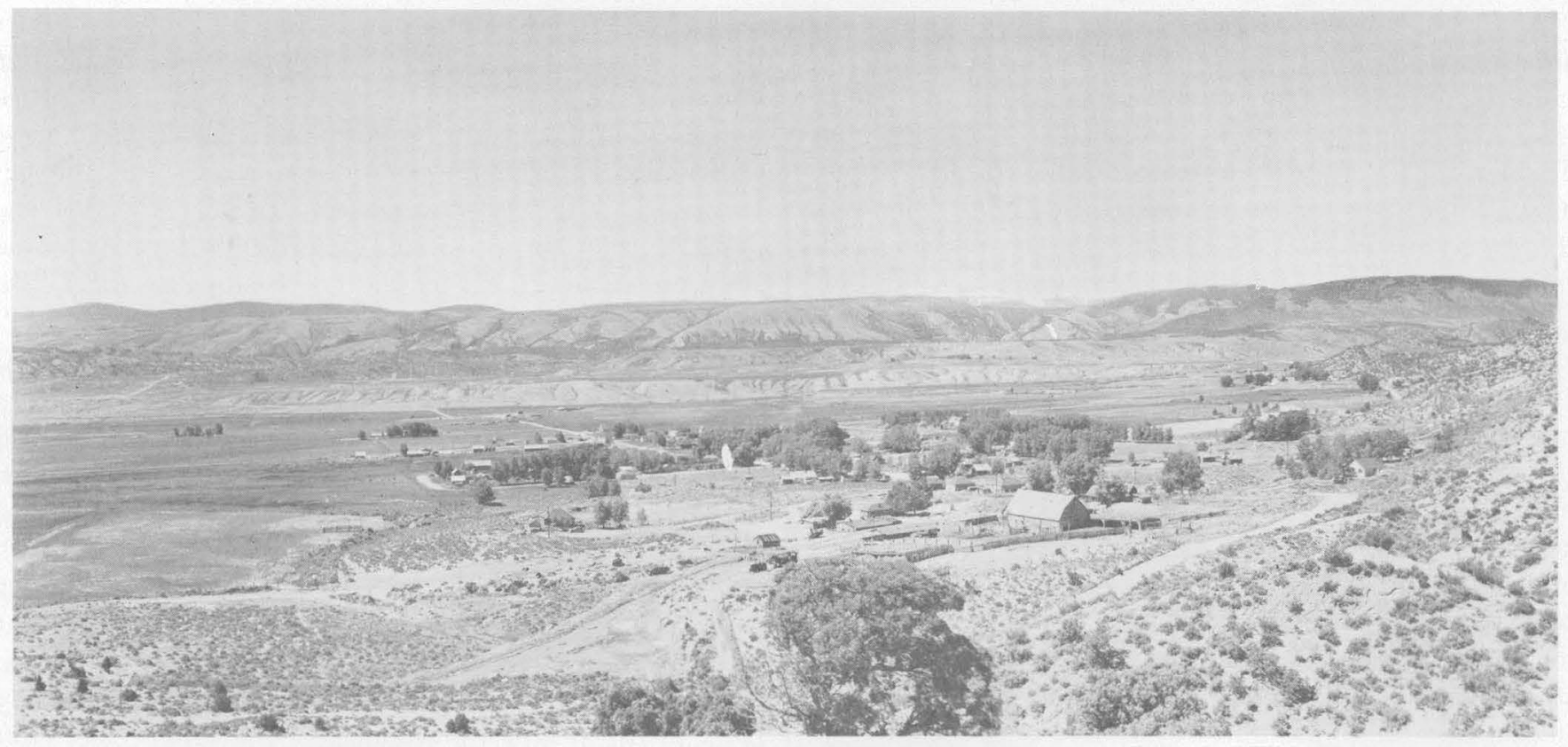

Frgure 33.-Lucerne Valley viewed southwest across town of Manila toward Leidy Peak in center distance. Valley is carved from soft Hilliard shale faulted against Wasateh Formation, right, Flat surface just below skvline is correlated with Gilbert Peak erosion surface, eut on Park City and older formations. Lower surfaces in middle distance are $Q_{2}$ and $Q b_{3}$ benches, cut on Hilliard Shale and capped with gravel. Manila stands on $\mathrm{Qb}_{4}$ bench, eut partly on Hilliard Shale and partly on Wasateh Formation.

Uinta Mountain Group. Pinching and swelling in response to changes in attitude of the underlying strata, the belt is widest in Clay Basin and toward the west end of Antelope Flat; it is narrowest on the north slope of Goslin Mountain where part of the formation is truncated by the Uinta fault and is overridden by Precambrian rocks. East of Clay Basin the formation is concealed by overlapping Tertiary rocks which themselves are faulted against Precambrian rocks adjacent to the Uinta fault zone.

Broad Lucerne Valley, Antelope Flat, and Clay Basin all are underlain by Hilliard Shale (figs. 33, 35). They owe their existence to the high differential erosibility of the formation as opposed to the more resistant formations to the north and south higher and lower, respectively, in the section. In a large part the Hilliard Shale in these valleys is concealed by terrace material deposited by aggrading streams in Pleistocene or Recent times. But extensive Hilliard Shale outcrops commonly border the fills of the major gullies and washes, and they flank the margins of the gravel-capped terraces. Well-exposed sections are seen in the bluffs overlooking the Green River north of Flaming Gorge, along both sides of Spring Creek in Antelope Flat, and along Red Creek in Clay Basin. The bluffs north of Flaming Gorge contain the best exposed section, but the lower part of the formation there is concealed beneath the flood plain of Henrys Fork and may also be faulted. A fairly good composite section of the full thickness of the formation can be examined in Antelope Flat.by traversing north through secs. $27,22,21$, and 15, T. 3 N., R. 22 E., toward Minnies Gap, which is just beyond the map boundary in Wyoming on the Linwood-Clay Basin road. Well-exposed sections of Hilliard Shale in Clay Basin are incomplete inasmuch as the greater part of the formation there has never been exposed by erosion.

Outerops of Hilliard Shale form drab rounded slopes or bandland tracts that support little vegetation. Flat areas may be coated with alkali. Alkali-tolerant shad scale saltbrush (Atriplex confertifolia), which also is drought resistant and is capable of growing in salt-rich soils (Cannon, 1957 , p. 403, 496), is a conspicuous characteristic plant.

\section{LITHOLOGY AND THICKNESS}

The Hilliard Shale consists of dark-gray mostly silty calcareous soft but fissile marine shale that contains occasional lenses and beds of sandstone and sandy modular limestone. In many places the shale is gypsiferous, and in some places it is bentonitic. Where weathered the shale is bleached to shades of light gray, yellow, tan, or very pale grayish orange, and its fissility is destroyed.

The proportion of sandy material to shale in the Hilliard Shale increases somewhat toward the west, owing partly to thickening of sandstone beds in that direction and party to the increase in number of sandstone beds in the section. One especially prominent 
sandstone unit about 4,000 feet above the base of the formation thickens gradually from a featheredge near the east end of Antelope Flat in section 24 to a thickness of 110 feet 3 miles to the west in section 21 . West from there it thickens gradually toward the Green River, where it passes beneath the flood plain of the river and reappears in the bluffs west of the river. Owing to cover, it cannot be traced west of the bluffs. This unit appears to have been deposited as an offshore bar. It is thin bedded and fine grained from bottom to top, is somewhat crossbedded, and contains casts of Inoceramus cf. I. barabini Morton.

Many thinner sandstone beds in the upper 2,000 feet of the Hilliard Shale, particularly toward the top of the formation, appear to be littoral deposits. They are mostly thin bedded and crossbedded, and many contain obscure markings that resemble such things as crustacean tracks, worm castings, and fucoidal casts that might have been left on a beach.

At its top the Hilliard Shale grades upward and laterally into the Blair and Rock Springs Formations. Remarkable intertonguings of shale and sandstone are displayed in the cliffs of The Glades north of Antelope Flat.

Because of intertonguing at the top of the formation and a gradational contact at the base, probably no two sections of the Hilliard Shale have precisely the same thickness or lithology. Sections drawn through Antelope Flat south of Minnies Gap indicate a thickness there of about 6,300 feet below the base of the first prominent ridge-forming littoral-sandstone bed. A thickness of about 6,200 feet is obtained for the Clay Basin section by adding the exposed thickness of the formation to the thickness penetrated by wells as given by Fidlar (1950b, p. 114). The'boundary between the Hilliard Shale and the Rock Springs Formation in Clay Basin, however, is gradational and may be placed arbitrarily at various horizons in a rather broad zone. $I$ have placed it at the base of a slope-forming sequence of friable fine-grained sandstone and interbedded shale which I regard as part of the Rock Springs Formation. Some geologists might place the contact higher in the section-possibly as much as 160 feet higher, at the base of a conspicuous white and tan sandstone bed.

Sections west of Antelope Flat are difficult to evaluate owing to structural involvement and changes. In the Henrys Fork and Manila areas, parts of the formation are truncated by the Henrys Fork fault. Near Williams' Ranch on Henrys Fork (sec. 24, T. 3 N., R. 20 E.) the outcrop belt of the formation narrows to about 4,600 feet. The bedding is vertical or nearly so, and about 1,500 feet of strata is probably deleted by faulting.
FOSSILS, AGE, AND CORRELATIONS

Fossils collected from the Hilliard Shale in Antelope Flat range in age from early Niobrara (Colorado Group, Iate Cretaceous) to Eagle (Montana Group. Late Cretaceous) or, in terms of the standard European section, from early Coniacian to early Campanian. The youngest fossils that M. G. Bonilla and I collected were found in sandy limestone 1,260 feet below the top of the formation. It seems probable that the Hilliard Shale contains rocks as young as Pierre (late Campanian), especially at Clay Basin where the top of the formation is stratigraphically higher than it is farther west.

Fossils collected by M. G. Bonilla and me were identified by John B. Reeside, Jr., as follows:

Collection 24001, from the NE1/4NW1/4 sec. 22, T. $3 N$., R. $21 E$., abuut 5,040 fect above the base of the formation. Fauna of Eagle age:

Lingula nitida Meek and Hayden Syncyclonema hallii (Gabb)

Lucina cf. L. subundata (Hall and Meek) Oligoptycha cf. O. concinma (Hall and Meek)

Baculites asper Morton

Baculites haresi Reeside

Scaphites hippocrepis (DeKay)

Placenticeras meeki Boehm

Fish scale, undet.

Fragments of fossil wood

Collection 24002, from the $S W 1 / .1 S W 1 / 4$ sec. 15, T. 3 N., R. $22 E$., about 4,000 feet above the base of the formation.

Probably of Montana age

Inoceramus cf. $I$. barabini Morton

Collection 24003, from near center $S W 1 / 4$ sec. 22, T. $9 N, \boldsymbol{R}$. $22 \mathrm{E}$., about 1,170 feet above base of formation.

Fauna of middle Niobrara age

Inoceramus stantoni Sokolow

Inoceramus cf. I. grandis (Conrad)

Inoceramus cf, I. erectus Meek

exogyra sp.

Collection 24004, from the SE1/4 SW1/4 sec. 22, T. 9 N., R. 22 E..

About 950 fect above base of formation.

Fauna of early Niobrara age

ostrea congesta Conrad

Inoceram.us deformis Meek

Scaphitcs ventricosus Meek and Harden

Although fossils are not abundant in the Hilliard Shale, careful systematic search undoubtedly would yield larger faunas than those listed above.

Mention has been made already of the correlation of the Hilliard Shale of Antelope Flat and Clay Basin with the upper shale member of the Mancos Shale section of Vermilion Creek in Colorado (described by Reeside, 1955, p. 85) and with the upper shale member of the Mancos of the eastern Uinta Basin. The section exposad in the southern part of the Rock Springs uplift also is very similar and correlates closely with that in Clay Basin. The Cody Shale of the Big Horn 
Basin of Wyoming is at least partly equivalent to the Hilliard, and the Steele Shale of southeastern Wyoming is equivalent to the upper part of the Hilliard. For a synoptic view of the correlations of the Cretaceous formations of the Western Interior of the United States, including the Hilliard and its counterparts, reference is made to chart $10 \mathrm{~b}$ of Cobban and Reeside (1952a).

\section{DEPOSITIONAL CONDITIONS}

The Hilliard Shale was deposited in open circulating marine waters in a seaway that had spread across the Western Interior region during Colorado and Montana times. This seaway marked an area of subsidence that coincided with the foredeep of the Rocky Mountain geosyncline. It was receiving sediments from highlands that lay to the west. Offshore conditions that accompanied deposition of the Hilliard Shale in the eastern Uinta Mountains area passed westward into shoreward and nonmarine conditions at the west end of the Uinta Mountains. As the seaway began to fill with sediment toward the end of the Hilliard depositional cycle, the shoreline regressed and readvanced across the area many times. Fluctuations of the shoreline gave rise to the intertonguings of offshore littoral, and onshore deposits that mark the transition from the Hilliard Shale to the Blair and Rock Springs Formations. Marine shales were still accumulating at the site of Clay Basin when coal was forming in an area near the mouth of Spring Creek.

\section{ENGINEERING CHARACTERISTICS}

So far as physical behavior is concerned, the Hilliard Shale and its counterparts have been notoriously troublesome ever since construction work first began in the West. One compensating asset of the Hilliard is its ease of excavation, for it is readily dug without recourse to explosives, although some sandstone and limestone beds would require drilling and blasting for removal. But the formation as a whole has very low bearing strength and is very susceptible to slumping or failure under load: It also has low porosity and permeability, hence transmits water slowly, if at all; tends to become waterlogged; is plastic when wet; and tends to erode rapidly. Unpaved roads become virtually impassable with every rainstorm, and paved roads deteriorate rapidly unless supported by well-designed subgrades. Agricultural lands undergo cumulative alkali damage caused by surfaceward precipitation of soluble salts unless good drainage is provided and careful irrigation is practiced.

\section{BLAIR FORMATION}

The Blair Formation was named by Schultz (1920, p. 32) for exposures near the old Blair Ranch east of
Aspen Mountain in the Rock Springs uplift. Rocks assigned to this formation form a sharp outcrop along The Glades north of Antelope Flat (fig. 35). They also crop out across the Green River north of Henrys Fork. These rocks were referred to somewhat picturesquely by Powell $(1876$, p. 157) as the Golden Wall Sandstone and were assigned by him to his Point of Rocks Group, which corresponds to the Mesaverde Group of current usage. The Mesaverde Group includes the Blair, Rock Springs, and Ericson Formations in the Uinta Mountains area (fig. 34). King (1878, p. 326) referred these formations to the Fox Hills Group, noting their occurrence at "Big Horn Ridge," now called The Glades, and at Red Creek. King's correlation was quite proper for the time, although the Mesaverde Group of the Uinta Mountains area is now known to be largely the time equivalent of the Pierre Shale (Cobban and Reeside, 1952a, chart 10b) rather than of the Fox Hills Sandstone.

Some question might arise as to the propriety of using the name Blair in the Uinta Mountains area. My inclination in first viewing the Mesaverde section in that area was to exclude the name Blair and to include in the Rock Springs Formation all the rocks between the Hilliard and the Ericson, inasmuch as the'sandstone beds throughout this section have much in common. Most of them are fine-grained marine or littoral deposits, and all of them thin eastward and pass ultimately into shale.

Sandstone beds here included in the Blair Formation form a particularly conspicuous tongue which thins eastward from the Green River toward Goslin Mountain before feathering out. In stratigraphic position and lithology this tongue resembles Hale's Chimney Rock Tongue $(1950$, p. $52 ; 1955$, p. 92) of the Rock Springs uplift and may be its lateral equivalent. The Chimney Rock Tongue of Hale was included in the Blair Formation by Schultz (1920, pl. 8c) and was at first so included by Hale. But Hale (1955, p. 92) subsequently included it in the Rock Springs Formation without making clear his basis for redefining the BlairRock Springs boundary or for differentiating the two units on the map. One difficulty in placing the BlairRock Springs boundary lies in the fact that facies changes rise in the section toward the southeast so that time lines cannot serve as adequate boundaries for any considerable distance. Beds that are distinctly like the Rock Springs Formation near the old strand line are more like the Blair farther seaward. In any event, the tongue of sandstone that crops out along The Glades is sufficiently distinctive to warrant separate mapping regardless of its formational assignment. 
DISTRIBUTION, PHYSTOGRAPHIC EXPRESSION, THICKNESS, AND IITHOLOGY

The sandstone beds of the Blair Formation are resistant to erosion and form a prominent hogback in The Glades north of Antelope Flat. The Glades is a striking double hogback-expecially impressive as viewed from the west. Thus viewed, it consists of two sharp ridges separated by a flat-bottomed trough. Its arcuate trend has earned it the sometimes-name of Devils Racetrack. The Blair Formation forms the south ridge, the Rock Springs the trough, and the Ericson the north ridge. Farther east the Blair outcrop diminishes in height and width to a modest ledge, and The Glades assumes the form of a single bold hogback. West of the Green River the outcrop of the Blair is conspicuous only in the bluffs above the flood plain; back from the bluffs the entire Mesaverde Group has been beveled off by the lateral sweepings of a higher earlier stage of Henrys Fork. In that area the Blair Formation lacks any clear distinction from the overlying Rock Springs Formation.

Near the mouth of Spring Creek, where Spring Creek flows across the Mesaverde section in sec. 16, T. $3 \mathrm{~N}$, R. $21 \mathrm{E}$., the Blair Formation is 350 feet thick and consists of pale-grayish-orange to yellowish-brown finegrained sandstone interbedded with Hilliard-like marine shale. The sandstone beds are thick, massive, and crossbedded, and their foresetting has a predominant eastward component of initial dip. Each sandstone beds thins eastward and wedges out. Stratigraphically upward, each succeeding sandstone bed extends farther east than the one below before it wedges out, thus indicating a pulsating but generally regressing shoreline. The shale interbeds thicken eastward at the expense of the sandstone, merge, and lose their identity in the Hilliard Shale, so that the base of the Blair Formation rises stratigraphically toward the east. The Blair-Rock Springs contact is placed arbitrarily at the base of the lowest coal bed in the combined section; as thus placed it also coincides with a change from littoral sandstone and marine shale to littoral sandstone and predominantly paludal shale.

The highest sandstone bed referred to the Blair Formation at the mouth of Spring Creek extends east at least 9 miles, or almost to the foot of Goslin Mountain, before it feathers out. In that distance the lower 600 feet of the overlying Rock Springs Formation also feathers out into marine Hilliard Shale (fig. 34). The Blair, therefore, is overlain by nonmarine beds at the mouth of Spring Creek and by marine beds only a few miles to the east near Goslin Mountain. The total thickness, however, of the stratigraphic interval between the top of the Blair and the base of the Ericson is about the same near Goslin Mountain as at the mouth of Spring Creek. Farther east in Clay Basin the time equivalent of the Blair Formation consists entirely of marine Hilliard Shale.

The following section illustrates the lithologic character of the Blair Formation; the thicknesses reported cannot be extrapolated away from the line of section, owing to rapid lateral facies changes:

Section of the Blair. Formation at west end of The Glades in $S E 1 / 4$ sec. 16, T. 3 N., R. $21 \mathrm{E}$.

[Measured by W. R. Hansen and M. G. Bonilla, Aug. 14, 1952]

Rock Springs Formation : shale, brown, soft, punky ; coal bed at base.

Blair Formation :

Sandstone, gray to rusty, fine-grained, friable ; beds 4-6 in. thick; well jointed ; limonitic concretions at top_-

Shale, dark-gray, marine, gypsiferous; a few very thin sandstone beds.

Sandstone, very pale orange; middle third is jellowish gray (5Y 8/1). Fossil bone fragment near base--Shale, dark-gray, marine; thin sandstone partings..--

Sandstone, mottled light-grayish-orange, fine-grained, crossbedded; forms irregular outcrop containing

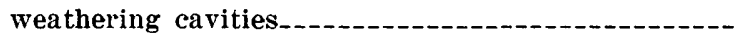

Sandstone, moderate-yellowish-brown, fine-grained, crossbedded. Very dark desert varnish. Base irregular; channels with $10 \mathrm{ft}$. of relief. Top an even

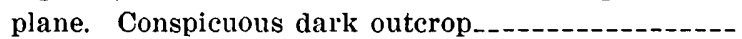

Sandstone, light-grayish-orange, massive, fine-grained. Upper $35 \mathrm{ft}$. partly covered.

Shale, light-gray, silty ; contains thin standstone beds --

Sandstone, light-grayish-orange $(10 Y R \quad 7.5 / 3)$, finegrained, even-bedded.

Shale, dark-gray, silty; contains thin evenly bedded sandstone; weather's light gray in lower $16 \mathrm{ft}$. and light tan in upper $40 \mathrm{ft}$

Sandstone, very pale orange, fine-grained, crossbedded, massive, fairly well sorted; subangular grains. Pinches out a quarter of a mile to the east.--.-----

Total Feet

Hilliard Shale : shale, dark-gray, silty, gypsiferous, evenbedded; contains fine-grained light-brown calcareous sandstone.

\section{AGE AND CORRELATIONS}

Diagnostic fossils have not been found in the Blair Formation in The Glades-Henrys Fork area, although diligent search might yield a few. The stratigraphic position of the formation and its lateral gradation into the uppermost part of the Hilliard Shale indicate a Campanian Age. The unit probably is the equivalent of the lowermost part of the Pierre Shale or of the Eagle Sandstone.

Some of the correlations of the Blair have already been pointed out. The hogback-forming tongue exposed along The Glades probably is equivalent to Hale's Chimney Rock Tongue of the Blair Formation of the 
Rock Springs uplift. Toward the west and north the Blair Formation probably merges with and becomes indistinguishable from the Rock Springs Formation, which in turn passes into the Adaville Formation of western Wyoming (Hale, 1955, p. 91). Stratigraphic equivalents of the Blair to the south and east are marine shales in the upper part of the Mancos Shale.

\section{DEPOSITIONAL CONDITIONS}

The Blair Formation accumulated in freely circulating shallow marine water, under the influence of an oscillating but generally regressing shoreline. The trend of the shoreline was generally northeast (Hale, 1950, p. 56), and the direction of regression was toward the southeast. Sandstone beds were deposited in littoral to neritic environments; the interbedded shales were deposited offshore.

\section{ENGINEERING CHARACTERISTICS}

Because of its restricted areal extent and unusual topographic expression, the Blair Formation is not likely to become involved in major engineering undertakings in the foreseeable future. In the event that it is, however, drilling and blasting would be needed to excavate any of the sandstones. The shales could be removed without the use of explosives.

In general, the formation has high bearing strength, especially where sandstone predominates over shale. It should stand without support in most cuts; along The Glades, individual sandstone beds form vertical breaks or sheer cliffs (fig. 35).

Porosity and permeability in the sandstone seem to be high, particularly in the thicker shoreward parts of individual beds. Shale beds have low permeability and could be expected to retard ground-water movement; they also would erode more readily than would the sandstone beds.

\section{ROCK SPRINGS FORMATION}

The Rock Springs Formation is typically exposed in the coal fields of Rock Springs, Wyo., where it was named by Schultz (1910, p. 227). Schultz referred to it as the "Rock Springs coal group" and assigned it to the Mesaverde Formation. Years before it had been included by Powell $(1876$, p. 157) in his Point of Rocks Group and by King $(1878$, p. 326) in the Fox Hills Group. Both Powell and King noted its occurrence in The Glades-Henrys Fork area. It was also noted by Gale $(1910$, p. 236$)$, who referred to it simply as the Mesaverde Formation. Sears (1926, p. 20) elevated it to formational rank, elevated the Mesaverde to group rank, and thereby provided the stratigraphic framework now used by all geologists working in the Rock Springs uplift-Flaming Gorge--Browns Park area.
Near-continuous outcrops of the Rock Springs Formation extend east from a point just northeast of Linwood to the east end of Clay Basin-a distance of about 25 miles. In that distance the formation tapers from a thick coal-bearing sequence of sandstones, shales, and pebbly conglomerates northeast of Linwood to a single fine-grained sandstone bed at the east end of Clay Basin. At the extreme east end of Clay Basin the formation is unrecognized; its absence there may be due to (1) pinching out, (2) concealment by mantle rock, or (3) deletion by faulting. A combination of all three possibilities is not unlikely. Certainly, the formation is much attenuated at that point and is feathering out rapidly toward the east.

In Wyoming, the Rock Springs Formation just north of Linwood contains the caved workings of an abandoned coal mine. This mine was afire and smoldering at the time of my mapping (1951). Reportedly, it had been so burning for 40 years.

Good sections of the Rock Springs Formation can be seen at many places. An excellent section is fully exposed near the center of sec. 16, T. 3 N., R. 21 E., where Spring Creek swings across the west end of The Glades just before flowing into the Green River. The bedding at this locality dips steeply to the north at angles of about $50^{\circ}-55^{\circ}$, thus affording easy access to the full thickness of the formation. Good but less completely exposed sections of the formation are accessible $11 / 2$ miles to the west in the bluffs above the west (right) bank of the Green River. Incomplete or partial sections are numerous between the mouth of Spring Creek and Clay Basin.

LITHOLOGY AND THICKNESS

As exposed near the mouth of Spring Creek, the Rock Springs Formation is 1,093 feet thick and consists mostly of pale-grayish-orange, light-gray, and almost white thin-bedded to crossbedded to massive fine-grained sandstone interbedded with brown punky carbonaceous shale and bituminous coal. Individual sandstone beds attain a maximum thickness of about 160 feet. Shale units are of comparable thickness and include two tongues of marine shale which thicken eastward and merge with the Hilliard Shale (fig. 34). Coal beds reach a maximum thickness of about 3 feet, but most beds are less than 1 foot thick. The sandstone beds are chiefly littoral deposits; the shales and coal beds are coastal swamp deposits, except the marine shales already noted. The boundary between the Rock Springs Formation and the overlying Ericson Sandstone is placed at a change from sandstones and sales having the above-noted characteristics to coarser grained fluviatile sandstone. This contact appears to be isochronous throughout the area. 
Following is a section of the Rock Springs Formation as measured at the west end of The Glades near the mouth of Spring Creek:

Section of the Rock Springs Formation in $S E^{1 / 1}$, sec. 16, T. I N., R. $21 \mathrm{E}$.

[Measured by W. R. Hansen and M. G. Bonilla, Aug. 14-16, 1952]

Ericson Sandstone: sundstone, medium-grained; contains dark chert grains.

Rock Springs Formation :

Shale, brown, punky ; occasional sandstone beds...-

Saudstone, light-gray, fine-grained, massive; limonite strains

Shale, brown, punky; contains abundant carbonized stem and amber; 36-in. coal bed $1 \mathrm{ft}$ above base; 30 -in. coal bed $21 \mathrm{ft}$ above base. Beds or lenses of ironstone near middle contain plant and leaf fragments. Upper $15 \mathrm{ft}$ a transition zone containing interbedded shale and sandstone. Very rusty, reddish-brown bed at top

Sandstone, almost white but containing rusty streaks; fine grained; crossbedded; occasional carbonaceous partings. Upper $7 \mathrm{ft}$ is thin bedded, even bedded, very fine grained and contains "tractor-tread" ripple marks. Shale partings_.-.--

Sandstone, gráy to brown, soft, fine-grained, carbonaceous. Interbedded punky shale beds toward top.-

Shale, brown, punky ; 12-in. coal bed $3 \mathrm{ft}$ above base; thin coal seams (about 6 in. thick) near middle. Grades upward into brown sandstone.

Sandstone, pale-whitish-yellow, fine-grained, even

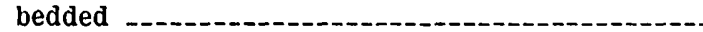

Sandstone, rusty brown, even-bedded, fine-grained; fresh exposures are light grayish orange.......-

Shale, dark-brown, punky. Coal bed $1 \mathrm{ft}$ thick 8 ft below top.

Sandstone, rusty, thin-bedded.

Shale, punky. Coal bed $1 \mathrm{ft}$ thick $3 \mathrm{ft}$ above base

Sandstone, almost white but containing rusty streaks; very crossbedded. Highly sculptured outcrop; many small cavities. Punky shale partings $4-5 \mathrm{ft}$ thick near middle. Bedding of sandstone contorted in places.

Shale, punky; contains a few thin sandstone beds

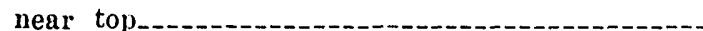

Sandstone, light-gray, fine-grained, crossbedded..... Shale, brown, punky ; $11 / 2$-ft coal bed $3 \mathrm{ft}$ above base_Sandstone, light-gray, even-bedded, fine-grained...-

Shale, brown, punky; 1 -ft coal bed $5 \mathrm{ft}$ above base; $11 / 2-\mathrm{ft}$ transition zone of sandstone and shale at top

Sandstone, light-gray but containing rusty streaks; massive; fine grained; hard. Channeling at base. Forms rounded outcrop.

Shale and sandstone; punky brown shale containing thin rusty-brown sandstone layers; carbonaceous layers

Sandstone, light-gray, fine-grained, indistinct but even bedded.

Coal, bituminous

Shale, brown, punky, carbonaceous
Rock Springs Formation-Continued

Feet

Sandstone, light-gray ; a transition zone between units above and below. Contains thin carbonaceous shale partings

Sandstone, white but containing rusty and greenishgray streaks; fine grained ; crossbedded ; forms conspicuous outcrop. A punky shale break $11 / 2 \mathrm{ft}$ thick $90 \mathrm{ft}$ above base. At the base of the unit are abundant sandstone "tubes," some several feet long and gently curved, some with branches, some parallel to and some across bedding
26

96
Sandstone, light-grayish-orange, even-bedded ; a transition zone between units above and below

Shale, gray, marine (unlike punky paludal shales) -Sandstone, light-grayish-orange to rusty, fine-grained, even-bedded; beds a few inches to several feet thick

Covered interval. Appears to be mostly gray marine shale. Sandy toward top.-

Sandstone, yellowish-gray, friable, even-bedded...-. Shale, brown, punky ; thin coal seam $3 \mathrm{ft}$ above base--

Sandstone, pale-grayish-orange, fine-grained, very crossbedded

Shale, brown, punky; a few thin sandstone beds.--

Sandstone, light-gray to grayish-orange, fine-grained, thick-bedded

Shale, brown, soft; punky toward base. Abundant carbonaceous plant impressions.......................

Clay, carbonaceous.

Coal carbonaceous-

Total 1,093

Blair Formation.

East from the mouth of Spring Creek the sandstones of the Rock Springs Formation tapar out and intertongue with marine shales in the upper part of the Hilliard Shale. One tongue of marine shale extends west into the Rock Springs Formation as far as the bluffs on the west bank of the Green River (fig. 34). This tongue thickens rapidly toward the east and marges with the main body of the Hilliard Shale at the pinch out of the Blair Formation a short distance west of Goslin Mountain. It has been correlated with a similar tongue of shale in the Rock Springs uplift referred to by Hale $(1955$, p. 92 ) as the Black Butte tongue of the Mancos shale, a name which unfortunately is preempted by an earlier named formation (Wilson and others, 1957, p. 40).

At the pinchout of the Blair Formation in sec. 24, T. 3 N., R. 22 E. (Dutch John Mountain quadrangle), the so-called Black Butte Tongue is about 600 feet thick and the overlying Rock Springs formation is about 440 feet thick. Seven miles farther east, on the west plunge of the Clay Basin anticline, the Rock Springs formation is only 260 feet thick.

In Clay Basin the Rock Springs Formation is a sequence of interbedded littoral to neritic sandstones and paludal to marine shales. Only the upper few sand- 


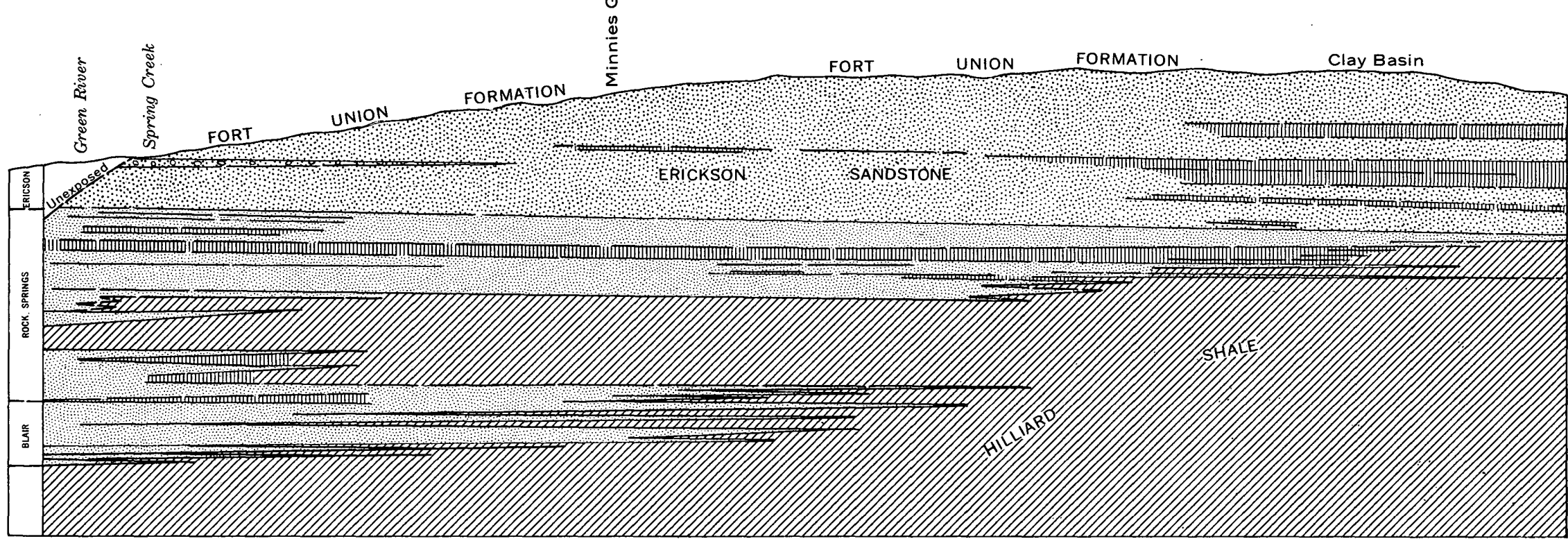


stone beds of the typical Rock Springs Formation were deposited here, as is shown by the fact that time equivalents of lower beds represented at Spring Creek are marine shale (fig. 35). The contact of the Rock Springs with the underlying Hilliard Shale is mapped arbitrarily at the base of a grayish-orange fine-grained sandstone bed 24 feet thick that separates a predominantly shale sequence below from interbedded shale, sandy shale, and sandstone above. The basal sandstone bed is well exposed in many small gullies below the rims of Clay Basin, but it is poorly exposed on the slopes between the gullies. The upper limit of the formation is mapped at the top of a conspicuous massive very fine grained päle-grayish-orange sandstone bed that is white toward the top and is 100 feet thick. The top of this sandstone bed is an excellent mapping horizon as it can be traced westward in almost continuous exposure to the Green River north of Flaming Gorge. It also crops out conspicuously in the rim of South Baxter Basin 20 miles northeast of Clay Basin where its twofold coloration is very distinct. At Clay Basin I have included it in the Rock Springs Formation rather than in the overlying Ericson Sandstone because of its ready identification with similar littoral sandstones of typical sections of the Rock Springs Formation, including those near the mouth of Spring Creek, and because of its dissimilarity from the coarser grained fluviatile sandstones of the Ericson. Some geologists, however, have included it in the Ericson.

The following section was measured on the western plunge of the Clay Basin anticline.

Section of the Rock Springs Formation in NW corner sec. 19, T. 3 N., R. $24 E$.

[Measured by W. R. Hansen and M. G. Bonilla, Sept. 23, 1953]

Ericson Sandstone: slope of interbedded sandstone and shale below massive sandstone cliff.

Rock Springs Formation :

Sandstone, pale-grayish-orange to almost white, very. flne grained; a few shaly breaks in lower $8 \mathrm{ft}$; upper most $14 \mathrm{ft}$ is white.

Shale, nonmarine; punky toward top; interbedded toward top with thin-bedded fine-grained sandstone.--

Shale, dark-gray to dark-brown, gypsiferous, marine; contains friable sandstone breaks. Prominent sandstone bed 4 feet thick $15 \mathrm{ft}$ above base

Sandstone, pale-grayish-orange, fine-grained, massive-Shale, dark-gray, nonmarine, somewhat carbonaceous; a few thin fine-grained friable sandstone beds.......

Sandstone, very flne grained, friable; moderate grayish orange on weathered surfaces; light olive brown where fresh; individual bedis mostly less than $2 \mathrm{ft}$. thick.

Total
FOSSILS, AGE, AND CORRELATIONA

Diagnostic fossils have not been found in the Rock Springs Formation of this area, but little effort has been made to find them, and careful search probably would be rewarding. Spores or pollen, especially, could probably be obtained from many of the punky bituminous shales or from some of the coal beds. Fragments of leaves and stems are abundant in some of the coals and associated shales near the mouth of Spring Creek; most of this material is very fragile and is difficult to collect. Undetermined Inoceramus sp. have been found in float from marine units of the Hilliard Shale that intertongue with the Rock Springs Formation at the foot of The Glades east of Minnies Gap.

Work by Reside (1955, p. 85). in the Vermilion Creek area indicates that the upper part of the Mancos Shale of that area is late(?) Campanian in age and is equivalent to the lower part of the Pierre Shale. As the Rock Springs Formation of The Glades-Clay Basin area appears to occupy the same stratigraphic position as the upper part of the Mancos Shale of Vermilion Creek, a similar age is probable. Such a correlation from Baxter Basin to Vermilion Creek was first made years ago by Sears (1926, pl. 5 and pl. 21). The Rock Springs Formation is thus correlated temporally with the uppermost part of the Mancos Shale of northwest Colorado, and possibly of the Uinta Basin also. It is considered to be equivalent to the Adaville Formation of western Wyoming (Hale, 1950, p. 53).

$$
\text { DEPOBITIONAL CONDITIONB }
$$

At the time the Rock Springs Formation as accumulating, marine conditions existed in the Clay Basin area and a coastal plain existed farther west. A broad temporary expansion of the sea about midway in the deposition cycle left marine shale as far west as the west bank of the Green River. Nonmarine conditions again followed withdrawal of this seaway on the west and north, but marine conditions remained to the east and south. The Glades-Clay Basin area was the site of repeated oscillations of the shoreline; Clay Basin was under water more often than The Glades. While coal swamps flourished behind the beaches, marine water circulated freely offshore. Circulation may have been impeded from time to time, however-perhaps owing to the very shallowness of the water-and gypsum was precipitated along with the muds. Complete and final withdrawal of the seaway followed immediately after deposition of the Rock Springs Formation, and the fluviatile cycle of the Ericson Sandstone began. Reincursions of the sea followed in the Baxter Basin area to the north, as indicated by the accumulation of the marine Lewis Shale; but so far as the Flam- 

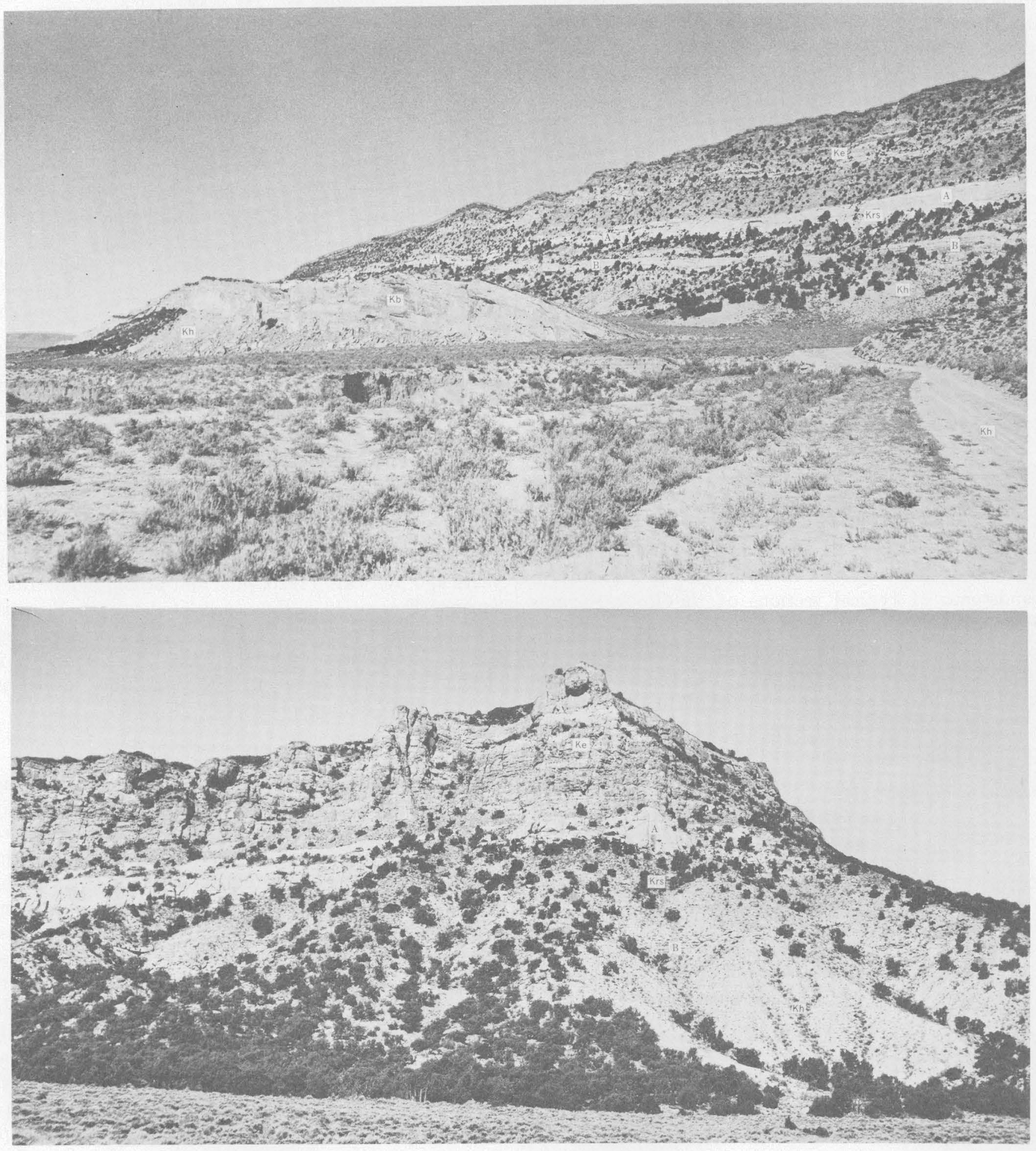

FIGURE 35.-Comparative views of Mesaverde Group at The Glades (upper photograph) and at Clay Basin (lower). Kh, Hilliard Shale; Kb, Blair Formation; Krs, Rock Springs Formation; Ke, Ericson Sandstone. Blair Formation feathers out eastward from The Glades and is lacking at Clay Basin. Most of Rock Springs Formation is lacking there also. Persistent bed at " $\mathrm{A}$ " extends length of Clay Basin, but bed at "B" feathers out in eastern part of basin. See also figure 34. 
ing Gorge area is concerned, the sea never returned, unless evidence for its so doing has been removed by post-Ericson erosion. The Rock Springs Formation thus contains the youngest marine beds in the area.

\section{ENGINEERING CHARACTERISTICS}

Like the underlying Blair Formation, the Rock Springs Formation presents a highly varied group of engineering properties, owing to its diverse lithology. Its topographic setting, however, makes it only slightly more likely to become involved in engineering undertakings in the forseeable future than the Blair Formation. Massive sandstone beds that characterize the western outcrops of the Rock Springs Formation contrast with shale and friable thin-bedded sandstone toward the east. Punky, friable carbonaceous shale occurs here and there in the section from the west end of the area to the east end.

Most of the sandstone beds in the formation, including even the more friable ones, could not be excavated without the use of explosives. By the same token, they are highly stable under steep slopes and possess relatively great bearing strength. Under suitable topographic conditions they form prominent ledges or even cliffs.

Virtually all the shale beds, in contrast, could be excavated by power machinery without recourse to explosives. The nonmarine shales appear to have greater stability on slopes than the marine ones. All have low bearing strength.

Coal is common in the Rock Springs Formation, especially toward the west, but it occurs in such generally thin beds as to be of negligible concern in most possible engineering problems. It generally is a good conduit for the movement of ground water, however, and under certain conditions may be a source of seepage.

Water circulates freely through most of the sandstone beds of the formation, but circulation is impeded somewhat by the nonmarine shales and almost completely by the marine shales. The thicker sequences of marine shale, except that they contain many interbeds of sandstone, are basically the same in engineering character as the thick Hilliard Shale which underlies them and into which they pass laterally.

\section{ERICSON SANDSTONE}

Sears (1926, p. 20) introduced the name Ericson Sandstone for a previously unnamed sequence of beds in the Mesaverde Group overlying the Rock Springs Formation. He named the formation for exposures near the old Ericson Ranch (now abandoned) in Baxter Basin adjacent to Wyoming Highway 430. Along with the Blair and Rock Springs Formations, the Ericson was included by Powell (1876, p. 156) in his Point of
Rocks Group; Powell used the name Upper Hogback Sandstone for the Ericson, and he published a description of the section at The Glades in his report.

The outcrop of the Ericson Sandstone is approximately coextensive with that of the underlying Rock Springs Formation, extending west to east almost uninterruptedly for 25 miles. Its westernmost exposure, northeast of Linwood, is about 2 miles west of the Green River. Although the bedding there is verticaldragged by the Henrys Fork fault-the outcrop is unimposing. East of the river, however, the Ericson forms the impressive north hogback. of The Glades (fig. 35). The prominence of The Glades as a topographic feature, in fact, is due largely to the superior resistance of the Ericson Sandstone to erosion as compared with the rocks stratigraphically below and above.

East of The Glades the Ericson Sandstone is locally concealed by overlapping Tertiary (Fort Union) beds north of Goslin Mountain. At that point, which is adjacent to the Uinta fault, the Ericson dips vertically or is overturned, whereas the overlapping Fort Union dips gently northward. Resistant beds of the Ericson protrude through the Fort Union at one point as erosional windows in a small badlands tract tributary to Pigeon Basin (Goslin Mountain quadrangle) near the center of sec. 21, T. 3 N., R. 23 E.

A mile farther east, at Martin Draw, the Ericson reappears at the surface, flattens rapidly in dip on the flank of the Clay Basin anticline, and forms the broad cliff-bounded rimrock of Clay Basin. Just north of the -Wyoming-Utah line at Richards Gap the rimrock is breached by Red Creek, which flows south through Clay Basin to the Green River. East of Richards Gap the strike of the beds swings southeast around the north flank of the Clay Basin anticline so that the Ericson dips gently northeast in a series of steep-sided alcovelike canyons and stairstep ridges. This area is shown on the topographic map as the Teepee Mountains, although Teepee Mountain proper lies to the north in Wyoming.

At the east end of the Teepee Mountains near Clay Basin Meadows the Ericson Sandstone bends sharply to the east and is overturned in response to the drag effects of the Uinta fault. .Just east of Clay Basin Meadows it passes again into concealment beneath Tertiary rocks.

\section{ITTHOLOGY AND THICKNESS}

Along the western parts of its outcrop, the Ericson Sandstone consists mostly of medium- to coarse-grained sandstone and minor quantities of shale and conglomerate. Toward the east at Clay Basin it contains considerable shale but no appreciable conglomerate, and the sandstone is generally finer grained than it is toward the west. The source of sediment apparently lay to 
the northwest, for a northward component of coarsening is evident in the Rock Springs uplift (Hale, 1950, p. 53).

At the mouth of Spring Creek the Ericson consists mostly of very pale orange to light-gray medium- to coarse-grained crossbedded sandstone. The grains are mostly subangular to subrounded, poorly sorted, and commonly loosely cemented with calcium carbonate. Dark chert grains are abundant. Shale is found as thin beds and flaky partings mostly near the base of the formation. Conglomerate is confined largely to short discontinuous lenses, but a continuous bed 35 feet thick crops out about 230 feet above the base of the formation. Individual pebbles in this bed and in most of the conglomeratic lenses consist chiefly of quartzite and darkgray chert; pebbles of limestone and waferlike fragments of shale or clay are subordinate. Abundant shale wafers in some places appear to have formed from the break up of dried, sun-cracked mud puddles.

As measured near the mouth of Spring Creek the Ericson Sandstone is about 290 feet thick, a figure that must be near a minimum for the formation. Eastward along The Glades it ranges from about 600 to 900 feet in thickness, the upper contact being an unconformity. At Clay Basin the formation ranges from about 800 to 900 feet in thickness and exhibits considerable lithologic variation. Detailed measurements have not been obtained at Clay Basin, but a generalized section on the northeast flank of the Clay Basin anticline consists of three cliff-forming sandstone units separated by slopeforming shales. In ascending order the approximate thicknesses are: Sandstone, 250 feet; shale, 145 feet; sandstone, 130 feet; shale, 75 feet; and sandstone, 300 feet. The sandstone beds are massive, medium to coarse grained, crossbedded, and contain occasional shaly partings. The shales are brown and carbonaceous-commonly containing many small fragments of carbonized wood or coal; locally containing thin beds or stringers of coal-soft, friable, and punky. They also contain many thin interbeds of sandstone.

The Ericson Sandstone exhibits many scour-and-fill structures that are clearly the product of fluviatile deposition. The unit also exhibits unusual penecontemporaneous deformational structures, apparently derived from subaqueous slumpage, that consist chiefly of rolls and deformed blocks of sandstone enclosed in highly disturbed masses of shale (fig. 36). Some rolls appear to have formed snowball fashion by downslipe gliding.

The unconformity at the top of the Ericson truncates the formation at various angles. In most places it is nearly concordant, so that the contact between the Ericson and the overlying Fort Union is difficult to locate precisely. But in some places, especially near the Uinta fault where the Ericson was sharply tilted by drag, the unconformity is markedly discordant. Excellent exposures showing marked discordances can be seen just north of Goslin Mountain in secs. 21 and 22, T. 3 N., R. 23 E.

The following section of the Ericson Sandstone was measured near the mouth of Spring Creek, and it illustrates the lithologic diversity of the formation:

Section of Ericson Sandstone near center of sec. 16, T. 3 N., R. $21 \mathrm{E}$.

[.Measured hy M. G. Bonilla and W. R. Hansen, Aug. 16, 1952]

Fort Union Formation.

Unconformity.

Eriçson Sandstone :

Sandstone, light-gray, coarse-grained, crossbedded_---

Conglomerate, gray; subrounded pebbles of chert, quartz, and occasionally limestone, mostly less than 1 in. across. Sandistone lenses in upper $6 \mathrm{ft}$ Sandstone, white, fine-grained.

Sandstone, gray; contains coarse granule conglomerate.

Sandstone, containing shale wafers

Sandstone, very pale orange to yellowish-orange; darker on weathered outcrops. Alternate stringers of fine and coarse sand. Conglomeratic lenses $2 \mathrm{ft}$. thick at base containing wafers of gray siltstone and a quartzite cobble 6 in. in diameter. Bedding very channeled.

Sandstone, coarse grained, lenticular, crossbedded; contains black chert grains and quartz. Wedges of varying thickness._._._.

Shale, dark-gray, flaky. Contains rolls and balls of de-

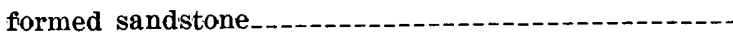

Sandstone, medium-grained, crossbedded; contains dark chert grains. Coarse-grained lenses; foresets from northeast. Upper $17 \mathrm{ft}$; very channeled shale fillings in some channels.

Total

Rock Springs Formation.

\section{AGE AND CORRELATION}

In the absence of fossils, the age of the Ericson formation must be inferred from relationships to adjacent formations and from correlations with dated formations in adjacent areas. The Ericson has been correlated with the Iles(?) Formation of northwestern Colorado (Sears, 1926, p. 21 and pl. 5), which is the time equivalent of part of the Pierre Shale and is of Campanian Age. This age for the Iles(?) Formation follows from Reeside's assignment (1955, p. 85) of a late(?) Campanian early Pierre age for the uppermost part of the Mancos Shale immediately underlying the Iles(?) Formation at Vermilion Creek in Colorado.

\section{DEPOSITIONAL CONDITIONB}

Withdrawal of the old Cretaceous seaway from the area accompanied deposition of the Ericson Sandstone. 


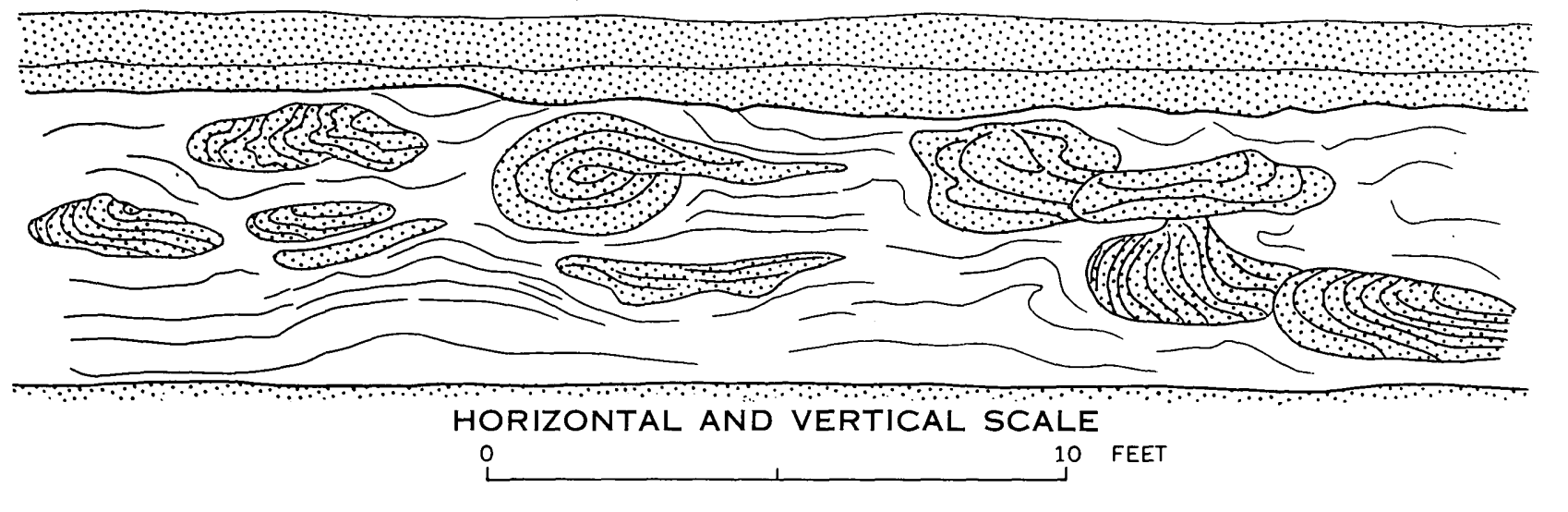

Fiounb 36.-Deformed blocks and rolls of sandstone in highly disturbed shale matrix, Ericson Sandstone near mouth of Spring Creek.

Shifting streams which aggraded across the newly emerged coastal plain deposited the sand and gravel that now constitute the Ericson. Carbonaceous mud accumulating in backwater areas formed the brown shale now exposed in Clay Basin.

The general direction of sediment transport probably was southeast; local deflections in the direction of drainage are suggested by westward foresetting in some beds. Marine conditions continued to exist southeast of the area in northwestern Colorado, where marine equivalents of the Ericson Sandstone occur in the Iles Formation. Region-wide environmental variations, drawn along a line from northwest to southeast, probably range from subaerial alluvial-fan environment to the northwest, now characterized by conglomerates, to offshore environments to the southeast, as represented by parts of the Iles Formation.

A reexpansion of the Cretaceous seaway into the Rock Springs area to the north is indicated by the marine deposits of the Almond Formation and Lewis Shale. These formations do not occur in the Uinta Mountains, and if they ever were deposited there, they have since been removed by pre-Tertiary erosion.

Sometime after deposition of the Ericson Sandstone but before deposition of the overlying Fort Union Formation, the Uinta Mountains began to rise in consequence of the first disturbances of the Laramide revolution.

\section{ENGINEERING CHARACTERISTICS}

The rugged topographic expression of the Ericson Sandstone, by itself, would tend to discourage development of most types of construction on its outcrop. Gaps in the outcrop, therefore, would have particular significance in the planning stage of any proposal to utilize land in the vicinity of the formation. The Glades, for example, are an effective obstacle to north-south travel and can be crossed only at Minnies Gap, just north of the Wyoming State line, where Spring Creek breaches the Ericson hogback. Minnies Gap probably will in- crease in significance when Flaming Gorge Reservoir is filled, inasmuch as it will provide access to the reservoir embayments and adjacent shore areas of Antelope Flat.

North of Clay Basin the Ericson outcrop, though imposing, is breached by natural drainage in several places and offers fewer obstacles to travel. Transit through Richards Gap and the several other breaches in Clay Basin, as well as Minnies Gap, is across alluvium and involves no crossing of bedrock. But at Martin Draw, the road from Clay Basin to Manila crosses the formation on bedrock. Improvement of this road would necessitate drilling and blasting in the Ericson Sandstone. Any other excavations into the formation would also require the use of explosives.

Cuts in the Ericson should stand at high angles without support. Even the shale beds seem to have relatively high stability and strength. Foundations set in the formation, therefore, should be able to support heavy loads.

Springs issue from the outcrop of the Ericson Sandstone at several localities. The formation transmits water readily, and drainage should not be a serious construction problem.

\section{CENOZOIC ROCKS}

TERTIARY SYSTEM

With the onset of the Cenozoic Era, sedimentation in the Flaming Gorge area took on a new complexion. The Uinta Mountains had begun to rise as a consequance of the first local disturbances of the Laramide revolution. Sediment shed from the newly formed highlands accordingly became a chief constitutent of the early Tertiary strata. Sharp uplift began sometime after deposition of the Ericson Sandstone but before deposition of the Fort Union Formation. As the mountains were denuded, progressively older formations were exposed to erosion and in turn contributed debris to the deposits accumulating in newly formed 
basins at the mountain flanks. As the mountains rose the basins sank, eventually to be filled by large freshwater lakes.

Conglomerates in the Fort Union Formation contain pebbles derived from the initially uplifted Uinta Mountains to the south, and together with angular discordances at the base of the Fort Union, substantiate strong uplift of the Uinta Mountains before Fort Union time. This evidence seems significant in view of divergent belief among geologists as to the time of initial uplift. In the Fort Union Formation, materials from several nearby formations of Mesozoic age can be recognized tentatively, such as wood fragments from the Dakota and gastroliths from the Morrison. Chips and balls of shale containing well-preserved fish scalesundoubtedly derived from the Mowry Shale-are abundant in exposures near Pigeon Basin north of Goslin Mountain. Because of their fragility, such shale fragments could not have traveled far and could not have endured long-sustained weathering, either on the outcrop or in transit; their source must have been nearby, and degradation of this source probably was rapid. It follows that uplift probably was rapid also, and hence probably took place in latest Cretaceous time or earliest Tertiary. To expose the Mowry Shale by Paleocene time, at least 8,000 feet of strata must have been stripped away, and possibly as much as 11,000 feet, if the Almond, Lewis, and Lance Formations ever were present. Clearly, the uplift was of major proportion.

A lack of clastic material coarser than pebble.conglomerate in the Fort Union Formation does not mean that the source of sediments was remote or that uplift was slow. Formations exposed by erosion of the Uinta arch by Paleocene time contained insufficient resistant rock material to provide a source for coarse conglomerate regardless of proximity of source and rate of mag. nitude of uplift.

By Wasatch time the Mesozoic and Paleozoic formations of the Uinta range were deeply eroded, inasmuch as pebbles and cobbles derived from these formations are abundant in the conglomerates of the Wasatch. To some extent they appear in the Wasatch Formation in inverse order from their original order of appearance in the section. In other words, coquina-limestone fragments derived from the Curtis Formation, for example, appear lower in the Wasatch than limetone fragments derived from Paleozoic formations but higher than petrified wood derived from the Dakota or Mor: rison. North of Manila, coarse orogenic deposits occur. about midway in the Wasatch section and suggest a nearby source higher than the present Uinta Mountains. Boulders 3 to 4 feet in diameter are common, and one limestone boulder probably derived from the Mississippian rocks measures 11 feet across and must have been transported at least 8 miles.

During Wasatch time the eastern part of the range was eroded to its Precambrian core. Northeast of Clay Basin the Wasatch contains abundant pebbles and cobbles derived from the Uinta Mountain Group. Farther west, however, Precambrian material has not been definitely recognized in the Wasatch, although Anderman (1955, p. 131) tentatively identified such material about 10 miles west of Manila in rocks he correlated with the Green River Formation.

North of Manila, deformation involving the Henrys Fork fault has been rather closely dated by Anderman $(1955$, p. 133) as early medial Eocene and affects rocks temporally equivalent to the Green River Formation. The same disturbance may have caused renewed movement on the Uinta fault (Hansen and Bonilla, 1954, p. 18; Hansen, 1957b, p. 37).

Broad lakes that covered much of the Green River and Uinta Basins during part of Eocene time (Bradley, 1936b, 1948) barely lapped into the Flaming Gorge area. The coarse clastic deposits that accumulated in this area are largely fluviatile and hence are here assigned to the Wasatch Formation rather than to the lacustrine Green River Formation with which the Wasatch intertongues. Lacustrine beds assigned to the Green River Formation crop out only in the extreme northwestern part of the area and are the youngest early Tertiary beds in the area. The shore of the Green River lake thus lay generally to the north. A sloping alluvial plain was built across the area by debris-choked streams that flowed on steep gradients from the mountains on the south to the lake on the north.

A gap of several million years is left in the stratigraphic section between the time of deposition of the Green River and Browns Park Formations. Deposits of intermediate age-the Bridger Formation and the Bishop Conglomerate-crop out to the north in the Green River Basin, but if they ever were deposited in the Flaming Gorge area, they have since been eroded away. All that is left is a record of degradation; sediments carried off the mountains were swept from the area to the Green River Basin or beyond. The Browns Park Formation was later deposited in a complex episode that combined degradation with fluviatile and lacustrine aggradation, vitric ash falls from some remote volcanic center, crustal warping, and gravity faulting. These events, which will be discussed in greater detail later, probably consumed much of later Tertiary time, although datable deposits within the area have not yet been found. 


\section{FORT UNION FORMATION (PALEOCENE)}

The Fort Union Formation was named many years ago by Meek and Hayden for exposures at old Fort Union, N. Dak. (Wilmarth, 1938, p. 761). In the few years that followed, the formation was widely recognized over parts of the northern Great Plains, Montana, Wyoming, northwestern Colorado, and New Mexico. In all probability the formation thus recognized never extended blanketlike and unbroken across the whole of this great area but instead probably filled several basins of deposition separated more or less by the newly formed Laramide highlands of the Rocky Mountain system.

North of Flaming Gorge, Goslin Mountain, and Clay Basin, the name Fort Union is assigned to a thick sequence of drab nonmarine strata between the Ericson Sandstone below and the Wasatch Formation above. Assignment of these strata to the Fort Union Formation rests in part on stratigraphic position, lithology, and general appearance, and in part on a contained Paleocene flora. Prior to the discovery of diagnostic dating fossils, the name was used tentatively (Hansen and Bonilla, 1954, p. 4; Hansen, 1955a). Anderman $(1955$, p. 130) referred the same beds to Nightingale's Hiawatha Member of the Wasatch Formation. Much earlier, Schultz (1920, pl. 1) had mismapped the formation as Lewis Shale. Still earlier, Powell (1876, p. 45) had included the unit in his Bitter Creek Group and King (1878, p. 360) had included it in his Vermilion Creek Group. 'The names Bitter Creek and Vermilion Creek are synonymous, as they were applied to identical stratigraphic intervals. They comprised the present Fort Union and Wasatch Formations of the Uinta Mountain area and included all strata between the uppermost Cretaceous rocks and the base of the Green River Formation.

DISTRIBUTION AND PHYSIOGRAPHIC EXPRESSION

Owing to its inferior hardness and nonresistance to erosion, the Fort Union Formation forms a broad low strike valley between the Ericson Sandstone below and the Wasatch above. In part its outcrop is concealed by soil or terrace deposits, but in some local areas where recent erosion has been vigorous the outcrop is carved to badlands. Most notable of these is a much dissected amphitheaterlike area tributary to Pigeon Basin that covers perhaps 100 acres near the center of sec. 21, T. 3 N., R. 23 E., and features countless rill channels, miniature pediments and alluvial fans, and other microrelief features. Although the tract is small in areal extent, its pattern of dissection has a much finer grain than that of most of the many badland tracts of the Green River Basin area, such as the famous Bridger badlands or the various tracts on the Wasatch, Hilliard, and Morrison Formations.

Outcrops of the Fort Union Formation extend west to east principally along the Utah-Wyoming boundary from a point about 2 miles west of the Green River to the east side of Clay Basin, a distance of about 25 miles. The greater part of the outcrop belt is north of the mapped area in Wyoming. North of The Glades and Ciay Basin the belt bows north completely into Wyoming. Within the mapped area, the formation crops out northwest of The Glades near the Green River, just across the river to the west, north of Goslin Mountain (especially at Pigeon Basin), and northeast of Clay Basin. The best exposures are at Pigeon Basin, particulary in the amphitheaterlike area cited above, where the formation extends unconformably across the Ericson Sandstone, and Rock Springs Formation and partly overlaps the Hilliard Shale.

\section{LITHOLOGY AND THICKNESS}

The Fort Union Formation is a thick sequence of drab gray to pale-yellowish-gray compact friable noncalcareous silts and clays, gray or rusty friable lenticular sandstones, and pebble conglomerates. Northwest of The Glades it contains considerable lignitic shale which contains abundant leaf impressions. Extreme lenticularity characterizes most beds, so that the formation differs in detail from place to place, although it maintains a general overall uniformity. . Along the Uinta Mountains the formation is nowhere fully exposed, and no attempt has been made to measure the section in detail. In general it thickens from west to east. At Phil Pico Mountain, which is about 12 miles west of Manila, it is 2,880 feet thick, according to American Stratigraphic Company's $\log 703$. Near Manila it is about 2,300 feet thick (Anderman, 1955, p. 131). (Anderman correlated these beds with Nightingale's Hiawatha Member of the Wasatch Formation.) This thickness compares with about 1,200 feet at Clay Basin, 658 feet at Middle Mountain oil field 10 miles northeast of Clay Basin in Wyoming (Olson, 1955, p. 148), and 747 feet at Vermilion Creek in Colorado (Gras, 1955, p. 177). At Church Buttes gas field about 35 miles northwest of Manila, the unit is about 1,570 feet thick (Fidlar, 1950c, p. 111). Hence, it apparently thins rather rapidly to the north away from the mountains also.

FOSSIIS, AGE, AND CORRELATIONS

A Paleocene age for the Fort Union Formation of the Uinta Mountains area is verified by a floral assemblage collected just north of The Glades in the SW1/4 sec. 24, T. 12 N., R. 108 W., Sweetwater County, Wyo. The following plant remains, collected by Lawrence $P$. 
Buck and me, were identified and dated by Roland W. Brown :

Sparganium antiquum (Newberry) Berry
Carya antiguorum Newberry
Quercus penhallowi Trelease
Platanus raynoldsi Newberry
Fragments of other dicotyledonous leaves

Over broad expanses of outcrop, fossils are sparse to lacking in the Fort Union Formation. Chances seem good, however, that additional forms could be collected from outcrops in the above-cited vicinity, especially if collecting were done by a paleobotanist or if identifications were made directly in the field. The above-listed flora were found in a moderately hard flaggy crossbedded sandstone. Abundant leaf and twig impressions occur nearby in friable bituminous shales which deteriorate rapidly on exposure and are difficult to handle.

Precise correlations of the Fort Union Formation with equivalent rocks in adjacent areas have not been made, owing to the discontinuity of individual beds or groups of beds and to rapid lateral variations in lithology. Disagreement exists, moreover, as to the exact name designation most applicable to the beds here called Fort Union. Anderman (1955, p. 130) referred them to Nightingale's Hiawatha Member of the Wasatch Formation, recognizing, however, a possible Paleocene age. The propriety of using the name Hiawatha in areas where the Wasatch is not divided by the Tipton Tongue of the Green River Formation is open to question (McKenna, 1955, p. 105). Rocks of similar position and lithology in the Rock Springs uplift were included in the Wasatch by Schultz (1910, p. 236), although he regarded them as of Fort Union age, on the basis of abundant plant remains identified by F. H. Knowlton. Yourston (1955, p. 197) used the name Fort Union for the same rocks. Pipiringos (1955, p. 100) used the name Fort Union tentatively for the Paleocene rocks of the Great Divide Basin east of the Rock Springs uplift.

The so-called post-Laramie Formation (Gale, 1910, p. 79 ; Sears, 1924 b, p. 291 ; Sears and Bradley, 1924, pl. 24 ; Nightingale, 1930, p. 1020) of Moffat County, Colo., was tentatively correlated by Gale with the Fort Union Formation and probably is equivalent to the Fort Union of the Flaming Gorge area. In Moffat County at Powder Wash the name Fort Union was applied to Paleocene beds by Folsom (1955, p. 157), and at Vermilion Creek, also in Moffat County, the name was applied by Gras (1955, p. 177) ; these are the beds that earlier were called post-Laramie.

Toward the west, the Fort Union has been identified in the subsurface in oil-test holes. Along the Uinta Mountain front, however, it is concealed by overlapping younger beds. Farther west the formation probably passes into some part of the Evanston Formation.
DEPOSITIONAL CONDITIONS

The Fort Union Formation accumulated under highly varied nonmarine conditions. Most of the formation is fluviatile, but some fine-grained silty beds appear to be lacustrine, and some clearly are paludal. Even coal accumulated locally.

At the time the formation was accumulating, the newly formed and still rising Uinta Mountains were close at hand and were being degraded rapidly by erosion. The mountains influenced markedly the character and composition of the accumulating sediments.

Shale chips derived from the Mowry Shale and found near the base of the Fort Union Formation north of Goslin Mountain indicate deep erosion of the uplifted Uinta Mountains by early Fort Union time. Erosion had cut through at least 8,000 feet of pre-Tertiary rocks and possibly as much as 11,000 feet.

As was already pointed out, a lack of coarse clastic material in the Fort Union Formation does not indicate slow or distant uplift, because hard, resistant formations had not yet been exposed to erosion by Fort Union time. Most of the Cretaceous rocks had been stripped from the Uinta arch, but few, if any, Jurassic rocks had been removed. (Rocks tentatively identified as gastroliths derived from the Morrison Formation occur in the Fort Union north of Goslin Mountain, but these may be of Early Cretaceous age.) The more deeply buried, more competent earlier Mesozoic and Paleozoic rocks were not exposed until subsequent Wasatch time. Sharp angular unconformities between the Fort Union and the underlying Ericson Sandstone north of Goslin Mountain (Powell, 1876, p. 164) and east of Clay Basin further substantiate strong pre-Fort Union uplift (Hansen and Bonilla, 1954, p. 10). In both these areas the Fort Union overlaps the Eriscon Sandstone and rests partly on the Hilliard.

The floral assemblage collected just north of The Glades, though small, indicates a warm humid, temperate climate at the time the Fort Union Formation was deposited-a climate milder, perhaps, than at present. Deciduous trees-oak, hickory, and sycamoreflourished along overloaded probably swift-flowing streams and around the margins of grassy swamps.

\section{ENGINEERING CHARACTERISTICS}

Inasmuch as the Fort Union Formation is nonresistant to erosion, forms a strike valley, and occupies low ground, its outcrop is covered in many places by a soil mantle or by alluvium. Roads or other constructional features that might otherwise be built on the formation, therefore, would at least in part be built on the mantling surficial materials. The road from Antelope Flat to Clay Basin crosses the Fort Union

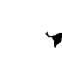

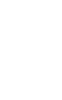


outcrop belt in Pigeon Basin, but it lies mostly on alluvium and is on bedrock in but a few places. Any major improvement of that road, however, would very likely mean considerable involvement with the Fort Union Formation.

Most parts of the formation probably could be stripped or excavated by power machinery without recourse to explosives. Explosives would be needed only to excavate some of the more resistant sandstone beds and conglomerates.

Owing to its high silt content, the formation probably lacks much bearing strength or slope stability. Where well-drained, however, it is capable of standing at high angles with little or no support; natural slopes in certain badland areas are nearly vertical. Also, because of its high silt content, the formation is very susceptible to erosion. It is characterized by rapid surface runoff and very little infiltration. Erosion protection would be advisable in situations where runoff is channeled across or near engineering structures. Provisions for drainage are advisable where waterlogging is a potential problem.

\section{WABATCH FORMATION (EOCENE)}

The Wasatch Formation is one of the most widespread stratigraphic units in the Rocky Mountain region, having been recognized from Montana to New Mexico. It was named by Hayden $(1869$, p. 91) for impressive exposures in the Weber Canyon-Echo Canyon area of the Wasatch Mountains about 90 miles due west of Manila. In the type area it contains thick sequences of coarse cliff-forming conglomerate.shed from nearby mountains; elsewhere, especially in more basinward areas, it more commonly consists chiefly of variegated sandstone, siltstone, and clay but includes subordinate conglomerate.

At about the same time that Hayden introduced the name Wasatch, the synonymous but now-obsolete names Bitter Creek Group (Powell, 1876, p. 45, 162) and Vermilion Creek Group (King, 1878, p. 360) were introduced for the same rocks in the Uinta MountainsGreen River Basin area. King (p. 354) stated rather clearly his reason for not following the lead of Hayden and for introducing his own nomenclature-namely, his belief that his type section represented the full thickness of the formation whereas Hayden's section was incomplete and atypical. Many geologists have since assented to King's reasoning, but the name Wasatch has stood. The complex stratigraphic relationships of the Wasatch Formation in areas adjacent to or near the Flaming Gorge area have been discussed by many geologists, most particularly by W. H. Bradley in his several definitive reports on the Green River Formation.
Some disagreement now exists as to what should be called Wasatch in the areas north of Manila, Flaming Gorge, and Clay Basin. All predominantly fluviatile deposits-conglomerate, sandstone, and siltstoneoverlying the Paleocene Fort Union Formation and underlying the typical lacustrine Green River Formation are here considered to be Wasatch. Rocks that I have mapped as Wasatch north of Manila, but which grade laterally into the Green River Formation, were mapped by Anderman (1955, p. 131) as Green River Formation. Rocks that I mapped as Fort Union (Hansen, 1955a, 1957a; Hansen and Bonilla, 1954, p. 10) were included in the Wasatch by Anderman (1955, p. 130).

As I have mapped it, the Wasatch crops out in many places along the north boundary of the Flaming Gorge area. Across the north boundary in Wyoming it forms a continuous belt of outcrops that extends from a point northwest of Manila eastward beyond the 109th meridian northeast of Kleins Hill in the extreme northeast corner of the area. In the northwestern part of the area, the Wasatch underlies part of the town of Manila, where it consists of variegated red beds and conglomerate, and it forms prominent hogbacks north and northwest of Manila. North of Linwood it forms hogbacks and, where dips are gentle, cliffs and backslopes. In the eastern part of the area, east from Clay Basin, it forms high round-topped hills at Bender Mountain, Willow Creek Butte, and Kleins Hill. The summit of Kleins Hill, which is underlain by conglomerate, is the highest point in the entire mapped area. Complete sections of the Wasatch Formation do not occur in the mapped area, either because the base is truncated by faults, as at Manila, or because the top is in Wyoming north of the mapped area.

\section{LITHOLOGY AND THICKNEGS}

The Wasatch Formation is characterized by marked lateral and vertical lithologic variations. It consists chiefly of lenticular variegated red, yellow, and gray sandstone, siltstone, clay, and conglomerate. Lenticularity is more marked toward the base of the formation than toward the top.

North of Manila, coarse conglomerate and massive lenticular sandstone are abundant near the middle of the formation. Conglomerates near the base of the exposed section contain large rounded fragments of petrified wood much the same as wood found in the Morrison Formation and Dakota Sandstone. Conglomerates higher in the section contain distinctive fossiliferous limestone cobbles and boulders derived from such units as the Curtis, Morgan, Round Valley, and Madison Formations. Still higher in the section, conglomerate 
becomes uncommon, the bedding becomes more regular and more uniform, and the texture becomes finer.

The coarse conglomerates north of Manila are regarded as orogenic deposits derived from the rising Uinta Mountains immediately to the south. Some of these conglomerates fill channels which before tilting had vertical sides and which at the time of formation must have been steep-sided ephemeral washes (fig. 37). Boulders several feet across are common and include lithologic varieties derived from most of the resistant Paleozoic and Mesozoic formations in the area. These formations now crop out 5-10 miles distant from the Wasatch outcrop and were considerably farther away at the time the Wasatch was deposited, if considerable erosion at the source since Wasatch time can be assumed-with erosion, the outcrop migrates northward down dip. One subrounded boulder, which measured 11 feet in longest diameter and was derived from limestone of Mississippian(?) age, must have been carried at least 8 miles from the nearest bedrock source. Extreme coarseness, marked channeling, and extreme lenticularity all suggest torrential discharge and deposition. Very strong topographic relief seems necessary to explain transport of such coarse material such distances. Certainly no similar material is being carried off the Uintas at the present time or was carried off in the recent past.

In the eastern part of the mapped area the Wasatch Formation consists chiefly of interbedded pebble to cobble conglomerate; friable poorly sorted yellow to red sandstone; and variegated gray, yellow, and red silty clay. The overall color as viewed from a distance is pale orange. Conglomerate, because of its superior resistance to erosion, is conspicuous on the outcrop but is subordinate to other rock types in total volume.

As in the Manila area, the conglomerate contains abundant pebbles and cobbles of limestone identifiable with the Paleozoic formations of the mountains, as well as sandstone and quartzite pebbles that might have been derived from any of several Paleozoic and Mesozoic formations such as, especially, the Weber, Park City, Navajo, and Entrada. In addition, some beds contain 5-10 percent red quartzite derived from the Uinta Mountain Group. During Wasatch time, therefore, the Mesozoic and Paleozoic strata of the Uinta Mountains were deeply eroded, and the Precambrian core of the range was exposed at least locally.

Relatively minor quantities of sandy lacustrine limestone occur in the Wasatch Formation at various places. Such beds on the north slope of Kleins Hill in the northeast corner of the area are interlayered with typically Wasatch fluviatile red beds but contain a fresh-water fauna of gastropods (Oxytrema or Goniabasis) and pelecypods that apparently led Schultz (1920, pl. 1) and subsequent workers to include the enclosing rocks in the Green River Formation (Tipton Tongue). Conceding the possibility, or even the probability, that these limestone beds may merge laterally eastward with the Tipton Tongue of the Green River Formation, I nevertheless included them in the Wasatch Formation because of the predominantly fluviatile character of the enclosing red beds and because of the difficulty of tracing thin individual limestone beds across the poorly exposed and in part heavily forested north slope of Kleins Hill. Similarly, limestone beds well below the main body of the Green River Formation north of Manila are included in the Wasatch because of the predominantly fluviatile, typically Wasatch-like character of the enclosing strata. Such limestone beds may be the products of rapid but short-lived expansions of the Green River lake or of smaller embayments, separate lakelets, or marshes on the Wasatch alluvial plain.

Owing to the incompleteness of the Wasatch section in the area, no effort has been made to measure its thickness. A minimum thickness of at least 2,000 feet is indicated by the width of the outcrop belt combined with the dip of the beds. At the Middle Mountain oil field a few miles north of Kleins Hill, 4,070 feet of Wasatch was penetrated by the No. 1 Unit oil well (Olson, 1955, p. 148). This thickness is exclusive of 165 feet of the Tipton Tongue of the Green River Formation and 69 feet of the overlying Cathedral Bluffs Tongue of the Wasatch. Near Manila, Anderman (1955, p. 131) measured a total thickness of 4,270 feet; this figure, however, includes beds mapped by me as Fort Union and excludes beds mapped by Anderman as Green River but by me as Wasatch.

\section{FOsBILS, AGE, AND CORRELATIONB}

Fossils are uncommon in the Wasatch Formation except in some of the interbedded lacustrine deposits, where they are abundant. A small collection from a limestone bed 270 feet below the top of the formation in the NW cor. sec. 24, T. 3 N., R. 19 E., just northwest of Manila was examined for mollusks by John B. Reeside, Jr., and for ostracodes by Raymond E. Peck. Mr. Reeside identified the gastropod Goniobasis simpsoni (Meek) and stated as follows:

With present knowledge this molluscan material cannot be placed more closely than late lower or early middle Eocene. Dr. Yen distinguishes a Wasatch from a Bridger assemblage, but it appears to me that elements of both are present in these collections. No Green River fauna, as such, has been isolated.

Mr. Peck reported as follows:

Ostracoda :

Candona sp., possibly $C$. whitei Scott and Smith or a closely related form. This ostracode has little stratigraphic significance 


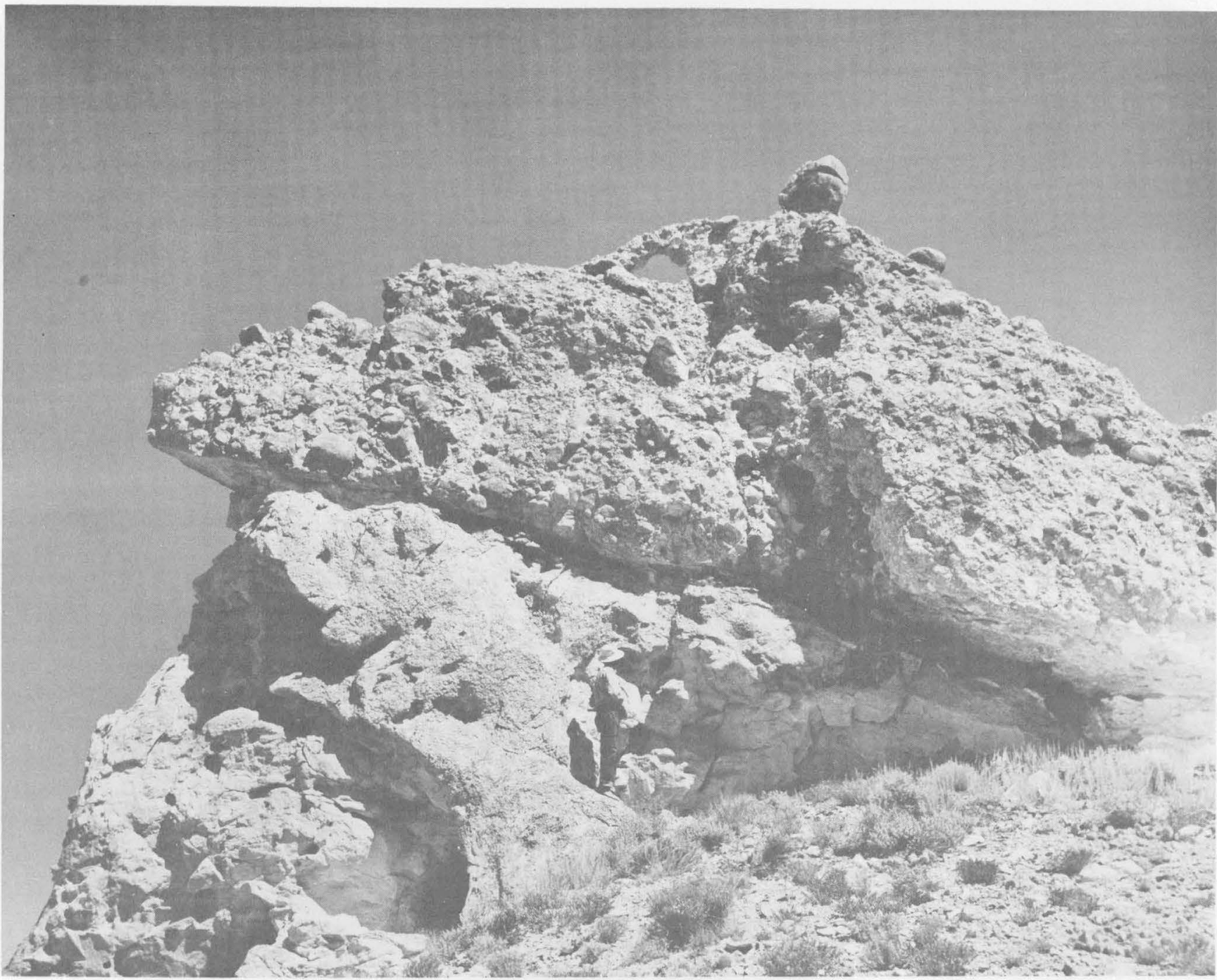

Figure 37.-Conglomeratic channel fll in Wasatch Formation northeast of Manila, Utah. Wall of channel, now sloping gently to right, was nearly vertical when cut. True bedding in light-colored sandstone below conglomerate dips steeply toward front of picture.

and ranges at least from the Paleocene through the Green River and probably higher. This form is very abundant in the sample.

Cypridea arvadensis (Swain) - relatively rare in the sample. This species ranges from the Paleocene (Flagstaff) into the lower part of the Green River and possibly into the middle Green River.

The exact stratigraphic equivalence of the Wasatch in the mapped area with that in adjacent areas is uncertain. Reconnaissance suggests that the uppermost part of the Wasatch northwest of Manila may contain beds as young as the Cathedral Bluffs Tongue of the Wasatch of areas east and north, although the Cathedral Bluffs Tongue as such, by definition, does not extend into the Manila area.

The Wasatch of the eastern part of the area-in Bender Mountain, Willow Creek Butte, and Kleins Hill-appears from reconnaissance to be older than the Cathedral Bluffs Tongue and hence correlative of the main body of the Wasatch of Sears and Bradley (1924, p. 99) or of Nightingale's Hiawatha Member (1930, p. 1023) of the Wasatch. However, the youngest part of this sequence, northeast of Kleins Hill, might conceivably be as young as some part of the Cathedral Bluffs Tongue.

\section{ENGINEERING CHARACTERISTICS}

Because of its extreme lithologic variability, the Wasatch Formation presents a wide range of engineering properties that warrant careful preliminary site examinations before any major engineering activity is undertaken on the outcrop.

Some parts of the formation are easily excavated without the use of explosives; other parts must be drilled and blasted. In general, those parts of the formation that express strong topographic relief would require the use of explosives for excavation. Such parts include the various conglomeratic and sandstone beds 
and some of the siltstones. Intricate interfingering of lithologic types means that special handling of many individual beds would be required and that specific measures required of any given cut would be difficult to prognosticate without detailed preliminary examination.

Although some clayey or silty zones have inferior strength and stability and may be plastic when wet, the greater part of the formation should be stable in moderately steep cuts-probably in cuts of as much as 2:1 (horizontal to vertical). Many beds, moreover, could be cut back nearly to vertical without fear of failure.

Clayey and silty parts of the formation are readily eroded, and in favorable topographic situations they form badlands. Sandstones and conglomerates are more resistant and form prominent, even bold, outcrops. Protection against erosion, therefore, should be provided for clayey or silty parts of the formation in exposed places near or adjacent to engineering structures, but most sandstone or conglomeratic sections need little or only precautionary protection. Clayey or silty sections should also be provided with suitable drainage works where waterlogging might be a potential engineering problem.

\section{GREEN RIVER FORMATION (EOCENE)}

The lacustrine Green River Formation crops out in the mapped area only in the extreme northwest corner, northwest of the town of Manila. From that locality, however, it extends many miles north and east in the Bridger Basin, to and beyond the type locality, along the Green River near the town of Green River, Wyo. East from Manila, but north of the mapped-area boundary, the formation is widely exposed near the Wyoming-Utah State line.

Described at length by many authors since the days of the territorial surveys, the formation was named by Hayden $(1869$, p. 89), but it is best known through the comprehensive studies of W. H. Bradley. It has become famous for its remarkably well preserved fossils, especially fish; for its vast reserves of oil shale; and, more recently, for its unusual chemistry and authigenic mineral assemblages (Jacobucci, 1955, p. 203; Milton, 1957, p. 136) and its enormously large deposits of sodium salts, some of which (trona beds) are now being mined on a large scale.

In the limited exposures northwest of Manila, only the lower beds of the formation are represented, and the lithology is not characteristic of the greater part of the formation as a whole; the mapped outcrop area covers less than 1 square mile. The rocks consist of hard dense fine-grained fossiliferous limestone interbedded with even-bedded calcareous sandstone and calcareous shale, all having an overall drab coloration. The contact with the underlying Wasatch Formation is mapped at the base of the lowest persistent limestone bed; as thus mapped, it also marks a conspicuous change from predominantly fluviatile deposits below to predominantly if not exclusively lacustrine deposits above. Mapped on this basis, the contact undoubtedly would shift temporally if extended laterally any great distance, owing to rapid interfingerings of lithologies and to the partial contemporaneity of the Wasatch and Green River Formations.

Fossils collected from the basal limestone of the Green River Formation northwest of Manila have elements of both a Wasatch and Bridger assemblage (John B. Reeside, Jr., written commun., 1953). The following forms were identified by Mr. Reeside :

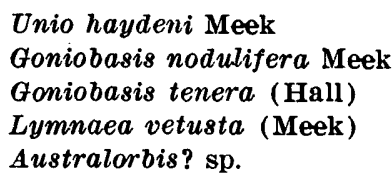

As indicated by the above fauna and by the character of the enclosing rocks, the Green River Formation northwest of Manila accumulated in slack fresh water. These data only serve to reaffirm the lacustrine origin of the formation as a whole which has been well known since the days of Hayden, Cope, King, Marsh, and Powell. West from Manila the lacustrine beds of the Green River pass rapidly into a very thick sequence of coarse conglomerate (Anderman, 1955, p. 131; American Stratigraphic Co. $\log 703,1954)$ derived from lofty mountains immediately to the south. Uplift during deposition of the formation is indicated by movement on the Henrys Fork fault and by an intraformational unconformity a few miles west of Manila (Anderman, 1955, p. 131-133).

The rather remote position of the Green River outcrop, separated as it is from Lucerne Valley by high ridges of Wasatch, and the very restricted areal extent of the outcrop seem to preclude any appreciable likelihood that the formation will become involved in any significant construction activity within the mapped area in the foreseable future. In the event that some such activity does occur, however, explosives would be needed for any excavation into firm rock; cuts would stand at steep angles without support; neither erosion nor drainage would present any special problems.

\section{BROWNS PARK FORMATION (MIOCENE?)}

Prior to the deposition of the Browns Park Formation there was a long interval of erosion, planation, drainage adjustment, and intermittent crustal unrest in the eastern Uinta Mountains. Filling of the Green River lake in Eocene time was followed immediately by deposition of the Bridger Formation. On the mar- 
gins of the lake, the Bridger Formation began to accumulate while the lake still existed, so that much of the Green River Formation, in fact, is temporally equivalent to the Bridger Formation. Remnants of the Bridger Formation are plentiful a few miles north of Manila in Wyoming, but none exists in the mapped area. Any part of the Bridger Formation that may have been deposited in the mapped area was subsequently eroded away.

In the interim, broad pediments were cut along the flanks of the mountains. The highest, oldest, most extensive, and most perfectly formed of these pediments is the Gilbert Peak surface of Oligocene or Miocene age (Bradley, 1936a, p. 163). This surface truncates rocks of all ages indiscriminately, from Bridger to Precambrian. Remnants of the Gilbert Peak surface are preserved on Goslin Mountain, Mountain Home, the Head of Cottonwood, Bender Mountain, O-Wi-YuKuts Mountain, and Cold Spring Mountain. As will be shown later, possible remnants are preserved also on Bear Mountain, on Dutch John Bench, and on adjacent smaller: unnamed hills. These remnants on the small unnamed hills were correlated by Bradley (1936a, p. 180) with his Bear Mountain erosion surface, a correlation that now seems doubtful.

In Bradley's view (1936a, p. 184), the Browns Park Formation was deposited on the Bear Mountain surface soon after the surface was formed, the basal beds perhaps as pediment gravel and the overlying deposits in response to a climatic shift and change in regimen. In many places the Browns Park Formation does indeed mantle broad remnants of pediments. In part, however, this relationship seems to be fortuitous rather than intrinsic. The formation is not confined to any single physiographic setting-its occurrence is random; it caps a pediment here, fills a valley there, or laps against a hillock somewhere else. In the Greendale, Dutch John, and Little Hole areas of Red Canyon it was deposited under highly varied conditions on a surface of sharp local relief, probably canyonlike in aspect. South of Browns Park it fills valleys along the maturely dissected main divide of the range. Heavy falls of volcanic ash from a distant unknown source, which now mantle the hillsides and clog and the valleys, were preceded and accompanied by tectonic adjustments and may have been a critical factor in triggering the shift from a degradational to an aggradational stream regimen. Thick beds of tuff, some the products of direct ash falls, others reworked by streams or winds, are principal constituents of the Browns Park Formation.

Recently reported occurrences of the Browns Park Formation (Kinney, Hansen, and Good, 1959), including those noted above, shed new light on the geomorphic history of the range and substantially modify the classic concept of Bradley. These occurrences suggest that the Green River in the Dutch John-Little Hole area flows through an exhumed canyon, that the initial course of the Green River across the Uinta Mountains was upon the Browns Park Formation, and that the Green River through Lodore Canyon is superimposed.

DISTRIBUTION AND PHYSIOGRAPHIC EXPRESSION

Named by Powell (1876, p. 44, 168), the Browns Park Formation is typically exposed in the valley of Browns Park astride the Utah-Colorado State line. From its type area the formation extends east as a continuous unbroken blanket almost to Craig, Colo. (Sears, 1924b. pl. 35), a distance west to east of about 85 miles; from Craig it extends discontinuously northward to and beyond Saratoga, Wyo. (Love, Weitz, and Hose, 1955). West from Red Creek it extends discontinuously another 30 miles or so in and along Red Canyon as detached, isolated patches and outliers. On the south slope of the Uinta Mountains, blanketlike deposits cover broad areas north of Vernal, Utah.

In the type area the Browns Park Formation is widely and well exposed, although it is concealed or veneered in many places by younger alluvium. Most, but by no means all, of the best exposures are in high bluffs along the Green River or along the lower reaches of tributaries. Along the north side of Browns Park valley the limit of outcrops is rather well defined by faulting, flexing, and erosion subsequent to deposition of the formation. Along the south side of the valley, however, the formation fills deep embayments where it extends part way up tributary valleys cut into the Uinta Mountain Group before the Browns Park was deposited.

Most of these tributary valleys, including Crouse Creek, Sears Creek, Tolivers Creek, Jackson Draw, Gorge Creek, and Cart Creek, also contain long tongueshaped remnants of Browns Park Formation in their high, headward portions south of the mapped area. These remnants have been physically separated from the main body of the formation in Browns Park by subsequent erosion that has stripped off or has cut completely through the formation into the underlying Uinta Mountain Group. Each of these tributary valleys now has a steep-inner canyon near its mouth.

The hard-rock surface on which the Browns Park Formation was deposited in its type area is highly irregular at its margins. In many places, windows, spurs, or salients of Precambrian rock protrude through the Browns Park Formation. In its present course, the Green River flows mostly near the south edge of the valley, so that many of the meanders impinge on the south valley wall, and the river has been forced to cut 
through several spurs of hard Precambrian rock. The most notable of these is Kings Point, through which the river has cut Swallow Canyon, a classic example of superposition. In such settings as this, the relationship of the Browns Park Formation to the underlying Uinta Mountain Group is made all the more striking by the tonal contrast between the billiant white tuffs of the Browns Park Formation and the somber red quartzites of the Uinta Mountain Group.

What configuration the hard-rock floor of Browns Park valley has near its axis is unknown. The deepest part of the buried valley probably coincides in a general way at least with the axis of the Browns Park syncline, which is a largely depositional structure formed chiefly by a combination of initial dip on a sloping floor of deposition, valleyward thinning of beds, and differential compaction of materials (Sears, 1924a, p. 287; Hansen, 1957a). The axis of the Browns Park syncline is far to the north of the present course of the Green River.

Westward from the type area, discontinuous remnants of the Browns Park Formation become progressively smaller, thinner, and more widely separated. At Little Hole south of Goslin Mountain, fairly extensive and rather thick remnants underlie several square miles of area at altitudes that range from river level (about $5,500 \mathrm{ft}$.) to more than 7,000 feet. These remnants, themselves now thoroughly dissected, were deposited on the sloping walls and on the floor of a deep irregular canyon which was cut well after the Gilbert Peak surface was formed. After its formation, the canyon was filled to the brim with tuff, tuffaceous sandstone, and conglomerate of the Browns Park Formation and was subsequently partly exhumed along the trend of the present-day Red Canyon.

West of Little Hole, additional remnants of the formation occur at Dutch John Flat-site of the new town of Dutch John-on Dutch John Bench above the town, on the dissected uplands west of Dutch John Draw, and above the rims of Cart Creek canyon south of the Green River. A small remnant covering perhaps 50 acres lies above the right abutment of Flaming Gorge Dam. Still farther west, remnants are well exposed in the Allen Creek-Trail Creek areas of Greendale and in the Eagle Creek drainage west of Green Lakes. In the above areas, including Little Hole, remnants of the Browns Park Formation are readily discernible even in distant views because of their rounded topographic expression and their tawny, gray, or white coloration, which sets them apart from the Uinta Mountain Group.

The westernmost outcrops of the Browns Park Formation yet known in the Red Canyon area are small conglomeratic remnants at Dowds Hole in the $\mathrm{N} 1 / 2$ sec. 29 , T. 2 N., R. 20 E. Assignment of these small remnants to the Browns Park Formation is somewhat tentative but is made from their physiographic relationships and from their physical resemblance to the more extensive deposits of the formation farther east in the Greendale-Dutch John-Little Hole areas, where more positive identification can be made.

Topographic relief on the Browns Park Formation is expressed in many ways. The dominant, most characteristic landform, especially in the type area, is a broad gently sloping erosional bench formed at various altitudes in several stages of Pleistocene planation and sharply delimited laterally by steep marginal slope: (fig. 38). Planation resulted from agencies and pror.esses that operated long after the Browns Park Formation was deposited, hence the bench as such is not a primary feature of the formation. But the easy erosibility of the formation and a flat bedding attitude contributed substantially to bench cutting and to the perfection of the bench as a landform characteristic of the Browns Park Formation. Such benches are not as well formed on the juxtaposed but more resistant Uinta Mountain Group.

All present relief features on the formation probably are erosional, although the upper flat surface in Little Hole appears to be, and conceivably could be, depositional. The surface slopes gently toward the river about parallal to the underlying bedding in the Browns Park Formation. Other considerations, such as the clearly superposed course of the Green River through Red Canyon, lead to the conclusion that the upper part of the Browns Park Formation has been removed by erosion and that its depositional top was higher than any existing remnant of the formation.

Here and there in the bluffs along the river, along the sides of many minor valleys and washes, and below the edges of terraces, the Browns Park Formation is eroded into badlands. The dissection in such tracts has a coarser texture than in badlands eroded on several other formations of the area, such as the Wasatch, Fort Union, Morrison, and Hilliard. Smoothly rounded hills and buttresses are characteristic. A few resistant tuff and conglomerate beds form slope breaks. A small but significant and instructive badland tract in the NW1/4 sec. 18, T. 2 N., R. 25. E. (Clay Basin quadrangle), is easily reached from the Clay Basin to Browns Park Road adjacent to Bake Oven Flat at the mouth of Jesse Ewing Canyon. This tract has a diverse bedrock lithology and portrays most of the characteristics noted above.

Remnants of the Browns Park Formation along Red Canyon west of the type area mostly lack distinctive 


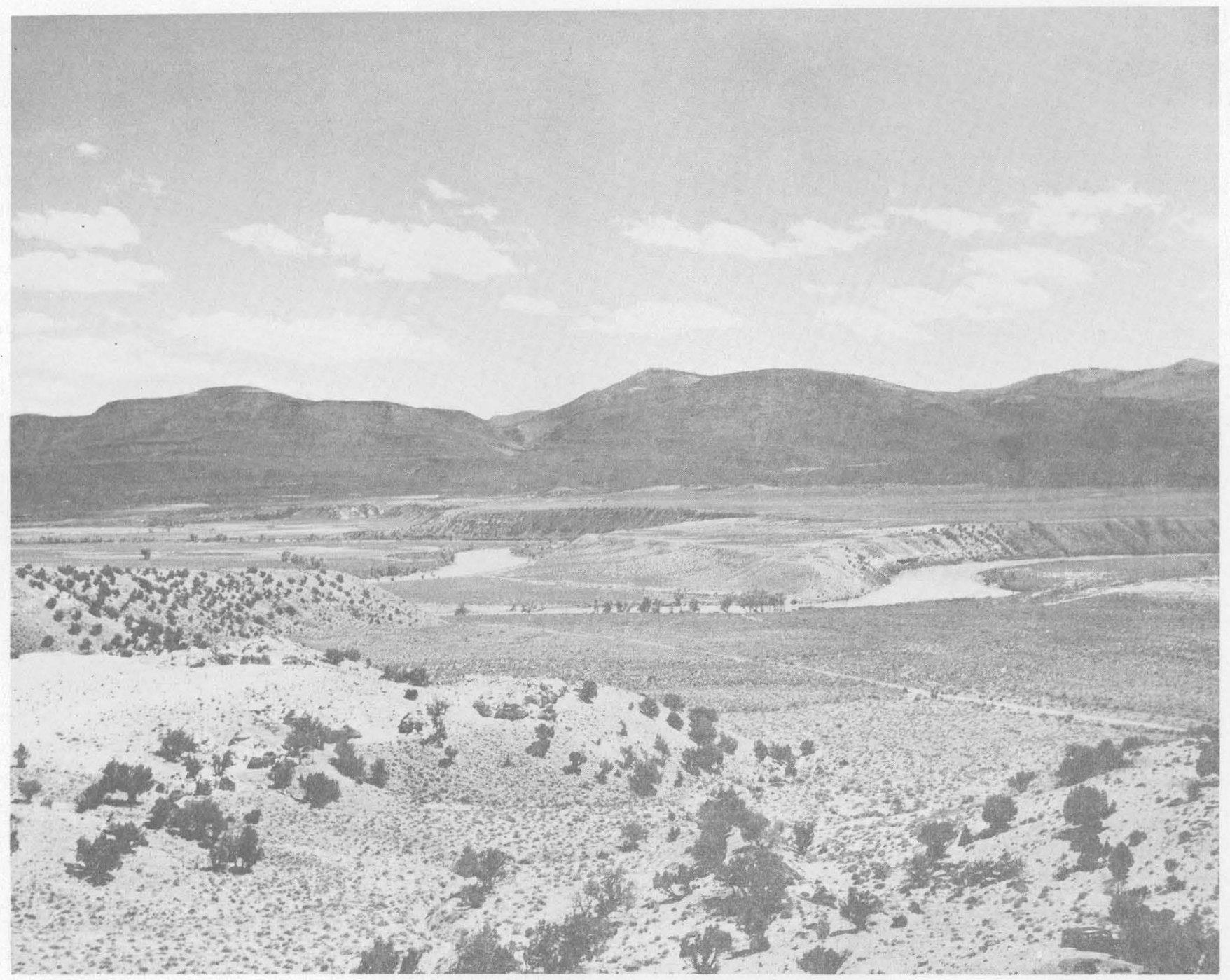

Frgure 38. - View south across Browns Park near mouth of Jesse Ewing Canyon, showing characteristic physiographic expression of Browns Park Formation (foreground and middle distance) and Uinta Mountain Group (distant hills). Light-colored material in foreground is rhyolitic tuff. Gravel-eapped Pleistocene benches in middle distance, left and across Green River. Clay Basin Road crosses Bake Oven Flat, center.

topographic expression. Their rather formless, generally subdued relief, however, distinguishes them from the sharply outlined cliff's and ledges of the Uinta Mountain Group on and against which they lie. Recent excavations for highways and gas lines in this area, especially near Dutch John and Little Hole, provide excellent exposures of these remnants not previously available for study.

\section{LITHOLOGY AND THICKNESS}

The Browns Park Formation contains rocks of diverse lithology, texture, and origin. In the type area, bedded to massive white vitric rhyolitic tuffs and lightgray tuffaceous sandstones are the most characteristic types, but congolmerates, including some exceedingly coarse, bouldery beds, are abundant or even predomi- nant locally (fig. 39). Finely laminated olive-drab clays, bentonites, pale-orange friable poorly sorted siltstones, and pale-orange fine- to coarse-grained quartzose sandstones are common minor constituents found in many exposed sections. Chalcedonic or opaline beds seemingly formed by the alteration of high-silica tuffs are found in a few places. Some clastic beds have a chalcedonic matrix. In general, tuffs predominate in stratigraphically lower sections. Conglomerates, sandstone, and clay are more abundant in higher sections.

The source of the tuffs is unknown, but most of the remaining material-at least the coarser fraction-was derived locally. Broad fans were built out intermittently from the highlands enclosing Browns Park and from the mountains south of Red Canyon; these deposits consist chiefly of pebbles and cobbles of red 
quartzite derived from the Uinta Mountain Group, but they contain occasional pebbles of limestone of Paleozoic age and, in Browns Park, many pebbles derived from the Red Creek Quartzite. From time to time the fans were buried by falls of vitric volcanic ash, some of which was reworked into tuffaceous sandstone. Periodically, much of Browns Park valley was flooded by lake waters that deposited blankets of sand and clay. The result is a complex interbedding of conglomerate, sand, tuff, and clay. The tuffs and clays retain remarkable uniformity over considerable distances, but the sands and conglomerates thin markedly from the sides of the valley toward the center.

Boulders of unusual size, some more than 15 feet in diameter, occur in the Browns Park Formation at and near the SW. corner sec. 21, T. 2.N., R. 24 E. (Clay Basin quadrangle), where the formation fills a steepsided channel cut in the Uinta Mountain Group just north of the existing trench of the Green River. These deposits pass into finer grained conglomerates which in turn interfinger with tuffaceous sandstones.

Patches of hard, well-cemented sandstone and conglomerate on and back from the rims of Red Canyon in the Little Hole, Dutch John, Greendale, Eagle Creek, and Dowds Hole areas are regarded as dissected remnants of old alluvial fans. Most if not all of the constituent material was derived from the Uinta Mountain Group. The deposits contain all textural graduations from fine-grained well-sorted sandstone to very heterogeneous bouldery conglomerate, of which the larger boulders exceed 10 feet in diameter. In the Little Hole and Dutch John areas, sandstone and conglomerate interfinger with tuffs and tuffaceous sandstone.

In overall color the sandstones and conglomerates along Red Canyon are tawny yellow to light gray. The characteristic reds and purples of the parent Uinta Mountain Group are largely bleached from the pebbles and cobbles, although some retain their parent color; others are mottled red with gray or brown, and still others have bleached shells covering fresh red cores. Calcite is the chief cementing material, and it coats most of the cobbles loosened by weathering; some of the sandstone is cemented with silica.

The tuffs themselves are of two general types-vitric and earthy. Some of the vitric tuffs are well bedded or even crossbedded, but many are wholly massive or show only the faintest lamination on the outcrop. They appear to be air-laid deposits that settled quietly from still air. Some of them, however, display crossbedding that evidently is eolian, hence they probably were reworked mildly by winds. The earthy tuffs, without exception, are well bedded, commonly in thin beds or laminae that suggest lacustrine deposition. Such a mode of deposition would help promote alteration of the glass to clay to produce the characteristic earthy texture.

To facilitate study, several vitric tuff samples were separated into density fractions by means of bromoform heavy liquid. The information thus obtained is summarized in table 3 . The several samples examined varied appreciably in their content of heavy minerals, but all samples contained the same suite of minerals with the same physical and optical characteristics. In general, hornblende is the most abundant mineral heavier than pure bromoform. Pyroxene (both augite and hypersthene), biotite, magnetite, hematite, zircon, and apatite follow in general descending order of abundance, although the proportions are variable. Samples collected for comparison from the south slope of the Uinta Mountains at Harpers Corner in Dinosaur $\mathrm{Na}$ tional Monument, Colo., and at Diamond Mountain north of Vernal. contain predominant biotite but also contain the other heavy minerals in about the same proportions as above. In addition, most of the samples contain a few anhedral grains of garnet.

Shapes of the heavy-mineral grains indicate a magmatic rather than a detrital origin for the heavy fraction, except perhaps the garnet. Many grains are euhedral, subhedral, or splintery forms that could not sustain the abrasion of an erosion cycle. Some of the pyroxenes, especially, have fragile ragged terminations that would be destroyed readily by abrasion. Some grains also may be seen adhering to or entrapped in glass. Even subrounded grains have been found entrapped in glass, a condition that suggests partial magmatic resorption rather than abrasion by reworking as the cause of rounding.

A heavier-than-glass fraction, separated by means of dilute bromoform, consists chiefly of quartz and feldspar but contains considerable detrital chert. Some of the quartz and feldspar appears to be detrital also. Contamination of the airborne ash by windblown dust probably accounts for detrital quartz, feldspar, and chert.

The lightweight fraction separated from samples collected in Browns Park and Dutch John Flat consists almost exclusively of glass shards, the characteristics of which are outlined in table 3. Comparative samples from Harpers Corner and Diamond Mountain contain abundant granules of hard clay. In general, the shards are fresh, angular, and vitreous. They consist chiefly of simple planar or gently curved forms that contain very few second-order vesicles. Complex shards are limited mostly to the larger fragments which range in size from about $0.25 \mathrm{~mm}$ to $0.4 \mathrm{~mm}$. Simple linear bubble junctures also predominate over curved or complex ones. In total weight and volume, the lightweight glassy fraction far exceeds the combined heavier-than- 
TABLE 3.-Summary description of selected tuff samples, Browns Park Formation

\begin{tabular}{|c|c|c|c|c|c|c|}
\hline $\begin{array}{l}\text { Sample } \\
\text { and } \\
\text { locality }\end{array}$ & $\begin{array}{l}\text { Lithologic } \\
\text { description }\end{array}$ & Shard characteristics & Shard size & $\begin{array}{l}\text { Heavy-mineral separation } \\
(>2.86 \mathrm{sp} \mathrm{gr})\end{array}$ & $\begin{array}{l}\text { Material of intermediate } \\
\text { specific gravity } \\
\quad(>2.39,<2.86)\end{array}$ & Remarks \\
\hline $\begin{array}{l}\text { 194-3 } \\
\text { Browns } \\
\text { Park. }\end{array}$ & $\begin{array}{l}\text { Tuff, vitric, very } \\
\text { flne grained, fri- } \\
\text { able, light-gray } \\
\text { to light-yellow- } \\
\text { ish-gray (about } \\
5 Y \text { 8/2). }\end{array}$ & $\begin{array}{l}\text { Mostly flat, but some curved } \\
\text { or tubular; pumiceous. } \\
\text { Elongate junctures com- } \\
\text { mon; a few complex shards } \\
\text { with recurved junctures. }\end{array}$ & $\begin{array}{l}\text { Many shards } 0.1- \\
0.25 \text { mm. } \\
\text { Maximum size } \\
\text { about } 0.4 \mathrm{~mm} . \\
\text { Shards thicker } \\
\text { than those of } \\
194-8 \text { or } 194-12 .\end{array}$ & $\begin{array}{l}\text { Hornblende, abundant; rag- } \\
\text { ged terminations; in part } \\
\text { euhedral. } \\
\text { Augite, abundant; ragged ter- } \\
\text { minations. } \\
\text { Hematite after magnetite. } \\
\text { Magnetite, rare. } \\
\text { Biotite, rare. } \\
\text { Garnets, occasional, anhedral. } \\
\text { Apatite, zircon, euhedral. }\end{array}$ & $\begin{array}{l}\text { Less than } 10 \text { percent of total } \\
\text { sample volume. } \\
\text { Grains mostly 0.1-0.25 mm.-- } \\
\text { Fraction contains quartz, } \\
\text { potassic feldspar, plagio- } \\
\text { clase, and chert. Some of } \\
\text { quartz and feldspar is } \\
\text { phenocrystic, some detri- } \\
\text { tal. }\end{array}$ & $\begin{array}{l}\text { Small heavy-mineral } \\
\text { fraction. } \\
\text { Zircon attached to } \\
\text { glass. }\end{array}$ \\
\hline $\begin{array}{c}\text { 194-7 } \\
\text { Browns } \\
\text { Park. }\end{array}$ & $\begin{array}{l}\text { Tuff, vitric, very } \\
\text { fine gralned, fri- } \\
\text { able, yellowish- } \\
\text { gray (about } 5 Y \\
7 / 2 \text { ). }\end{array}$ & $\begin{array}{l}\text { Flat shards predominate, } \\
\text { many striated by multiple } \\
\text { parallel junctures. } \\
\text { A fow complex shards in } \\
\text { larger size range. } \\
\text { Rare second-order vesicles. } \\
\text { Occasional grain of tubular } \\
\text { pumice. } \\
\text { Many shards "pitted" or } \\
\text { "frosted." }\end{array}$ & $\begin{array}{l}\text { Commonly } 0.05- \\
0.1 \mathrm{~mm} . \\
\text { Maximum size } \\
\text { about } 0.4 \mathrm{~mm} .\end{array}$ & $\begin{array}{l}\text { Most heavy minerals rounded } \\
\text { or subrounded. } \\
\text { orthopyroxene, abundant, } \\
\text { pale green; some with rag- } \\
\text { ged terminations. } \\
\text { Hornblende, abundant, green } \\
\text { to reddish-brown; some } \\
\text { splintery or euhedral. } \\
\text { Magnetite, abundant. } \\
\text { Augite. } \\
\text { Nematite after magnetite. } \\
\text { Biotite, sparse. } \\
\text { Zircon, euhedral. } \\
\text { Apatite, euhedral. }\end{array}$ & $\begin{array}{l}\text { About } 15 \text { percent of total } \\
\text { sample volume. } \\
\text { Quart, plagioclase, and } \\
\text { chert, mostly subrounded. } \\
\text { Grains mostly } 0.1-0.25 \mathrm{~mm} \text {. }\end{array}$ & $\begin{array}{l}\text { Much of zircon and } \\
\text { apatite partly en- } \\
\text { closed by glass. } \\
\text { Some orthopyroxene } \\
\text { adhering to glass. } \\
\text { Much of quartz and } \\
\text { chert probably detri- } \\
\text { tal. }\end{array}$ \\
\hline $\begin{array}{l}\text { 194-8 } \\
\text { Browns } \\
\text { Park. }\end{array}$ & $\begin{array}{l}\text { Tuff, vitric, very } \\
\text { fine grained, fri- } \\
\text { able, light-yel- } \\
\text { lowish-gray } \\
\text { (about } 6 \text { Y 8/2). } \\
\end{array}$ & $\begin{array}{l}\text { Shards mostly simple, flat, } \\
\text { or gently curved. } \\
\text { Linear junctures common. } \\
\text { Rare second-order vesicles. }\end{array}$ & $\begin{array}{l}\text { Commonly } 0.05- \\
0.1 \mathrm{~mm} \text {. } \\
\text { Maximum size } \\
\text { about } 0.25 \mathrm{~mm} .\end{array}$ & $\begin{array}{l}\text { Hornblende, abundant, some } \\
\text { euhedral. } \\
\text { Orthopyroxene, abundant, } \\
\text { green; ragged terminations. } \\
\text { Blotite, abundant. } \\
\text { Augite. } \\
\text { Zircon, abundant, euhedral. } \\
\text { Apatite, euhedral. } \\
\text { Garnet, rare. }\end{array}$ & $\begin{array}{l}\text { Less than } 1 \text { percent of total } \\
\text { sample volume. } \\
\text { Quartz and feldspar mostly } \\
\text { angular, some subhedral. } \\
\text { Mostly about } 0.1 \mathrm{~mm} \text {. }\end{array}$ & $\begin{array}{l}\text { Very small heavy- } \\
\text { mineral fraction. } \\
\text { Some hornblende ad- } \\
\text { hering to glass. } \\
\text { Zircon enclosed in } \\
\text { glass. } \\
\text { Apatite enclosed in } \\
\text { glass. }\end{array}$ \\
\hline $\begin{array}{l}\text { 194-12 } \\
\text { Browns } \\
\text { Park.1 }\end{array}$ & $\begin{array}{l}\text { Tuff, vitric, very } \\
\text { fine grained, } \\
\text { friable, light- } \\
\text { gray }(N 7) \text { to } \\
\text { light-yellowish- } \\
\text { gray (about } 5 Y \\
8 / 2) \text {. }\end{array}$ & $\begin{array}{l}\text { Simple flattish shards } \\
\text { mostly thin, occasionally } \\
\text { iridescent. } \\
\text { Mostly linear junctures in } \\
\text { coarser shards; junctures } \\
\text { rare in finer shards. } \\
\text { Rare second-order vesicles. } \\
\text { Rare tubular pumice. }\end{array}$ & $\begin{array}{l}\text { Commonly } 0.1- \\
0.25 \mathrm{~mm} . \\
\text { Maximum size } \\
\text { about } 0.4 \mathrm{~mm} \text {. }\end{array}$ & $\begin{array}{l}\text { Hornblende, abundant, green } \\
\text { to brown; in part euhedral. } \\
\text { Biotite, abundant. } \\
\text { Orthop yroxene, abundant, } \\
\text { pale green; in part euhedral. } \\
\text { Magnetite. } \\
\text { Hematite after magnetite. } \\
\text { Zircon, euhedral. } \\
\text { Apatite, euhedral. }\end{array}$ & $\begin{array}{l}\text { Less than } 5 \text { percent of total } \\
\text { sample volume. } \\
\text { Quart } 2 \text { in crystals and } \\
\text { rounded grains. } \\
\text { Oligoclase and microcline } \\
\text { in crystals and rounded } \\
\text { grains. } \\
\text { Chert in rounded grains. } \\
\text { Grains mostly } 0.1-0.25 \mathrm{~mm} \text {. }\end{array}$ & $\begin{array}{l}\text { Magnetite adhering to } \\
\text { glass. } \\
\text { Zircon enclosed in } \\
\text { glass. }\end{array}$ \\
\hline $\begin{array}{l}\text { 194-13 } \\
\text { Dutch } \\
\text { John } \\
\text { Flat. }\end{array}$ & $\begin{array}{l}\text { Tuff, vitric, very } \\
\text { flne grained, } \\
\text { friable, white. } \\
\text { Sample Is much } \\
\text { finer grained } \\
\text { than any of } \\
\text { above. }\end{array}$ & $\begin{array}{l}\text { Coarser complex shards, } \\
\text { many second-order vesi- } \\
\text { cles, complex junctures, } \\
\text { tubular pumice fragments. } \\
\text { Fine simple and flat shards. }\end{array}$ & $\begin{array}{l}\text { Mostly smaller } \\
\text { than } 0.05 \mathrm{~mm} \text {. } \\
\text { All but about } 5 \\
\text { percent pass } \\
\text { through 200- } \\
\text { mesh sleve. }\end{array}$ & $\begin{array}{l}\text { Hornblende, abundant. } \\
\text { Pyroxene, abundant, green } \\
\text { (hypersthene and augite } \\
\text { with ragged terminations; } \\
\text { in part euhedral. } \\
\text { Biotite. } \\
\text { Magnetite. } \\
\text { Hemstite. } \\
\text { Zircon, euhedral. } \\
\text { Apatite, euhedral. } \\
\text { Garnet, rare, anhedral. }\end{array}$ & $\begin{array}{l}\text { About } 2 \text { percent of total } \\
\text { sample volume. } \\
\text { Quartz, oligoclase, chert. } \\
\text { Considerable biotite re- } \\
\text { tained in this fraction. } \\
\text { Grains mostly } 0.1-0.25 \mathrm{~mm} \text {. }\end{array}$ & $\begin{array}{l}\text { Small heavy-mineral } \\
\text { fraction. } \\
\text { Biotite adhering to } \\
\text { glass. } \\
\text { Hypersthene adhering } \\
\text { to glass. } \\
\text { Apatite and zircon en- } \\
\text { closed in glass. } \\
\text { Hornblende adhering } \\
\text { to glass. }\end{array}$ \\
\hline $\begin{array}{l}\text { Dlamond } \\
\text { Moun- } \\
\text { taln. }\end{array}$ & $\begin{array}{l}\text { Crystal tuff, } \\
\text { light-gray, com- } \\
\text { pact, flrm; } \\
\text { abundant } \\
\text { megascopic } \\
\text { blotite. }\end{array}$ & $\begin{array}{l}\text { Shards curved; second-order } \\
\text { vesicles common to abun- } \\
\text { dant, round; in part pumi- } \\
\text { ceous. Partly altered to } \\
\text { clay. }\end{array}$ & $\begin{array}{l}\text { Mostly about } 0.25 \\
\text { mm. }\end{array}$ & $\begin{array}{l}\text { Biotite, abundant, euhedral. } \\
\text { Hornblende, a bundant, } \\
\text { brown and green; in part } \\
\text { euhedral. } \\
\text { Augite, euhedral. } \\
\text { Magnetite, euhedral. } \\
\text { Zircon, euhedral. }\end{array}$ & $\begin{array}{l}\text { Crystal fragments of quartz } \\
\text { and feldspar. } \\
\text { Aggregates of clay and } \\
\text { crystals. }\end{array}$ & $\begin{array}{l}\text { Large heavy-mineral } \\
\text { fraction. } \\
\text { Much of biotite } \\
\text { coarser than } 0.5 \mathrm{~mm} \text {. } \\
\text { Zircon inclusions com- } \\
\text { mon in feldspar. } \\
\text { Hornblende adhering } \\
\text { to glass. } \\
\text { Magnetite adhering } \\
\text { to glass. }\end{array}$ \\
\hline $\begin{array}{l}\text { Harpers } \\
\text { Corner. }\end{array}$ & $\begin{array}{l}\text { Tuff, altered, } \\
\text { clayey, me- } \\
\text { dium-light-gray } \\
(N 6) \text {, compact, } \\
\text { firm; abundant } \\
\text { megascopic bio- } \\
\text { tite; finer } \\
\text { grained than } \\
\text { Diamond } \\
\text { Mountain } \\
\text { sample. }\end{array}$ & $\begin{array}{l}\text { Shards mostly altered to } \\
\text { clay. }\end{array}$ & Not determined... & $\begin{array}{l}\text { Biotite, abundant, euhedral. } \\
\text { Hornblende, abundant, dark } \\
\text { green. } \\
\text { Pyroxene, green, euhedral. } \\
\text { Magnetite. } \\
\text { Zircon, euhedral. } \\
\text { Apatite, euhedral and an- } \\
\text { hedral. }\end{array}$ & $\begin{array}{l}\text { Aggregates of clay, quartz, } \\
\text { feldspar, and heavy min- } \\
\text { erals. }\end{array}$ & $\begin{array}{l}\text { Disaggregated with } \\
\text { difficulty in ultra- } \\
\text { sonic transducer. } \\
\text { zircon attached to } \\
\text { glass. }\end{array}$ \\
\hline
\end{tabular}

1 Bee measured section B-2.

glass and heavier-than-bromoform fraction. One sample contains more than 99 percent glass shards.

Five samples of vitric tuff described in table 3 were analyzed chemically to determine the percentages of major constituents and were analyzed spectrographically to determine semiquantitatively the percentages of minor elements. Also analyzed was a sample of sandy vitric tuff, 194-2, contaminated with silica sand and possibly reworked before final deposition. Results of these analyses are shown in tables 4 and 5. Chemical analyses were made by rapid methods similar to those described by Shapiro and Brannock (1956). These analyses indicate that all six samples are rhyolitic in composition and that all the samples except 194-2 have 
TABLE 4.-Rapid rock analyses, in weight percent, of tuffs, Browns Park Formation, Utah

[Sample 194-13 collected at Dutch John Flat: all others collected in Browns Park in measured section B-2. All are vitric tuffs except 194-2, which is a sandy vitric Botts, and M. D. Mack]

\begin{tabular}{|c|c|c|c|c|c|c|}
\hline Sample & 194-2 & 194-3 & $194-7$ & $194-8$ & $194-12$ & $194-13$ \\
\hline $\begin{array}{l}\mathrm{SIO}_{2} \\
\mathrm{Al}_{2} \mathrm{O}_{3} \\
\mathrm{Fe}_{2} \mathrm{O}_{8} \\
\mathrm{FeO} \\
\mathrm{MgO} \\
\mathrm{CgO} \\
\mathrm{Na}_{3} \mathrm{O} \\
\mathrm{K}_{8} \mathrm{O}_{2} \\
\mathrm{H}_{2} \mathrm{O} \\
\mathrm{THO}_{2} \\
\mathrm{P}_{8} \mathrm{O}_{8} \\
\mathrm{MnO} \\
\mathrm{CO}_{2}\end{array}$ & $\begin{array}{c}79.2 \\
9.4 \\
.8 \\
.86 \\
.66 \\
1.4 \\
1.7 \\
2.6 \\
2.5 \\
.28 \\
.05 \\
.06 \\
.06\end{array}$ & $\begin{array}{l}71.9 \\
11.1 \\
1.0 \\
1.1 \\
.57 \\
.80 \\
2.3 \\
5.1 \\
5.1 \\
.32 \\
.04 \\
.04 \\
.06\end{array}$ & $\begin{array}{r}73.2 \\
11.3 \\
.8 \\
1.1 \\
.44 \\
1.0 \\
1.9 \\
4.8 \\
4.5 \\
.34 \\
.05 \\
.04 \\
.06\end{array}$ & $\begin{array}{c}70.6 \\
11.7 \\
.9 \\
1.3 \\
.34 \\
.74 \\
1.9 \\
5.6 \\
5.5 \\
.36 \\
.04 \\
.05 \\
<.05\end{array}$ & $\begin{array}{r}72.1 \\
11.5 \\
.9 \\
1.2 \\
.61 \\
.94 \\
1.9 \\
5.2 \\
5.1 \\
.36 \\
.05 \\
.05 \\
.10\end{array}$ & $\begin{array}{r}70.2 \\
12.6 \\
.6 \\
.40 \\
.44 \\
1.3 \\
2.5 \\
5.6 \\
5.4 \\
.14 \\
.05 \\
.09 \\
.54\end{array}$ \\
\hline Total.... & 100 & 99 & 100 & 99 & 100 & 100 \\
\hline
\end{tabular}

high potash content. Siliceous contamination of sample 194-2 is indicated by a silica content several percent higher than that of any other sample and by correspondingly lower alumina, water, and potash contents. Most minor elements show essential agreement in all six samples. Lanthanum, however, was undetected in samples 194-2 and 194-13, although it was abundant in the other samples; yttrium and zirconium were proportionately scarce in sample 194-13; yttrium was proportionately abundant in sample $\mid 194-12$; molybdenum was proportionately abundant in sample 194-3.

The clays of the Browns Park Formation, as might be expected from their largely volcanic origin, are bentonitic and commonly swell on wetting and shrink on drying. Four samples of clay collected at widely separated localities in the Browns Park Formation were subjected to X-ray analysis to determined mineral content. All four samples showed patterns characteristic of montmorillonite. One sample also showed a pattern characteristic of dolomite and mica; another of minor quartz. Results of these analyses are tabulated as follows:

\begin{tabular}{|c|c|c|c|}
\hline \multirow[b]{2}{*}{ Sample } & \multicolumn{2}{|c|}{ [A. J. Gude 3d, analyst] } & \multirow{2}{*}{$\begin{array}{l}\text { Mineral identifi- } \\
\text { cation }\end{array}$} \\
\hline & Location & Field designation & \\
\hline DH-1 $\ldots$ & $\begin{array}{l}\text { Devils Hole near Green River } \\
\text { in SW } 1 / 4 \mathrm{NE} 1 / 4 \text { sec. } 14, \text { T. } 2 \\
\text { N., R. } 23 \mathrm{E} \text {. }\end{array}$ & Bentonite....... & $\begin{array}{l}\text { Montmorillonite, } \\
\text { minor quartz. }\end{array}$ \\
\hline $194-1$ & $\begin{array}{l}\text { Unit } 20 \text { measured section B-2, } \\
\text { SE1/4SE1/4 sec. 2, T. } 1 \text { N., } \\
\text { R. } 25 \text { E. }\end{array}$ & $\begin{array}{l}\text { White earthy } \\
\text { tuff. }\end{array}$ & $\begin{array}{l}\text { Dolomite, mont- } \\
\text { morillonite, mica. }\end{array}$ \\
\hline $16454 \ldots$ & $\begin{array}{l}\text { Cottonwood Draw near basal } \\
\text { contact of Browns Park } \\
\text { Formation, SEY/4 sec. 8, T.2 } \\
\text { N., R. 25 E. }\end{array}$ & Bentonitic tuff. & Montmorillonite. \\
\hline B-14-11. & $\begin{array}{l}\text { Unit } 11 \text { measured section B- } \\
14, \text { NW1/4 sec. } 18, \text { T. } 2 \text { N., } \\
\text { R. } 25 \text { E. }\end{array}$ & Bentonite...... & Montmorillonite. \\
\hline
\end{tabular}

Some understanding of the vertical and lateral lithologic variations in the Browns Park Formation can be had from the examination of several stratigraphic sections measured at favorably exposed localities in Browns Park (pl. 3). None of the following sections is complete, in that beds higher and lower are excluded owing to concealment or truncation. The absolute base of the formation is some depth-possibly hundreds of
TABLE E.-Semiquantitative spectrographic analyses of tuffs, Browns Park Formation, Utah

Figures are reported, in percent, to the nearest number in the series 10 (for example, $3,1,0.3) ; 80$ percent of the reported results may be expected to agree with the result
of quantitative methods: number, less than number shown-here standard sensitivities do detected; < with ple 194-13 collected at Dutch John Flat; all others collected in Browns Park at measured section B-2. All are vitric tuffs except 194-2, which is a sandy vitric tuff. Analyst, Katherine V. Hazel]

\begin{tabular}{|c|c|c|c|c|c|c|}
\hline Sample_.......... & $194-2$ & $194-3$ & $194-7$ & $194-8$ & $194-12$ & $194-13$ \\
\hline $\begin{array}{l}\mathrm{Ag} \\
\mathrm{As}\end{array}$ & 0.00001 & $\begin{array}{r}0.00001 \\
0\end{array}$ & 0.00001 & 0.0001 & $\begin{array}{r}0.0001 \\
0\end{array}$ & 0000 \\
\hline
\end{tabular}

$\mathrm{Ba}$

Ci.

Co...

Cr.

Er

Er

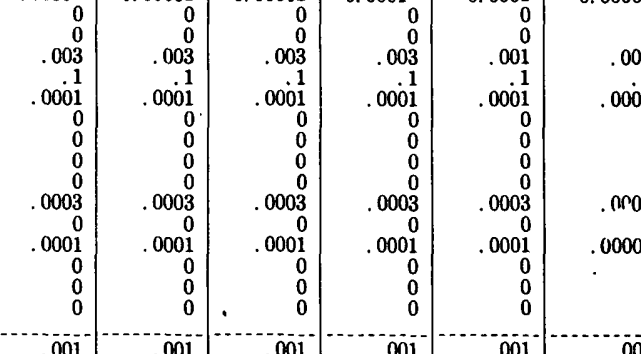

Gd.

Ge.-

$\mathrm{Hg}$

In

Li.

Lu..

$\mathrm{Nb}$

$\mathrm{Nd}$

Os...

$\mathrm{Pd}$ Pr.

$\mathrm{Rt}$.

Rh.

$\mathrm{Ru}$

Sc-

$\mathrm{Sr} . .$.

Ta..

Th..........

Tm

$\mathrm{V}$

$\mathrm{YH}$

$\mathrm{Zn}$

$\mathrm{Zr}$

\begin{tabular}{|c|c|c|c|c|c|}
\hline .001 & .001 & .001 & .001 & .001 & .00 \\
\hline & & 0 & 0 & $\begin{array}{l}0 \\
0 \\
0\end{array}$ & \\
\hline 0 & $\begin{array}{l}0 \\
0\end{array}$ & $\begin{array}{l}0 \\
0\end{array}$ & ${ }_{0}^{0}$ & $\begin{array}{l}0 \\
0 \\
0\end{array}$ & \\
\hline 0 & 0 & 0 & 0 & 0 & \\
\hline & 0 & 0 & 0 & $\begin{array}{l}0 \\
0 \\
0\end{array}$ & \\
\hline 0 & 0 & 0 & $\begin{array}{l}0 \\
0\end{array}$ & 0 & \\
\hline 0 & .01 & .01 & .01 & 01 & \\
\hline & 0 & $\begin{array}{l}0 \\
0\end{array}$ & 0 & 0 & \\
\hline $\begin{array}{r}0 \\
.001\end{array}$ & $\begin{array}{l}.01 \\
.003\end{array}$ & $\begin{array}{r}0 \\
.003\end{array}$ & $\begin{array}{r}0 \\
003\end{array}$ & $\begin{array}{r}0 \\
003\end{array}$ & \\
\hline 0 & 0 & 0 & 0 & $\begin{array}{r}.003 \\
0.023\end{array}$ & \\
\hline 0 & 0 & .0 & 0 & $\begin{array}{r}.000 s \\
0\end{array}$ & \\
\hline $\begin{array}{r}.001 \\
0\end{array}$ & .001 & .001 & $\begin{array}{r}.003 \\
0\end{array}$ & .001 & \\
\hline & 0 & 0 & 0 & 0 & \\
\hline 0 & 0 & 0 & 0 & 0 & \\
\hline & 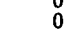 & 0 & 0 & 0 & \\
\hline & $\begin{array}{l}0 \\
0 \\
0\end{array}$ & 0 & 0 & $\begin{array}{l}0 \\
0\end{array}$ & \\
\hline .0003 & .0003 & .0003 & .0003 & .0003 & \\
\hline . 0003 & .0003 & .0003 & .0003 & .0003 & \\
\hline & $\begin{array}{r}.05 \\
0\end{array}$ & $\begin{array}{r}.03 \\
0\end{array}$ & $\begin{array}{r}.03 \\
0\end{array}$ & $\begin{array}{r}0.5 \\
0\end{array}$ & \\
\hline 0 & $\begin{array}{l}0 \\
0 \\
0\end{array}$ & $\begin{array}{l}0 \\
0 \\
0\end{array}$ & $\begin{array}{l}0 \\
0\end{array}$ & $\begin{array}{l}0 \\
0\end{array}$ & \\
\hline & 0 & 0 & 0 & $\begin{array}{l}0 \\
0 \\
0\end{array}$ & \\
\hline 0 & 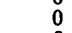 & 0 & 0 & 0 & \\
\hline & 0 & & 0 & 0 & \\
\hline .001 & .001 & .0003 & .001 & .001 & .00 \\
\hline $\begin{array}{r}0 \\
.001\end{array}$ & $\begin{array}{r}.003 \\
\end{array}$ & .003 & .003 & .01 & $<.0$ \\
\hline .0001 & .0003 & .0003 & .0003 & .001 & \\
\hline .01 & $\begin{array}{l}0 \\
.03\end{array}$ & .03 & .03 & $\begin{array}{l}.03 \\
.03\end{array}$ & \\
\hline
\end{tabular}

feet-below the level of the Green River in Browns Park, and the top of the formation is an erosional surface generally capped with alluvium.

Partial section B-1 of the Browns Park Formation in the bluffs north of the Green River approximately opposite the mouth of Crouse Creek, in the $S E 1 / 4 N E 1 / 4$ sec. 3, T. 1 N., R. $25 \mathrm{E}$.

[Measured by M. G. Bonilla, May 18, 1954. Thicknesses estlmated] Unit

Feet

Erosional bench, top of section.

Browns Park Formation:

A Gravel and sand, poorly sorted. Lower $5 \mathrm{ft}$. cemented, firm, forms overhang. Cobbles and boulders derived chiefly from Uinta Mountain Group. Other exposures show low-angle crossbedding and sandstone instead of gravel. Altitude at base about 5,520 ft." Base truncates bed below 

Unit

Browns Park Formation-Continued

B

Tuff, medium-light-gray, finely laminated, friable. By contrast with tuffs below, looks darker than indicated value on color chart. At 3-5 $\mathrm{ft}$ below top is 6 -in. bed of yellowish-gray $(5 Y$ 8/1) massive brittle altered tuff which parts parallel to bedding and has conchoidal fracture. Tuff beloiv is coarsely laminated.

$\mathrm{C}$

Tuft, yellowish:gray ( $5 Y 8 / 1$ ) to white, finegrained, friable, laminated ; orange pink on some joint surfaces

D

Tuff, yellowish-gray, fine-grained, friable, massive; locally nonexistent. Probably correlates with unit 13, section B-2

E

Tuff, friable, finely and distinctly laminated. Laminations not visible on some large joint faces. Color varies downward from yellowish gray to light gray. Many laminae dark yellowish orange, some white. Upper 6 in. or so is convoluted by penecontemporaneous deformation

Total $48+$

Alluvium, base of section.

The following section, B-2, was measured 1 mile east of $\mathrm{B}-1$, in the $\mathrm{SE} 1 / 4 \mathrm{SE} 1 / 4$ sec. 2 , T. 1 N., R. 25 E. Numbered samples collected from this section have been analyzed chemically, spectrographically, and petrographically, as shown in tables 3,4 , and 5 .

Section B-2 of the Browns Park Formation in the SE1/4 SE1/4 sec. 2, T. 1 N., R. $25 \mathrm{E}$.

[Measured by M. G. Bonllia, May 18, 1954]

Unit

Terrace gravel, top of section:

Contains cobbles and boulders as much as 2 ft in diameter derived mostly from Uinta Mountain Group. Sand 3-4 ft thick at base may belong to Browns Park Formation

Browns Park Formation :

1 Tuff, very light gray, light-gray, and paleolive $(10 Y 6 / 2)$, sandy, firm to friable. Mostly covered

2 Sandstone, medium-grained, loose to friable to firm, well-rounded but poorly sorted; yellowish gray but in part dark yellowish orange. Poorly exposed.

3 Tuff, very light gray to light-gray, friable to firm. Some layers weather to firm hard plates. Forms slope of about $35^{\circ}$; mostly covered.

4 Tuff, light-gray, fine-grained, friable, finely laminated. Limonitic spots along many laminae. Small-scale contortions of some layers, mostly sharp anticlines. Lowest 5 in. massive

$5 \quad$ Tuff, yellowish-gray (5Y 8/1), very fine grained, sandy, firm, brittle. Lower part forms paper-thin plates; middle section

\section{Browns Park Formation-Continued} Unit

parts less readily but has irregular fracture; upper part laminated but lacks parting.

6 Tuff, light-gray, fine-grained, firm. Parts into plates one-eighth inch thick or less. Hard aphanitic tuff in irregular 2-in. layer at top. Just below top layer is 6-in. zone of sandy tuff that has irregular fracture which crosses bedding.

7 Covered slope mantled with slabs of lightgray tuff. Probably alternate layers of hard and soft tuff

8 Tuff light-gray, fine-grained, friable, laminated and contorted. Thick white bands and thin yellowish-orange bands.

9 Tuff, light-gray, friable, sandy. Looks massive but has discontinuous banding made visible by limonitic staining. Many small hard nodules. Sample 194-7 collected in lower two-thirds of unit; sample 194-8 collected in upper third. Units 9-15 form cliff.

Tuff, light-gray, fine-grained, firm to friable, finely laminated. Upper 3-6 in. contorted locally. May be equivalent to upper part of unit B, section B-1

11 Tuff, yellowish-gray (5Y 8/1), fine-grained, massive, firm, brittle. Parts parallel to bedding. Possibly equivalent to middle part of unit B, section B-1, but coarser grained.

Tuff, light-gray, fine-grained; friable to firm, finely laminated. Laminations slightly wavy

light gray, fine-grained, frlable, vitric. Fine laminations of alternate white and light-gray layers. Laminae form smali open penecontemporaneous synclines. Unit correlated probably with unit $D$ and upper part of unit $E$, section B-1.

Tuff, light-gray, fine, friable. Appears massive but has fine indistinct laminations. Laminations wavy in places. At base of unit is a layer about 8 in. thick of brecciated aphanitic white stuff containing scattered subrounded sand grains. Local channeling near middle of unit. Uppermost $2 \mathrm{ft}$. of unit finer grained, firm, somewhat brittle. Sample 194-12 collected from lower part of unit. Unconformable on unit below

Tuff, firm to hard to brittle, aphanitic; white layers as much as 5 in. thick separated by thinner layers of pale-olive firm tuffaceous sandstone. A layer of friable fine-grained sandstone $1 \mathrm{ft}$. thick $1 \mathrm{ft}$. above base 
Browns Park Formation-Continued Unit

casional dark yellowish orange laminations. Bottom of unit marked by thin hard light-brown or moderate-brown ( $5 Y R$ 4/4) layer a few inches thick. Unit as whole forms covered slope

Tuff, light-gray, fine-grained, banded, friable to loose; very light gray to white toward top. Thin hard zones that weather to form slabs. Contact with overlying unit indefinite.

18

Mostly covered. Forms dusty slope. Chiefly friable sandstone, tuffaceous sandstone, and sandy tuff. Sample 194-3 collected about $10 \mathrm{ft}$ above base...-..-..-..-.

19

Sandstone, pale-yellowish-brown $(10 Y R 6 / 2)$, friable to loose, fine-grained, moderately well sorted, tuffaceous. Forms moist zone on hillside characterized by alkali efflorescence and salt grass. Forms small bench. Poorly exposed. May be thinner than measured. Sample 194-2.-...-...---

Covered but probably mostly tuff. Thin plates of tuff on slope. Near middle of slope is dark-yellowish-brown to darkyellowish-orange sand zone a few feet thick Sample 194-1

Total $\frac{36}{269} \frac{0}{2+}$

Water surface of the Green River, base of section.

The friable tuffs described in the above sections have a very loose texture and a very low bulk density and are easily crushed between the fingers. Most of the tuffs, especially the more massively bedded ones, appear to be air-laid deposits that accumulated directly as fallout from clouds of volcanic ash. Petrographic examination of the shards and the heavy-mineral fraction supports such a conclusion. The shards are fresh, angular, and vitreous. Many of the heavy-mineral grains are euhedral, splintery, or ragged-terminated forms that could not have withstood the abrasive action of reworking. (See table 3.) Firmer denser tuffs in the same sections, on the other hand, commonly present evidence of deposition by either wind or water. Most of these tuffs are partly altered to clay, and most of them present fine uniform planar bedding that suggests lacustrine deposition. Subaerial deposition apparently was interrupted from time to time by incursions of standing water. Some of the sandstones, moreover, are quite plainly fluviatile.

Clear evidence of intermittent inundation by standing water is indicated by interbedded clays, sandstones, and tuffs in several sections north of section B-2 (pl. 3). Some of the clays contain fresh-water ostracodes. No direct tie has been made between these sections and sec- tion $\mathrm{B}-2$, but section $\mathrm{B}-2$ is stratigraphically lower. The top of section $\mathrm{B}-2$ is stratigraphically near the base of section B-5; the top of section B-5 correlates with the base of section B-3.

Section $B-3$, in the $N W 1 / 4$ sec. 26, T. $2 N ., R$. 25 E., on the dissected west-facing margin of a gravel-capped pediment

[Unit numbers are assigned arbitrarily and have no specific relationship to unit numbers in other sections. Measured by M. G. Bonilla and W. R. Hansen, May 19 and June 11, 1954]

Unit

Ft in

Pediment gravel, top of section.

Browns Park Formation :

1 Sandstone, grayish-orange-pink (5YR $7 / 1)$ (dry slopes look light gray), medium- to fine-grained, very friable, well-sorted; in part laminated. Grains rounded.-..--

2 Sandstone, medium- to fine-grained, very friable, poorly sorted, laminated; rounded grains. Greenish-gray cast near top where bed contains brown mica. Concretions. Hard very light gray tuffaceous siltstone a few inches thick at base

3 Sandstone, very friable, silty to clayey, poorly to moderately well sorted.--_---

Clay, pale-olive $(10 Y 6 / 2)$, silty

Sandstone, very pale orange $(10 Y R 8 / 2)$, friable (in places firm), very fine grained, well-sorted. Toward top bed is medium to coarse grained, loose, poorly sorted. Thin light-olive-gray silty to clayey zones throughout. At $12 \mathrm{ft} 9 \mathrm{in}$. above base is unexposed, not measured.

Total _.. $\overline{211} \quad \overline{11}$ 17 in. of pure waxy light-olive-gray clay--

6 Tuff, greenish-gray, clayey; porcelanitic at base

7 Clay, firm; brittle when dry. Contains rare ostracodes.

(Offset in section $700 \mathrm{ft}$ north-northwest)

8 Tuff, greenish-gray ( $5 G Y 6.5 / 1.5)$, clayey; porcelanitic at base.

Clay, yellowish-gray

Sandstone, grayish-orange $(10 Y R 7 / 4)$, finegrained, friable to loose, well-sorted; subrounded grains._-_-

Clay, pale-olive $(10 Y 5 / 2)$, firm, blocky; probably plastic when wet.-..-

12 Sandstone, grayish-orange-pink (10R 8/2), flne-grained, friable, poorly sorted; wellrounded grains. Cemented and firm near base.

13 Clay, similar to unit 11 above

Silt, compact, and very fine grained, friable sandstone.--_.--

15 Clay, similar to unit 11 above. Thickens to west_-_._-

Sandstone, medium-grained, friable. Base

Base of section. 
Section $B-5$, in the center of $S W 1 / 4 S E 1 / 4$ sec. $22, T .2 N ., R .25$ $E$., is a stratigraphically downward continuation from the beds exposed at section $B-9$

[Unit 1 of section B-5 is equivalent to unit 15 of section B-3. Mensured by M. G. Bonilla, May 22, 1954]

Unit

Top of section.

Browns Park Formation:

1 Clay, pale-olive, firm, blocky. Correlates with unit 15 of section B-3 and with unit 7 of section B-15. Top eroded and not measured.

2 Sandstone, grayish-orange $(10 Y R \quad 7 / 4)$, fine- to medium-grained, friable, well-sorted ; rounded grains. Some layers cemented and hard. Correlates with unit 8 of section $B-15$

3 Clay and silt, light-olive-gray (5Y 5/2), firmbedded. Darker toward base. Correlates with unit 9 of section B-15.

4 Sandstone, light-brown $(5 Y R$ 6/4), fine-grained, friable, loose to firm, mostly well-sorted; rounded grains. Two hard cemented zones form small benches, one at top of unit and one 8-10 f.t above base. The color of this unit is distinctive. Correlates with unit 11 of section B-15.

$\tilde{5}$

Clay and sandy silt, pale-olive $(10 Y 6 / 2)$, firm. Ostracodes in zone 2-5 ft above base; zone occurs also in upper part of unit 12, section B-15

6

Tuff, sandy, and tuffaceous sandstone. Friable, white to medium light gray. Color contrasts greatly with units above. Tuffaceous sandstone in upper 2-3 ft of unit is hard, well cemented, and ripple marked. Base of unit is unexposed. Correlates partly with units 12 and 13 , section B-15

Total

$98+$

Alluvium, base of section.

Section B-15, about three-quarters of a mile northwest of section $B-5$ on the slopes of a prominent conical butte just west of George Draw in thic NW1/4 sec. 22, T. $2 \mathrm{~N}$., R. $25 \mathrm{E}$.

[Section B-15 colncldes stratigraphically in part with sections B-5 and $B-3$ and lllustrates a general northwestward thinning of beds be tween these sections. Top of section B-15 is erosional but is stratigraphically near the top of what remalns of the Browns Park Formation in the western part of the valley. Higher units, however, seem to occur to the east. Measured by M. G. Bonilla and W. R. Hansen, June 26 and 28, 1954]

Unit

Pediment gravel, capping butte.

Browns Park Formation:

1 Sand, very fine grained, friable to firm

2 Silt, clayey and silty clay. Pale grayish orange $(10 Y R$ 7.5/3) to pale yellowish brown $(10 Y R 6 / 2)$; friable to plastic laminated

Sandstone, pale-grayish-orange, friable. Hard pebbly sandstone $1 \mathrm{ft}$ thick at base which rests unconformably on unit below. Sandstone strikes N. $80^{\circ}$ W. and dips $10^{\circ} \mathrm{S}$

Ft in

6

0
Browns Park Formation-Continued Unit

4 Clay, tuffaceous and silty, and hard aphanitic to clayey tuff. Very fine crossbedded sand at top, dips $4^{\circ} \mathrm{S}$. Greenish-gray hard tuffaceous clayey silt and silty clay in up per $17 \mathrm{ft}$. Hard white to light-gray tuff in lower $6 \mathrm{ft} 4 \mathrm{in}$. Thin tuffs in upper 17 ft.

Clay, pale-olive, plastic, slightly brittle; silty and lighter colored toward top. Possibly correlates with unit 9 , section B-3.

6 Sandstone, pale-grayish-orange (10YR 7.5/3), very friable. A few thin beds of hard calcareous sandstone. Bench $31 \mathrm{ft}$ above base. Plastic light-olive-gray clay $11 / 2 \mathrm{ft}$ thick $54 \mathrm{ft}$ above base

Siltstone, light-greenish-gray, friable, clayey to sandy. Correlates with unit 1 , section $B-5$, and with unit 15 , section $B-3$

8 Sandstone, pale-grayish-orange (10YR 7.5/3), friable, loose. Correlates with unit 2 , section $\mathrm{B}-\mathbf{5}$

9 Clay and silty clay in alternate layers sev eral inches thick. Clay layers more abundant in lower $4 \mathrm{ft}$. Contains ostracodes. Correlates with unit $\mathbf{3}$, section $\mathbf{B}-\mathbf{5}$

10 Sandstone, silty, and sandy silt. Light gray to greenish gray; firm but friable to loose. Massive and loose in lower part; flrm and bedded in upper part

11 Sandstone, light-brown, friable. Cemented locally. Incompletely exposed. Correlates with unit 4, section $B-5$

(Offset in section about 1,000 ft to south)

11 Sandstone, light-brown ( $5 Y R 6 / 6)$, poorly sorted, friable, slightly silty, mediumgrained. Fine pebbles near top; base unexposed.

12 Tuff and sandy tuff. At top is 2-3 $\mathrm{ft}$ of light-gray friable to firm massive to crossbedded reworked tuff, underlain by paleolive sandy clayey silt $3 \mathrm{ft}$ thick containing rare ostracodes. Lower $5 \mathrm{ft}$ is cross bedded friable sandstone containing a layer of sandy tuff near middle. Sandstone at base has much lighter color than next unit below. Correlates partly with units 5 and 6 , section $B-5$

13 Tuff, fine-grained, sandy, and tuffaceous sandstone. Friable to frm; light greenish gray ( $5 G Y 8 / 1$ ) to light green. Bedding partly contorted. Correlates with lower part of unit 6 , section $B-5$

Sandstone, pale-brown, fine-grained, slightly silty; friable but contains a few hard layers. Firm conglomerate about $2 \mathrm{ft}$ thick at base._. 1

Total

Valley alluvium, base of section. 
A series of partial sections starting at river level in sec. 6, T. 1 N., R. 25 E., and extending north toward Jesse Ewing Canyon provides a nearly complete composite section of the exposed part of the Browns Park Formation (pl. 3). These sections, which are tied to sections B-1 and B-2 by means of key beds near the middle of section $\mathrm{B}-10$, show a marked upward and northward increase in the proportion of conglomerate, sandstone, and clay to tuff. The conglomerate beds thicken and coarsen northward. Sections B-3, B-5, and B-15, farther east, contain abundant sandstone and clay at equivalent levels, but they contain no appreciable conglomerate. Sections farther west, near Mountain Home Draw and Red Creek, contain conglomerate but in lesser proportions than those immediately south of Jesse Ewing Canyon. Apparently, a large alluvial fan covering several square miles of area had its apex somewhere near what is now the mouth of Jesse Ewing Caynon. Erosion and faulting have obliterated any possible remnants of the fan or of any part of the Browns Park Formation north of the Mountain Home fault, but the source of the fan very possibly was a stream that flowed down Jesse Ewing Canyon at a much higher level than the present bottom of the canyon and at a time prior to the excavation of Clay Basin by Red Creek and its tributaries. At that time, Jesse Ewing Canyon probably shared the drainage north of Clay Basin, a possibility weighed further in the part of this report dealing with geologic history.

Section $B-\dot{\gamma}$, in the bluffs on the left bank of the Green River in the NE1/4 sec. 6, T. 1 N., R. $25 \mathrm{E}$.

[This- section contains the stratigraphically lowest beds measured by Bonilla and me in the western part of Browns Park. Sections B-9 through B-13 contaln progressively higher and younger beds. The uppermost unit of section B-7 was correlated in the field approximately and tentatively with the lowermost unit of section B-9. Measured by M. G. Bonilla and W. R. Hansen, June 23, 1954]

Pediment gravel, top of section.

Browns Park Formation:

1 Tuff, light-gray to medium-light-gray, finely and regularly laminated.

2 Tuff, very light gray, firm. Lowermost 1-11/2 ft contorted by penecontemporaneous deformation; overlain successively by about 5 in. of finely crossbedded tuff, about $2 \frac{1}{2}$ ft of massive tuff with irregular partings, and about 5 in. of very fine grained brittle tuff with irregular subconchoidal fracture, some of which crosses bedding planes. Slight unconformity at base of unit......

(Offset in section)

3 Clay, sandy, to clayey sand. Pale olive to dark yellowish-orange to dusky yellow green, in places mottled ; plastic to friable.

4 Sand, friable, moderately sorted; subrounded grains. Variable lithology and
Browns Park Formation-Continued Unit

color. Very light gray and calcareous at top. Contains a few thin pale-olive clay beds, especially near base. Most of sand is yellow $(5 Y 8 / 6)$ or dark yellowish orange

Clay, and sandy clay, light-greenish-gray $(5 F Y 7 / 1)$ to grayish-yellow-green (5GY $6 / 2)$, hard to plastic; interlayered with dark-yellowish-orange to light-gray tuffaceous sandy silt and fine sand. Sand grains subrounded. Clay beds thin. Grades into unit above

Clay, sandy, and silt, interbedded in varying proportions; distinctive pale red $(10 R$ $5 / 2)$; friable to plastic

Clay, pale-green, massive, hackly. A bed of sandstone $3 \mathrm{in}$. thick near middle of unit_-

8 Clay, rusty, massive, hackly, sandy, silty ---

9 Clay, pale-olive-green to very light gray, fissile: in part silty and in part tuffaceous. Bed of altered tuff 3 in. thick at top

Tuff, light-gray, fine-grained, platy, hard, sandy ; forms break.

11 Clay, light-olive-green, compact, massive to fissile. Thin stringers of rusty sand.---

Sandstone, very pale greenish gray, tuffaceous, in part calcareous. Bedding thin to massive, obscure. Upper 3 in. is thin bedded, hard ; forms overhanging ledge_-

Tuff, light-gray, fine-grained, thin-bedded, friable. Contains thin stringers of coarsegrained rusty sandstone toward base

Sand and sandstone, pale-olive to pale-grayish-brown; pink tint where weathered. Thin beds of medium-grained poorly sorted hard calcareous sandstone 3-4 ft apart. Unit mostly very fine grained, approaching silt size. Upper $2 \frac{1}{2} \mathrm{ft}$ of unit is pale olive green and tuffaceous

Tuff, gray; interbedded with beds of very pale olive green fine-grained thin-bedded friable silty clay.

Sandstone, light-grayish-brown, fine-grained, poorly sorted, even-bedded. Mostly loosely cemented, but thin hard beds at intervals of about $5 \mathrm{ft}$.

Limestone, gray, sandy, nodular. Looks spongy where weathered

Tuff, gray, fine-grained, massive, friable

Mostly covered, but apparently most is lightolive-brown loosely cemented poorly sorted subrounded fine- to medium-grained sand. Thin break of fine-grained bedded altered tuff $65 \mathrm{ft}$ above base. Nodular gray limy sandstone $1 \mathrm{ft}$ thick $1 \frac{1}{2} \mathrm{ft}$ below top of unit

Total

\begin{tabular}{rr}
73 & 4 \\
\hline 210 & 10
\end{tabular}

Water surface of Green River, base of section. 
Section $B-9$, just south of the county road in the $S W 1 / 4$ sec. 32, T. 2 N., R. $25 \mathrm{E}$.

[Section is an upward continuation of the beds exposed in section B-7. Measured by M. G. Bonilla and W. R. Hansen, June 23 1954]

Unit

Mantle rock, top of section.

Ft in

Browns Park Formation:

1. Tuff, light-gray, loose and powdery to friable, vitric. Contorted laminations. Contains a thin calcareous conglomerate layer.---

2 Sand, friable to loose, tuffaceous. Lowest 7-12 in. is hard, crops out, and has irregular base.

3 'Tuff, greenish-gray, fine-grained. In part has a stockwork of hard calcareous veins. Correlates with unit 15, section B-10.--

4 Tuff, silty, and clay. Clay in thin layers. Bench-forming hard white slightly calcareous porcellanite at top.

5 Sand, silty, and sandy silt; yellowish orange; friable

6 Sand, firm, silty, tuffaceous. Green clay bed 4 in. thick at top. Thin white aphanitic tuff 3 ft above base.

7 Tuff, pale-greenish-yellow, very tine grained, firm. Friable yellowish-orange finegrained sand beds 5 in. thick at top and base.

8 Tuff, light-gray, laminated, sandy, friable. Rusty in beds, spots, and streaks. A few thin white hard beds.

Tota

Mantle rock, base of section.

Section B-10, just north of the county road in the $S W 1 / 4 N E 1 / 4$ sec. $32, T .2 N$., R. $25 E$.

[Section repeats the upper 3 units of section B-9 and continues upward. It also repents most of the units exposed in section $B-2$ $31 / 2$ mlles to the southenst. The resemblance between sections B-2 and $\mathrm{B}-10$ is remarkable, even to the similarity of minor detalls. Mensured by $M$. G. Bonilla and W. R. Hansen, June 24, 1954] Unit

Sediment gravel, top of section :

Ft $\cdot$ in

Browns Park Formation :

1 Upper $22 \mathrm{ft}$ is light-greenish-gray friable to firm sand and sandstone. Yellowishorange $(10 Y R 7 / 6)$ thin clayey and tuffaceous zones toward base.

Next lower $7 \mathrm{ft}$ is altered sandy tuff, and friable to slightly plastic greenish-gray tuffaceous sand and thin clay beds. Some thin white tuff beds.

Lowest $5 \mathrm{ft}$ is friable poorly sorted sand; grains rounded. Unit 1 correlates with unit 2 of section $\mathrm{B}-2$.

Total thickness of unit 1

$2 \quad$ Tuff, fine-grained, firm, in part platy, poorly exposed. Hard irregular white porcelanitic bed 2-6 in. thick about 5 ft above base. Several porcelanitic beds near top.-

\section{Browns Park Formation-Continued} Uivit

3 Tuff, firm to friable, laminated. Hard calcareous zone 3 in. thick at top. Lower 3 ft vitreous and identical with unit 4 of section B-2, but lacks limonite. Upper 2-3 ft contains concretions $1 / 4-1$ in. in diameter.-

4 Tuff, yellowish-gray ( $5 Y 8 / 1)$, very fine grained, sandy, firm, brittle, laminated. Identical with unit 5 , section $\mathrm{B}-2$

Identical with unit 5 , section B-2.-nitic bed at top equivalent to top of unit 6 , section B-2.

Tuff, light-gray, massive, friable to firm. Irregular limonitic stain. Wind sculptured. Locally contorted bedding at top. Resembles unit.9, section B-2

7 Tuff, friable to firm, laminated. Laminae wavy in places. Penecontemporaneous "microsynclines" in lowest 6-8 in. Lower part of unit correlates with unit 13 , section B-2.

8 Tuff, in part sandy, massive to highly contorted.

9 Tuff, sandy, and tuffaceous sandstone; crossbedded in part; friable to firm. Breccia zone 7 in. thick 16 in, above base contains fragments of unit below plus sand. Unconformity at base. Units 8 and 9 correlate with unit 14, section $B-2$

10 Tuff, sandy and tuffaceous sandstone. Thin platy partings. Slight bench $10 \mathrm{ft}$ above base. Hard porcelanitic beds near middle and near top of unit. Upper part correlates with unit 15 , section B-2, lower part with unit 16

11 Tuff, light-gray, friable, laminated, vitric

12 Tuff, white to greenish-gray, sandy, friable. A few hard white platy beds, including one at top. Irregular hard calcareous zones near top and base.

Tuff. Most of unit friable, fine grained, light gray ; contuins irregular laminations, limonitic layers, spots, and streaks. Upper $10 \mathrm{ft}$ finely laminated, wavy, medium light gray. Bed of pale-greenish-yellow tuff about $10 \mathrm{ft}$ thick $30 \mathrm{in}$. above base of unit; contains stringers of sand. Basal 30 in. is massive fine-grained powdery friable vitric tuff; correlates with unit 1 , section B-9. Basal contact irregular.---

14 Sand, greenish-gray, tuffaceous, firm. At base is irregular layer of hard dolomitic sandy tuff

15 Tuff, greenish-gray clayey to light-gray, fiue-grained

Total

$28 \quad 0$

40

Tuff, porcelanitic hard white; forms bench. Correlates with top bed of unit 4, section B-9. Thickness not obtained. rock, base of section. 
Section $B-11$, in the N1/2SE1/4 sec. 29, T. 2 N., R. $25 E$.

[Measured by M. G. Bonilla and W. R. Hansen, June 24, 1954, to obtain a sampling of beds stratigraphically higher than those in section B-10. Uppermost unit of section B-10 was traced about 4,000 feet northward, where measurement was resumed as section B-11. Clay, sandstone, and conglomerate are conspicuous constituents of this section]

Unit

Pediment gravel, top of section.

Ft in

Browns Park Formation

1 Conglomerate, firm, sandy ; in part tuffaceous. Cobbles mostly of quartzite from the Uinta Mountain group and limestone of Paleozoic age; cobbles subrounded and as much as $18 \mathrm{in.}$ in diameter. Matrix ranges from light brown $(5 Y R 6 / 6)$ to light greenish gray

2. Clay, olive-gray, tuffaceous, silty, firm. Scattered tuff beds

3 Clay, olive-gray (5Y 4/2), slightly sandy. Shrinkage cracks, gypsiferous, laminated and silty in places.

4 Sandstone, tuffaceous; clayey near base. Friable to loose. Pale-olive clay bed 18 in. thick 1. ft above base. Unit is mostly poorly exposed

5 Sandstone, silty, tuffaceous, friable to firm. In part crossbedded. Some gypsum. Hard platy bed at top. Unit mostly poorly exposed.

6 Tuff, light-gray, sandy, friable. Thin platy partings. Clay bed 3 in. thick at top.--

7 Sandstone, crossbedded, hard, calcareous, tuffaceous. Small weathering cavities. Breccia and unconformity at base

8 Tuff, light-gray, friable, massive; contains fine cross beds in lower $1 \mathrm{ft}$ and confused contortions in remainder. To the west and northwest this unit is cut out by an unconformity. Unconformity at base also. Correlates with unit 1, section B-2

9 Sandstone. Yellowish-orange in lower part, yellowish-gray in upper part; firm to friable. Correlates with unit 2, section 'B-2, and with unit 1 , section $B-10$

Total

Mantle rock, base of section.

Section B-12, in the SW1/4NE1/4 sec. 29, T. $2 N ., R, 25 E$.

[Section is about $800 \mathrm{ft}$ northwest of section B-11 and continues stratigraphically upward from that section. Measured by $M$. G. Bonilla and W. R. Hansen, June 24, 1954]

Unit

Mantle rock, top of section.

Ft in

Browns Park Formation :

1 Conglomerate and sandstone. Cobbles of quartzite from the uinta mountain Group as much as $10 \mathrm{in.}$ across

2 Clay, pale-olive $(10 Y 7 / 2)$, silty; interbedded with clayey silt; firm to friable. Brownish-orange sandstone bed $18 \mathrm{in}$. thick $3 \mathrm{ft}$ below top. Conglomerate a few in. thick about $12 \mathrm{ft}$ below top
Browns Park Formation-Continued Unit

3 Conglomerate and sandstone. Similar to unit 1. Pale-olive clay bed 10 in. thick $81 / 2$ ft above base. Unit correlates with unit 1 of section $\mathrm{B}-\mathbf{1 1}$. $\begin{array}{ll}30 & 7 \\ 73 & -\end{array}$ Mantle rock, base of section.

Section $B-13$, a half mile north of section $B-12$, in the $\$ 1 / 2,8 e c$. 20, T. 2 N., R. 25 E., just south of Whisky Peak

[This section contains lateral equivalents of the beds meacured in sections $B-11$ and $B-12$, and it extends an additional 180 feet or so stratigraphically upward. Measured by M. G. Bonilla and W. R. Hansen, June 25, 1954]

Browns Park Formation:

Unit

Pediment gravel.

1 Clay, pale-olive, silty, gypsiferous

2 Sandstone, grayish-orange, crosbedded, silty, friable. Thin hard beds....-

3 Clay, yellowish-gray $(5 Y 6 / 2)$ to pale-olive, silty, firm. Wood and grass impressions_-

Sandstone, grayish-orange, flne-grained, partly crossbedded, friable. Interbedded olive clay layers $1 / 8$ in.-2 ft thick

Clay, pale-olive to olive-gray

Conglomerate and sandstone

Clay, olive, in part silty. Interbedded calcareous sandstone

Conglomerate.

Clay, silty to sandy, plastic. Shrinkage cracks

Conglomerate and sandstone, firm to friable. Hard sandstone at base.

Clay and silty clay, olive gray (5Y 6/2), firm

Conglomerate and sandstone, grayish-orange $(10 Y R 7 / 4)$, firm to friable

Siltstone, olive, clayey, sandy, friable....-.

Conglomerate and sandstone, grayish-orange $(10 Y R 7 / 4)$, friable to hard

Clay and siltstone, light-olive-gray to yellowish-gray ( $5 Y 6 / 2$ to $5 Y 8 / 1)$, firm; slightly sandy ; some gypsum. Gray sandy siltstone $3 \mathrm{ft}$ thick at base

Sandstone and conglomerate, light-brown, friable to firm. Correlates with unit 1, section $\mathbf{B}-11$

Clay, silty, firm. Interbedded tuffaceous sandstones. Correlates with unit 2, section B-11...-

Clay, olive $(10 Y 5 / 2)$, silty, slightly sandy, plastic to firm, gypsiferous. Correlates with unit 3, section $\mathrm{B}-11$

Ft

$9 \quad 0$

13

19 Tuff, light-gray, very fine grained, platy, slightly sandy, firm. Hard thin platy bed at top. Thin clay interbeds. Sandstone 8 in. thick $5 \mathrm{ft}$ above base.

20 andstone and conglomerate, light-brown,
50

10

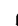

5
22

19

96

16

3

8

3

316

21

0

20

6

24

0

0

0

6

o

6

8

0

8

6

6

6

o friable to hard. Mostly sandstone in lower $15 \mathrm{ft}$ 
Browns Park Formation-Continued

Unit

21 Sandstone, light-gray, medium-grained, fairly well sorted, friable to loose, subrounded grains. White calcareous nodules. Base not exposed:

Total

Mantle rock, base of section.

Section B-14, about 2 miles northwest of section $B-13$ in a strongly dissected badland tract just east of the county road in the S $W 1 / 4 N W^{1 / 4}$ sec. $18, T .2 N$., $25 \mathrm{E}$.

[The base of the section is at road level; the top is at the top of a knoll at an altitude of about 5,890 feet. In the same sequence of beds as that beginning with section B-7. The section is nearer the apex of the old fan cited earlier, and consists chiefly of friable sandstone and conglomerate, although it contains tuff and clay bed as well. At least $150 \mathrm{ft}$ of additional beds-mostly conglomerate and sandstone-is exposed on another hill nearby. Measured by M. G. Bonilla and W. R. Hansen, June 26, 1954]

Top of knoll.

Ft in

Browns Park Formation:

1 Conglomerate and sandstone, firm to friable. Correlates with unit 16 , section $\mathrm{B}-13$, and with unit 1 , section $\mathrm{B}-11$.

2 Clay, greenish-gray, sandy, silty, calcareous, friable

3 Clay and silt, light-gray to greenish-gray, laminated, sandy, firm to friable, tuffaceous. Contains an irregular discontinuous layer of thin hard white aphanitic tuff about $6 \mathrm{ft}$ above base

4 Tuff, light-gray, slightly sandy, firm. Aphanitic tuff 2 in. thick at base

5 Tuff, white, clayey, firm

6 Clay. Yellowish gray and firm at base; white, firmer, and slightly sandy at top. At top is hard white aphanitic tuff $1-1 \frac{1}{2}$ in. thick

7 Conglomerate and sandstone, firm to friable; forms cliff. Irregular base fills channels cut into underlying unit. (See fig. 39.)

8 Sandstone, grayish-orange to grayish orangepink; lowest $5 \mathrm{ft}$ is yellowish gray ( $5 Y$ $6.5 / 3)$; fine-grained; moderately sorted; friable; grains rounded to subangular. Appears massive from distance but has faint bedding and crossbedding. Prominent vertical jointing. Conglomerate lenses or stringers in upper $10 \mathrm{ft}$. Many hard smooth concretions flattened parallel to bedding and as much as $2 \mathrm{ft}$ long. Forms cliff

9 Tuff, light-greenish-gray, bedded. Massive light-gray tuff in upper $2 \mathrm{ft}$. Thin interbeds of crossbedded orange sandstone

Tuff and reworked sandy tuff, light-gray to greenish-gray, friable to firm. Flat regular bedding and fine crossbedding. Rare quartzite pebbles from the Red Creek Quartzite and Uinta Mountain Group. Hard coarse vitric tuff $2-3$ in. thick $6 \mathrm{ft}$ above base
Browns Park Formation-Continued Unit

11 Tuff, very light gray, medium-grained, massive, friable. Some planar bedding at top. Hard bed at top. Some contortions in upper part. A pebble of quartzite from the Uinta Mountain Group in upper part. Ripple marks in lower part. At base to a layer of soft greenish-yellowish-gray bentonite 1-3 in. thick (sample B-14-11); shows X-ray pattern for montmorillonite_-

Conglomerate and sandstone, poorly exposed. Boulders, derived from Uinta Mountain Group, as much as $2 \mathrm{ft}$ in diameter

Total

in

Base of section, at road level where road crosses wash.

The total thickness of the Browns Park Formation in the type area is unknown, inasmuch as the lowest beds lie at an unknown depth beneath the floor of Browns Park. A composite thickness of exposed beds, however, can be obtained by correlating and adding together parts of exposed sections (pl. 3). Between section B-7 at river level in sec. 6, T. 1 N., R. 25 E., and section B-13 near Whisky Peak in sec. 20, T. 2 N., R. 25 E., a composite thickness of about 820 feet of exposed beds is indicated. Of this thickness, about 370 feet is nontuffaceous sandstone (not obviously tuffaceous) and conglomerate combined, about 290 feet is tuff and tuffaceous sandstone, and about 160 feet is clay and (or) siltstone; or, roughly, 45 percent is nontuffaceous sandstone and conglomerate, 35 percent is tuff

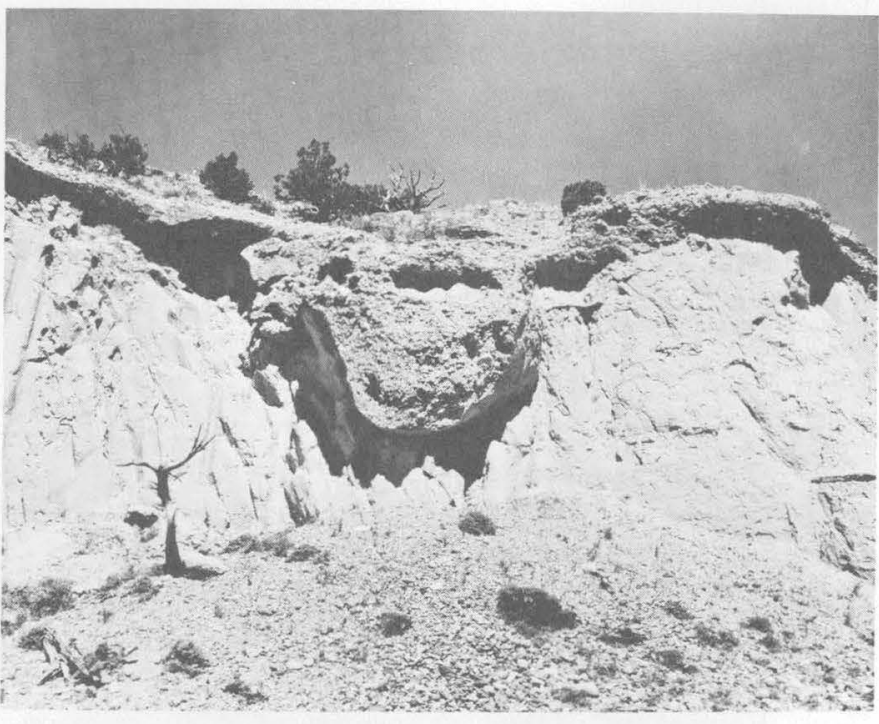

Figure 39.-Conglomeratic channel fill in Browns Park Formation at measured section B-14, unit 7, near mouth of Jesse Ewing Canyon. Channel is about 10 feet deep at base of conglomeratic sequence 64 feet thick. Conglomerate is derived mainly from Uinta Mountain Group but contains pebbles and cobbles derived from Red Creek Quartzite and from reworked limestones of Paleozoic age. 
and tuffaceous sandstone, and 20 percent is clay and (or) siltstone (fig. 40). The large amount of conglomerate in this section reflects the proximity of the previously mentioned old alluvial fan near Jesse Ewing Canyon to several of the measured sections.

A composite thickness obtained between sections B-7 and B-3, by way of sections B-9 and B-10, is about 765 feet thick. Of this thickness, about 395 feet, or 51 percent, is nontuffaceous sandstone; 280 feet, or 37 percent, is tuff and tuffaceous sandstone; and 90 feet, or 12 percent, is clay and (or) siltstone. The amount of conglomerate is negligible.

No single restored vertical section, it must be emphasized, would yield the same thicknesses and proportions of rock types as the composite sections reported above. Sections nearer to the valley margins probably would be thicker and would contain greater proportions of coarse clastic material; sections nearer the axis of the buried valley probably would be thinner and would contain greater proportions of tuff and clay. It also is reemphasized that tuff is proportionately more abundant in the lower parts of the composite sections than in the upper parts.

\section{CONTACT RELATIONBHIPS}

The contact of the Browns Park Formation with the subjacent Uinta Mountain Group is exposed in many places both in the type area and elsewhere. In Browns Park, exposed contacts are restricted to the margins of the valley where the Uinta Mountain Group emerges laterally from beneath the thick fill of the Browns Park Formation.

Owing partly to strong relief on the contact and partly to marked lateral variations in beds, the lithologic character of the beds resting on the contact varies widely from place to place. In many places in Browns Park the basal bed consists of tuff, fluviatile sandstone, or transported conglomerate. In other places the old pre-Browns Park regolith is preserved, and it passes gradationally downward into the Uinta Mountain Group and upward into the Browns Park Formation.

At several places in Red Canyon near Greendale, large blocks of red quartzite-some blocks hardly moved from their original in-place positions in the Uinta Mountain Group-have been cemented into hard coherent autochthonous breccias that pass transitionally downward into the Uinta Mountain Group and upward into mixed breccias and fanglomerates in the Browns Park Formation. Good exposures of such relationships can be seen above Skull Creek and Trail Creek in Greendale and above Cart Creek and Dutch John Creek to the east near Flaming Gorge damsite. In places, low cliffs and ledges are buried beneath cemented rubble. Some of the best exposures west of Dutch John Creek are below the planned high-water line of Flaming Gorge Reservoir and will be flooded intermittently by reservoir waters.

\section{FOSSILS, AGE, AND CORRELATIONS}

Ostracodes and diatoms are the only fossils that have been found in the Browns Park Formation within the area shown on the geologic map (pl. 1). Neither of these groups of organisms is plentiful in the collections that have been taken, and diagnostic assemblages have not been found despite a fair number of individual species. Ostracodes are rare and are difficult to find. They were first noted by M. G. Bonilla and were subsequently observed in clay beds at several horizons. The ostracode specimens listed below were collected by $\mathrm{Mr}$. Bonilla and me and were identified by I. G. Sohn. Diatoms listed below were collected by S. W. Lohman and were identified by K. E. Lohman.

Ostracodes:

Sample collected from unit 7 , measured section

$B-3, N W 1 / 4 S E 1 / 4 N W 1 / 4$ sec. $26, T .2 N$., R. $25 E$. Candona sp., female, large

Candona sp., female, smaller than above

Candona (Lineocypris?) sp., similar to middle Pliocene of Wyoming

Candona? sp.

Limnocythere? sp., one valve

Sample collected from unit 5 , measured section

$B-5$, center $S W 1 / 4 S E 1 / 4$ sec. $22, T .2 N$., R. $25 E$.

Limnocythere spp., abundant

Genus indet. large, round dorsum, three fragments

Candona?, one specimen

In regard to the age of the above fossils, Mr. Sohn reported as follows:

Because of lack of published data it is not possible to determine whether the age is Miocene or Pliocene. One species. Candona (Lineocypris?) $\mathrm{sp}$. is very close to an undescribed species from the Middle Pliocene of Jackson Hole, Wyoming, but since the stratigraphic range of the Wyoming species is not known, this fact does not help in determining the age. Ecologic inferences would be that the clays were deposited in fresh water, permanent ponds or lakes.

The species of Limnocythere differ from those in the Middle Pliocene of Wyoming, and the faunule differs from those described from the Salt Lake formation, Utah, and from Pliocene faunules of Hungary.

Diatoms :

U.S. Geological Survey diatom locality 4693; diatoms collected in the center of $W 1 / 2 S E 1 / 4 \mathrm{sec} .35$, $T .2 N$., $R .25 E$., at the south side of a road junction, altitude 5,772 feet. Collected by S. W. Lohnan, 1958. An assemblage of 32 species and varieties of nonmarine diatoms was collected. As shown below, their relative abundance is 
indicated as $C$, common; $F$, frequent; and $R$, rare.

Amphora ovalis Kützing.

sp. A.

Anomoeoneis sp.-

Caloneis bacillum (Grunow) Meresch-

kowsky_-_....... R

Cymbella cymbiformis (Kutzing) Van

Heurck -.---.-.--

parva (William Smith) Cleve

Epithemia turgida (Ehrenberg) Grunow_ construens var. binodis (Ehrenberg)

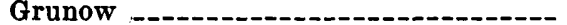
construens var. subsalina Hustedt.-.cf. $\boldsymbol{B}$. leptostaruron (Ehrenberg) Hustedt

Frustulia $\mathrm{sp}$

Gomphonema parvulum (Kützing) -.....-

$M$ Mastogloia $\mathrm{sp}$

Melosira distans (Ehrenberg) Kützing--granulata (Whrenberg) Ralfs italica (Ehrenberg) Kützing sp. A-1.--_sp. B sp-_-_.-_-

Navicula sp. A

Nitzschia amphibia Grunow--..--.-.--

Pinnularia microstauron (Ehrenberg)

Cleve.

sp. A._._.

Rhopalodia gibberula (Ehrenberg) Muller gibberula var. bultioa Muller.

Stauroneis dilatata Ehrenberg-_...-...-.-

Synedra ulna (Nitzsch) Ehrenberg.-.----

ulna var. biceps (Kützing) Schönfeldt ulna var. spathulifera Grunow

Tetracyclus $\mathrm{sp}$

In reference to the age of the above diatoms, $\mathrm{Mr}$. ILohman reported as follows:

Of the 27 identifled species and varieties in this assemblage, 2 have been found previously in lower Pliocene beds only, 3 are known only from beds of late and middle.Miocene to early Pliocene age. Among the longer ranging species, 6 are known from middle Miocene to Recent and 8 from Pliocene to Recent. Based on this analysis, the most probable age for this assemblage is late Miocene to early Pliocene. This sample had a fairly large number of species in it, but very few individuals, so that I do not feel that my age determination of late Miocene to early Pliocene is final.

Regarding the biotic environment in which the diatoms lived, Mr. Lohman made the following inference:

The high ratio of attached to pelagic forms suggests a shallow lake of moderate temperature and somewhat alkaline water. Many of the diatoms, those of Frustulia sp., are distorted, a characteristic of species living in an alkaline environment.

A late Miocene or early Pliocene age for the Browns Park Formation is generally considered probable. The diatom assemblage listed above and its tentative age assignment support such an age for the formation. Re-

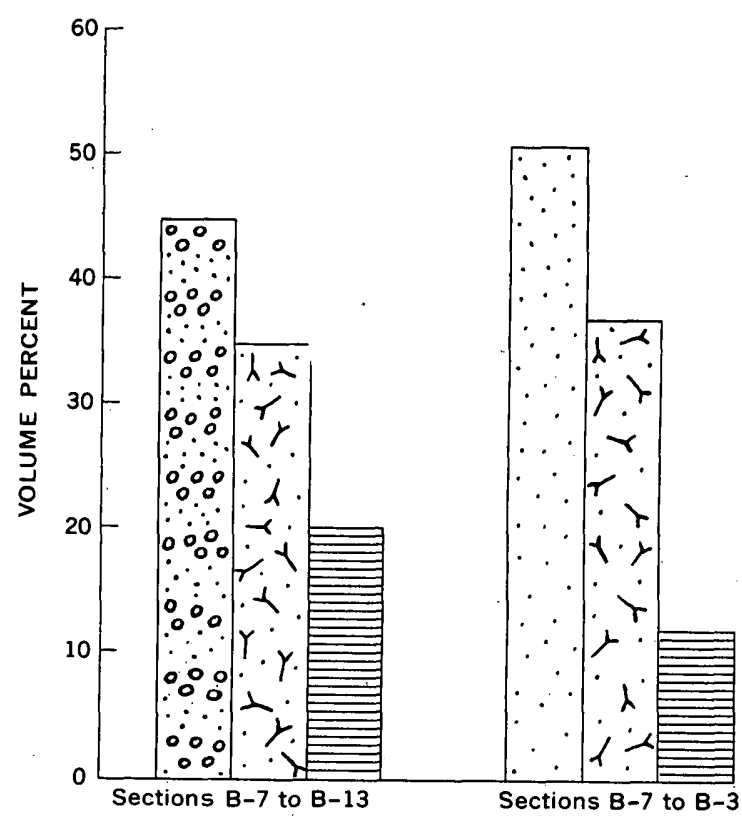

EXPLANATION

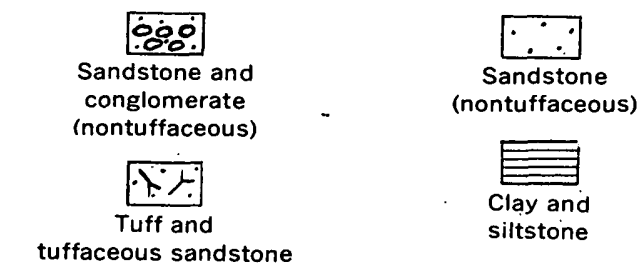

Fioure 40.- Lithologic proportions in Browns Park Formation, taken from composite stratigraphic sections.

cent studies by McGrew (1951, p. 56), however, suggest that a middle Miocene age is more likely. For at least part of the formation, moreover, McGrew (1953, p. 61), judging from new vertebrate collections obtained in Saratoga Basin and at Split Rock in Wyoming and from restudy of collections from Colorado, favors a lower and middle Miocene age.

\section{DEPOSITIONAL CONDITIONS}

The physical environment under which the Browns Park Formation accumulated varied locally and temporally in response to geologic processes then acting within and outside the immediate area. Detailed consideration of the tectonic events of that time is presented in the section of this report dealing with geologic history. In brief, large-scale gravity faulting had started in the eastern Uinta Mountains before the formation was deposited. The ancestral valley of Browns Park was partly erosional-carved by streams-but its depth was due in part to foundering along well-defined zones of faulting, particularly along the north side of the valley. The resulting trough provided a natural stilling basin for the accumulation and preservation of 
water-laid tuffs, sands, and clays. In the waters of these basins, ostracodes and diatoms thrived. Intermittent draining and dessication is indicated by local unconformities, eolian crossbedding, fluviatile crossbedding, and accumulations of fluviatile gravels or conglomerates. Evidence of climatic aridity has been found by Bradley (1936a, p. 184), who reported an occurrence of halite-crystal molds near the west end of Browns Park and found wind-faceted stones in the Browns Park Formation in Washakie Basin to the northeast in Wyoming.

Physical relief in the immediate vicinity of Browns Park probably was only slightly greater then than now. Browns Park valley was appreciably deeper, though, and was canyonlike in aspect. A tremendous amount of erosion was yet to be accomplished, but most of the major topographic landmarks nearby were already delineated in their present general forms. To the north were high remnants of the Gilbert Peak erosion surface-broader and less dissected than now. To the south, all major existing valleys, including those of Crouse Creek, Sears Creek, Warren Draw, Jackson Draw, Gorge Creek, and Cart Creek, were already well defined. The narrow inner gorges at their mouths, however, had not yet been cut, and most of the drainage flowed southward rather than northward as at present. These old drainage lines became completely blocked by accumulations of Browns Park sediments; gorge cutting and reversal of drainage direction followed deposition of the Browns Park Formation.

Although the epoch in which the Browns Park Formation accumulated was clearly a time of repeated and probably intense volcanism, the thick tuffs of the Browns Park area are due only in part to direct fallout of airborme material. A large part of the tuff that ultimately accumulated in Browns Park probably fell initially on adjacent, and perhaps even remoter, highlands, was washed away by streams, and was then redeposited where it now is found. Such an origin seems likely for many of the contaminated tuffs and for most of the tuffaceous sandstones. Air-laid tuffs, however, may be contaminated without reworking by any agency-contaminants may be absorbed directly by the rising magma from the walls or throat of the volcanic vent; may be drawn into the ash cloud by strong updrafts caused by the rising ash column itself, especially during violent eruptions; or may be mixed with the airborne ash by the passage of ordinary dust storms.

The source of the tuffs and tuffaceous sandstones of the Browns Park Formation has not been determined. The volcanic center nearest Browns Park is the Leucite Hills area north of Rock Springs, Wyo., but this center is ruled out on petrologic grounds and incompatible age relationships. The rocks of Leucite Hills are unusually rich in potash and are proportionately low in silica (Schultz and Cross, 1912, p. 11). Recent radiometric dating indicates an age of only 1.25 million years (W. H. Bradley, written commun., 1961). A volcanic center east of Craig, Colo., contains rocks mostly of mafic composition, although acidic rocks, including light-colored tuffs, are present also (Bass, Eby, and Campbell, 1955, p. 163 ; Fenneman and Gale, 1906, p. 32). This center may have contributed material to the Browns Park Formation, but it seems to be unfavorably oriented with respect to the prevailing westerly winds that probably transported the ash. In all probability, therefore, the major source was to the west, perhaps in the Heber CityPark City volcanic center of the Wasatch Range, or even in western Utah, Nevada, or Idaho. Extrusive rocks of the Park City district are mostly andesitic (Boutwell, 1912, p. 70) and seem to have a heavymineral fraction unlike that of the Browns Park Formation. They also may be older than the Browns Park Formation (Eardley, 1944, p. 845). The general lack of reported tuffaceous sediments westward along the Uinta Mountains is curious but may be due in part to deeper erosion in the western areas flanking the Uinta Basin as opposed to shallower erosion in the protected valleys in and adjacent to Browns Park. The younger Tertiary rocks along the south slope of the Uinta Mountains have had little attention or study; conceivably, rocks akin to the Browns Park Formation may be present but undescribed. Conceivably, also, some part of the Salt Lake Formation of the Wasatch Mountain area may be equivalent to the Browns Park Formation. Still another possible source for the tuffs of the Browns Park Formation is the Yellowstone-Absaroka volcanic center of northwestern Wyoming. This center, however, seems to be less favorably oriented with respect to probable upper air currents than the above-cited sources. Additional centers that may have contributed ash are the Marysvale district of Utah and the West Elk and San Juan Mountains of Colorado.

\section{ENGINEERING CHARACTERISTICS}

The engineering characteristics of the Browns Park Formation vary as widely, perhaps, as those of any other formation in the area, owing to the unit's diverse lithologic types and to its ranges in degree of consolidation and cementation. Even so, valid generalizations as to probable behavior are possible; for the most part, the formation has few properties that are likely to present special problems to the potential land user. 
Most of the formation is loosely consolidated, hence is easily excavated by power shovel or by bulldozer equipped with rippers. All the clays, nearly all the tuffs, most sandstones, and most conglomerates can be so handled. A few well-indurated sandstone and conglomerate beds would require special handling; many of those in Red Canyon, especially, could not be excavated without preliminary drilling and blasting.

The greater part of the formation, despite slight induration, has moderately high slope stability. Natural slope failures are rare. Least stable are the clay beds, which contain montmorillonite and hence are likely to be plastic when wet and subject to failure under load. Natural slopes of $30^{\circ}$ on clay terranes are common.

Probably the most stable deposits, as a group, are the massive vitric tuffs. In many exposures these deposits form vertical breaks or low cliffs. The angularity of the constituent glass shards undoubtedly contributes to coherency and stability, despite the low density and open texture of the rock.

Sandstones and conglomerates mostly range between the clays and tuffs in stability, but they deviate widely from the mean. Some beds are so loosely cemented that they are easily dug with a pick. Others, such as those along Red Canyon, are hard and resistant and form bold outcrops; compared with the quartzites of the subjacent Uinta Mountain group, however, they are relatively incompetent.

Clayey parts of the Browns Park Formation are very susceptible to rill erosion inasmuch as they are nearly impervious to water and promote rapid total runoff. Tuffs, sandstones, and conglomerates all absorb water more readily. All these rocks, however, are very susceptible to scour-for example, in-the footing of a bridge across a wash or at the opening of a culvert. In many places, small seeps issue from perched water tables in sandstone beds resting on clay.

\section{QUATERNARY SYSTEM}

In a region such as the Uinta Mountains, where bedrock is widely and well exposed and where many outcrops are truly imposing, Quaternary deposits are likely to seem insignificant and unimportant to the casual visitor. On the contrary, however, they are very important, and they bear strongly on the economic development of the area. They determine to a large extent the quality of land for agriculture and pasturage; the foundation conditions of most roads and buildings, both existing and potential; the trafficability of the unpaved roads, which still predominate in the area; and the quality and quantity of most local construction materials. Quaternary deposits comprise several types of surficial materials of several modes of origin.

\section{ALIUVIOM}

Alluvium is the most widespread surficial material in the area. It forms cappings on Pleistocene benches, the flood plain of the Green River, the fillings along the tributary streams, and the fans at the mouths of gullies. Of the various kinds of alluvial deposits, bench gravels are the most extensive areally and volumetrically. These gravels were deposited as alluvial veneers on pediments or rock fans at the foot of mountains and on corresponding terraces cut by the meandering Green River and its tributaries. (See figs. 33, 41.)

\section{BENCH GRAVELS OF PLEIBTOCENE AGE}

Several different levels of bench gravel are recognized in the Flaming Gorge area. In most local drainage basins, as many as three surfaces are preserved; but in some places, as along the lower reaches of Henrys Fork, five different levels occur side by side (fig. 42). The highest level is the oldest. Each depositional episode was preceded by a period of lateral planation, during which a rock-cut platform was formed, and was succeeded by a period of stream entrenchment, during which the bench was produced. No attempt has been made to correlate the alluvial sequence of the area with other sequences in adjacent parts of the Rocky Mountain region, although such a correlation probably could be made, given sufficient time and study. Even within the area, correlations from place to place are difficult; and the results, though probable, are tentative.

Much of the difficulty met in attempting to correlate bench deposits from place to place stems from the poorly developed soil profiles formed on the various surfaces. The gravel and sand constituents of the deposits are predominantly quartzitic material derived from the Uinta Mountain Group and hence are resistant to the formation of strong soil profiles. In addition, the generally coarse permeable texture of the deposits favors the development of a thick but weakly developed profile. A and B horizons commonly are poorly formed or unrecognized. In view of these limitations, tentative age assignments are made with utmost reservations.

All five levels of bench gravel in the Flaming Gorge area are regarded as of Pleistocene :rather than of Recent age. As a guideline, the Pleistocene-Recent boundary definition proposed by Hunt $(1953$, p. 18) is followed. Rather heavy impregnations of calcium carbonate in various soil profiles suggest that the three highest benches, at least, are pre-Wisconsin. In the deposits of these benches, the upper several feet-commonly at least $3-4$ feet- is heavily enriched with calcium carbonate despite the siliceous character of the parent material; pockets and stringers of calcium car- 


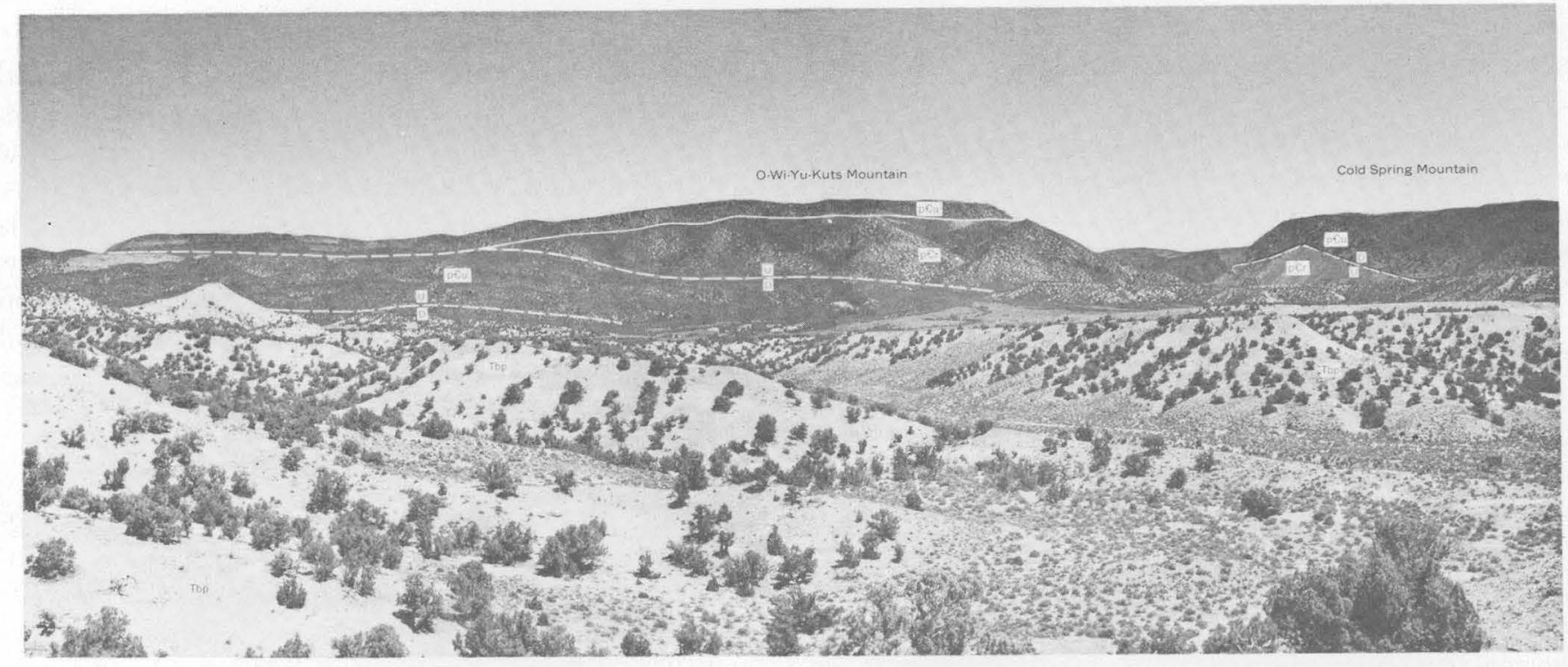

Figure 41.-Vlew northeast in Browns Park from George Draw toward O-Wi-Yu-Kuts Mountain. Partly dissected gravel-capped rock fans of Pleistocene age truncate Browns Park Formation in middle distance. Broad surface in middle distance is $\mathrm{Qb}_{2}$ bench. Remnant of higher surface at right and topping conical butte at left is $\mathrm{Qb}_{1}$ bench. Gilbert Peak erosion surface forms skyline. Deep notch at right is canyon of Beaver Creek. P€r, Red Creek Quartzite; P€u, Uinta Mountain Group; Tbp, Brown Park Formation.

bonate commonly extend on downward to a depth of 6 feet or more.

Lithologically the bench gravels reflect the composition of their source, especially in their coarse fraction. They are of value, therefore, in reconstructing the Pleistocene geologic history of the area. Deposits in the upper part of Lucerne Valley contain a wide assortment of lithologic types and also present the best developed soil profiles. Deposits toward the mouth of Henrys Fork consist chiefly of red quartzite derived from the Uinta Mountain Group but contain many rock types from other units, including chalcedony from the Green River Formation. Deposits in Antelope Flat also consist chiefly of material derived from the Uinta Mountain Group, material that probably has passed through several cycles of erosion; terrace remnants above Spring Creek along the north side of Antelope Flat, however, contain abundant material reworked from the Wasatch Formation and apparently admixed with material derived from the Uinta Mountain Group of the Goslin Mountain area. In Clay Basin, bench gravels south of Martin Draw and Clay Basin Creek contain pebbles and cobbles derived chiefly from the Uinta Mountain Group and the Red Creek Quartzite in the highlands to the south. Deposits north of Martin Draw and Clay Basin Creek consist largely of resistant cobbles derived from limestone of Paleozoic age. These cobbles have been reworked from conglomerates in the Wasatch Formation and mixed with fines derived probably from several formations. Some of the limestone cobbles probably have undergone several cycles of erosion.
In Browns Park, bench gravels north of the Green River consist chiefly of material derived from the Uinta Mountain Group and the Red Creek Quartzite; some of the fines have come from the Browns Park Formation. In deposits south of the Green River the coarse fraction is derived largely from the Uinta Mountain Group. Finally, terraces along the Green River contain small quantities of exotic material transported down the river from remote sources-for example, occasional granitic rocks foreign to this area but abundant in the Wind River Mountains of Wyoming.

In general, the bench gravels are poorly sorted, and particle sizes range widely in any given bed as well as from bed to bed; poorly sorted cobbly gravels are interlayered with beds and lenses of poorly sorted sand and silt. Roundness of particles also varies widely, depending to a great extent on the distance the material has traveled from its source and on the number of erosion cycles through which it has passed. Deposits along major drainageways are generally better rounded than those along minor ones, and deposits on low benches are generally better rounded than those on higher ones. Near-perfect sphericity can be found among the stones on the lower terraces along the Green River. Subrounded stones predominate on the several levels near the mouth of Henrys Fork and in Lucerne Valley, Clay Basin, and Browns Park. Angular and subangular material is uncommon except near the heads of sloping rock fans and pediments-for example, on bench 2 south of Martin Draw and Clay Basin Creek. 


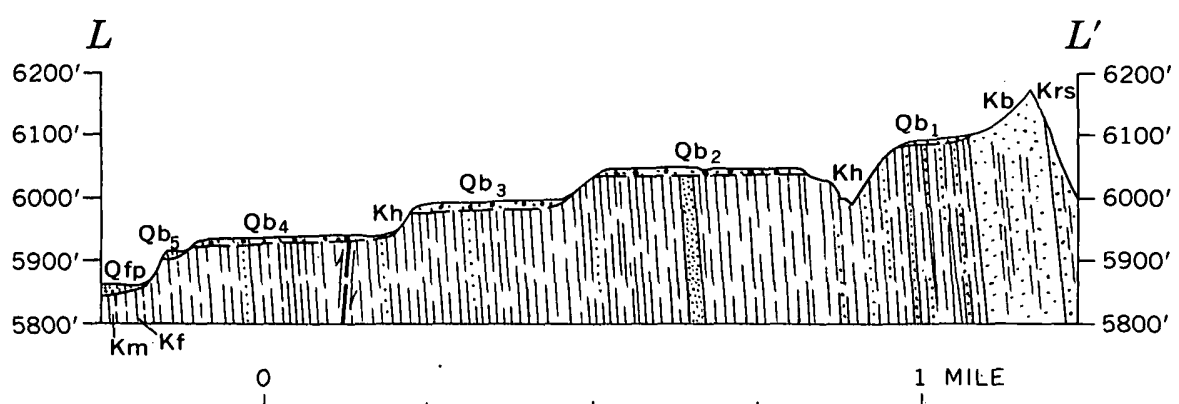

Fiadre 42.-Geologlc section $L-L^{\prime}$ across benches north of Henrys Fork. Qfp, flood-plain deposits; Qbs-Qbi, bench deposits 1-5; Krs, Rock Springs Formation; Kb, Blair Formation; Kh, Hilllard Shale; Kf, Frontier Formation; Km, Mowry Bhale. Location of section shown on plate 1. Vertical exaggeration $\times 5$.

RECENT ALIUVIAI FILIS

Less widespread than bench gravels, but nevertheless extensive, are the Recent alluvial fills deposited along such tributary streams as Birch Spring Draw, Spring Creek, Clay Basin Creek, Willow Creek, and Beaver Creek, and built up of coalesced fans at such places as Pigeon Basin, Bake Oven Flat,. and the mouth of Whisky Springs Draw. At present these deposits are being entrenched by vigorous downcutting along nearly all drainageways. $\mathbf{A}$ far-reaching result has been a lowering of the water table along alluviated bottomlands and a consequent transformation of wild meadowlands into tracts of greasewood and shad scale; there seems little doubt that gullying has contributed significantly to the disappearance of the grasslands noted by early visitors to Browns Park and still recalled by old-time residents of the area. In a few places a low cut terrace lies about midway between existing drainageways and the top surface of the alluvial fill, as along Red Creek in Clay Basin downstream from Martin Draw.

Although the Recent alluvial fills of the area vary greatly in appearance from place to place, especially from one drainage basin to another, they have many characteristics common to all. In general, they have gently sloping to nearly flat cross profiles. The greater part of the alluvium is fine-grained material-in the sand and silt size range-which suggests perhaps, an admixture of colian with fluviatile material. Variations in grain sizes, however, are wide and depend considerably on the lithology of the rocks in the source area and on the distance of the deposits from the source area. The many small fans along Sheep Creek, for example, are nearly all rubbly deposits composed of subangular fragments in the gravel size range.

Fills of Recent alluvium rarely exceed 20 feet in thickness, although in some places they exceed 30 feet. Good exposures can be seen along almost any gullied valley bottom in the area. Exposures in Lucerne Val- ley along Birch Spring Draw are typical. Equally good exposures can be seen along Spring Creek in Antelope Flat, along Martin Draw in Clay Basin, and along Clay Basin Meadows.

In all these areas, small fresh-water snails are fairly common fossils; at Spring Creek they are abundant. At Clay Basin Meadows a large skull and several articulated vertebrae of Bison bison were found 8 feet below the fill-terrace surface, together with abundant freshwater snails. Bison bison substantiates the Recent age of the deposit (Hunt, 1953, p. 1).

The Recent alluvial fills of the area strongly resemble, and seem to correlate with, the Tsegi Formation of Hack (1942, p. 51) of northeast Arizona and with the Piney Creek Alluvium of Hunt (1955, p. 114) of the Denver area, Colorado. Similar deposits occur throughout the Rocky Mountain region.

\section{MODERN FLOOD-PLAIN DEPOSTTS}

Flood-plain deposits are forming actively along the Green River, Henrys Fork, Sheep Creek, and Red Creek. All other streams of the area are entrenching their beds rather than building them. Along the Green River, Henrys Fork, and Sheep Creek, flood-plain deposits accumulate mainly during the short period of high water when the streams overflow their banks after the snow pack of the high-mountains melts in early summer. But in many years, even these streams fail to attain flood stage. Red Creek floods chiefly during or after heavy summer rainstorms; melting of the light snow pack on its watershed rarely causes flooding.

The flood plain of the Green River is discontinuous. Large segments lie upstream from Flaming Gorge and downstream from the mouth of Red Canyon in Browns Park. Between these points the river flows fast between steep canyon walls and has built rudimentary patches of flood plain only where its gradient is flattened locally by channel obstructions. Even in Browns 
Park, large flood plains are lacking upstream from about the Colorado State line.

The broad bottomlands above Flaming Gorge, both along the Green River and along Henrys Fork, are graded to a local base level several miles below Flaming Gorge at Beehive Point, where the first white-water rapids appear in the canyon section of the river at the mouth of Kingfisher Canyon. Between Flaming Gorge and Beehive Point, despite a low gradient, the river has not constructed wide flood plains because of its confinement in narrow canyons.

Sheep Creek is graded throughout its length from the west boundary of the mapped area to its junction with the Green River. Its flooded plain, though narrow, is continuous in that distance, but it is too narrow to show on the map in its lower reach across the Weber Sandstone.

Red Creek, in its reach across Clay Basin, is graded to a base level in the canyon of Red Creek below Two Horse Butte. Upstream from this canyon, Red Creek is overloaded with sediment most of the time and, on a small scale, has a shifting braided channel. Its narrow flood plain coincides with its meander belt. Below the canyon of Red Creek, Red Creek is degrading a Recent alluvial fill and has no mappable flood plain.

Flood-plain deposits of the Green River and Henrys Fork consist mostly of compact silt and fine- to mediumgrained sand. These materials have low bearing strength and are very slippery when wet. Also included, however, are lenses and sheets of channel gravel, which in places is very coarse. On the map, islands and bars in the channel of the Green River are shown as flood-plain deposits also. These deposits upstream from Beehive Point and downstream from Swallow Canyon consist mostly of silty sand; in Red Canyon and in Browns Park above Swallow Canyon they consist mostly of coarse gravel.

\section{TALUS}

Talus is widespread in the area, particularly in the more rugged parts, but patches of mappable size are not numerous and many small accumulations are unmapped. For the most part, talus does not seem to be accumulating to any great extent at the present time. Many deposits are being attacked vigorously by erosion, and some have been beheaded by recession of the slopes behind them through gullying and rill erosion along the talus cone-hillside contact. Some such cones have been reduced to scree-covered bedrock ramparts that stand well out from the face of the main hill slope.

The process leading to the beheading of alluvial cones has been described by Bradley (1936a, p. 193). It is favored by a resistant caprock, which provides the rubble for the talus, and a nonresistant slope-forming unit beneath, on which the rubble accumulates and into which the gullies are cut. Good examples are seen along Sheep Creek a mile or two downstream from Sheep Creek Gap. In the Sheep Creek area, the Navajo Sandstone provides the rubble, and the Moenkopi Formation provides the slope.

Small talus deposits are still accumulating in some places. At Flaming Gorge, an active rockfall on the high northwest cliff contributes talus to the slopes below. (See frontispiece.) This rockfall has been active for at least 90 years; its white scar shows plainly on photographs taken in 1870 by W. H. Jackson, pioneer photographer of the Old West, who at that time was associated with the Hayden Survey. Since Jackson's time, the scar at Flaming Gorge has enlarged greatly and has progressed upward from the middle of the cliff to the top. Similar but smaller rockfalls are active on the northwest slope of Boars Tusk. Talus also is accumulating here and there in Red Canyon, locally in the canyon of Beaver Creek, and in various other places as small thin patches.

\section{LANDSLIDES}

Several types of landslides occur in the area, chiefly on steep slopes where failure of incompetent zones in the rock or in the soil mantle has caused mass movement of material. Such failures have been most abundant in the Hilliard Shale, especially along the Uinta fault between the east end of Dutch John Mountain and Bender Mountain. Slides in that area range from small discrete. slump blocks to large vaguely bounded tracts covering many acres. They also range in activity from currently moving masses to stabilized eroded remnants. Many small slides are not shown on the map.

Slides in the Hilliard Shale in the above area commonly involve one or more adjacent formations in addition to the Hilliard; some slides at the east end of Dutch John Mountain appear to involve primarily the Morrison Formation; others involve shale zones in the Frontier. Most of these slides are old and dissected, but a few that are still active display fresh scarplets and enclosed basins at their heads and rubbly hummocks at their toes. Elsewhere, slides have formed in the Red Creek Quartzite, in the Uinta Mountain Group, in the Carmel Formation, and in the Frontier Formation.

LANDSLIDES ALONG THE UINTA FAULT

A combination of several factors has led to the abundant landslides along the Uinta fault. (1) The fault plane dips southward so that competent Precambrian rocks in the hanging wall have ridden up over incompetent Hilliard Shale and other rocks in the footwall. (2) The Hilliard has been dragged upward to a near- 


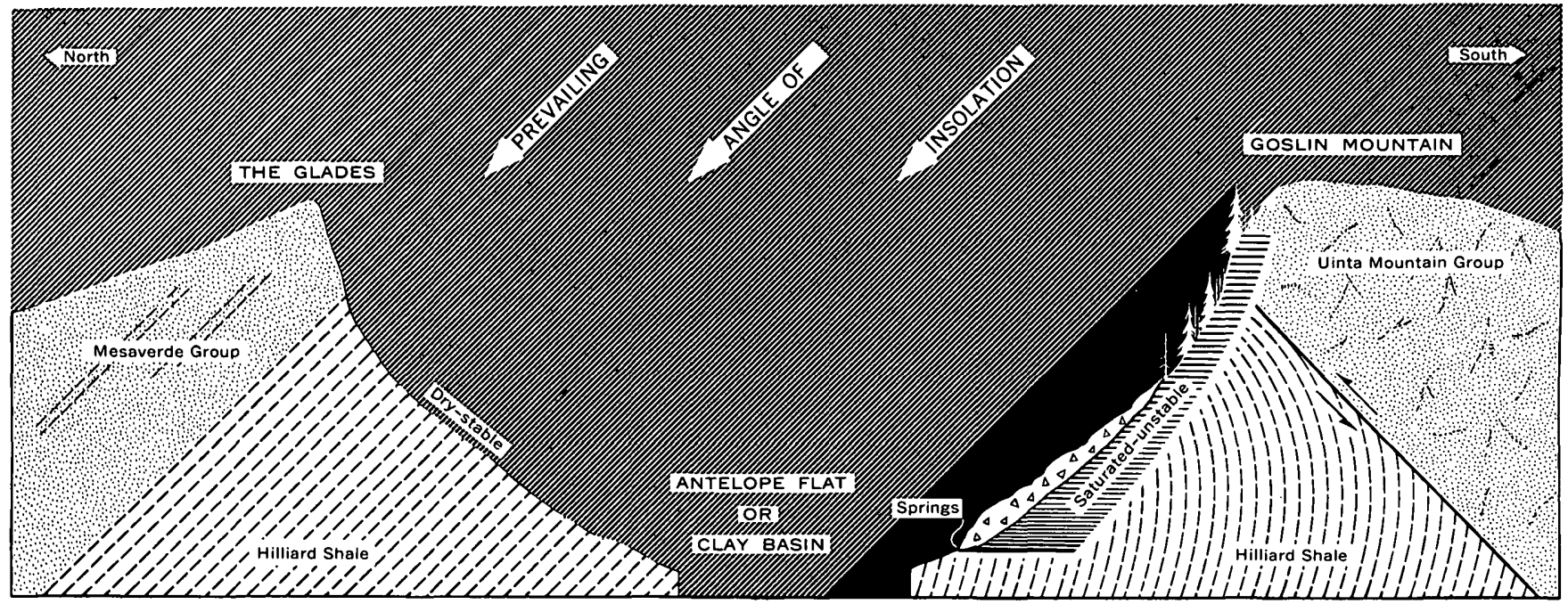

Fiadre 43.-Diagram showing effect of differential insolation on stability of slopes underlain by Hilliard Shale. On hot, south-faclng slope of The Glades (left), direct insolation dries slope, inhibits growth of vegetation, and promotes rapid runoff; on cool, north-facing slope of Goslin Mountain, inclined Insolation favors growth of vegetation, promotes inflitration of molsture, and precipitates landsliding.

vertical to overturned attitude, which has further reduced its stabiilty. (3) Differential erosion along the fault has produced a high fault-line scarp which affords the required topographic unstability needed to cause landsliding. (4) Heavy masses of competent Precambrian rock rest unsupported on Hilliard Shale, setting up a shear component of gravity in the same direction as the slope of the hill. (5) Northward slope exposure promotes the growth of vegetation, which encourages and is encouraged by retention and infiltration of moisture. Infiltration further reduces the stability of the Hilliard Shale and precipitates slope failure.

A saturated condition on the slopes along the Uinta fault is indicated by many small springs. Most of these springs are mere seeps, but some of them, such as Ford Spring and Edith Aspden Spring at Edith Aspden Park on the slopes of Goslin Mountain and Fighting Spring on the slope of Bender Mountain, yield several gallons of water per minute.

The significance of factor 5-the direction of slope exposure-in precipitating slope failure is emphasized by an area along the Hilliard-Mesaverde Group contact north of Antelope Flat and Clay Basin (fig. 35). Here, conditions are mechanically similar to those along the Uinta Fault, but the slope exposure is southward and there are no landslides. In this area, steeply dipping unsupported Mesaverde overlies eroded Hilliard. The south-facing Mesaverde escarpment (fig. 43) receives intense direct insolation which dries the underlying slopes, inhibits growth of vegetation, and prornotes rapid runoff. Factor 5 gains further credence from the observation that virtually all landslides in the mapped area, including those on other formations as well as the Hilliard, are on northward-facing slopes.

\section{I.ANDSLIDES CAUGED BY IRRIGATION WATER}

Small slides on the north side of a high bench $21 / 2$ miles southwest of Manila involve Hilliard Shale and gravels on bench 2. Though small, these slides are significant because they encroach on cultivated fields at the top of the bench, hence have a small but cumulative economic consequence. Excess irrigation water drains down through the very permeable bench gravels and saturates the subjacent shale, which then fails. Small seeps issue from the toes of the slides and from the gravel-shale contact.

\section{LANDSLIDE ON BOARS TUSK}

A large slide on the northeast slope on Boars Tusk 2 miles east of Flaming Gorge (fig. 44) involves failure in several formations. This slide is old, partly dissected, and apparently stabilized, but its surface remains chaotic and hummocky. Failure was due essentially to the same factors that caused sliding in the Hilliard Shale farther east along the Uinta fault. Failure of steeply inclined incompetent beds in the Morrison and Carmel Formations caused sliding in parts of the Navajo, Carmel, Entrada, Curtis, Morrison, Dakota, Mowry, and Frontier Formations. The slide motion was complex, and jumbled frágments of the several involved formations are much intermixed. At the head of the slide, motion was simple and rotational; farther downslope, it was more complex. At the west margin of the slide, a fingerlike branch is separated from the main slide mass by a buttressing outcrop of the Frontier Formation. At the toe of this branch, great tilted blocks of sandstone torn from the upper unit of the Frontier Formation have slid northward downdip on the lower shaly unit of the Frontier. 


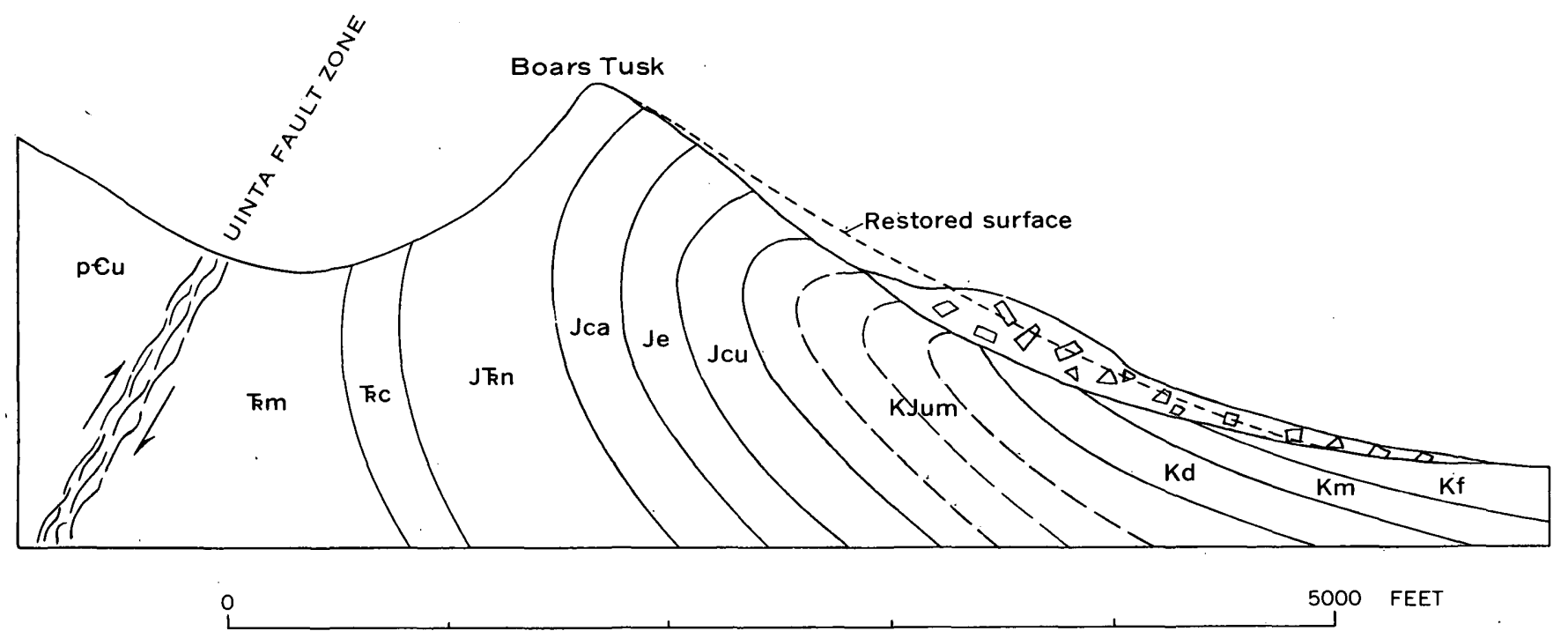

Figure 44.-Diagram showing general relationships of landslide on northeast slope of Boars Tusk. Initial failure apparently was in Morrison Formation. p€u, Uinta Mountain Group; Km, Moenkopi; Kc, Chinle; J kn, Navajo; Jca, Carmel; Je, Entrada; Jcu, Curtis; KJum, Unnamed Lower Cretaceous rocks and Morrison; Kd, Dakota; Km, Mowry; Kf, Frontier. Vertical scale exaggerated about one-third.

The sandstone blocks are so large that they could be mistaken for bedrock and could lead to anomalous structural'interpretations.

\section{LANDSLIDES IN THE RED CREEK QUARTZITE}

Very few landslides have been observed in the Red Creek Quartzite. Several slides along the Uinta fault involve the Red Creek indirectly, where slope failures have originated in adjacent Hilliard Shale or in fault gouge, but initial failures within the Red Creek itself are rare because the formation normally possesses high slope stability.

Three small slides are mapped in the Red Creek Quartzite near the head of Willow Creek. In that area the Red Creek contains abundant chloritic, micaceous schistose material which is highly disturbed by the effects of two adjacent faults-the Uinta fault on the north and the Bender fault on the south. 'The formation in that area, therefore, is more susceptible than usual to sliding.

One of these slides is still active. In the recent past it blocked the course of Galloway Creek, a tributary of Willow Creek, which then alluviated its bed upstream from the point of blockage. Galloway Creek has since gullied through the alluvium and, by also attacking the toe of the slide, has caused renewed movement.

A small slide in the canyon of Red Creek is unusual in that its rubble contains traces of uranium mineralization. Failure on the part of prospectors to recognize the true nature of the slide has led to fruitless exploration for uranium. An exploratory adit penetrates the sole of the slide and extends a few feet into undisturbed mica schist. The sole of the slide has been interpreted by some geologists as a low-angle normal fault. The slide has a maximum length of about a quarter of a mile and an area of about 12 acres. It appears to be inactive and, in fact, is partly dissected. Its age may be early Recent, if its relationship to younger alluvial remnants along Red Creek is any indication. These remnants overlap the toe of the slide. Sliding was caused by failure of steeply dipping mica schist, which in turn dislodged metaquartzite higher upslope. The chaotic rubble of the slide consists chiefly of metaquartzitesome canted blocks must weigh more than 200 tons.

LANDSLIDES IN THE UINTA MOUNTAIN GROUP

Most landslides in the Uinta Mountain Group have resulted from failure of steeply inclined shaly zones in areas of strong relief. Such failures have resulted chiefly where erosion has removed the support of normally competent rock, such as quartzite, resting on shale, so that the competent rock has slid downdip on the bedding plane of the shale. Slides of this sort are found on the northwest slopes of Dowd Mountain and Bear Mountain, in Red Canyon south of Dutch John Bench, and on the slope of Cold Spring Mountain in the canyon of Beaver Creek. Most of these slides have chaotic, hummocky surfaces which contrast with the more orderly appearing topography of adjacent slopes.

Two slides in the canyon of Beaver Creek are unusual in structure and appearance in that they have moved as simple, essentially coherent slabs. The cause of sliding, however, was the same - namely, slippage of quartzite on shale. Both slides lie on a steep dip slope; the bedding dips north at about $38^{\circ}$ or $40^{\circ}$. Beaver Creek, in its narrow canyon, has undercut quartzite resting on 
shale, so that support downslope was taken from the quartzite, and it slid. The larger slide is about 1,500 feet long, about 600 feet wide, and has an area of about 16 acres; the smaller slide is about the same length as the larger one but is much narrower and has less than half the area. In a snowplowlike motion, both slides pushed up marginal ridges of jumbled quartzite.

LANDSLIDES IN THE CARMEL AND FRONTIER FORMATIONS

A few small landslides have been observed in the Carmel and Frontier Formations. Causes and structural characteristics of these slides are nearly identical with those of slides in the Uinta Mountain Group. Slope failure is due to a combination of steep dips, oversteepened slopes, saturation, and slippage of competent beds such as limestone or sandstone on incompetent beds such as gypsum or shale.

\section{EOLIAN DEPOSITS}

Dune sand is found in many places on the flood plain of the Green River and in various other physiographic settings also. It consists chiefly of fine well-sorted sand, most of which is derived locally. Dunes near the river are derived mainly from the flood plain itself and from dry bars in high-water channels. At higher altitudes, dunes are derived from bench gravels, Recent alluvial fills, and weathered sandstone formations. In the western part of the area, the Weber and Navajo Sandstones support many small tracts of wind-laid sand. These tracts range in size from a few square yards to several acres. Many of them are still accumulating, but many others are stabilized and grassed over. In the eastern part of the area, the Browns Park Formation is the source of many dunes. Even the Uinta Mountain group, locally, is a source of dune sand.

In many places, small dunes or pockets of sand have accumulated to the lee of a high bench or in the shadow of a cliff. Such tracts are good places to search for Indian artifacts as they were much favored by the Indians for campsites. Sandy areas sheltered by pinyon pine or juniper and provided with a good view of the countryside were especially favored. Here, the young brave could sit comfortably in the warm sand, flake his arrowheads, and scan the distant slopes for enemies or game. Many such places are almost literally paved with rock chips.

The largest single dune tract in the area is inactive and well stabilized. This tract covers an area of about 300 acres in the west-central part of Antelope Flatchiefly in secs. 23 and 24, T. 3 N., R. 21 E. It retains its original rolling to somewhat hummocky relief but has a soil profile that indicates long stability; a yellowishbrown oxidized zone that is slightly humified at the surface extends downward from the surface to a depth of about 1 foot, where it is underlain by a lime-enriched zone about $11 / 2$ to 2 feet thick. This enriched zone in turn is underlain by fresh unaltered sand. The character of the soil profile suggests a middle Wisconsin age for the deposit.

\section{STRUCTURE}

\section{GENERAL SETTING}

The dominant structural feature of the Flaming Gorge area is the Uinta anticline. This great fold, from its western plunge at the town of Kamas, Utah, to its eastern plunge at the Little Snake River in Colorado has an axial length of about 160 miles. It has a mean width of about 30 miles, but it is twice that width in its eastern part if subsidiary folds are included as part of the structure. In a general way the fold coincides with the mountainous mass of the Uinta range. The outermost hogbacks on the limbs of the fold, however, extend well out from the mountains proper in many places, and near the east end of the range the crest of the fold itself passes beneath thick sediments in the broad valley of Browns Park. 'The fold axis otherwise extends west and east well beyond the Uinta Mountains. To the west it emerges at the Wasatch front in the Big Cottonwood uplift (Crittenden, 1955, p. 20) 30 miles west of the town of Kamas; to the east it continues as the Axial Basin anticline (Gale, 1910, p. 97 ; Sears, 1924b, p. 290) and eventually merges with the southeast-trending folds of the White River uplift.

The Uinta anticline is broadly arcuate in plan, concave to the south. It is compound in that it consists of two major elongate domes, subequal in size, alined on a single east-west axis (Hansen, 1957b, fig. 1). These domes are expressed by structural closures in the Uinta Mountain Group and by inward bowings in the outcrop belts of the flanking formations (fig. 45). They are thus separated by a shallow structural swale across the fold axis roughly in line with the towns of Manila and Vernal. The inward bowing of this swale on the north flank of the range has been referred to as the Sheep Creek synclinal reentrant (Hansen and Bonilla, 1956); the inward bowing on the south flank has been called the Vernal Valley trough (Walton, 1944, p. 124). The west dome of the Uinta anticline culminates near Gilbert Peak in the high western part of the range; the east dome culminates in the valley of Browns Park but is concealed by the Browns Park Formation. The Flaming Gorge area is mainly on the north limb of the east dome, although part of Browns Park is on the south limb.

In cross section the Uinta anticline is markedly asymmetrical. The crestline of the fold is much closer to the north flank than to the south flank, and the north 


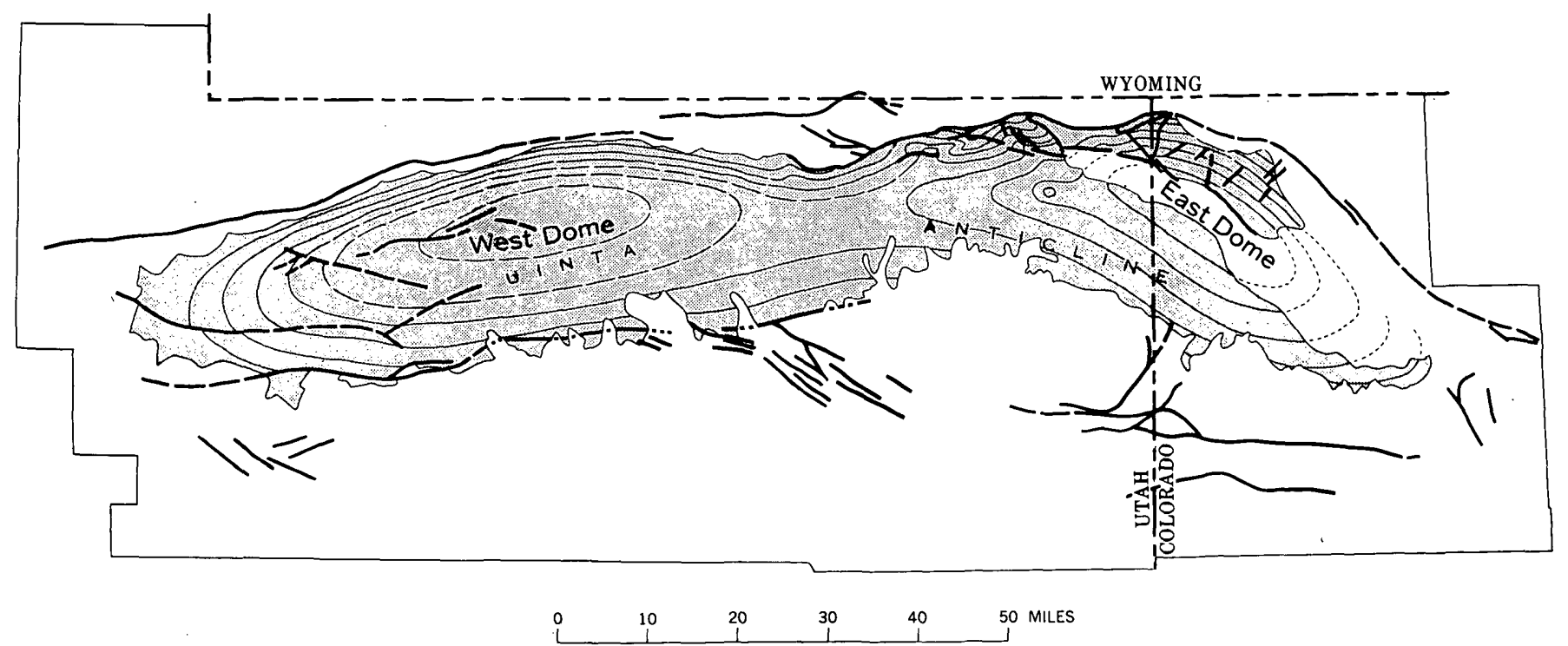

Figure 45.-Generalized structure map of Uinta Mountains showing compound form of Uinta anticline. Form lines on Precambrian Uinta Mountaln Group (shaded) inferred from bedding attitudes and aerial photographs. Heavy lines are faults. Geology modifled after Hansen (1957b, fig. 1).

limb is much steeper than the south limb. Dips rarely exceed $30^{\circ}$ on the south limb and are generally less than $15^{\circ}$. Dips steeper than $45^{\circ}$ are commonplace on the north limb, and in many places the beds are overturned. In a large measure the high dips and overturning are related to high-angle reverse faults.

The mountainous core of the Uinta Range is nearly enclosed by faults. The largest and most conspicuous of these have been known since the days of the Territorial Surveys. Most of the major faults have easterly trends subparallel to the elongation of the range itself-hence, are basically strike faults. Most of them dip southward at angles greater than $45^{\circ}$ and are downthrown on the south. Faults on the south flank thus are predominantly normal in habit; on the north flank they are predominantly reverse faults. Normal faults, however, are abundant in the northeastern part of the range, from Red Canyon east to Cold Spring Mountain, but they are smaller than the large reverse faults in the same area. In general, the reverse faults on the north flank of the range have greater displacements than the normal faults on the south flank, and the deformation in adjacent rocks is more severe; much of this deformation is drag caused by flexing along the faultlines prior to rupture.

One of the largest faults in the Uinta Mountains is the Uinta fault. This fault extends the entire length of the Flaming Gorge area and several miles beyond, separating Precambrian rocks on the south or upthrown block from Paleozoic, Mesozoic, and Tertiary rocks on the north or downthrown block. It is, therefore, one of the dominating structural features of the area.
Structural features of the Flaming Gorge area fall into two major groups which, for discussion, lend themselves to separate description: (1) structural features confined to the Red Creek Quartzite and formed in earlier Precambrian time; and (2) structural features found in the younger rocks, as well as in the Red Creek, and formed mostly during or since the Laramide orogeny. Structural features confined to the Red Creek Quartzite include tight folds, faults, minor folds and wrinkles, foliations, cleavages, and lineations. All these features were imposed on the Red Creek by intense deformation and metamorphism at great depth before the overlying Uinta Mountain Group was deposited.

Younger structural features of the Flaming Gorge area resulted from milder deformation at much shallower depths. They include broad open folds (including the Uinta anticline), reverse and normal faults and related drag structures, and joints. The deformations that formed these structures were not accompanied by metamorphism, at least not at the levels to which the rocks are now exposed.

\section{OLDER PRECAMBRIAN STRUCTURE}

The Red Creek Quartzite crops out in seven separate areas. Each of these areas is separated from the others by intervening outcrops of the Uinta Mountain Group. The distribution of the Red Creek Quartzite and its relationship to adjacent formations, except for two small outcrop areas a few miles west along the Uinta fault, are shown in figure 46. For convenience, the five major outcrop areas shown in figure 46 are listed as areas 1-5 from west to east. The two smaller 

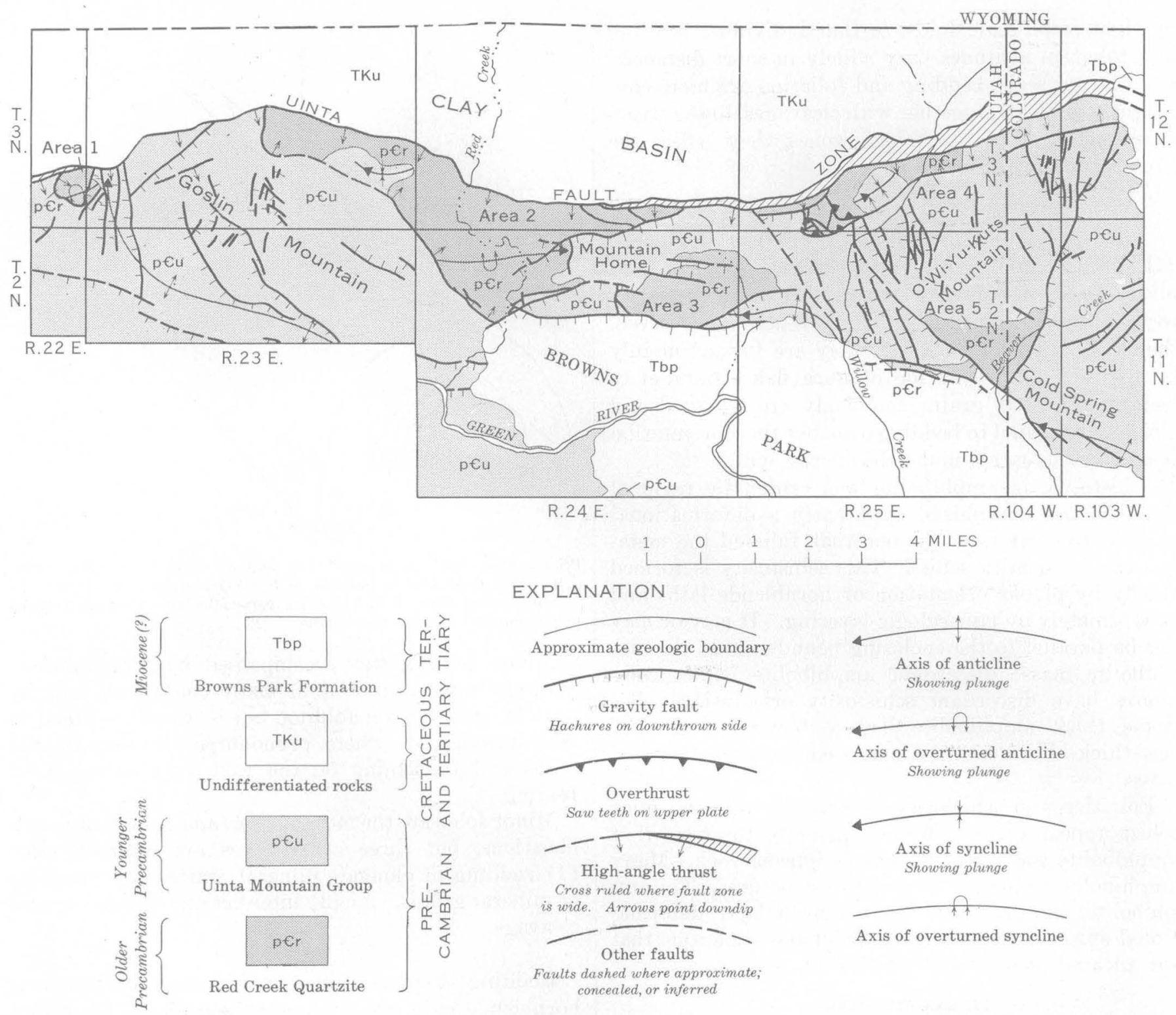

EXPLANATION
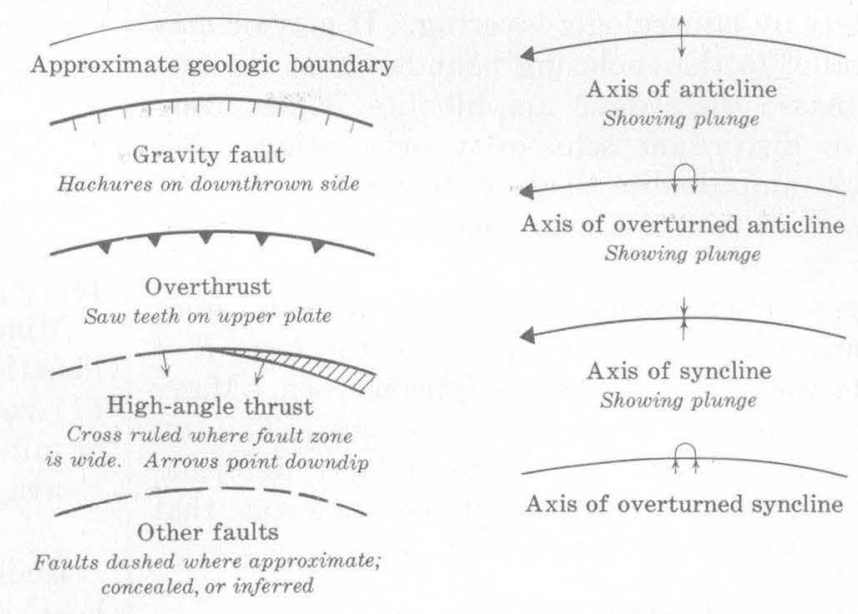
Showing plunge

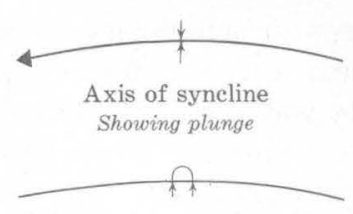

Axis of overturned syncline concealed, or inferred

FigURE 46.-Generalized geologic map showing distribution of Red Creek Quartzite in eastern Uinta Mountains. Modified after Hansen (1957e).

areas to the west are shown on the geologic map (pl. 1). Areas 1 and 4 and the two smaller areas to the west are enclosed by faults; areas 2,3 , and 5 are bounded partly by faults and partly by unconformities.

For reasons noted further in the pages that follow, some of the faults that enclose the Red Creek Quartzite are regarded as thrust faults that were active prior to the arching of the Uinta anticline; arching tilted the fault planes to attitudes much steeper than they had initially. Subsequent normal faulting and erosion then isolated some thrust remnants from their roots. Probably rootless remnants include area 1 and the small remnants of the Red Creek Quartzite west of area 1. Area 4 may lack roots, also. The rootless character of at least one small mass of the Red Creek Quartzite in the Dutch John Mountain quadrangle is indicated in the SW $1 / 4$ SW $1 / 4$ sec. 34, T. 3 N., R. 22 E., where the U.S. Bureau of Reclamation drilled a test well for water. This well passes downward from the Red Creek Quartzite into the Uinta Mountain Group at a depth of 440 feet.

Major structural elements in the several separate outcrop areas lack obvious continuity from one area to the next, but reasonable inferences can be made to explain their relationships. In detail, the structure is complex, but the overall structural framework appears to be simple. Except in area 5, strongly implicated folds trend and plung northeastward; axial planes dip steeply northward. In area 5 , folds trend and plunge southeastward. In all areas, the bedding is contorted 
by tight small-scale folds, so that individual bedding and foliation attitudes vary widely in short distances. On a larger scale, bedding and foliation are more consistently oriented; together with cleavages, linear structures, and traceable lithologic zones, they reflect the gross structure of the area.

\section{MINOR SRUCTURAL FEATURES FOLIATION AND SCHISTOSITY}

Foliation and schistosity in the metaquartzite and mica schist are secondary structural features caused by regional dynamic metamorphism. Wherever observed, they are parallel to bedding; they are formed mainly by a preferred orientation of mica flakes parallel to bedding. Quartz grains commonly are flattened and elongated parallel to bedding also, but their orientation is not obvious except under the microscope.

Schistosity in amphibolite was caused by regional dynamic metamorphism. apparently a deformational episode younger than the one that foliated the metaquartzite and mica schist. This schistosity is formed chiefly by planar orientation of hornblende laths and subordinately by mineralogic layering. It may or may not be parallel to the enclosing boundaries of the amphibolite mass; discordant amphibolite bodies commonly have discordant schistosity orientations also. Some thick amphibolite bodies-tens or scores of feet thick-have schistose shells enclosing nonfoliated cores.

Foliation and schistosity in metaquartzite and mica schist appear to have formed prior to the time that amphibolite was injected as mafic igneous rock. Many amphibolite bodies cut across these structures. The amphibolite, in turn, was foliated by a later deformational episode, possibly at or about the same time that the mica, schist was tightly wrinkled.

\section{IINEAR STRUCTURES}

\section{MINOR FOLDS}

The Red Creek Quartzite contains countless minor folds. These folds range downward in size from structures a few score feet across the limbs to minute wrinkles a fraction of a centimeter across. The size of each fold depends partly on the competence and thickness of the affected bed; in metaquartzites a coarse mullion structure is formed from multiple folds, each fold several inches to less than an inch across and many times longer than wide. Tens of thousands of such folds may appear on a single outcrop. In mica schists, tight accordionlike wrinkles are more characteristic; there may be as many as 20 wrinkles per inch, or as few as 5 . Minor folds of the Red Creek Quartzite constitute a strong $b$-axis lineation (parallel to the major structural trend, fig. 47). This lineation has marked consistency over wide areas.

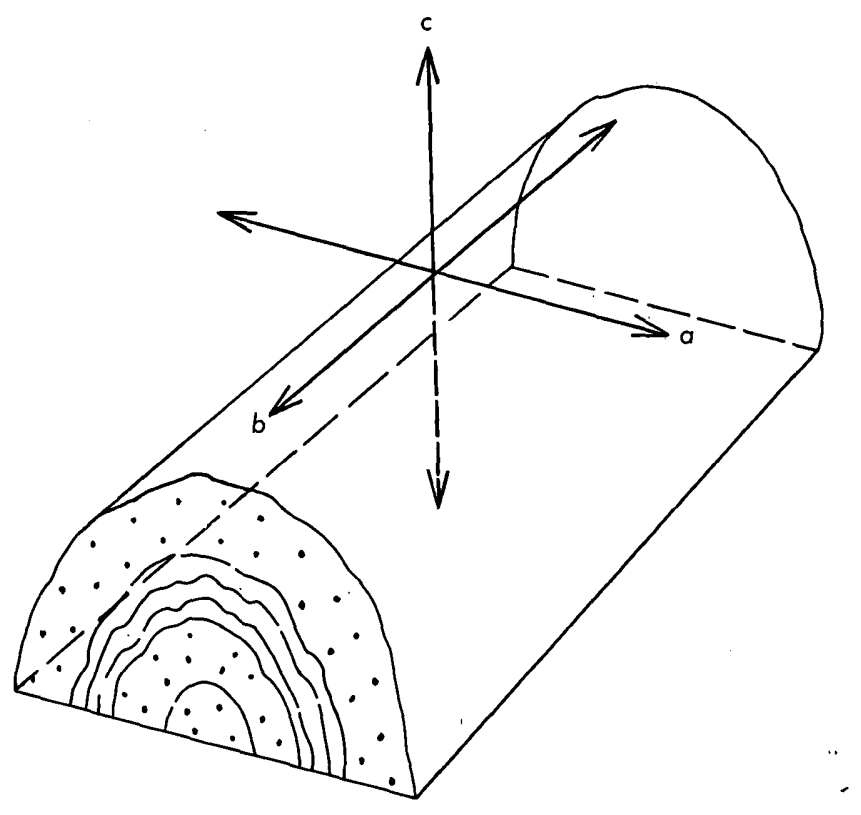

Figure 47.-Axial coordinates of a fold as applied by Cloos (1937, p. 54). Fold axis is parallel to $b$. Axtal plane is bc plane. In nonplunging folds, $a, b$, and $c$ are perpendicular. Slippage between beds during folding is in ac plane.

Minor folding was accompanied by rock flowage. Flowage was minimized in many competent beds by parallel and chevron folding, but it was widespread in incompetent beds where pronounced thinning on the limbs and thickening on the fold axes accompanied folding.

Minor folds are the most obvious and abundant $b$-axis lineations, but three other types are common also: (1) rodding of elongate mineral grains, (2) streaking of mineral grains, and (3) intersections of bedding and cleavage.

$$
\text { RODDING }
$$

Rodding is common in amphibolite; the individual hornblende laths are oriented subparallel to the $b$ fold axis, commonly in the plane of foliation. Some amphibolites that lack planar foliation show rodding. Rare examples of rodding are shown by large crystals of staurolite in tightly folded metaquartzite and mica schist. Staurolite generally is randomly oriented in the plane of foliation or bedding, but it occasionally has a strong preferred orientation parallel to $b$.

\section{STREAKING}

Streaking of nonelongate mineral grains is most common on bedding planes in metaquartzite; trains of mica grains are alined parallel to $b$. Staurolite occasionally forms this lineation also; rarely, it forms both rodding and streaking in combination (fig. 48).

$$
\text { IN'TERSECTIONS OF BEDDING AND CLEAVAGE }
$$

Mica schists in the Red Creek Quartzite commonly have a secondary cleavage parallel or subparallel to the 
axial planes of minor folds. Where cleavage intersects bedding, it forms a lineation parallel to $b$. This lineation is most prominent in interbedded mica schists and metaquartzites.

\section{SLICKENSIDES}

Slickensides are caused by slippage between beds during folding, hence are in the ac plane rather than in $b$ (fig. 47). These lineations are of less value for interpreting structural trends than are lineations parallel to $b$ inasmuch as they vary widely in orientation from place to place. Their orientation depends on the amount of plunge of the fold and on the position of the particular lineation on the fold-lineations near the fold axis bear and plunge differently from lineations on the limbs. Their orientation is consistent only on nonplunging folds. Slickensides are most common on the bedding planes of competent metaquartzites, where rock flowage has been minimal.

One unusual type of $a c$ lineation or slickenside, noted only in the Beaver Creek area, is useful for determining the sequence of beds--that is, top and bottom relationships. This lineation is here referred to for convenience as tadpole structure (fig. 49). It is caused by dragging of garnets along bedding planes as a result of slippage between beds during folding. On the outcrop, each garnet is seen to have a "tail" that points in the direction of slippage; in aggregate, the garnets resemble a school of tadpoles. Inasmuch as each bed during folding moved toward the anticlinal crest relative to the bed immediately underlying, the orientation of the "tadpoles" indicates indirectly the attitude of the beds: if the beds dip normally, the "tails" point downdip; if the beds are overturned, the "tails" point updip. This rule applies to bedding planes that face upward; the reverse would apply to the undersides of beds-for example, in an overhanging ledge. The consistency of this relationship is verified in the field by other sequence indicators, such as cleavage-bedding relationships and drag fold-bedding relationships.

\section{SIGNIFICANCE OF LINEAR STRUCTURES}

Complex minor folding in the Red Creek Quartzite causes almost infinite variations of dip and strike in very short lateral and vertical distances. Linear struc-

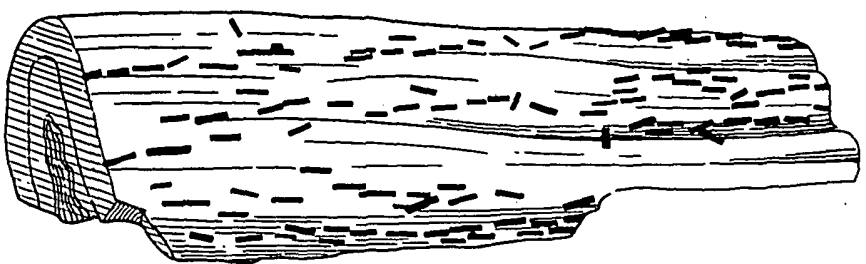

Fiqure 48.-Lineation formed by staurolite crystals oriented parallel to fold axis; minor fold in Red Creek Quartzite, canyon of Red Creek. Specimen is 10 inches long.
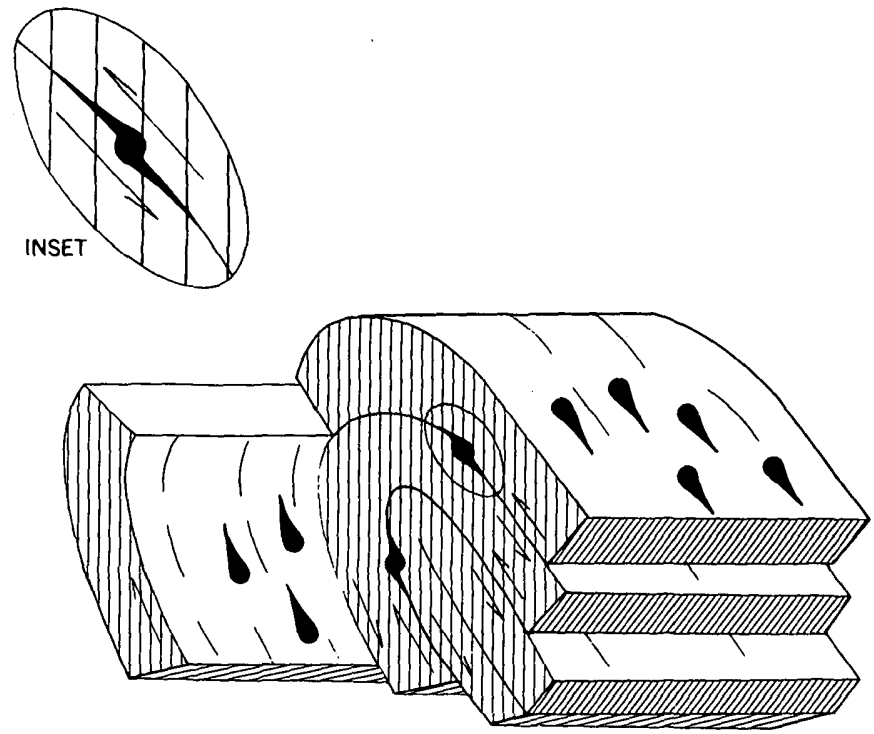

Fraure 49. - Ose of tadpole structure in determining sequence of beds. Garnets on bedding planes are dragged by slippage between beds during folding. On upward-facing bedding planes, "talls" point downdip if beds are rightside up, updip if beds are overturned. Mineral gralns other than garnets, or pebbles in a conglomerate, should comply with rule also.

tures produced by the same folding, however, have remarkable uniformity over wide areas, both as to direction and as to plunge. Linear structures, therefore, are highly useful indicators of the major structural trends in the Rəd Creek Quartzite.

Contour diagrams prepared from lineation measurements in the Red Creek, Mountain Home Draw, and Beaver Creek areas (fig. 50) show two distinct maxima in each diagram. These maxima are concentrations of $b$-axis lineations, and they represent two sets of fold axes. At Red Creek, one set plunges gently eastward and the other set plunges somewhat more steeply northeastward. At Mountain Home Draw, one set plunges gently northeastward and the other set is about horizontal--some folds plunge slightly northeast, others southwest. At Beaver Creek, one very strong set plunges about $40^{\circ}$ SE.; a weaker but still strong set plunges about $20^{\circ} \mathrm{S}$

Similar contour patterns in all three areas suggest that lineations in all three areas were caused by the same forces. Such differences as are shown in the diagrams are due mainly to flatter plunges at Mountain Home Draw as compared with those at the other two areas, and to a heavy concentration of southeast plunges in the Beaver Creek area. If the diagram for Beaver Creek is rotated counter clockwise $90^{\circ}$, the distribution of maxima is very similar to that shown by the diagram for Red Creek (fig. 51). One area possibly has been rotated tectonically relative to the other; such rotation could best be accomplished by subhorizontal movement along low-angle faults. Faults capable of such movement are abundant in the intervening area. 


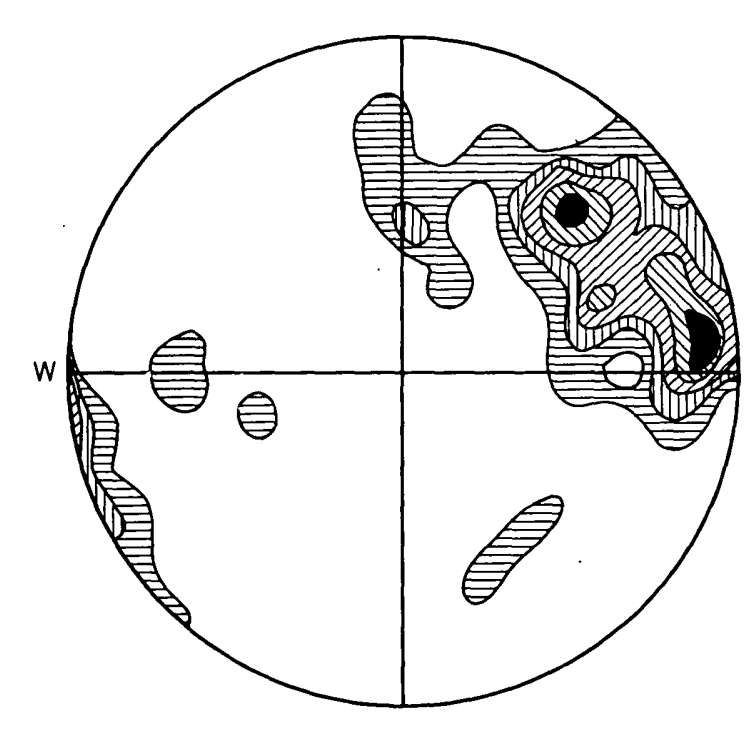

RED CREEK, area 3

Measured on 112 outcrops

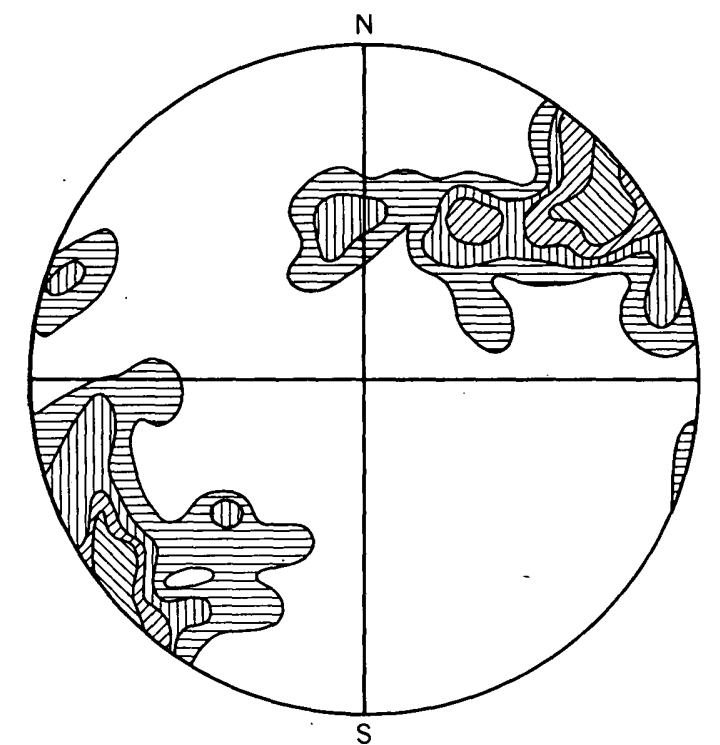

MOUNTAIN HOME DRAW, area 4 Measured on 56 outcrops

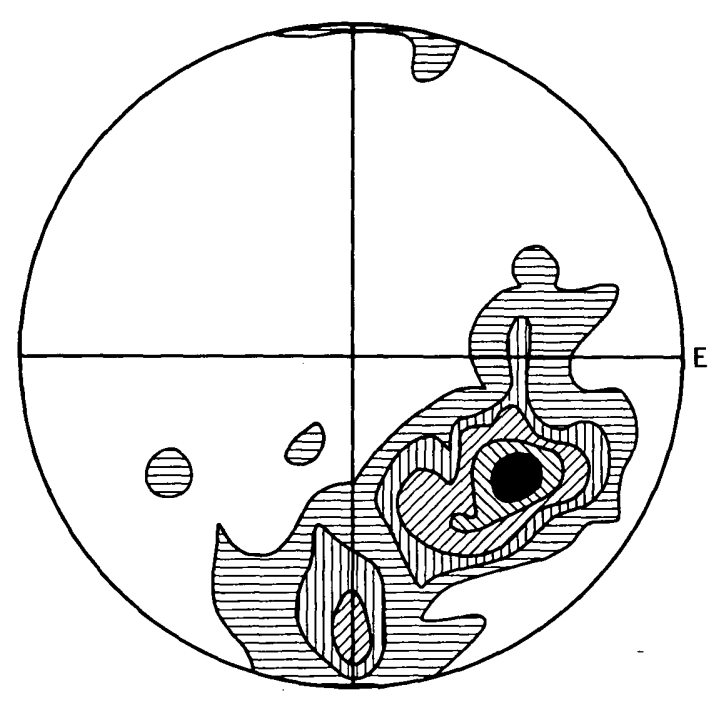

BEAVER CREEK, area 5

Measured on 115 outcrops

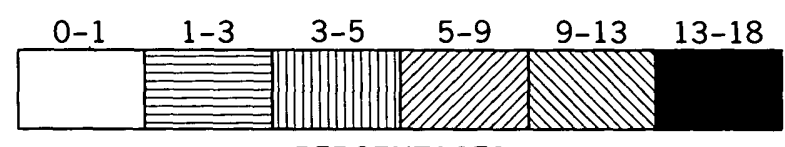

PERCENTAGES

FTavBE 50.-Contour dlagrams of linear structures in Red Creek Quartzite. Lower hemisphere projectlons. 


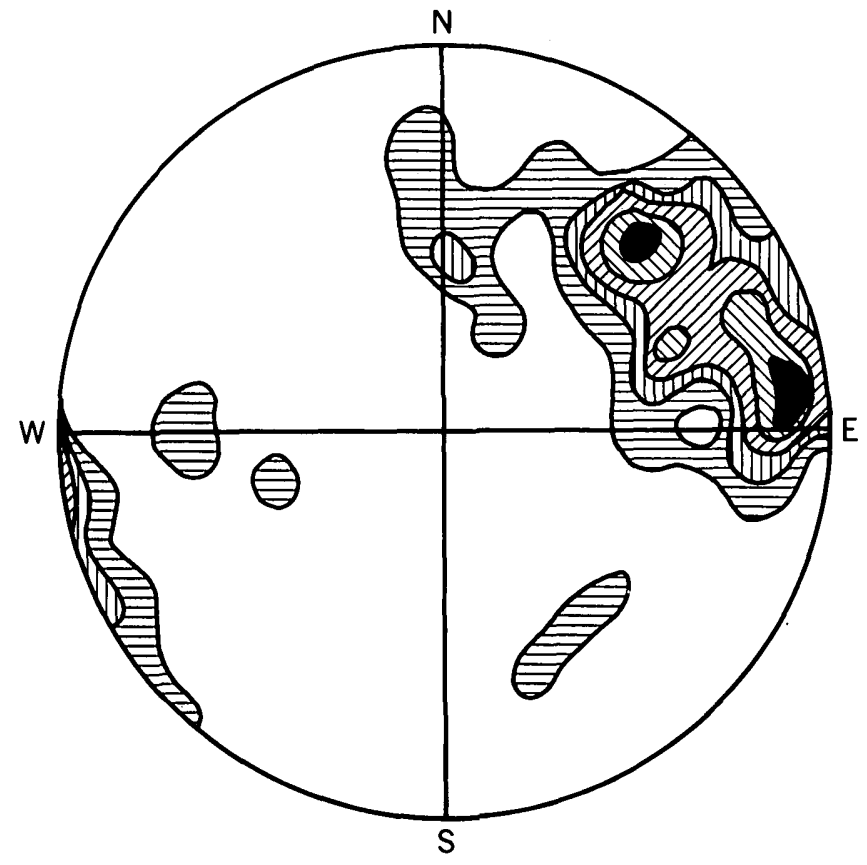

RED CREEK

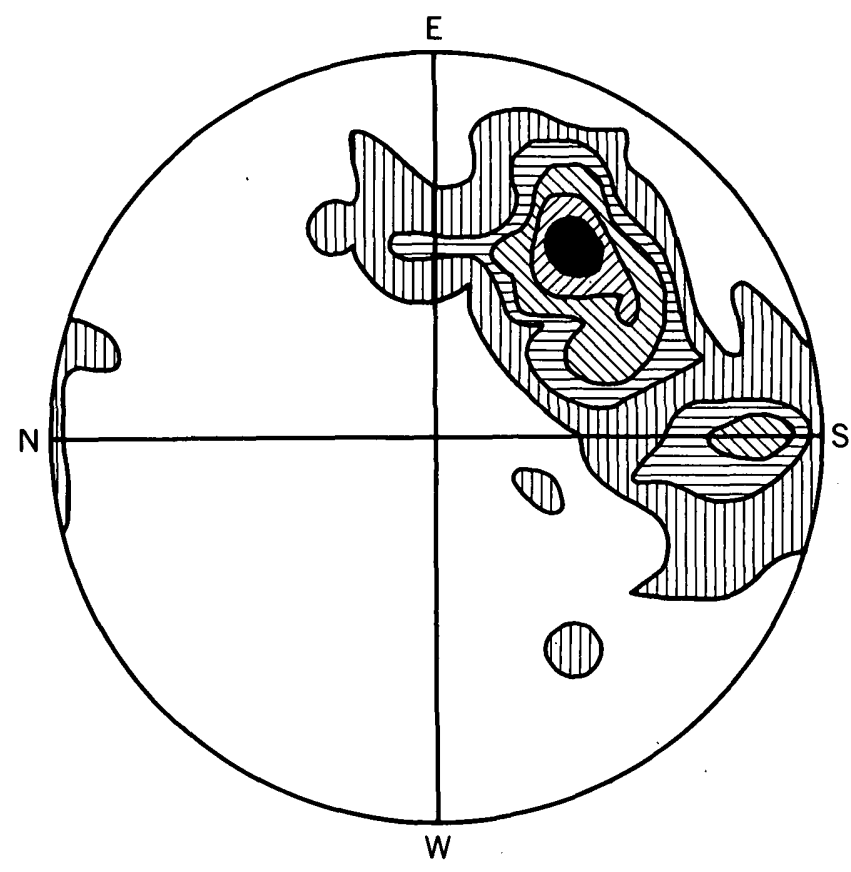

BEAVER CREEK

\begin{tabular}{|c|c|c|c|c|}
\hline $0-1$ & $1-3$ & $3-5$ & $5-9$ & $9-13$ \\
\hline & & & & \\
\hline
\end{tabular}

\section{PERCENTAGES}

Figurn 51.-Contour diagrams of linear structures measured at Red Creek and Beaver Creek. Diagrams are identical with those In figure 50 except that diagram for Beaver Creek has been rotated counterclockwise $90^{\circ}$ to show its similarity to the diagram for Red Creek.

\section{cleavage}

Cleavage related to folding is restricted mostly to the mica schists. It is caused by rupture of the limbs of microfolds or wrinkles. Such cleavage is largely mechanical, hence would be called fracture cleavage by most geologists. It is obscure but detectable in many places; it is well formed and well displayed in Mountain Home Draw.

Cleavage, as well as drag folds and tadpole structures, helps to verify the attitudes of larger scale structures. It has proved useful in reconstructing the major structural framework of the Red Creek Quartzite (fig. 52).

\section{MAJOR STRUCTURAL FEATURES}

The several outcrop areas of the Red Creek Quartzite are bounded partly by faults and partly by the unconformity between the Red Creek and the overlying Uinta
Mountain Group (pl. 1). The ages of some of the bounding faults are problematical; some of the faults clearly are Miocene or younger, hence are discussed in detail in connection with the younger structural features of the area. Some mention of them is needed here, however, to clarify the spatial relations of the Red Creek Quartzite to the adjacent younger rocks.

Areas 1, 2, and 4 (fig. 46) are bounded on the west and south by high-angle faults. These faults have some characteristics of thrust faults, such as recurved traces and pronounced drag effects in the walls. If these faults predate the updoming of the Uinta anticlineas seems highly probable-they originally dipped northward at low angles.

\section{STRUCTURE IN AREA}

Area 1 is a small subcircular tract of about 300 acres, completely enclosed by faults. It is bounded on the 


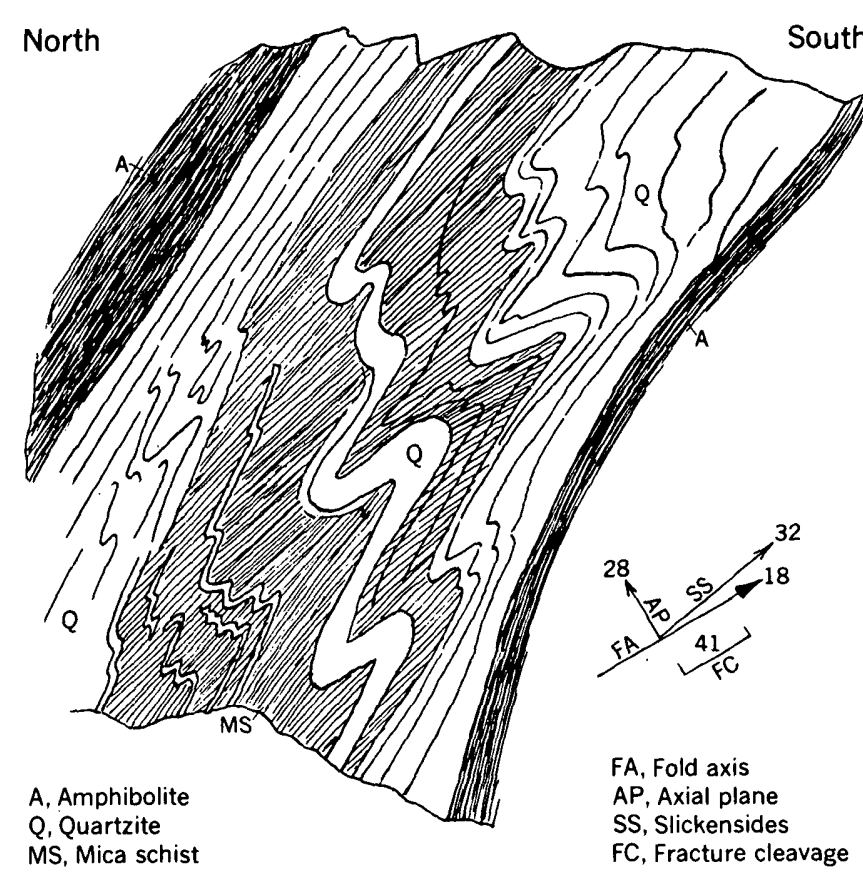

Frgure 52.-Cleavage and drag folds in Red Creek Quartzite, Canyon of Red Creek. Thin-bedded quartzite and mica schist dragged between walls of competent amphibolite. Sequence is on overturned limb of Garnet Canyon anticline. Outcrop shown in section is about 2 feet across. Structural diagram in lower right-hand corner is a plan view.

west and south by a recurved fault of the above-noted type: the trace indicates steep dips; the wallrock is strongly dragged. On the north, area 1 is bounded by the Uinta fault; on the east, by high-angle gravity faults (pl. 1). Area 1 thus appears to be a rootless normally faulted remnant of a thrust plate; the Red Creek Quartzite was thrust southwestward, apparently, over the Uinta Mountain Group. (See fig. 60.)

Internally, area 1 has the structure of a tightly folded asymmetrical syncline. Attitudes of foliation and linear elements indicate that its axial plane trends about N. $55^{\circ}$ E. and dips steeply north. Linear elements parallel to $b$ trend and plunge gently northeastward.

\section{STRUCTURE IN AREA 2}

Area 2 is the largest single surface expanse of the Red Creek Quartzite. It covers about $81 / 2$ square miles in the Goslin Mountain-Red Creek area, including the type locality along the canyon of Red Creek. Area 2 also presents the greatest lithologic diversity in the Red Creek Quartzite and the best developed assemblages of the high-grade minerals garmet, staurolite, and kyanite.

Area 2 is bounded on the southwest by the Goslin fault, a high-angle fault of large displacement which appears to predate the updoming of the Uinta anticline; initially, therefore, the fault probably was a lowangle thrust. On the north, area 2 is bounded by the Uinta fault; on the east and south, by high-angle grav- ity faults; and locally, by an unconformity with the Uinta Mountain Group.

Internally, area 2 is dominated structurally by a highly implicated overturned fold, the Garnet Canyon anticline (section $F-F^{\prime}$, pl. 1 ). On the map this fold is reflected by the crescentic outcrop pattern of a belt of mica schist and by the attitudes of foliation and linear structures. On the ground the fold is seen to best advantage from the east spur of Goslin Mountain, about in the center of sec. 5, T. 2 N., R. 24 E. From this position, looking east, the crestal area and both limbs are visible in one view. The crestline of the fold cannot be located precisely, inasmuch as it is partly masked by intricate small-scale folding; but it trends about west to east, approximately through the centers of secs. 6,5 , and 4, T. 2 N., R. 24 E., and it plunges gently eastward. The crest, moreover, is rather broad and flat, if minor folds are discounted. Both limbs are very steep, the south limb being mostly overturned. Prior to the updoming of the Uinta anticline, the Garnet Canyon anticline must have been nearly recumbent. To the west the Garnet Canyon anticline is truncated by the Goslin fault.

On the northwest flank of the Garnet Canyon anticline is a small tightly closed syncline. This fold can be reached by field car from the top of Goslin Mountain. It is noteworthy for containing an unusual infolded prism of basal conglomerate of the Uinta Mountain Group (fig. 53). Dips in the infolded prism of conglomerate are steep, but they are lower than in the subjacent Red Creek Quartzite. The syncline apparently has been folded more than once-initially, before the Uinta Mountain Group was deposited ; subsequently, after the Uinta Mountain Group was deposited.

\section{STRUCTURE IN AREA 8}

Area 3 covers about $21 / 2$ square miles centered between Mountain Home Draw and Jesse Ewing Canyon. Area 3 is bounded partly by faults and partly by the unconformity between the Red Creek Quartzite and the Uinta Mountain Group. Band Box Butte, for example, is a conspicuous outlier of Uinta Mountain Group basal conglomerate resting unconformably on the Red Creek Quartzite.

In area 3 the structure of the Red Creek Quartzite is essentially homoclinal. The rocks trend mostly about N. $70^{\circ} \mathrm{E}$., but some trends vary as much as several degrees in either direction. The rocks dip steeply both to the northwest and to the southeast, although northwestward dips predominate. Cleavages and drag folds indicate that the sequence is mostly overturned, that the rocks face southeast, and that the top of the sequence, therefore, is to the southeast. Area 3 appears to have good structural continuity with area 2 ; the homocline of 

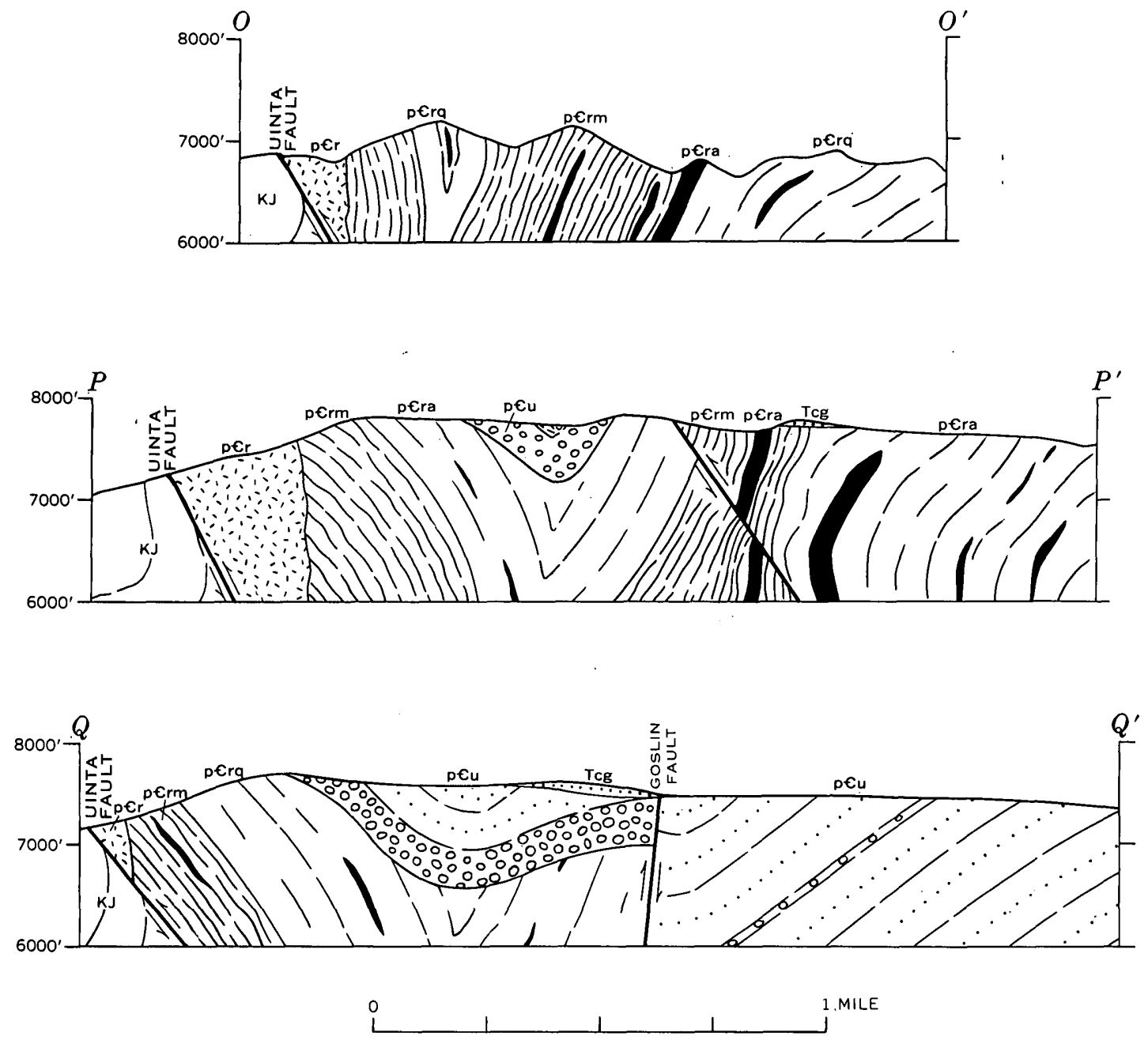

Fioure 53.-Geologic sections $O-O^{\prime}, P-P^{\prime}$, and $Q-Q^{\prime}$ across northeast corner of Goslin Mountain, area 2. Tcg, conglomerate of Tertiary age; KJ, Cretaceous and Jurassic rocks; $p € a$. amphibolite; $p € r$, epidiorite, $p € r m$, mica schist, p€rq, metaquarzite, all of the Red Creek Quartzite; $p \in u$, Uinta Mountain Group. Lines of sections shown on plate 1.

area 3 is probably an extension of the overturned south limb of the Garnet Canyon anticline.

Area 3 contains the largest and thickest masses of amphibolite in the Red Creek Quartzite. These masses intruded the metaquartzite and mica schist as mafic sheets and have since been metamorphosed. Bowings in the trends of metaquartzite and mica schist adjacent to amphibolite probably are due to forceable intrusion by these sheets of mafic rock.

\section{STRUCTURE IN AREA 4}

Area 4 overlooks Clay Basin from the shoulder of Bender Mountain near the head of Willow Creek. This area can be reached on foot or by way of rough jeep trails from either Clay Basin or O-Wi-Yu-Kuts Mountain. It extends about 4 miles west to east, averages about half a mile in width, and covers about 2 square miles.
Structurally, area 4 is complex. It is enclosed by faults of diverse habit and attitude and is folded and faulted internally. On the north it is bounded by the wide Uinta fault zone; on the south, by the Bender fault. The Bender fault is a north-dipping high-angle reverse fault throughout most of its length, but toward the west it passes into a recurved, probably low-angle thrust similar in conformation to the western part of the Goslin fault in area 2 and to the fault that bounds area 1 on the west. The westernmost outcrops of area 4 are part of a sliverlike mass of steeply dipping metaquartzite and amphibolite adjacent to the Uinta fault. This mass forms a short strike ridge north of the Head of Cottonwood. The easternmost outcrops in area 4 are bounded by a cross fault between the Uinta fault and the Bender fault.

Area 4 contains a tightly infolded synclinal prism of basal Uinta Mountain Group quartzite and conglom- 


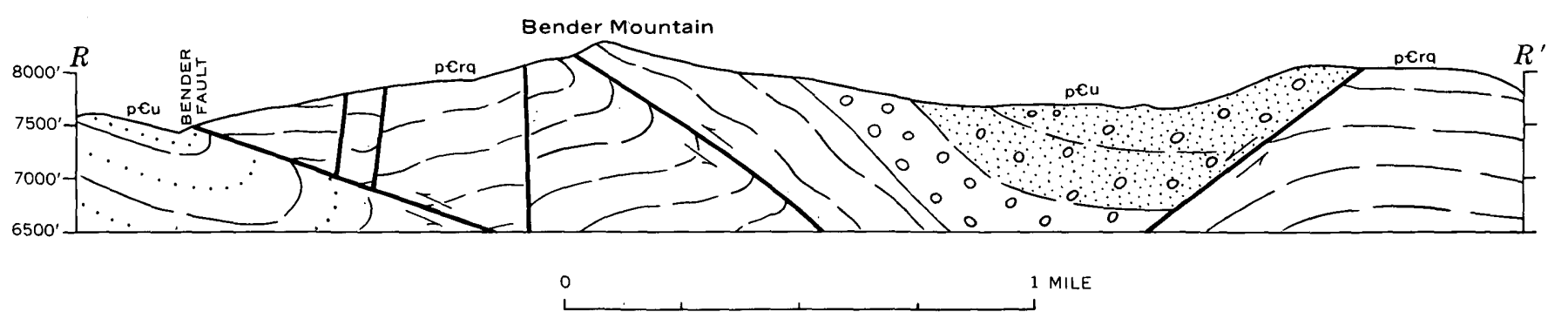

Figdre 54.-Geologic section $R-R^{\prime}$ through area 4, showing prism of basal Uinta Mountain Group conglomerate and quartzite infolded into Red Creek Quartzite. Thrust faults at left merge laterally, : p pu, Uinta Mountain Group; $p €_{r q}$, Red Creek Quartzite, metaquartzite. Line of section shown on plate 1.

erate analogous structurally to the synclinal prism of area 2 on Goslin Mountain. (See figs. 53, 54, and sec. $J-J^{\prime}$, pl. 1). Both prisms are superimposed on steeper dipping, more tightly folded beds in the Red Creek Quartzite, and both are closely associated structurally with reverse faults. Area 1, it may be recalled, has a synclinal structure, also.

West of the infolded syncline on Bender Mountain (area 4), between the Uinta fault on the north and the Bender fault on the south, is a segment of a thrust fault which probably passes eastward beneath the syncline. It crosses Bender Mountain in a shinglelike relationship to the Bender fault, joining the Bender fault at the surface on the south and terminating against the Uinta fault on the north. This fault is discernible from Clay Basin; although the fault plane is concealed by rubble, its dip appears to be about $30^{\circ} \mathrm{NE}$. Its upper plate, which contains the infolded syncline, is strongly lineated by wrinkles and mullion structures in the Red Creek Quartzite. Lineations plunge gently north (fig. 55 ). The lower plate of the fault-or the slice between the fault and the Bender fault-is much contorted and quite shattered; lineation attitudes, accordingly, are scattered and inconsistent.

\section{STRUCTURE IN AREA G}

Area 5 covers slightly more than $11 / 2$ square miles, mainly on the south slope of $\mathrm{O}-\mathrm{Wi}-\mathrm{Yu}$-Kuts Mountain, where it is deeply incised by the canyon of Willow Creek. In plan, area 5 is shaped like a scalene triangle whose base faces north and apex points south. The area is bounded on the north by the unconformity between the Red Creek Quartzite and the Uinta Mountain Group, on the southwest by the Beaver Creek normal fault, and on the southeast by the O-Wi-Yu-Kuts normal fault.

Several small inliers of the Red Creek Quartzite crop out southwest of the main area, in secs. 14 and 15, T. 2 N., R. 25 E. These inliers are brought to the surface along the upthrown sides of two normal step faults at the foot of O-Wi-Yu-Kuts Mountain (sec. $K-K^{\prime}$, pl. 1 ). Good exposures of the unconformity between the
Red Creek Quartzite and the Uinta Mountain Group can be seen along the boundaries of these outliers, especially near the center of sec. 15 where small ravines cut across the contact.

The structure in area 5, including inliers, is essentially homoclinal, although it is modified by intense small-scale folding. In general the foliation and bedding trend north to northeast and dip $30^{\circ}-50^{\circ}$ eastward or southeastward ; local departures from the general attitude are abundant. Drag folds, cleavages, and $a c$ plane lineations (tadpole structure) indicate that the sequence of bedding is right side up and that the rocks, therefore, pass from older to younger from west to east.

Linear structures parallel to the $b$ fold axis are abundant and well formed in area 5. (See fig. 50.) These lineations consist mostly of mullion structures in meta-

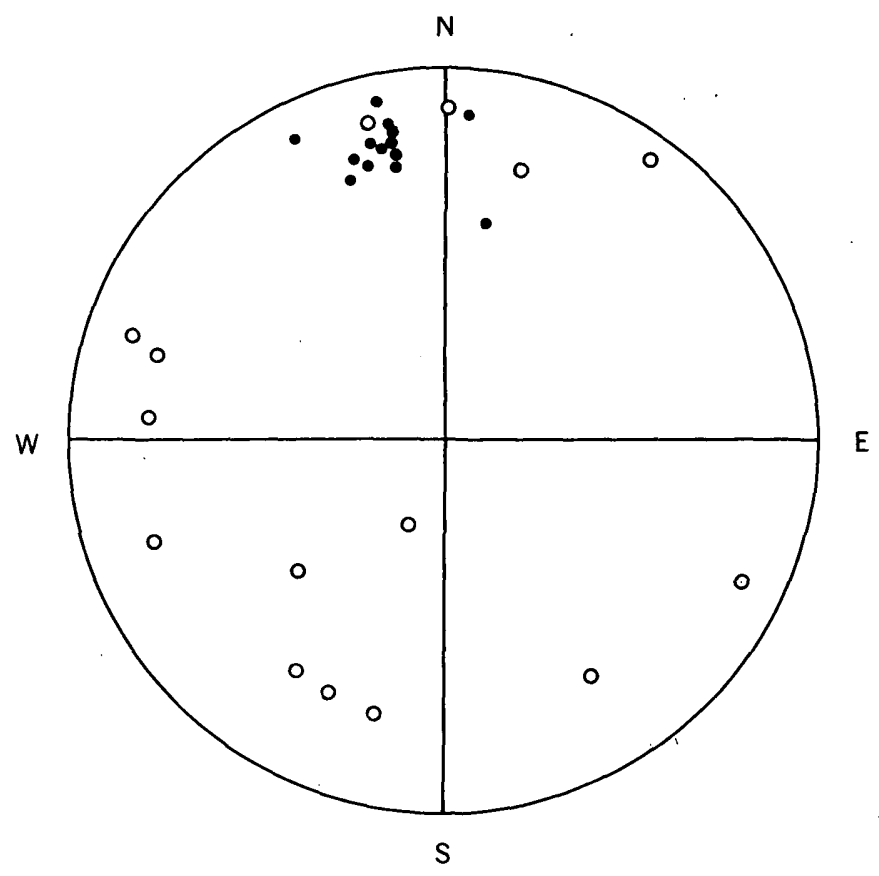

Figure 55.-Plot of lineation plunges in Red Creek Quartzite along thrust fault on Bender Bountain, area $4, \mathrm{SE} 1 / 4$ sec. $32, T$. 3 N., R. 25 E. Solid dots represent plunges in upper plate; open dots represent plungers in lower plate. Note concentration of plunges in upper plate and scatter of plunges in lower plate. 
quartzite and rodding in amphibolite. Two sets are present: one that trends and plunges gently due south, and another trends about S. $50^{\circ}$ E. and plunges about $40^{\circ} \mathrm{SE}$. The latter set, which is the stronger of the two, contains the lineation formed by rodding in amphibolite. The south-plunging set thus apparently was formed before injection of the amphibolite, the southeast-plunging set after injection.

\section{STRUCTURAI SIMILARITIES OF THE SEVERAI RED CREEK} OUTCROP AREAS

Structural similarities of the Red Creek Quartzite in the several outcrop areas are summarized below :

1. In all areas, the Red Creek Quartzite is highly deformed by intricate small-scale folding.

2. Small-scale folds constitute a strong consistently oriented $b$-axis lineation which has a uniform relationship to major structural trends.

3. In most localities there are two sets of $b$-axis lineations. One set is confined to metaquartzite and mica schist and presumably was formed before amphibolite was injected as mafic magma; the other set was formed after amphibolite was injected and occurs in amphibolite as well as in metaquartzite and mica schist.

4. The several separate outcrop areas of the Red Creek Quartzite are brought to the surface on the flank of the Uinta anticline by large-scale faulting and deep erosion. All areas are bounded partly by faults; some areas are enclosed by faults.

5. Strongly recurved faults partly bound areas 1, 2, and 4 . These faults probably are segments of thrusts that have been tilted, after initial movement, by the updoming of the Uinta anticline in Laramide time. Small outcrop areas along the Uinta fault west of area 1 probably are refaulted remnants of a thrust plate, also. At one point a water well penetrated one of these remnants and passed downward into the Uinta Mountain Group-that is, from older into younger rocks.

\section{YOUNGER STRUCTURE}

Younger structural features of the area include features imposed on any or all formations, including the Red Creek, but they date from times later than the complex structure imposed only on the Red Creek Quartzite. The younger structural features are relatively simple in geometry and sequence. They are relatively straight forward, clearly defined, and well exposed. They include unconformities at several stratigraphic horizons, folds of two orders of magnitude, faults of various sizes and habits, and joints. Some features, however, are incompletely understood insofar as geometry, age, and temporal relationships are con- cerned, and diverse interpretations have been placed on them. Controversies center around interpretations of various faults and unconformities.

\section{UNCONFORMITHES}

As stratigraphic features, unconformities have been noted individually in the descriptions of the several rock formations of the area, under the heading of stratigraphy. As structural features, they are described collectively below.

Major unconformities that denote significant tectonic or erosional activity occur at five horizons in the stratigraphic section as follows: (1) At the base of the Uinta Mountain Group, (2) between the Uinta Mountain Group and the overlying Paleozoic sequence, (3) at the base of the Paleocene Series, (4) at the base of the Browns Park Formation (Miocene?), and (5) at the base of the Quaternary System.

Less significant unconformities that denote gentle uplift without appreciable deformation or erosion occur (1) possibly at the base of the Mississippian upper shale unit, (2) possibly within the Morgan Formation, (3) possibly at the base of the Park City Formation, (4) possibly at the base of the Dinwoody Formation, (5) at the base of the Chinle Formation, (6) at the base of the Carmel Formation, (7) at the base of the Dakota Sandstone, and (8) probably at the base of the Frontier Formation. Very minor unconformities occur at several horizons within the Browns Park Formation and within the Pleistocene and Recent sequence. Only the five major unconformities noted in the preceding paragraph have major local tectonic significance; only those unconformities are described below.

\section{UNCONFORMITY AT THE BASE OF THE UINTA MOUNTAIN GROUP}

The unconformity between the Uinta Mountain Group and the Red Creek Quartzite delimits a most marked difference in structural complexity and history between the rocks below and above, and it probably represents a longer time span than any succeeding unformity in the Uinta Mountains area. The Red Creek Quartzite was subjected to high-grade metamorphism, was severely deformed at least twice, was mildly deformed subsequently at least once, and was deeply eroded before the overlying Uinta Mountain Group was deposited. Boulders, cobbles, and pebbles derived from the Red Creek Quartzite were then deposited in the basal beds of the Uinta Mountain Group and, in places, at higher levels also.

This unconformity has been recognized since the days of the Territorial Surveys, although the magnitude of the relief on its surface was grossly overestimated by early workers, largely because the Goslin and $\mathrm{O}-\mathrm{Wi}$ - 
$\mathrm{Yu}$-Kuts faults were misidentified as depositional contacts. As near as can now be estimated, the relief at most is of the order of hundreds of feet rather than thousands, and in most places is only tens of feet or less (Hansen, 1955b, p. 27). In the Jesse Ewing Canyon area, where the contact relationships are well shown, coarse bouldery basal conglomerate fills a broad swale eroded into the old surface on the Red Creek Quartzite. The depth of this swale, over a distance of about a mile, appears to be about 300 feet, possibly more. A few miles to the east in the Beaver Creek area, the basal beds of the Uinta Mountain Group are nonconglomeratic quartzite, and the unconformity is a nearly plane surface.

\section{UNCONFORMITY AT THE BASE OF THE PALEOZOIC SEQUENCE}

Inasmuch as the Uinta fault forms the surface contact between the Paleozoic sequence of the area and the Uinta Mountain Group, the depositional contact between these units occurs only at depth. Immediately to the west and to the east of the area, however, the depositional contact reaches the surface. To the east on Cold Spring Mountain, where the unconformable character of this contact is very well displayed by aerial photographs, the thick-bedded limestones of Mississippian age truncate probably 5,000 feet or more of Precambrian strata (Uinta Mountain Group) in a horizontal distance of about 4 miles. Truncation of such magnitude indicates strong uplift, tilting, and erosion between late Precambrian and late Paleozoic time or, in other words, between the time of deposition of the Uinta Mountain Group and the time of deposition of the limestone of Mississippian age. Whether or not Cambrian rocks are present in this sequence is unclear, owing partly to poor exposures and partly to a lack of detailed mapping. In any event, Cambrian rocks probably were present at one time (Lochman-Balk, 1955, p. 36) ; if now lacking, they have been removed by post-Cambrian erosion. Other lower and middle Paleozoic rocks quite clearly are lacking and probably never were deposited. Part of the pre-Mississippian uplift of the eastern Uinta Mountain area thus is clearly post-Cambrian. An unconformity between the Cambrian and the Precambrian in the eastern Uinta Mountains has been known since the early work of Powell.

\section{UNCONFORMITY AT THE BASE OF THE PALEOCENE SERIES}

The unconformity at the base of the Fort Union Formation (Paleocene) marks the resumption of deposition in the area following the Laramide uplift of the Uinta Mountains. This unconformity was recognized by the Territorial Surveys (Powell, 1876, p. 164; King, 1878, p. 358). It is sharply angular near Clay Basin on

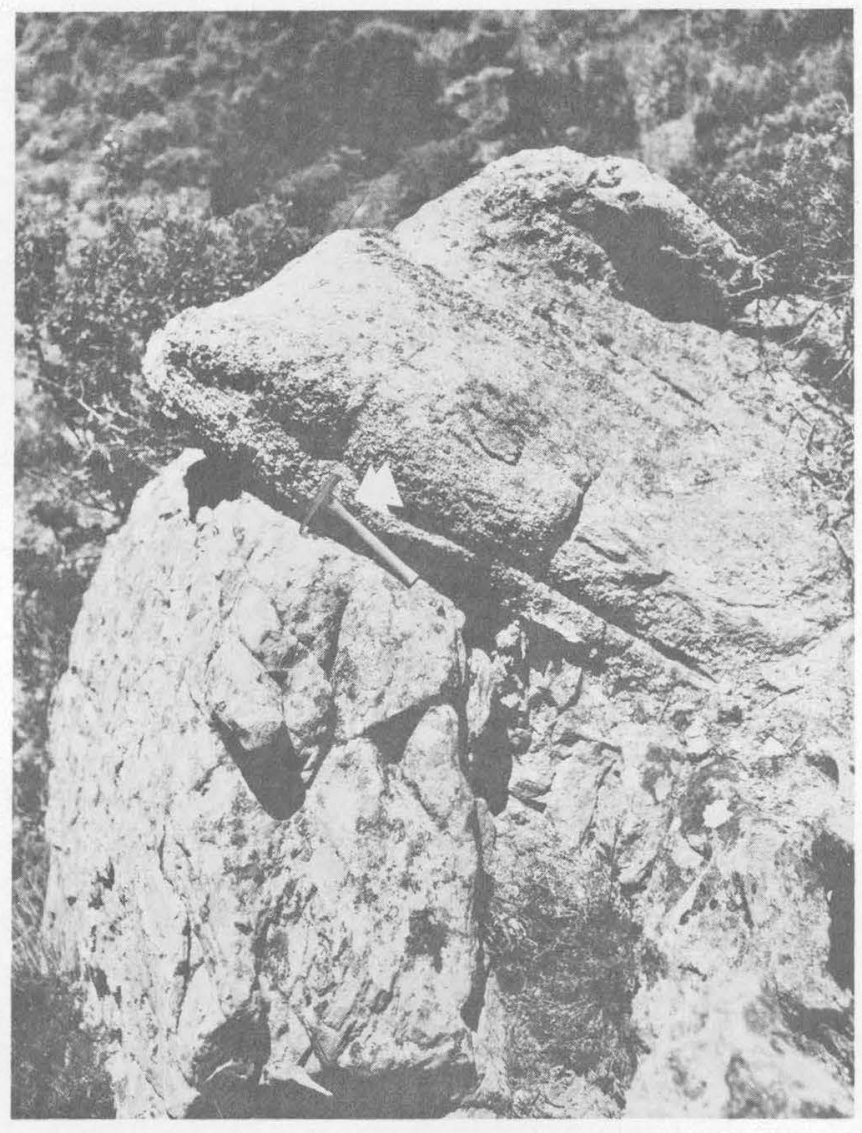

Figure 56.-Unconformity between Ericson Sandstone (under hammer) and Fort Union Formation, northwest slope of Goslin Mountain. Erieson Sandstone dips $85^{\circ}$ to left and is overturned ; Fort Union Formation dips $35^{\circ}$ to right.

the flanks of Goslin and Bender Mountains. At these points, outcrops of the Fort Union Formation are closely juxtaposed with the Uinta fault; adjacent Cretaceous rocks of Montana age, including the Hilliard, Rock Springs, and Erieson Formations, are overturned and dip southward, but the Fort Union dips gently northward (fig. 56). At Goslin Mountain, low hogbacks formed by the Erieson Sandstone were buried beneath overlapping beds of the Fort Union; near Ford Spring, in secs. 21 and 22, T. 3 N., R. 23 E., the Fort Union Formation truncates the entire Mesaverde Group and rests on the Hilliard Shale.

Away from the Uinta fault where uplift was less sharp, the unconformity is less angular, and the beds approach concordance. In some such places the unconformity is located with difficulty, although in most places where exposure is adequate, pebble conglomerate at the base of the Fort Union Formation channels into or truncates the underlying beds.

Before the oldest Tertiary beds were deposited, at least 8,000 feet of Cretaceous strata and possibly as 
much as 11,000 feet was stripped from the flank of the Uinta Mountains in the Clay Basin area. The time span and tectonic history represented by the unconformity thus are large. Continued and possibly even accelerated uplift and erosion of the mountainous area to the south is indicated above the unconformity by orogenic conglomerates in the succeeding Paleocene and Eocene rocks.

\section{UNCONFORMITY AT THE BASE OF THE BROWNS PARK} FORMATION

The unconformity at the base of the Browns Park Formation reflects Tertiary tectonic activity and degradation in a topographic environment of strong local relief-a relief as great as that of today, and possibly greater. Along Red Canyon west of the type area of the Browns Park Formation, local relief on the unconformity is as much as 1,500 feet and is marked by sharp minor irregularities. It probably was that great in Browns Park also, before the formation was partly eroded away. In some places the old surface clearly was canyonlike. Low cliffs, knobs, and ledges on the floor and sides of the old valley were buried beneath the accumulated sediments. In some adjacent localities, outside the area here mapped, the Browns Park Formation rests on gently sloping pediments (Bradley, 1936a, p. 180), and the unconformity, accordingly, has subdued relief. In such areas the unconformity is overlain by a thick basal conglomerate which consists mostly of locally derived pebbles and cobbles (Sears, 1924a, p. 284; Bradley, 1936a, p. 182-184). Similar basal conglomerate lies on the unconformity in many localities in Browns Park itself, but in some places, tuffs or tuffaceous sandstones lie directly on the quartzites of the Uinta Mountain Group.

Post-Laramide pre--Browns Park gravity faulting in the Browns Park area is indicated by large normal faults that displace the older rocks north of Browns Park and elsewhere but do not offset the unconformity. Subsequent faulting, after deposition of the Browns Park formation, is well known, especially from the work of Sears (1924a, p. 293-298). These faults displace the Browns Park Formation as well as the older rocks.

UNCONFORMITY AT THE BASE OF THE QUATERNARY SYSTEM

Quaternary deposits of the area rest almost everywhere with marked angular unconformity on the older rocks; the reason is simply that nearly all older formations were tilted and deeply eroded before Quaternary deposition began. A single exception is found in Browns Park, where some Quaternary deposits and some parts of the Browns Park Formation are nearly parallel and nearly concordant in attitude and bedding, despite a time break of several million years. In some such places the Quaternary deposits are not readily distinguished from the Browns Park Formation, especially where both units are lithologically similar-for example, where conglomeratic pediment gravels rest on conglomeratic or sandy tongues of the Browns Park Formation. In such places the unconformity is little more distinctive than some of the diastems within the Browns Park Formation.

\section{FOLDS \\ NORTH-FLANK HOMOCLINE}

The large Uinta anticline has been described briefly in connection with the general structural setting of the area. Inasmuch as the greater part of the area is on the north limb of this fold, the local structure is mainly and basically homoclinal, although it is modified by faults and subsidiary folds. The axis of the Uinta anticline crosses the southeastern part of the area near the head of Tolivers Canyon and the mouth of Sears Canyon; viewed toward the west from Browns Park it is indistinctly discerned. Near the mouth of Sears Creek the axis passes into concealment eastward and southeastward beneath the sediments of Browns Park. It finally emerges about 40 miles to the southeast near the east plunge of the fold. Because the crestal part of the fold is thus concealed through the whole length of Browns Park, the beds on the north side of the Park dip homoclinally northeastward and the beds on the south side dip homoclinally southwestward. In general, dips are steeper on the north-flank homocline than on the south. Again, both homoclines are modified by faults and subsidiary folds; accordingly, bedding attitudes vary widely from place to place, both in dip and in strike.

Dips on the north-flank homocline are steepest in a rather narrow zone along both sides of the Uinta fault, owing to drag in both walls before and after faulting. In this zone, which rarely is more than about a mile wide, overturning is commonplace; elsewhere on the homocline dips are mostly less than $45^{\circ}$-commonly they are much less. Structural effects similar to those along the Uinta fault, including overturning, are caused by the Henrys Fork fault. The zone of disturbance, however, is narrower. Additional minor modifications of the homocline are caused by some of the faults to the east in the area between Clay Basin and Browns Park.

Strike deflections along the trend of the north-flank homocline are considerable, locally being as much as $50^{\circ}-60^{\circ}$. These deflections are caused by subsidiary folds superimposed on the main homocline. Subsidiary folds are described below. 
SUBSIDIARY FOLDS

Subsidiary folds along the north-flank homocline of the Uinta anticline can be classified or described in terms of (1) magnitude, (2) geologic setting, and (3) orientation.

In terms of magnitude they can be considered to be third-order folds-the Uinta anticline, as a first-order fold, is divided into second-order west and east domes that are subequal in size and which in turn are modified by much smaller subsidiary third-order folds. The west and east domes of the main anticline have already been described.

In terms of geologic setting, the subsidiary folds can be separated for discussion purposes into two classes: (1) folds imposed on Precambrian rocks south of the Uinta fault and (2) folds imposed on the younger rocks north of the fault. (See Hansen, 1957b, p. 36.) This does not mean that class 2 folds do not extend downward into the Precambrian rocks; they undoubtedly do, and class 1 folds originally probably extended upward into younger rocks since removed by erosion. Folds of the two classes seem to complement one another on opposite s:des of the fault; in other words, folds south of the fault seem to be laterally displaced complements of the folds north of the fault (Hansen and Bonilla, 1954, p. 14; Hansen, 1955a). From west to east, the apparent lateral displacement of fold axes increases proportionately with the increasing stratigraphic throw of the fault.

In terms of orientation the subsidiary folds can be divided further into two types-those parallel in trend to the Uinta anticline (type A) and those normal in trend to the Uinta anticline (type B). Although no genetic significance is implicit in this classification, the two types of folds probably were formed during separate episodes of deformation.

Type A folds, which are subparallel to the Uinta anticline, commonly possess closure; this characteristic is true of type A folds on both the north and south flanks of the anticline. Type B folds, on the other hand, are mostly open noses that are normal in orientation to the Uinta anticline and plunge down its limbs. Type $\mathrm{B}$ folds are further characterized by marked asymmetry of cross section, particularly in the Flaming Gorge area-the east limb of each fold is steep to overturned; the west limb is broad and gentle.

From west to east, the following subsidiary folds (anticlines) are recognized in the area: The Linwood nose (class 2, type B), the Red Canyon anticline (class 1 , type A), the Spring Creek nose (class 2, type B), the Dutch John nose (class 1, type B), and the Clay Basin anticline (class 2, type A). These folds alternate with synclines to which a similar classification could be ap- plied. Just west of the area is the Lodgepole Creek nose (type B imposed on both Precambrian and younger rocks) ; the east limb of the Lodgepole Creek nose (Curtis, 1950, p. 96) extends into the area south of Manila. A few small anticlines and synclines in the Uinta Mountain Group north of Browns Park do not fit any of the above classifications; they are drag features related to faults along the north side of the valley.

\section{LIN WOOD NOSE}

Impressive views of the Linwood nose can be had from Flaming Gorge (frontispiece). The Linwood nose (Curtis, 1950, p. 96) is an asymmetrical plunging type $\mathrm{B}$ anticline. Its axis trends about N. $20^{\circ} \mathrm{W}$. and is slightly arcuate, convex to the west. Its plunge steepens northward from about $12^{\circ}$ to $15^{\circ}$ at Horseshoe Canyon to near vertical near Henrys Fork. Section $B-B^{\prime}$ (pl. 1), drawn along the fold axis, illustrates the variations of attitude down the plunge. The fold is markedly asymmetrical, as is shown by its broad gently sloping northwest limb and steep partly overturned northeast limb (fig. 57).

On the north the linwood nose is truncated by the Henrys Fork fault but appears to continue across the fault, though displaced westward on the north or downthrown side of the fault. Just west of the point of truncation, in Wyoming, the Henrys Fork fault bows sharply northward; the Wasatch Formation, on the downthrown side, does likewise in an apparent northward continuation of the Linwood nose. All surface expression of the fold dies out rapidly, however, in the Green River Formation.

On the south, in a zone of intense drag and overturning, the Linwood nose is truncated by the Uinta fault. A possible southward continuation of the nose, dis. placed eastward, is the Red Canyon anticline.

$$
\text { RED CANYON ANTICLINE }
$$

The Red Canyon anticline (Hansen and Bonilla, 1954, p. 15) is a broad open modified type A fold entirely within rocks of the Uinta Mountain Group. It is seen to advantage from Bear Mountain looking east (fig. 58) and is visible from the heights above Dutch John Draw looking west. Its axis is somewhat sigmoid, forming a northward-concave arc in the western part of the fold and a southward-concave arc in the easterm part. On the east the fold plunges gently into, and merges with, the north-flank homocline of the Uinta anticline; on the west it terminates against the Uinta fault. Its length along its axis is about 7 miles.

The relation of the Red Canyon anticline and the Linwood nose to each other and to the Uinta fault suggests that both folds are complementary displaced segments of a single anticline that has been offset by strike- 


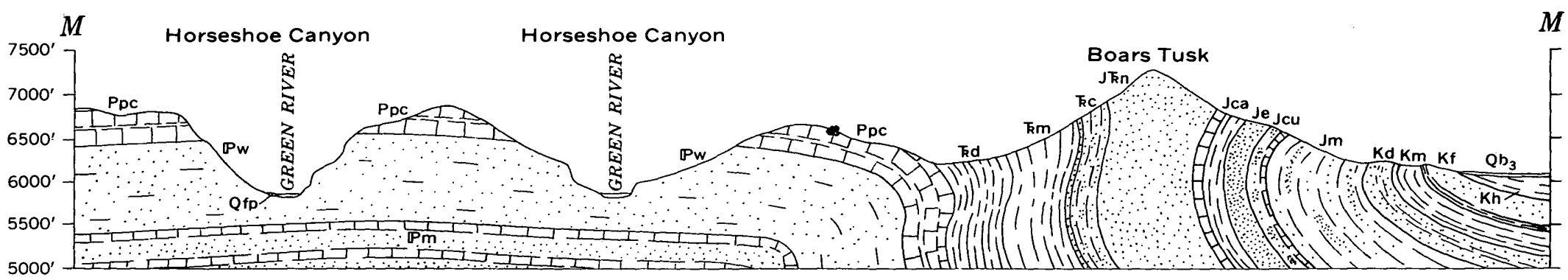

FiguRE 57.-Geologic section $M-M^{\prime}$ across Linwood nose northwest of Horseshoe Canyon. Qfp, flood-plafn deposits; Qbz, bench deposit 3; Kh, Hulliard Bhale; Kf, Frontier Formation; Km, Mowry Shale;

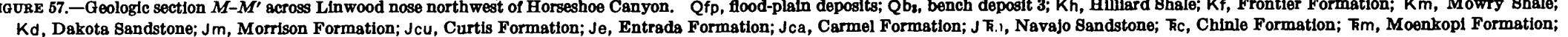
Kd, Dakota Sandstone; Jm, Morrison Formation; Jcu, Curtis Formation; Je, Entrada Formation; Jca, Carmel Formation; $J$ F.l, Navajo
Kd, Dinwoody Formation; Ppc, Park City Formation; Pw, Weber Sandstone; P, Morgan Formation, Line of section shown on plate 1. 


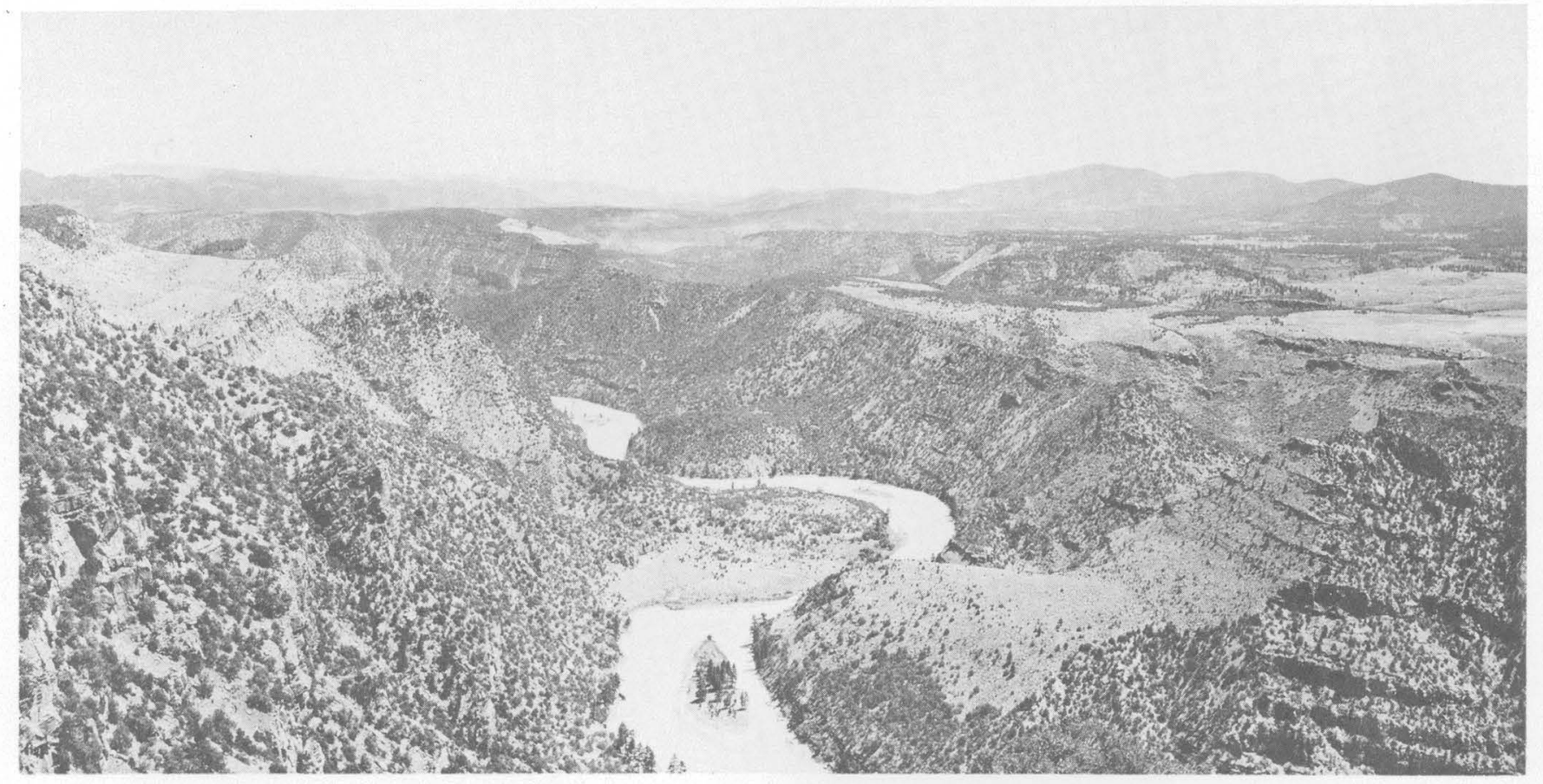

Frgure 58.-View east from Bear Mountain along axis of Red Canyon anticline in Uinta Mountain Group. Axis about coincides with bottom of Red Canyon. Sharp deflection in course of Green River (center) caused by alluvial fan at mouth of North Skull Creek, which enters river from left. Broad remnants of Gilbert Peak erosion surface on Goslin Mountain (upper left) on Cold Spring Mountain (extreme distance), and in Greendale (upper right). Grassy meadows at upper right underlain by Browns Park Formation. Flaming Gorge Reservoir will just cover bench in canyon to right of center foreground.

slip movement on the Uinta fault. The strike component of slippage on the fault between the two fold axes thus appears to be about $1 \frac{1}{2}$ miles.

SPRING CREEK NOSE

The Spring Creek nose (Curtis, 1950, p. 96) is a very broad north-plunging bowing in the strata on the northflank homocline of the Uinta anticline, centered over the Spring Creek-Antelope Flat area. It is plainly visible from the Manila area, 10 to 15 miles to the west. The configuration of this nose is strongly influenced by the Uinta fault, which truncates it on the south; the adjacent beds are dragged into steep or overturned attitudes. The oldest formation exposed on the axis of the fold is the Navajo Sandstone. To the north the fold dies out in the Green River Formation in Wyoming.

Like the Linwood nose, the Spring Creek nose is asymmetrical (type B). Its east limb, which is in the Hilliard Shale and Ericson Sandstone, is partly overturned. The fold has a very small surface closure in the Iakota Sandstone near the SE. corner sec. $28, \mathrm{~T}$. 3 N., R. 22 E. The exact position of the fold axis in that vicinity, however, is difficult to ascertain, owing to the breadth of the fold and the flatness of its crest. A dry hole drilled on the Spring Creek nose in the $\mathrm{S} 1 / 2$ NE $1 / 4$ NW $1 / 4$ sec. 34 , 'T. 3 N., R. 22 E., in 1956 by the
Ohio Oil Co. was started in the Morrison Formation and bottomed in what seems to be the Park City Formation at a depth of 3,277 feet, although the sample log shows 63 feet of penetration into the Weber Sandstone.

South of the Uinta fault, a possible eastwarddisplaced complement of the Spring Creek nose is the Dutch John nose. The horizontal distance between the axes of these two noses, taken along the trace of the Uinta fault, is about 3 miles.

\section{DUTCH JOHN NOSE}

The Dutch John nose is a recurved type B anticline imposed on the rocks of the Uinta Mountain Group (Hansen and Bonilla, 1954, p. 15). It plunges gently down the north-flank homocline of the Uinta anticline between the crest of the Uinta anticline to the south and the Uinta fault to the north. It rises south of the mapped area at Jackson Draw as a small nearly symmetrical dome centered on the boundary between secs. 2 and 12, T. 1 N., R. 23 E., and superimposed on the axis of the Uinta anticline. From Jackson Draw the Dutch John nose trends northward to Little Hole, then westward along the south slope of Goslin Mountain, and again northward to Dutch John Mountain where it terminates against the Uinta fault. Thus, the trend of the axis is a sweeping sigmoid curve that is somewhat anal- 
ogous to the trend of the Red Canyon anticline but which is oriented more generally north-south rather than west-east.

Some idea of the form of the Dutch John nose as seen in cross section can be had by reference to section $E-E^{\prime}$ (pl. 1), drawn through Little Hole and Goslin Mountain. In that line of section the reversal across the axis is about 1,000 feet. In plan the fold is well shown by aerial photographs, especially the northern part of the fold in the Goslin Mountain-Dutch John Canyon area. Good ground views of the fold can be had from various vantage points in Little Hole, particularly when one looks north toward Goslin Mountain from points near the fold axis at Devils Hole

\section{CLAY BASIN ANTICLINE}

The Clay Basin anticline is a doubly plunging type A fold, whose east-west axis is curved slightly to the north. The fold has surface closure of about 400 feet within the Hilliard Shale and, as indicated from well data, a known structural reversal of 450 feet toward the west (Fidlar, 1950b, p. 116). Rocks younger than Hilliard do not close about the structure but form a broad nose which extends north into Wyoming; on the south this nose abuts against the Uinta fault. A broad bowing in the trends of bedding in the Uinta Mountain Group south of the Uinta fault suggests that a corresponding flexure is expressed in the Precambrian rocks south of the fault and that the Clay Basin anticline, therefore, is but a local closure on a much larger nose that plunges northward off the north-flank homocline of the Uinta anticline. The part of this nose south of the Uinta fault seemingly has been carried eastward relative to the Clay Basin anticline by a strike-slip component of movement on the fault. Although the amount of horizontal separation is not clearly evident, owing to structural complexities south of the fault, it seems to be about $21 / 2$ miles.

Natural gas was discovered in the Clay Basin anticline in 1927 and has been in production since 1937. The principal production is from the Dakota Sandstone. Minor production comes from the Frontier. A deep test (R. D. Murphy well 6-W) penetrated 330 feet of the Weber Sandstone before bottoming at a depth of 9,355 feet but yielded only noncombustible gas (Fidlar, 1950b, p. 116).

BMALL ANTICLINES IN BROWNS PARK

Several small anticlines at the base of the mountains on the north side of Browns Park appear to be drag structures formed where the rocks north of Browns Park failed by flexing rather than by faulting during gravitative collapse of the eastem Uinta Mountains.
(See Sears, 1924a, p. 296.) Two such folds appear in the mapped area-one at the mouth of Jesse Ewing Canyon and one on the southwest slope of Cold Spring Mountain near the mouth of the canyon of Beaver Creek. Both of these folds extend eastward from the ierminations of large faults.

The small anticline at the mouth of Jesse Ewing Canyon rises just west of the canyon in a predominantly shaly sequence of the Uinta Mountain Group that is wedged between two faults. The larger of these faults-the Mountain Home fault-dies out eastward on the south limb of the fold. The fold, which plunges gently west, trends from west to east about 2 miles and is slightly arcuate to the north. On the east it passes unconformably beneath the Browns Park Formation; moderately steep dips in the adjacent Browns Park Formation indicate, however, that the Browns Park Formation was involved in the flexing as well as in the sharp faulting to the west. The fold is well exposed on the east wall of Jesse Ewing Canyon (fig. 59) and is especially well exposed in the next draw to the east, but it dies out downward in Jesse Ewing Canyon and lacks clear expression at stream level.

The small anticline on the southwest slope of Cold Spring Mountain has an axial length of about 3 miles; the eastern limit of the fold is outside the area, however, and has not been mapped. The rocks chiefly involved are red quartzites of the Uinta Mountain Group and, to a lesser degree, the Browns Park Formation. On the west the fold terminates against the Beaver Creek fault. This fault dies out a few thousand feet to the southeast, where its movement apparently was taken up mainly by flexing on the south limb of the fold but partly by displacement on two other small faults of sim-

$\mathrm{N}$

Red Creek
Quartzite
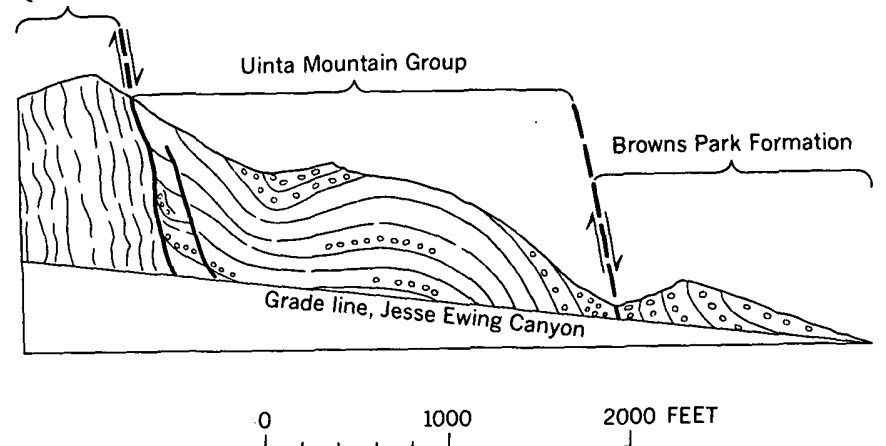

Figure 59.- Small anticline at mouth of Jesse Ewing Canyon, as. seen from west wall of canyon looking east. Fold is probably a drag structure caused by gravitative collapse along margin of Browns Park valley. Drawn from a field sketch. Scale approximate. 
ilar habit arranged en echelon across the crestal part of the fold.

\section{BROWNS PARK BYNCLINE}

The long tongue-shaped deposit of Browns Park Formation in the type area has the structure of a shallow flat-bottomed syncline (Powell, 1876, p. 208; Sears, $1924 a$, p. 287). This structure is unusual in that it is superimposed directly on the axis of the Uinta anticline, the anticline having been breached along its axis by an ancestral east-flowing stream. Deposited in this valley, the Browns Park Formation assumed a synclinal structure largely through depositional rather than tectonic processes. The syncline probably was formed by a combination of three factors: (1) initial dip on the sloping floor of the old filled valley, (2) valleyward thinning of beds, especially conglomerates, and (3) differential compaction of materials, the total compaction being greatest in the thickest part of the deposit over the deepest part of the buried valley. Dips attributable to these factors rarely exceed $5^{\circ}$, and most are less. Steep dips along the north margin of the valley, on the other hand, are due clearly to drag and flexing along or near faults which moved after the Browns Park Formation was deposited. Although the syncline formed independently of these drag features, its north limb was accentuated by drag.

Whether or not the syncline axis coincides exactly with the deepest part of the hard-rock floor beneath Browns Park is problematical and cannot be determined from,surface evidence alone. The present valley bottom is far to the south of the syncline axis in most places, and there is no doubt that the buried valley bottom is well to the north of the present one; the Green River in several places impinges on the south valley wall where it flows across the Uinta Mountain Group.

\section{FAULTS}

Faults are abundant in some parts of the area but scarce in others. In general they are much more abundant in the Precambrian rocks than elsewhere. Their relative abundance in the Precambrian rocks suggests that the mountainward block (south of the Uinta fault) was the actively moving element during Laramide deformation and that the basinward block (north of the Uinta fault) was passive or stationary. Only a small number of faults occur in the younger rocks north of the Uinta fault; most of these, and the largest, are found in the western part of the area between the overlap of the Uinta fault on the south and the Henrys Fork fault on the north.

Recognition of faults in the thick Uinta Mountain Group south of the Uinta fault presents a special problem, owing to the massive character of the group and hence to a general lack of traceable key beds. Some faults are easily discerned either on the ground or on aerial photographs, but others-small ones at leastprobably have gone unnoticed during mapping. Several indicators which became apparent during the course of the mapping have proved useful in locating faults or probable faults in thick sequences of quartzite where key beds or obvious offsets are lacking. Taken alone, these indicators, as follows, are not necessarily diagnostic; but in aggregate, they afford strong circumstantial evidence of faulting:

1. Strong lineaments on aerial photographs.

2. Straight, linear gullies or ravines seemingly anomalous to the rest of the drainage pattern in the immediate vicinity, especially those gullies across which ledges or prominent beds cannot be correlated.

3. Zones of brecciated or shattered rock. Commonly bleached from the usual red shades of the Uinta Mountain Group to shades of dull yellow or rusty brown.

4. Low escarpments transecting bedding.

5. Appreciable differences in bedding attitude across any of the above indicators (suggesting rotational movement).

6. Sharp changes of bedding attitude adjacent to any of the above indicators (suggesting drag).

7. Abrupt terminations of prominent ledges or outcrops.

8. Zones of closely spaced sheeting.

\section{Discrete fractures.}

Faults that can be discerned easily commonly show several of the above indicators in addition to clearly defined bedding offsets. On aerial photographs, faults are well defined on flat upland erosion remnants, such as the Gilbert Peak erosion surface at Goslin and $\mathrm{O}-\mathrm{Wi}-\mathrm{Yu}$-Kuts Mountains, but are obscure or difficult to follow in strongly dissected areas. Some such faults are reflected on aerial photographs by vegetation patterns in areas of poor outcrop-grass, sage, or aspen, for example, which often grow on argillitic soils, present markedly different textural patterns from conifers, which more commonly thrive on sandstone or quartzitic terranes. Faults expressed by vegetation patterns, though clearly evident on aerial photographs, are generally undiscernible on the ground. Faults that are clearly visible on the ground, on the other hand, may be indistinguishable on aerial photographs, particularly those faults that transect steep slopes in dissected areas.

Faults of the area conform to three habits dependent upon time and cause of failure: (1) modified high- and 
low-angle thrust faults, (2) high-angle thrust or reverse faults, and (3) normal or gravity faults.

Modified high- and low-angle thrust faults are restricted to areas of Precambrian rock, either within the Red Creek Quartzite or between the Red Creek and the Uinta Mountain Group. Initially, most of these faults probably were overthrusts, but subsequently they have been tilted by the arching of the Uinta anticline, so that some of them now dip steeply. The Goslin and Bender faults are typical examples. Their time of movement is uncertain, but it quite clearly preceded movement on the Uinta fault and may have been Precambrian.

High-angle thrust or reverse faults include the largest and longest faults of the area, such as the Uinta and J-Tenrys Fork faults, as well as several much smaller ones. These faults are Iaramide in age, as they moved during the culminating compressional phases of the Laramide orogeny.

Normal or gravity faults are much more abundant than high-angle thrust faults, but they are much shorter in average length and have a much smaller average throw. They probably were active during a long span of time; some probably moved in Oligocene time or earlier, others moved in Miocene or Pliocene time, and some probably moved more than once.

\section{MODIFIED HIGH- AND LOW-ANGLE THRUST FAULTS}

Several faults that displace the Uinta Mountain Group, the Red Creek Quartzite, or both, are regarded as thrust faults that moved prior to the uplift of the Uinta anticline and hence have been modified in attitude by the ensuing tilting of the north limb of the fold. These faults now have generally steep dips despite evidence of compressional histories. By the same token, if the involved rocks were to be restored to the attitudes that they must have had before the Uinta anticline was formed, their original dips would be low.

Modified thrust faults are recognized on Dutch John Mountain, Goslin Mountain, Mountain Home, and Bender Mountain. The small inlier of Red Creek Quartzite at the east end of Dutch John Mountain (area 1) is partly bordered by such a fault; in fact, it owes its seemingly anomalous position to the fault. The Goslin fault and the Bender fault are of the same category, as probably is the fault that crosses the top of Mountain Home. All these faults have uplifted the Red Creek Quartzite relative to the Uinta Mountain Group. Subsequent uplift of the Uinta anticline, movement along the Uinta fault, and erosion have brought the Red Creek into its several outcrop positions on the flank of the fold.

Additional spatial modifications of the Red Creek Quartzite have been caused by transverse normal faults in the Dutch John Mountain area (area 1). Area 1 of the Red Creek Quartzite has been preserved from erosion because it has been normally downfaulted on the east into the Uinta Mountain Group. Its structural relationship is depicted in figure 60 , where it is shown as a rootless upper-plate remnant of a thrust fault. Figure 60 is an east-west section; in a north-south section the attitude of the modified thrust fault remnant would appear to be much steeper.

The modified thrust faults are characterized by strongly recurved traces and by pronounced drag in the wallrocks. Drag effects along the Goslin fault, for example, extend $1 / 1-1 / 2$ mile back from the fault plane, and a large inclusion of quartzite torn from the Uinta Mountain Group has been dragged into tight " $S$ " folds by the slippage in the adjacent walls (center of sec. 36, T. 3 N., R. 23 E.). Such characteristics as these, in normally competent rocks, are identified with compressional faulting rather than with tensional faulting.

The fault that crosses the top of Mountain Home shows strong drag effects only toward its east end in sec. 35 , T. 3 N., R. 24 E., where strata in the Uinta Mountain Group veer sharply in trend adjacent to the fault and turn over. Farther west toward the canyon of Red Creek the fault is unusual in that it contains inclusions of red quartzite torn from the Uinta Mountain Group and caught between walls of Red Creek Quartzite. Two branches of the fault near the north rim of Mountain Home contain similar inclusions. Various mechanisms could be invoked to explain the positioning of such inclusions. Their emplacement is most simply explained by thrust faulting across previously folded rocks. They could also be emplaced, however, by multiple, in part reversed, movements on either a thrust fault or a gravity fault.

Easternmost of the modified thrust faults is the Bender fault. This fault extends northeastward from Bender Mountain past the south side of Buck Knoll toward the east boundary of the mapped area, where it passes under the Browns Park Formation. Its displacement seems to diminish from west to east. Through most of its length it probably dips north at a high angle. But at its west end it passes into a recurved, probably low-angle thrust (fig. 54). That part of the fault is similar in conformation to the west end of the Goslin fault and to the modified thrust fault on Dutch John Mountain. The Uinta Mountain Group in the lower plate is dragged sharply into a near-vertical attitude.

Near the west end of the Bender fault, a short segment of a low-angle thrust fault branches from the Bender fault in a shinglelike arrangement. This segment of a fault has the Red Creek Quartzite in both 


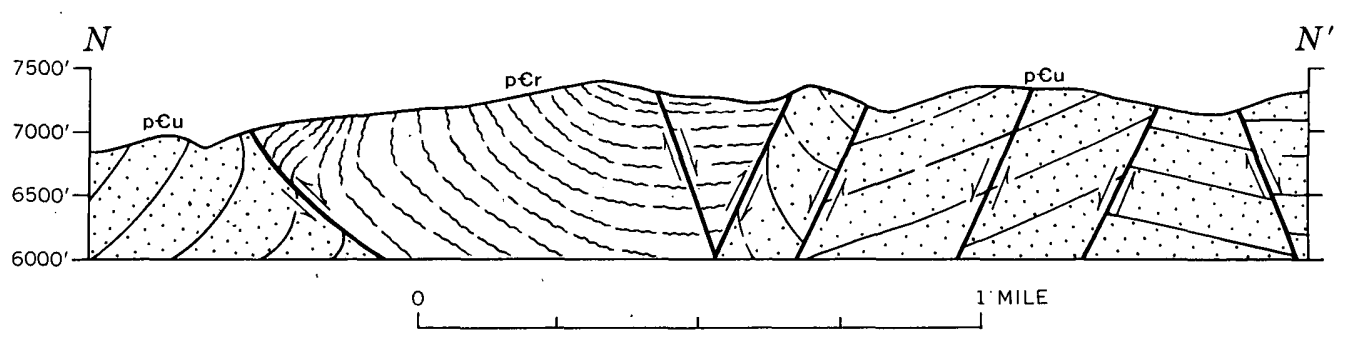

Fradre 60.-Geologic section $N-N^{\prime}$ through area 1, Red Creek Quartzite (per) and Uinta Mountain Group (p€u). Line of section shown on plate 1 .

its upper and lower plates. Its upper plate is wrinkled by strong uniformly oriented lineations; its lower plate is variably contorted between the Bender fault below and the upper plate above (figs. 54, 55) and has random lineations.

\section{HIGH-ANGLE ThRUST FAULTB}

\section{UINTA FAULT ZONE}

The Uinta fault zone was named and first described by Powell $(1876$, p. 177). Including the Sparks faultits eastward continuation in Colorado-it is the longest and most continuous fault zone in the Uinta Mountains and has the greatest stratigraphic throw. From its termination southwest of Manila, the Uinta fault zone trends sinuously east-northeast for about 45 miles as a continuous break, increasing in throw and width to about the 109th Meridian, where it passes beneath the Browns Park Formation. About 10 miles to the east, outside the mapped area, it emerges as the Sparks fault and is essentially continuous for another 20 miles; it continues at least another 30 miles southeastward as a zone of discontinuous faults (Sears, 1924b, pl. 35), thus bringing its total length to 100 miles or more.

Not a simple fracture, the Uinta fault zone has many subsidiary branches, and considerable minor fracturing generally characterizes the walls. Through most of its length the fault zone contains large blocks or slices of competent rock torn from the walls and dragged into the zone; these fragments are derived from most of the competent formations of the area but especially from the resistant limestones of Carboniferous age. Among the latter are slices of unusual size, including one mass near the east end of Dutch John Mountain that is more than 2 miles long-possibly 3 miles-and as much as 400 feet across. Most of these fragments have high, nearvertical dips, although some have been rotated between the walls of the fault zone to lower attitudes.

Clayey gouge is a chief constituent of the fault zone. Its color ranges from black to red and in many places is a mottled mixture of several colors. In good exposures it displays a fissility or cleavage that generally dips $50^{\circ}-60^{\circ} \mathrm{S}$. The gouge contains abundant angular rock fragments derived from the various formations involved in the faulting, including many formations not locally exposed along the fault but present at depth. With an increase in the proportion of coarse fragmental material, the gouge passes into fault breccia. In places it is cemented loosely with limonitic gossan, which has led prospectors in the past to open many small pits along the fault zone, especially along the north slopes of Mountain Home and Goslin Mountain where the gouge and breccia commonly are pyritic.

In the Mountain Home area, the width of the gougebreccia zone increases markedly from west to east. West of Mountain Home the zone is rarely more than about a hundred feet across, although the distance between the walls of the fault may be considerably more where the fault contains large slices or inclusions of competent rock. Eastward along the flank of Mountain Home the gouge-breccia zone increases to a width of 800 feet or more. Farther east at Bender Mountain and Kleins Hill, it locally exceeds 3,000 feet across. This great width probably is due partly to the oblique truncation of the zone by the ground surface; the true thickness appears to be more nearly about 1,000 feet. Besides gouge and breccia, this wide zone contains many large elongate tabular fragments of quartzite and limestone. These fragments are mostly oriented with their longer dimension parallel to the trend of the fault zone and their bedding planes dipping steeply southward.

Back from the fault zone proper, disturbance in the form of overturning extends into both walls (fig. 61). Overturning is especially strong in the footwall (fig. $62)$, possibly because of the greater competence of the Precambrian rocks in the hanging wall as opposed to the lesser competence of the younger rocks in the footwall. In the footwall, overturning extends back half a mile or more in many places and nearly a mile from the faultline at the east end of The Glades northwest of Goslin Mountain. Overturning appears to be greatest opposite northward-projecting salients in the faultline and least opposite intervening reentrants. In the hanging wall, overturning rarely extends more than a few hundred feet from the faultline; in some places the rocks have normal but steep attitudes right up to the faultline. The Uinta fault appears to be a stretch 

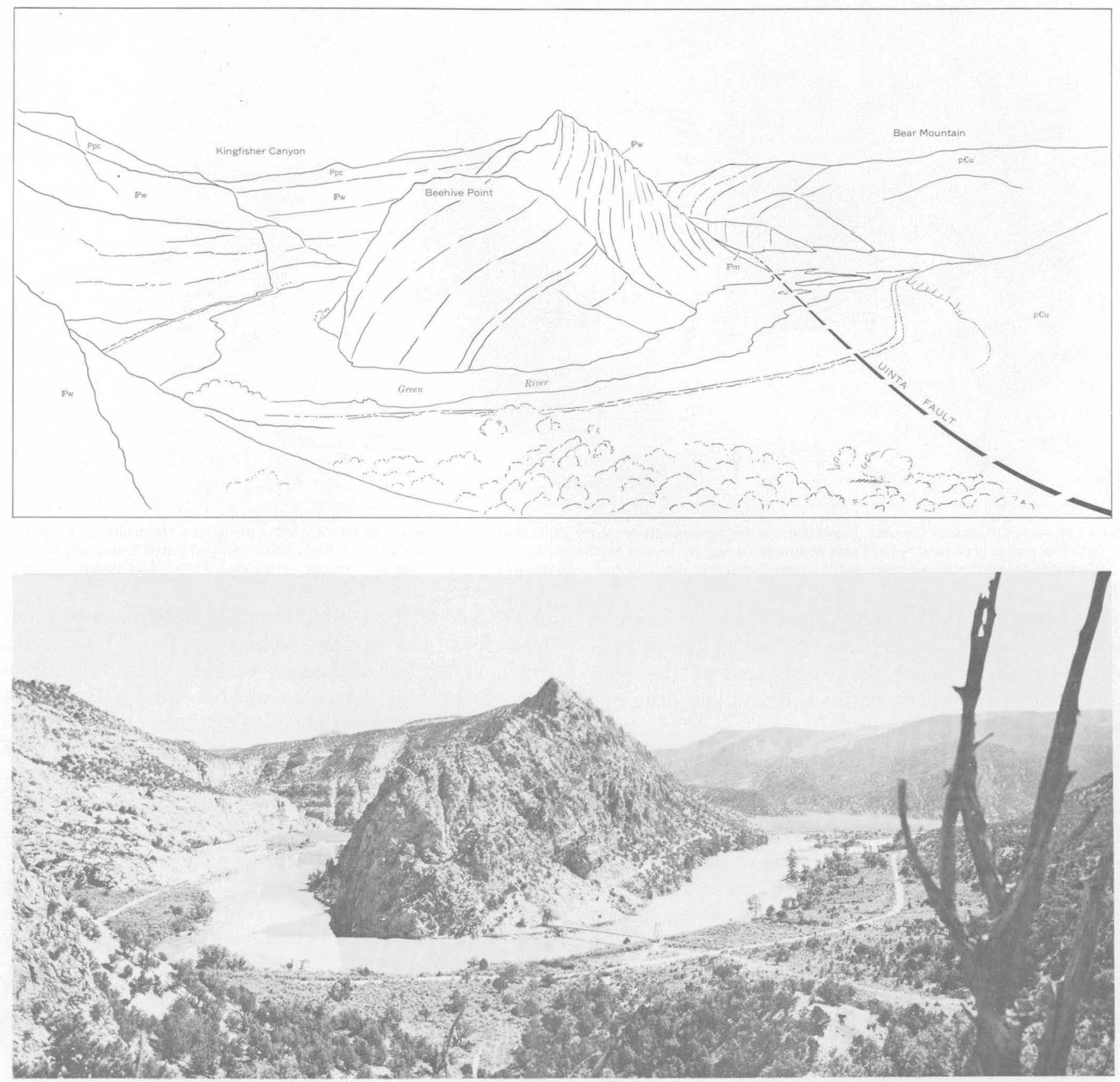

FIGURE 61-View northeast toward Beehive Point from Hideout Canyon showing sharp flexure in footwall of Uinta fault; bedding at left of picture dips gently northwest, steepens abruptly, and overturns beneath peak in center. Uinta Mountain Group (right) overrides Morgan Formation and Weber Sandstone. Superior resistance of Weber Sandstone to erosion as opposed to soft shales in adjacent Uinta Mountain Group has produced a high obsequent faultline scarp. Ppc, Park City Formation; Pw, Weber Sandstone; Pm, Morgan Formation; p€u Uinta Mountain Group.

thrust (Billings, 1942, p. 172) in that overturning along the north limb of the Uinta anticline probably preceded rupture. Drag effects subsequent to rupture could not alone account for the extensive deformation back from both walls.

Where Tertiary rocks form the footwall of the fault, they display very little drag away from the fault plane despite low competence and despite strong overturning in the immediate underlying Cretaceous rocks. Such relationships are well shown on the north slope of Goslin Mountain and on the west slope of Bender Mountain, where north-dipping Tertiary rocks lie directly on overturned Cretaceous rocks adjacent to the fault (fig. 56). Apparently the fault has had two distinct periods of movement: the first and strongest movement in Late Cretaceous or earliest Tertiary time caused 


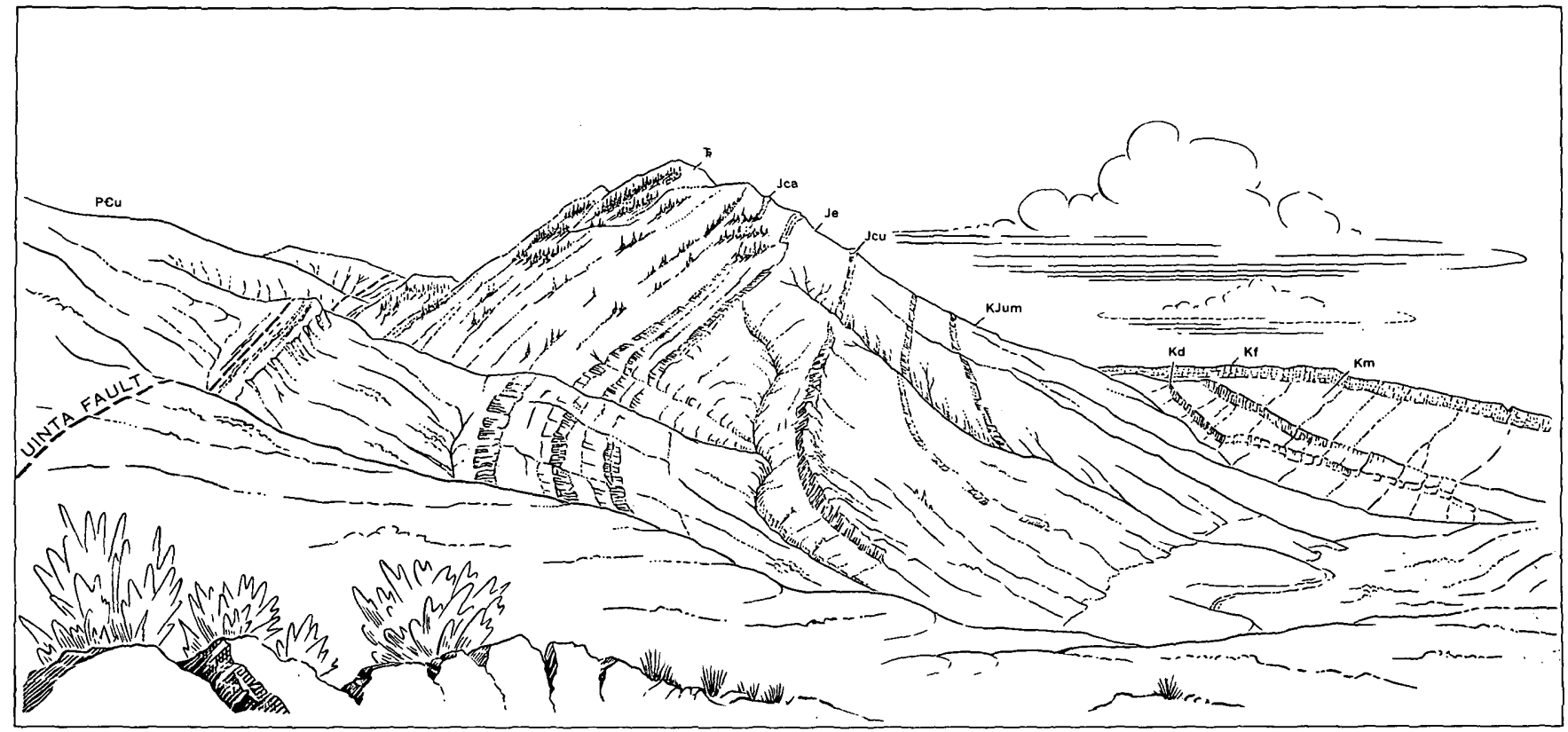

Fiaure 62.-Boars Tusk from the east. Showing strong overturning adjacent to the Uinta fault. Fault trends from saddle at left of Boars Tusk diagonally down toward lower left corner of picture. p£u, Uinta Mountain Group; Jn, Navajo Sandstone; Jca, Carmel Formation; Je, Entrada Sandstone; Jcu, Curtis Formation; KJum, Unnamed Lower Cretaceous rocks and Morrison Formation; Kd, Dakota Sandstone; Km, Mowry Shale; Kf, Frontier Formation. From a fleld sketch.

most of the drag in the walls; the second movement, in Tertiary (post-Wasatch) time and along the already established thrust plane, simply sheared off the overlapping Tertiary rocks without flexing or dragging them.

The maximum stratigraphic throw of the Uinta fault is not known precisely, but a reasonably reliable figure can be deduced. The stratigraphic throw increases gradually from west to east-from the western termination of the fault southwest of Manila to the vicinity of Clay Basin, where it probably attains a maximum. Juxtaposition of the Red Creek Quartzite against the fault at several places near Clay Basin gives a misleadingly large figure for the maximum stratigraphic throw, as it suggests that the entire Uinta Mountain group, totaling perhaps 24,000 feet in thickness, is faulted out. The Red Creek, however, has a fault relationship to the Uinta Mountain Group that antedates movement on the Uinta fault, hence the apparent stratigraphic separation on the Uinta fault exceeds the actual separation. The point at which the Uinta Mountain Group itself is most deeply truncated by the Uinta fault is opposite the head of Jesse Ewing Canyon near the east end of Clay Basin. West and east from that point, successively younger beds in the Uinta Mountain Group are against the Uinta fault. At the head of Jesse Ewing Canyon, about 4,000 feet of the Uinta Mountain group remains between the Uinta fault and the basal sedimentary contact of the group with the Red Creek Quartzite to the south. 'Thus, at that point, perhaps
20,000 feet of the Uinta Mountain Group has been deleted from the surface section by the Uinta fault. About 14,000 feet of younger rocks on the downthrown side of the fault has been deleted also, indicating a stratigraphic throw of about 34,000 feet.

A possible strike-slip component of movement on the Uinta fault has been noted previously elsewhere (Hansen and Bonilla, 1954, p. 15), as well as in this report in the discussion of flanking folds. Evidence supporting this view is found in the truncated and apparently displaced folds that flank the main Uinta anticline along the line of the Uinta fault. The apparent lateral displacement of these folds increases eastward in roughly direct proportion to the eastward increase in stratigraphic throw on the fault. The strike-slip component of movement appears to be about four-tenths as great as the dip-slip component.

\section{HENRYS FORK FAULT}

The Henrys Fork fault was named by Bradley (1936a, pl. 34). Structurally it resembles the Uinta fault, but it is shorter and has less displacement; strata in both walls are generally, but not everywhere, overturned; slivers or slices are common. Northeast of Manila, where the fault was first recognized, its throw probably is about 4,000 feet. Ten miles or so to the west its throw exceeds 12,000 feet (Anderman, 1955, p. 132). At Manila, Hilliard Shale on the upthrown or hanging wall is against the Wasatch Formation on the footwall. 
Iike the Uinta fault, the Henrys Fork fault appears to be a stretch thrust. Evidence of pre-Tertiary rupture, however, is lacking. Detailed studies by Anderman $(1955$, p. 132) indicated that the Henrys Fork fault moved during deposition of the Green River Formation in early medial Eocene time.

The Henrys Fork fault extends west several miles beyond the mapped area. To the east it terminates north of Flaming Gorge in three probable branches. The northernmost branch, which strikes northeastward into Wyoming and disappears near the Green River, is confirmed by deletion of beds and discordances in bedding attitudes in the Wasatch Formation. The middle branch is indicated by discordances of attitude and by deletion of the Fort Union Formation. The southernmost branch, which is only inferred and is not closely located, is indicated by an apparent deletion of about 1,500 feet of Hilliard Shale near the mouth of Henrys Fork. This branch probably dies out beneath the flood plain of the Green River, but it may extend a short distance east of the river. In any event, it does not join the Uinta fault at the surface, although it may possibly do so at depth. The sharp flexing and overturning along the north slope of Boars Tusk probably manifest the termination of the Henrys Fork fault.

\section{SMALI THRUST FAULTS NEAR SHEEP CREEK}

Two small thrust faults, with maximum throws of perhaps 400 feet, transect the rocks that form the north wall of Sheep Creek Canyon. One of these faults is well displayed at Sheep Creek Gap, where the Navajo Sandstone and the Carmel Formation have a fault relationship. The other fault is exposed in the canyon walls $1 / 2$ mile and $21 / 2$ miles farther east. The fault at Sheep Creek Gap has a decidedly concave upward profile, hence had a rotational movement about a horizontal axis parallel to the strike of the fault. As a result, the Navajo in the upthrown wall of the fault is nearly vertical, whereas the Carmel Formation in the downthrown wall dips gently northward, except for minor drag effects. Farther west along the fault, the Carmel Formation on the upthrown side is faulted against the Morrison Formation locally, and the Entrada and Curtis are deleted; sharp overturning characterizes this segment of the fault zone.

The other small thrust fault near Sheep Creek places the Moenkopi Formation against the Navajo Sandstone about half a mile east of Sheep Creek Gap. The trace of this fault is somewhat problematical as it cannot be followed with any assurance across the Navajo Sandstone outcrop. Where it presumably crosses the Navajo, the sandstone is brecciated and partly silicified to quartzite. Anderman's (1955, map opposite p. 130) inter- pretation of the relationship was different from that shown on plate 1 ; he mapped the eastern part of the fault as a separate break branching from the South Valley normal fault.

\section{NORMAL FAUITS}

Normal faults, as already pointed out, are abundant in the area, especially in the Precambrian rocks south of the Uinta fault. Most of these faults have eastward or southeastward trends and can be grouped into zones that consist of several or many individual faults, in part with en echelon relationship between individual faults. By far the majority of these faults are downthrown on the south or west. Possibly they are related to tensional release of stress following compressional Laramide folding and accompanying foundering of the crestal part of the range relative to the flanks. Other faults trend nearly at right angles to the Uinta fault and terminate against it. Some of these bear no clear relationship to the zones noted above and may have resulted from different stress conditions; some of them appear to be tear faults formed at the same time as the Uinta fault by differential forward and upward movement of the overriding mountainward block. Recent experimental work with models suggests that divergent fault systems may form under a single system of external forces without alterations in the direction of tectonic forces (Beloussov, 1960, p. 1258-1261).

\section{NORMAL FAULTS OF UPPER RED CANYON AREA}

The westernmost zone of abundant normal faults in the mapped area extends from the southern and eastern margins of Bear Mountain eastward 8 miles or so along Red Canyon to the vicinity of Flaming Gorge Dam. Exposures in this area are poor except in the walls of Red Canyon, and more faults probably exist than are mapped. Some faults that are clearly visible in the canyon walls cannot be traced with assurance any distance back from the walls. A few faults, however, can be traced for several miles. Vertical displacements on individual faults range from a few feet to perhaps 200 feet. Total cumulative movement on opposite sides of the zone appears to be slight, owing to compensatory displacements on individual faults. The net result of their movements seems to have been a relative collapse of the Red Canyon anticline and a slight lowering of the area south of the faulted zone relative to the area north of it. The time of movement is uncertain: the erosion surface on Bear Mountain does not appear to be displaced, nor do remnants of the Browns Park Formation along the fault zone in the Greendale area. Movement, therefore, may be as early as Oligocene. 
NORMAL FAULTS OF THE DUTCH JOHN AND LITTLE HOLE AREA

A second zone of normal faults extends eastward from the vicinity of Dutch John Flat north of Flaming Gorge Dam, hence rises north of and overlaps the zone just described. It extends eastward through Little Hole along the west and south slopes of Goslin Mountain to Browns Park, a distance of about 10 miles. It may extend eastward into Browns Park, but if it does, it is concealed by the Browns Park Formation. Individual faults average about 2-3 miles in length and tend to overlap one another en echelon. Most of them trend southeastward, although several west of Goslin Mountain trend almost due south. Almost without exception they are downthrown toward the west or southwest so that the accumulated displacement across the zone is considerable, possibly more than 2,000 feet. Stratigraphic throw on individual faults is considerable, also, although it cannot be determined precisely on many faults, and some faults may have a strike-slip component of movement.

One fault, which arises near Cow Spring in sec. 32, T. 3 N., R. 23 E., and extends southeastward toward Little Hole, displaces a conglomeratic marker bed stratigraphically about 1,200 feet. Most of this displacement preceded cutting of the Gilbert Peak erosion surface (Oligocene?) on Goslin Mountain, but the surface itself is displaced perhaps 50 feet or so.

The series of an echelon faults along the south base of Goslin Mountain suggests that the steep lower south slope of the mountain is a modified fault scarp, especially in the vicinity of Dripping Spring. If so, the scarp has been heightened somewhat by erosion at its base. The eastward continuation of the slope toward and beyond Manns Spring may be a fault scarp also, but it too has been erosively modified-in this instance, by the Green River. Possibly, the erosion-surface remnants on Dutch John Bench and Goslin Mountain are correlatives of one another that have been displaced by faulting-in other words, the typical Bear Mountain surface is a downfaulted part of the Gilbert Peak surface. The apparent displacement along the base of Goslin Mountain is perhaps 200-400 feet. The surface on Goslin Mountain has been tilted southward also.

NORMAL FAULTS NORTH OF BROWNS PARK

A third zone of normal faults extends east from Red Creek along the north side of Browns Park to and beyond the east boundary of the mapped area. This zone may be regarded as an eastward extension of the zone in the Dutch John and Little Hole areas, although the two zones are not perfectly aligned.

This zone is not strictly linear but contains several sets of faults that trend in several directions. In the
Mountain Home area the major trends are about eastwest, but significant departures from that trend may be as much as $30^{\circ}$. The largest fault of this group is the Mountain Home fault, which separates the Browns Park Formation in the valley to the south from the Precambrian rocks of the uplands to the north. East of the Mountain Home area, on the top and west slopes of $\mathrm{O}-\mathrm{Wi}$-Yu-Kuts Mountain, many faults have southeastward trends; two or more sets of faults intersect at acute angles. Still farther east, on Cold Spring Mountain in an area bounded on the west by the $\mathrm{O}$-Wi-Yu-Kuts fault and extending east far beyond the limits of the mapped area, many small faults trend northeast.

The same generalization made before-that downthrow is predominantly toward the south or west-applies to the normal faults north of Browns Park. Cumulative downthrow to the south across the zone, therefore, is great. Southwest of O-Wi-Yu-Kuts Flats, for example, the contact between the Uinta Mountain Group and the Red Creek Quartzite is displaced about 1,500 feet vertically and about 3,500 feet stratigraphically by steplike displacements on three faults, includ. ing the Beaver Creek fault. Displacements probably are comparable in the Mountain Home area.

Throws of as much as 600 feet are evident on some faults; other faults have moved even more. The O-WiYu-Kuts fault, which trends about S. $30^{\circ} \mathrm{W}$. and seems to have a hingelike displacement that increases southward, is among the largest. Its stratigraphic throw near the mouth of Beaver Creek must be at least 4,000 feet and probably is as much as 7,000 feet; 4,000 feet is the approximate height to which the contact between the Uinta Mountain Group and the Red Creek Quartzite on the upthrown (northwest) side, if projected southward, would rise above the oldest exposed beds in the Uinta Mountain Group on the downthrown side. The figure is minimal inasmuch as the contact is not exposed on the downthrown side.

A stratigraphic throw of about 7,000 feet on the $\mathrm{O}-\mathrm{Wi}-\mathrm{Yu}-\mathrm{Kuts}$ fault is suggested by a tentative correlation of beds across the fault (fig. 11). This correlation is tentative because no way has been found to establish firmly the identity of beds on opposite sides of the fault. Nevertheless, the correlation is made with considerable confidence. In lieu of a positive ground identification, sequences of beds as viewed stereoscopically on aerial photographs were matched as to thickness and spacing of ledges, alternations of resistant and nonresistant beds, similarities of vegetative cover, and tonal values. Comparisons were made in areas of similar physiographic expression on essentially undissected remnants of the Gilbert Peak erosion surface to avoid the masking effect of strong topographic. relief. As thus 
matched, the prominent ledge about 600 feet south of Summit Spring on Cold Spring Mountain (Willow Creek Butte quadrangle), in sec. 17, T. 11 N., R. 103 $\mathrm{W}$., is correlated with the prominent rim-forming ledge about 800 feet south of $\mathrm{O}-\mathrm{Wi}-\mathrm{Yu}$-Kuts Spring, near the center of sec. 36, T. 12 N., R. 104 W. A widely exposed sequence of relatively thinly bedded quartzites south of Summit Spring in secs. 17 and 18 on Cold Spring Mountain is likewise correlated with a similar-appearing sequence south of O-Wi-Yu-Kuts Spring on O-WiYu-Kuts Flats; a sequence of alternate quartzites and shales that extend northward from Summit Spring is similarly correlated with a sequence of quartzites and shales that extend northward from O-Wi-Yu-Kuts Spring. If these correlations are valid, the O-Wi-YuKuts fault has a stratigraphic throw of about 7,000 feet.

NORMAL FAULTS IN THE YOUNGER ROCKS NORTH OF THE UINTA FAULT

As noted before, normal faults are scarce in the younger rocks north of the Uinta fault, and the few that are mapped are mostly small. A half dozen small faults on the Spring Creek nose south of Antelope Flat offset the Dakota; Mowry, and Frontier Formations.

A large fault southeast of Manila, the South Valley fault, trends about $\mathrm{N}$. $70^{\circ} \mathrm{W}$. from a junction with the Uinta fault at Beehive Point 5 miles into South Valley, where it dies out in the Morrison Formation. The South Valley fault is well displayed in the valley of Sheep Creek where it displaces the Dinwoody, Moenkopi, Chinle, and Navajo Formations, and along Utah Highway 44 where it displaces the prominent outcrop of the Curtis Formation. It is downthrown on the southwest and dips steeply southwest. Its"stratigraphic throw probably does not greatly exceed 300 feet. Its map pattern (pl. 1) suggests possible strike slip, but its apparent horizontal displacement can also be explained by dip slip only. A narrow zone of drag in the upthrown (footwall) side is well displayed in the Moenkopi Formation in the valley of Sheep Creek.

A small but unusual fault extends west 2 miles from the Uinta fault at Hideout Canyon toward the switchbacks of the old Vernal-Manila Road. This, fracture is a so-called scissors fault whose displacement is reverse in its western part and normal in its eastern part. Its movement thus apparently was rotational about a horizontal axis normal to its strike. Its dip, where observed, is $60^{\circ}-70^{\circ} \mathrm{S}$.

TIME AND SIGNIFICANCE OF NORMAL FAULTING

Normal faulting probably extended over a long span of time in the eastern Uinta Mountains-a history of deformation many times repeated in the Rocky Moun- tain and Great Basin regions. Some faults apparently moved more than once. The great majority of faults by themselves cannot be dated on any direct basis as they involve only Precambrian rocks and noncommittal topographic relationships. But most of them can be dated by inference or by the relationships they hold to other faults that are datable relative to stratigraphic units or to physiographic features. In brief, the time of normal faulting seems to have extended from perhaps Oligocene time, or possibly even earlier, through Miocene time and possibly into Pliocene time. No field evidence yet suggests any movements later than Pliocene.

Most faults in the upper Red Canyon area seem to be older than the high erosion remnant preserved on Bear Mountain. Some of these faults cross remnants of this surface without displacing the surface. The surface is not closely dated, but if it correlates with the Gilbert Peak surface, as seems probable, it may be as old as Oligocene. Similarly, although the field evidence is not conclusive, several faults appear to pass beneath remnants of the Browns Park Formation in the Red Canyon area without displacing them. These Browns Park remnants probably are Miocene in age, but they may be as young as Pliocene.

On Goslin Mountain a fault cited previously displaces the Gilbert Peak erosion surface about 50 feet but has a stratigraphic throw of about 1,200 feet. It thus moved both before and after development of that surface, but its greatest movement was before, perhaps in Oligocene time. Most of the other faults on Goslin Mountain do not obviously displace the Gilbert Peak surface. The surface, however, has been modified by erosion since it formed, and minor scarps could have been erased. Some faults, moreover, are in deeply eroded areas where all traces of the Gilbert Peak surface have been obliterated; among these are the faults near the junction of Goslin Mountain and Dutch John Mountain. Faults along the base of Goslin Mountain through Iittle Hole, on the other hand, suggest strong post-Gilbert Peak displacements.

Farther east - east of O-Wi-Yu-Kuts Mountain-the $\mathrm{O}-\mathrm{Wi}-\mathrm{Yu}$-Kuts fault has a stratigraphic throw of perhaps 7,000 feet. Most of this movement predated the cutting of the Gilbert Peak surface there, but the fault appears to displace the surface as much as 200-300 feet in the vicinity of Honeymoon Spring and possibly as much as 700 feet between O-Wi-Yu-Kuts Flats and Cold Spring Mountain. Its major movement was clearly pre-Gilbert Peak, but it apparently moved afterward also, possibly in Miocene or Pliocene time.

Faults are uncommon within the body of the Browns Park Formation in its type area, and several faults that have been traced through Precambrian rocks up to the Browns Park boundary apparently do not displace the 
Browns Park Formation. Nevertheless, the Browns Park Formation is displaced by several faults along the north margin of the valley; hence, post-Browns Park movements; probably Pliocene, are indicated. Along the Mountain Home fault the Browns Park For. mation is sharply dragged against the Red Creek Quartzite and the Uinta Mountain Group in a zone of gouge and breccia as much as 100 feet wide. The fault relationship is well exposed at the mouth of Jesse Ewing Canyon; 3 miles to the west a prospect hole exposes the full width of the fault zone. Just east of Jesse Ewing Canyon the fault terminates, and the Uinta Mountain-Browns Park contact is depositional; displacement is taken up by warping, in place of faulting, along a small drag anticline. Between Jesse Ewing. Canyon and Cottonwood Draw a strong lineament in the Browns Park Formation south of the contact is caused by a local steepening of the dip in a sequence of conglomerates; the lineament suggests possible faulting at depth and raises the possibility that some faulting in the hard-rock floor of Browns Park may die out upward in the thick loosely consolidated deposits of the Browns Park Formation.

Near the Utah-Colorado State line the Beaver Creek fault clearly involves the Browns Park Formation in relationships illustrated both to the west and to the east of the valley of Beaver Creek, particularly to the east. East of Beaver Creek the homoclinal Uinta Mountain Group is dragged downward into a small anticline and the Browns Park Formation is dragged sharply upward into a vertical attitude. Discounting drag in the walls, the fault zone is about 20 feet across; it probably is wider farther west.

Evidently then, normal faulting began in the area long before the Browns Park Formation was deposited. It clearly began before the Gilbert Peak surface was cut (Oligocene?) and continued or was resumed after the Browns Park Formation had been deposited. What evidence is available suggests that most of the larger and more numerous displacements preceded cutting of the Gilbert Peak surface and deposition of the Browns Park Formation; the great number of faults just north of Browns Park and the paucity of them within the Browns Park Formation support this view, as do the large pre-Gilbert Peak displacements on certain faults previously described.

GRAVITATIVE MOVEMENTS ON THE UINTA FAULT

Since the early work of Powell (1876, p. 205-208), a late gravitative reversal of movement has been recognized on the Uinta fault. This view has been verified and elaborated by several geologists, particularly by Sears (1924a, p. 291) and by Brạdley (1936a, p. 185) in their detailed analyses of the problem. In brief, the earlier Laramide thrusting movements along the Uinta fault carried the south or mountainward block upward over the north or basinward block. Later gravitative movements dropped the mountainward block relative to the basinward block, thus reducing somewhat the net slip on the fault. Bradley presented cogent evidence to show that gravitative movement on the Uinta fault followed cutting of the Gilbert Peak erosion surface on Cold Spring Mountain. Gravitative movement in that area amounted to about 1,700 feet (Bradley, $1936 a$, p. 183). Warping of this surface on O-Wi-YuKuts, Bender, the Head of Cottonwood, Mountain Home, and Goslin Mountains further supports Bradley's view.

Placing a minimum limit on the time of gravitative movement on the Uinta fault is more difficult. In the Vermilion Creek area near the east end of Cold Spring Mountain (outside the mapped area), the Browns Park Formation is clearly involved in the reversal of movement on the Uinta fault (Sears, 1924b, pl. 35). Just east of Kleins Hill, however, near the extreme northeast corner of the mapped area and 10-15 miles west of the Vermilion Creek area, the Browns Park Formation appears to extend across the Uinta fault zone without any disturbance. Exposures east of Kleins Hill emphatically are poor, and the relationships there probably are susceptible to more than one interpretation. But in view of the large gravitative displacement on the Uinta fault, it seems improbable that the Browns Park Formation would now extend across the zone if it predated the movement. More probably, the displacement came, or at least started, first. Powell seems to have reached this view in 1876 (p. 209), for he stated:

When the downthrow commenced it is probable that the Brown's Park beds were not yet deposited, but after it had continued for some time the region was so depressed that the waters of the stream were ponded and a lake formed. In this lake, then, the Brown's Park beds were accumulated.

We know that the Brown's Park beds were involved in a part at least of this downthrow, and hence were deposited before the downthrow was accomplished, because the beds themselves were involved in the displacement; they are severed by faults and bent by fractures where they are seen to overlap or extend beyond the area of downthrow.

\section{TERTIARY WARPING AND TILTING}

EXTENT AND CHARACTER

Extensive middle to late Tertiary warping and tilting along the northeast flank of the Uinta Mountains is closely related to the normal faulting and probably was concomitant in its development. Evidence of such warping is found mainly in areas where remnants of preexisting datum planes, such as erosion surfaces, are 


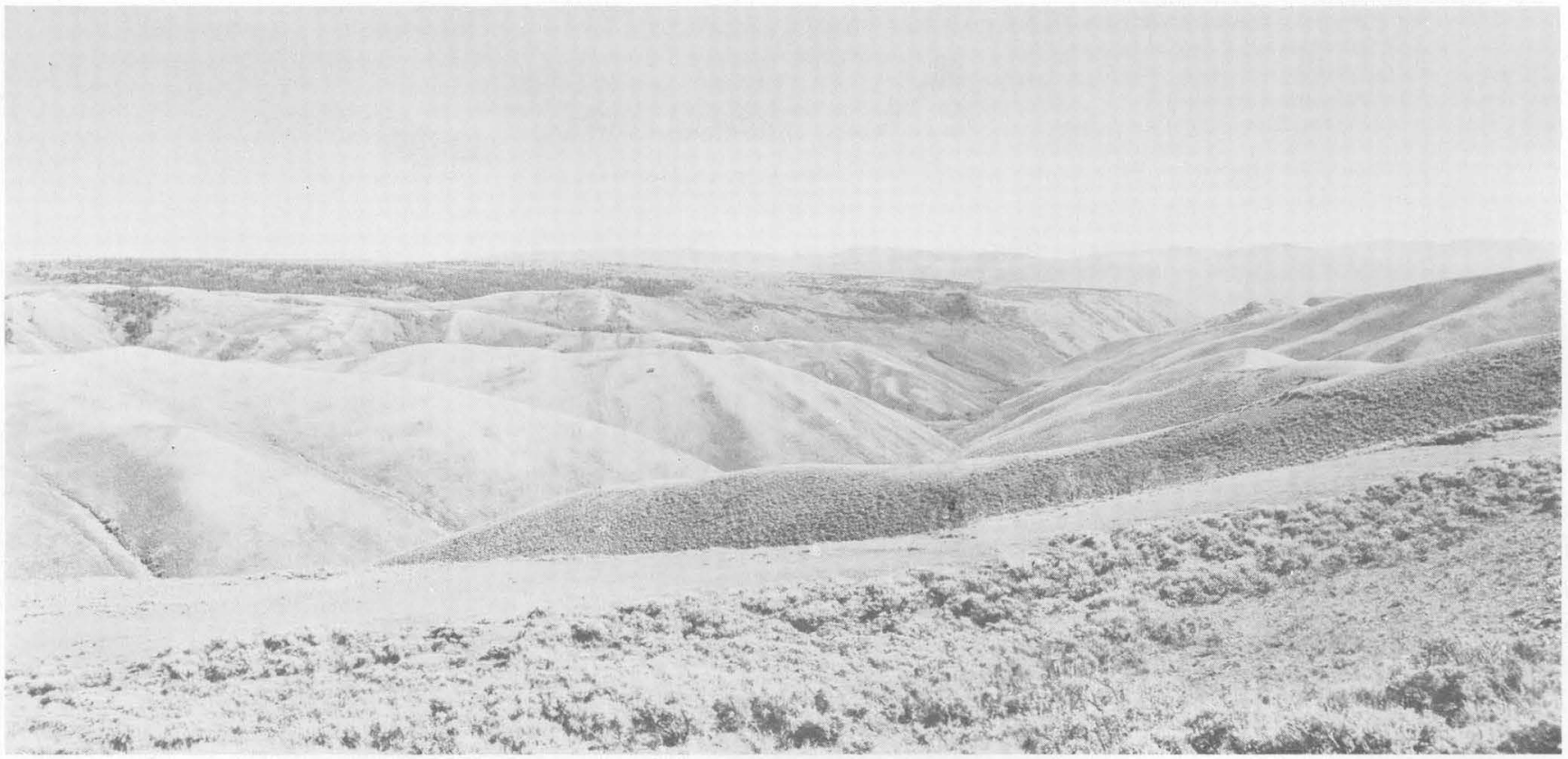

Frgere 63.-View south from Willow Creek Butte showing westward tilt of Gilbert Peak erosion surface on O-Wi-Yu-Kuts Mountain in middle distance. Canyon of Willow Creek in center. Crestline of Uinta Mountains on skyline.

preserved. In such areas, tilted distorted remnants of the Gilbert Peak erosion surface afford cogent evidence of Tertiary warping. Evidence of warping is less obvious elsewhere, owing to dissection or to the masking eflects of more complicated older structure.

Bradley (1936a, p. 170) has described in detail the characteristics of the Gilbert Peak erosion surface, its physiographic relationships, and the events that led up to and followed its dislocation along the line of the Uinta fault. In brief, the surface was carved by laterally abrading streams under semiarid climatic conditions. Flowing down the north slope of the Uinta Mountains, these streams eroded a broad north-sloping pediment, which in its outer reaches was capped by the Bishop Conglomerate (Rich, 1910, p. 601).

At the time of its formation, as reconstructed by Bradley, this wide, remarkably uniform surface sloped gradually north to northeastward off the mountains, far into the Green River Basin. Its gradient flattened gradually basinward, so that its profile was broadly concave upward-steeper near the mountains and flatter toward the basin. Westward along the north flank, where warping has not occurred or was minimal, the profile of the surface is preserved just as it formed. Eastward, however, as Bradley has shown, the surface is distorted by faulting and warping. In particular, the flat summit of Cold Spring Mountain was dropped about 1,700 feet relative to remnants of the same surface to the north across the Uinta fault on Little, Bishop, and Diamond Mountains (Bradley, 1936a, p. 183). South of the Uinta fault, the several erosion remnants preserved between Cold Spring Mountain and Bear Mountain manifest marked departures east to west from the original configuration of the surface.

The highest point on the Gilbert Peak erosion surface south of the Uinta fault is on O-Wi-Yu-Kuts Mountain near the Colorado-Utah State line. Points higher than the Gilbert Peak erosion surface in that immediate area, such as Buck Knoll and Kleins Hill, appear to be monadnocks that stood above the original surface before warping. Viewed from Bishop Mountain (or Pine Mountain) to the north, O-Wi-Yu-Kuts Mountain resembles a broad flat dome. It slopes abruptly, then gently east to Cold Spring Mountain. Similarly, it slopes west toward the Head of Cottonwood, where the maximum tilt to the west is about 320 feet per mile (fig. 63). Between O-Wi-Yu-Kuts Mountain and the Head of Cottonwood, the flat south end of Bender Mountain in the SE $1 / 4$ sec. 5, T. 2 N., R. 25 E., is a remnant of the Gilbert Peak surface also, but the greater part of Bender Mountain is a monadnock which stood above the surface.

West from O-Wi-Yu-Kuts Mountain the Gilbert Peak erosion surface has a southward component of tilt as well as a westward component. This tilt is readily perceptible but not marked on O-Wi-Yu-Kuts Flats ; it increases gradually westward to Goslin Mountain where it is about $5^{\circ} \mathrm{S}$. or about 450 feet per mile. The lowest points on the old surface still remaining in the Goslin Mountain-Mountain Home area are at altitudes of about $6,800-7,000$ feet. 
If the initial northward slope of the old surface were restored, it could be seen that several points stand above the surface as monadnocks. Bender Mountain, Buck Knoll, and Kleins Hill have already been mentioned. Another conspicuous remnant is hill 7685, on the southeast slope of Goslin Mountain in sec. 1, T. 2 N., R. 23 E. Hill 7685 stood about 160 feet above the adjacent graded surface.

On Mountain Home the rolling summit area represents a group of incompletely graded monadnocks. The ridge lines that extend south from Mountain Home in secs. 1, 2, and 3, T. 2 N., R. 24 E., as seen in profile from the Head of Cottonwood, are accordant imperfectly preserved remnants of the Gilbert Pêak surface that have been all but destroyed by erosion; the southward tilt along these ridges cannot be measured precisely and probably is not uniform, but it appears to range from less than 200 feet per mile to more than 400 . Hill 7985 in the NW1/4 sec. 3, T. 2 N., R. 24 E., clearly stand's above the restored surface as a monadnock.

TILTING SOUTH AND WEST FROM GOSLIN MOUNTAIN

South and west from Goslin Mountain, additional complications in the present form of the Gilbert Peak surface are caused by a combination of tilting and faulting which apparently occurred after the Browns Park Formation had been deposited. In that area, several well-preserved erosion remnants, including Bear Mountain and Dutch John Bench, were correlated by Bradley with his Bear Mountain erosion surface. These remnants are here correlated with the Gilbert Peak surface, and their topographic discontinuity is attributed to tilting and faulting. This discontinuity ranges from about 200 to 400 feet in altitude in the area between Goslin Mountain and Dutch John Bench; it seems to be almost nonexistent a few miles to the east at the head of Browns Park, where remnants both north and south of the Green River slope toward one another and project eastward into the air above Browns Park.

From Dutch John Bench the surface rises west toward Bear Mountain, Greendale, and Dowd Mountain. The slope is about 100 feet per mile. There is also a perceptible northward component of slope in that area, particularly at Dutch John Bench where it is about 50 feet per mile. This slope contrasts with the southward slope of nearby Goslin Mountain. The highest part of Dutch John Bench is thus along its south margin adjacent to Red Canyon; the river, therefore, was either entrenched in its present course before the surface was tilted - otherwise it would have shifted its course to the north side of the bench-or superposed through soft sediments since stripped off after tilting. The latter view is favored here, partly because it is more compatible with other facets of the geologic his- tory of the area and partly because an inordinate amount of local warping would otherwise be required to explain the steep slope away from the rim of Red Canyon (Goslin Mountain quadrangle) in sec. 19, T. 2 N., R. 23 E.

REgIONAL EVIDENCE OF TILTING SOUTH AND WEST OF GOSIIN MOUNTAIN

Reconnaissance south of Red Canyon, along and south of the main crestline of the Uinta Mountains as far south as Diamond Mountain, provides evidence of tilting on a regional scale. This tilting was predominantly northward but had an eastward component also. It evidently occurred after the Browns Park Formation had been deposited. The high erosion surface preserved on Diamond Mountain is capped with the Browns Park Formation (fig. 64). As seen in north-south profile, especially as viewed from the west, the surface has a distinct northward slope, although its initial slope must have been to the south away from the crestline; the Browns Park Formation that caps the surface seems to dip northward also. Several miles west of Diamond Mountain-also on the south slope of the range-northward tilt has been noted in the Little Mountain, Farm Creek Peak, and Whiterocks areas (Walton, 1944, p. 127-128).

Indirect evidence of northward tilting is found at the very crest of the range at a point about on line with Little Mountain on the south slope of the range and Manila on the north slope. About half way between Manila and Little Mountain, a tributary of Carter Creek, which flows down the north slope of the range, has captured the headwaters of Ashley Creek, which flows down the south slope. The point of capture, well portrayed on the old Marsh Peak 30-minute quadrangle sheet, is 4 miles northeast of Leidy Peak. Capture probably was aided by tilting toward the north.

Further evidence of northward tilting-inconclusive but suggestive-is expressed in the drainage patterns south and southwest of the mapped area. Most of the major north-flowing tributaries of the Green River south and southwest of the mapped area occupy valleys that formerly drained south (fig. 64). These tributaries include Cart Creek, Gorge Creek, Jackson Creek, Tolivers Creek, Sears Creek, and Crouse Creek. Southward drainage in these valleys predated deposition of the Browns Park Formation, which now partly fills all of them. The pattern of pre-Browns Park drainage was dendritic, and with respect to present northward drainage, nearly all of the second-order tributaries are barbed. Northward drainage probably was initiated by tilting toward the north after the Browns Park Formation had been deposited in the valleys. Drainage probably was consequent on the old tilted depositional sur- 


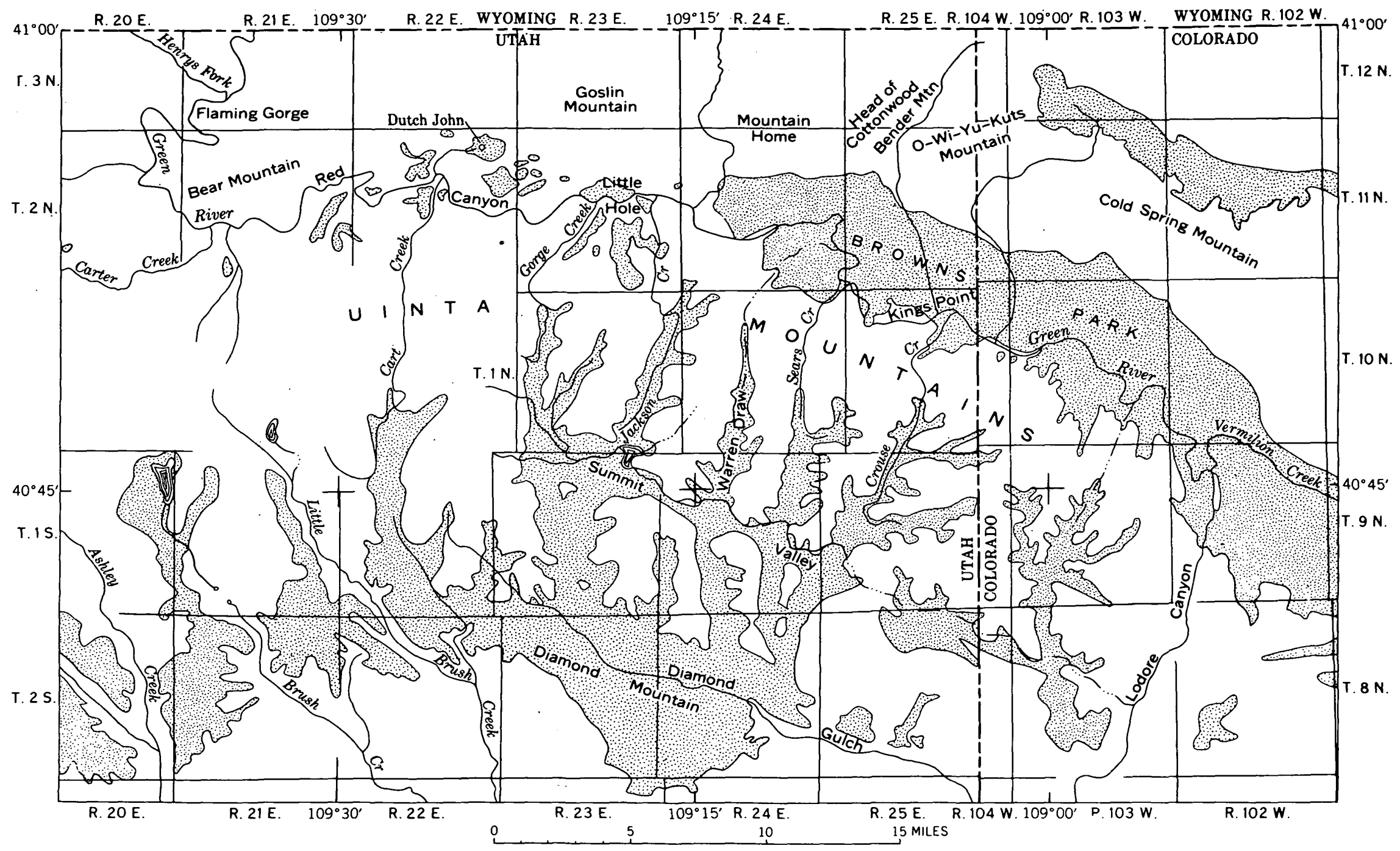

Fiovra 64.-Sketch map showing general distribution of Browns Park Formation (stippled) in part of eastern Ointa Mountains, Utah-Colorado. Based on detailed mapping on north slope by Hansen and on south slope by Kinney, and on reconnaissance and photogeology along crestal area. After Hansen, Kinney, and Good (1960, p. B258) 
face of the Browns Park Formation. This surface, however, has been stripped away by erosion.

\section{TIME OF WARPING}

Tertiary warping both preceded and followed deposition of the Browns Park Formation. The greater part of the Tertiary warping that is indicated by distorted remnants of the Gilbert Peak erosion surface within the mapped area clearly preceded deposition of the Browns Park Formation by a considerable lapse of time. It may be as old, therefore, as late Oligocene or early Miocene time: remnants of the Gilbert Peak surface project into the sky above existing deposits of the Browns Park Formation; an earlier canyon was eroded in the Red Canyon area, probably after eastward tilting and clearly before deposition of the Browns Park Formation; the hard-rock floor of Browns Park valley also was excavated after tilting, as is indicated by skyward projections of the tilted surface above it, and before deposition of the Browns Park Formation, which, of course, now fills it. In all probability, tilting after the Gilbert Peak surface had formed but before the Browns Park Formation was deposited helped to direct the eastward flow of drainage that carved the valley of Browns Park and the old canyon to the west in the Red Canyon area.

Warping accompanied by faulting probably continued intermittently through Browns Park time. Evidence for such faulting has already been noted. Strong localized movements that occurred on faults along the north side of Browns Park probably were accompanied by more widespread but less evident warping away from the faultlines. If so, however, such warping is not at all obvious in the strata of the Browns Park formation in Browns Park. But many of these strata probably had initial dips sufficiently high to mask or obscure subsequent tilting of a few degrees or so. Near the Beaver Creek fault, some strata which now dip southward contain crossbedding structures which indicate that the source of the material was to the south. These structures, however, are close enough to the fault to have been effected by drag. In the Red Canyon area, the northward component of tilt at Dutch John Bench may have postdated deposition of the Browns Park Formation. Reconnaissance south of Red Canyon along the main crestline of the Uinta Mountains and on the south slope of the range provides additional evidence of post-Browns Park tilting toward the north.

In summary, it appears that tilting or warping between the Uinta fault and the line of east-west faulting north of Little Hole and Browns Park was mainly southward and westward. This tilting followed cutting of the Gilbert Peak erosion surface and preceded deposition of the Browns Park Formation. Evidence of regional tilting toward the north, and in part toward the east, on the other hand, is found south of the eastwest line of faulting in Little Hole and Browns Park. This tilting followed deposition of the Browns Park Formation.

\section{GEOLOGIC HISTORY}

Beginning with deposition of the Red Creek Quartzite in Precambrian time and extending through entrenchment of modern drainage into Recent alluvial fills, the geologic history of the Flaming Gorge area is long and detailed. The record for so long a span of grologic time is documented by an unusually straightforward and well-displayed stratigraphic section; for excellence of exposure and completeness of detail it is exceeded by few others. Even so, some major divisions of geologic time-notably the early Paleozoic-lack representation in the section, and their histories can only be inferred. Opinions, moreover, vary greatly among geologists as to what interpretations should be put on many facets of the geologic history, even on well-displayed stratigraphic intervals and structural features. The section that follows summarizes briefly the sequence of events as they seem to have happened in the area. The physical history and depositional environment of each formation is presented more fully in the section of this report dealing with stratigraphy.

\section{OLDER PRECAMBRIAN HISTORY}

Older Precambrian events are summarized in seven steps.

Step 1.--The earliest event for which there is exposed evidence was the deposition and accumulation of the sediments which now constitute the Red Creek Quartzite. These sediments were mainly well-washed sands and clays, though they included some limy muds. They probably accumulated on a rather stable, slowly subsiding shelf-an inference that is supported by the high purity of much of the quartzite in the formation and by the simple mineralogy of the schists-for only through repeated washing and winnowing before burial could such sediments be produced. Thick sections of quartzite, as pointed out before, contain as much as 99.5 percent silica.

Step 2.-Deposition of the Red Creek Quartzite was followed by severe deformation. The formation was crumpled into tight overturned folds thousands of feet to miles across the limbs. Stress was directed subhorizontally, chiefly from a source to the north. Myriads of minor folds ranging from minute wrinkles to structures hundreds of feet across the limbs were imposed on the larger structures. Deformation was accompanied by rock flowage, especially in sequences of variable competence. The sandstones were converted to 
quartzite, the shales to mica schist. Certain carbonate rocks are now marbleized limestones.

Step 3.-Mafic magma was then injected as dikes, sills, and irregular intrusive masses. Here it cut across an earlier formed fold; there it followed the partings between bedding planes or schistosity. Locally it engulfed small fragments of the wallrock.

Step 4.--Renewed deformation followed mafic injection. The rocks again were tightly folded and, concomitantly, subjected to regional high-grade metamorphism. Tight wrinkles and fracture cleavage were imposed on the mica schists. The mafic igneous rocks were metamorphosed-chiefly to well-foliated amphibolite, but the cores of some of the thicker igneous masses were converted to nonfoliated epidiorite or metagabbro. Two major mineralogic changes accompanied metamorphism of the mafic igneous rocks: pyroxene was converted to amphibole, and calcic plagioclase was converted to more sodic varieties; the calcium thus released went into the formation of epidote and carbonate rock, the latter as irregular masses and veinlets ramifying through the country rock. High-grade metamorphic mineral assemblages which formed in quartzite, mica schist, and amphibolite indicate metamorphism at great depths under high confining pressure and elevated temperature. Garnet, staurolite, and kyanite, as well as minor biotite and tourmaline, formed in quartzite and mica schist; garnet formed also in amphibolite.

Step 5.-Pegmatization and albitization then followed on a modest scale; albitization possibly began fir:st, but the two processes seem to have been about synchronous. For a rock that has been subjected to highgrade metamorphism, the Red Creek Quartzite contains surprisingly little pegmatite. Albite and quartz were introduced locally into certain amphibolites and converted them to gneissic or granitelike rocks. In some places, quartzite was albitized also.

Step 6.-A third severe deformation then ensued. 'This deformation, however, was unaccompanied by metamorphism. It was expressed chiefly by discrete shearing and faulting, though in some places the quartzite was intensely fractured or crushed over fairly wide areas. Slippage along bedding planes dragged out and crushed garnets that had formed during earlier metamorphism, causing the unusual $a$-axis lineation herein called tadpole structure. Pegmatites and albitized rocks, though deformed, were not metamorphosed. The third deformation was relatively shallow; by the time it started, the Red Creek Quartzite had been brought nearer to the surface of the earth by uplift and erosion.

Step \%.-Uplift may have been concomitant with the third deformation of the Red Creek Quartzite. At any rate, degradation followed, and the surface of the old Red Creek terrane was reduced to a rolling plain, in part quite flat but in part marked by low cliffs. On this surface, the Uinta Mountain Group began to accumulate.

\section{YOUNGER PRECAMBRIAN HISTORY}

The Uinta Mountain Group accumulated mostly in shallow water in a rapidly subsiding east-trending trough.. Little time, therefore, was available to wash, grade, and winnow the sediments before they were buried, and the resultant rocks are mostly poorly sorted. Thick coarse conglomerates accumulated in the Jesse Ewing Canyon area, perhaps as a great alluvial fan built southward from a nearby mountain range which stood to the north in Wyoming. The nearness of this source is suggested by the coarseness of the cobbles and boulders and by their lithologic identity with several rock types-mainly metaquartzites-in the Red Creek Quartzite.

The red coloration of the Uinta Mountain Group is attributed to lateritic alteration of the source rocks, promoted by a warm humid climate in the source area. Chemical alteration of amphibolite in the source area thus explains the ferric iron content of the Uinta Mountain Group and also accounts for the paucity of amphibolitic material in the conglomerates of the Uinta Mountain Group. Silica carried into solution at the same time probably contributed to the quartz overgrowths that characterize the sandstones and quartzites of the Uinta Mountain Group.

Deposition of the Uinta Mountain Group was terminated by broad regional uplift. The succeeding Paleozoic rocks were deposited on the truncated beds of the Uinta Mountain Group with an unconformity that ranges from near concordance to an angle of several degrees.

\section{PALEOZOIC HISTORY}

In the Flaming Gorge area, the surface contact between Paleozoic and Precambrian rocks is a fault (Uinta fault); so the stratigraphic relationship is undisclosed. Adjacent areas, however, clearly show that broad regional uplift preceded Paleozoic deposition. Cambrian rocks of the eastern Uinta Mountains (sandstones and shales of Late Cambrian age) rest on the Precambrian with a slight angular unconformity, generally of a few degrees, a relationship that has been noted by many geologists. Early and Middle Cambrian rocks apparently were never deposited. Thus, the eastern Uinta Mountains probably were a positive landmass in latest Precambrian time and in Early and Middle Cambrian time. Shallow seas covered the area in Late Cambrian time. 
Cambrian rocks are lacking from much of the eastern Uinta Mountains, but Upper Cambrian rocks (the Lodore Formation) probably once covered the entire area. Where lacking, the Cambrian rocks probably have been removed by pre-Mississippian erosion. Ordovician and Silurian rocks are lacking from the Uinta Mountains and probably never were deposited. Devonian rocks have been identified only in the westernmost and easternmost parts of the range. Chances seem good, therefore, that the eastern Uinta Mountains were a positive area following Late Cambrian and preceding Early Mississippian time. Strong pre-Mississippian uplift is indicated just east of the mapped area on Cold Spring Mountain, where Mississippian rocks truncate about 5,000 feet of Precambrian rocks (Uinta Mountain Group) in a horizontal distance of about 4 miles.

A general downwarping in Mississippian time caused shallow epeiric seas to spread widely over the Western Interior of the United States, including the Uinta Mountain area. Throughout most of succeeding late Paleozoic time a shallow intermittently subsiding trough coincided approximately with the old Precambrian Uinta trough and with the present Uinta Mountains. First described by Forrester (1937, p. 631), this trough can be outlined in its general configuration by means of isopachs; but the details must be generalized, owing to incomplete data in many places and a complete lack of data in others. By and large, the trough deepened to the west, for in that direction it merged with the Cordilleran miogeosyncline. It shallowed gradually to the east and rapidly to the north and to the south, although its shape and depth and its rate of subsidence differed from time to time.

A good summary of Carboniferous paleogeography has been presented by Sadlik (1955, p. 49). In Early Mississippian time the whole Western Interior of the United States was flooded by marine waters. The Madison Limestone was deposited at that time in the eastern Uinta Mountains, succeeded in later Mississippian time by an unnamed lower limestone unit and an unnamed middle sandstone and limestone unit. By this time the sea had begun to shoal, and much red siltstone and sandstone were deposited. Complete emergence probably followed-succeeded in turn again by shallow submergence during deposition of the marine upper shale unit. The presence of coal in the upper shale a few miles west of the area at Sols Canyon indicates at least local emergence--probably a coastal coal swamp-at that time also.

Marine conditions continued during deposition of the overlying Round Valley Limestone in Early Pennsylvanian time. Freely circulating water and slow uniform subsidence are indicated by the faunas and lithologic uniformity of the Round Valley Limestone.
The succeeding Morgan Formation is marine also, although the presence of interbedded limestones, red shales and siltstones, and sandstones indicates an unstable sea bottom or a fluctuating sea level. Stratigraphic evidence of a time break, hence emergence, between the Round Valley and Morgan seems to be lackalthough Sadlik (1955, p. 58) reported faunal evidence of such a break. An unconformity within the Morgan Formation southeast of Death Valley is suggested by intraformational breccias.

Systematic variations in thickness in the Morgan Formation from place to place suggest that a shallow trough existed in the Linta Mountain area during deposition of the Morgan Formation. Various geologists, however, have selected various horizons for the top and base of the formation, and isopachs must be plotted with caution and reservation. In any event, shallow seas must have covered most of the Uinta Mountains, the Green River Basin, and areas to the west, although the Morgan Formation is unreported in some parts of the Wasatch Range and in southwest Wyoming. To the southeast and east, landmasses stood in the Uncompahgre and Front Range areas; north of the Uncompahgre area, a deep trough lay in central western Colorado.

The Weber Sandstone was deposited after the Morgan Formation without any apparent break in sedimentation. What evidence is available suggests a welldefined trough over the Uinta Mountains during Weber (Des Moines and Younger) time (fig. 17). Slow uniform subsidence is indicated by the great thickness of remarkably uniform well-sorted sandstone; an onshore to near-shore environment seems probable. Most of the sand probably was deposited on a beach, but some of it may have accumulated in onshore dunes. Tangential crossbedding supports such a view. Transgressive and regressive fluctuations of the shoreline, however, are indicated by interbedded fossiliferous limestones in the lower part of the formation. These beds probably accumulated in shallow but freely circulating waters.

An upper age limit for the Weber Sandstone has never been satisfactorily established. Inference and field relationships, however, suggest that a long time break followed deposition of the Weber and preceded deposition of the overlying Park City Formation. The eastern Uinta Mountains area, therefore, probably stood above sea level at that time.

The Park City Formation accumulated under varied marine conditions-mainly on a shallow but unstable sea floor. Marked vertical variations indicate local physical-chemical changes in environment caused chiefly by changing depths of water, which in turn are believed to have been caused chiefly by mild tectonic activity (Sheldon, 1957 , p. 153). The carbonate-sandstone sequences 
of the lower and upper members of the formation probably accumulated in shallow but freely circulating waters; the phosphorite-mudstone-chert sequence of the Meade Peak Tongue of the Phophoria Formation probably accumulated in relatively deep water-down to probable depths of 1,000 meters (McKelvey, Swanson, and Sheldon, 1953, p. 59); the red beds and evaporites of the Franson (upper) Member accumulated in very shallow water under conditions of restricted circulation, high rate of evaporation, and high salinity.

\section{MESOZOIC HISTORY}

The Mesozoic Era began without any marked tectonic activity in the Flaming Gorge area and with only a mild shift in depositional environment from that of the Paleozoic. Although regional relationships suggest a possible stratigraphic break between the Permian and Triassic Systems, cogent local evidence of such a break is lacking and the system boundary is inconspicuous. A shallowing of the seaway that covered the area is indicated by an abrupt upward lithologic change from thick-bedded carbonate rocks at the top of the Park City Formation to thin-bedded in part ripple-marked siltstones and shales at the base of the Dinwoody Formation. Continued shoaling and restriction of circulation in the seaway are indicated by evaporites and red beds higher in the Triassic section.

During most of the Mesozoic Era the area lay on the unstable shelf between the craton on the east and the Cordilleran geosyncline on the west. The old Uinta trough, which was poorly defined in the Permian and Triassic Periods, once more exerted influence on sedimentation during the Jurassic and Cretaceous Periods. A column of sediments more than 12,000 feet thick accumulated over the site of the eastern Uinta Mountains; appreciably thinner sections accumulated to the north and south.

Mild tectonic activity brought recurrent invasions of marine waters across the area, and a great variety of marine and nonmarine sediments accumulated. Marine conditions existed during at least part of Early Triassic time (Dinwoody and Moenkopi times). Two incursions followed in Late Jurassic time (Carmel and Curtis times). After Dakota time, marine conditions extended almost continuously into Late Cretaceous (Montana) time-that is, the Mowry, Frontier, and Hilliard Formations all consist predominantly of marine rocks; the Mesaverde Group contains interbedded marine and nonmarine rocks deposited along a fluctuating shoreline. An interval of nondeposition apparently occurs at or near the base of the Frontier Formation (Reeside, 1955 , p. 86). Parts of the Frontier, moreover, are nonmarine.
Throughout the Triassic Period and during most of the Jurassic, sediments were derived largely from the craton to the east. A deep geosynclinal trough lay to the west. As the sea oscillated back and forth across the shelf, marine sed ments extended into the area from the west and interfingered with nonmarine sediments from the east. A marked change in direction of sedimentation followed in Late Jurassic time (beginning with the Morrison Formation) as a result of the rise of the ancestral Nevadan Mountains to the west. Thenceforth, sediments were derived chiefly from this new landmass.

As a further effect of orogenic impulses mounting in the west, the shelf on which the Triassic, Jurassic, and Early Cretaceous sediments had been deposited subsided into the broad foredeep of the Late Cretaceous seaway. The thickest deposits in this trough accumulated generally to the west of the area (Reeside, 1944), but more than 8,000 feet of marine sediments accumulated in the area. This seaway was displaced from the area by continental sediments encroaching from the northwest in Late Cretaceous (Ericson). time. As a structural feature, it was destroyed by uplift during the Laramide orogeny.

The fluctuating depositional conditions of the Mesozoic Era are summarized in table 6 .

\section{LARAMIDE OROGENY}

The Laramide orogeny began in the eastern Uinta Mountains sometime after deposition of the Ericson Sandstone (equal in age to part of the Late Cretaceous Pierre Shale) and before deposition of the Fort Union Formation (Paleocene). Rocks of Laramie age are lacking in the Uinta Mountains and probably never were deposited. Compressional uplift accompanied by high-angle thrust faulting continued intermittently until about middle Eocene time.

Geologists do not agree fully as to the exact time when the Laramide orogeny culminated in the Uinta Mountains, possibly because evidence is fragmentary in most parts of the range. Deformation, moreover, may not have been contemporaneous throughout the range. Fairly widespread evidence indicates that compressional uplift began in Montana time and extended intermittently at least well into Eocene time. In the southwestern part of the Uinta Mountains, uplift accompanied deposition of the Currant Creek Formation in Montana(?) time (Walton, 1944, p. 126). Probable Paleocene uplift is indicated in the Vermilion Creek area, where the lower part of the Wasatch Formation contains great boulders derived from the nearby Uinta Mountains (Sears and Bradley, 1924, p. 96), and in the Rimrock area southeast of Jensen, Utah, where an angu- 
TABLE 6.-Mesozoic depositional environments

\begin{tabular}{|c|c|c|}
\hline Epoch & Formation & Depositional environment \\
\hline \multirow{5}{*}{ Late Cretaceous } & Ericson & Nonmarine: flood plains and swamps. \\
\hline & Rock Springs & $\begin{array}{l}\text { Alternate nonmarine swamp and onshore } \\
\text { to shoreward marine. }\end{array}$ \\
\hline & Blair & Shoreward marine to offshore marine. \\
\hline & Hilliard & Offshore marine. \\
\hline & Frontier & $\begin{array}{l}\text { Onshore to shoreward marine; coastal } \\
\text { swamps. Offshore marine but shallow } \\
\text { water. }\end{array}$ \\
\hline \multirow{3}{*}{$\underset{\text { Cretaceous }}{\text { Early }}$} & Mowry & Offshore marine. \\
\hline & Dakota & Nonmarine, fluviatile, swamp. \\
\hline & robable hiatus - & \\
\hline \multirow[b]{3}{*}{ Late Jurassic } & $\begin{array}{l}\text { Morrison and } \\
\text { younger } \\
\text { rocks }\end{array}$ & $\begin{array}{l}\text { Nonmarine, mainly fluviatile, flood } \\
\text { plain. }\end{array}$ \\
\hline & Curtis & Marine, shallows offshore. \\
\hline & Entrada & $\begin{array}{l}\text { Possibly shoreward marine (red facies) } \\
\text { Nonmarine eolian (gray facies). }\end{array}$ \\
\hline $\begin{array}{l}\text { Late and Middle } \\
\text { Jurassic }\end{array}$ & \multirow{2}{*}{$\begin{array}{l}\text { Carmel } \\
\text { Hiatus } \\
\text { Navajo }\end{array}$} & $\begin{array}{l}\text { Restricted marine. } \\
\text { Marine offshore. }\end{array}$ \\
\hline $\begin{array}{l}\text { Early Jurassic and Late } \\
\text { Triassic(?) }\end{array}$ & & Nonmarine, eolian. \\
\hline Late Triassic & \multirow{2}{*}{$\begin{array}{l}\text { Chinle } \\
\text { Hiatus } \\
\text { Moenkopi }\end{array}$} & Nonmarine, fluviatile; minor swamps. \\
\hline \multirow{2}{*}{$\begin{array}{l}\text { Middle(?) and Early } \\
\text { Triassic }\end{array}$} & & Marine near shore, restricted. \\
\hline & Dinwoody & Marine near shore; restricted in part. \\
\hline
\end{tabular}

lar unconformity separates the Mesaverde Formation from the overlying Wasatch. In the Clay Basin area an unconformity separates the Ericson Sandstone from the Fort Union. Where this unconformity is close to the Uinta fault it is sharply angular. Away from the fault, beds above and below the contact are nearly concordant, although part of Montana time and all of Laramie time are represented only by a hiatus. The fact that both the Ericson and the Fort Union dip as much as $40^{\circ}$ or more in concordant sections distant from the fault indicates strong post-Fort Union uplift in the area also.

The relationship of the Ericson Sandstone and Fort Union Formation to the Uinta fault is especially significant. Both formations are truncated by the fault, but only the Ericson and older formations are sharply dragged; the Fort Union and younger formations (Wasatch and Green River) merely were sheared off without appreciable flexing or dragging. Thus the fault had two periods of movement: in the first movement, before Fort Union time, the rocks were sharply flexed and dragged before rupture; in the second movement, after the fault plane was established, the over]apping Tertiary rocks were faulted without appreciable drag.

Inasmuch as the Uinta fault is the largest and most continuous displacement in the Uinta Mountains, its movements probably coincided with the culmination of the Laramide orogeny in the vicinity. In the first and probably greatest movement of the Uinta fault, the
Ericson and older formations were displaced and overturned before the Fort Union Formation was deposited. By Fort Union time the Uinta arch was deeply eroded; the Mowry Shale was exposed at the surface, where it contributed shale chips to the conglomerates of the Fort Union Formation. At least 8,500 feet of strata, therefore, was partly stripped from the arch. Possibly the Dakota and Morrison Formations were exposed also. By Wasatch time (Hiawatha? Member of Nightingale=early Eocene?), the Precambrian core of the range was exposed by erosion in the Clay Basin and Vermilion Creek areas, and a flood of quartzitic debris was deposited in the Wasatch Formation.

In a subsequent movement, the Tipton Tongue of the Green River Formation was displaced and tilted along the Sparks fault northeast of Cold Spring Mountain, but the overlying Cathedral Bluffs Tongue of the Wasatch Formation was not involved. Similar relationships along the Henrys Fork fault west of Manila have been noted by Anderman (1955, p. 131-132). It seems possible that these movements coincided approximately with the second movement on the Uinta fault. In passing, it is noted that Precambrian material has not been found in the conglomerates of Wasatch age in the Manila area, although Paleozoic rock types are abundant: structurally, the area south of Manila is less elevated than the area to the east near Clay Basin and Vermilion Creek (fig. 45), and hence was less susceptible to attack by deep erosion in Eocene time.

\section{EARLY TERTIARY TECTONIC AND DEPOSITIONAI HISTORY}

Laramide deformation had a very marked effect on sedimentation. Early Laramide or pre-Laramide uplift halted deposition for a time and initiated erosion, so that deposits of Laramie age either did not accumulate or were removed before Tertiary time.

Most of the lower Tertiary rocks that accumulated in the area during or following mountain building were derived from the newly formed Uinta Mountains. As the mountains rose, the adjacent basin subsided. Tertiary sediments shed from the mountains thickened rapidly basinward from a wedge edge along the mountains; in texture, however, they coarsened mountainward. The nearness of the source of these sediments is especially evident in the coarser grained deposits, which contain recognizable pebbles, cobbles, and boulders of local provenance. Some of the boulders are several feet across.

Downwarping in the Green River Basin produced a topographic as well as structural basin. The basin enclosed a large lake which lapped against the slopes of the Uinta Mountains to the south in the Flaming Gorge area. This lake probably extended but a short distance 
into the area; its deposits are preserved only in the extreme northwestern part of the area. If they ever extended much farther south, they have since been stripped away by erosion. At the time that lake beds were accumulating to the north, near but outside the area, fanglomerates and alluvium were accumulating within the area. The coarseness of some of these deposits suggests a nearby source higher than the present Uinta Mountains.

Inasmuch as the Green River lake lay mostly to the north of the area, little direct evidence of its character or history can be obtained from within the area. The lake, its deposits, and its history have been described by many geologists, most particularly by W. H. Bradley in his several definitive works on the subject. At its maximum extent the lake may have overflowed around the east end of the Uinta Mountains into a similar lake in the Uinta Basin (Bradley, written commun., 1961). The extent and depth of the lake varied greatly from time to time, however; and at one time the lake must have shrunk below its outlet to the confines of the Bridger Basin, for the deposits of that time are saline (Bradley, 1959, p. 1073). Throughout the history of the lake, deposition was augmented periodically by falls of volcanic ash (Bradley, 1959, p. 1074).

Lacustrine deposition ended in middle Eocene time, probably because nonlacustrine deposits encroached onto the shorelines of the lake and into the lake basin. Rocks of this interval (Bridger) are lacking from the mapped area, and if ever deposited, they have been stripped away by erosion.

Tectonic activity, meanwhile, continued, although the compressional phases of the Laramide orogeny seem to have ended. In their place, rather large-scale normal faulting displaced the rocks on the flank of the range, possibly as a tensional release of stresses accumulated earlier during compression. At this time, many faults, including the large O-Wi-Yu-Kuts fault near Beaver Creek, were active in the Red Canyon, Dutch John, Little Hole, and Browns Park areas; the greater part of the throw-perhaps 7,000 feet-on O-Wi-Yu-Kuts fault preceded cutting of the Gilbert Peak erosion surface.

MIDDLE AND LATE TERTIARY TECTONICS, EROSION, AND DEPOSITIONAL HISTORY

GILBERT PEAK EROSION SURFACE

Early Tertiary tectonic activity was followed by a long interval of crustal stability. At this time the broad Gilbert Peak erosion surface was forming on the north flank of the range, and a comparable surface was forming on the south (Bradley, 1936a, p. 170). Sufficient time was required for lateral planation to extend the surface mountainward-across soft and hard rocks alike-from some distant base level near the center of the basin southward across the area and nearly to the crest of the range. Judging from the concave profile of the surface, from the shapes of certain residual island mounts, and from the apparent lack of soil on the erosion surface, Bradley (1936a, p. 176) concluded that the surface formed under semiarid climatic conditions. He further concluded (p. 179) that deposition of the Bishop Conglomerate on the Gilbert Peak surface was promoted by a shift to even greater aridity.

Remnants of the Bishop Conglomerate do not occur in the mapped area, although they cap large mesas northwest and northeast of the area. At the time the conglomerate was accumulating the mapped area was being graded, or degraded, by laterally corrading streams. The general direction of drainage across the area was northward, and floods of quartzite, amphibolite, and schistose cobbles from the Uinta Mountain Group and the Red Creek Quartzite were carried from the area to points as far north as Bishop, Miller, Little, and Aspen Mountains in Wyoming.

Although the Gilbert Peak surface may have extended locally across the crest of the range farther west (Bradley, 1936a, pl. 37), incomplete gradation of the surface within the mapped area is indicated by numerous monadnocks, or island mounts, in the Goslin, Mountain Home, Bender, and O-Wi-Yu-Kuts areas. The mapped area, therefore, was probably near the mountainward border of the surface where nongraded erosion remnants rose above the level of the surface. The area was higher than the Bishop-mantled apron to the north, although at present it is substantially lower, owing to collapse and gravity faulting since the surface was cut.

\section{GRA VITY FAULTING FOILOWING CUTTING OF THE GILBERT PEAK EROSION SURFACE}

Cutting of the Gilbert Peak erosion surface probably was terminated by renewed tectonic activity, which also brought about notable changes in the pattern and regimen of drainage. The effect was degradation. Large-scale gravity faulting occurred in a zone or zones of displacement extending eastward from Bear Mountain into Browns Park. Some faults that had moved earlier probably were reactivated. The net effect of faulting was to drop the crestal part of the range relative to the north flank and, in so doing, to initiate eastward drainage along the faultlines in the present Red Canyon-Browns Park area. Drainage began to erode west along the collapsed faulted alinement of Browns Park, Little Hole, Dutch John, and Bear Mountain. In doing so, it excavated the hardrock floor of Browns Park and the old, later filled valley to the west along the site of the present Red Canyon. 
The Browns Park Formation was later deposited in these newly excavated valleys. Before Browns Park time, therefore, a great deal of rock was eroded away, and a long interval of time must have ensued.

Gravitative movement also occurred on the Uinta fault; this movement lowered the Gilbert Peak erosion surface south of the fault possibly hundreds of feet relative to remnants of the surface north of the fault. My interpretation of the sequence of events differs somewhat from those of Sears (1924a, p. 301) and of Bradley (1936a, p. 185), who envisaged collapse along the Uinta fault as being largely subsequent to deposition of the Browns Park Formation. In my opinion, gravity movements occurred on the Uinta fault before as well as after deposition of the Browns Park Formation. Powell held this opinion in 1876 (p. 209).

Gravitative collapse in the eastern Uinta Mountains after the Gilbert Peak erosion surface had formed was accompanied by marked warping and tilting between the Uinta fault zone on the north and the Red Canyon-Little Hole-Browns Park alinement of faults on the south. Tilting also occurred north of the Uinta fault zone (Bradley, 1936a, p. 185). South of the Uinta fault, O-Wi-Yu-Kuts Mountain was bowed upward relative to Cold Spring Mountain on the east and Bender Mountain on the west. Renewed movement of perhaps 300-500 feet occurred on the O-Wi-Yu-Kuts fault, probably at that time though it may have happened later.

The greatest east-west collapse between the two fault zones was in the Mountain Home-Head of Cottonwood area, where the Gilbert Peak erosion surface now stands lowest. A southward component of tilt was present also; it was slight at $\mathrm{O}-\mathrm{Wi}-\mathrm{Yu}$-Kuts Mountain and gradually increased westward to Goslin Mountain. Inasmuch as the present southward slope of Goslin Mountain is about 450 feet per mile and the initial slope of the surface was in the opposite direction, possibly as much as 200 feet per mile (Bradley, 1936a, p. 174), the amount of southward tilting on Goslin Mountain probably was about 650 feet per mile.

North to south, Goslin Mountain is about $31 / 2$ miles across. If tilted south at 650 feet per mile, the south end of the mountain has been lowered about 2,275 feet relative to the north end since Gilbert Peak time. The area just south of Goslin Mountain, as noted earlier, has been lowered perhaps an additional 400 feet. Thus the area south of Goslin Mountain has been lowered about 2,675 feet relative to the north end of the mountain since Gilbert Peak time.

This figure makes possible an estimate of the total collapse of the main crestline of the Uinta Mountains south of Goslin Mountain since Gilbert Peak time: the highest point of Goslin Mountain is about 640 feet lower than O-Wi-Yu-Kuts Flats, which in turn is perhaps 600 feet lower than the base of the Bishop Conglomerate (that is, the buried Gilbert Peak surface) on Bishop Mountain. Assuming an initial northward slope of 200 feet per -mile on the restored Gilbert Peak surface between O-Wi-Yu-Kuts Flats and Bishop Mountain, an additional 600 feet of collapse may be assumed. These figures $(2,675+640+600+600)$ total 4,515 feet or, in round numbers, about 4,500 feet as the total relative collapse of the crestline south of Goslin Mountain. If this figure is added to the present mean altitude of the crestline south of Goslin Mountain-now about 9,000 feet-the restored altitude is about 13,500 feet. This altitude is almost exactly the same as that of the high western part of the range, which was unaffected by post-Gilbert Peak collapse.

East-west collapse combined with southward tilt produced a broad shallow sag in the Gilbert Peak surface centered over the Goslin Mountain, Mountain Home, and Head of Cottonwood areas. Newly formed drainage lines quickly established themselves in this sag. They eroded limestone, chert, and quartzite cobbles from the Wasatch Formation on higher ground to the north and redeposited them as cobble gravel on Goslin Mountain and the Head of Cottonwood. Small patches of this gravel still exist.

New drainage lines became fixed approximately along the present courses of Red Creek, Jesse Ewing Canyon, and Willow Creek, although the timing of these events is uncertain and may have been much later. With modifications, these drainage lines have remained to the present time. Jesse Ewing Canyon probably originally headed well to the north of its present head, probably across the Uinta fault in the vicinity of Clay Basin Meadows or Teepee Mountain. Its headwaters were later captured, probably in Pleistocene time, by Clay Basin Creek, a tributary of Red Creek that is eroding its course headward across the soft Hilliard Shale in Clay Basin.

\section{BROWNS PARK FORMATION AND CANYON CUTTING}

Deposition of the Browns Park Formation seems to have been accompanied by continued but diminished crustal activity. An angular unconformity within the Browns Park Formation toward the east end of Browns Park valley was noted by Sears (1924a, p. 296) and by Bradley (1936a, p. 185). Local disconformities are common farther west. Periodically, the drainage into the valley of Browns Park was ponded during Browns Park time, either by alluvial barriers or perhaps by tectonically formed enclosures. At such times, di- . atoms and ostracodes thrived in the standing water, and lacustrine clays accumulated on the bottom. 
Sands and gravels were carried into the basin of Browns Park by tributary streams. A large alluvial fan accumulated near the mouth of what is now Jesse Ewing Canyon; cobbles of limestone of Paleozoic age, now present in the conglomerates of the Browns Park Formation there, must have been carried from points as far north as Teepee Mountain, where the Wasatch Formation contains such cobbles, unless they were reworked from higher level gravels carried earlier from the same source.

Vitric rhyolitic ash, borme by winds from distant volcanoes, was deposited blanketlike over the whole areaonto alluvial fans, into the intermittent lakes, and onto upland surfaces alike. Much: volcanic ash was reworked and carried into Browns Park by streams. Some of it probably was stripped from highland areas almost as fast as it fell. 'Tongues of ash and reworked ash filled the valleys to the south of Browns Park also and lapped high against $\mathrm{O}-\mathrm{Wi}-\mathrm{Yu}$-Kuts Mountain at the headwaters of Beaver Creek to the north. Ultimately, Browns Park was filled to overflowing by a thick continuous blanket of tuff, sand, clay, and gravel. To the south the blanket extended across the crest of the range and merged with like deposits on the south flank (Hansen, Kinney, and Good, 1960 , p. B257). In the Red Canyon area, the Browns Park Formation filled the old valley which had been carved there earlier and spread out onto the Gilbert Peak erosion surface. The extent and thickness of the Browns Park Formation at that time was expressed by Sears (1.924a, p. 301) as follows:

Browns Park became filled with a great thickness of this sand, which spread up the valley by headward overlap beyond the earlier deposits of conglomerate. Overlap also gradually covered the slopes of the hills and mountains eastward to and including Cross and Juniper Mountains, until in all the eastern part of the Cinta Range only the highest remnants of the older rocks protruded above the cover of white sand.

When the Browns Park Formation stopped accumulating is unknown. It may have been late in Miocene time or even in Pliocene time. Just when it happened and what caused it to happen cannot be determined from the evidence now available, certainly not from the evidence provided from within the rather narrow limits of the mapped area. The problem has regional scope. Three factors that bear on the problem but cannot yet be fully evaluated are: (1) Renewed degradation, (2) renewed tectonic activity, and (3) cessation of distant volcanic activity at the source of the volcanic ash that became incorporated into the formation. Factors 1 and 2 may have gone hand in hand, inasmuch as tectonic uplift may have led to degradation. There is no doubt that tectonic activity, at least gravity faulting, followed deposition of the Browns Park Formation, but whether it was accompanied by net uplift or by net subsidence is unknown. Factor 3, cessation of volcanism, probably acted independently, as all signs point to a source for the tuffs beyond the influence of local tectonics.

If the early drainage of the area was eastward to the Gulf of Mexico as suggested by Bradley (1936a, p. 177), a major step in the evolution of modern drainage was the shift from eastward to southward drainagethat is, a shift from drainage by way of southern Wyoming to the Gulf of Mexico to newly directed drainage through the Uinta Basin to the Gulf of California via the present Green and Colorado Rivers. In the event that drainage had been eastward, degradation could have been initiated by a vigorous tributary of the Colorado (the ancestral Green) eroding headward across the Uinta Basin, capturing the east-flowing drainage of the Uinta Mountains, and thus rejuvenating the entire drainage system. Such capture would have been facilitated by broad upwarping of the present continental divide athwart the course of east-flowing drainage. On a regional scale, such upwarping would have stagnated eastward drainage and, at the same time, would have invigorated westward drainage. And as a consequence of capture, a cycle of rejuvenation and entrenchment would have led to the cutting of the present canyons of the area.

The concept of capture of east-flowing drainage by a stream eroding headward from the south, as outlined above, is a modification of earlier views held by Sears and Bradley. The point of capture and the events that led up to postulated capture, in my opinion, are different, but the basic concept is the same and stems from the earlier views. For the record, it should be pointed out that Sears (written commun., 1960) no longer adheres to his early view but favors the hypothesis that the drainage of the eastern Uinta Mountains-at least of the Yampa River-has been into the Colorado River system, or southward, since before the Browns Park Formation was deposited.

Major canyon cutting in the area probably commenced shortly, if not immediately, after deposition of the Browns Park Formation had ended. During this time Flaming Gorge, Horseshoe Canyon, Kingfisher Canyon, and Red Canyon were eroded almost to their present size. The oldest recognized Pleistocene terrace deposits are only about 300 feet above present river level. As neither the upper nor the lower time limit of canyon cutting is well dated, however, outting may have extended through most of Pliocene time and into Pleistocene time. At some time after the Green River had become incised into the Browns Park Formation, or possibly even into the underlying older rocks, further 
tectonic activity caused widespread, almost regional, tilting.

\section{POST-BRowns PARK TILTING}

At some time after the Browns Park Formation was deposited, but apparently before Pleistocene time, a large segment of the eastern Uinta Mountains was tilted northward and eastward. The evidence for this tilting has been outlined in the section of this report on structure, under the heading of Tertiary warping and tilting. This action initiated a northward flow of drainage along the crest of the range south of the mapped area from Cart Creek eastward. Valleys that had drained southward before the Browns Park Formation was deposited now drained north. Drainage probably was consequent on the old depositional surface of the Browns Park Formation. Remnants of the Browns Park Formation that now fill these valleys once presumably merged with the main body of the Browns Park Formation to the north in the type area, although they are now separated from it by deep canyons eroded in the Uinta Mountain Group. Newly established northward drainage eroded through these fills into the underlying hard-rock floors of the valleys just south of Browns Park, so that each valley now has a precipitous inner canyon near its mouth, cut into the Uinta Mountain Group.

Post-Browns Park tilting on a large scale in the extreme eastern part of the Uinta Mountains has been described by Sears (1924a, p. 287) and by Bradley (1936a, p. 185). This tilting probably was concurrent with that described above. Along Vermilion Creek, the Browns Park Formation was tilted to angles of $20^{\circ}-30^{\circ}$.

\section{QUATERNARY HISTORY PLANATION AND TERRACING}

The Quaternary Period has been a time of repeatedly interrupted erosion cycles. Each incomplete cycle started with degradation, was followed by lateral planation, and ended with aggradation. The degradation at the start of each cycle terminated the aggradation of the previous one; the physiographic result is a succession of gravel-capped terraces or benches, each representing a cycle of planation, alluviation, and gullying. Successive benches stand one below another in the major valleys and along the major streams (figs. 33 and 41 ).

Repeated erosion cycles and their attendant gravelcapped benches suggest that a common cause has been responsible for each cycle. Various geologic factors and processes have participated as causative agents, but the most significant single factor has been a cyclic variation of climate during the Pleistocene Epoch. Although
Pleistocene glaciers did not occupy any part of the mapped area, the same climatic factors that led to glaciation in the high mountains farther west in the Uinta range and in other ranges surrounding the Green River Basin undoubtedly modified the local climate of the mapped area.

The Green River, which is the master stream of the area, drains the high mountains of the Green River Basin and hence must have responded directly to the effects of glaciation in the high mountains. Principal tributaries of the Green such as Henrys Fork also drain areas that were occupied periodically by glaciers and hence also must have responded directly to the effects of glaciation. The smaller streams responded indirectly; in their catchment basins, climatic changes modified the average relative humidity as well as the rates of precipitation and evaporation, which in turn affected the vegetative cover, the infiltration rate, and the runoff. In addition, the base levels of the smaller streams rose or fell in response to the rising or falling bed level of the Green River. As the Green degraded its bed, so did its tributaries; when it deposited a fill, its tributaries did the same.

Gravel fills along the Green River and Henrys Fork, and to a lesser extent along Sheep Creek and Carter Creek, were deposited in direct response to glaciations in the high mountains enclosing the basin; in a large part the fills are glacial outwash deposited during deglaciation. In response to the rising grade level of the Green River at such times, bench gravels accumulated on pediment surfaces and in the channels of minor tributaries.

If the gravel cappings on terraces and pediments thus accumulated in response to a warming, drying climate, the underlying planation surfaces themselves probably were cut during the intervals of relatively cool moist climate that preceded and accompanied the glaciations. Stream runoff should have been relatively uniform at such times, and base levels should have maintained the enduring stability required for cutting the broad planation surfaces that have been preserved. Gullying, on the other hand, probably was a response to the relatively hot dry climates of the interglacial stages. These times were characterized by low humidity, sparse vegetative cover, low infiltration, and erratic rapid runoff.

Recent alluvial fills form the flood plain of the Green River and the valley alluvium of the tributaries. These fills were deposited after an interval of incision that ended in early Recent time. Hunt (1953, p. 18) suggested that the unconformity marked by this incision denotes the boundary between the Pleistocene and Recent Epochs in the Rocky Mountain region. Incision 
probably coincided with the hot dry postglacial climatic optimum of about 5,000 years ago. The alluviation that followed seems to have developed in response to a somewhat wetter and cooler climate during the last 5,000 year's. Minor climatic variations within the last 5,000 years have caused local terracing within the Recent alluvial fill, as along Red Creek. In the past 70 years or so, vigorous renewed downcutting by the tributaries has incised the modern drainage into the Recent alluvial fills to depths of $10-30$ feet or more and has thus formed fill terraces 10-30 feet or so high. According to long-time local residents, much of this incision has happened in the last 30 years.

\section{QUATERNARY DRAINAGE ADJUSTMENTS}

When drainage incision began shortly after the Browns Park depositional cycle was terminated, most streams of the area probably flowed in consequent courses down initial depositional slopes or down tectonically modified initial slopes. The Green River itself meandered freely across a loose fill of the Browns Park Formation. On rejuvenation, the Green quickly incised the fill and began cutting deep canyons into the harder underlying formations. With very minor exceptions, its course has been unchanged since that time, and throughout its length it has largely ignored the geologic structure over which it flows. Many of its tributaries, however, have modified their courses materially since Pliocene or early Pleistocene time; many of them follow courses well adjusted to the structure of the underlying bedrock.

Structural adjustments by streams in the area have been mainly in response to differential erosibility of the underlying bedrock. Streams favored by rapid headward erosion along belts of soft nonresistant rock have from time to time captured the drainages of streams that were flowing across resistant rock formations in consequent courses. This process still is operative, and several minor stream captures have happened only recently, geologically speaking, or are imminent. Significant drainage adjustments have taken place on Sheep Creek, Spring Creek, Clay Basin Creek, and Beaver Creek. Minor adjustments have occurred on many other streams, not all of which are recounted here.

\section{SHEEP CREEK}

Sheep Creek through most of its length across the mapped area is an outstanding example of a structurally adjusted subsequent stream; its lowermost reach, however, is structurally anomalous. Sheep Creek has taken part in several complex drainage adjustments that have also involved Carter Creek, Death Valley, Lodgepole Creek, and Birch Spring Draw. Some of these adjustments are shown in figure 65. Sheep Creek rises in the high glaciated mountains southwest of the area. Its course in its headwaters and upper reaches is mostly consequent on glacial deposits and on the Gilbert Peak erosion surface. Its course in its middle reach just west of the mapped area is consequent across hard Precambrian and Paleozoic rocks. Through the greater part of its lower reach across the mapped area to the Green River, it is subsequent on soft Triassic rocks.

\section{CAPTURE UPSTREAM}

At an early time-before bench 3 had formed in Lucerne Valley but until after the higher bench 2 had formed-Sheep Creek seems to have emerged from its consequent canyon in the Weber Sandstone just west of the mapped area and to have flowed northeast through Lucerne Valley to a junction with Henrys Fork near Linwood (fig. 65). Its present course is a result of stream capture by a headward-eroding subsequent stream. In its former course, Sheep Creek flowed across several belts of relatively hard resistant rock, including resistant beds in the Navajo, Entrada, Curtis, Dakota, and Frontier Formations. Just prior to capture, Sheep Creek was flowing at the level of bench 2. Small remnants of this bench are preserved along its former course along the south side of Lucerne Valley; the accordant crestline of the Frontier Formation hogback south of Lucerne Valley - seen to advantage in longitudinal profile-was beveled at that time also by the horizontal sweeping action of Sheep Creek which was then flowing at that altitude (bench 2 level).

In like manner, several smaller streams possibly flowed northward into Lucerne Valley at high levels athwart the present course of Sheep Creek; one such stream may have coincided with modern Death Valley, and one may have occupied what is now Sheep Creek gap. If these streams existed, however, they left no deposits in evidence; they are only inferred from modern topographic relationships.

Subsequent drainage, meanwhile, was eroding headward parallel to the strike of the soft Dinwoody and Moenkopi Formations along the present course of Sheep Creek. With this advantage, it captured one by one the northward flowing streams across its path. It captured Sheep Creek itself near the point where it now swings from a northeastward course to a southeastward course just west of the mapped area at Bennett's Ranch ; in so doing it beheaded the major drainage of Lucerne Valley. After capturing Sheep Creek it continued to erode west along the Dinwoody Formation outcrop, where ultimately it captured the drainage of Sols Canyon and Lodgepole Creek and left in Lucerne Valley 

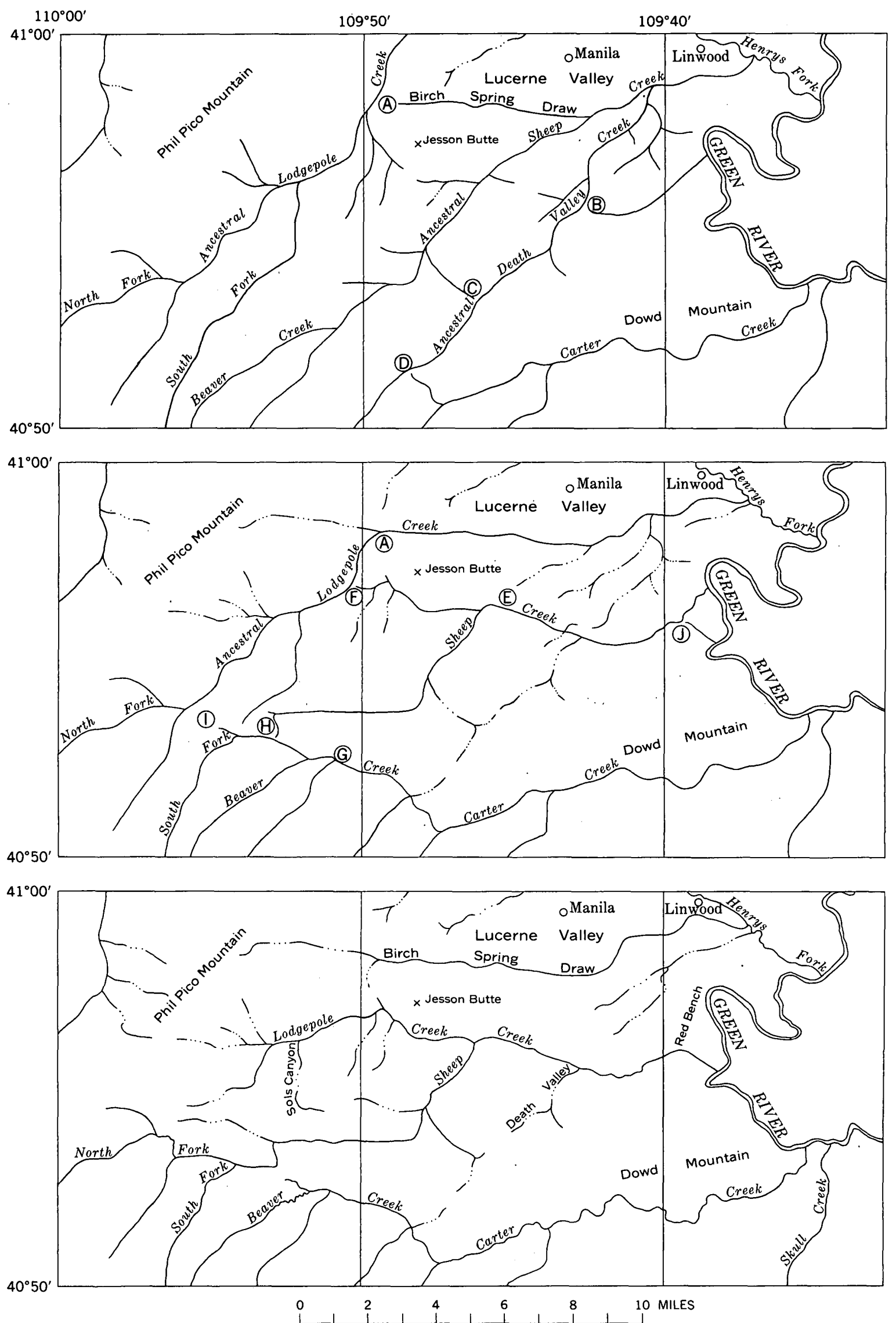
only the modest intermittent flow of Birch Spring Draw. Lodgepole Creek appears to have been captured after bench 3 was formed in Lucerne Valley.

CAPTURE NEAR MOUTH

While the previously mentioned capturing was occurring upstream, a short obsequent tributary of the Green River was eroding headward across the Weber and Park City Formations in the right (west) wall of Kingfisher Canyon at the present mouth of Sheep Creek. Sheep Creek was flowing at the level of bench 4 into the Green River via Red Bench $13 / 4$ miles to the north. At this level, it was captured by the short tributary of the Green near the point where Sheep Creek now crosses the Dinwoody-Park City contact (fig. 66).

Capture of a major stream such as Sheep Creek so near to its mouth by what must have been a very minor, possibly ephemeral stream suggests unusual conditions of balance between the regimen of Sheep Creek on the one hand and that of the capturing stream on the other. At the time of its capture, Sheep Creek was overloaded with outwash from an upstream source and, therefore, lacked competence to incise its bed. The Green River itself was loaded with debris and was building extensive terrace deposits upstream from Flaming Gorge. The short tributary, however, was neither loaded nor at grade.

Very possibly a local base level was imposed on the Green River by resistant beds in the Park City Formation between the former mouth of Sheep Creek at the north end of Red Bench and the mouth of the short tributary at the present mouth of Sheep Creek. If so, the Green may have been aggrading above the barrier and degrading below it, and the short tributary would have had the additional hydraulic advantage of a much steeper gradient. At any rate, whether such a barrier existed or not, the short tributary had at least a moderately steeper gradient and was underloaded whereas Sheep Creek was overloaded. Having these advantages, the short tributary cut down the divide at its head until it intercepted the drainage of Sheep Creek and diverted it into its present course. At the point of capture, Sheep Creek has since lowered its bed about 160 feet.

\section{SPRING CREEK}

The drainage history of Spring Creek has been marked by a simple capture just downstream from Minnies Gap at the Utah-Wyoming State line (fig. 67). This capture involved diversion of a consequent stream, ancestral Jarvies Creek, by a subsequent stream, ancestral Spring Creek. The course of modern Spring Creek is composite in that it is consequent from its headwaters on Little Mountain in Wyoming downstream to Minnies Gap and is subsequent from Minnies Gap to within about a mile of its mouth; its lowermost mile, more or less, is superposed from Pleistocene terrace gravels (bench 4 ) onto the underlying bedrock formations.

Ancestral Jarvies Creek initially drained southwestward in a consequent course from Little Mountain to the Green River via Minnies Gap, Antelope Flat, Dutch John Gap, and Jarvies Canyon. In this course, it flowed across relatively resistant rock formations at Minnies Gap, at Dutch John Gap, and down Jarvies Canyon to its mouth. It was easily captured, therefore, by ancestral Spring Creek, which was eroding rapidly headward in the soft Hilliard Shale of Antelope Flat.

Since the time of capture, Antelope Flat has been deeply eroded by Spring Creek and by tributaries of both Spring Creek and the Green River. All traces of the old course of ancestral Jarvies Creek between Minnies Gap and Dutch John Gap, therefore, have been obliterated. But from the difference in altitude between modern Spring Creek at Minnies Gap and ancestral Jarvies Creek at Dutch John Gap, it seems probable that ancestral Jarvies Creek was flowing at about the level of the highest Pleistocene bench at the time of its capture. The difference in altitude-about 260 feet-is approximately the same as the height of bench 1 just west of the Green River above the present mouth of Spring Creek.

\section{CLAY BASIN CREEK}

Clay Basin Creek (fig. 68) is the chief tributary of Red Creek. Draining an area underlain by soft, easily eroded rocks, it has enlarged its watershed at the expense of Jesse Ewing Canyon, Cottonwood Draw, and

Figdre 65.-Drainage adjustments of the Sheep Creek-Lucerne Valley area.

Top.-Consequent drainage in all major valleys; subsequent drainage developing in first-order tributaries. The course of the Green River already is well fixed in a series of deep canyons. Birch Spring Draw is about to capture ancestral Lodgepole Creek at point A. Capture of ancestral Denth Valley Creek by subsequent drainage is imminent at points B, C, and D. Ancestral Sheep Creek, flowing at the level of the $Q_{2}$ bench, joins Henrys Fork near Linwood. Henrys Fork meanders freely on the $Q b_{2}$ bench.

Mid.lle.-Ancestral Lodgepole Creek has been captured at point $A$, and is flowing on the $Q b_{3}$ bench in Lucerne Valley. Sheep Creek has been captured by subsequent drainage at point $\mathbf{E}$ (Bennett's Ranch). Capture of Lodgepole Creek is imminent at point F. Carter Creek has captured Benver Creek at point G, has captured South Fork near point H, and is threatening North Fork near Point I. Sheep Creek, however, is about to recapture South Fork at point H. Sheep Creek is flowing directly to the Green RIver across Red Bench at the $Q b$, level. Meanwhile, a short tributary of the Green River is threatening Sheep Creek near its mouth at point $J$.

Bottom.-Present drainage. Birch Spring Draw now contains only the feeble runoff of the east slope of Phil Pico Mountain. Lodgepole Creek, North Fork, and South Fork are tributaries of Sheep Creek. 


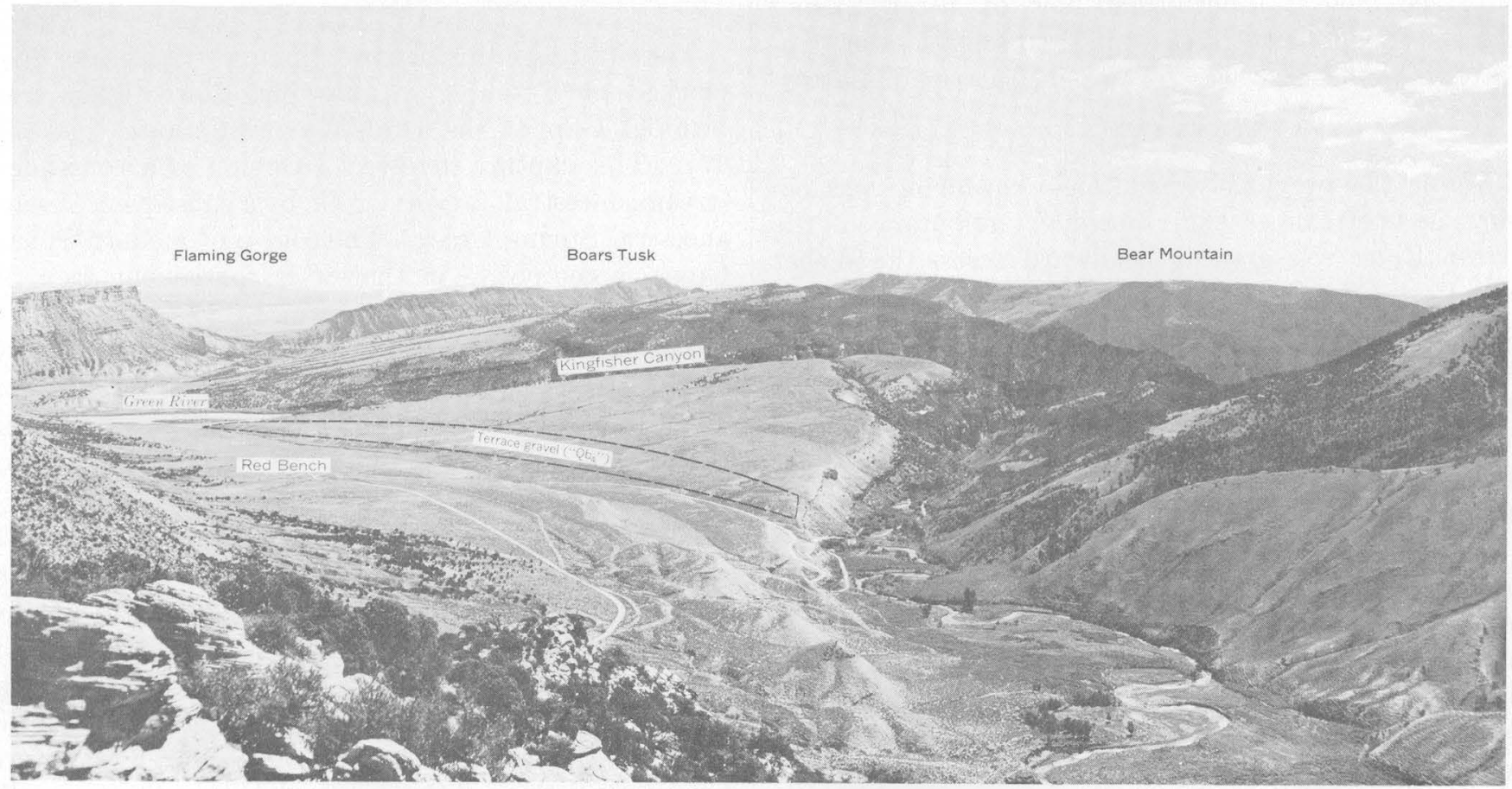

Figure 6.6.-View due east down Sheep Creek Canyon from rimrock of Navajo Sandstone. Sheep Creek formerly entered Green River at upper left via Red Bench but was captured by short obsequent tributary of Green River at point near center foreground. Note dip slopes of Park City Formation. Old terrace gravels mantle east side of Red Bench at foot of dip slope.

Bender Draw, all of which drain southward in consequent courses across hard Precambrian rocks.

BEHEADING OF JESSE EWING CANYON

Jesse Ewing Canyon formerly headed 3-4 miles farther north than at present in the Teepee Mountain area of Wyoming. As early as Miocene time its drainage-or that of a stream which coincided approximately with it-carried cobbles of limestone of Paleozic age from the conglomerates of the Wasatch Formation and redeposited them in the conglomerates of the Browns Park Formation near the mouth of the canyon. Its headwaters were captured by Clay Basin Creek during the Pleistocene Epoch at a time when it was flowing at about the level of bench 1 at an altitude of about 7,020 feet. This altitude is the approximate height of the broad pass at the head of Jesse Ewing Canyon overlooking Clay Basin to the north. If any bench gravels still remain in the pass, they are buried beneath Recent alluvium and slope wash.

BEHEADING OF COTTONWOOD DRAW

Cottonwood Draw formerly headed east of Teepee Mountain and drained the Clay Basin Meadows area between Teepee Mountain and Bender Mountain. In terms of drainage budget, the beheading of Cottonwood Draw was more significant than the beheading of Jesse Ewing Canyon, inasmuch as most of the modest peren- nial drainage of Clay Basin Creek now rises in the Clay Basin Meadows area. (At present, all this drainage is diverted from its channel for irrigation.)

The beheading of Cottonwood Draw left a high gravel-capped wind gap in the SW1/4 sec. 32 , T. 3 N., R. $25 \mathrm{E}$. The gravels in this gap contain a high percentage of cobbles of limestone of Paleozoic age derived from conglomerates in the Wasatch Formation near Clay Basin Meadows. These gravels have not been correlated with any of the bench deposits in the area; their altitude suggests an age greater than that of bench 1. It seems probable, therefore, that Cottonwood Draw was beheaded before Jesse Ewing Canyon. In that event, Cottonwood Draw probably was beheaded by a tributary of Jesse Ewing Canyon, which in turn was beheaded by Clay Basin Creek.

\section{BEHEADING OF BENDER DRAW}

Bender Draw heads at a saddle on Bender Mountain, between hill 8198 and Chokecherry Spring, and drains south into Willow Creek. It formerly headed about three-quarters of a mile farther north just below the summit of Bender Mountain, but its headwaters were captured just south of Chokecherry Spring by a westflowing tributary of Clay Basin Creek.

The beheading of Bender Draw was not a momentous geomorphic event, as the drainage area involved and the stream flow diverted are small, but it has consider- 


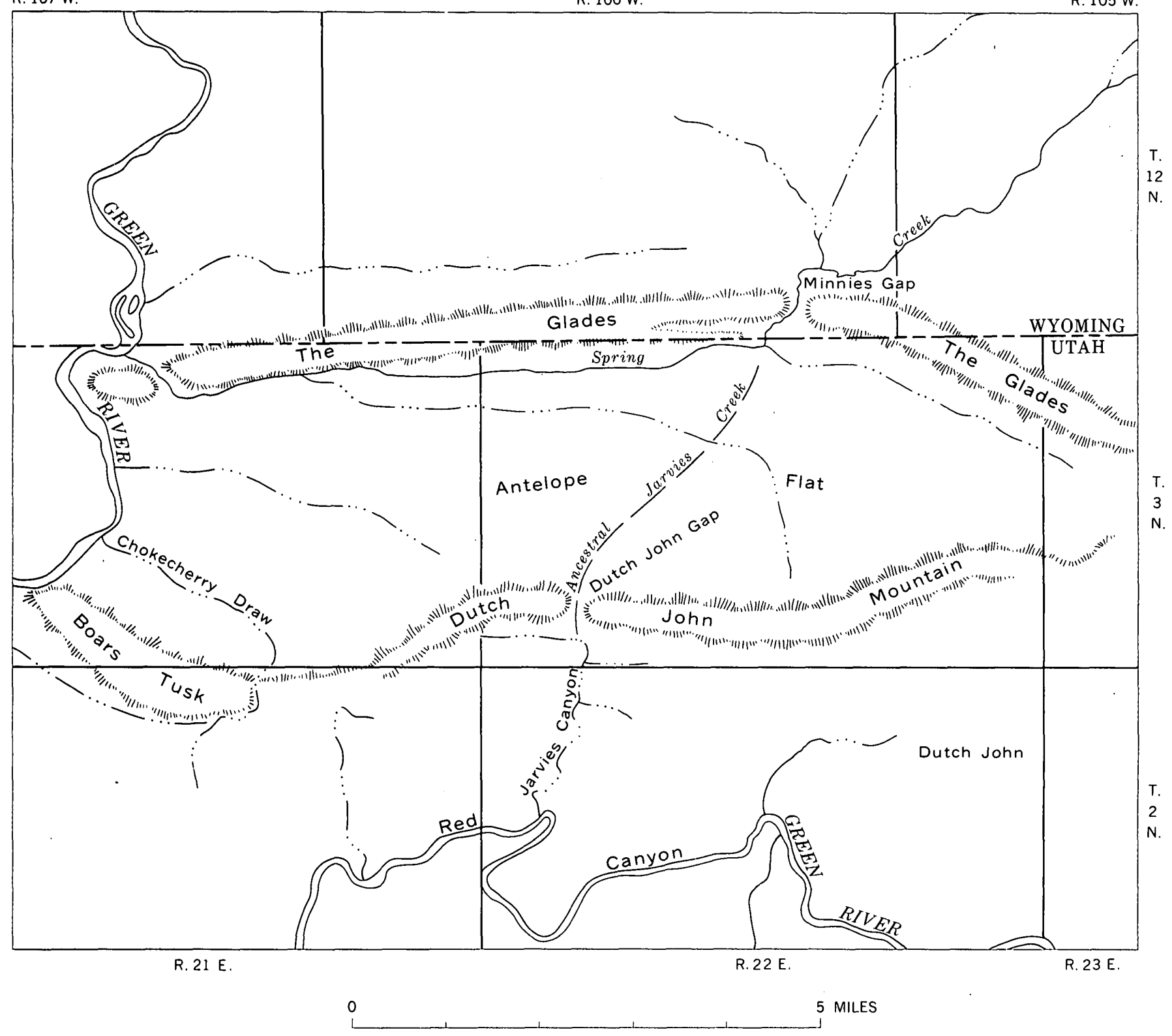

Figure 67.- Dralnage diversion at Minnies Gap. Ancestral Jarvies Creek, flowing southwestward to Green River in a consequent course across resistant rock formations, was captured by Spring Creek, which was eroding rapidly headward in the soft Hilliard Shale of Antelope Flat. Note also imminent beheading of Chokecherry Draw by short subsequent stream just south of Boars Tusk.

able significance because it happened so recently, in terms of geologic time, and because the evidence of capture is so freshly preserved. Whereas most significant drainage diversions in the area happened during or before Pleistocene time, the beheading of Bender Draw must have happened in Recent time, possibly within the last few hundred years. It is particularly well portrayed by aerial photographs viewed stereoscopically.

Bender Draw formerly rose in the Wasatch Formation above Chokecherry Spring, from whence it flowed south across the Uinta fault zone and onto the resistant rocks of the Red Creek Quartzite, and Uinta Mountain
Group. The tributary of Clay Basin Creek that beheaded Bender Draw flows across nonresistant rocks its entire length; in its last 4,000-foot reach below the point of capture it has a gradient twice as steep as that of Bender Draw. With the double advantage, therefore, of a much steeper gradient and a more easily eroded bed, it beheaded Bender Draw at a point near Chokecherry Spring in the soft gouge of the Uinta fault zone.

\section{BEAVER CREEK}

Beaver Creek, (fig. 68) is one of the chief tributaries of the Green River in the eastern part of the area. Its 


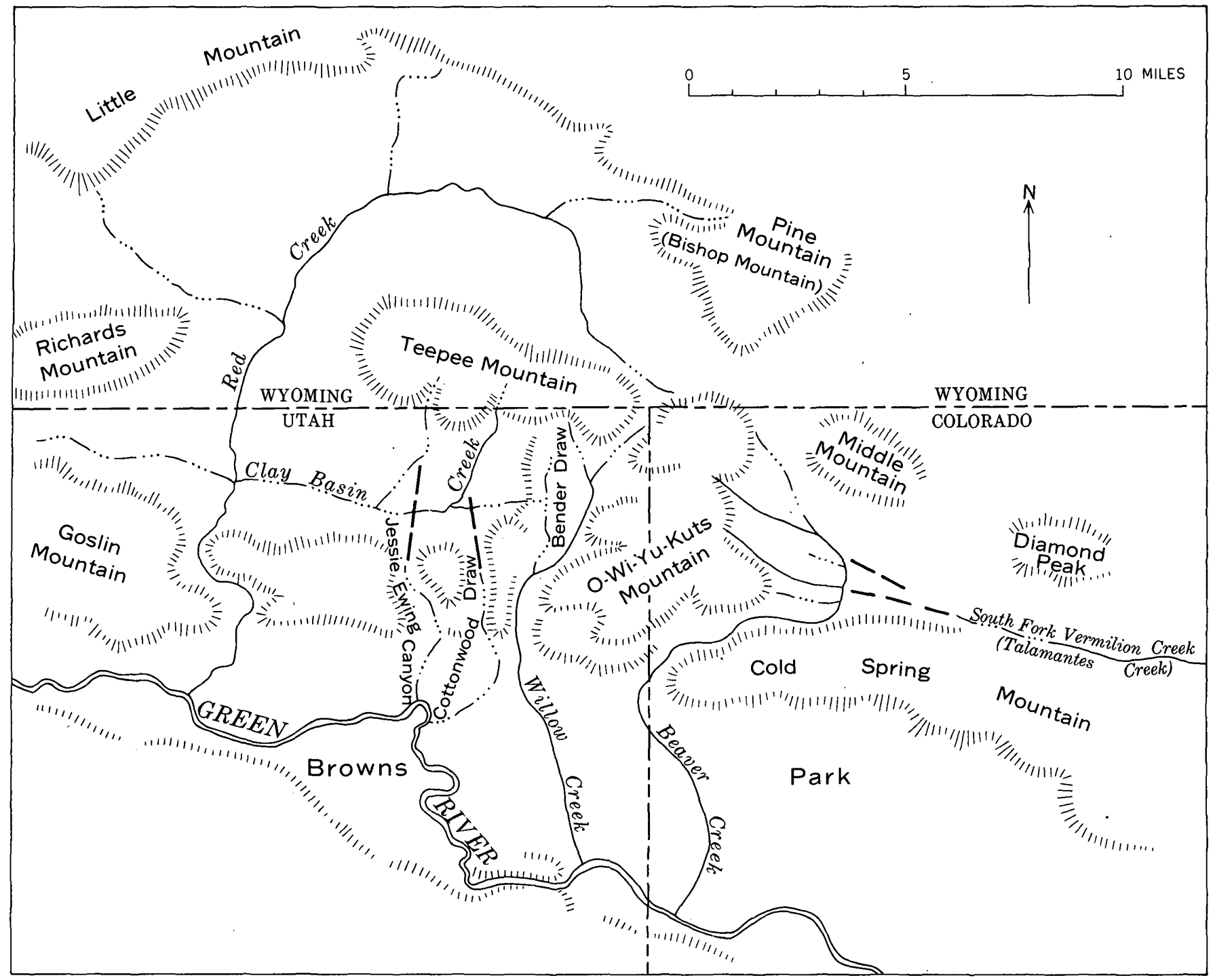

Fig URE 68.-Drainage adjustments of the Red Creek area. Clay Basin Creek has captured the headwaters of Jesse Ewing Canyon, Cottonwood Draw, and Bender Draw. Beaver Creek has captured the headwaters of South Fork of Vermillon Creek (also known as Talamantes Creek). Ancestral drainage shown by black dashes.

southward course to the Green from the heights of Cold Spring and O-Wi-Yu-Kuts Mountains is essentially consequent. It also receives the drainage of several eastward-flowing subsequent streams, however, such as 2 Bar Creek and Skeltcher Creek, which drain the east slopes of Kleins Hill, Buck Knoll, and O-Wi-Yu-Kuts Mountain. This drainage formerly flowed eastward beyond the mapped area down Talamantes Creek (also called South Fork) to Vermilion Creek and ultimately reached the Green River many miles distant near the head of Lodore Canyon. With the advantage of a much steeper gradient, Beaver Creek was able to capture the eastward drainage in what is now Beaver Basin just east of the mapped area after working its way headward through the divide at the northwest end of Cold Spring Mountain.

\section{OTHER DRAINAGE ADJUSTMENTS}

Minor drainage adjustments along intermittent or ephemeral streams are abundant in various parts of the area, particularly where consequent drainage is vulnerable to attack by subsequent drainage and where aggrading streams on alluvial slopes tend to shift their courses in response to sudden changes in load, as sometimes happens during the heavy runoff of flash floods after thunderstorms. Minor adjustments of the former sort--that is, consequent versus subsequent drainageare common in belts of alternate resistant and nonresistant dipping strata and along the trace of the Uinta fault. Adjustments of the latter sort-where aggrading streams shift their courses in response to changes in their own regimens-are less common and are generally less significant physiographically. Several adjustments 
have occurred at the foot of the mountains along the north side of Browns Park-for example, at the mouth of Birch Creek. An excellent example in Clay Basin is described below.

Recent alluvium derived from the Teepee Mountain area northeast of Clay Basin Camp forms a large fan where the alluvium emerges from its canyon and spreads out into Clay Basin. Distributary washes now entrenched on the fan carry drainage in two directions from the apex of the fan in the SW1/4 sec. $14, \mathrm{~T} .3 \mathrm{~N}$., R. 24 F.-west to Red Creek and south to Clay Basin Creek. Physiographic relationships are well portrayed on aerial photographs. Drainage in the two directions has almost identical gradients for the first $11 / 2$ miles below the point of distributary flow, but farther down slope the west-flowing drainage is steeper. With that slight advantage the west-flowing drainage might ultimately assume the entire flow of the upstream drainage. Capture, therefore, may be regarded as incipient and may be consummated at any time, probably during the rapid runoff of a heavy cloudburst.

Still other drainage adjustments of the area are due wholly to advantages of gradient, to mere chance apparently, or to factors that are unclear. At Whisky Peak in Browns Park (sec. 20, T. 2 N., R. 25 E.), for example, for no clear reason the west-flowing draw upstream from Whisky Springs has captured drainage that formerly flowed southwest around the southeast side of Whisky Peak. Similar captures on a small or even miniature scale are abundant in various badlands of the area.

A potential capture that is well portrayed on aerial photographs is developing at the mouth of the canyon of Willow Creek in the NE cor. sec. 17, T. 2 N., R. 25 E. At that point a steep tributary of Cottonwood Draw is threatening Willow Creek across a very narrow divide. Both streams at that point flow on the Browns Park Formation or on surficial deposits that thinly veneer the Browns Park. Although the tributary of Cottonwood Draw is favored by a much steeper gradient than is Willow Creek, its flow is ephemeral; Willow Creek, on the other hand, has a good perennial flow, hence has relatively high competence which diminishes the chance of its being captured.

\section{RECENT CHANGES IN THE COURSE OF THE GREEN RIVER}

'Throughout most of its length across the area the Green River is well entrenched in deep canyons that prevent its course from shifting greatly from side to side. Exceptions are found upstream from Flaming Gorge and downstream from Red Canyon where the river has built a flood plain and, accordingly, swings laterally with the downstream sweep of its meanders. Early photographs taken by the King Survey show that in the latter part of the 1860's the channel of the Green impinged tightly against the outcrop of the Curtis Formation at the mouth of Henrys Fork just above Flaming Gorge. This outcrop is the steep buttresslike cliff at the very head of the gorge. Since the time of King, the channel has swung nearly a quarter of a mile to the southeast and Henrys Fork has been lengthened the same distance. The old meander scar of the 1860's, the low terrace that it forms, and the scroll pattern of the flooded plain are clearly discernible on aerial photographs or from the heights of Boars Tusk to the south.

As the master stream and by far the largest stream of the area, the Green is virtually invulnerable to attack or capture by any other stream, at least in the near geologic future, barring unforeseen crustal or tectonic activity. Deep within its canyons, however, minor channel changes are being caused by debouching tributaries, which dump coarse rubble into the channel of the river during infrequent but intense flash floods. Most of the major rapids in Red Canyon are opposite the mouths of such streams; a notably fast one is at the mouth of Red Creek. At Hideout Flat a broad alluvial fan has crowded the river against its right bank and in so doing has shifted its course perhaps a quarter of a mile. Even more striking is the deflection of the river by alluvial fans at the mouth of North Skull Creek (fig. 58), well shown by the topographic and geologic maps. Many other similar deflections are apparent farther downstream.

\section{DRAINAGE MODIFICATIONS CAUSED BY MAN}

In the past 100 years man himself has caused many changes in the courses and regimens of streams in the northeastern Uinta Mountains. These changes have proceeded at a pace probably unmatched in previous geologic time. Some of them have been deleterious from man's own point of view, but others have been beneficial. Drastic changes have resulted from overgrazing, which reduces infiltration and speeds runoff; from forest and brush fires, whose effects are similar; and from irrigation. In the Lodgepole Creek, Sheep Creek, and Carter Creek areas, through various diversions and impoundments, man has reestablished to a large extent the initial drainage pattern that existed before the natural stream diversions and captures of the Pleistocene Epoch. Water originating in Carter Creek or its tributary Beaver Creek has been diverted into Sheep Creek, from which it in turm has been diverted down Sols Canyon to Lodgepole Creek, thence to Birch Spring Draw and to distributary canals and ditches of Lucerne Valley.

After filling of Flaming Gorge Reservoir-under construction at this writing-the Green River and its Uinta Mountain tributaries will undergo the greatest 
change in their regimens since the deposition of the Browns Park Formation and the carving of Red Canyon millions of years ago. The full geologic impact of this event cannot be forecast here; it will not be wholly realized for many years to come. Aside from inundating hundreds of square miles of desert lands and putting others under cultivation, man will have the capacity to completely regulate the flow of the river downstream from the dam and, in so doing, will level out the peaks and lows of runoff. Early summer flooding, for one thing, will cease, as will the various hydrologic effects of flooding such as flood-plain construction, channel scour, and, to a large extent, meander migration. New effects will be seen at the mouths of tributaries both below and above the dam; debris which now is swept downstream from the mouths of tributaries below the damsite will tend to accumulate in the main channel. Tributaries that now dump their loads directly into the river above the damsite will construct deltas out from the shorelines of the new lake. But most significant, the great quantity of energy now lost with the unchecked flow of the river will be harnessed and utilized to the benefit of mankind.

\section{MINERAL RESOURCES}

\section{NATURAL GAS}

Natural gas, by virtue of long production in the Clay Basin field, has been by far the most valuable single mineral resource in the mapped area and very probably will continue to be for a long time to come. Natural gas was discovered in the Clay Basin anticline in 1927 and has been produced commercially since 1937 when Mountain Fuel Supply Co. connected the field by pipeline to the Salt Lake City market area. The Clay Basin field has been described briefly by Fidlar (1950b, p. 114 ; in Hansen, G. H., and Bell, 1949, p. 261). It had been mapped previously by Dobbin and Davison (1945). Gas is produced from the Frontier and Dakota Formations, and varying amounts of natural gasoline and condensate are separated from the gas at the well head. A deep test drilled on the crest of the anticline penetrated 330 feet of the Weber Sandstone before bottoming at a depth of 9,335 feet but no additional producing horizons were discovered (Fidlar, 1950b, p. 116). The 10 producing wells of the field delivered $85,136,6: 8$ cubic feet of gas and 201,850 barrels of condensate through 1961.

Despite fairly intensified prospecting, additional gas or petroleum discoveries have not been made in the area. A single dry hole was drilled by the Ohio Oil Co. in the $\mathrm{S} 1 / 2 \mathrm{NE} 1 / 4 \mathrm{NW} 1 / 4$ sec. 34 , T. 3 N., R. 22 E., on the Spring Creek nose south of Antelope Flat. This well was drilled to a depth of 3,277 feet and seems to have bottomed in the Park City Formation although the sample log showed 63 feet of penetration into the Weber Sandstone. A slight show of gas and some saturation was reported from the Dinwoody Formation.

\section{COAL}

Coal is found in the Rock Springs Formation, in the Frontier Formation, and in very minor traces in the Ericson and Fort Union Formations, and the Mississippian upper shale unit. Coal has never been mined within the mapped area, although it once was mined from the Rock Springs(?) Formation just north of Linwood in Wyoming in the so-called Henrys Fork coalfield. The entry to this mine was caved at the time of my mapping. The mine, moreover, was afire and reportedly had been smouldering for many years.

Coal in the Rock Springs Formation seems to be most abundant near the mouth of Spring Creek just east of the Green River in the SW1/4 sec. 16, T. 3 N., R. 21 E. Coal has not been observed in the bluffs of the Rock Springs Formation west of the river, although it might be present there under concealment. East from the mouth of Spring Creek the Rock Springs Formation changes rapidly in lithology from onshore, coastal swamp, and near-shore facies to predominantly offshore facies, so that coal is lacking. Near the mouth of Spring Creek, thick littoral sandstone beds alternate with punky paludal shales which contain abundant carbonaceous material and occasional beds of bituminous coal. A few coal beds are as much as 3 feet thick, but most of them are thinner. The coal is hard, black, and shiny, but is much slacked on the outcrop.

Bituminous coal crops out in the Frontier Formation in the Flaming Gorge quadrangle in secs. 35 and 36 , T. 3 N., R. 21 E., where it forms a bed about 2 feet thick. Soft lignitic or subbituminous coal forms thin discontinuous seams or partings in the Ericson Sandstone in Clay Basin and in the Fort Union Formation just east of the Green River. Bituminous coal fragments have been observed in deformed remnants of the upper shale unit (Mississippian) in the Uinta fault zone in Hideout Canyon; the presence of coal there and west of the mapped area at Sols Canyon suggests that coal may be present but concealed elsewhere in the upper shale unit.

Coal deposits of the area seem to lack any potential for production in the foreseeable future. Despite apparently good quality, individual beds are too thin to be mined profitably even under favorable economic and marketing conditions. Surface outcrops of coal near the mouth of Spring Creek will be inundated by highwater storage when Flaming Gorge Reservoir is filled. 


\section{METAILIC MINERALS}

\section{COPPER}

Despite a long history of prospecting and early recognition of widespread but rather sporadic mineralization, no metallic ore body of commercial importance has ever been discovered in the area, and no ore has ever been shipped from the area. Major Powell's atlas (1876) shows a "copper and silver area" coextensive with the Red Creek Quartzite; most of the copper prospects of the area are associated with the Red Creek, but a few deposits south of Dutch John Mountain near the Uinta fault are found in rocks as young as the Chinle Formation. The copper minerals most commonly seen on the dumps of old prospects and in bedrock outcrops are the carbonates azurite and malachite and the secondary sulfate brochantite. These minerals form encrustations on joints and fractures and minute veinlets or disseminations in mica schist, amphibolite, and quartzite. Green staining, as a guide to potential copper mineralization, occasionally led early-day prospectors to open pits unknowingly in such unlikely occurrences as epidote veins, saussurite, chlorite schist, and even green quartzite.

Although the copper minerals are unaccompanied by obvious gangue in some places, they commonly are associated with some of the following minerals: Quartz, pyrite, calcite or red or brown carbonate, manganese oxides, opal, and hematite. Butler (in Butler, Loughlin, and Heikes, 1920, p. 605) reported occurrences also of bornite, chalcocite, and carnotite-the bornite and chalcocite being replacements of pyrite, and possibly of chalcopyrite. Wilmarth $(1953$, p. 5) reported tyuyamunite, volborthite, and hyalite, in addition to most of the minerals cited above, at prospects in the canyon of Red Creek in the SE1/4 sec. 5, T. 2 N., R. 24 E. These prospects, which have been opened in the rubble of an old landslide, contain the only occurrences of uranium minerals known to me in the area, although, reportedly, uranium minerals have been found also at localities in Jesse Ewing Canyon.

Sparse copper mineralization is widespread in the Red Creek Quartzite; prospects or occurrences have been noted in nearly every Red Creek outcrop area, including the small outcrop areas along the Uinta fault south of Dutch John Mountain, Dutch John Mountain itself, Goslin Mountain, Red Creek, Jesse Ewing Canyon, Willow Creek, and Beaver Creek. As most of the minerals observed have been secondary carbonates, the time of primary mineralization is uncertain. A copperbearing cobble derived from the Red Creek Quartzite was discovered in the basal conglomerate of the Uinta Mountain Group at Band Box Butte by Fred W. Cater of the Geological Survey during a field conference in 1960, hence an earlier Precambrian age is indicated. Elsewhere in the Uinta Mountains, however, copper minerals including the sulfide chalcocite have been found in rocks of younger Precambrian, Cambrian, and Mississippian age (Kinney, 1955, p. 159 ; Butler, Loughlin, and Heikes, 1920, p. 604). Occurrences of copper in the Chinle Formation south of Dutch John Mountain (near the center of sec. 33, T. 3 N., R. 22 E.), so far as I have observed, consist entirely of secondary carbonates. One copper prospect in sec. 33 is known as the Terry Mine. This prospect was recently examined and appraised by Robert G. Pruitt of the U.S. Bureau of Land Management, who commented as follows (written commun. 1960) :

Bryan J. Cox, of Provo, who helped sink the shafts on the property back in 1915-1917, tells me that the short adit on the southwestern slope and the larger caved adit on the west slope of the hill were old and caved when he worked there in 1915. I surmise from this that these workings were made by earlier locators in 1902-1906, or possibly as early as 1897, which is the first location in this area. Cox also tells me that all the flurry of interest in this property over the years stemmed from a large boulder of azurite-malachite which stood on the claim for years. Chip samples from the boulder ran as high as 60 percent copper, but it has since been chipped away by visitors until it just disappeared. Everybody theorized that there just ought to be more where that boulder came from, but no one has ever found anything to compare with it. Surprisingly enough, in all its 53 years of activity, not a single shipment of ore was ever made from the property.

\section{GOLD}

Known gold deposits of the area are confined to placers along the Green River in Red Canyon. These deposits have recently been examined and appraised by Robert G. Pruitt of the U.S. Bureau of Land Management, who described them briefly (written commun., 1960) as follows:

Very fine placer gold occurs in a number of points in Red Canyon. The two most important localities are (1) the point just above the mouth of Cart Creek, on what the old-timers called Gold Point (sec. 10, T. 2 N., R. 22 E.) and (2) a point about one mile upstream from the mouth of Gorge Creek, on the south bank of the Green River (secs. 16 and 17, T. 2 N., R. 23 E.).; The deposit at Gold Point was worked in the early 1900 's and 1930's, and a small shack, some pits, and pieces of old machinery can still be seen there today [1960], on the south bank of the Green River. The fine "flour" gold is concentrated in natural riffles formed by the southward dipping disintegrated shale bands in bedrock. Gold values range from a few cents to a maximum of $\$ 1.60$ per cubic yard, with a reasonable mean value of about $\$ 0.10$ to $\$ 0.40$ per cubic yard. The best goldbearing material is very limited in quantity, and is generally buried by talus blocks and soil. A select sample of the richest shale at bedrock yields over 200 gold colors per pan, but all this gold is worth only about one cent (referred to as " 200 colors to the cent" sized gold). I understand that the old-timers eked 
out a meager living during the off-seasons, but it was not what I'd call a paying mine. At the placer about a mile upstream from the mouth of Gorge Creek similar pits and broken machinery are found today, and possibly the deposit was worked by the same men. Claims on the deposits were located in 1906 and the 1930's. I don't have any assays from this deposit, but visual estimates from panning make it look very similar to the Gold Point deposit.

Other small gold workings, hardly more than shallow pits, are found near the mouths of Trail and Bear Canyons, and for a short distance above Ashley Falls. All the deposits seem to be restricted to the south bank of the river, apparently where south-dipping shale or quartzite bedrock formed natural riffles. There are no gold claims above the mouth of Jarvies Canyon, and so far as I know, none in Little Hole.

\section{MANGANESE}

Low-grade manganese deposits have been observed in sandstone, mudstone, and conglomerate beds of the Morrison Formation. Prospects have been opened in one deposit just west of the mapped area in sec. $34, \mathrm{~T}$. 3 N., R. 19 E., but no ore has been stockpiled or shipped. This deposit was described briefly in a report by Heim and Allsman (1950). Heim and Allsman noted that the manganese occurs interstitially and as nodules formed chiefly of pyrolucite, psilomelane, and wad. Manganiferous calcite and manganite are minor constituents. A deposit of manganiferous conglomerate at about the same level in the Morrison Formation but farther east, in sec. 31 , T. 3 N., R. 20 E., was noted by G. G. Anderman. ${ }^{11}$

\section{URANIUM}

Uranium has already been noted as an element associated with copper in the Red Creek Quartzite where it has been found in the minerals tyuyamunite (predominant) and carnotite (subordinate). As noted previously, the only prospects in the Red Creek Quartzite known to me to show visible uranium mineralization are in the rubble of an old landslide above Red Creek in the SE $1 / 4$ sec. 5, T. 2 N., R. 24 E. After I had ascertained to my own satisfaction that the hillslope was indeed a landslide, I traversed areas uphill from the slide with a scintillation counter but found no additional traces of uranium mineralization.

The mode of occurrence of tyuyamunite in the Red Creek was described by Wilmarth $(1953$, p. 5) as follows :

Tyuyamunite occurs, for the most part, as thin coatings, less than 3 millimeters thick, on fracture surfaces and as crystalline aggregates that partially fill small vugs, as much as 5 centimeters across, in the quartzite. The truyamunite grains are commonly thin bright-lemon-yellow to pale-yellow, nonfluorescent, tabular to subhedral flakes with their flat sides parallel to the surface on which they occur. Small but well-developed tabular crystals coat the more open fracture surfaces in the quartzite. The

\footnotetext{
11 Thesis, 1955 ; see footnote 4, p. 14 .
}

largest and best developed crystals of tyuyamunite were found in the hematite-filled vugs. Locally, botryoidal masses of tyuyamunite less than 1 millimeter across occur on the massive tyuyamunite fracture coatings. Gradations from the bright yellow characteristic of the tyuyamunite crystals to the paleyellow tyuyamunite grains on the fracture surfaces may be found.

Moderately heavy prospecting during the 1950's brought to light other uranium occurrences in the area, but no deposit of workable grade has been discovered. No visible uranium mineral, moreover, has been distinguished in any occurrence outside the canyon of Red Creek; the uranium has been identified radiometrically and chemically. Two occurrences listed in the files of the Geological Survey are in Navajo Sandstone-one in the canyon of Sheep Creek 5 miles south of Manila near Utah Highway 44 and another near Dutch John Mountain in the NW1/4SE1/4 sec. 34, T. 3 N., R. 22 E. A third occurrence, also near Sheep Creek about $71 / 2$ miles southeast of Manila apparently is in a fault zone, but further information is lacking. All these occurrences were discovered after my mapping was finished and I have examined none of them. The Navajo Sandstone occurrence in the canyon of Sheep Creek reportedly appears to have a large tonnage of very low grade material. A part of the radioactive zone, which is highly ferruginous, can be traced along the face of the Navajo outcrop for a distance of at least 1,000 feet. The exposure is vertical, and the radioactive zone is about 4 feet thick. Tested samples show 0.06 percent equivalent $\mathrm{U}_{3} \mathrm{O}_{3}$ and 0.064 percent chemically analyzed $\mathrm{U}_{3} \mathrm{O}_{8}$. The two other occurrences noted above and listed in the files of the Geological Survey seem to have no potential for production of uranium.

Many outcrops of tuff or tuffaceous sandstone in the Browns Park Formation have background radiation several times normal. Prospecting in Browns Park, however, has failed to discover any potential uranium ore, and no visible uranium minerals have been seen or reported.

\section{PHOSPHATE}

The phosphate deposits of the Sheep Creek-Kingfisher Canyon-Horseshoe Canyon area have been known for many years. These deposits are found in the Meade Peak Phosphatic Shale Tongue of the Phosphoria Formation, a unit known until the last few years as the middle phosphatic shale member of the Park City Formation. The deposits were first examined and described by Schultz (1918, p. 81-82), who also published (p. 92) analyses showing the phosphate content of selected samples. More detailed studies have been made in recent years by Cheney and others (1953, p. $22,23)$, whose analytical results are summarized below 
TABLE 7.-Phosphate analyses, Horseshoe Canyon section [Modifled from Cheney and others (1953)]

\begin{tabular}{|c|c|c|c|c|c|}
\hline \multirow{2}{*}{ Bed } & \multirow{2}{*}{$\underset{\text { (feet) }}{\text { Thickness }}$} & \multicolumn{2}{|c|}{$\begin{array}{c}\text { Chemical analyses, in } \\
\text { percent }\end{array}$} & \multirow{2}{*}{$\begin{array}{c}\text { Cumulative } \\
\text { thickness } \\
\text { (feet) }\end{array}$} & \multirow{2}{*}{$\begin{array}{l}\text { Thickness } \\
\times \text { percent } \\
\mathrm{P}_{2} \mathrm{O}_{\text {o (cumu }} \\
\text { lative) }\end{array}$} \\
\hline & & $\mathrm{P}_{2} \mathrm{O}_{3}$ & $\underset{\text { insoluble }}{\text { Acid }}$ & & \\
\hline 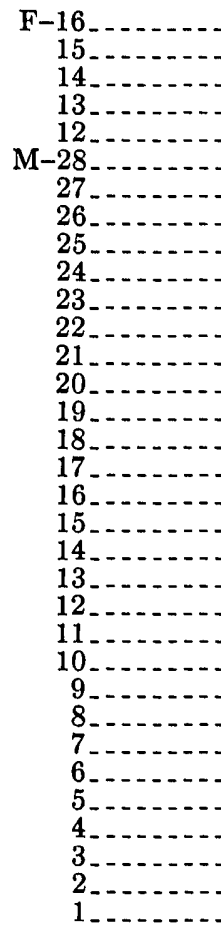 & $\begin{array}{l}3.6 \\
1.9 \\
2.9 \\
2.1 \\
3.1 \\
1.5 \\
1.3 \\
1.9 \\
3.0 \\
1.4 \\
1.2 \\
2.7 \\
2.0 \\
3.1 \\
2.0 \\
1.1 \\
1.5 \\
.9 \\
.5 \\
1.6 \\
1.8 \\
1.2 \\
1.4 \\
1.5 \\
1.9 \\
1.1 \\
.6 \\
1.7 \\
1.4 \\
3.6 \\
1.1 \\
.5\end{array}$ & $\begin{array}{r}0.2 \\
.2 \\
.2 \\
.2 \\
.4 \\
8.4 \\
9.1 \\
8.1 \\
2.7 \\
16.0 \\
14.3 \\
6.8 \\
10.2 \\
6.8 \\
6.8 \\
11.1 \\
6.3 \\
20.1 \\
18.0 \\
22.4 \\
8.7 \\
4.6 \\
8.7 \\
13.0 \\
24.6 \\
20.1 \\
5.6 \\
19.8 \\
7.8 \\
23.8 \\
26.7 \\
16.0 \\
7.9\end{array}$ & $\begin{array}{l}68.8 \\
68.0 \\
74.5 \\
73.6 \\
70.7 \\
24.4 \\
25.8 \\
36.8 \\
58.0 \\
30.2 \\
25.3 \\
10.9 \\
36.2 \\
43.9 \\
50.7 \\
44.0 \\
52.3 \\
30.8 \\
10.8 \\
15.3 \\
36.8 \\
40.3 \\
35.8 \\
10.4 \\
26.0 \\
18.8 \\
39.8 \\
30.2 \\
53.6 \\
16.8 \\
11.4 \\
36.6 \\
43.7\end{array}$ & $\begin{array}{r}117.7 \\
119.6 \\
122.5 \\
124.6 \\
127.7 \\
1.5 \\
2.8 \\
4.7 \\
7.7 \\
9.1 \\
10.3 \\
11.0 \\
13.2 \\
15.2 \\
18.3 \\
20.3 \\
21.4 \\
22.9 \\
23.8 \\
24.3 \\
25.9 \\
27.7 \\
28.9 \\
30.3 \\
31.8 \\
33.7 \\
34.8 \\
35.4 \\
37.1 \\
38.5 \\
\cdot 42.1 \\
43.2 \\
43.7\end{array}$ & $\begin{array}{r}0.72 \\
1.10 \\
1.68 \\
2.10 \\
3.34 \\
\text { 12. } 60 \\
24.43 \\
39.82 \\
47.92 \\
70.32 \\
87.48 \\
92.24 \\
114.68 \\
128.28 \\
149.36 \\
171.56 \\
178.49 \\
208.64 \\
224.84 \\
236.04 \\
249.96 \\
258.24 \\
268.68 \\
286.88 \\
323.78 \\
361.97 \\
368.13 \\
380.01 \\
393.27 \\
426.59 \\
522.71 \\
540.31 \\
544.26\end{array}$ \\
\hline
\end{tabular}

in table 7. Samples were obtained from the section exposed at the mouth of Horseshoe Canyon, sec. 36, T. 3 N., R. 20 E., and were analyzed by the U.S. Bureau of Mines laboratory at Albany, Oreg. Bed numbers correspond to those given for the measured sections of the Franson Member of the Park City Formation and the Meade Peak Phosphatic Shale Tongue of the Phosphoria Formation under the stratigraphic description of the Park City Formation presented elsewhere in this report.

As indicated by the above table, the phosphate deposits of the area should be considered low grade. Individually, beds range in grade from low to medium, but the overall composition-12.4 percent $\mathrm{P}_{2} \mathrm{O}_{5}$-is low grade. $^{12}$ Large reserves of low-grade phosphate are present in the Sheep Creek-Kingfisher Canyon-Horseshoe Canyon area. Possible exploitation is discouraged, however, by the overall low grade of the deposits

19 The arbitrary lower $11 \mathrm{mit}$ of medium-grade phosphate is placed at 22.9 percent $\mathrm{P}_{2} \mathrm{O}_{5}$, or 50 percent tricalclum phosphate. Good summary discussions of phosphate terminology, lithology, and petrology were presented by Kinney (1955, p. 162-169) in his report on the phosphate deposits of the Uinta River-Brush Creek area, and by Sheldon (1957, p. 116-124) in his report on the Phosphoria Formation of northwestern Wyoming. and by the great thickness of overburden, which would almost preclude the possibility of large-scale open-pit mining. A factor favoring possible future exploitation is the local source of hydroelectric power to be available when the Flaming Gorge project is completed.

\section{BARITE}

A single occurrence of barite was noted in the Red Creek Quartzite on Bender Mountain (Willow Creek Butte guadrangle) about 1,600 feet due east of VABM 8297 in the NW $1 / 4 \mathrm{SW}^{1} / 4$ sec. 33, T. $3 \mathrm{~N}$., R. $25 \mathrm{E}$. Though small, this deposit suggests by implication that similar and perhaps larger deposits may occur elsewhere in the area. The deposit is roughly oval-about 8 feet wide by 18 feet long-its long dimension trending about north. Its contacts with the enclosing Red Creek Quartzite are irregular, and the deposit contains fragments of brecciated quartzite. No other minerals appear to be associated. Some of the barite is in the form of coarse pink cleavage fragments several inches long. At a short distance from the outcrop the barite is easily overlooked or mistaken for pegmatite.

\section{CLAY AND SHALE}

Several formations in the area contain clays that might have industrial value. These formations include the upper shale unit of Mississippian age, the Dakota Sandstone, the Mowry Shale, the Hilliard Shale, and the Fort Union Formation. Most of these clays probably are illitic, but some are bentonitic. The greater part of the Hilliard Shale is calcareous and commonly is silty. Recent use of the Pierre Shale of northern Colorado for expanded aggregate and cinder block suggests that similar shales such as the Hilliard might be suitable for the same purpose. The Manning Canyon Shale of north-central Utah, which resembles the upper shale unit of the Flaming Gorge area, has been used for the manufacture of brick in the Salt Lake City area.

Bentonite is exposed intermittently along the outcrop of the Mowry Shale. Several claims for bentonite have been staked in the formation southeast of Manila, but no apparent effort has been made to develop or exploit any of them. A bed of bentonite 4 feet thick and ap. parently quite free of impurities was measured by $\mathbf{M}$. G. Bonilla and me 23 feet below the top of the Mowry Shale in the NE1/4 sec. 27, T. 3 N., R. 22 E. A similar bed $2 \frac{1}{2}$ feet thick and $31 / 2$ feet below the top of the formation was noted also at the same locality.

Siliceous shales such as the Mowry have been utilized as pozzolanic admixtures in concrete. Such admix. tures are first calcined at a temperature of about $1,000^{\circ} \mathrm{F}$ and are then interground with Portland cement clinker. 
Argillaceous shales similar to those in several formations of the area are also burned or calcined to produce pozzolans.

\section{TUFF (VOLCANIC ASH)}

The Browns Park Formation contains a great quantity of vitric rhyolitic tuff that seems to have considerable industrial potential. Much of this tuff is loose and friable and in industrial terminology would be classed as pumicite or volcanic ash. An excellent summary of present and potential uses of volcanic ash was presented by the Geological Survey of Kansas (Carey and others, 1952). Much of the information that follows is taken from that report.

Volcanic ash is now used in a surprising number of highly diversified fields. Until just a few years ago it was used chiefly as an abrasive in polishing, scouring, and cleansing agents such as soaps and powders. As a pozzolanic admixture in concrete it has been used for hundreds of years, but widespread use in this field is relatively new. Carey and others $(1952$, p. 31) pointed out that volcanic ash can also be used in place of powdered pumice wherever the latter material is suitable. Such uses include polishing powders for metals, wood, and varnished finishes, bone, celluloid, hard rubber, and dental tape.

Volcanic ash is being used in ceramic glazes and bodies in partial or whole substitution for feldspar and shale or clay, respectively (Carey and others, 1952. p. 32-37). As the glass shards of the ash approximate the composition of a feldspar-quartz frit but have a decidely lower fusion temperature, they permit the use of lower kiln temperatures with little difference in the character of the final glaze. They also have, therefore. a distinct economic advantage. As a substitute for shale or clay, $7-15$ percent volcanic ash has been found to lower the vitrification temperature, increase the firing range, and produce a greater rigidity in the ware at the maximum temperature. "These qualities produced by the volcanic ash additions permit economy in use of fuel; and reduce losses in the kiln due to the less critical temperature range requirements and the ability of the ware to stand up under its own weight at the maximum temperatures attained in the kiln" (Carey and others, 1952, p. 36).

Volcanic ash is used in glass and vitreous enamels, where its function is the same as in ceramic glazes. A limiting factor here is the percentage of iron oxide in the ash, which causes a slight darkening of the color of the glass. (Analyzed samples of tuffs from the Browns Park Formation, table 4, contain from 1.0 to 2.2 percent iron oxide).
Volcanic ash is used commercially in Kansas in the production of very lightweight aggregates and cellular blocks (Carey and others, 1952, p. 38). Various methods are used to produce several types of products that will meet various requirements and have various properties. One extremely lightweight product investigated by the Oklahoma Geological Survey is a cellular glass that has high insulating value and can be sawed or nailed. Another product developed in the laboratory of the Oklahoma Geological Survey consists of bubbly glass beads that are used in acoustical and insulating plasters, wallboards, lightweight blocks, and slabs.

Volcanic ash has been used as a pozzolan since GrecoRoman times. According to R. C. Mielenz (unpub. data, U.S. Bureau of Reclamation, 1948), 10-30 percent by weight of ash is substituted for Portland cement. In varying degrees, the resulting product generally is less expensive and has a lower heat of hydration and an earlier maximum rate of heat development, so that heat generation is reduced in massive structures. Some Portland-pozzolan cements possess several advantages over ordinary Portland cements, but most of them have certain disadvantages as well; some, for example, have undesirable shrinkage characteristics on drying. Empirical tests are generally needed to determine the suitability of pozzolanic materials for specific uses.

Most of the more suitable appearing grades of tuff or volcanic ash in the Browns Park Formation are found in deposits along the central (axial) to southern part of the valley of Browns Park. In more northern sections of the formation the relative proportion of pure tuff is reduced by increased amounts of interbedded sandstone and conglomerate derived from the adjacent mountains. Promising deposits of clean, uncontaminated vitric tuff are found in measured section B-2, in units $9-14$, and in sections B-9 and B-10. Deposits measured in sections B-9 and B-10 crop out adjacent to the road from Browns Park to Clay Basin in sec. 32, T. 2 N., R. 25 E. (See pl. 3; also measured sections under description of Browns Park Formation.)

\section{LIMESTONE}

Few earth materials have as varied industrial uses as limestone. It is used as dimension stone, riprap, and crushed aggregate; in the production of cement, agricultural and chemical lime; for refractory and metallurgical lime including fluxes for the reduction of metallic ores; and for many other minor purposes. Past production of limestone in the Flaming Gorge area has been largely for crushed aggregate. A very minor amount of limestone has been handpicked from the Curtis Formation for use as dimension stone-flagging, 
patio stones, and rough building stones for cellar walls and building foundations.

Large undeveloped reserves of limestone are in the Round Valley, Weber, Park City, Carmel, and Curtis Formations. Just outside the area, the Madison Limestone contains large reserves also. Within the area, the most exploitable limestone deposits are in the Park City and Curtis Formations, both of which form broad well-exposed dip slopes south of Lucerne Valley west of the Green River. Many of the limestone beds in the Park City Formation are cherty, however, and many are dolomitic (fig. 19). Large reserves of limestone in the lower member of the Weber Sandstone (upper member of the Morgan Formation of some reports) are well exposed along the Uinta fault just northwest of Hideout Flat. The bedding in these deposits is nearly vertical to overturned, and the unit forms great flatirons at or near the shoreline of Flaming Gorge Reservoir.

Limestone beds in the lower part of the Carmel Formation (in members $\mathrm{C}, \mathrm{D}$, and $\mathrm{E}$ ) are best exposed in sec. 5, T. 2 N., R. 20 E., and in secs. 33 and 34, T. 3 N., R. 20 E. (Manila quadrangle), where they form dip slopes along the dry washes south of Lucerne Valley (fig. 26). Farther east in secs. 25, 26, and 27, T. 3 N., R. 20 E., the limestone beds of the Carmel Formation are equally well exposed but have a narrower outcrop owing to steeper dips.

\section{SAND AND GRAVEL}

Great quantities of sand and gravel suitable for use in construction work are available in the Pleistocene bench deposits of Lucerne Valley, Henrys Fork, Browns Park, and Clay Basin. Smaller quantities are available also in various alluvial fan deposits, recent alluvial fills, and flood-plain (channel) deposits; these deposits are less predictable as to extent and quality than the bench deposits. Present local needs for aggregate are being filled mostly from various sand and gravel deposits in bench 4 south and east of Manila. Most of these deposits have been reworked through several cycles of erosion, hence are relatively well sorted and are relatively uniform in grade and lithology. Aggregate for Flaming Gorge Dam, at the time of this writing, is being obtained chiefly from bench 4 near the mouth of Henrys Fork.

Sand and gravel from most bench deposits must be washed and graded before being used as aggregate for concrete. Deposits vary appreciably in lithologic composition, depending on the varied composition of the rocks in the source area. Quartzite pebbles and cobbles derived from the Uinta Mountain Group predomi- nate in most deposits in Lucerne Valley, along Henrys Fork, and in Browns Park. Limestone is a major constituent of some deposits, "specially those in parts of Clay Basin and in the sniall terrace remnants along Sheep Creek. Deleterious material such as chert or chalcedony is rare in most deposits; it is relatively more common in deposits that have a large limestone fraction, mainly because the chert, chalcedony, and limestone mostly have a common source. Some of the bench deposits in Browns Park contain a small proportion of schistose material derived from the Red Creek Quartzite. The uppar several feet of most bench deposits is unsuited for use as concrete aggregate owing to concentrations of calcium carbonate in the form of nodules, powdery interstitial material, and coatings on pebbles and cobbles.

\section{RIPRAP}

Several formations in the area contain material suitable for use as riprap. Most foreseeable local needs could be met easily by short haulages from deposits near at hand. The best large sources of riprap are the sandstones and quartzites of the Uinta Mountain Group and the Red Creek Quartzite and the limestones of various Paleozoic and Mesozoic formations. Some bench deposits contain abundant boulders of sandstone, quartzite, and limestone derived from the above formations and suitable for local use. Many torrential fan deposits contain abundant material that could be handpicked for small projects. Most sandstones of Paleozoic, Mesozoic, or Tertiary age are too soft to have much value as riprap.

\section{SIIICA}

Crushed silica of various forms, including quartzite, is used as an acid lining for refractory furnaces, as a flux, as an abrasive, and for various other purposes. As a possible source of silica, the Red Creek Quartzite contains large quantities of highly pure quartzite. A grab sample of quartzite collected in a traverse about 400 feet long across the strike of a large outcrop on Goslin Mountain in the NW1/4 sec. 27, T. 3 N., R. 23 $\mathrm{E}$., contained only about 0.5 percent total impurities, mostly aluminum and iron, according to a semiquantitative spectrographic analysis. Field examinations suggest that much of the Red Creek has comparable purity. In much of the formation the only visible impurities are minor quantities of interlayered mica shist or amphibolite, which probably are amenable to selective handling and discard.

\section{GYPSUM}

Modest reserves of gypsum are in the Carmel Formation (member $\mathbf{F}$ ) in the western part of the area. It 
may be recalled that the Carmel formation thins markedly across the area toward the east (fig. 27) ; likewise, the reserves of gypsum thin and disappear. The thickest bed of gypsum noted in the formation is 10 feet thick at Sheep Creek Gap, 4 miles south of Manilla, where it forms a low cliff or ledge. It thins to 6 feet in a distance of about 4 miles to the northeast. Two other beds 5 feet thick and 3 feet thick at Sheep Creek Gap thin to 2 feet and 1 foot, respectively, in the same distance.

Most of the gypsum in the Carmel Formation is the massive variety, alabaster. Many thin beds and seams consist of the fibrous variety, satinspar; the fibers commonly are perpendicular to the bedding or to the sides of the seam.

Considerable gypsum is in the Dinwoody Formation and in the lower unit of the Moenkopi Formation. In these formations it appears to have little or no industrial potential because it forms very thin beds or seams interbedded with shale or siltstone.

\section{REFERENCES CITED}

Anderman, G. G., 1955, Tertiary deformational history of a portion of the north flank of the Uinta Mountains in the vicinity of Manila, Utah, in Wyoming Geol. Assoc. Guidebook, 10th Ann. Field Conf., 1955 : p. 130-134.

Anderson, A. L., 1934, Contact phenomena associated with the Cassia batholith, Idaho: Jour. Geology, v. 42, no. 4, p. 376-392.

Baker, A. A., 1947, Stratigraphy of the Wasatch Mountains in the vicinity of Provo, Utah: U.S. Geol. Survey Oil and Gas Inv. Prelim. Chart 30.

Baker, A. A., Dane, C. H., and Reeside, J. B., Jr., 1936, Correlation of the Jurassic formations of parts of Utah, Arizona, New Mexico, and Colorado: U.S. Geol. Survey Prof. Paper $183,66 \mathrm{p}$.

Baker, A. A., Huddle, J. W., and Kinney, D. M., 1949, Paleozoic geology of north and west sides of Uinta Basin, Utah; Am. Assoc. Petroleum Geologists Bull., v. 33, no. 7, p. 1161-1197.

Baker, A. A., and Williams, J. S., 1940, Permian in parts of Rocky Mountain and Colorado Plateau regions: Am. Assoc. Petroleum Geologists Bull., v. 24, no. 4, p. 617-635.

Bass, N. W., 1944, Correlation of basal Permian and older rocks in southwestern Colorado, northwestern New Mexico, northeastern Arizona, and southeastern Utah: U.S. Geol. Survey Oil and Gas Inv. Prelim. Chart 7, sheet 2.

Bass, N. W., Eby, J. B., and Campbell, M. R., 1955, Geology and mineral fuels of parts of Routt and Moffat Counties, Colorado: U.S. Geol. Survey Bull. 1027-D, p. 143-250.

Bassett, C. F., 1939, Paleozoic section in the vicinity of Dotsero, Colorado: Geol. Soc. America Bull., v. 50, no. 12, pt. 1, p. $1851-1865$.

Beloussov, V. V., 1960, Tectonophysical investigations: Geol. Soc. America Bull., v. 71, no. 8, p. 1255-1269.

Berkey, C. P., 1905, Strat:graphy of the Uinta Mountains: Geol. Soc. America Bull., v. 16, p. 517-530.

Billings, M. P., 1942, Structural geology : New York, PrenticeHall, 473 p.
Blackwelder, Eliot, 1910, New light on the geology of the Wasatch Mountains, Utah: Geol. Soc. America Bull., v. 21 , p. 517-542.

1918, New geological formations in western Wyoming: Washington Acad. Sci. Jour., v. 8, no. 13, p. 417-426.

- 1926, Precambrian geology of the Medicine Bow Mountains: Geol. Soc. America Bull., v. 37, no. 4, p. 615-658.

Boutwell, J. M., 1904, Iron ores in the Uinta Mountains, Utah: U.S. Geol. Survey Bull. 225, p. 221-228.

1907, Stratigraphy and structure of the Park City mining district, Utah: Jour. Geology, v. 15, p. 434-458.

1912, Geology and ore deposits of the Park City district, Utah, with contributions by L. H. Woolsey: U.S. Geol. Survey Prof. Paper 77, 231 p.

1933, The Wasatch Front, in Boutwell, J. M., and others, The Salt Lake Region: Internat. Geol. Cong., 16th, United States 1933, Guidebook 17, Excursion C-1, 149 p.

Bradley, W. H., 1936a, Geomorphology of the north flank of the Uinta Mountains [Utah]: U.S. Geol Survey Prof. Paper 185-I, p. 163-199.

1936b, The biography of an ancient American lake: Sci. Monthly, v. 42, no. 5, p. 421-430; Smithsonian Inst. Ann. Rept., 1937, Pub. 3451, p. 279-289 [1938].

1948, Limnology and the Eocene lakes of the Rocky Mountain region: Geol. Soc. America Bull., v. 59, no. 7, p. $635-648$.

1959, Revision of stratigraphic nomenclature of Green River formation of Wyoming: Am. Assoc. Petroleum Geologists Bull., v. 43, no. 5, p. 1072-1075.

Brill, K. G., Jr., 1944, Late Paleozoic stratigraphy, west-central and northwestern Colorado: Geol. Soc. America Bull., v. 55, no. 5, p. 621-655.

1952, Stratigraphy in the Permo-Pennsylvanian zeugogeosyncline of Colorado and northern New Mexico: Geol. Soc. America Bull., v. 63, no. 8, p. 809-880.

Butler, B. S., Loughlin, G. F., and Heikes, V. C., and others, 1920, The ore deposits of Utah: U.S. Geol. Survey Prof. Paper 111, 672 p.

Calkins, F. C., and Butler, B. S., 1943, Geology and ore deposits of the Cottonwood-American Fork area, Utah: U.S. Geol. Survey Prof. Paper 201, 152 p.

Cannon, Helen L., 1957, Description of indicator plants and methods of botanical prospecting for uranium deposits on the Colorado Plateau: U.S. Geol. Survey Bull. 1030-M. p. 399-516.

Carey, J. S., Frye, J. C., Plummer, Norman, and Swineford, Ada, 1952, Kansas volcanic ash resources: Kansas Geol. Survey Bull. 96, pt. 1, p. 1-68.

Cheney, T. M., 1955, Facies and oil possibilities of the Phosphoria formation and equivalent strata in eastern Utah and southwestern Wyoming, in Wyoming Geol. Assoc. Guidebook, 10th Ann. Field Conf., 1955: p. 65-67.

Cheney, T. M., Smart, R. A., Waring, R. G., and Warner, M. A., 1953. Stratigraphic sections of the Phosphoria formation in Utah, 1949-51: U.S. Geol. Survey Circ. 306, 40 p.

Cloos, Ernst, 1937, The application of recent structural methods in the interpretation of the crystalline rocks of Maryland : Maryland Geol. Survey [Rept.], v. 13, p. 27-105.

Cobban, W. A., and Reeside, J. B., Jr., 1952a, Correlation of the Cretaceous formations of the Western Interior of the United States: Geol. Soc. America Bull., v. 63, no. 10, p. 1011-1043. 
Cobban, W. A., and Reeside, J. B., Jr., 1952b, Frontier formation, Wyoming and adjacent areas: Am. Assoc. Petroleum Geologists Bull., v. 36, no. 10, p. 1913-1961.

Cressman, E. R., 1955, Physical stratigraphy of the Phosphoria formation in part of southwestern Montana: U.S. Geol. Survey Bull. 1027-A, p. 1-31.

Crittenden, M. D., Jr., 1955, Precambrian rocks west and south of the Green River Basin [Utah], in Wyoming Geol. Assoc. Guidebook, 10th Ann. Field Conf., 1955: p. 20-22.

- 1959, Mississippian stratigraphy of the Central Wasatch and western Uinta Mountains, Utah : Intermountain Assoc. Petroleum Geologists Guidebook, 10th Ann. Field Conf., 1959 , p. $63-74$.

Curtis, B. F., 1950, Structure of the north flank of the Uinta Mountains, in Wyoming Geol. Assoc. Guidebook, 5th Ann. Field Conf., Southwest Wyoming, 1950: p. 93-102.

Dobbin, C. E., and Davison, Robert, 1945, Geologic and structure contour map of the Clay Basin gas field and vicinity, Daggett County, Utah, and Sweetwater County, Wyoming: U.S. Geol. Survey.

Donovan, J. H., 1950, Intertonguing of Green River and Wasatch formations in part of Sublette and Lincoln Counties, Wyoming, in Wyoming Geol. Assoc. Guidebook, 5th Ann. Field Conf., Southwest Wyoming, 1950: p. 59-65.

Eardley, A. J., 1933, Stratigraphy of the southern Wasatch Mountains, Utah: Michigan Acad. Sci. Papers, v. 18, p. 307-344.

1039, Structure of the Wasatch-Great Basin region: Geol. Soc. America Bull., v. 50, no. 8, p. 1277-1310.

- 1944, Geology of the north-central Wasatch Mountains, Utah: Geol. Soc. America Bull., v. 55, no. 7, p. 819-894.

Eardley, A. J., and Hatch, R. A., 1940, Proterozoic(?) rocks in Utah: Geol. Soc. America Bull., v. 51, no. 6, p. 795-843.

Eldridge, G. H., 1896, in Emmons, S. F., Cross, Whitman, and Eldridge, G. H., Geology of the Denver Basin in Colorado: U.S. Geol. Survey Mon. 27, $556 \mathrm{p}$.

Emmons, S. F., 1877, Descriptive geology : U.S. Geol. Explor. 40th Parallel (King), v. 2, 890 p.

1907, Uinta Mountains: Geol. Soc. America Bull., v. 18, p. $287-302$.

Fenneman, N. M., and Gale, H. S., 1906, The Yampa coal field, Routt County, Colorado: U.S. Geol. Survey Bull. 297, 96 p.

Fidlar, M. M., 1950a, Baxter Basin gas fields, Sweetwater County, Wyoming, in Wyoming Geol. Assoc. Guidebook, 5th Ann. Field Conf., Southwest Wyoming, 1950 : p. 109-110.

1950b, Clay Basin gas field, Daggett County, Utah, in Wyoming Geol. Assoc. Guidebook, 5th Ann. Field Conf., Southwest Wyoming, 1950 : p. 114-116.

1950c, Church Buttes gas fleld, Sweetwater and Uinta Counties, Wyoming, in Wyoming Geol. Assoc. Guidebook, 5th Ann. Field Conf., Southwest Wyoming, 1950: p. 111113.

Folsom, L. W., 1955, Powder Wash-Ace fleld, Moffat County, Colorado, in Wyoming Geol. Assoc. Guidebook, 10th Ann. Field Conf., 1955: p. 157-160.

Forrester, J. D., 1937, Structure of the Uinta Mountains: Geol. Soc. America Bull., v. 48 no. 5, p. 631-666.

Fyfe, W. S., Turner, F. J., and Verhoogen, John, 1958, Metamorphic reactions and metamorphic facies: Geol. Soc. America Mem. 73, 259 p.

Gale, H. S., 1910. Coal fields of northwestern Colorado and northeastern Utah: U.S. Geol. Survey Bull. 415, 265 p.
Gast, P. W., Kulp, J. L., and Long. L. E., 1958, Absolute age of early Precambrian rocks in the Bighorn Basin of Wyoming and Montana, and southeastern Manitoba: Am. Geophys. Union Trans., v. 39, no. 2, p. 322-334.

Giletti, B. J., and Gast, P. W., 1961, Absolute age of Precambrian rocks in Wyoming and Montana: New York Acad. Sci. Annals, v. 91, p. 454-458.

Gilluly, James, 1929, Geology and oil and gas prospects of part of the San Rafael Swell, Utah: U.S. Geol. Survey Bull. 806-C, p. 69-130.

1932, Geology and oil deposits of the Stockton and Fairfield quadrangles, Utah : U.S. Geol. Survey Prof. Paper $173,171 \mathrm{p}$.

Gilluly, James, and Reeside, J. B., 1928, Sedimentary rocks of the San Rafael Swell and some adjacent areas in eastern Utah : U.S. Geol. Survey Prof. Paper 150-D, p. 61-110.

Goddard, E. N., chm., and others, 1948, Rock-color chart: Natl. Research Council (2d printing, 1951, by Geol. Soc. America).

Graham, E. H., 1937, Botanical studies in the Uinta Basin of Utah and Colorado: Pittsburgh, Pa., Carnegie Mus. Annals, v. 26, $432 \mathrm{p}$.

Granger, A. E., 1953, Stratigraphy of the Wasatch Range near Salt Lake City, Utah: U.S. Geol. Survey Circ. 296, 14 p.

Granger, A. E., and Sharp, B. J., 1952, Geology of the Wasatch Mountains east of Salt Lake City, in Marsell, R. E., ed.. Utah Geol. Soc. Guidebook 8 : p. 1-37.

Gras, V. B., 1955, Vermilion Creek Basin area, Sweetwater County, Wyoming, and Moffat County, Colorado, in Wyoming Geol. Assoc. Guidebook, 10th Ann. Field Conf., 1955: p. 177-181.

Gregory, H. E., 1915, The igneous origin of the "glacial deposits" on the Navajo Reservation, Arizona and Utah : Am. Jour. Sci., 4th ser., v. 40, p. 97-115.

1938, The San Juan Country, a geographic and geologic reconnaissance of southeastern Utah, with contributions by M. R. Thorpe and H. D. Miser: U.S. Geol. Survey Prof. Paper 188, $123 \mathrm{p}$.

Hack, J. T., 1942, The changing environment of the Hopl Indians of Arizona: Harvard Univ., Peabody Mus. Am. Arch. eol. and Ethnologic Papers, v. 35, no. 1, 85 p.

Hale, L. A., 1950, Stratigraphy of the Upper Cretaceous Montana group in the Rock Springs uplift, Sweetwater County, Wyoming, in Wyoming Geol. Assoc. Guidebook, 5th Ann. Field Conf., Southwest Wyoming, 1950 : p. 49-58.

1955, Stratigraphy and facies relationship of the Montanan group on south-central Wyoming, northeastern Utah, and northwestern Colorado, in Wyoming Geol. Assoc. Guidebook, 10th Ann. Field Conf., 1955: p. 89-94.

Hansen, G. H., and Bell, M. M., 1949, The oil and gas possibilities of Utah, with individual sections by 16 authors: Utah Geol. Mineralog. Survey, $341 \mathrm{p}$.

Hansen, W. R., 1955a, Geology of the Flaming Gorge quadrangle; Utah-Wyoming: U.S. Geol. Survey Geol. Quad. Map GO-75.

$1955 \mathrm{~b}$, Precambrian geology of the area between Clay Basin and Browns Park in Utah and Colorado, in Wyom. ing Geol. Assoc. Guidebook, 10th Ann. Field Conf., 1955, p. 23-28.

1957a, Geology of the Clay Basin quadrangle, Utah: U.S. Geol. Survey Geol. Quad. Map GQ-101. 
Hansen, W. R., 1957b, Structural features of the Uinta arch [Colorado-Utah], in Intermountain Assoc. Petroleum Geologists Guidebook, 8th Ann. Field Conf., 1957: p. 35-39.

-1957c, Precambrian rocks of the Uinta Mountains [Utah], in Intermountain Assoc. Petroleum Geologist Guidebook, 8th Ann. Field Conf., 1957: p. 48-52.

Hansen, W. R., and Bonilla, M. G., 1954, Laramide faulting and orogeny on the north flank of the Uinta Mountains in eastern Daggett County, Utah: Colorado Sci. Soc. Proc., v. 17, no. 1,29 p.

1956, Geology of the Manila quadrangle, Utah-Wyoming : U.S. Geol. Survey Misc. Geol. Inv. Map I-156.

Hansen, W. R., Kinney, D. M., and Good, J. M., 1960, Distribution and physiographic significance of the Browns Park formation, Flaming Gorge and Red Canyon areas, UtahColorado, in Short papers in the geological sciences: U.S. Geol. Survey Prof. Paper 400-B, p. B257-B259.

Hayden, F. V., 1869, Preliminary field report of the United States Geological Survey of Colorado and New Mexico: U.S. Geol. Geog. Survey Terr., 3d Ann. Rept., 155 p.

1872, Preliminary report of the United States Geological Survey of Wyoming and portions of contiguous territories (being a second annual report of progress): U.S. Geol. Geog. Survey Terr., 4th Ann. Rept., 511 p.

Heaton, R. L., 1933, Ancestral Rockies and Mesozoic and late Paleozoic stratigraphy of Rocky Mountain region: Am. Assoc. Petroleum Geologists Bull., v. 17, no. 2, p. 109-168. 1939, Contribution to Jurassic stratigraphy of Rocky Mountain region: Am. Assoc. Petroleum Geologists Bull., v. 23 , no. 8 , p. 1153-1177.

Heim, G. W., and Allsman, P. T., 1950, Investigation of Daggett Chief manganese deposit, Manila, Daggett County, Utah: U.S. Bur. Mines Rept. Inv. 4731, 9 p.

Huddle, J. W., and McCann, F. T., 1947a, Geologic map of Duchesne River area, Wasatch and Duchesne Counties, Utah: U.S. Geol. Survey Oil and Gas Inv. Prelim. Map 75. 1947b, Late Paleozoic rocks exposed in the Duchesne River area, Duchesne County. Utah: U.S. Geol. Survey Circ. 16, $21 \mathrm{p}$.

Huddle, J. W., Mapel, W. J., and McCann, F. T., 1951, Geology of the Moon Lake area, Duchesne County, Utah: U.S. Geol. Survey Oil and Gas Inv. Map OM-115.

Hunt, C. B., 1953, Pleistocene-Recent boundary in the Rocky Mountain region: U.S. Geol. Survey Bull. 996-A, p. 1-25.

1955 Pleistocene and Recent deposits in the Denver area, Colorado: U.S. Geol. Survey Bull. 996-C, p. 91-140.

Huntington, Ellsworth, and Goldthwait, J. W., 1904, The Hurricane fault in the Toquerville district, Utah : Harvard Coll. Mus. Comp. Zoology Bull., v. 42, p. 199-259.

Imlay, R. W., 1950a, Jurassic rocks in the mountains along the west side of the Green River Basin, in Wyoming Geol. Assoc. Guidebook, 5th Ann. Field Conf., Southwest Wyoming, 1950 : p. $36-48$.

- $1950 \mathrm{~b}$, Paleoecology of Jurassic seas in the western interior of the United States, in Natl. Research Council, Rept. of the Committee on a treatise on marine ecology and paleoecology, 1948-1949, no. 9 : p. 72-104.

1952a, Correlation of the Jurassic formations of North America, exclusive of Canada: Geol. Soc. America Bull., v. 63, no. 9, p. 953-992.

$1952 \mathrm{~b}$, Marine origin of the Preuss sandstone of Idaho, Wyoming, and Utah: Am. Assoc. Petroleum Geologists Bull., v. 36, no. 9, p. 1735-1753.
1953, Characteristics of the Jurassic Twin Creek limestone in Idaho, Wyoming, and Utah, in Intermountain Assoc. Petroleum Geologists Guidebook, 4th Ann. Field Conf., 1953 : p. 54-62.

Jacobucci, John, 1955, Discovery and development of trona deposits in Sweetwater County, Wyoming, in Wyoming Geol. Assoc. Guidebook, 10th Ann. Field Conf., 1955: p. 203-204.

Keller, W. D., 1952, Analcime in the Popo Agie member of the Chugwater formation [Wyoming]: Jour. Sed. Petrology, v. 22 , no. 2 , p. $70-82$.

- 1953, Analcime in the Chinle formation of Utah correlative with the Popo Agie of Wyoming: Jour. Sed. Petrology, v. 23, no. 1, p. 10-12.

King, Clarence, 1876, Paleozoic subdivisions on the 40th Parallel : Am. Jour. Sci., 3d ser., v. 11, p. 475-482.

1878, Systemic geology: U.S. Geol. Explor. 40th Par allel (King), v. 1, 803 p.

Kinney, 1). M., 1955, Geology of the Uinta River-Brush Creek area, Duchesne and Uintah Counties, Utah: U.S. Geol. Survey Bull. 1007, $187 \mathrm{p}$.

Kinney, D. M., Hansen, W. R., and Good, J. M., 1959, Distribution of Browns Park formation in eastern Uinta Mountains, northeastern Utah and northwestern Colorado [abs.] : Geol. Soc. America Bull., v. 70, no. 12, pt. 2, p. 1630.

Kinney, D. M., and Rominger, J. F., 1947, Geology of the Whiterocks River-Ashley Creek area, Uintah County, Utah: U.S. Geol. Survey Oil and Gas Inv. Prelim. Map 82.

Knight, W. C., 1902, The petroleum fields of Wyoming: Eng. Mining Jour., v. 73, p. 720-723.

Krumbein, W. C., and Garrels, R. M., 1952, Origin and classification of chemical sediments in terms of $\mathrm{pH}$ and oxidation-reduction potentials : Jour. Geology, v. 60, no. 1, p. 1-33.

Kummel, Bernhard, Jr., 1954, Triassic stratigraphy of southeastern Idaho and adjacent areas [Wyoming, Montana] : U.S. Geol. Survey Prof. Paper, 254-H, p. 165-194.

Lochman-Balk, Christina, 1955, Cambrian stratigraphy of the south and west margins of Green River Basin [Utah-Wyoming], in Wyoming Geol. Assoc. Guidebook, 10th Ann. Field Conf., 1955 : p. 29-37.

Longwell, C. R., 1928, Geology of the Muddy Mountains, Nevada, with a section Through the Virgin Range to the Grand Wash Cliffs, Arizona: U.S. Geol. Survey Bull. 798, 152 p.

Love, J. D., 1948, Mesozoic stratigraphy of the Wind River Basin : central Wyoming, in Wyoming Geol. Assoc. Guidebook, 3d Ann. Field Conf., Wind River Basin, 1948: p. 96-111.

1950, Paleozoic rocks on the southwest flank of the Wind River Mountains, near Pinedale, Wyoming, in Wyoming Geol. Assoc. Guidebook, 5th Ann. Field Conf., Southwest Wyoming, 1950 : p. 25-27.

Love, J. D., and others, 1945, Stratigraphic sections and thickness maps of Triassic rocks in central Wyoming: U.S. Geol. Survey Oil and Gas Inv. Prelim. Chart 17.

Love, J. D., Weitz, J. L., and Hose, R. K., 1955, Geologic map of Wyoming: U.S. Geol. Survey.

McCann, F. T., Raman, N. D., and Henbest, L. G., 1946, Section of Morgan formation, Pennsylvanian, at Split Mountain in Dinosaur National Monument, Utah: U.S. Geol. Survey Misc. pub. on mineral resources, $18 \mathrm{p}$.

McGrew. P. O., 1951, Tertiary stratigraphy and paleontology of south-central Wyoming, in Wyoming Geol. Assoc. Guidebook, 6th Ann. Field Conf., 1951: p. 54-57. 
McGrew, P. O., 1953, Tertiary deposits of southeastern Wyoming, in Wyoming Geol. Assoc. Guidebook, 8th Ann. Field Conf., 1953: p. 61-64.

MCKee, E. D., and others, 1956, Paleotectonic maps of the Jurassic system: U.S. Geol. Survey Misc. Geol. Inv. Map I-175.

McKelvey, V. E., Swanson, R. W., and Sheldon, R. P., 1935, The Permian phosphorite deposits of western United States, in Saint Guilhem, P.L.R., ed., Origine des gisements de phosphates: Internat. Geol. Cong., 19th, Algiers 1952, Comptes rendus, sec. 11 , pt. 11, p. 45-64.

McKelvey, V. E., and others, 1956, Summary description of Phosphoria, Park City, and Shedhorn formations in western phosphate field: Am. Assoc. Petroleum Geologists Bull., v. 40 , no. 12 , p. $2826-2863$.

McKenna, M. C., 1955, Age of the Four Mile local fauna, northeast Sarid Wash basin, Colorado, in Wyoming Geol. Assoc. Guidebook, 10th Ann. Field Conf., 1955: p. 105-107.

MacLachlan, Marjorie E., 1957, Triassic stratigraphy in parts of Utah and Colorado, in Intermountain Assoc. Petroleum Geologists Guidebook, 8th Ann. Field Conf., 1957 : p. 82-91.

Mansfield, G. R., 1927, Geography, geology, and mineral resources of part of southeastern Idaho: U.S. Geol. Survey Prof. Paper 152, 409 p.

Marsh, O. C., 1871, On the geology of the eastern Uinta Mountains : Am. Jour. Sci., 3d ser., v. 1, p. 191-198.

Miller, A. K., Furnish, W. M., Jr., and Clark, D. L., 1957, Permian ammonoids from western United States : Jour. Paleontology, v. 31, no. 6, p. 1057-1068.

Milton, Charles, 1957, Authigenic minerals of the Green River formation of the Uinta Basin, Utah, in Intermountain Assoc. Petroleum Geologists Guidebook, 8th Ann. Field Conf., 1957 : p. 136-143.

Morris, W. J., 1954, An Eocene fauna from the Cathedral Bluffs tongue of the Washakie basin, Wyoming: Jour. Paleontology, v. 28, no. 2, p. 195-203.

Nace, R. L.; 1939, Geology of the northwest part of the Red Desert, Sweetwater and Fremont Counties, Wyoming: Wyoming Geol. Survey Bull. 27, 51 p.

Newell, N. D., and Kummel, Bernhard, Jr., 1942, Lower EoTriassic stratigraphy, western Wyoming and southeast Idaho: Geol. Soc. America Bull., v., 53, no. 6, p. 937-995.

Nightingale, W. T., 1930, Geology of Vermilion Creek gas area in southwest Wyoming and northwest Colorado: Am. Assoc. Petroleum Geologists Bull., v. 14, no. 8, p. 1013-1040.

Nolan, T. B., 1943, The Basin and Range province in Utah, Nevada, and California: U.S. Geol. Survey Prof. Paper 197-D, p. 141-196.

Olson, R. B., 1955, Middle Mountain field, Sweetwater County, Wyoming, in Wyoming Geol. Assoc. Guidebook, 10th Ann. Field Conf., 1955 : p. 148-149.

Opdyke, N. D., and Runcorn, S. K., 1960, Wind direction in the western United States in the late Paleozoic: Geol. Soc. America Bull., v. 71, p. 959-972.

Pipiringos, G. N., 1955, Tertiary rocks in the central part of the Great Divide Basin, Sweetwater County, Wyoming, in Wyoming Geol. Assoc. Guidebook, 10th Ann. Field Conf., 1955 : p. 100-104.

Powell, J. W., 1876, Report on the geology of the eastern portion of the Uinta Mountains and a region of country adjacent thereto: U.S. Geol. Geog. Survey Terr., 218 p.
Reeside, J: B., Jr., 1944, map showing thickness and general character of the Cretaceous deposits in the western interior of the United States: U.S. Geol. Survey Oil and Gas Inv. Prelim. Map 10.

1955, Revised interpretation of the. Cretaceous section on Vermilion Creek, Moffat County, Colorado, in Wyoming Geol. Assoc. Guidebook, 10th Ann. Field Conf., 1955: p. $8 \overline{-}-88$.

Rich, J. L., 1910, The physiography of the Bishop conglomerate, southwestern Wyoming: Jour. Geology, v. 18, p. 601-632

Richards, R. W., and Mansfield, G. R., 1912, The Bannock overthrust, a major fault in southeastern Idaho and northeastern Utah: Jour. Geology, v. 20, p. 681-709.

Ritzma, H. R., 1959, Geologic atlas of Utah, Daggett County : Salt Lake City, Utah, Utah Geol. and Mineralog. Survey Bull. 66, p. 1-111.

1960, Geologic atlas of Utah, Daggett County, by Howard R. Ritzma, in Review by Wallace R. Hansen, Reply by Howard R. Ritzma: Am. Assoc. Petroleum Geologists Bull., v. 44, no. 8, p. 1441-1445.

Rubey, W. W., 1928, Origin of the siliceous Mowry shale of the Black Hills region: U.S. Geol. Survey Prof. Paper 154-D, p. 153-170.

Sadlick, Walter, 1955, Carboniferous formations of northeastern Uinta Mountains [Colorado-Utah], in Wyoming Geol. Assoc. Guidebook, 10th Ann. Field Conf., 1955: p. 49-59.

Schemel, M. P., 1950, Carboniferous plant spores from Daggett County, Utah: Jour. Paleontology, v. 24, no. 2, p. 232-244.

Schultz, A. R., 1910, The southern part of the Rock Springs coal field, Sweetwater County, Wyoming: U.S. Geol. Survey Bull. 381, p. 214-281.

1918, A geologic reconnaissance of the Uinta Mountains, northern Utah, with special reference to phosphate: U.S. Geol. Survey Bull. 690-C, p. 31-94.

1920, Oil possibilities in and around Baxter Basin, in the Rock Springs uplift, Sweetwater County, Wyoming: U.S. Geol. Surrey Bull. 702, 107 p.

Schultz, A. R., and Cross, Whitman, 1912, Potash-bearing rocks of the Leucite Hills, Sweetwater County, Wyoming: U.S. Geol. Survey Bull. 512, 39 p.

Scott, H. W., and Summerson, C. H., 1943, Non-marine Ostracoda from the Lower Pennsylvanian in the southern Appalachians, and their bearing on intercontinental correlations: Am. Jour. Sci., v. 241, no. 11, p. 654-675.

Sears, J. D., 1924a, Relations of the Browns Park formation and the Bishop conglomerate and their role in the origin of the Green and Yampa Rivers: Geol. Soc. America Bull., v. 35, no. 2, p. 279-304.

- 1924b, Geology and oil and gas prospects of part of Moffat County, Colorado, and southern Sweetwater County, Wyoming: U.S. Geol. Survey Bull. 751-G, p. 269-319.

1926, Geology of the Baxter Basin gas field, Sweetwater County, Wyoming: U.S. Geol. Survey Bull. 781-B, pt. 2, p. 13-27.

Sears, J. D., and Bradley, W. H., 1924, Relations of the Wasatach and Green River formations in northwestern Colorado and southern Wyoming: U.S. Geol. Survey Prof. Paper 132C-F, p. 93-107.

Shapiro, Leonard, and Brannock, W. W., 1956, Rapid analysis of silica rocks: U.S. Geol. Survey Bull. 1036-C, p. 19-56.

Sheldon, R. P., 1957, Physical stratigraphy of the Phosphoria formation in northwestern Wyoming: U. S. Geol. Survey Bull. 1042-E, p. 105-185. 
Stewart, J. H., and Smith, J. F., Jr., 1954, Triassic rocks in the San Rafael Swell, Capitol Reef, and adjoining parts of southeastern Utah, in Intermountain Assoc. Petroleum Geologists Guidebook, 5th Ann. Field Conf., 1954 ; p. 25-33.

Stokes, W. L., 1944, Morrison formation and related deposits in and adjacent to the Colorado Plateau : Geol. Soc. America Bull., v. 55, no. 8, p. 951-992.

- 1948, Pediment concept applied to certain continental formations of the Colorado Plateau [abs.]: Geol. Soc. America Bull., v. 59, no. 12, pt. 2, p. 1383.

- 1955, Non-marine Late Jurassic and Early Cretaceous formations, in Wyoming Geol. Assoc. Guidebook, 10th Ann. Field Conf., 1955 : p. 80-84.

Stokes, W. L., and Holimes, C. N., 1954, Jurassic rocks of southcentral Utah, in Intermountain Assoc. Petroleum Geologists Guidebook, 5th Ann. Field Conf., 1954: p. 34 41.

Stokes, W. L., and Phoenix, D. A., 1948, Geology of the EgnarGypsum Valley area, San Miguel and Montrose Counties, Colorado: U. S. Geol. Survey Oil and Gas Inv. Prelim. Map 93.

Thomas, C. R., McCann, F. T., and Raman, N. D., 1945, Mesozoic and Paleozoic stratigraphy in northwestern Colorado and northeastern Utah: U.S. Geol. Survey Oil and Gas Inv. Prelim. Chart 16.

Thomas, H. D., and Krueger, M. L., 1946, Late Paleozoic and early Mesozoic stratigraphy of the Uinta Mountains, Utah : Am. Assoc. Petroleum Geologists Bull., v. 30, no. 8, pt. 2, p. 1255-1293.

Thompson, M. L., 1945, Pennsylvanian rocks and fusulinids of east Utah and northwest Colorado correlated with Kansas section: Kansas Univ. Geol. Survey Bull. 60, pt. 2, 84 p.

Thompson, W. O., 1937, Original structures of beaches, bars, and dunes: Geol. Soc. America Bull., v. 48, no. 6, p. 723751.

Tower, G. W., and Smith, G. O., 1899, Geology and mining industry of the Tintic district, Utah: U.S. Geol. Survey Ann. Rept. 19, 1897-98, pt. 3, p. 601-767.

Untermann, G. E., and Untermann, B. R., 1949, Geology of Green and Yampa River Canyons and vicinity, Dinosaur National Monument, Utah and Colorado: Am. Assoc. Petroleum Geologists Bull., v. 33, no. 5, p. 683-694.

- 1954, Geology of Linosaur National Monument and vicinity, Utah-Colorado: Utah Geol. Mineralog. Survey Bull. 42, 228 p.

Van Hise, C. R., and Leith, C. K., 1909, Precambrian geology of North America: U.S. Geol. Survey Bull. 360, 939 p.
Varnes, D. J., 1946, Geologic mapping by means of graphic locator: U.S. Geol. Survey Circ. 12, 4 p.

Veatch, A. C., 1907, Geography and geology of a portion of southwestern Wyoming, with special reference to coal and oil: U.S. Geol. Survey Prof. Paper 56, 178 p.

Walton, P. T., 1944, Geology of the Cretaceous of the Uinta Basin, Utah : Geol. Soc. America Bull., v. 55, no. 1, p. 91-130.

Ward, L. F., 1901, Geology of the Little Colorado Valley : Am. Jour. Sci., 4th ser., v. 12, p. 401-413.

Weeks, F. B., 1907, Stratigraphy and structure of the Uinta range: Geol. Soc. America Bull., v. 18, p. 427-448.

White, C. A., 1889, On the geology and physiography of a portion of northwestern Colorado and adjacent parts of Utah and Wyoming: U.S. Geol. Survey, $\theta$ th Ann. Rept., 1886-87, p. 677-712.

Williams, Howel, Turner, F. J., and Gilbert, C. M., 1958, Petrography: San Francisco, W. H. Freeman and Company, $406 \mathrm{p}$.

Williams, J. Stewart, 1939, "Park City" beds on the southwest flank of the Uinta Mountains, Utah : Am. Assoc. Petroleum Geologists Bull., v. 23, no. 1, p. 82-100.

1943, Carboniferous formations of the Uinta and northern Wasatch Mountains, Utah: Geol. Soc. America Bull., v. 54 , no. 4 , p. $591-624$.

1945, Nomenclature of Triassic rocks in northeastern Utah: Am. Jour. Sci., v. 243, no. 9, p. 473-479.

- 1955, Resume of Paleozoic stratigraphy, Ordovician to Pennsylvanian, of the Green River Basin area, Wyoming [Utah and Idaho], in Wyoming Geol. Assoc. Guidebook, 10th Ann. Field Conf., 1955 : p. 43-47.

Williams, N. C., 1953, Late Precambrian and early Paleozoic geology of western Uinta Mountains, Utah: Am. Assoc. Petroleum Geologists Bull., v. 37, no. 12, p. 2734-2742.

Wilmarth, M. Grace, 1938, Lexicon of geologic names of the United States (including Alaska) : U.S. Geol. Survey Bull. 896,2396 p.

Wilmarth, V. R., 1953, Yellow Canary uranium deposits, Daggett County, Utah: U.S. Geol. Survey Circ. 312, 8 p.

Wilson, Druid, Sando, W. J., and Kopf, R. W., 1957, Geologic names of North America introduced in 1936-1955: U.S. Geol. Survey Bull. 1056-A, p. 1-405.

Yourston, R. E., 1955, The Rock Springs coal field, in Wyoming Geol. Assoc. Guidebook, 10th Ann. Field Conf., 1955: p. 197-202.

Zirkel, Ferdinand, 1876, Microscopical petrography : U.S. Geol. Explor. 40th Parallel (King), v. 6, 297 p. 


\section{INDEX}

[Page numbers in italic indicate major references]

A

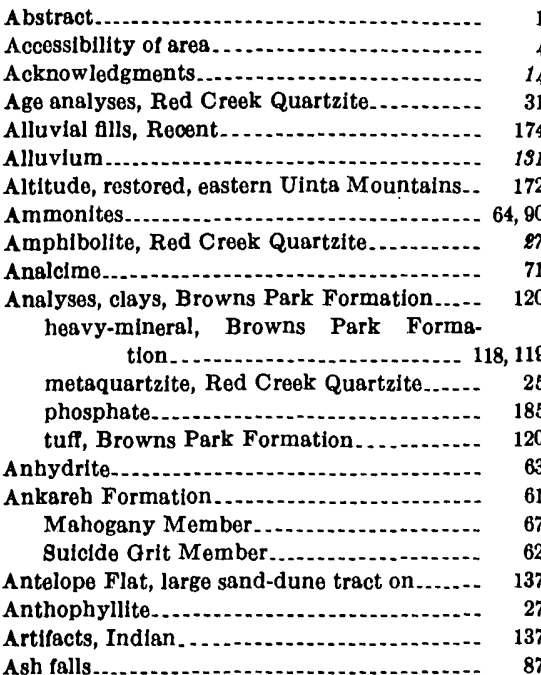

Ash falls....... 87

Ashley Creek, capture of .................. 164

B

Badlands...................... 72, 87, 96, 109, 114, 116 Band Box Butte, outlier of Uints Mountain Group............................ 14

Barite

Barnett, P. R., analyst.

Baxter Bhale

Bear Mountain oroslon surfaces--

Beaver Creek, drainage adjustments of...... Beaver Creek fault

Belemnite.

Bench

use of...

Bender Draw, beheading of.................. 178

Bender fault

Bender Mountain, barite deposit on .......... 185

infolded syncline on .................... 148

Bentonite............................ 87, 90, 91, 185

Bishop Conglomerate......................... 171

Blair Formation

age and correlations.

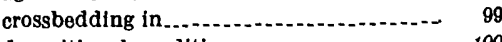

depositional conditions

distribution, physiographic expression, thickness, and lithology ...........

engineering characteristics.................. section of

Boars Tusk, active rockfalls on .............. 134 landslides on . . .

Botts, S. D., analyst...................... 120

Brachlopods................. 43, 44, 46, 50, 57, 58, 82, 97

Breccia, fault...................................... 156

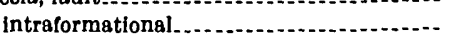

Brill, K. G., Jr., quoted.......................

Browns Park, normal faults north of ......... small anticlines in
Page

Browns Park Formation . . . . . . . . . . . .... 114 analyses, tuffs....................... 120 composite thickness....................... 127 contact relationships...................... 128 crossbedding in ...................... 130

depositional conditions . . . displacement by faults...................... 162 distribution and physiographic expression. 116 engineering characteristics................. 190

fossils, age, and correlations............. 128 halite-crystal molds in..................... 130 lithology and thickness....................... 117 sections of ............................... 120-127 summary description of tuffs in unconformity at base of................... 149 use of tuff in ............................. 186

Browns Park syncline...................... 154

Bryozoans ................................... 44, $4^{6}$

Buckhorn Conglomerate.................... $\quad 8^{9}$

Burro Canyon Formation.

\section{C}

Canyon cutting, Tertiary ...................... 173

Carbonate rock, Red Creek Quartzite......... so

Carey, J. S., and others, quoted .............. 186

Carmel Formation.......... depositional conditions................ 78,169 displacement by faults...................... 159 distribution and physiographic expression. $\quad 76$ engineering characteristics................... $7 \theta$ fossils, age, and correlations.................... 78 gypsum reserves in................... 187 landslides in $\ldots \ldots \ldots$ 134, 135, 197 limestone reserves in ....................... 187 lithology and thickness................... 76 sections of .............. 76, 77

Cenozoic rocks

Cephalopods................................... 97

Ceramic glazes. . . . . . .

Charcoal . . .

Charophytes

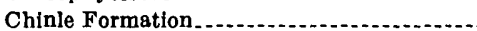
age and correlations. copper in..

depositional conditions displacement by faults.................... 161 distribution and physlographic expression. engineering characteristics

fossils in.

lithology and thickness.....................

Moss Back Member.

petrifled wood in

section of

Chokecherry Spring

hugwater Formation Popo Agie Member

Red Peak Member....................... 67

Clay, use of . . . .

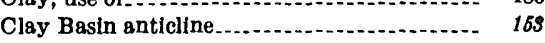
measured section on $. . . \ldots \ldots \ldots \ldots . . . . . . . . .103$ natural gas in................................ 182
Page

Cleavage......................... 149 Cliffs, formed on Navajo Sandstone.......... $\quad 72$ Climate ..................................... 10 Coal................. 93, 98, 99, 100, 103, 105, 106, 182 Coal prospect.

Coal swamps.................................. 41

Cobban, W. A., quoted................. 94

Cold Spring Mountain, small anticline on southwest slope of................... 153

Concretions, cannonball..................... 88

Conglomerate............................... 33

Copper........ 30,189

Corals................... 50

Correlations, Blair Formation............... $\quad 98$

Browns Park Formation................ 128

Carmel Formation.

Chinle Formation ....................... 70

Curtis Formation . .

Dakota Sandstone

Dinwoody Formation.................. 68

Entrada Sandstone....................... 80

Ericson Sandstone..................... 106

Fort Union Formation.

Frontier Formation. ...................... $9_{4}$

Hilliard Shale..............................

Mississippian System, upper shale unit.-

Moenkopl Formation.............................

Morrison Formation .........................

Mowry Shale....................................

Navajo Sandstone.............................

Park City Formation

Red Creek Quartzite.

Rock Springs Formation

Uints Mountain Group...........................

Wasatch Formation.

Cottonwood Draw, beheading of ....................

Cretaceous 8ystem

Crinoid columnals..................................

Crinoids

Crossbedding, Blair Formation................

Browns Park Formation. . . . .

Curtis Formation. ...........................

Dakota Sandstone............................

Entrada Sandstone.........................

Frontier Formation .........................

Hilliard Shale............................

Navajo Sandstone............................

Weber Sandstine......................... 49, 58

Crouse Creek, measured section at mouth of ..- 120 measured section near...................... 121

Curtis Formation. .............................. 81

crossbedding in ............................ 83

depositional conditions.................., 89,169

displacement by faults................... 159, 161

distribution and physiographic expression. engineering characteristics.

(ossills, are, and correlations

limestone reserves in.......................

lithology and thickness

source of potable water.........................

section of.

use of limestone from. 
$\mathrm{D}$

Dakota Sandstone-..... age and correlations. crossbedding in.

depositional conditions

displacement by faults..................... 161

distribution and physiographic expression. $\quad 87$ engineering characteristics............... $\quad 89$

lithology and thickness................... 88

natural gas in ...

section of

water in.

Depositional environments, Mesozoic

Diatoms

Differential erosion.................... 73, 96,175

Dinosaur remains.......................... 84, 86

Dinwoody Formation

age, contact relationships, and correlations. ...................................

depositional conditions. .................. 65,169

displacement by faults

distribution and physiographic expression.................................

engineering characteristics.................

gypsum in ...............................

lithology and thickness......................

natural gas in.

section of

reversal of by tilting.................. 164

Drainage changes, caused by man........... 181

during late Tertiary ................. 172, 173, 174

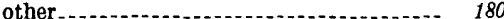

Quaternary

Dutch John Flat, normal faults in............ 160

Dutch John Gap, measured scction near...... 90

Navajo Sandstone at.................. 72

Dutch John nose.

East-west collapse-.............................. Echinoderms.

Echinoid spines

Edith Aspden Spring

(1).................. 31, 120 Browns Park Formation................. 190 Carmel Formation. ........................

Chinle Formation .........................

Curtis Formation ............................. Dakota Sandstone

Dinwoody Formation. .

Entrada Sandstone...........................

Erieson Sandstone.........................

Fort Union Formation. ...................

Frontier Formation.

Hilllard Shale

Mississippian System, lower and middle units

upper shale unit.

Moenkopl Formation

Morgan Formation

Morrison Formation.

Mowry Shale.

Nevajo Sandstone

Park City Formation

Red Creek Quartzite.

Round Valley Limestone

Uinta Mountain Grou

Wasatch Formation.

Weber Sandstone

Entrada Sandstone

age and correlations.

depositional conditions.

displacement by faults.

distribution and physiographic oxpression engineering characteristics.
Entrada Sandstone-Continued

lithology and thickness.

section of.-

Page

Entrenched meander, classic example

Eolian deposition $\quad 51,73,74,8$

137

Epidiorite, Red Creek Quartzite............. 28

Ericson Sandstone........................... 105

age and correlations. ................... 106

coal in ......................... 182

depositional conditions ............... 106, 169

engineering characteristics............... 107

lithology and thickness.................. 105

scour-and-fill structures in............... 106

section of ............. 106

water in.

\section{$\mathrm{F}$}

Faults.

Beaver Creek fault

Henrys Fort fault

indicators for...

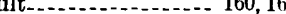

O-Wi-Yu-Kuts fault

South Valley fault................ 161

Uinta fault.............. 15, 38, 138, 148, 162, 167

Feldspar, saussuritized........................ 28

Finch Draw, eroded Navajo Sandstone at...- 72 measured sections in ................. $82,85,88$

Fish remains. ......... 114

Fish scales............................ 90, 108

Flaming Gorge, measured section in .......... 66

Flaming Gorge Dam..................... 4

Flaming Gorge Reservoir

Flatirons.............................. 49, 53, 75

Flood-plain deposits, modern ................ 198

Floral zones. ............................. 10, 11

Folds. subsidiary, classiflcation of...............

Ford Spring.

Fort Union Formation

coal in.

depositional conditions

displacement by faults.

distribution and physiographic expression

engineering characteristics.

fossils, age, and correlations...................

lithology and thickness.

unconformity at base of

Fossils, Browns Park Formation.

Carmel Formation.

71

Dinwoody Formation...................... 63

Early Cretaceous..................... 86, 9

Early Pennsylvanian.................... 43, 44

Early Triassic

Eocene......................... 112

Fort Union Formation............... 109

Frontier Formation ..................... 83, 9

Green River Formation. ................ 114

Hilliard Shale................................ 97

in Recent alluvium .................... 133

Jurassic......... 78

Late Cretaceous........................... 94, 97

Late Jurassic . . . .

Late Mississippian......................... 41

middle Miocene

Middle Pennsylvanian..................... 46, 50

Moenkopi Formation ......................

Morgan Formation.

Morrison Formation

Mowry Shale............................

Paleocene.

Park City Formation

Permian

Rock Springs Formation.
Fossils-Continued

Page

43

Wasatch Formation....................... 118

Weber Sandstone

Franson Member, Park City Formation..... 58, 169

Frontier Formation coal in....................................... 182 crossbedding in ........................ 9 depositional conditions................... 94,169 displacement by faults................. 161 distribution and physiographic expression. $\quad 98$ engineering characteristics................. 95

fossils, age, and correlations .............. 94

landslides in ..................... 95, 134, 135, 187

lithology and thickness................ 92

natural gas in ........................ 92, 153, 182

sections of .

water in

Fucoid casts...... 97

Garnet Canyon

Garnet Canyon anticline

Garnets

Garta Grit Member

Gastropods..

$58,67,112,114$

Geographic setting of area ................... 6

Geologic factors influencing plant associations.- $\quad 10$

Geologic history ................................ 15, 166 early Tertiary tectonic and depositional_. 170

Laramide orogeny....................... $\quad 169$

Mesozoic......................... 169

middle and late Tertiary tectonics, erosion, and deposition.

Paleozoic.

Quaternary................. 174

younger Precambrian..................... 167

George Draw, measured section near......... 123

Gilbert Peak erosion surface......... 115, 163, 166, 171 displacement by faults...................... 161 gravity faulting after cutting of Glaciation

Glades, The, measured sections at.......... 99, 101

Glauconite...................... 82, 83

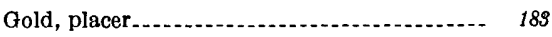

Gordon, Mackenzie, Jr., quoted ..............

Goslin fault . . . . . . . . .

Goslin Mountain, analysis of metaquartzite on

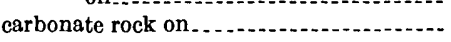

tilting south and west from

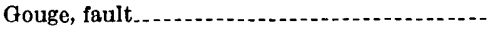

Granitic variants of epidiorite and amphibolite, Red Creek Quartzite..........

Gravitative collapse in the eastern Uinta Mountains..........................

Green River, gold placers along

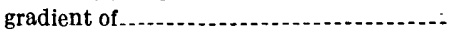

recent changes in course . ...................

Green River Formation. . ................... 114

Green River lake.............................. 171

Gude, A. J., analyst...................... 120

Gypsum

\section{H}

Halite-crystal molds......................... 130

Hayden, F. V., quoted ................. 13, 36 territorial survey by ..................... 13

Hazel, K. V., analyst............. 120

Hedge, C. E., analyst....................... 31

Hematitic gossan, produced on carbonate rocks.-

Henrys Fork fault

ideout Canyon. . . . . . measured section in 


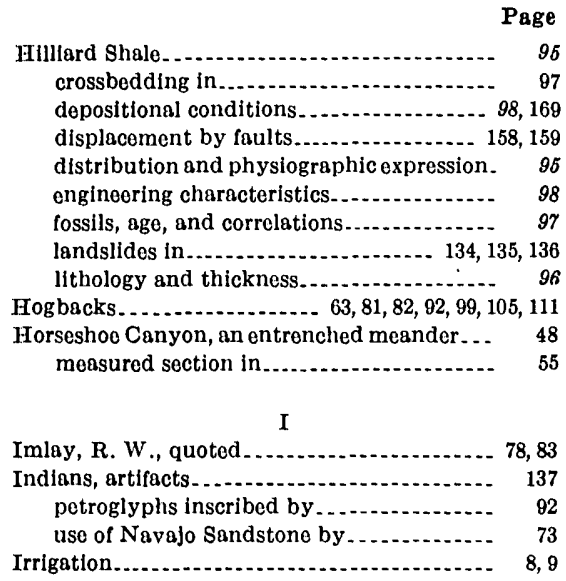

J

Jesse Ewing Canyon, beheading of ........... 178 small anticline at mouth of ................ 153 Jointing.................... 75, 81 Jurassic System.

\section{$\mathbf{K}$}

King, Clarence, territorial survey by ......... 13 Kings Point, classic superposition at.......... 116 Kummel, Bernhard, Jr., quoted...............

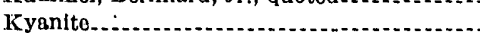

Landslides... . . . . . . . . along Uinta Fault........................ 194 caused by irrigation water............... 195 in Carmel Formation.................... 197 in Frontier Formation.................... 197 in Red Creek Quartzite................... 196 in Uinta Mountain Group................. 196 on Boars Tusk . . . . 195

Laramide orogeny

Leucoxeno...................................... 28

Limestone, uso of ............................ 186

Linear features............................... 140

Linear structures, signiflcance of............... 141

Linwood, measured section near............... $\quad 94$

Linwood nose $\ldots . . . .160$

Little Hole, normal faults in ................... 160

Location of area........................................

Lohman, S. W., quoted.

Mack, M. D., analyst....

McKelvey, V. E., Swanson, R. W., and sheldon, R. P., quoted..........

Mackentire "Rod-beds" Tongue...

Mahogany Member, Ankareh Formation...

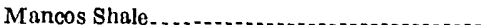

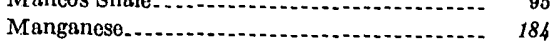

Marsh, O. C., quoted.......... 13,72

Marvin, R. F., analyst...................... 31

Morde Peak Tongue of Phosphoria

Peak Tongue of Phosphoria
Formation....... phosphate in..

Mesaverde Group

169

environments.......... $\quad 170$

Mesozolc history . ......................... 169

Mesozoic rocks................................... $\quad 60$

Metamorphism, reglonal high-grade.......... 167

retrograde................................ 28

Metaquartzite, Red Creek Quartzite......... 24

Method of investigation......................

Mica, in pegmatite..................................

Mica schist, Red Creek Quartzite............. $\quad 25$
Page

Mineral resources.

barite.

clay and shale...................... 185

coal . . . ......... 93, 98, 99, 100, 103, 105, 106, 188 gypsum .................. 63, 65, 66, 68, 75, 78, 187

limestono............ 186 metallic minerals ........................ 188

natural gas. ........... 13, 75, 79, 88, 92, 153, 188 phosphate-............................. 184

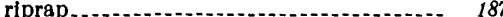
sand and gravel....................... 187

sillca.

Mining, coal trona.

Minor folds.

Mississipplan System ............................

lower and middle units. depositional conditions. engineering characteristics.

upper shale unit.

(n)

(1)

correlations............................

depositional conditions.................

engineering characteristics.............

Modern flood-plain deposits...................

Moenkopi Formation.

depositional conditions.................. 67,169

displacement by faults................... 159, 16

distribution and physiographic expression.

engineering characteristics.

fossils, age, and correlations................

gypsum in.

lithology and thickness

section of

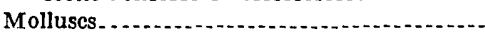

Monadnocks

Morgan Formation ................... 44

depositional conditions.................. 46,168

distribution and physiographic expression. englneering characteristics.

possils and age ...............................

lithology and thickness...................... section of

depositional conditions.................. 86, 169

dinosaur remains in

displacement by faults..................... 159

distribution and physiographic expression. $\quad 84$

engineering characteristics............... 87

fossils, age, and correlations............. 86

landslides in ............................. 134, 135

lithology and thickness........... 85

manganese in ............................... 184

petrifled wood in.

section of .....................................

Moss Back Member, Chinle Formation......

Mountain Home, pegmatite on

Mountain Home fault

Mowry Shale........................ 89, 169 displacement by faults.................... 161 engineering characteristics................ 91

fossils, age, and correlations................ lithology and thickness...................

section of ...................................

Natural gas............... 13, 75, 79, 88, 92, 153, 182

Navajo Sandstone-............................ 71 age and correlations..................... 74 cliffs formed on ....................... 72 crossbedding in ........................ 71, 72, 73 depositional conditions................... 74 displacement by faults.................. 159, 161 distribution and physiographic expression. $\quad 7 \%$ engineering characteristics................ 75 lithology and thickness................. 79
Navajo Sandstone-Continued

Page

possibly equivalent to entire Glen Canyon Group.

uranium in....................

use of by Indians.....................

Nielsons Bench, measured section near....... $\quad 70$

Normal faulting, time and signiflcance........ 161

Normal faults. . . . . .

North-flank homocline.

Nugget Sandstone...............................

\section{0}

Oil shale.

114

$41,86,112,128$

Outwash, glacial
O-Wi-Yu-Kuts fault.

$\mathbf{P}$

Paleozoic history ............................ $\quad 167$

Paleozoic rocks................ 98

unconformity at base of

Park City Formation........ 51

contact relationships.....................

depositional conditions.................. 68,168

distribution and physiographic expression_ $\quad 52$

engineering characteristics................. $\quad 59$

fossils, age, and correlations............. $\quad 67$

Franson Member............................. 59,169

flatirons formed by ..................

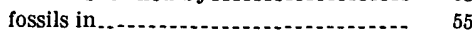

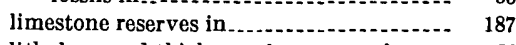

lithology and thickness, lower member... $\quad 68$

Meade Peak Tongue of the Phosphoria

Formation ...................... 58, 169, 184

section of .

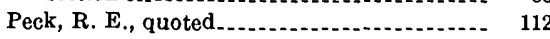

Pegmatite, Red Creek Quartzite............... so

Pelecypods................ 46, 63, 67, 78, 03, 94, 97, 114

Pennsylvanian System................... 48

Permian System ............................... 51

Petrifled wood..................... 69, 86, 88, 93, 11

Petroglyphs, inscribed by Indians............ 92

Phosphate...................................... 59, 184

Phosphoria Formation...................... 51

Meade Peak Tongue..................... 68, 169 phosphate in............ 184

Pigmy forest................................. 11

Planation, Quaternary . .................. 174

Plant remains............................... 109, 110

Pleistocene bench gravels................... 191

Popo Agie Member, Chugwater Formation... 69, 70

Porcelanite... 90

Powell, J. W., quoted ........... territorial survey by ..................... 13

Pozzolan...................................... 186

Precambrian history, older.................. 166

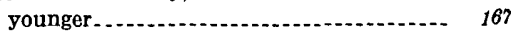

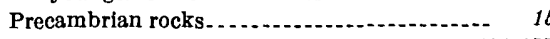

faults in.............................. 154, 155

general stratigraphic framework.......... 22

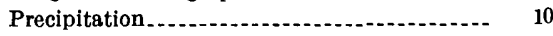

Previous investigations........................ 11

Pruitt, R. G., quoted.............. 183

Pyrite......................................... 63, 65

\section{Q}

Quartzite, vitreous............................ 33

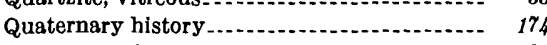

Quaternary System............................ 191

unconformity at base of ................. 149

\section{R}

Recent alluvial flls......................... 198 use of .........

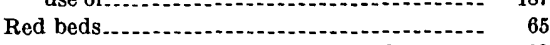
Red Bench, exposures of Triassic rocks....... $\quad 60$

Red Canyon anticline........................ 150 Red Canyon area, upper, normal faults in .... 169 


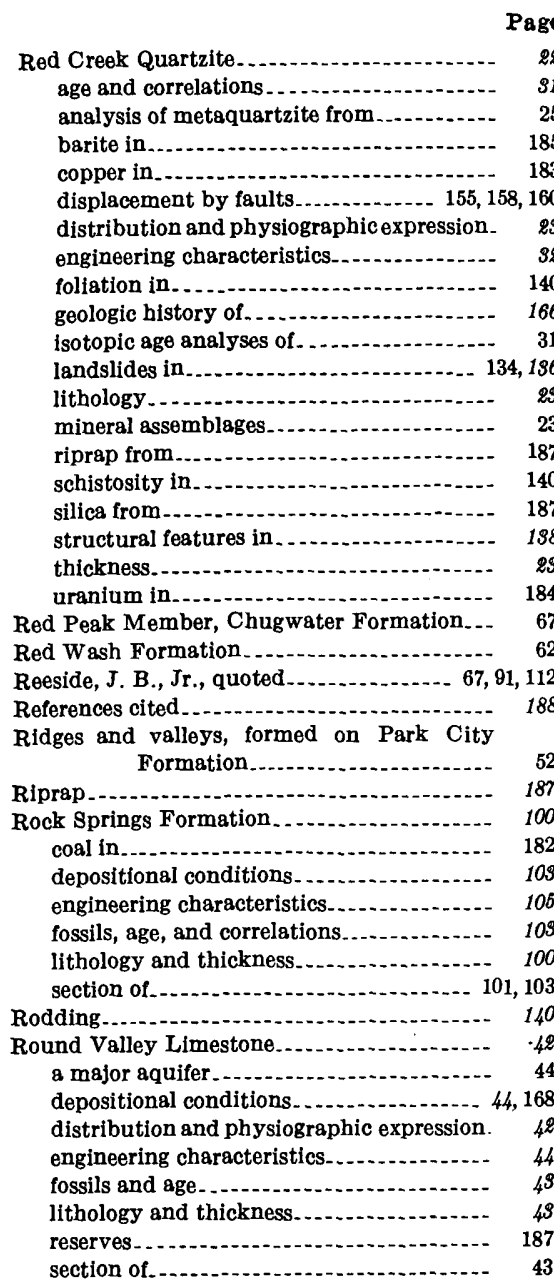

$\mathbf{S}$

Sand and gravel, use of

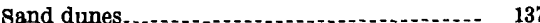

Sandstones.......................................... 33

Sadlick, Walter, quoted............................

Scaphopod............................................

Sears, J. D quoted

Shale................ 35

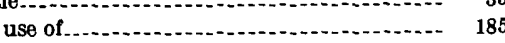

Sheep Creek, drainage adjustments of .......- 175 exposures of Dinwoody Formation along - $\quad 63$ Mississippian section exposed near......... $\quad 39$ small thrust faults near.................... 159 Sheep Creek Canyon, exposures of Moenkopi Formation in ....-.............. exposures of Triassic rocks....................

Sheep Creek Gap

gypsum bed at

tion at.......................... 76

Shinarump Conglomerate.............. 61, 62, 68

Shinarump Group........................... 60

Sillica, use of

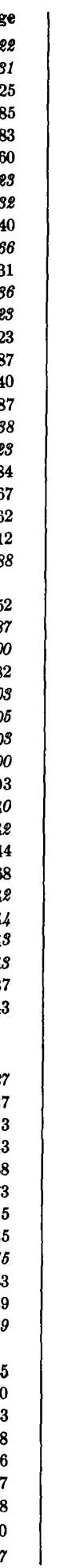

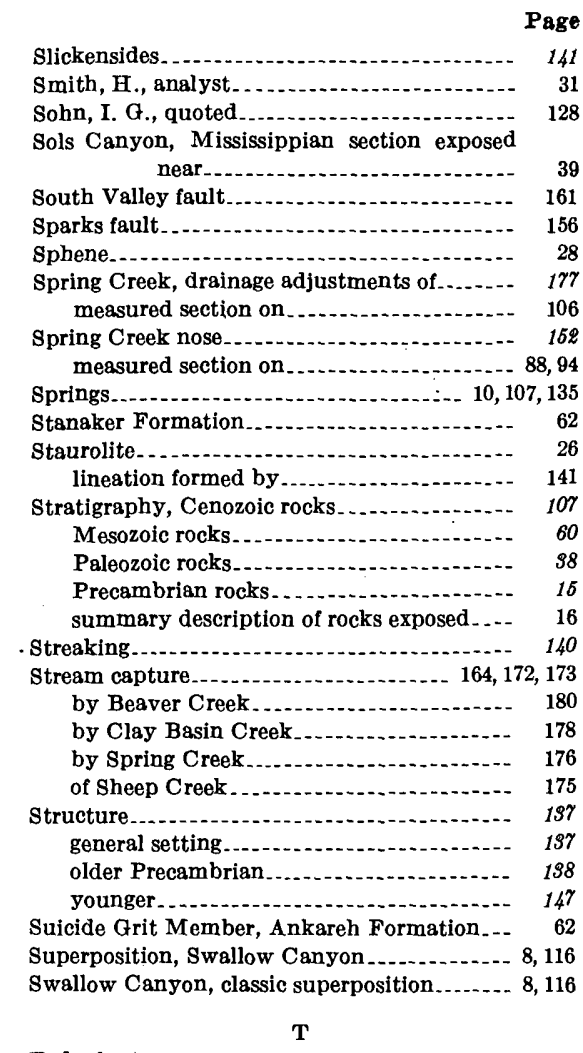

Tadpole structure

141,146

Talus

Temperature

Terraces, gravel-capped.........................

Terracing, Quaternary

Tertiary canyon cutting

Tertiary history middle and late Tertiary tectonics, erosion, and deposition.......................

Tertiary System.

107

Thaynes Formation

The Glades, measured sections at

Thrust faults, high-angle.................... 156 modifled high- and low-angle............. 156

Tilting, post-Browns Park .................... 174 regional evidence of ..................... 164 south and west from Goslin Mountain.... 164

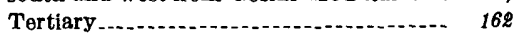

Topographic features influencing plant associ-

Triassic System

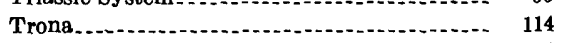
Tuffs, Browns Park Formation $\ldots . . . . . .117,173,186$ summary description of ................. 119

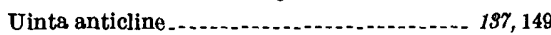
Uinta fault............................. 158, 138, 148, 167 gravitative movements on ................ 162 landslides along.
141

31

$\gamma$

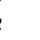

16

6

10

180

0

176

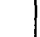

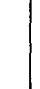

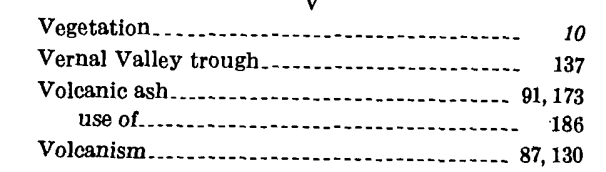

\section{W}

Walthall, F. G., analyst................. 31

Warping, age of ................................... 166

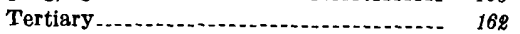

Wasatch Formation ........................... 111

displacement by faults............... 158, 159

engineering characteristics.................. 119

fossils, age, and correlations.............. 118

litbology and thickness.................... 111

Water, Curtis Formation...................... 84

Dakota Sandstone................. 89

Ericson Sandstone........................... 107

from springs.......................

Frontier Formation

Weber Sandstone.............................. 47

contact relationships....................... 60

depositional conditions................ 50,168

distribution and physiographic expression. $\quad 47$

engineering characteristics................. $\quad 61$

flatirons formed by ......................... 49

fossils and age

honeycomb structure in .................. 49

limestone reserves in....................... 187

lithology and thickness.................... 48

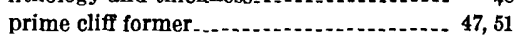

section of ........ 49

Whisky Peak ................................... 181

measured section near. .................. 126

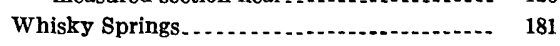

Willow Creek, analysis of metaquartzite near. . $\quad 25$

Wilmarth, V. R., quoted.................... 184

Woodside Formation.

Worm casts.................................. 97 